US Army Corps

of Engineers.

Portland District

Prepared for the U.S. Army Corps of Engineers, Portland District,

Under a Government Order with the U.S. Department of Energy

Contract DE-AC05-76RL01830

\title{
Acoustic Telemetry Evaluation of Juvenile Salmonid Passage and Survival at John Day Dam with Emphasis on the Prototype Surface Flow Outlet, 2008
}

$\begin{array}{llll}\text { MA Weiland } & \text { TJ Monter } & \text { SA Zimmerman } & \text { J Kim } \\ \text { GR Ploskey } & \text { GE Johnson } & \text { RE Durham } & \text { ES Fischer } \\ \text { JS Hughes } & \text { F Khan } & \text { DM Faber } & \text { MM Meyer } \\ \text { Z Deng } & \text { MC Wilberding } & \text { RL Townsend } & \\ \text { T Fu } & \text { AW Cushing } & \text { JR Skalski } & \end{array}$

\section{FINAL REPORT}

December 2009

\section{Pacific Northwest}

NATIONAL LABORATORY 


\title{
DISCLAIMER
}

This report was prepared as an account of work sponsored by an agency of the United States Government. Neither the United States Government nor any agency thereof, nor Battelle Memorial Institute, nor any of their employees, makes any warranty, express or implied, or assumes any legal liability or responsibility for the accuracy, completeness, or usefulness of any information, apparatus, product, or process disclosed, or represents that its use would not infringe privately owned rights. Reference herein to any specific commercial product, process, or service by trade name, trademark, manufacturer, or otherwise does not necessarily constitute or imply its endorsement, recommendation, or favoring by the United States Government or any agency thereof, or Battelle Memorial Institute. The views and opinions of authors expressed herein do not necessarily state or reflect those of the United States Government or any agency thereof.

\author{
PACIFIC NORTHWEST NATIONAL LABORATORY \\ operated by \\ BATTELLE \\ for the \\ UNITED STATES DEPARTMENT OF ENERGY \\ under Contract DE-AC05-76RL01830
}

Printed in the United States of America

Available to DOE and DOE contractors from the

Office of Scientific and Technical Information,

P.O. Box 62, Oak Ridge, TN 37831-0062;

ph: (865) 576-8401

fax: $(865) 576-5728$

email: reports@adonis.osti.gov

\footnotetext{
Available to the public from the National Technical Information Service, U.S. Department of Commerce, 5285 Port Royal Rd., Springfield, VA 22161 ph: (800) 553-6847 fax: $(703) 605-6900$

email: orders@ntis.fedworld.gov

online ordering: http://www.ntis.gov/ordering.htm
}

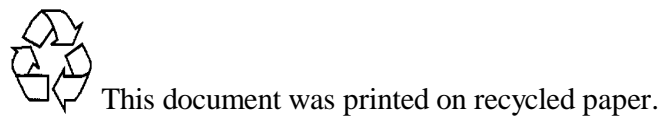




\section{Acoustic Telemetry Evaluation of Juvenile Salmonid Passage and Survival at John Day Dam with Emphasis on the Prototype Surface Flow Outlet, 2008}

$\begin{array}{llll}\text { MA Weiland } & \text { TJ Monter } & \text { SA Zimmerman } & \text { J Kim }^{(\mathrm{b})} \\ \text { GR Ploskey } & \text { GE Johnson } & \text { DM Faber } & \text { ES Fischer }^{(\mathrm{b})} \\ \text { JS Hughes } & \text { F Khan } & \text { RE Durham } & \text { MM Meyer }^{(\mathrm{b})} \\ \text { Z Deng } & \text { MC Wilberding } & \text { RL Townsend } & \\ \text { T Fu } & \text { AW Cushing } & \text { JR Skalski }^{(\text {a) }} & \end{array}$

FINAL REPORT

December 2009

Prepared for the

U.S. Army Corps of Engineers, Portland District

Under a Government Order with

the U.S. Department of Energy

Contract DE-AC05-76RL01830

Prepared by

Pacific Northwest National Laboratory

P.O. Box 999

Richland, Washington 99352

(a) University of Washington, Seattle, Washington

(b) Pacific States Marine Fisheries Commission, Portland, Oregon 
This report should be cited as follows:

Weiland MA, GR Ploskey, JS Hughes, Z Deng, T Fu, TJ Monter, GE Johnson, F Khan, MC Wilberding, AW Cushing, SA Zimmerman, DM Faber, RE Durham, RL Townsend, JR Skalski, J Kim, ES Fischer, and MM Meyer. 2009. Acoustic Telemetry Evaluation of Juvenile Salmonid Passage and Survival at John Day Dam with Emphasis on the Prototype Surface Flow Outlet, 2008. PNNL-18890, Pacific Northwest National Laboratory, Richland, Washington. 


\section{Preface}

The study reported herein was funded as part of the Anadromous Fish Evaluation Program, which is managed by the U.S. Army Corps of Engineers (USACE). The Anadromous Fish Evaluation Program study code is SPE-P-08-03: Studies of Surface Spill at John Day Dam. The study was led by the Pacific Northwest National Laboratory (PNNL) for the USACE Portland District. The USACE technical leads were Robert Wertheimer and Brad Eppard. The PNNL study project manager was Mark Weiland (509 427-5923). The data are archived at PNNL offices in North Bonneville, Washington. 


\section{Executive Summary}

Improving survival rates of juvenile salmonids through the Federal Columbia River Power System (FCRPS) continues to be a high priority for the U.S. Army Corps of Engineers, Portland District. Many of these fish are from populations listed as threatened or endangered under the Endangered Species Act of 1973. Increased survival rates are necessary to meet performance standards set forth in the 2008 Biological Opinion (BiOp) on FCRPS operations. The BiOp mandates $96 \%$ and $93 \%$ survival rates be achieved for spring and summer downstream migrating juvenile salmonids, respectively. At John Day Dam, the Portland District is evaluating the provision of surface flow outlets (SFOs) as a means to increase fish-passage efficiency and in turn increase passage survival rates by reducing turbine passage of juvenile salmonids. The goal of the study reported herein is to provide the passage and survival data necessary to evaluate the performance of the prototype SFO and the dam as a whole relative to the standards in the BiOp. The study was conducted by the Pacific Northwest National Laboratory and the University of Washington. The Portland District and regional fisheries managers will use the data to adaptively manage the configuration and operation of John Day Dam to maximize the survival rates of juvenile salmonids.

\section{Objectives}

In this report, we present survival estimates, passage efficiencies, and fish behavior data for acoustictagged steelhead (STH), yearling Chinook salmon (YC), and subyearling Chinook salmon (SYC) passing through John Day Dam during 2008. We examined the data relative to two spill treatments, 30\% versus $40 \%$ spill out of total water discharge through the dam, to assess the performance of SFOs, called topspill weirs (TSWs). The field study period was from April 29 to August 20, 2008. The objectives were as follows:

\section{- Survival Rates}

- Estimate single- and paired-release, route-specific, dam-passage, and concrete-passage survival rates for YC, STH, and SYC passing through John Day Dam for each of two spillway operational treatments.

- Fish Passage

- Estimate passage proportions among major passage routes, and calculate efficiency and effectiveness metrics for each of two spillway operational treatments for YC, STH, and SYC separately.

- Estimate travel times (forebay residence and tailrace egress) of YC, STH, and SYC for each of two spill treatments.

- Fish Behavior

- Characterize fish behaviors, including forebay approach paths, for YC, STH, and SYC and compare approach paths with the final route of passage for each of two spill treatments.

- Describe vertical and horizontal distributions and residence times of YC, STH, and SYC within the dam forebay. 
The study area included 187 river kilometers (rkm) of the Columbia River from Arlington, Oregon (rkm 390), 41.4 km upstream of John Day Dam, to Lady Island (rkm 192) near Camas, Washington. John Day Dam is located at rkm 348.6 and consists of a powerhouse with 16 turbine units, 4 skeleton bays, and a 20-bay spillway. The prototype TSWs were installed at spill bays 15 and 16 .

\section{Methods}

This study used the Juvenile Salmon Acoustic Telemetry System (JSATS). We surgically implanted acoustic tags and passive integrated transponder tags in $3447 \mathrm{YC}$ and $3450 \mathrm{STH}$ in spring and in 5931 $\mathrm{SYC}$ in summer. Median lengths of tagged fish were as follows: $\mathrm{YC}=158 \mathrm{~mm} ; \mathrm{STH}=217 \mathrm{~mm} ; \mathrm{SYC}=$ $117 \mathrm{~mm}$.

Tagged YC and STH were released daily over a 29-day spring period (5/1 to 5/29) at Arlington, Oregon (at 0600, 1200, and 1800 hours) and in the John Day Dam tailrace (at 0100, 1300, and 1900 hours). Similarly, acoustic-tagged SYC were released in summer over a 29-day period (June 15 to July) in three release groups at Arlington, Oregon (at 0600, 1200, and 2100 hours) and in the John Day Dam tailrace (at 0100, 1300, and 1900 hours). To receive signals from tagged fish, we deployed shallow and deep JSATS cabled hydrophones on the upstream face of John Day Dam. We also deployed and maintained autonomous node arrays at six river cross sections including $2 \mathrm{~km}$ upstream of John Day Dam, 9.4 km downstream of John Day Dam, $2 \mathrm{~km}$ upstream of The Dalles Dam spillway, $2 \mathrm{~km}$ upstream of the Bonneville Dam Second Powerhouse, Reed Island in the Bonneville Dam tailwater, and Lady Island downstream near Camas, Washington.

Using tagged fish regrouped at the John Day Dam-face array and released in the John Day Dam tailrace, paired release-recapture methods were applied to estimate the concrete-passage survival rate for each fish stock. The detection arrays at The Dalles Dam forebay, the Bonneville Dam forebay, and Reed Island provided eight possible capture histories for each release group. When detection counts associated with sequences of detection probabilities for the three downstream arrays were homogeneous over time, fish composing virtual releases were pooled for the entire season, but this was rare. Most of the time counts for the eight possible capture histories were heterogeneous and the number of fish in individual virtual releases was used to calculate a weighted mean survival rate for each season. Separate concretepassage survival estimates were made for YC released at Arlington, Oregon, and downstream of Lower Granite Dam in spring. We also made single-release dam-passage survival estimates for STH and YC passing The Dalles Dam in spring and single and paired-release estimates of The Dalles Dam-passage survival rate for SYC in summer. To derive tag-life corrections for the John Day Dam concrete-passage survival estimates and The Dalles Dam-passage survival estimates, we conducted a tag-life study using 50 three-second tags randomly sampled from the same lots of tags that were surgically implanted in fish for the study. The fraction of transmitting tags remaining was plotted against days since tag activation and the Kaplan-Meier estimator of tag survival rate was used to derived tag-life corrections. We did not make tag-life corrections for comparing survival rates among spill conditions or day and night periods. Testable assumptions of the survival models were evaluated using established techniques.

Fish passage and behavior at John Day Dam relative to the TSW and spill treatments were investigated using detections at dam-face and forebay hydrophones and acoustic tracking. Acoustic tracking is a common technique in bioacoustics based on time-of-arrival-differences from different hydrophones. Typically, tracking requires a 3-hydrophone array for two-dimensional (2D) tracking and a 4-hydrophone array for 3D tracking. For this study, 3D tracking was performed. 


\section{Results}

\section{Survival Rates}

For the dam as a whole, paired-release concrete-passage survival rates were highest for YC $(0.957)$ and STH (0.986) and lowest for SYC (0.861) (Table ES.1). Single-release estimates were generally a few hundredths lower than the corresponding paired-release estimate. The highest survival rates were at the juvenile bypass system (JBS; 0.973 to 1.002). The TSW had the second highest route-specific survival rates in spring ( 0.961 for $\mathrm{YC} ; 0.992$ for $\mathrm{STH})$ and summer ( 0.927 for $\mathrm{SYC})$. The lowest survival rates were observed at the turbine route (Table ES.1). Dam-passage survival rates for each tagged stock did not differ between the two spill treatments (Table ES.2).

Table ES.1. Tag-life-corrected, paired-release estimates of concrete-passage and route-specific survival rates

\begin{tabular}{lcccccc}
\hline & \multicolumn{2}{c}{ Yearling Chinook Salmon } & \multicolumn{2}{c}{ Steelhead } & \multicolumn{2}{c}{ Subyearling Chinook Salmon } \\
\cline { 2 - 7 } \multicolumn{1}{c}{ Route } & $\begin{array}{c}\text { Paired } \\
\text { Release }\end{array}$ & $1 / 295 \%$ CI & $\begin{array}{c}\text { Paired } \\
\text { Release }\end{array}$ & $1 / 295 \%$ CI & Paired Release & $1 / 295 \%$ CI \\
\hline Concrete & 0.957 & 0.013 & 0.986 & 0.019 & 0.861 & 0.017 \\
Non-TSW & 0.966 & 0.011 & 0.985 & 0.023 & 0.844 & 0.044 \\
TSW & 0.961 & 0.020 & 0.992 & 0.023 & 0.927 & 0.016 \\
Turbine & 0.855 & 0.034 & 0.749 & 0.062 & 0.728 & 0.056 \\
JBS & 0.976 & 0.045 & 1.002 & 0.019 & 0.973 & 0.057 \\
\hline CI = confidence interval. & & & & & \\
JBS = juvenile bypass system. & & & & & \\
TSW = top-spill weir. &
\end{tabular}

\section{Fish Passage}

Various passage efficiencies were similar for the two spill treatments for each of the three tagged stocks (Table ES.2). Interestingly, the point estimates for TSW-passage efficiency were higher for 30\% than $40 \%$ spill for all three stocks. During 2008, the TSWs passed almost $24 \%$ of the total number of acoustic-tagged YC passing through John Day Dam (Table ES.3). Combining the TSW spill bays with non-TSW spill bays resulted in over three-quarters of the YC passing through the spillway. Of the YC passing into the powerhouse, over two-thirds were diverted by the intake screens into the JBS. About $8 \%$ of total YC passage was through turbines. For steelhead at John Day Dam during 2008, the TSWs passed almost $50 \%$ of the total number of acoustic-tagged STH passing the dam (Table ES.3). Combining the TSW spill bays with non-TSW spill bays resulted in over three-quarters of the STH passing through the spillway. Of the STH passing into the powerhouse, about $89 \%$ were diverted by the intake screens into the JBS. About $3 \%$ of total STH passage was through turbines. Passage data for acoustic-tagged subyearling Chinook salmon at John Day Dam show that the TSWs passed about $20 \%$ of the total number of SYC passing the dam (Table ES.3). Combining the TSW spill bays with non-TSW spill bays resulted in about $69 \%$ of the SYC passing through the spillway. Of the SYC passing into the powerhouse, almost half were diverted by the intake screens into the JBS. About $17 \%$ of total SYC passage was through turbines. 
Table ES.2. Estimates of dam-passage survival rates and passage efficiencies by spill condition. ${ }^{(a)}$ Confidence intervals are provided in corresponding tables in the main body of the report and in all instances overlapped with those of the alternative spill condition. These estimates were not corrected for tag life, because tag-life bias was small and common to both spill conditions.

\begin{tabular}{lcccccc}
\hline & \multicolumn{2}{c}{ Yearling Chinook Salmon } & \multicolumn{2}{c}{ Steelhead } & \multicolumn{2}{c}{ Subyearling Chinook Salmon } \\
\hline Metric & $30 \%$ & $40 \%$ & $30 \%$ & $40 \%$ & $30 \%$ & $40 \%$ \\
\hline $\begin{array}{l}\text { Dam-Passage } \\
\text { Survival }\end{array}$ & 0.955 & 0.956 & 0.991 & 0.972 & 0.852 & 0.866 \\
FPE & & & & & & \\
SE & 0.929 & 0.911 & 0.974 & 0.967 & 0.820 & 0.844 \\
FGE & 0.759 & 0.768 & 0.758 & 0.724 & 0.657 & 0.711 \\
TSWE & 0.704 & 0.615 & 0.894 & 0.881 & 0.476 & 0.462 \\
\hline
\end{tabular}

(a) During spring, spill treatment conditions were met for most of Blocks 1 through 3 but not for large parts of Blocks 4 through 7. During summer, treatment conditions were not met for Blocks 1 through 4 , but were met for most of Blocks 5 through 7. Blocks were 4 days long. As a result, post-hoc spill conditions were identified: fish passage when spill was $<35 \%$ was designated as a $30 \%$ spill condition and spill between 35 and 45 was designated as a $40 \%$ spill condition.

$\mathrm{FGE}=$ fish-guidance efficiency.

$\mathrm{FPE} \quad=$ fish-passage efficiency.

$\mathrm{SE} \quad=$ spillway-passage efficiency.

TSWE $=$ top spillway weir passage efficiency.

Table ES.3. Summary of passage efficiency and effectiveness data. Confidence intervals are provided in corresponding tables in the main body of the report.

\begin{tabular}{lccc}
\hline \multicolumn{1}{c}{ Metric } & Yearling Chinook Salmon & Steelhead & Subyearling Chinook Salmon \\
\hline Fish-Passage Efficiency & 0.921 & 0.972 & 0.833 \\
Spillway-Passage Efficiency & 0.762 & 0.744 & 0.686 \\
Fish-Guidance Efficiency & 0.669 & 0.889 & 0.468 \\
TSW-Passage Efficiency & 0.236 & 0.496 & 0.206 \\
JBS-Passage Efficiency & 0.159 & 0.227 & 0.147 \\
Spillway-Passage & 2.32 & 2.25 & 1.94 \\
Effectiveness & & & \\
TSW-Passage Effectiveness & 3.41 & 7.21 & 3.14 \\
\hline JBS = juvenile bypass system. & & & \\
TSW = top-spill weir. & & & \\
\hline
\end{tabular}

Travel time from the Arlington release location to the John Day Dam forebay was about 1 day for each tagged stock. YC and SYC spent about 2 to 3 hours in the forebay before passing the dam, whereas STH residence time was 3 to 6 hours depending on passage route. Durations between passage time and exit at the egress array were about 1.5 hours for the three stocks. The $\sim 1.5$-hour egress time did not differ much between the $30 \%$ and $40 \%$ spill treatments, except turbine-passed STH had a 2.2-hour egress time during the $40 \%$ spill treatment. Travel times from the John Day Dam egress array to the forebay array at 
The Dalles Dam were 7 to 11 hours depending on stock. Travel times from The Dalles Dam forebay to the Bonneville Dam forebay were shortest for STH (22 hours), followed by YC ( 24.4 hours), then SYC (30 hours).

\section{Fish Behavior}

To investigate fish behavior, fish detections were classified into "arrival blocks" based on forebay array data and "passage blocks" based on dam-face array data. The blocks corresponded to areas of the dam, moving from south to north: powerhouse turbine units 1-8, units 9-16, skeleton bays 17-20, spill bays $17-20$, TSW bays $15-16$, and spill bays $1-14$. Skeleton bays were included in arrival blocks but not in passage blocks because fish could not pass there. The data generally show that at least half of the tagged fish arriving upstream of the turbine units and skeleton bays moved north to ultimately pass at the spillway, including the TSWs. This pattern was strongest for STH and weakest for SYC. Tagged fish arriving upstream of the spillway, however, did not tend to move south toward the powerhouse.

Specifically, of the YC detected arriving in the entire forebay, about $45 \%$ and $16 \%$ approached the powerhouse upstream of turbine units 1-16 and the skeleton bays, respectively (Figure ES.1a). Arrivals at the spillway involved about $12 \%$ upstream of spill bays $17-20$, the area between the skeleton bays and the TSWs, $5 \%$ at the TSWs, and $22 \%$ at spill bays $1-14$. However, almost $60 \%$ of the YC that arrived at the powerhouse moved north and passed at the spillway, mostly at spill bays 17-20 and the TSWs. On the contrary, few YC arriving at the spillway moved south and passed at the powerhouse. YC approaching at the spillway usually passed at the spillway.

For acoustic-tagged STH detected arriving in the forebay, about $52 \%$ and $12 \%$ approached the powerhouse upstream of turbine units 1-16 and the skeleton bays, respectively (Figure ES.1b). Arrivals at the spillway included about $9 \%$ at spill bays $17-20,4 \%$ at the TSWs, and $23 \%$ at spill bays $1-14$. Importantly, almost $66 \%$ of the STH that arrived at the powerhouse moved north and passed at the spillway, mostly at the TSWs. Again, few STH arriving at the spillway moved south and passed at the powerhouse. As with YC, STH approaching at the spillway typically passed at spill bays 1-14 or the TSWs. Overall, a noticeable portion of STH moved toward the TSWs regardless of arrival block.

About $60 \%$ of the total number of tagged SYC detected in the forebay arrived upstream of the powerhouse turbine units and the skeleton bays (Figure ES.1c). About half of these fish moved north to ultimately pass at the spillway, mostly at spill bays $17-20$ and the TSWs. Of the $25 \%$ of total SYC arrivals at units 9-16, over half passed there or at units 1-8 and did not apparently move north toward the spillway. The SYC arriving at the spillway tended to pass there.

Detailed horizontal distribution data on fish passage into the dam support the behavioral trends described above for fish movements in the forebay, i.e., horizontal distributions were highly skewed toward the TSWs and spill bays 17-20 for all three tagged stocks. Horizontal distributions were relatively uniform elsewhere at the dam. Fish passage was not proportional to discharge when the powerhouse and spillway were compared. Discharge proportions were higher and passage proportions lower at the powerhouse than they were at the spillway, and fish passage per unit discharge was by far highest at the TSW spill bays. 


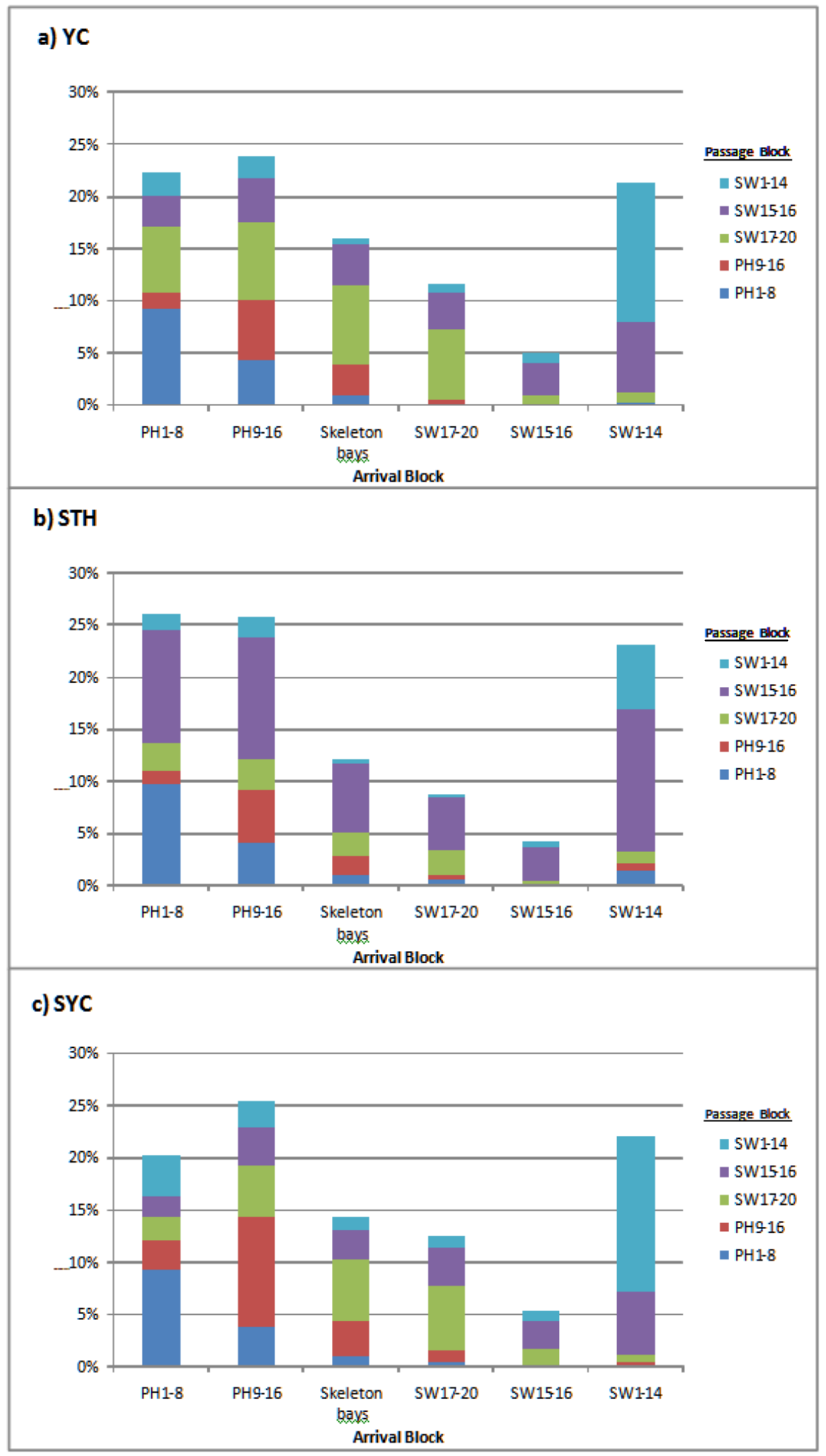

Figure ES.1. Fish behavior patterns - relationships between where fish arrived in the forebay (arrival block) and where they ultimately passed the dam (passage block) by tagged stock: a) YC; b) STH; and c) SYC. The blocks are areas at the dam: powerhouse turbine units 1-8; units 9-16, skeleton bay 17-20; spill bays 17-20, TSW bays 15-16, and spill bays 1-14. 
Vertical distribution data were based on 3D tracking of individual acoustic-tagged fish in the John Day Dam forebay. As smolts moved from $75 \mathrm{~m}$ to within $10 \mathrm{~m}$ of the powerhouse face, travel depths often decreased, but there was a sudden increase to over $20 \mathrm{~m}$ at a distance of less than $5 \mathrm{~m}$ from the powerhouse. Note that powerhouse piers on which hydrophones were mounted do not extend more than about $1 \mathrm{~m}$ upstream of the powerhouse face so that sounding fish within $5 \mathrm{~m}$ of the dam face can be tracked moving down toward intake openings. The turbine intake ceilings at John Day Dam are about $20 \mathrm{~m}$ deep. At the spillway, detection depths were less than $5 \mathrm{~m}$ regardless of distance upstream from the face of the spillway. There was no difference in diel vertical distributions for powerhouse or spillway passed YC. For STH, vertical distribution was shallow for fish passed through the spillway; this pattern was quite evident at the TSW. The last-detection depths at the powerhouse were much deeper. Most SYC in the forebay of the powerhouse and skeleton bays traveled at depths between 5 and $11 \mathrm{~m}$, while median depths of smolts within $5 \mathrm{~m}$ of the powerhouse or skeleton bays were between 20 and $25 \mathrm{~m}$. As with YC and STH, the last-detection depths for SYC were relatively shallow at the spillway. Notably, as SYC approached the TSW, they migrated up in the water column; this trend was not evident for approach at non-TSW spill bays. Fish approaching spill gates were not detected diving to pass under conventional tainter gates because hydrophones were mounted on the upstream face of piers about $10 \mathrm{~m}$ upstream of the gates. Sounding to pass under tainter gates likely occurs between piers where fish could not be detected.

\section{Conclusions}

During the 2008 evaluation of juvenile salmonids at John Day Dam, the JSATS provided reliable data about survival rates, fish passage, and fish behavior.

Tag-life-corrected paired-release estimates of concrete-passage survival rates for YC $(0.957 \pm 0.013$ [1/2 95\% confidence level (CI)]) and STH [0.986 \pm 0.019 (1/2 95\% CI] were high and close to the 96\% performance standard set forth in the $2008 \mathrm{BiOp.} \mathrm{Similar} \mathrm{estimates} \mathrm{for} \mathrm{SYC,} \mathrm{however,} \mathrm{were} \mathrm{about} \mathrm{86 \% ,}$ which would be $7 \%$ below the BiOp standard of $93 \%$. The highest route-specific survival rates were for the JBS and TSW ( 97\%); fish passing through turbines had the lowest survival rates (73\% to 86\%).

Fish passage metrics were generally highest for STH and lowest for SYC. Proportionately more SYC than YC or STH passed through the dam via turbines.

The comparison of $30 \%$ versus $40 \%$ post-hoc spill conditions was inconsequential. Stock-specific survival estimates, passage efficiencies, and fish behaviors were similar between the two spill conditions. The increase in spill discharge from $30 \%$ to $40 \%$ of total water discharge through the dam basically served to pass incrementally more fish at non-TSW bays and incrementally fewer at the TSWs. Spillwaypassage effectiveness was significantly higher at $30 \%$ spill than it was at $40 \%$ spill for STH smolts (one tailed $\mathrm{P}=0.0293)$ and for SYC smolts $(\mathrm{P}=0.0020)$.

Spill and TSW operations attracted downstream migrant juvenile salmonids. About half of the tagged fish arriving in the forebay of the powerhouse and skeleton bays moved toward and passed at the spillway including the TSWs. In contrast, few smolts approaching the spillway passed at the powerhouse, and fish approaching the spillway had the shortest median residence time. The longest residence time was for fish approaching the powerhouse and then passing at the spillway or vice versa. 
Tagged fish were surface-oriented, being distributed in the upper portion of the water column on approach to the dam. The median depths of smolts last detected within $5 \mathrm{~m}$ of the powerhouse ranged from 21 to 24 m depending on the stock of fish, and turbine-passed fish had median depths that were about $5 \mathrm{~m}$ deeper than the median depth of JBS-passed fish. Most fish approaching the spillway piers were high in the water column.

The prototype TSWs performed well. Using about $20 \mathrm{kcfs}$, the TSW bays passed half of the STH, a quarter of the YC, and a fifth of the SYC of the respective total number of fishes passing John Day Dam. As was the intent of the design, the TSW surface flows appeared to attract, or at the least provide a surface outlet opportunity for, fish that had originally arrived at the dam in the powerhouse forebay. Passage at the TSW bays was much higher during the day than it was at night, which is consistent with observations at many other surface flow outlets (Johnson and Dauble 2006; Sweeney et al. 2007). 


\section{Acknowledgments}

Many people made valuable contributions to this study and deserve acknowledgment. The Pacific States Marine Fisheries Commission Supervisor at the John Day Dam Smolt Monitoring Facility (SMF), Greg Kovalchuk, was very helpful in coordinating fish collections with daily fish sampling at the respective locations. Seasonal staff of the Pacific States Marine Fisheries Commission also helped with tagging fish: Laura Daniel, Steve Goss, Kenneth Kenny, John Mathieus, and Randy Wall. Karah Prather with Cascade Aquatics helped as well.

Many PNNL staff assisted in study project management (Geoff McMichael), surgery training (Rich Brown and Kate Deters), fish collection (Robin Durham), fish transport and release, tag-life monitoring (Rich Brown and Kathleen Carter), Juvenile Salmon Acoustic Telemetry System (JSATS) development (Eric Choi, Brian LaMarche, Daniel Deng, Tao Fu, Thomas Seim, and Thomas Carlson), and database entry and management (Jessica Carter). Dr. Kenneth Ham developed filters for autonomous node data. Dr. David Geist was the Ecology Group Manager at PNNL, and Dr. Dennis Dauble was the line Manager during this study.

Advanced Telemetry Systems (ATS), Inc. manufactured the JSATS acoustic tags. Autonomous and dam-mounted hydrophones were manufactured by Sonic Concepts, Seattle, Washington. Precision Acoustic Systems, also in Seattle, made the quad channel receivers and conducted node acceptance tests for PNNL. Cascade Aquatics, Inc. in Ellensburg, Washington, activated and delivered the acoustic tags. Schlosser Machine Shop fabricated anchors for autonomous nodes and frames for star clusters that were deployed in the spillway forebay. 


\section{Acronyms and Abbreviations}

A1CR351

A2CR339

A3CR312

A4CR236

A5CR203

A6CR192

ATS

BiOp

${ }^{\circ} \mathrm{C}$

$\mathrm{CF}$

cfs

CI

CSV

d

DART

$\mathrm{dB}$

FCRPS

FPE

FGE

$\mathrm{ft}$

$\mathrm{g}$

GPS

$\mathrm{h}$

JBS

JBSE

JSATS

kcfs

$\mathrm{km}$

$\mathrm{L}$

LRT

$\mathrm{m}$

$\min$

$\mathrm{mL}$
John Day Dam forebay entrance array

John Day Dam tailwater egress array

The Dalles Dam forebay entrance array; John Day Dam primary survivaldetection array

Bonneville Dam forebay entrance array; John Day Dam secondary survivaldetection array; The Dalles Dam primary survival-detection array

$1^{\text {st }}$ Bonneville tailwater array; John Day Dam tertiary survival-detection array; The Dalles Dam secondary survival-detection array

$2^{\text {nd }}$ Bonneville Dam tailwater survival detection array; The Dalles Dam tertiary survival-detection array

Advanced Telemetry Systems, Inc.

Biological Opinion

degree(s) Celsius or Centigrade

Compact Flash (card)

cubic feet per second

confidence interval (1/2 95\%)

comma-separated variables

day(s)

Data Access in Real Time

decibel(s)

Federal Columbia River Power System

fish-passage efficiency

fish-guidance efficiency (in-turbine screens)

foot/ft

$\operatorname{gram}(\mathrm{s})$

global positioning system

hour(s)

juvenile bypass system

juvenile bypass system-passage efficiency

Juvenile Salmon Acoustic Telemetry System

thousand cubic feet per second

kilometer

liters

likelihood ratio test

meter(s)

minute(s)

milliliter 


$\begin{array}{ll}\text { mm } & \text { millimeter } \\ \text { MSL } & \text { mean sea level } \\ \text { NA } & \text { not applicable } \\ \text { NOAA } & \text { National Oceanic and Atmospheric Administration } \\ \text { PIT } & \text { passive integrated transponder } \\ \text { PNNL } & \text { Pacific Northwest National Laboratory } \\ \text { rkm } & \text { river kilometer } \\ \text { RMS } & \text { root mean square } \\ \text { S } & \text { second(s) } \\ \text { SAS } & \text { Statistical Analysis System } \\ \text { SE } & \text { spillway-passage efficiency } \\ \text { SEF } & \text { spillway-passage effectiveness } \\ \text { SFO } & \text { surface-flow outlet } \\ \text { SMF } & \text { Smolt Monitoring Facility (John Day Dam) } \\ \text { STH } & \text { steelhead } \\ \text { SW } & \text { spillway or spillway block } \\ \text { SYC } & \text { subyearling Chinook salmon } \\ \text { TOA } & \text { time of arrival } \\ \text { TOAD } & \text { time of arrival difference } \\ \text { TSW } & \text { top-spill weir } \\ \text { TSWE } & \text { top spillway weir passage efficiency } \\ \text { TSWEF } & \text { top spillway weir passage effectiveness } \\ \mu \text { Pa } & \text { micro-Pascal } \\ \text { USACE } & \text { U.S. Army Corps of Engineers } \\ \text { UW } & \text { University of Washington } \\ \text { WEL } & \text { Wells Dam } \\ \text { YC } & \text { yearling Chinook salmon } \\ & \end{array}$




\section{Contents}

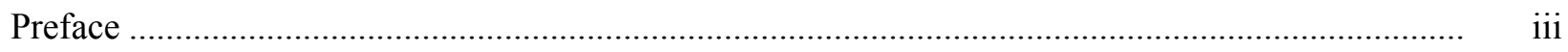

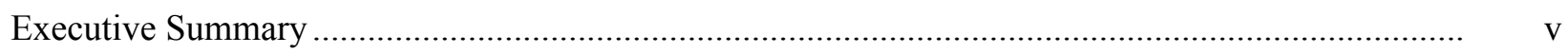

Acknowledgments..........................................................................................................

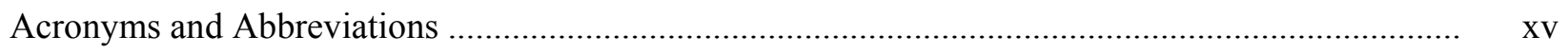

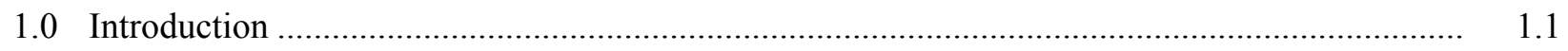

1.1 Previous Passage and Survival Studies ....................................................................... 1.1

1.2 Surface-Flow Outlet Development.......................................................................... 1.2

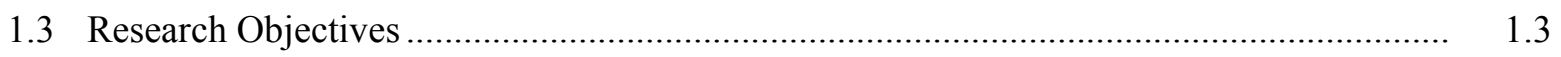

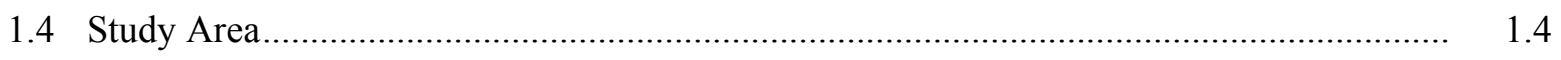

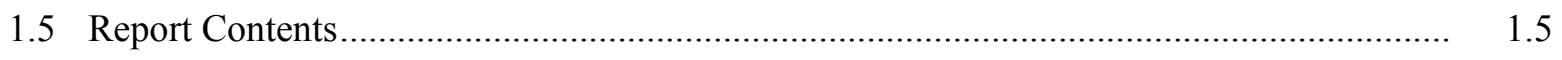

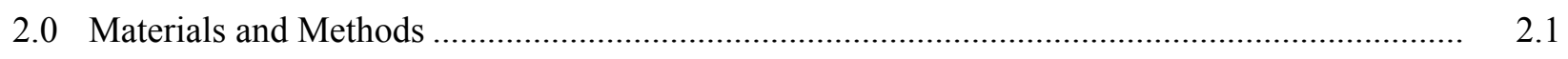

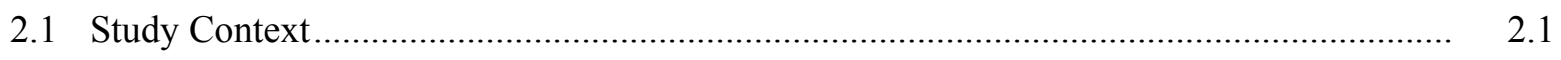

2.1.1 Water Discharge and Temperature ................................................................ 2.1

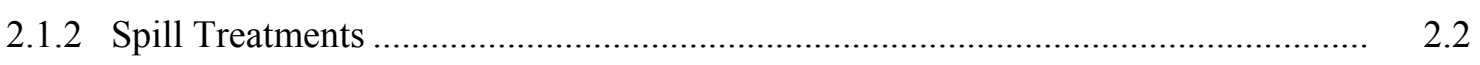

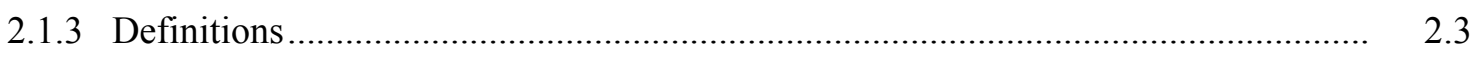

2.2 Fish Collection, Tagging, Transportation, and Release ….......................................... 2.4

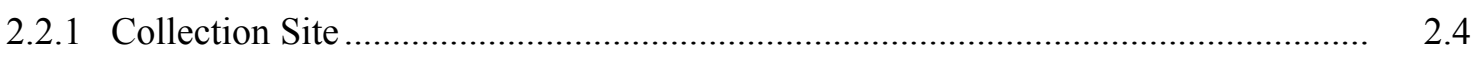

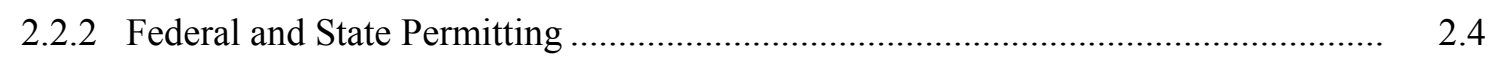

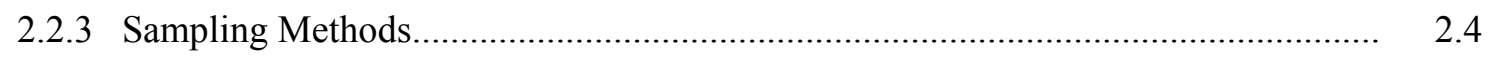

2.2.4 JSATS Acoustic Micro-Transmitter and Tag Implantation .................................. 2.6

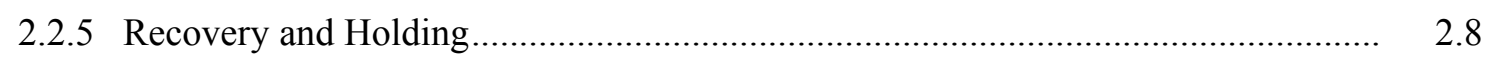

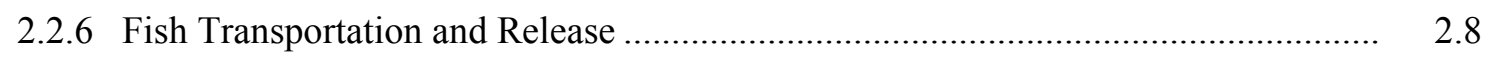

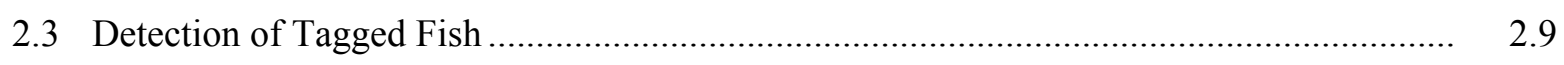

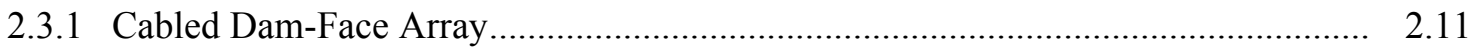

2.3.2 Autonomous Nodes and Arrays ..................................................................... 2.13

2.3.3 Node Retrieval, Servicing, and Redeployment ................................................ 2.15

2.3.4 Autonomous Node Deployment ..................................................................... 2.15

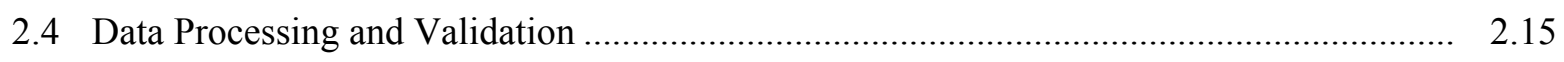

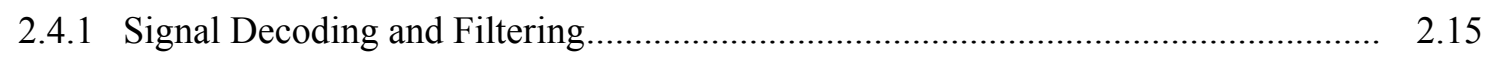

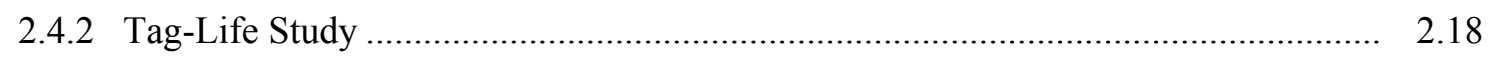

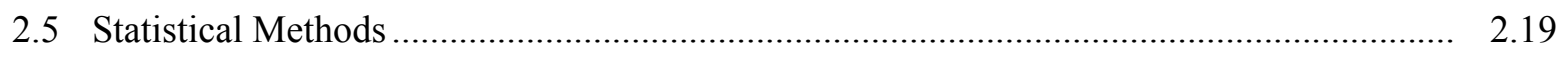

2.5.1 Defining Releases for Estimating Survival Rates ............................................... 2.19

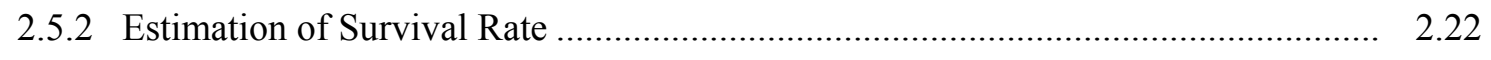

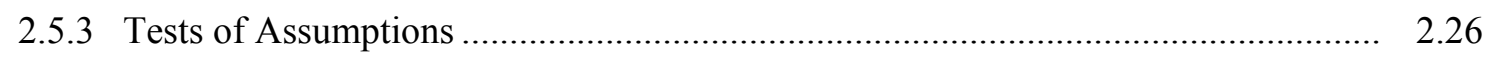

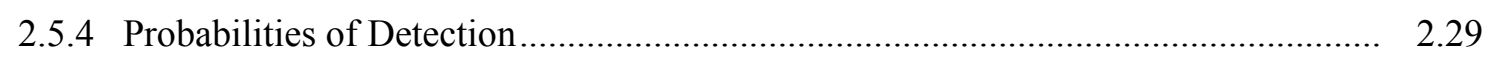

2.5.5 Route-Specific Relative Survival Rates ........................................................... 2.32

2.5.6 Route-Specific Passage Survival Rates ........................................................... 2.32 
2.5.7 Concrete-Passage Survival Rates ..................................................................... 2.33

2.5.8 Lower Granite Dam Tagged Fish - John Day Dam Concrete-Passage Survival Rate ............................................................................... 2.34

2.5.9 Dam-Passage Survival Rate for The Dalles Dam................................................ 2.35

2.6 Statistical Methods - Fish Passage ........................................................................... 2.36

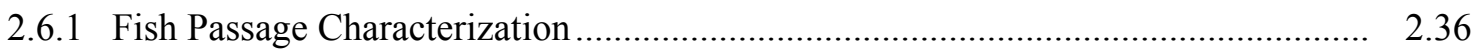

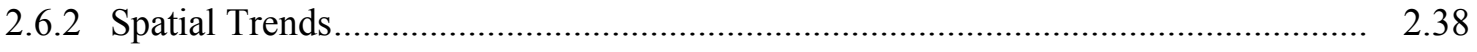

2.6.3 Residence and Egress Times and Travel Rates .................................................. 2.39

2.7 Statistical Methods - Fish Tracking …............................................................................. 2.39

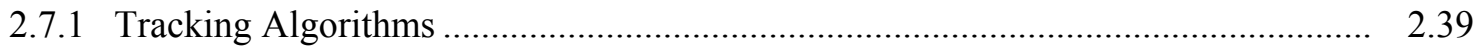

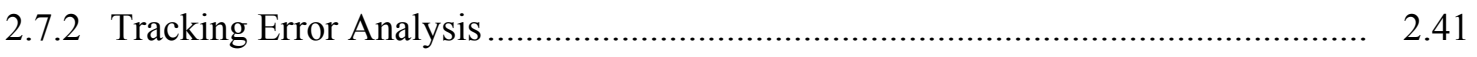

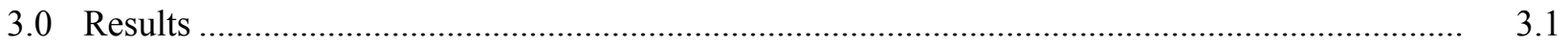

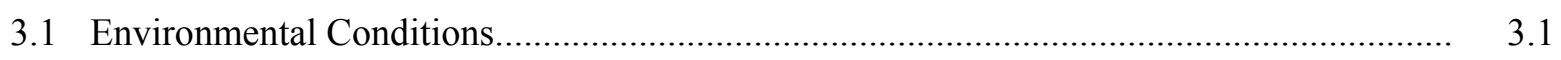

3.1.1 Dam Discharge and Temperature .............................................................. 3.1

3.1.2 Realized Spill Treatment Conditions ….......................................................... 3.2

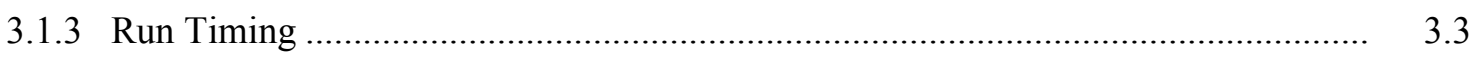

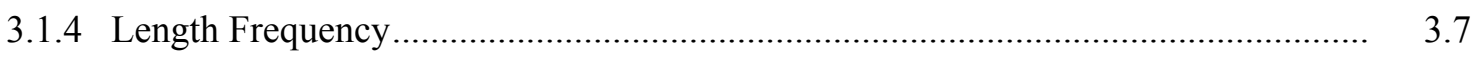

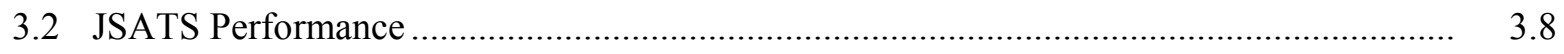

3.2.1 Detection of Dead Fish............................................................................. 3.8

3.2.2 Detection Probabilities at Dam-Face Arrays.................................................... 3.8

3.2.3 Detection Probabilities and Fish Distributions at Autonomous Nodes .................... 3.8

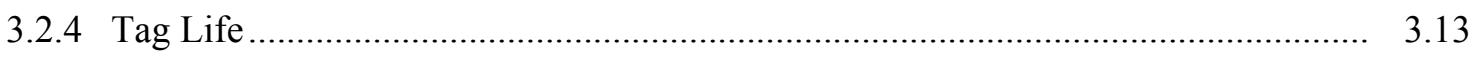

3.3 Survival Rates of Yearling Chinook in Spring............................................................. 3.13

3.3.1 John Day Dam Concrete-Passage Survival and Detection History ........................ 3.13

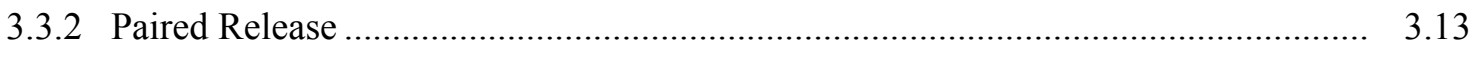

3.3.3 The Dalles Dam Survival and Detection History .................................................. 3.14

3.3.4 John Day Dam Concrete-Passage Survival Rate for Lower Granite Dam Yearling Chinook Salmon......................................................................... 3.15

3.4 Survival Rates of Steelhead in Spring .................................................................... 3.15

3.4.1 John Day Dam Concrete-Passage Survival and Detection History ......................... 3.15

3.4.2 The Dalles Dam Survival and Detection History .............................................. 3.17

3.5 Survival Rates of Subyearling Chinook Salmon in Summer .......................................... 3.17

3.5.1 John Day Dam Concrete-Passage Survival Survival and Detection History ........... 3.17

3.5.2 The Dalles Dam Survival and Detection History ............................................... 3.19

3.6 Spatial and Temporal Trends at John Day Dam and Spill-Condition Effects.................... 3.19

3.6.1 Yearling Chinook Salmon .............................................................................. 3.19

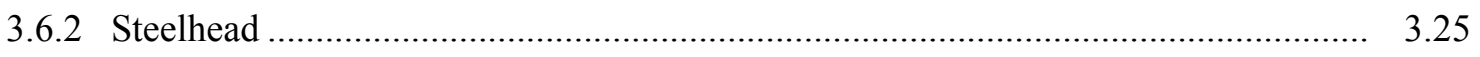

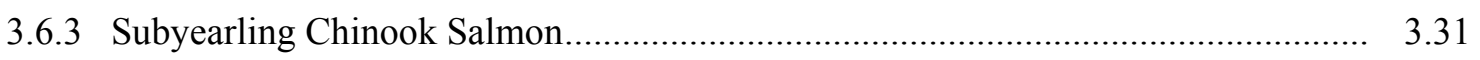

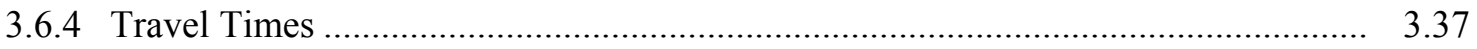




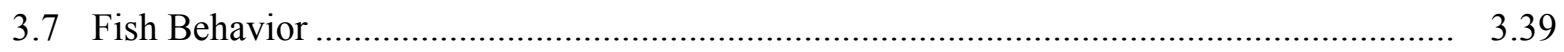

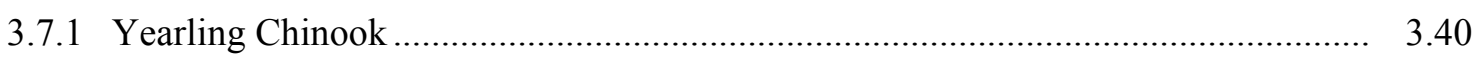

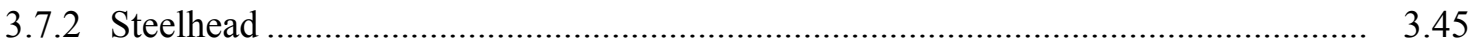

3.7.3 Subyearling Chinook Salmon............................................................................... 3.51

3.8 Detailed Data on Tagging, Release, Virtual Releases, and Dam Operations ...................... 3.56

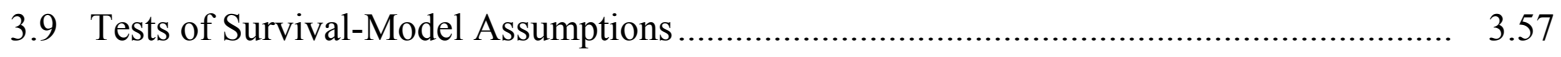

3.9.1 Burnham Test Results ................................................................................... 3.57

3.9.2 Arrival Distribution Tests................................................................................ 3.57

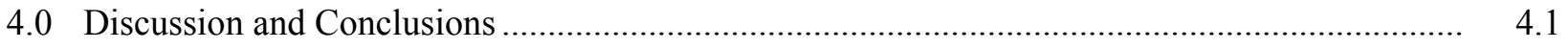

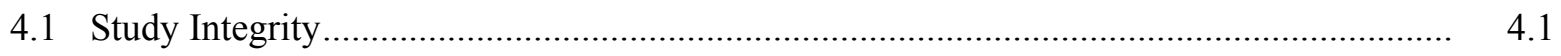

4.2 Comparison with Previous Survival and Passage Studies at John Day Dam...................... 4.2

4.2.1 Yearling Chinook Salmon .............................................................................. 4.2

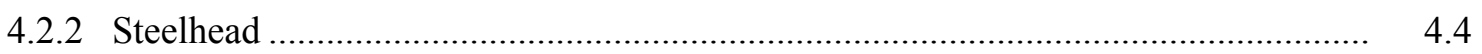

4.2.3 Subyearling Chinook Salmon............................................................................. 4.4

4.3 Performance of the Prototype TSW Surface Flow Outlets ................................................ 4.6

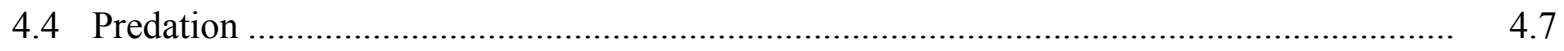

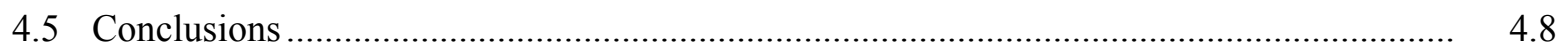

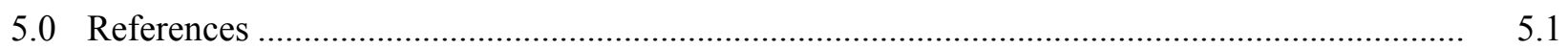

Appendix A - Tagging Tables ........................................................................................ A.1

Appendix B - Hydrophone and Autonomous Node Deployment Tables............................................. B. B.1

Appendix C - Tag-Life Plots............................................................................................ C.1

Appendix D - Survival and Detection Probabilities for Single- and Paired-Releases without

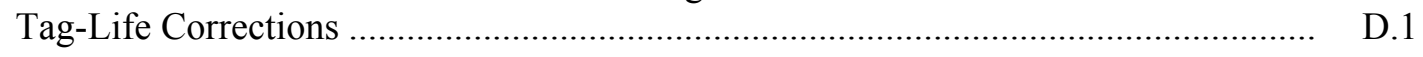

Appendix E - Tag-Life-Corrected John Day Concrete-Passage and Route-Specific Survival Rates for John Day Dam Yearling Chinook Salmon ...................................................... E. E.1

Appendix F - Tag-Life-Corrected Survival Rates for Yearling Chinook at The Dalles Dam............. F.1

Appendix G - Tag-Life-Corrected Survival Rates for Lower Granite Dam Yearling Chinook at John Day Dam ........................................................................................... G.1

Appendix H - Tag-Life-Corrected Survival Rates for Steelhead at John Day Dam .......................... H.1

Appendix I - Tag-Life-Corrected Survival Rates for Steelhead at The Dalles Dam........................... I.1

Appendix J - Tag-Life-Corrected Survival Rates at John Day Dam for John Day Dam Subyearling Chinook .................................................................................................. J.1

Appendix K - Tag-Life-Corrected Survival Rates at The Dalles Dam for Subyearling Chinook Salmon

K.1

Appendix L - Tables on Tagging, John Day Dam Tailwater Releases, John Day Dam Virtual Releases, John Day Dam Operations Data, and Capture History Data at John Day Dam or Downstream ................................................................ L.1

Appendix M - Burnham Test 2 and 3 Tables ............................................................................... M.1

Appendix N - Time-of-Arrival Plots for Treatment and Reference Releases of Fish Used for Paired-Release Survival Estimation. 


\section{Figures}

ES.1 Fish behavior patterns - relationships between where fish arrived in the forebay and where they ultimately passed the dam by tagged stock: YC; STH; and SYC.... ... X

1.1 John Day Dam on the Columbia River........................................................................... 1.1

1.2 Study area on the lower Columbia River from Arlington, Oregon, to Camas,

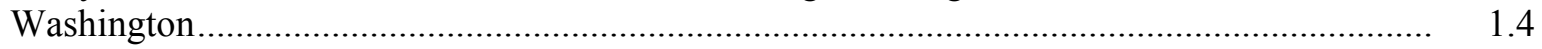

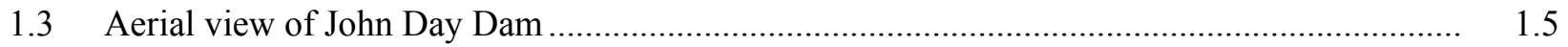

2.1 Spill treatments for the spring study at John Day Dam from May 4 through

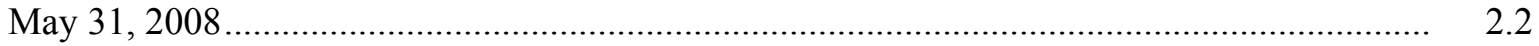

2.2 Summer spill treatments at John Day Dam from June 17 through July 14, 2008 .................. 2.2

2.3 JSATS 0.425 -g acoustic micro-transmitter and PIT tag surgically implanted in subyearling Chinook salmon

2.4 Surgery being conducted in the Smolt Monitoring Facility at John Day Dam......................... 2.8

2.5 Post-surgery holding tank with recovery buckets.............................................................. 2.9

2.6 Schematic of the JSATS Dam-Face Receiver System showing the main components and the direction of signal acquisition and processing

2.7 Location of JSATS hydrophones on the dam face and in the forebay of John Day Dam

2.8 Trolley pipe mounted on a main pier of the John Day Dam powerhouse

2.9 A 4-in.-diameter trolley with hydrophone for slotted pipes on powerhouse piers and an 8-in.-diameter trolley with hydrophone for slotted pipes on spillway piers

2.10 Side and bottom view of an autonomous node top.

2.11 Locations of autonomous node arrays and fish release locations in the Lower Columbia River in 2008

2.12 Autonomous node rigging in 2008

2.13 Example of time-domain waveforms and corresponding cross-correlations acquired at the John Day Dam spillway.

2.14 Schematic of the paired-release design and virtual releases for estimating dam- and concrete-passage survival rates at John Day Dam.

2.15 Schematic of the paired-release design for estimating dam- and concrete-passage survival rates at John Day Dam for YC released downstream of Lower Granite Dam

2.16 Schematic of the paired-release design for estimating fish passage survival rates at The Dalles Dam for subyearling Chinook.

2.17 Schematic of route-specific passage and downstream recoveries for virtual releases at the spillway, TSW, powerhouse, and JBS.

2.18 Test locations at the John Day Dam spillway for 3D-tracking error analysis ...

2.19 Test locations at John Day Dam powerhouse for 3D-tracking error analysis ...

2.20 Contour plots of route mean square errors in the position estimation of acoustic tags located $2 \mathrm{~m}$ below the water surface upstream of the John Day Dam spillway $\mathrm{x}, \mathrm{y}, \mathrm{z}$

2.21 Contour plots of route mean square errors in the position estimation of acoustic tags located $2 \mathrm{~m}$ below the water surface upstream of the John Day Dam powerhouse $\mathrm{x}, \mathrm{y}, \mathrm{z}$ 
3.1 Average daily water discharge from John Day Dam and The Dalles Dam during the 2008 study and for the preceding 10-year period

3.2 John Day Dam and The Dalles Dam average daily forebay water temperatures during the 2008 study and for the preceding 10-year period

3.3 Spill treatments for the spring study at John Day Dam from May 4 through May 31, 2008

3.4 Spill treatments in summer at John Day Dam from June 14 through July 16, 2008

3.5 Smolt Monitoring Program passage index for April 2-June 20, 2008, and fish tagged per day for steelhead based upon data from the John Day Dam Smolt Monitoring Facility.....

3.6 Smolt Monitoring Program passage index for April 2-July 16, 2008, and fish tagged per day for yearling Chinook salmon based upon data from the John Day Dam Smolt Monitoring Facility

3.7 Smolt Monitoring Program passage index for June 1-July 31, 2008, and fish tagged per day for subyearling Chinook salmon based upon data from the John Day Dam Smolt Monitoring Facility

3.8 Length frequency of steelhead tagged and all steelhead collected at the John Day Dam SMF in spring 2008.

3.9 Length frequency of yearling Chinook salmon tagged and all yearling Chinook salmon collected at the John Day Dam SMF in spring 2008.

3.10 Length frequency of all subyearling Chinook salmon tagged and all subyearling Chinook salmon collected by percent for summer.

3.11 Detection probabilities by reach for the autonomous arrays

3.12 Percentage of acoustic tag detections by fish stock on autonomous nodes deployed in arrays in the John Day Dam forebay, The Dalles Dam forebay, Bonneville Dam forebay, Bonneville Dam tailwater near Reed Island, and Bonneville Dam tailwater near Lady Island and Camas, Washington

3.13 Frequency of detections on multiple autonomous nodes in arrays located in the John Day Dam forebay entrance, The Dalles Dam forebay entrance, Bonneville Dam forebay entrance, and Bonneville Dam tailwater.

3.14 Detection probabilities as a function of water discharge in two river reaches below Bonneville Dam....

3.15 Survival rates by release period for yearling Chinook salmon.

3.16 Survival rate by release period for yearling steelhead.

3.17 Paired-release estimates of concrete-passage survival rate by release date for subyearling Chinook salmon

3.18 Yearling Chinook salmon smolt passage and discharge by individual passage route in spring 2008

3.19 Guided and unguided passage of yearling Chinook salmon smolts and discharge by turbine unit.

3.20 Yearling Chinook salmon passage and discharge by spill bay.....

3.21 Average percent passage of yearling Chinook salmon smolts and percent discharge per spill bay within groups of bays.

3.22 Spill treatments as prescribed and actual conditions in spring 
3.23 Day and night differences in passage rate for yearling Chinook salmon smolts

3.24 Diel passage rates for yearling Chinook salmon smolts and percent of water discharge for groups of spill bays.

3.25 Steelhead smolt passage and percent discharge by individual passage route in spring 2008 .

3.26 Guided and unguided passage of steelhead smolts in spring

3.27 Steelhead smolt passage and percent discharge by spill bay

3.28 Percent passage of steelhead smolts and discharge for an average spill bay within groups of bays.....

3.29 Spill treatments as prescribed and actual conditions in spring .......................................... 3.28

3.30 Hourly rate of steelhead passage by passage route........................................................ 3.30

3.31 Diel passage rates for steelhead and percent discharge for groups of bays ............................. 3.30

3.32 Subyearling Chinook salmon passage and discharge by individual passage route in spring 2008 .....

3.33 Guided and unguided passage of subyearling Chinook salmon in summer

3.34 Percent discharge and passage of subyearling Chinook salmon smolts by spill bay

3.35 Percent discharge and passage for subyearling Chinook salmon per individual spill bay within groups of bays

3.36 Spill conditions during summer

3.37 Day and night passage rates by route for subyearling Chinook salmon smolts

3.38 Hourly passage rates and percent discharge per bay for subyearling Chinook salmon within groups of spill bays

3.39 Yearling Chinook salmon approach and passage distributions at John Day Dam

3.40 Yearling Chinook salmon approach and passage distributions by passage blocks at John Day Dam

3.41 Yearling Chinook salmon smolt approach and passage distributions during day and night.

3.42 Approach and passage distributions for yearling Chinook salmon during daytime at John Day Dam

3.43 Approach and passage distributions for yearling Chinook salmon passing John Day Dam at night.

3.44 Day and night passage of acoustic tagged juvenile yearling Chinook salmon at each passage route at John Day Dam.

3.45 Median depths of last detection of tagged yearling Chinook salmon smolts at John Day Dam.

3.46 Differences in the median depths of the last detection of yearling Chinook salmon smolts that passed into the JBS and turbines.....

3.47 Spring Chinook salmon median passage times

3.48 Spring Chinook salmon diel median passage times by approach and passage blocks at John Day Dam

3.49 Steelhead percent passage by approach and passage blocks at John Day Dam . 
3.50 Steelhead approach and passage distributions by approach and passage blocks at John Day Dam

3.51 Steelhead approach and passage distributions during day and night.................................... 3.46

3.52 Steelhead day passage behaviors by blocks at John Day Dam............................................ 3.47

3.53 Steelhead night passage behaviors by blocks at John Day Dam ......................................... 3.47

3.54 Day and night passage of acoustic-tagged steelhead smolts at each passage route

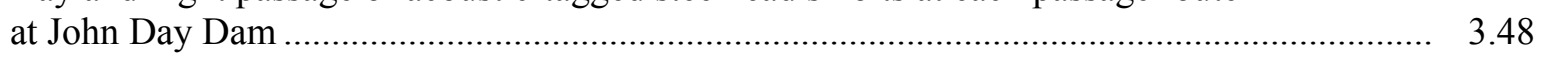

3.55 Median depths of last detection of tagged steelhead smolts at John Day Dam ....................... 3.48

3.56 Median depths of last detection of tagged steelhead smolts at John Day Dam during the day

3.57 Median depths of last detection of tagged steelhead smolts at John Day Dam at night........... 3.49

3.58 Steelhead median last-detection depths for turbine and JBS-passed fish .............................. 3.50

3.59 Steelhead median passage times by approach and passage routes at John Day Dam................ 3.50

3.60 Steelhead diel median passage times at John Day Dam .................................................... 3.51

3.61 Subyearling Chinook salmon approach and passage behaviors at John Day Dam .................. 3.51

3.62 Subyearling Chinook salmon approach and passage distributions by blocks at John Day Dam...

3.63 Subyearling Chinook salmon smolt approach and passage distributions at John Day Dam during day and night

3.64 Subyearling Chinook salmon day approach and passage distributions at John Day Dam

3.65 Subyearling Chinook salmon night approach and passage distributions at John Day Dam

3.66 Day and night passage of acoustic-tagged subyearling Chinook salmon smolts at each passage route at John Day Dam......

3.67. Median depths of the last detection of tagged subyearling Chinook salmon smolts at John Day Dam....

3.68. Subyearling Chinook salmon median last-detection depths for turbine- and JBSpassed fish

3.69. Median residence times of subyearling Chinook salmon smolts at John Day Dam ................ 3.56

3.70. Subyearling Chinook salmon diel median passage times at John Day Dam .......................... 3.56

4.1. Plot of the lower end of the cumulative length frequency distribution of subyearlings in routine SMF samples

4.2. Plot of seasonal trends in the smolt index and the number of gulls counted in the John Day tailrace in 2009 .

4.3. Regression line fit to daily gull counts and smolt indices by date. 


\section{Tables}

ES.1 Tag-life-corrected, paired-release estimates of concrete-passage and route-specific survival rates

ES.2 Estimate of dam-passage survival rates and passage efficiencies by spill condition

ES.3 Summary of passage efficiency and effectiveness data.

1.1 Radio-telemetry estimates of survival rates for three salmonid stocks passing routes at John Day Dam during 2000, 2002, and 2003

1.2 Some radio-telemetry and hydroacoustic estimates of fish-passage efficiency and spillway-passage efficiency for John Day Dam

1.3 Lookup table for determining distances between locations referenced in this study

2.1 Number of fish rejected by criteria during spring and summer tagging at John Day Dam ........

2.2 Description, location, name, and survival model function of arrays deployed in 2008

2.3 Detection histories and expected probabilities of occurrences for releases $R_{1}$ and $R_{2}$ in the presence of tag failure.

2.4 Median and route mean square errors in the position estimates of acoustic tags located $2 \mathrm{~m}$ below the water surface upstream of the John Day Dam spillway.....

2.5 Median and route mean square errors in the position estimates of acoustic tags located $2 \mathrm{~m}$ below the water surface upstream of the John Day Dam powerhouse.....

3.1 Ten-year average of percent of the run of yearling Chinook salmon passing at the John Day Dam SMF at percentiles of the passage index

3.2 Ten-year average of percent of the run of steelhead passing at the John Day Dam SMF at percentiles of the passage index

3.3 Ten-year average of percent of the run of subyearling Chinook salmon passing at the John Day Dam SMF at percentiles of the passage index.

3.4 Percent of the run passing at the John Day Dam SMF on the first and last day of tagging and dates that $10,25,50,75$, and 90 percent of the run passed at the John Day Dam SMF

3.5 Detection probabilities for the dam-face arrays

3.6 Tag-life-corrected, paired-release estimates of survival rates for yearling Chinook salmon smolts regrouped at the corresponding routes at the dam to form virtual releases

3.7 Tag-life-corrected, single-release estimates of route-specific survival rates for yearling Chinook salmon smolts in virtual releases at John Day Dam based on detections at three downstream arrays.

3.8 Tag-life-corrected, paired-release estimates of survival rates for steelhead smolts regrouped at the corresponding routes at the dam to form virtual releases

3.9 Cormack-Jolly-Seber, tag-life-corrected, single-release estimates of survival rates for steelhead smolts released near Arlington, Oregon

3.10 Tag-life-corrected, paired-release estimates of survival rates for subyearling Chinook smolts regrouped at the corresponding routes at the dam to form virtual releases.

3.11 Tag-life-corrected, single-release estimates of survival rates for subyearling Chinook smolts in virtual release at John Day Dam based on three downstream arrays 
3.12 Estimates of major passage metrics for yearling Chinook salmon during spring

3.13 Estimates of dam-passage survival rates by post-hoc spill condition for yearling Chinook salmon during spring

3.14 Estimates of major passage metrics by spill treatment for yearling Chinook salmon during spring.....

3.15 Comparison of diel paired-release estimate of survival rates for yearling Chinook salmon during spring. These relative estimates were not corrected for tag life.

3.16 Estimates of major passage metrics for yearling steelhead during spring.

3.17 Estimates of dam-passage survival rates by post-hoc spill condition for steelhead smolts during spring.

3.18 Estimates of major passage metrics by post-hoc spill condition for steelhead smolts during spring.

3.19 Comparison of diel non-tag-life-corrected paired-release survival rate trends for steelhead smolts during spring

3.20 Estimates of major passage metrics for subyearling Chinook salmon smolts.....

3.21 Paired-release estimates of dam-passage survival rates by post-hoc spill condition for subyearling Chinook salmon during summer

3.22 Estimates of major passage metrics by spill treatment for subyearling Chinook salmon

3.23 Comparison of diel non-tag-life-corrected paired-release survival trends for subyearling Chinook salmon during summer.

3.24 Distance of travel and median travel time for yearling Chinook salmon smolts passing through specific river reaches between Arlington, Oregon, and the Bonneville Dam forebay.....

3.25 Distance of travel and median travel time for steelhead smolts passing through specific river reaches between Arlington, Oregon, and the Bonneville Dam forebay....

3.26 Distance of travel and median travel time $( \pm 1 / 295 \% \mathrm{CI})$ for subyearling Chinook salmon smolts passing through specific river reaches between Arlington, Oregon, and the Bonneville Dam forebay.

4.1 Estimates of major fish passage metrics for yearling Chinook salmon smolts from previous radio-telemetry studies relative to estimates from this 2008 acoustic telemetry study

4.2 Estimates of major fish passage metrics for steelhead smolts from previous radiotelemetry studies relative to estimates from this 2008 acoustic telemetry study

4.3 Estimates of major fish passage metrics for subyearling Chinook salmon smolts from previous radio-telemetry studies relative to estimates from this 2008 acoustic telemetry study

4.4 Comparison of performance for various surface-flow outlets 


\subsection{Introduction}

Improving the survival rate of juvenile salmonids migrating downstream through the Federal Columbia River Power System (FCRPS) continues to be a high priority for the U.S. Army Corps of Engineers (USACE) Portland District. Many of these fish are from populations listed as threatened or endangered under the Endangered Species Act. The increased survival rate is necessary to meet performance standards set forth in the 2008 Biological Opinion (BiOp; NMFS 2008) on operation of the FCRPS (NOAA Fisheries 2008). The BiOp mandates that $96 \%$ and $93 \%$ survival rates be achieved for spring and summer downstream-migrating juvenile salmonids, respectively. At John Day Dam, the Portland District is evaluating the provision of surface-flow outlets (SFOs) as a means to increase fishpassage efficiency and in turn increase the fish passage survival rate by reducing turbine passage of juvenile salmonids. The goal of the study reported here was to provide fish passage and survival data necessary to evaluate the performance of the prototype SFO and the dam as whole relative to the performance standards in the BiOp. The Portland District and regional fisheries managers will use the data to adaptively manage the configuration and operation of John Day Dam to maximize the survival rate for juvenile salmonids.

This is the report of research for the acoustic telemetry evaluation of juvenile salmonids during 2008 at John Day Dam (Figure 1.1). The study also provides estimates of dam-passage survival rates for The Dalles Dam. The study was conducted by the Pacific Northwest National Laboratory (PNNL) and the University of Washington (UW) for the USACE Portland District.

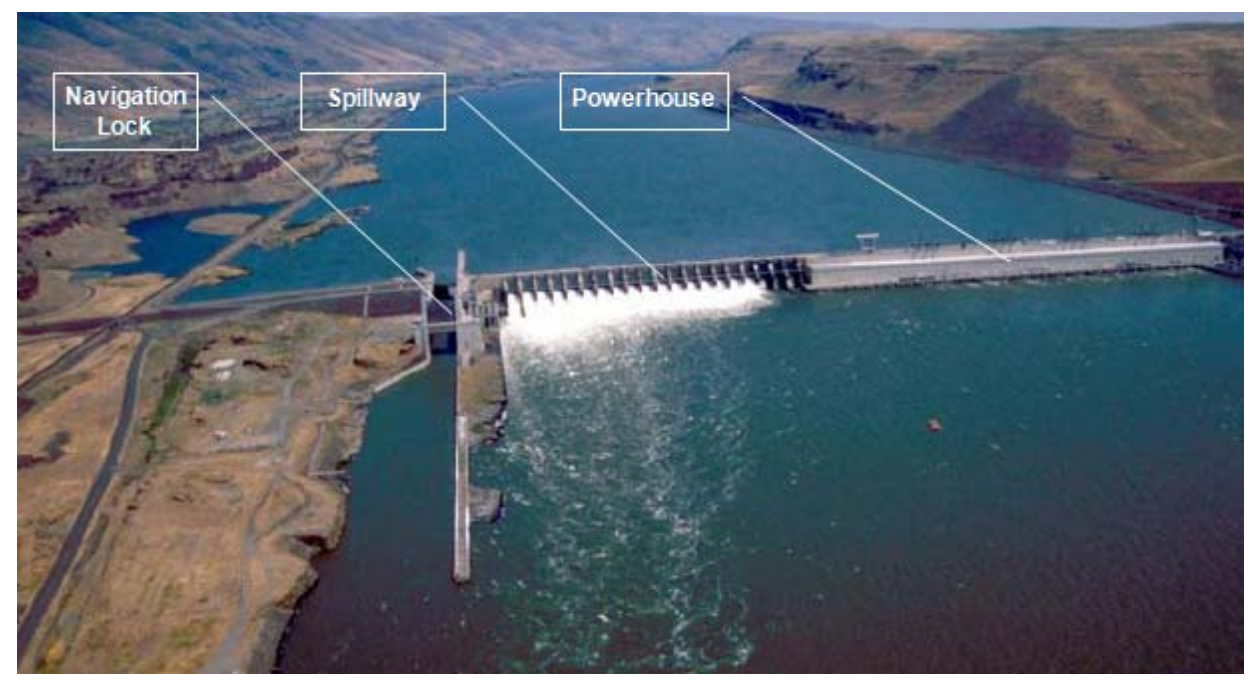

Figure 1.1. John Day Dam on the Columbia River

\subsection{Previous Passage and Survival Studies}

Radio telemetry was first used at John Day Dam in 1999 to estimate fish survival rates (Counihan et al. 2002a) and passage proportions for turbine, screen bypass, and spillway routes through the dam (Hansel et al. 2000). For three stocks of salmonids that have been studied, estimates of the rate of fish passage survival tend to be higher at the spillway than at the powerhouse, with whole-dam estimates in between (Table 1.1). The differences in survival rates between the powerhouse and spillway were greater 
for yearling Chinook salmon (YC) and subyearling Chinook salmon (SYC) than for steelhead (STH) (Table 1.1). These data indicate that the BiOp performance standard would not be met under most conditions.

Table 1.1. Radio-telemetry estimates of survival rates for three salmonid stocks passing routes at John Day Dam during 2000, 2002, and 2003. The ranges are for point estimates under different treatments.

\begin{tabular}{lcccl}
\hline $\begin{array}{c}\text { Study Year } \\
\text { (Passage Route) }\end{array}$ & Steelhead & $\begin{array}{c}\text { Yearling } \\
\text { Chinook }\end{array}$ & $\begin{array}{c}\text { Subyearling } \\
\text { Chinook }\end{array}$ & Reference \\
\hline 2000 (Dam) & 90.5 to $98.8 \%$ & 93.7 to $98.6 \%$ & & Counihan et al. 2002b \\
2002 (Spillway) & 93.2 to $95.8 \%$ & 99.3 to $100 \%$ & 98.5 to $100 \%$ & Counihan et al. 2006c \\
2002 (Powerhouse) & 89.9 to $93.0 \%$ & 77.8 to $83.2 \%$ & 86.6 to $96.6 \%$ & Counihan et al. 2006c \\
2002 (Dam) & 91.5 to $94.0 \%$ & 92.9 to $96.3 \%$ & 92.8 to $99.2 \%$ & Counihan et al. 2006c \\
2003 (Spillway) & & 93.4 to $93.9 \%$ & 90.1 to $95.5 \%$ & Counihan et al. 2006d \\
2002 (Powerhouse) & & 76.4 to $82.0 \%$ & 71.9 to $72.2 \%$ & Counihan et al. 2006d \\
2002 (Dam) & & 92.2 to $94.0 \%$ & 84.5 to $88.6 \%$ & Counihan et al. 2006d \\
\hline
\end{tabular}

At least five studies have estimated fish-passage efficiency ${ }^{1}$ and spill efficiency ${ }^{2}$ at John Day Dam (Table 1.2). The radio-telemetry studies indicated that fish-passage efficiency ranged from $88 \%$ to $94 \%$ for STH, $82 \%$ to $92 \%$ for YC, and from $70 \%$ to $75 \%$ for SYC. A hydroacoustic study in 2002 estimated a similar range of fish-passage efficiency for spring stocks but the estimate for SYC ( $88 \%$ to $92 \%)$ was higher than the radio-telemetry estimate that year. Estimates of spill efficiency for the three fish stocks were highly variable among years (Table 1.2).

\subsection{Surface-Flow Outlet Development}

Sweeney et al. (2007) provides a compendium on SFO development in the Pacific Northwest. Although the Portland District's SFO program for juvenile salmonids commenced in 1994 (USACE 1995), SFO development is in its early stages at John Day Dam. To support this effort, baseline biological data on fish distributions were summarized by Giorgi and Stevenson (1995) and Anglea et al. (2001). Generally, yearling migrants approach the dam along the Washington side of the forebay, and SYC approach using migration pathways near both shorelines. Tagged fish have been observed traversing the forebay laterally before passing.

Field work on a prototype surface spill SFO was conducted in 1997 when "over/under" weirs were placed at spill bays 18 and 19 at John Day Dam. BioSonics (1999) found that passage at the prototype bays was higher during spring when the weirs were removed than when weirs were in place. During summer, passage rates between "in" and "out" treatment conditions were comparable. This study, however, was affected by very high spill through adjacent bays during a year of above-average river discharge.

\footnotetext{
${ }^{1}$ Fish-passage efficiency is defined as total passage through non-turbine routes divided by total dam passage.

${ }^{2}$ Spillway-passage efficiency is defined as total spillway passage divided by total dam passage.
} 
Table 1.2. Some radio-telemetry and hydroacoustic estimates of fish-passage efficiency and spillwaypassage efficiency for John Day Dam. The ranges are for point estimates under different treatments.

\begin{tabular}{lcccc}
\hline \multicolumn{1}{c}{ Study Year/Type } & Steelhead & Yearling Chinook & Subyearling Chinook & Reference \\
\hline FPE & & & & \\
1999 RT & 90 to $94 \%$ & 82 to $88 \%$ & & Hansel et al. 2000 \\
2000 RT & 91 to $93 \%$ & 90 to $92 \%$ & & Beeman et al. 2003 \\
2002 RT & 88 to $91 \%$ & 84 to $85 \%$ & 80 to $72 \%$ & Beeman et al. 2006 \\
2002 HA & 89 to $94 \%$ & & 71 to $75 \%$ & Moursund et al. 2003 \\
2003 RT & & 84 to $86 \%$ & & Hansel et al. 2004 \\
Spill Efficiency & & & & Hansel et al. 2000 \\
1999 RT & 45 to $53 \%$ & 53 to $66 \%$ & 42 to $58 \%$ & Beeman et al. 2003 \\
2000 RT & 61 to $79 \%$ & 75 to $86 \%$ & 58 to $61 \%$ & Moursund et al. 2003 \\
2002 RT & 54 to $64 \%$ & 48 to $57 \%$ & 48 to $62 \%$ & Hansel et al. 2004 \\
2002 HA & 72 to $78 \%$ & & & \\
2003 RT & & 47 to $57 \%$ & & \\
\hline FPE $=$ fish-passage efficiency. & & & \\
HA = hydroacoustic. & & & \\
RT $=$ radio-telemetry. &
\end{tabular}

Engineering and model studies examining skeleton bays as potential SFO sites were conducted in the 1990s (Montgomery Watson et al. 2000). At a physical model at the USACE Engineering, Research, and Development Center, observations of a 20,000-cfs SFO in a skeleton bay showed strong forebay flow nets, indicating a potential for fish to discover the SFO flow. However, because of concerns about cost and tailrace egress caused by a large eddy that formed in the spillway stilling basin adjacent to the SFO outfall plume, this effort was tabled.

The Portland District identified SFO development as a major priority in the John Day Configuration and Operation Plan (USACE 2007). Accordingly, new numerical and physical model investigations and engineering design work were undertaken to develop a prototype SFO for John Day Dam. In winter 2007/2008, the Portland District installed prototype SFOs, called top-spill weirs (TSWs), at spill bays 15 and 16. A bulkhead on top of the weir provided hydraulic control, creating a critical entrance flow regime. The discharge was about 10,000 cfs per bay. The weir was designed to minimize the angle of SFO jet impact on the ogee. The intent was to increase the fish-passage efficiency and passage survival rates of downstream-migrating juvenile salmonids at John Day Dam.

\subsection{Research Objectives}

The overall purpose of the acoustic telemetry study at John Day Dam during 2008 was to estimate fish survival rates and passage efficiencies to assess the performance of a prototype SFO composed of TSWs installed at spill bays 15 and 16. We also estimated dam-passage survival rates and fish passage proportions for each of two spill conditions (30\% versus $40 \%$ spill out of all water discharged through the dam) and compared the respective estimates. Randomized block experimental designs were developed for spring and summer, and each 4-day block was supposed to have one 2-day treatment randomly 
selected to be $30 \%$ or $40 \%$ spill followed by the alternate treatment. The field study period was from April 29 to August 20, 2008. The five study objectives are listed below within three categories: survival rate, fish passage, and fish behavior.

- Survival Rate

1. Estimate route-specific, dam-passage, and concrete-passage survival rates ${ }^{1}$ for $\mathrm{YC}, \mathrm{STH}$, and SYC passing through John Day Dam for each of two spill treatments (30\% or 40\% spill), pooled treatments, and during day and night periods.

- Fish Passage

2. Estimate passage proportions among major passage routes, and calculate efficiency and effectiveness metrics for each of two spillway treatments, both treatments pooled, and for day and night periods for YC, STH, and SYC.

3. Estimate travel times (forebay residence and tailrace egress) of YC, STH, and SYC for each of two 2-day long spill treatments and both treatments pooled.

- Fish Behavior

4. Characterize fish behaviors, including forebay approach paths, for YC, STH, and SYC and compare approach paths with the final route of passage for each of two spill treatments.

5. Describe vertical and horizontal distributions and residence times of YC, STH, and SYC within the dam forebay during day, night, and pooled time periods.

\subsection{Study Area}

The area for this research study included 198 river kilometers (rkm) of the lower Columbia River from Arlington, Oregon (rkm 390), 41.4 km upstream of John Day Dam (rkm 348.6), to Lady Island (rkm 192) near Camas, Washington (Figure 1.2). John Day Dam is a single structure located at rkm 348.6; it consists of a powerhouse with 16 turbine units and 4 skeleton bays (bays where turbines were never installed) on the Oregon side and a 20-bay spillway on the Washington side (Figure 1.2).

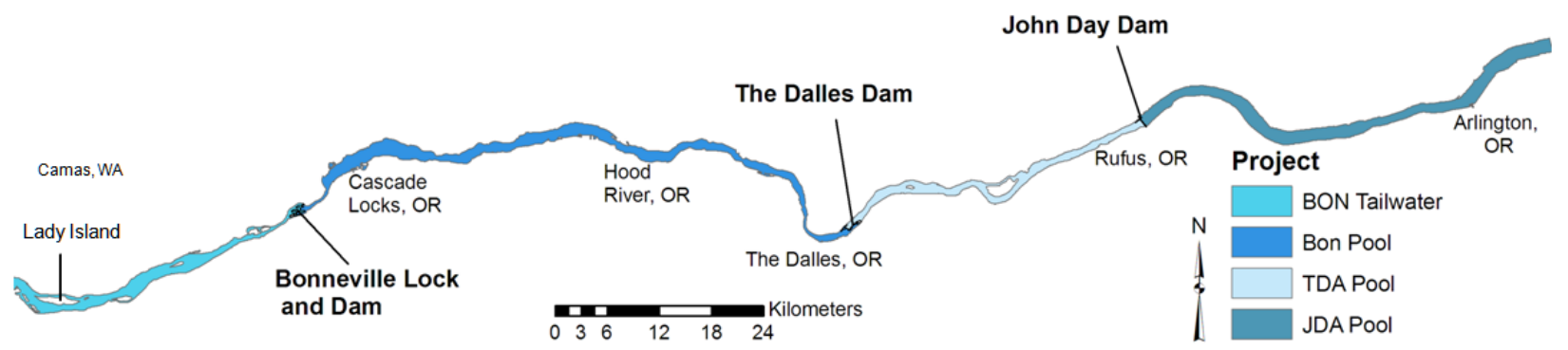

Figure 1.2. Study area on the lower Columbia River from Arlington, Oregon, to Camas, Washington

All fish implanted with acoustic tags were collected and processed in the Smolt Monitoring Facility (SMF), which is located at the downstream end of the juvenile bypass system (JBS; Figure 1.3) at John

\footnotetext{
${ }^{1}$ See Section 2.1.3 for definitions.
} 
Day Dam. These fish were diverted by extended-length submersible bar screens from the upper part of the powerhouse turbines to the gatewell slots. They passed through one of two gatewell orifices into a bypass channel that runs the length of the powerhouse. The channel volume is reduced by dewatering to a volume small enough to pass through pipes to the SMF, where fish could be sampled or routed to an outfall pipe to the tailrace. Monitoring of tagged smolts was accomplished by deploying underwater listening devices at strategic locations above, on, and below John Day Dam. Throughout this report, we refer to locations on the river that are varying distances apart, so we created Table 1.3 to provide a quick reference to determine distances between locations. Distances upstream of the mouth of the Columbia River are highlighted in light yellow and columns and rows associated with dam locations are highlighted in gray.

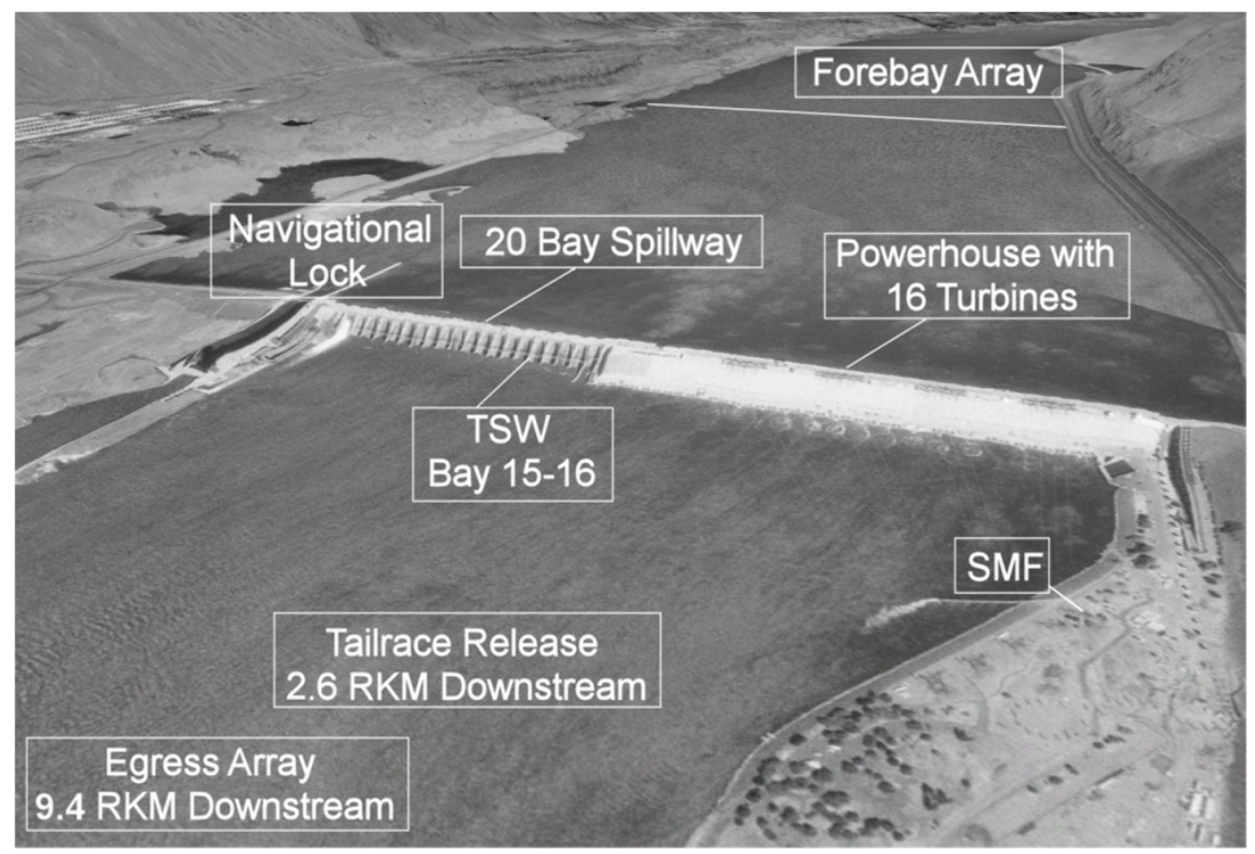

Figure 1.3. Aerial view of John Day Dam

\subsection{Report Contents}

The ensuing sections of this report present the materials and methods (Section 2.0), results (Section 3.0), and discussion (Section 4.0). References may be found in Section 5.0. Fourteen appendices contain tagging data tables (Appendix A); hydrophone locations (Appendix B); plots of tag life, time of arrival at survival-detection arrays, and tag-life probabilities (Appendix C); survival and detection probabilities without tag-life corrections (Appendix D); tag-life-corrected concrete-passage and route-specific survival rates for John Day Dam (Appendices E through K); tagging, release, capture histories, and dam operations data (Appendix L); Burnham Tests (Appendix M); and time-of-arrival plots to test mixing assumptions (Appendix N). 
Table 1.3. Lookup table for determining distances $(\mathrm{km})$ between locations referenced in this study

\begin{tabular}{|c|c|c|c|c|c|c|c|c|c|c|c|c|c|c|c|}
\hline Location & Study Function & $\begin{array}{c}\text { Km } \\
\text { Upstream } \\
\text { of CR } \\
\text { Mouth }\end{array}$ & 옵 & $\vec{\alpha}$ & $\begin{array}{l}\sqrt{n} \\
\hat{n} \\
\frac{0}{2}\end{array}$ & 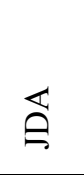 & $\begin{array}{l}\stackrel{3}{E} \\
\stackrel{\Xi}{\Theta}\end{array}$ & 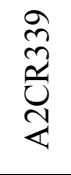 & $\frac{\sim}{2}$ & $\overleftrightarrow{\leftrightarrows}$ & $\begin{array}{l}\text { 当 } \\
\text { 䏍 }\end{array}$ & 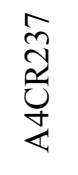 & Z̆ & 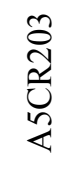 & 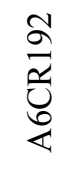 \\
\hline & & & 696 & 390 & 351 & 349 & 346 & 339 & 312 & 309 & 306 & 237 & 235 & 203 & 192 \\
\hline LGR & Release Site - Spr & 696 & 0 & 306 & 345 & 347 & 350 & 357 & 384 & 387 & 390 & 459 & 461 & 493 & 504 \\
\hline ARL & Release - Spr \& Sum & 390 & & 0 & 39 & 41 & 44 & 51 & 78 & 81 & 84 & 153 & 155 & 187 & 198 \\
\hline A1CR350 & Survival & 351 & & & 0 & 2 & 5 & 12 & 39 & 42 & 45 & 114 & 116 & 148 & 159 \\
\hline JDA & Effects & 349 & & & & 0 & 3 & 10 & 37 & 40 & 43 & 112 & 114 & 146 & 157 \\
\hline JDA TW & Release - Spr \& Sum & 346 & & & & & 0 & 7 & 34 & 37 & 40 & 109 & 111 & 143 & 154 \\
\hline A2CR339 & Egress & 339 & & & & & & 0 & 27 & 30 & 33 & 102 & 104 & 136 & 147 \\
\hline A3CR312 & Survival & 312 & & & & & & & 0 & 3 & 6 & 75 & 77 & 109 & 120 \\
\hline TDA & & 309 & & & & & & & & 0 & 3 & 72 & 74 & 106 & 117 \\
\hline TDA TW & Release Site -- Sum & 306 & & & & & & & & & 0 & 69 & 71 & 103 & 114 \\
\hline A4CR237 & Survival & 237 & & & & & & & & & & 0 & 2 & 103 & 114 \\
\hline $\mathrm{BON}$ & Effects & 235 & & & & & & & & & & & 0 & 32 & 43 \\
\hline A5CR203 & Survival & 203 & & & & & & & & & & & & 0 & 11 \\
\hline A5CR192 & Survival & 192 & & & & & & & & & & & & & 0 \\
\hline $\begin{array}{l}\text { A1CR351 } \\
\text { entrance a } \\
\text { secondary } \\
\text { BON tailw } \\
\text { JDA TW = } \\
\text { TW = The }\end{array}$ & $\begin{array}{l}\text { JDA forebay entrance } \\
\text { ray and primary surviva } \\
\text { urvival-detection array f } \\
\text { ter near Reed Island; A } \\
\text { John Day tailwater fish } \\
\text { Dalles Dam tailwater rel }\end{array}$ & $\begin{array}{l}\text { array; A2CR } \\
\text { l-detection a } \\
\text { for JDA; A5 } \\
\text { RL = Arling } \\
\text { release site; }\end{array}$ & LGR & Ore & 30 & $N=1$ & 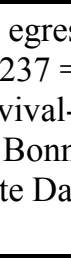 & 11 & e Dam & ; CR & C & $\mathrm{m}$ & & $\begin{array}{l}\text { bay } \\
\text { nd the } \\
\text { din th }\end{array}$ & $\begin{array}{l}\text { e } \\
\text { nDA }\end{array}$ \\
\hline
\end{tabular}




\subsection{Materials and Methods}

In this section, we describe the materials and methods used for the 2008 acoustic telemetry evaluation at John Day Dam. The primary research tool was the Juvenile Salmon Acoustic Telemetry System (JSATS).

The Portland District has been directing and funding the development of the JSATS to evaluate juvenile salmonid passage performance and survival rate. Currently, two types of JSATS receivers are used: autonomous nodes can be deployed in most environments where external power is not available, and cabled systems can be deployed were an external power source is available. The autonomous nodes are best suited for detecting tagged fish and estimating survival rate, whereas the cabled array has the advantage of precise synchronized time keeping and is well suited for two-dimensional (2D) or 3D tracking and for determining the route of passage. The JSATS technology has several advantages over previously used radio telemetry. The acoustic tag does not require an external antenna, making it less invasive to the fish than a radio transmitter. Acoustic telemetry can detect acoustic signals over a greater range and depth than radio telemetry, thereby increasing the detection area and reducing depth-related bias. When appropriate, an acoustic telemetry system can be deployed for $2 \mathrm{D}$ and $3 \mathrm{D}$ tracking that can be used to determine route of passage, forebay residence behavior, and aid in estimating route-specific survival rates.

Acoustic telemetry has been used on the lower Columbia River to describe fish passage and approach behavior at Bonneville Dam (Faber et al. 2001) and The Dalles Dam (Cash et al. 2005). The JSATS has been used in the Columbia River Estuary to estimate in-river survival rates since 2004 (McComas et al. 2004, 2005, 2006, 2007, 2008). In 2006, the JSATS receivers were deployed at various locations between John Day Dam and Camas, Washington (a 150-km reach of the river), to estimate turbine passage and tailwater survival rates at John Day Dam, and dam-passage and tailwater-passage survival rates for The Dalles Dam and Bonneville Dam (Ploskey et al. 2007). The first deployment of the JSATS cabled system was in 2007 at the Bonneville spillway to estimate route-specific passage and survival rates (Ploskey et al. 2008).

\subsection{Study Context}

The study context includes water discharge and temperature conditions, the spill treatments $(30 \%$ versus $40 \%$ spill out of total water discharge through the dam), and definitions of various estimates of survival rates.

\subsubsection{Water Discharge and Temperature}

Water discharge data by spill bay and turbine unit and elevation data for the forebay and tailwater were acquired in 5-minute increments by the automated data-acquisition system at John Day Dam, and provided to us weekly by John Day Dam operators. The 5-minute discharge data for the entire dam and spillway were averaged by day and plotted together with daily averages for the previous 10 -year period to provide some historical perspective for 2008 observations. Average water discharge and forebay water temperature data from 1998 through 2007 were downloaded from the DART (Data Access in Real Time) website (http://www.cbr.washington.edu/dart). 


\subsubsection{Spill Treatments}

We evaluated the effects of $30 \%$ and $40 \%$ spill treatments on fish passage and survival rates while TSWs were installed at spill bays 15 and 16. The effects on fish-passage efficiency, spill efficiency, spill effectiveness, dam-passage rates, and route-specific survival rates of JSATS-tagged juvenile salmonids were evaluated. Randomized block experimental designs were developed for spring (Figure 2.1) and summer (Figure 2.2). Each 4-day block was supposed to have one 2-day treatment randomly chosen to be $30 \%$ or $40 \%$ spill followed by the alternate treatment. Treatment changes were made at 0600 hours. The first treatment each season was in place a couple of days before the first study block, and a few fish that arrived before the first treatment but under the same spill conditions were assigned to the first treatment. Similarly, the last treatment each season continued for more than 2 days and late-arriving fish under the same spill conditions were assigned to the last 2-day treatment.

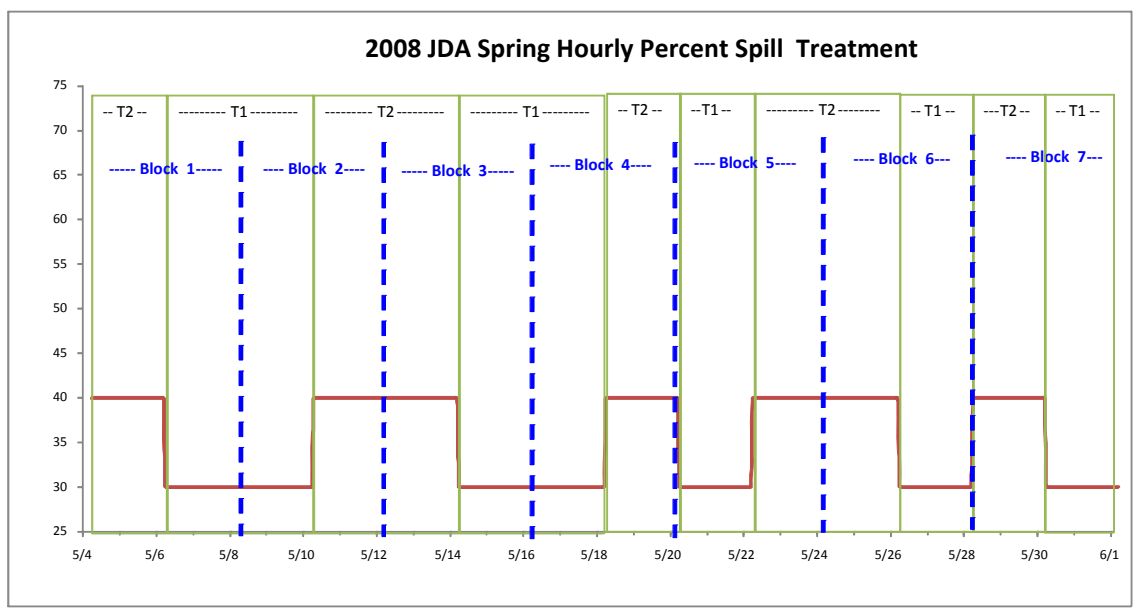

Figure 2.1. Spill treatments for the spring study at John Day Dam from May 4 through May 31, 2008. There were seven treatment blocks with two treatments per block. Treatment 1 (T1) was $30 \%$ spill and Treatment 2 (T2) was $40 \%$ spill.

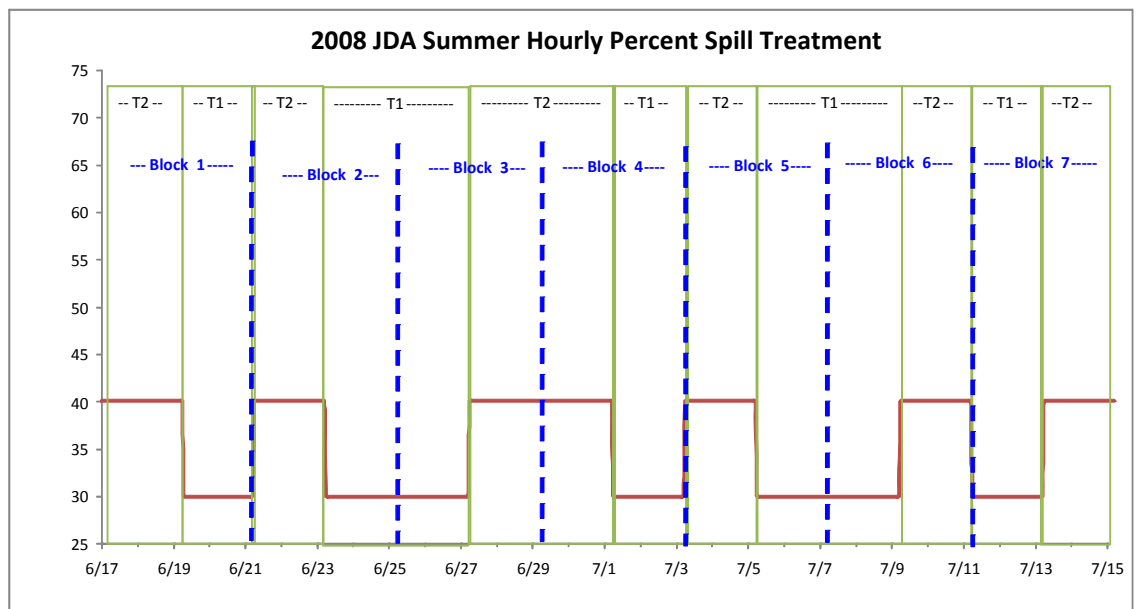

Figure 2.2. Summer spill treatments at John Day Dam from June 17 through July 14, 2008. There were seven treatment blocks with two treatments per block. Treatment 1 (T1) was 30\% spill and Treatment 2 (T2) was $40 \%$ spill. 


\subsubsection{Definitions}

We define estimates of single-release reach survival rates by the upstream and downstream boundaries of the reach of interest. The following additional definitions are needed to clarify pairedrelease survival metrics (Peven et al. 2005 provide other definitions):

- Forebay is the segment of river immediately upstream of a dam where operations at the dam are the primary contributing factor to velocity and direction of water flow. The upstream boundary is where a significant alteration in the allocation of water flow through dam operational changes affects water velocity or direction of flow. Locations of the forebay entrance arrays of autonomous nodes for John Day Dam and The Dalles Dam were $2 \mathrm{~km}$ upstream of the dam face. The downstream boundary is the upstream face of the dam, where we installed cabled arrays for tracking fish.

- Tailrace is the segment of river immediately downstream of the dam where dam operations are the primary factor affecting velocity and direction of flow. The upstream boundary of the tailrace is the downstream face of the dam and the downstream boundary is where operational changes at the dam no longer affect the direction of water flow and mixing from the spillway and powerhouse is complete. Tailrace release locations below John Day Dam and The Dalles Dam were at rkm 346 and 305 , respectively, approximately $3 \mathrm{~km}$ downstream of each dam.

- Reservoir or pool is the segment of river impounded by a dam where volume and water-surface elevations are controlled by the dam. A reservoir or pool may extend upstream to the tailrace of another dam. For example, The Dalles Dam pool extends from The Dalles Dam upstream to near the tailrace of John Day Dam, although it also could be referred to as the tailwater of John Day Dam.

- Tailwater is the segment of river downstream of a dam tailrace, and it is synonymous with reservoir or pool when it lies between two dams.

- The project-passage survival rate is the probability of fish surviving when passing from the upstream boundary of the reservoir or pool upstream of a dam to the downstream boundary of the tailrace of the dam.

- The dam-passage survival rate is the probability of fish surviving when passing from the upstream boundary of the forebay to the downstream boundary of the tailrace and includes the forebay, all routes of passage, and the tailrace of a given dam. In this study, the dam-passage survival rate is loosely defined as being from a forebay detection line to the tailrace release location for reference release groups of fish.

- The concrete-passage survival rate is the probability of fish surviving when passing from the upstream dam face to the downstream boundary of the tailrace and does not include survival in the forebay. (This is how the $2008 \mathrm{BiOp}$ defines the dam-passage survival rate.)

- The passage-route survival rate is the probability of fish surviving when passing through any individual route (i.e., spillway, turbine, bypass, etc.) to the downstream boundary of the tailrace (release location of a tailrace reference group). In this study, the passage-route survival rate was estimated for fish passing the powerhouse (turbines and JBS), spillway, and TSW spill bays at John Day Dam. 


\subsection{Fish Collection, Tagging, Transportation, and Release}

The following sections describe the collection site, associated record-keeping related to meeting permitting requirements for fish collection and handling, sampling methods, JSATS acoustic microtransmitter and tag implantation, fish recovery and holding, and transportation and release.

\subsubsection{Collection Site}

Juvenile Chinook salmon and STH were collected and tagged at the John Day Dam SMF. The SMF is situated on the south side of John Day Dam at the downriver edge of the fish bypass system where bypassed juvenile salmonids and other fishes are routed through a series of flumes and dewatering structures. Smolts can be diverted into the SMF as part of a sample of the JBS population for routine smolt monitoring or directed into the tailrace through an outfall pipe located downstream of the facility. Routinely sampled smolts also were rerouted to the tailrace outfall after they were examined unless they were selected for tagging as part of this study of survival rates.

\subsubsection{Federal and State Permitting}

Records were kept on all smolts handled and collected (both target and nontarget species) for permit accounting. Collections were conducted in conjunction with routine sampling at the SMF to minimize handling impacts. Surgical candidates collected from routine SMF target sample sizes were accounted for under permits issued to the SMF. Additional fish needed to meet research needs (beyond SMF goals) were accounted for under separate federal and state permits. A federal scientific take permit was authorized for this study by the National Oceanic and Atmospheric Administration (NOAA) Fisheries Hydropower Division's FCRPS Branch and administered by NOAA; permit number 20-08 PNNL-40. The Oregon Department of Fish and Wildlife authorized take for this study under permit number OR2008-4600. The federal and Oregon permits were both authorized under the 2004 FCRPS BiOp. All requirements and guidelines of both permits were met and reports of collection and release were reported to both agencies.

\subsubsection{Sampling Methods}

Juvenile salmonids were diverted from the bypass system and routed into a 1795-gal holding tank in the SMF. About 150-200 smolts and other fishes were crowded with a panel net into a 20- by 24-in. preanesthetic chamber. Water levels in the chamber were lowered to about 8 in. $(48 \mathrm{~L})$ at which point fish were anesthetized with $60 \mathrm{~mL}$ of a stock tricaine methanesulfonate (MS-222) solution prepared at a concentration of $50 \mathrm{~g} / \mathrm{L}$. Once anesthetized, fish were routed into the examination trough. Technicians added MS-222 as needed to maintain sedation, and 5 to $10 \mathrm{~mL}$ of PolyAquaTM was added to reduce fish stress. Water temperatures were monitored in the main holding tank and in the examination trough, and water in the trough was refreshed before temperatures there increased more than $2^{\circ} \mathrm{C}$ above those observed in the main holding tank. 
Once in the examination trough, smolts targeted for surgical procedures were evaluated in accordance with the following specific acceptance and rejection criteria:

\section{Qualifying (Acceptable) Conditions}

- sized $>95 \mathrm{~mm}$

- visible elastomer tag(s) present or absent

- adipose-fin clipped or unclipped

- trematodes, copepods, leeches

- short operculum

- healed (moderate) injuries (e.g., bird strikes)

- $\leq 3 \%$ fungal patch

- minor fin blood

- partial descaling (3-19\%)

- STH with eroded pectoral or ventral fins (likely hatchery steelhead).

Disqualifying Conditions

- $\geq 20 \%$ descaling

- body punctures (showing blood e.g., predator marks, bird strikes, head wounds, nose/snout injuries)

- obvious signs of bacterial kidney disease

- eye hemorrhage or pop eye

- $>3 \%$ coverage with fungus

- deformed

- holdovers (fish not "spring" yearling or "summer" subyearling)

- passive integrated transponder (PIT)- or radio-tagged or other post-surgical fishes

- notable operculum damage (except short operculum)

- columnaris, furuncles

- injured caudal peduncles

- injured caudal fins

- fin hemorrhage.

Nontarget species and fish that did not meet the above criteria were released to the river through the SMF holding system after a 30-minute recovery period. Accepted fish were counted and released into transfer buckets containing fresh river water before being moved to one of six 80 -gal pre-surgery holding tanks, where they were held for 18 to 30 hours before surgery. The pre-surgery holding duration depended on the time of collection and the time of tagging on the next day. 
During spring and summer tagging seasons, 91 total fish were rejected for tagging. Fish that were rejected during the tagging process were placed in a recovery tank to allow for the anesthesia to be displaced from their system before releasing them. The total number of fish rejected and reason for their rejection are listed below in Table 2.1 .

Table 2.1. Number of fish rejected by criteria during spring and summer tagging at John Day Dam

\begin{tabular}{lc}
\hline \multicolumn{1}{c}{ Rejection Criteria } & Number Rejected \\
\hline Descaling & 5 \\
Fungus & 8 \\
BKD & 1 \\
Skeletal deformities & 0 \\
Parasites & 1 \\
Emaciation & 0 \\
Cuts/lacerations & 32 \\
Hemorrhaging & 13 \\
Popeye & 0 \\
Fin rot & 0 \\
Head deformities & 0 \\
Lesions & 4 \\
Moribund & 0 \\
Other & 9 \\
Operculum damage & 18 \\
Total fish collected & 12,876 \\
Number of fish rejected & 91 \\
Percent total fish rejected & $0.71 \%$ \\
\hline
\end{tabular}

\subsubsection{JSATS Acoustic Micro-Transmitter and Tag Implantation}

The size of JSATS acoustic micro-transmitters surgically implanted in fish differed between spring and summer. In spring, the mean weight of tags was $0.485 \mathrm{~g}$ in air and $0.324 \mathrm{~g}$ in water, and tags were nominally $12.46 \mathrm{~mm}$ long, $5.30 \mathrm{~mm}$ wide, and $3.70 \mathrm{~mm}$ high. In summer, the mean weight of tags was $0.425 \mathrm{~g}$ in air and $0.29 \mathrm{~g}$ in water. Summer tags averaged $12.04 \mathrm{~mm}$ long, $5.27 \mathrm{~mm}$ wide, and $3.74 \mathrm{~mm}$ high (Figure 2.3). The acoustic tags used in this study had a ping rate of 1 pulse every 3 seconds to provide an expected tag life of at least 23 days.

A team of eight people was part of the tagging process to reduce the handling time between netting and post-surgery recovery. The team followed the latest guidelines for surgical implantation of acoustic transmitters in juvenile salmonids. Procedure development is an ongoing process initiated by the USACE for contractors conducting survival studies. Numerous steps were taken to minimize the handling impacts of collection and surgical procedures. Most smolts used for tagging were part of the routine collection for SMF monitoring and additional fish did not have to be collected to meet the tagging quota on most days. 


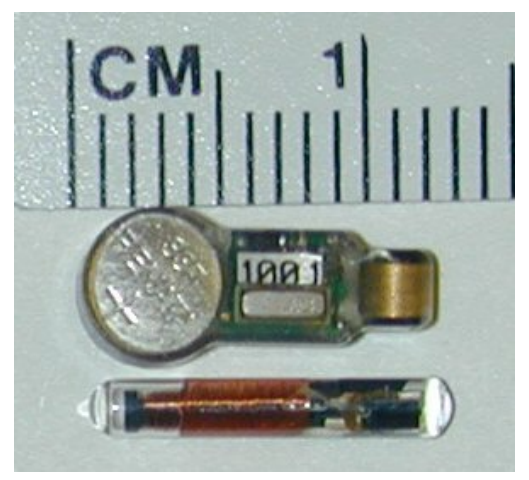

Figure 2.3. JSATS 0.425 -g acoustic micro-transmitter and PIT tag surgically implanted in subyearling Chinook salmon

The number of personnel on hand was the biggest contributor to ensuring that all tagged fish were handled as efficiently and un-intrusively as possible to minimize handling times. One individual was responsible for anesthetizing fish and delivering them to be weighed and measured. Two people were responsible for weighing, measuring, and recording data; three to four people performed surgeries to implant tags in the fish, and one or two people were responsible for moving tagged fish into the postsurgery tanks.

Fish were netted in small groups from the 80-gal holding tanks and placed in a 5-gal "knockdown" bucket with water and $20 \mathrm{~mL}$ of a $40-\mathrm{g} / \mathrm{L}$ stock solution of MS-222. Once a fish lost equilibrium, it was transferred to a processing table in a small container of river water. Each fish was measured (fork length $\pm 1 \mathrm{~mm})$, the species type and whether its adipose fin was intact or clipped were recorded on a GTCO CalComp Drawing Board VI digitizer board. Fish were weighed $( \pm 0.01 \mathrm{~g})$ on an Ohaus Navigator scale and returned to the small transfer container along with an assigned PIT tag and an activated acoustic tag. Length, weight, species type, tag codes, and fin clip were all added automatically into the tagging database by PIT Tag Information System (PTAGIS) P3 software to minimize human error. The transfer container, fish, and tags were assigned a recovery bucket number and passed to a surgeon for tag implantation.

An established protocol was used in the tagging process to help minimize the handling impact on tagged fish. All surgical instruments were sterilized daily in an autoclave and each surgeon used four complete sets of instruments during each day's tagging. When a set was not being used, it was placed in a $70 \%$ ethanol solution for approximately 10 minutes. The instruments were then transferred to a distilled water bath for 10 minutes, to remove residual ethanol and any remaining particles, before being used again. To reduce the disruption of the mucus membrane at the incision, Poly-Aqua was used to help replace the membrane that was removed from the fish's epidermal layers. Anesthesia buckets were kept within $\pm 1^{\circ} \mathrm{C}$ of river temperature. Anesthesia solutions were either replaced or cooled with ice when temperatures exceeded protocols. Recovery buckets were also kept within $\pm 1^{\circ} \mathrm{C}$ of river water temperature.

During surgery (Figure 2.4), each fish was placed ventral side up and a gravity-fed anesthesia supply line was placed into its mouth. The dilution of this "maintenance" line was $40 \mathrm{mg} / \mathrm{L}$. A 6-8-mm incision, using a \#15 stainless steel surgical blade or a Micro-Sharp stab scalpel with a 5-mm blade (depending on the surgeon's preference), was made ventrally, $3 \mathrm{~mm}$ from and parallel to the mid-ventral 
line and equidistant from the pelvic girdle and pectoral fin. The PIT tag was inserted first, followed by the acoustic tag. Both tags were inserted toward the anterior portion of the fish. Two interrupted sutures of 5-0 monofilament with an RB-1 needle were used to close the incision. With the incision closed, fish were then taken to an aerated recovery bucket containing river water.

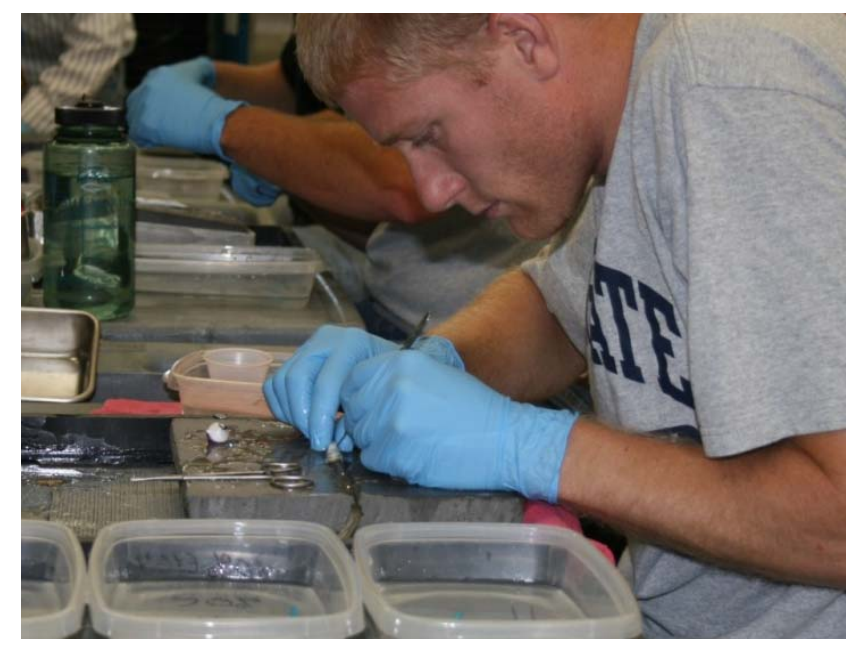

Figure 2.4. Surgery being conducted in the Smolt Monitoring Facility at John Day Dam

\subsubsection{Recovery and Holding}

Tagged fish were placed in 5-gal aerated recovery buckets and closely monitored until fish had reestablished equilibrium. Each bucket held two to seven fish depending on the size of the fish and the number to be released at each site. The buckets were then carried to a larger holding tank where they were supplied with a continuous feed of river water (Figure 2.5). Fish were held and monitored for 18 to 30 hours prior to being released. The large holding tanks were insulated to keep the water temperature within acceptable limits.

\subsubsection{Fish Transportation and Release}

To transport tagged fish, a 3/4-ton truck was outfitted with one 180-gal Bonar insulated tote and one 70-gal Bonar insulated tote. The 180-gal tote could hold ten 5-gal fish buckets, and the 70-gal tote could hold four 5-gal fish buckets. The totes had snug-fitting lids and some extra space inside so that ice could be added for cooling on hot days. A network of valves and plastic tubing was attached to an oxygen tank for delivering oxygen to the totes from a 2200-psi oxygen tank during transport. The Bonar totes were filled with fresh river water before fish buckets were removed from the post-surgery holding tanks and placed in the totes. Air lines were then placed into the totes. A YSI meter was used to measure the dissolved oxygen and the temperature of water in the totes before and after transport to make sure that these properties stayed within acceptable limits.

The JSATS tagged fish from each of the three stocks (STH, YC, and SYC) were released $41 \mathrm{rkm}$ upstream of John Day Dam near Arlington, Oregon (rkm 390), and John Day Dam reference fish were released in the John Day Dam tailwater at rkm 346. In summer only, SYC smolts also were released in the tailrace below The Dalles Dam to provide reference groups for estimating paired-release dam-passage 
survival rate for The Dalles Dam and to supplement the number of treatment fish available to pass the Bonneville Dam and support two survival rate studies there. All fish were released from a boat at three locations along a line transect across the river at each site, unless river conditions were too rough to safely release fish by boat. For boat releases, fish buckets were moved from the Bonar transport totes into the stern of the boat. Fish buckets were opened to check and record all mortalities. Dead fish were scanned with a BioMark portable transceiver PIT-tag scanner to identify the implanted PIT-tag code in each dead fish. The associated acoustic tag codes were identified later. In preparation for fish release, the boat operator maneuvered the boat to the release waypoint using an on-board global positioning system (GPS) and put the motor in neutral. Each bucket was submerged in the water so that fish could swim out on their own volition. The release site and time were recorded to the nearest minute on data sheets.

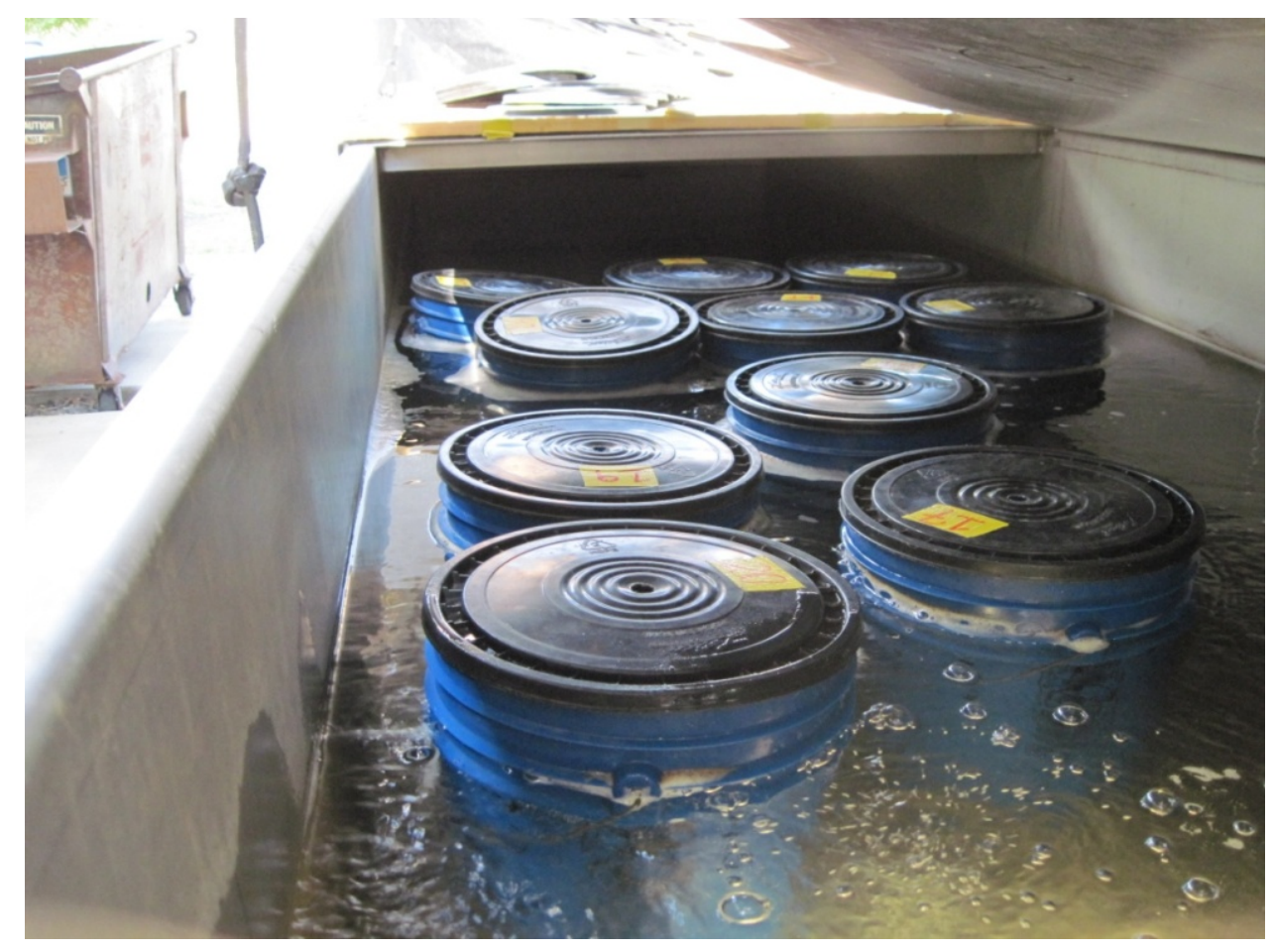

Figure 2.5. Post-surgery holding tank with recovery buckets

When conditions were too rough to release fish from a boat, alternate locations were used. Upstream of John Day Dam, fish were released from the grain elevator platform in Arlington, Oregon, by lowering the fish buckets into the water with a rope. Below John Day Dam, fish were released into the SMF outfall. The numbers of fish tagged and released in spring and summer are listed in Appendix A.

A 2008 tag-effects study (Dr. Richard Brown, PNNL, Personal Communication) released YC in the JBS outfall at Lower Granite Dam (also listed in Appendix A), and those fish also had the potential to be detected on receivers deployed for this study, as described in the next section.

\subsection{Detection of Tagged Fish}

Two types of JSATS arrays, cabled and autonomous, were deployed to detect fish tagged with JSATS acoustic transmitters as they passed downstream through the study reach between Arlington, Oregon, at 
rkm 351, and Camas, Washington, at rkm 192 (Table 2.2). The John Day Dam forebay array was used to create a virtual release for fish as they enter the forebay $2 \mathrm{~km}$ upstream of John Day Dam. The John Day Dam dam-face array was used to create a virtual release for fish known to have passed John Day Dam and to estimate route of passage at the dam using 3D tracking and last-detection data. The time of last detection by the dam-face array minus the time of first detection on the forebay array provide an estimate of forebay residence time. The time of first detection by the John Day Dam tailwater egress array minus the time of last detection on the dam-face array provided an estimate of relative egress time. The Dalles Dam forebay array was the primary array for estimating the survival rate for tagged smolts passing through John Day Dam and for defining the virtual release of fish to estimate the survival rate for smolts passing through The Dalles Dam. The Bonneville Dam forebay array was used as the secondary array for estimating the dam-passage survival rate at John Day Dam and as the primary survival-detection array for virtual and reference releases of fish at The Dalles Dam. The Bonneville Dam forebay array was also used to create a virtual release for Bonneville Dam survival studies (at Bonneville Dam Powerhouse 2 [B2] and the Bonneville Dam spillway); although those study results are not discussed in this report. The first Bonneville Dam tailwater array was used as the tertiary survival-detection array for estimating the survival rate of tagged smolts passing through John Day Dam and as the secondary survival-detection array for estimating The Dalles Dam-passage survival rate. The second Bonneville Dam tailwater array near Lady Island was used as a tertiary survival-detection array for estimating the product of survival and detection probabilities for estimating The Dalles Dam-passage survival rate. The GPS positions of individual dam-face hydrophones and autonomous nodes are presented in Appendix B.

Table 2.2. Description, location, name, and survival model function of arrays deployed in 2008. Array names were a concatenation of "A" for autonomous or " $\mathrm{D}$ " for dam face with a sequential number for each type (from upstream to downstream) with "CR" for Columbia River, and the nearest whole rkm.

\begin{tabular}{llll}
\hline Array Description & \multicolumn{1}{c}{ Location } & Array & \\
\hline JDA Forebay & $2 \mathrm{~km}$ upstream JDA & A1CR351 & Regroup fish for virtual releases \\
JDA Dam Face & JDA & D1CR349 & Regroup fish for route-specific virtual releases \\
JDA Tailwater & $2.6 \mathrm{~km}$ downstream & A2CR339 & Detect tagged fish to estimate egress rate \\
& JDA & & \\
TDA Forebay & $2 \mathrm{~km}$ upstream TDA & A3CR312 & JDA primary; regroup fish for virtual releases \\
BON Forebay & 1.5 km upstream & A4CR237 & JDA secondary; regroup fish for virtual releases; \\
B2 Dam Face & BON PH2 & D2CR235 & B2 route-specific passage assignments \\
BON Spill Dam & BON spillway & D3CR234 & Spillway route-specific passage assignments \\
Face & & \\
BON Tailwater 1 & Reed Island & A5CR203 & JDA tertiary; TDA secondary; BON primary; \\
BON Tailwater 2 & Lady Island & A6CR192 & TDA tertiary; BON secondary; \\
\hline B2 = Bonneville Dam Powerhouse 2. & & \\
BON = Bonneville Dam. & & \\
JDA = John Day Dam. & & \\
TDA $=$ The Dalles Dam. &
\end{tabular}




\subsubsection{Cabled Dam-Face Array}

The cabled dam-face receiver was designed by PNNL for the USACE Portland District using an offthe-shelf user-build system goal. Each cabled receiver consists of a computer, data-acquisition software, digital signal-processing cards with field-programmable logic gate array (DSP+FPGA), GPS card, fourchannel signal-conditioning receiver with gain control, hydrophones, and cables (Figure 2.6). The software that controls data acquisition and signal processing is the property of the USACE and is made available by the USACE as needed.

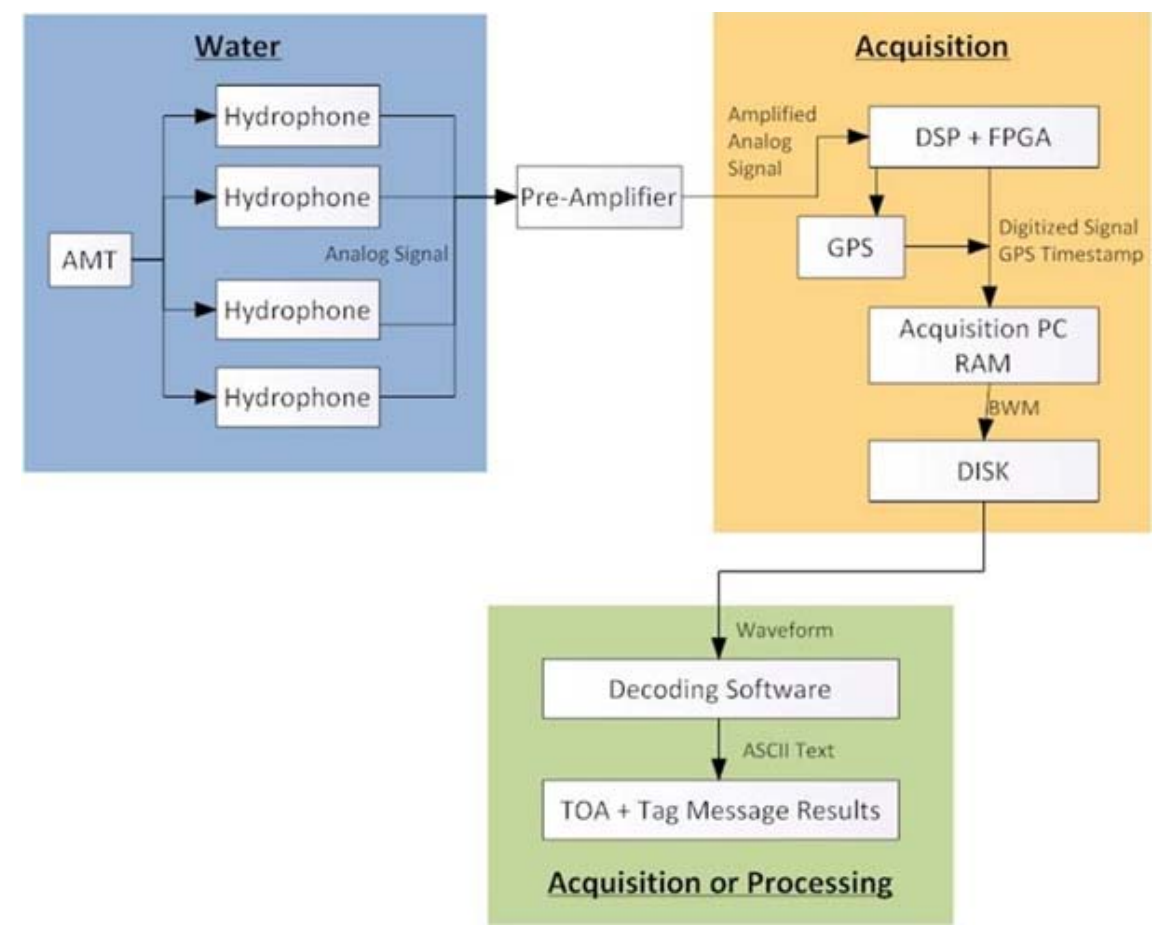

Figure 2.6. Schematic of the JSATS Dam-Face Receiver System showing the main components and the direction of signal acquisition and processing. Abbreviations are as follows: $\mathrm{AMT}=$ acoustic micro-transmitter implanted in fish; DSP = digital signal processing card; FPGA = field programmable logic gate array; GPS = global positioning system; $\mathrm{PC}=$ personal computer; $\mathrm{RAM}=$ random access memory; $\mathrm{BWM}=$ binary waveform; TOA = time of arrival.

A modular JSATS dam-face cabled array was deployed along the upstream face of John Day Dam on each main pier and in the forebay (Figure 2.7) to detect smolt tagged with an acoustic micro-transmitter as they approached and passed the dam. The dam-face cabled array consisted of 23 cabled receivers each supporting four hydrophones. The receivers were housed in trailers on the dam forebay deck. The four hydrophones per cabled receiver were deployed on trolleys in pipes attached to the main piers at the powerhouse and spillway (Figure 2.7) in a known fixed geometry. Trolley pipes at the powerhouse were 4 in. in diameter, and made of powder-coated schedule 40, 4-in.-internal-diameter steel pipes that were slotted down one side for deployment of the trolley. A cone was attached to the top of the pipe to assist with insertion of trolleys (Figure 2.8). Pipes at the powerhouse were $120 \mathrm{ft}$ long and extended from deck level at elevation $281 \mathrm{ft}$ above mean sea level (MSL) down to a mid-intake depth at elevation $164 \mathrm{ft}$ above MSL. Two hydrophones were deployed at each main pier. One hydrophone was deployed at a 
shallow elevation (at $255.5 \mathrm{ft}$ above MSL) and the other was deployed at a deep elevation (at $166.5 \mathrm{ft}$ above MSL) to provide acceptable geometries for tracking an acoustic-tagged fish in three dimensions and then assigning it a route of passage through the dam.

O Dam Mounted Hydrophones

- Forebay Hydrophones

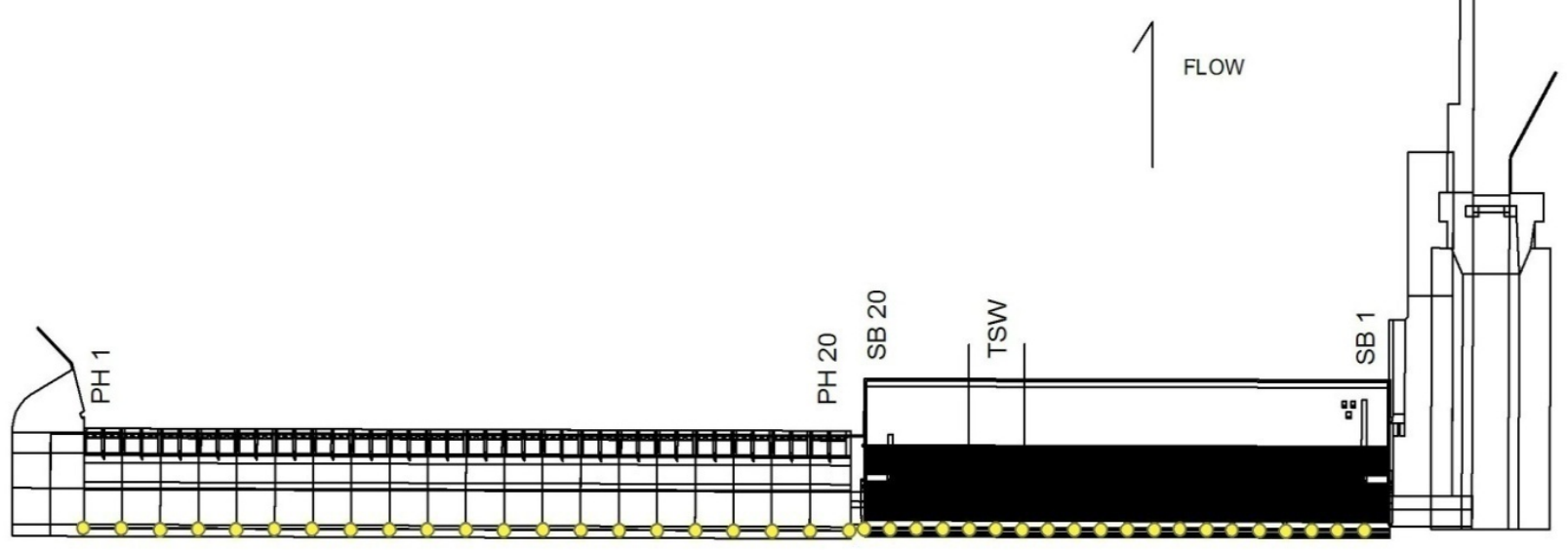

Figure 2.7. Location of JSATS hydrophones on the dam face and in the forebay of John Day Dam

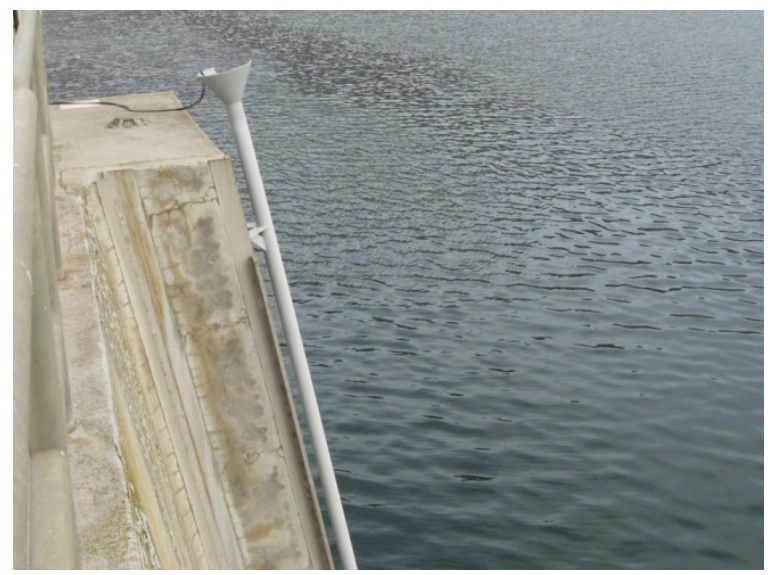

Figure 2.8. Trolley pipe mounted on a main pier of the John Day Dam powerhouse

At the spillway, hydrophones were mounted on trolleys that were deployed in 40-ft-long 8-in.diameter slotted pipes installed previously for radio-telemetry studies. Cones were added to the tops of the pipes to aid with installation of trolleys from the deck. At each spillway pier, one hydrophone was deployed at a shallow elevation (259.5 ft above MSL) and the other at a deep elevation ( $232.5 \mathrm{ft}$ above MSL). Each steel trolley slid down inside the pipe and was guided by an extension arm that protruded from the slot. The arm positioned the anechoic baffled hydrophone perpendicular to the face of the dam (Figure 2.9). Hydrophones were also deployed on clump mounts in the forebay upstream of spill bays 15 and 17 to provide additional detection and greater 3D resolution of tagged smolt as they passed at the TSWs. 


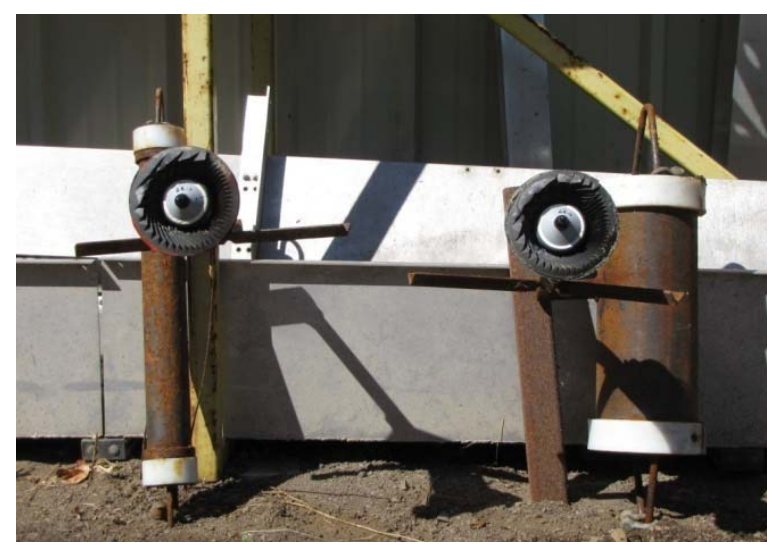

Figure 2.9. A 4-in.-diameter trolley with hydrophone (left) for slotted pipes on powerhouse piers and an 8-in.-diameter trolley with hydrophone (right) for slotted pipes on spillway piers. Each trolley had a steel arm to support a hydrophone that was surrounded by a plastic cone lined with anechoic material to prevent sound reception from a downstream direction.

\subsubsection{Autonomous Nodes and Arrays}

Autonomous acoustic telemetry receivers were deployed in arrays at specific sites in the lower Columbia River study area (Figure 2.10). An array is defined as a group of autonomous nodes deployed across the entire width of a river cross section to detect passing fish that have been surgically implanted with acoustic tags. Most arrays had autonomous nodes that were deployed within $400 \mathrm{ft}$ of each other and less than $300 \mathrm{ft}$ from shore. The hydrophone, pair of electronic circuit boards, compact flash (CF) card, and battery connectors were located in the node top (Figure 2.10).

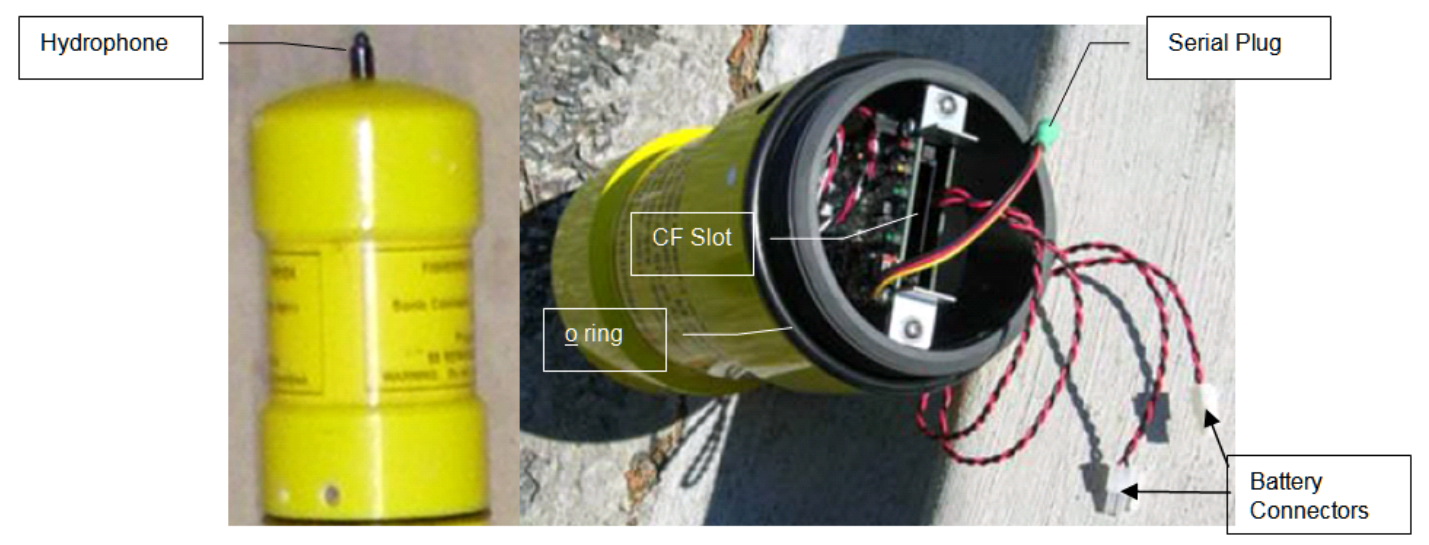

Figure 2.10. Side (left) and bottom (right) view of an autonomous node top

Five arrays of autonomous nodes were deployed for this study (Figure 2.11). Arrays were named by concatenating several letters and numbers. For example, the first array was A1CR351, which is the concatenation of "A" (for autonomous node), a sequential array number (counting from upstream to downstream), "CR" (for Columbia River), and 351, which is the nearest river kilometer to that array site. This array was located $2 \mathrm{~km}$ upstream of John Day Dam, and it was used to detect and regroup acoustictagged fish as they entered the John Day Dam forebay and, thereby, define virtual releases of fish for estimating the forebay survival rate. The last time of detection on the dam-face array described in 
Section 2.4.1 minus the time of first detection on the forebay entrance array provided estimates of forebay residence time. A tailwater egress array (A2CR339) was located at rkm 339.2 about $7.8 \mathrm{~km}$ below John Day Dam. The first time of detection on the egress array minus the last time of detection on the dam-face array provided a relative estimate of tailrace egress time. The Dalles Dam forebay entrance array (A3CR312) was located $2 \mathrm{~km}$ upstream of The Dalles Dam spillway. This array was the primary array for estimating the survival rate of fish passing at John Day Dam and was used to detect and define virtual releases for estimating the rate of The Dalles Dam-passage survival rate. The Bonneville Dam forebay array (A4CR237) was located about $2 \mathrm{~km}$ upstream of B2. This array was the secondary array for estimating the survival rate of fish passing John Day Dam. The tertiary array for estimating the product of detection and survival rates for John Day Dam (A5CR203) was located near Reed Island in the Bonneville Dam tailwater. See Appendix B for the nominal GPS coordinates of autonomous nodes deployed in this study.

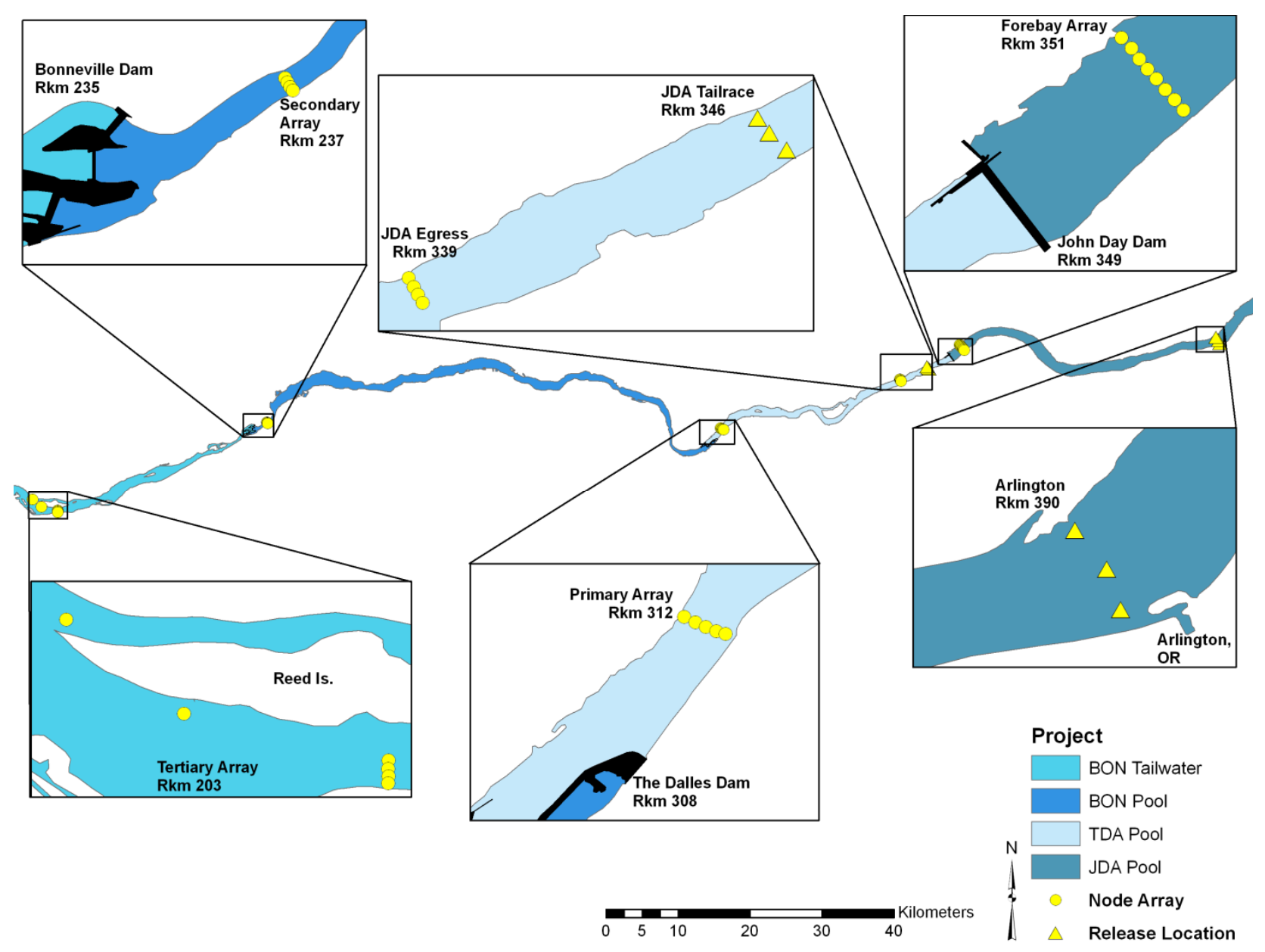

Figure 2.11. Locations of autonomous node arrays and fish release locations in the Lower Columbia River in 2008 


\subsubsection{Node Retrieval, Servicing, and Redeployment}

We usually retrieved nodes by boat and downloaded data every week. The first step in servicing a node was to trigger its acoustic release. Staff entered a release-specific code into a topside command transceiver, and it transmitted an electrical signal to an underwater transducer, which in turn converted the electrical signal into underwater sound detectable by a specific release mechanism. Upon receipt of a recognized sound by an acoustic modem at the upper end of the acoustic release, the mechanism usually would open and free the positively buoyant package from the anchor so that it would surface and could be retrieved by staff in the boat. The next step was to dry the node with a towel, open it, eject the CF card, and download the data from the card to a laptop computer. Each file was checked to verify that data were collected during the entire deployment, records were continuous, and records included time stamps and tag detections. The CF card was replaced every time nodes were retrieved and batteries were changed at about 28-day intervals. When the data were corrupt, the node top was replaced with a new one and the faulty top was sent to Sonic Concepts for repair. Damage to the relatively delicate hydrophone tip was the most common problem. Nodes were deployed and serviced from April 25 until August 20, 2008.

\subsubsection{Autonomous Node Deployment}

Autonomous nodes were rigged with the configuration shown in Figure 2.12. A 5-ft section of rope with three 6-lb buoyancy floats was attached to a strap half way between the node tip and the bottom of the battery housing. An InterOcean Systems Mode 111 acoustic release was attached to the other end of the 5-ft line. A 1-, 3-, or 6-ft length of wire rope was attached to the bottom of the acoustic release, depending on water depth, and the other end of that cable was shackled to a 75-1b steel anchor. The shorter 1-ft length of wire rope was used in water less than $40 \mathrm{ft}$ deep; the 3 - $\mathrm{ft}$ length was used in water over $40 \mathrm{ft}$ deep; and 6-ft lengths were used in deep locations were sandy substrates had the potential to gum up release mechanisms.

\subsection{Data Processing and Validation}

Signals were decoded and filtered and tag life was studied as part of data processing and validation efforts.

\subsubsection{Signal Decoding and Filtering}

Data collected by the JSATS cabled hydrophones were encoded candidate messages saved in binary time-domain waveform files. Figure 2.13 shows the waveforms of an actual example acquired at the John Day Dam spillway on June 18, 2008. The waveform files were then processed by a decoding utility (Waveform Utilities developed by USACE and PNNL) that identifies valid tag signals and computes the tag code and time of arrival using Binary Phase Shift keying. Binary Phase Shift keying is a digitalmodulation technique that transmits messages by altering the phase of the carrier wave. Several filtering algorithms were then applied to the raw results from the decoding utilities to exclude spurious data and false positives. 


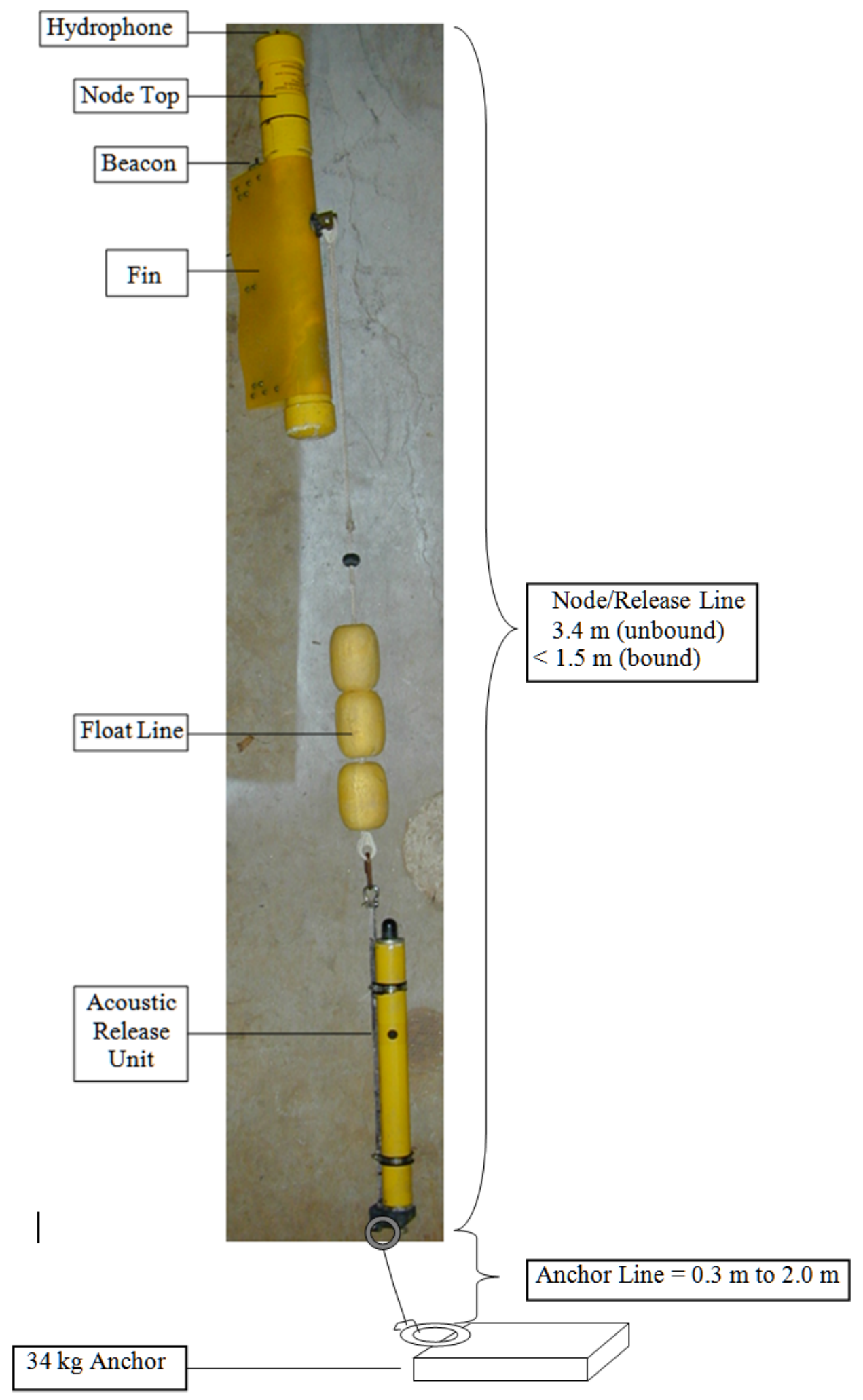

Figure 2.12. Autonomous node rigging in 2008 

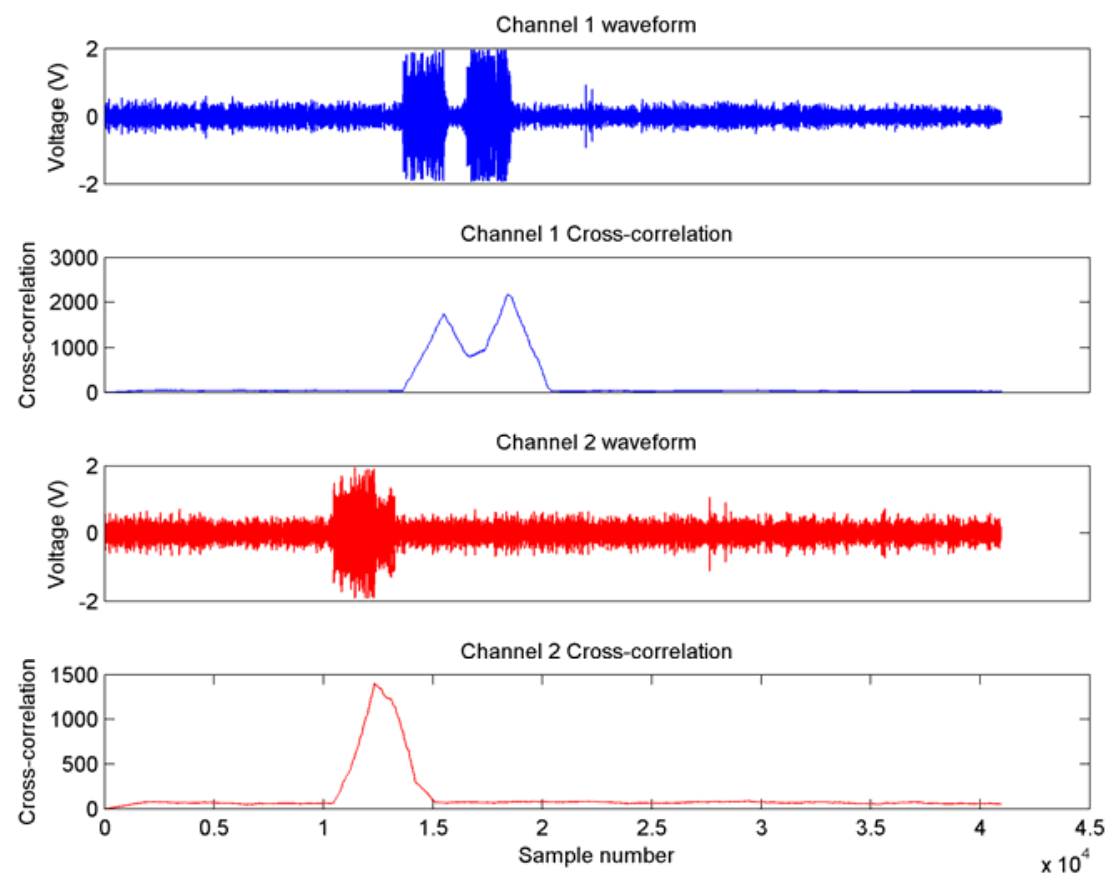

Figure 2.13. Example of time-domain waveforms and corresponding cross-correlations acquired at the John Day Dam spillway. The message portion was 1860 samples $(744 \mu \mathrm{s}$ long). Note that multipath components were present in both channels. Decodes from the multipath components were filtered out in post-processing.

Tag-detection data from JSATS autonomous nodes were processed by two independent groups as a quality-control measure as in previous studies (Ploskey et al. 2007; Ploskey et al. 2008) using standardized methods. One method processed data using programs written in Python, and the other involved processing data with programs written in the Statistical Analysis System (SAS). No significant difference was found in estimates of the detection and survival rates based upon detection histories generated by the two processing methods. Regardless of processing method, tag, release, and detection data were merged into a single data set, and the same rules were applied to identify valid detections and to generate detection histories for every tag.

Steps for filtering raw autonomous node data to produce a clean detection data set included the following:

1. Decodes of the same tag within 0.156 seconds of the previous decode were assumed to be multipath and deleted.

2. Invalid detection events were deleted. A detection event was started when the time interval between any four identical decodes was $\leq 47.8$ seconds ( 3 -s tags), $\leq 79$ s ( 5 -s tags), or $\leq 157$ s (10-s tags). Once started, the event continued until the time lapse between any two successive decodes exceeded the same time durations.

3. Decodes within valid detection events, as described in Filter 2 above, were deleted if the time interval from the original decode in the series did not closely match an even multiple of one of the modes of the estimated pulse-repetition interval. 
4. Remaining detection events for tag codes that were not used during the study year were flagged as orphans in hope of explaining the presence of those codes at a later date. Flagged detections were not used in any analysis unless they were explained. Resources for resolving issues included the list of codes of tags implanted in fish, lists of codes of beacons deployed on autonomous nodes or in forebays, and coordination with other researchers in the basin.

5. We flagged remaining detections that occurred before a tag was released, at sites upstream of the listed release location, or on upstream arrays after a series of detections on downstream arrays. Analysts attempted to explain and resolve the flagged problems by examining all available information in the tagging, release, autonomous array, and cabled array data sets. Flagged detections were not used in any analysis unless the spatial or temporal discrepancies were adequately explained and resolved. Discrepancies might be explained by fish being released at the wrong site or incorrect data and time settings on an autonomous node.

Steps for filtering cabled array data to produce a clean detection data set included the following:

1. Decodes of a tag code within 0.156 seconds of a previous decode of the same code were assumed to be multipath and deleted.

2. Invalid detection events were deleted. A detection event was started when the time interval between any four identical decodes was $\leq 47.8$ seconds ( 3 -s tags), $\leq 79$ seconds (5-s tags), or $\leq 157$ seconds (10-s tags). Once started, the event continued until the time lapse between any two successive decodes exceeded the same time durations.

3. Decodes within valid detection events, as described in Filter 2 above, were deleted if the time interval from the original decode in the series did not closely match an even multiple of one of the modes of the estimated pulse-repetition interval.

4. Remaining detection events for tag codes that were not used during the study year were flagged as orphans in hope of explaining the presence of those codes at a later date. Flagged detections were not used in any analysis unless they were explained. Resources for resolving issues included the list of codes of tags implanted in fish, lists of codes of beacons deployed on autonomous nodes or in forebays, and coordination with other researchers in the basin.

5. We flagged remaining detections that occurred before a tag was released, at sites upstream of the listed release location, or on upstream arrays after a series of detections on downstream arrays. Analysts attempted to explain and resolve the flagged problems by examining all available information in the tagging, release, autonomous array, and cabled array data sets. Flagged detections were not used in any analysis unless the spatial or temporal discrepancies were explained and resolved. Discrepancies might be explained by fish being released at the wrong site or incorrect data and time settings on an autonomous node.

The final results from the steps above included a complete detection history for each tag: detection time (TOA), detection hydrophone location, and the signal-to-noise ratio.

\subsubsection{Tag-Life Study}

Acoustic tags were used to characterize tag life from systematically sampling tags used in the $\mathrm{YC}$ and STH survival rate studies. As part of the 2008 Tag Effects Study, Dr. Richard Brown and colleagues implanted tags subsampled from all tags used in this study into juvenile Chinook salmon from Priest 
Rapids Hatchery and monitored transmissions from those tags until every tag quit transmitting. When a tagged fish died, the tag was re-implanted in another fish until the tag died. A JSATS mobile node was used to listen for tags daily and tag-life history data were compiled to produce tag-life curves, which indicate the percent of each tag type transmitting as a function of days since activation. In addition, 44 Advanced Telemetry Systems, Inc. (ATS) 3-s tags, 40 ATS 5-s tags, and 27 10-s tags. There also 94 5-s tags were recovered when fish were removed from the river at SMFs using a sort-by-code diversion. The fraction of tags transmitting and the cumulative frequency of arrivals of tagged fish at survival-detection arrays as a function of time since tag activation were used to derive tag-life corrections. We did not fit curves to the fraction of tags still transmitting after tag activation and instead used the raw data as a Kaplan-Meier estimator of tag survival rate.

\subsection{Statistical Methods}

In this section of the report, the statistical methods used and descriptions of the testing conducted are characterized and defined.

\subsubsection{Defining Releases for Estimating Survival Rates}

The release locations and virtual release locations used in calculating survival rate estimates for tagged fish are described here, along with the JSATS detection arrays used in calculating fish survival rates.

\subsubsection{Fish Released at John Day Dam in Spring and Summer}

The PNNL team released YC and STH in spring and SYC in summer into the river near Arlington, Oregon, at rkm 390. Some of these tagged fish were detected by the forebay entrance array (A1CR351) and detections were pooled over several days to define virtual releases for estimating forebay- and dampassage survival rates. Some of the fish also were detected on the dam-face array (D1CR349) and pooled over several days to define virtual releases for estimating concrete-passage and route-specific survival rates. The concrete-passage survival rate at John Day Dam was estimated using The Dalles Dam forebay array (A3CR312, primary), Bonneville Dam forebay array (A4CR237, secondary), and the Bonneville Dam tailwater array (A5CR203, tertiary) (Figure 2.14).

Some of the YC and STH released at sites designated as R1 and R2 (Figure 2.14) also were detected on The Dalles Dam forebay entrance array (A3CR312) and pooled over several days to define virtual releases for making single-release estimates of The Dalles Dam-passage survival rate. Paired-release estimates could not be made in 2008 because no YC or STH were released in The Dalles Dam tailrace.

\subsubsection{Yearling Chinook Salmon Released in the Lower Granite Tailrace in Spring}

Yearling Chinook were released at Lower Granite Dam through the juvenile bypass outfall into the Snake River at rkm 173, which is $696 \mathrm{rkm}$ upstream of the mouth of the Columbia River. Some Lower Granite Dam fish were detected by the dam-face array (D1CR349) and used to define virtual releases for estimating the rate of concrete-passage survival based on subsequent detections on The Dalles Dam forebay entrance array (A3CR312, primary), the Bonneville Dam forebay entrance array (A4CR237, secondary), and Bonneville Dam tailwater array (A5CR203, tertiary) (Figure 2.15). 
(R) $390 \mathrm{~km}$

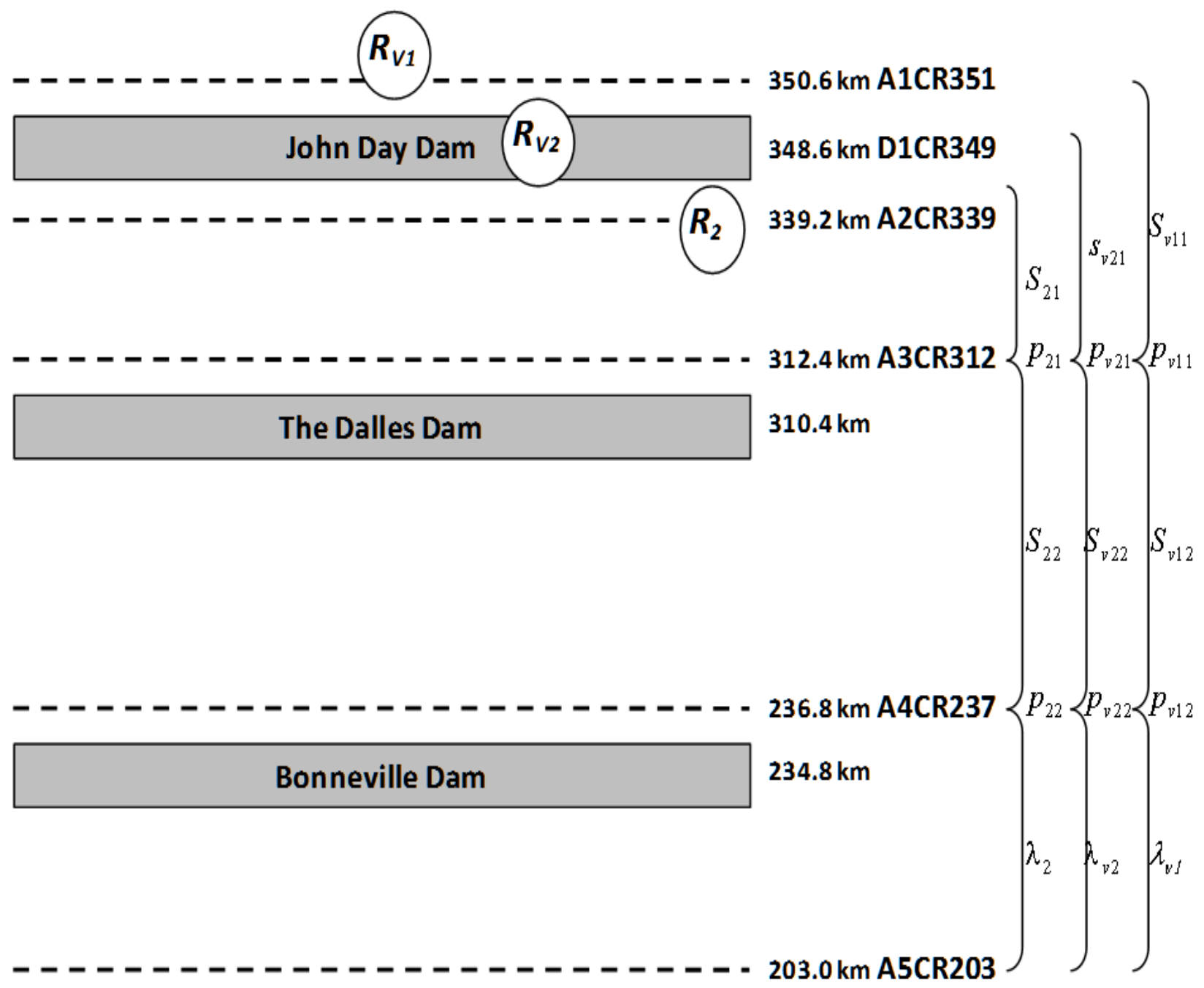

Figure 2.14. Schematic of the paired-release design $\left(\mathrm{R}_{1}\right.$ and $\left.\mathrm{R}_{2}\right)$ and virtual releases $\left(\mathrm{R}_{\mathrm{v} 1}, \mathrm{R}_{\mathrm{V} 2}\right)$ for estimating dam- and concrete-passage survival rates at John Day Dam

\subsubsection{Paired-Release Estimates of TDA Dam-Passage Survival Rate for SYC}

In summer, SYC were released in The Dalles Dam tailrace at rkm 306 (R3), and these releases were paired with virtual releases defined by detections of smolts from the John Day Dam pool and tailrace releases on The Dalles Dam forebay entrance array (Figure 2.16). We made single- and paired-release estimates of The Dalles Dam-passage survival rate using detection histories from the Bonneville Dam forebay array (A4CR237, primary), and two Bonneville Dam tailwater arrays (A5CR203 = secondary and A6CR192 = tertiary). 


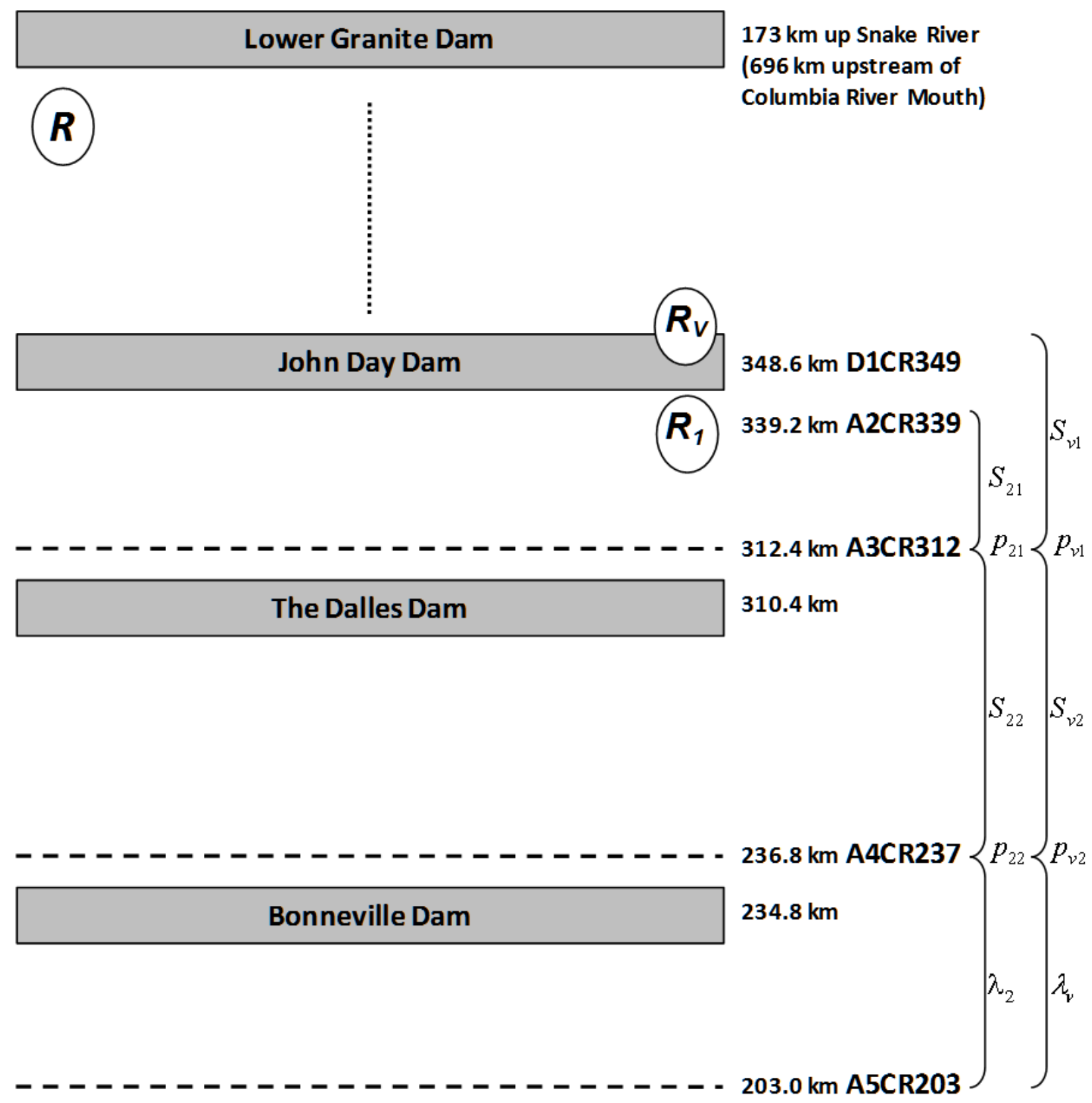

Figure 2.15. Schematic of the paired-release design $\left(R_{V}\right.$ and $\left.R_{1}\right)$ for estimating dam- and concretepassage survival rates at John Day Dam for YC released downstream of Lower Granite Dam 


\section{(R.) $30 \mathrm{om}$}

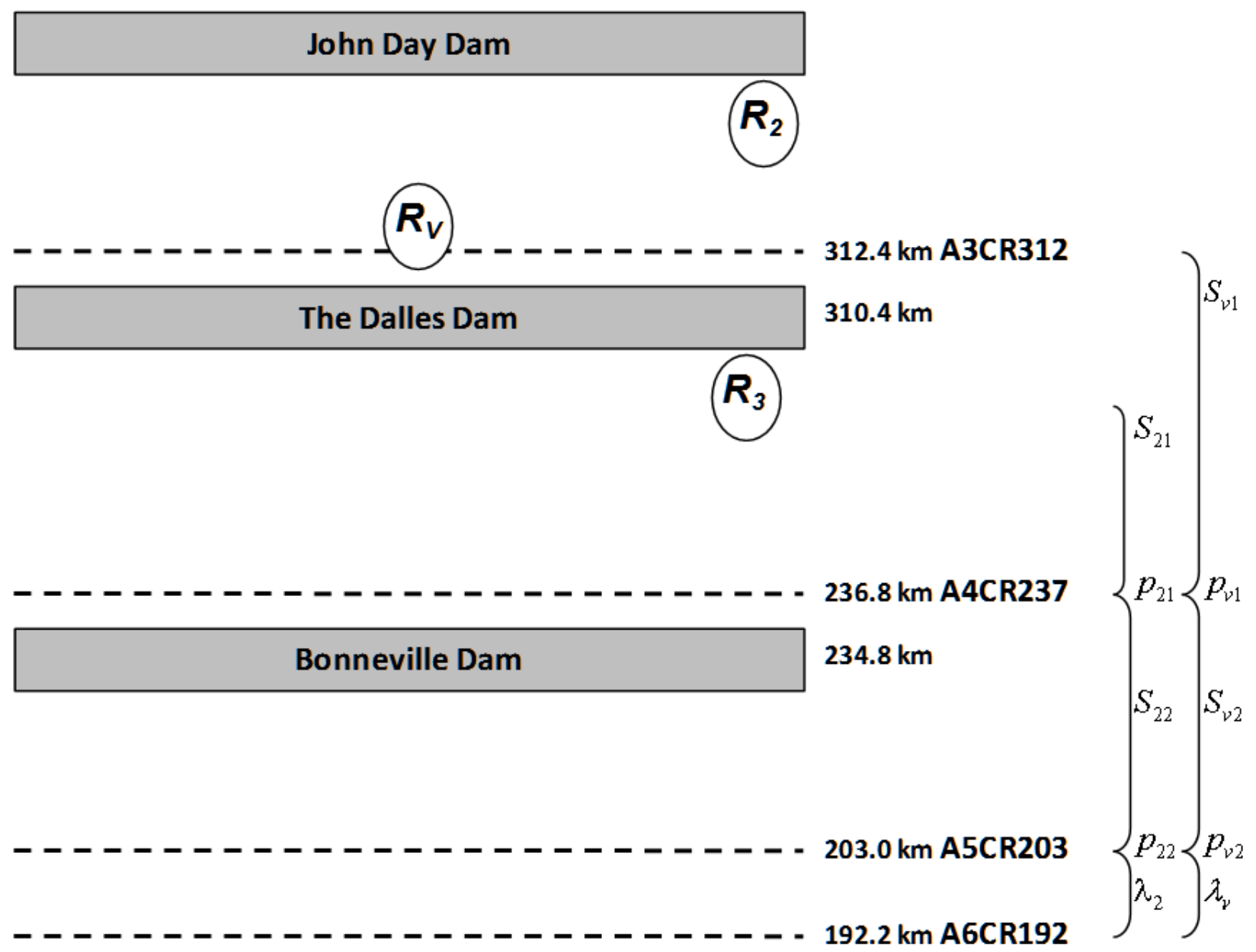

Figure 2.16. Schematic of the paired-release design for estimating fish passage survival rates at The Dalles Dam for subyearling Chinook. Tagged fish were regrouped for a virtual release in The Dalles Dam forebay $\left(R_{V}\right)$ paired with a fish release in The Dalles Dam tailwaters $\left(R_{3}\right)$.

\subsubsection{Estimation of Survival Rate}

Using tagged fish regrouped at the John Day Dam-face array $\left(R_{V 2}\right)$ and released in the John Day Dam $\left(R_{2}\right)$ tailrace, paired release-recapture methods were used to estimate the rate of concrete-passage survival for each fish stock. The detection arrays at A3CR312, A4CR237, and A5CR203 provided $2^{3}=8$ possible capture histories for each release group. Virtual releases were pooled for the entire season when detection probabilities for the three downstream arrays were homogeneous over time. When detection probabilities as a function of release date were heterogeneous, as indicated by a significant Chi square test, we calculated a weighted-mean survival rate for the season. The number of fish in each virtual release was 
used to weight individual estimates of survival rate. In estimating the dam-passage survival rate at John Day Dam, the fully parameterized paired release-recapture model can be written as follows:

$$
\begin{aligned}
L= & \left(\begin{array}{c}
R_{V 2} \\
\underset{\sim}{n}
\end{array}\right)\left(S_{11} p_{11} S_{12} p_{12}\right)^{n_{111}}\left(S_{11}\left(1-p_{11}\right) S_{12} p_{12} \lambda_{1}\right)^{n_{011}} \\
& \cdot\left(S_{11} p_{11} S_{12}\left(1-p_{12}\right) \lambda_{1}\right)^{n_{101}}\left(S_{11}\left(1-p_{11}\right) S_{12}\left(1-p_{12}\right) \lambda_{1}\right)^{n_{011}} \\
& \cdot\left(S_{11} p_{11} S_{12} p_{12}\left(1-\lambda_{1}\right)\right)^{n_{110}}\left(S_{11}\left(1-p_{11}\right) S_{12} p_{12}\left(1-\lambda_{1}\right)\right)^{n_{010}} \\
& \cdot\left(S_{11} p_{11}\left(\left(1-S_{12}\right)+S_{12}\left(1-p_{12}\right)\left(1-\lambda_{1}\right)\right)\right)^{n_{100}} \\
& \cdot\left(\left(1-S_{11}\right)+S_{11}\left(1-p_{11}\right)\left(\left(1-S_{12}\right)+S_{12}\left(1-p_{12}\right)\left(1-\lambda_{1}\right)\right)\right)^{n_{000}} \\
& \cdot\left(\begin{array}{c}
R_{2} \\
\underset{\sim}{m}
\end{array}\right)\left(S_{21} p_{21} S_{22} p_{22} \lambda_{2}\right)^{m_{111}}\left(S_{21}\left(1-p_{21}\right) S_{22} p_{22} \lambda_{2}\right)^{m_{011}} \\
& \cdot\left(S_{21} p_{21} S_{22}\left(1-p_{22}\right) \lambda_{2}\right)^{m_{101}}\left(S_{21}\left(1-p_{21}\right) S_{22}\left(1-p_{22}\right) \lambda_{2}\right)^{m_{011}} \\
& \cdot\left(S_{21} p_{21} S_{22} p_{22}\left(1-\lambda_{2}\right)\right)^{m_{110}}\left(S_{21}\left(1-p_{21}\right) S_{22} p_{22}\left(1-\lambda_{2}\right)\right)^{m_{010}} \\
& \cdot\left(S_{21} p_{21}\left(\left(1-S_{22}\right)+S_{22}\left(1-p_{22}\right)\left(1-\lambda_{2}\right)\right)\right)^{m_{100}} \\
& \cdot\left(\left(1-S_{21}\right)+S_{21}\left(1-p_{21}\right)\left(\left(1-S_{22}\right)+S_{22}\left(1-p_{22}\right)\left(1-\lambda_{2}\right)\right)\right)^{m_{000}}
\end{aligned}
$$

where $\underset{\sim}{n}$ and $\underset{\sim}{m}$ are the vector of counts associated with the downstream capture histories of releases $R_{V 2}$ and $R_{2}$, respectively. For example, $n_{101}$ is the number of $R_{V 2}$ fish detected at A3CR312, not detected at A4CR237, and subsequently detected at A5CR203.

The concrete-passage rate was estimated as the following ratio

$$
\hat{S}_{\mathrm{JDA}}=\frac{\hat{S}_{11}}{\hat{S}_{21}}
$$

with the following associated variance estimator

$$
\widehat{\operatorname{Var}}\left(\hat{S}_{\mathrm{JDA}}\right)=\hat{S}_{\mathrm{JDA}}^{2}\left[\frac{\widehat{\operatorname{Var}}\left(\hat{S}_{11}\right)}{\hat{S}_{11}^{2}}+\frac{\widehat{\operatorname{Var}}\left(\hat{S}_{21}\right)}{\hat{S}_{21}^{2}}\right]
$$

For historical release-recapture studies like this, modeling could be performed to simplify the likelihood for common survival or detection probabilities downriver between the two release groups. However, modeling was not conducted because of the need to apply a different tag-life correction to the tags detected at each array for each release, and the fact that release sizes and detection probabilities were sufficient to meet precision requirements. Tag-life corrections were applied to the individual release Cormack (1964), Jolly (1965), and Seber (1965) (CJS) survival estimates. 
Tag-life corrections were applied to single-release estimates of survival rate for treatment releases of fish passing through John Day Dam and The Dalles Dam and to associated reference releases. In the case of potential tag failure, additional parameters had to be added to the basic survival rate model based on methods of Townsend et al. (2006). Table 2.3 presents the expected probabilities of occurrence for each of the possible capture histories under tag failure where:

- $L_{11}=$ probability a tag from release $R_{1}$ survives the first reach

- $L_{12}=$ probability a tag from release $R_{1}$ survives both reach 1 and reach 2

- $L_{13}=$ probability a tag from release $R_{1}$ survives reaches 1 through 3

- $L_{21}=$ probability a tag from release $R_{2}$ survives the first reach

- $L_{22}=$ probability a tag from release $R_{2}$ survives both reach 1 and reach 2

- $L_{23}=$ probability a tag from release $R_{1}$ survives reaches 1 through 3 .

Table 2.3. Detection histories and expected probabilities of occurrences for releases $R_{1}$ and $R_{2}$ in the presence of tag failure

\begin{tabular}{|c|c|c|}
\hline Release & $\begin{array}{l}\text { Detection } \\
\text { History }\end{array}$ & Expected Probabilities \\
\hline \multirow[t]{8}{*}{$R_{1}$} & 111 & $S_{11} p_{11} S_{12} p_{12} \lambda_{1} L_{13}$ \\
\hline & 011 & $S_{11}\left(1-p_{11}\right) S_{12} p_{12} \lambda_{1} L_{13}$ \\
\hline & 101 & $S_{11} p_{11} S_{12}\left(1-p_{12}\right) \lambda_{1} L_{13}$ \\
\hline & 001 & $S_{11}\left(1-p_{11}\right) S_{12}\left(1-p_{12}\right) \lambda_{1} L_{13}$ \\
\hline & 110 & $S_{11} p_{11} S_{12} p_{12}\left(L_{12}-L_{13} \lambda_{1}\right)$ \\
\hline & 010 & $S_{11}\left(1-p_{11}\right) S_{12} p_{12}\left(L_{12}-L_{13} \lambda_{1}\right)$ \\
\hline & 100 & $S_{11} p_{11}\left[\left(L_{11}-L_{12} S_{12}\right)+S_{12}\left(1-p_{12}\right)\left(L_{12}-L_{13} \lambda_{1}\right)\right]$ \\
\hline & 000 & $\left(1-L_{11} S_{11}\right)+S_{11}\left(1-p_{11}\right)\left[\left(L_{11}-L_{12} S_{12}\right)+S_{12}\left(1-p_{12}\right)\left(L_{12}-L_{13} \lambda_{1}\right)\right]$ \\
\hline \multirow[t]{8}{*}{$R_{2}$} & 111 & $S_{21} p_{21} S_{22} p_{22} \lambda_{2} L_{23}$ \\
\hline & 011 & $S_{21}\left(1-p_{21}\right) S_{22} p_{22} \lambda_{2} L_{23}$ \\
\hline & 101 & $S_{21} p_{21} S_{22}\left(1-p_{22}\right) \lambda_{2} L_{23}$ \\
\hline & 001 & $S_{21}\left(1-p_{21}\right) S_{22}\left(1-p_{22}\right) \lambda_{2} L_{23}$ \\
\hline & 110 & $S_{21} p_{21} S_{22} p_{22}\left(L_{22}-L_{23} \lambda_{2}\right)$ \\
\hline & 010 & $S_{21}\left(1-p_{21}\right) S_{22} p_{22}\left(L_{22}-L_{23} \lambda_{2}\right)$ \\
\hline & 100 & $S_{21} p_{21}\left[\left(L_{21}-L_{22} S_{22}\right)+S_{22}\left(1-p_{22}\right)\left(L_{22}-L_{23} \lambda_{2}\right)\right]$ \\
\hline & 000 & $\left(1-L_{21} S_{21}\right)+S_{21}\left(1-p_{21}\right)\left[\left(L_{21}-L_{22} S_{22}\right)+S_{22}\left(1-p_{22}\right)\left(L_{22}-L_{23} \lambda_{2}\right)\right]$ \\
\hline
\end{tabular}


The joint likelihood can be expressed as

$$
L=L\left(S_{11}, p_{11}, S_{12}, p_{12}, \lambda_{1} \mid R_{1}, \underset{\sim}{n} \underset{\sim 1}{L}\right) \cdot L\left(S_{21}, p_{21}, S_{22}, p_{22}, \lambda_{2} \mid R_{2}, \underset{\sim}{m}, \underset{\sim 2}{L}\right)
$$

The estimates of survival rate from likelihood model (Equation 2.4) should be more reliable because it takes into account possible tag failure and tag-life probabilities less than one.

The estimates of the survival rates and capture parameters in the likelihood model (Equation 2.4) were calculated treating the estimates of tag life (i.e., $\hat{L}_{11}, \hat{L}_{12}, \hat{L}_{21}$, and $\hat{L}_{22}$ ) as known constants. However, to calculate a realistic variance estimator for the survival-rate parameters, the error in the estimation of the tag-life probabilities had to be incorporated into an overall variance calculation.

The variance of the estimates of survival rates can be calculated using the total variance formula

$$
\operatorname{Var}\left(\hat{S}_{P R}\right)=\operatorname{Var}_{\hat{\sim}}\left[E\left(\hat{S}_{P R} \mid \underset{\sim}{\hat{L}}\right)\right]+E_{\hat{L}}\left[\operatorname{Var}\left(\hat{S}_{P R} \mid \underset{\sim}{\hat{L}}\right)\right]
$$

The above variance can therefore be estimated in stages using the expression

$$
\operatorname{Var}\left(\hat{S}_{P R}\right)=s_{\hat{S}_{P R} \mid \hat{L}}^{2}+\operatorname{Var}\left(\hat{S}_{P R} \mid \underset{\sim}{\hat{L}}\right)
$$

The second term in Equation (2.6) was derived from the maximum likelihood model (Equation 2.4) conditioning on the tag-life probabilities (i.e., $\underset{\sim}{\hat{L}}$ ). The first variance component in Equation (2.6) was calculated using bootstrap resampling techniques (Efron and Tibshirani 1993). Alternative estimates of $\hat{\sim}$ were computed by bootstrapping both the observed tag-life data and travel-time data. For each estimated vector of tag-life parameters, survival rate was estimated using the likelihood model (Equation 2.4). One thousand bootstrap estimates of the tag-life parameters were calculated along with the corresponding conditional maximum likelihood estimates of survival rate. The first variance component in Equation (2.6) was then estimated by the quantity

$$
S_{\hat{S}_{P R} \mid \hat{L}}^{2}=\frac{\sum_{b=1}^{1000}\left(\hat{S}_{b}-\hat{\bar{S}}\right)^{2}}{(1000-1)}
$$

where $\hat{S}_{b}=$ the $b$ th bootstrap estimate of survival rate $(b=1, \ldots, 1000)$,

$$
\hat{\bar{S}}=\frac{\sum_{b=1}^{1000} \hat{S}_{b}}{1000}
$$


Use of Equations (2.5) and (2.6) also permitted us to estimate the contribution of sampling error in tag-life parameters to the overall variance in survival-rate estimates.

\subsubsection{Tests of Assumptions}

Each release group (i.e., $R_{v 2}$ and $R_{2}$ ) provides the data to estimate reach survival rate based on the single release-recapture model (Skalski et al. 1998). The assumptions of the single release-recapture model are as follows:

1. Individuals marked for the study are a representative sample from the population of interest.

2. Survival and capture probabilities are not affected by tagging or sampling. That is, tagged animals have the same probabilities as untagged animals.

3. All sampling events are "instantaneous." That is, sampling occurs over a negligible distance relative to the length of the intervals between sampling events.

4. The fate of each tagged individual is independent of the fate of all others.

5. All tagged individuals alive at a sampling location have the same probability of surviving until the end of that event.

6. All tagged individuals alive at a sampling location have the same probability of being detected at that event.

7. All tags are correctly identified and the status of the smolt (i.e., alive or dead) is correctly assessed.

The first assumption concerns making inferences from the sample to the target population. For example, if inferences are sought to Chinook salmon smolts, then the sample of tagged fish should be drawn from that class of fish. Otherwise, nonstatistical inferences are necessary, justifying the similarity between the target population and the representative of acoustic-tagged fish. These assumptions could also be violated if smolts selected for acoustic tagging differ from the target population in a way that biases survivals (either lower or higher).

Assumption 2 again relates to making inferences to the population of interest (i.e., untagged fish). If tagging has a detrimental effect on fish survival, then survival-rate estimates from the single releaserecapture design will tend to be negatively biased (i.e., underestimated).

The third assumption specifies that mortality is negligible immediately in the vicinity of the sampling stations, so that the estimated mortality is related to the river reaches in question and not during the sampling event. In the case of outmigrating smolts, the time they spend in the vicinity of a hydrophone array is brief relative to the size of the river reaches in question. This assumption is for the sake of mathematical convenience and should be fulfilled by the nature of the outmigration dynamics and deployment of the hydrophone array.

The assumption of independence (4) implies that the survival or death of one smolt has no effect on the fates of others. In the larger river system with tens of thousands of smolts, this is likely true. Furthermore, this assumption is common to all tag analyses with little or no evidence collected to suggest it is not generally true. Nevertheless, violations of assumption 4 have little effect on the point estimate but might bias the variance estimate with precision being less than calculated. 
Assumption 5 specifies that a smolt's prior detection history has no effect on its subsequent survival. This could be violated if some smolts were self-trained to repeatedly go through turbine or spill routes or, alternatively, avoid routes because of prior experience. This occurrence is unlikely and can be assessed from the detection histories of the individual smolts. The lack of handling following initial release of acoustic-tagged smolts further minimizes the risk that subsequent detections influence survival. Similarly, assumption 6 could be violated if downstream detections are influenced by upstream passage routes taken by the smolts. Violation of this assumption is minimized by placing hydrophone arrays across the breadth of the river or below the mixing zones for smolts following different passages at the dam.

Assumption 7 implies that the smolts do not lose their tags and are not subsequently misidentified as dead or not captured, nor are dead fish falsely recorded as alive at detection locations. The use of surgically implanted tags should minimize the change of tag loss. Tag loss and tag failure would tend to result in a negative bias (i.e., underestimation) of smolt survival rates. The possibility of tag failure will depend on travel time relative to battery life. Dead fish drifting downstream could also result in a falsepositive detections and upwardly bias estimates of survival rates. For this reason, tailrace hydrophone arrays are not proposed for this set of analyses.

To estimate survival rates from the paired releases, two additional assumptions for valid survival-rate estimates are necessary. These assumptions are

8. Survival in the lower river segment of the first reach is conditionally independent of survival in the upper river segment.

9. Releases $R_{V 2}$ and $R_{2}$ experience the same survival probabilities in the lower river segment of the first reach they share in common.

Assumption 8 implies that there is no synergistic relationship between survival processes in the two river segments within the first reach. In other words, smolts that survive the first river segment are no more or less susceptible to mortality in the second river segment than smolts released in the second river segment. Assumption 9 is satisfied by the in-river mixing of the release groups but can also be satisfied if the survival processes are stable over the course of smolt passage by the releases. A stable survival process might well be expected for one to a few days under similar flow and spill conditions. Furthermore, unlike paired-release methods of the earlier Mid-Columbia survival studies, the assumption of equal capture probabilities is unnecessary for estimation.

\subsubsection{Tests Within a Release}

For the single release-recapture model to be valid, certain data patterns should be evident from the capture histories. Both releases $R_{V 2}$ and $R_{2}$ permit tests of goodness-of-fit to the release-recapture 
model. A series of tests of assumptions was performed to determine the validity of the model (i.e., goodness-of-fit). The data from release $R_{V 2}$ were summarized by an m-array matrix of the form provided below:

\begin{tabular}{|c|c|c|c|}
\hline \multirow[b]{2}{*}{ Release Site } & \multicolumn{3}{|c|}{ Recovery Site } \\
\hline & A3CR312(2) & A4CR237 (3) & A5CR203 (4) \\
\hline JDA Dam Face & $m_{12}$ & $m_{13}$ & $m_{14}$ \\
\hline JDA Tailwater (2) & & $m_{23}$ & $m_{24}$ \\
\hline TDA Tailwater & & & $m_{34}$ \\
\hline
\end{tabular}

The value of $m_{i j}$ are the number of smolts detected at site $i$ that are next detected at site $j$.

Burnham et al. (1987:65, 71-74) present a series of tests of assumptions called Test 2 that examine whether upstream detections affect downstream survival and/or detection. For release $R_{V 2}$, a contingency table test can be performed using a table constructed as follows:

Test 2.2

\begin{tabular}{|l|l|}
\hline$m_{13}$ & $m_{14}$ \\
\hline$m_{23}$ & $m_{24}$ \\
\hline
\end{tabular}$\quad \chi_{1}^{2}$

Burnham et al. (1987:65, 71-74) also present a series of tests of assumptions called Test 3 that examine whether upstream capture histories affect downstream survival and/or capture. For release $R_{V 2}$, a contingency table can be constructed of the form:

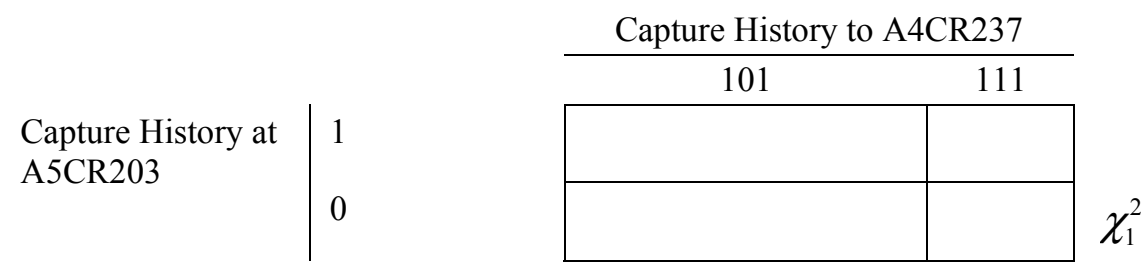

This contingency table tests whether detection at A3CR312 has a subsequent effect on the capture history at A5CR203.

\subsubsection{Tests of Mixing}

For the estimates of dam-passage, concrete-passage, and route-specific survival rates to be valid, the detection data need to conform to the assumptions of statistical model. One assumption is the downstream mixing of release groups. A chi-square $\mathrm{R} \times \mathrm{C}$ contingency tables was used to evaluate the 
assumption of homogeneous arrival distributions for releases $R_{V 2}$ and $R_{2}$ at A3CR312 for JDA pairedrelease estimates. The chi-square contingency table tests of homogeneity are of the following form:

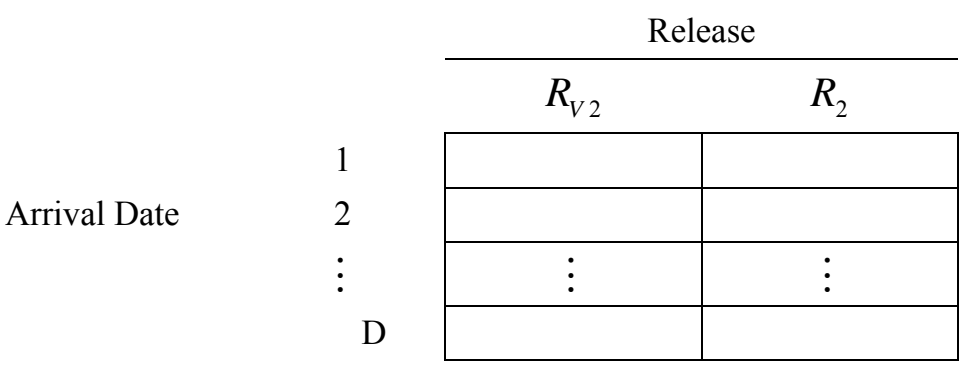

Instead of running specific chi-square tests on the TOA data, which are notoriously sensitive to slight departures in distributions, we plotted the cumulative hour of arrival of fish in each release pair (e.g., $R_{V 2}$ and $R_{2}$ ), fish stock, and dam (John Day Dam and The Dalles Dam) at the primary survival-detection array and looked for systematic deviations between the two arrival distributions over time. These plots and the plots of arrival times before and after midnight were used to assess the efficacy of the mixing assumption for the 2008 survival models.

To test whether releases with a paired-release (e.g., $R_{V 2}$ and $R_{2}$ ) have similar downstream survival and capture histories for Arlington, Oregon and below, likelihood ratio tests (LRTs) were performed to compare models. Sequential LRTs were used to help determine the most parsimonious model for the estimation of $p_{11}, p_{21}, S_{12}, S_{22}, p_{12}, p_{22}, \lambda_{1}$, and $\lambda_{2}$ (Figure 2.14).

\subsubsection{Probabilities of Detection}

Detection probabilities are an integral part of the survival estimation. For any particular passage route the following variables are defined (Figure 2.17):

- $n_{10}=$ number of tagged smolts detected at the first array but not the second

- $n_{01}=$ number of tagged smolts detected at the second array but not the first

- $n_{11}=$ number of tagged smolts detected at both the first and second arrays.

From these counts of smolts with various route-specific detection histories, absolute passage abundance $(\hat{N})$ of tagged smolts can be estimated as

$$
\hat{N}=\frac{\left(n_{10}+n_{11}+1\right)\left(n_{01}+n_{11}+1\right)}{\left(n_{11}+1\right)}-1
$$

or 


$$
\hat{N}=\frac{\left(n_{1}+1\right)\left(n_{2}+1\right)}{\left(n_{11}+1\right)}-1
$$

where $n_{1}=n_{10}+n_{11}$ and $n_{2}=n_{01}+n_{11}$ with associated variance estimate (Seber 1982:60)

$$
\widehat{\operatorname{Var}}(\hat{N})=\frac{\left(n_{1}+1\right)\left(n_{2}+1\right)\left(n_{1}-n_{11}\right)\left(n_{2}-n_{11}\right)}{\left(n_{11}+1\right)^{2}\left(n_{11}+2\right)}
$$

The estimated probability of detection $\left(p_{1}\right)$ in the first array is calculated as

$$
\hat{p}_{1}=\frac{n_{11}}{n_{2}}
$$

and the probability of detection $\left(p_{2}\right)$ in the second array as

$$
\hat{p}_{2}=\frac{n_{11}}{n_{1}}
$$

The overall probability of a smolt being detected in the double-array system is given by

$$
\hat{P}=1-\left(1-\hat{p}_{1}\right)\left(1-\hat{p}_{2}\right)=\frac{n_{11}\left(n_{1}+n_{2}+n_{11}\right)}{n_{1} n_{2}}
$$

Passage abundance was estimated for the powerhouse $\hat{N}_{P H}$, spillway $\hat{N}_{S P}$, and $\operatorname{TSW}\left(\hat{N}_{T S W}\right)$. For the fish entering the JBS, the PIT-tag detection system was used to provide a complete tally of that passage abundance $\left(\hat{N}_{J B S}\right)$, assuming $100 \%$ detection efficiency.

The proportion of the acoustic-tagged smolts passing through the powerhouse $\hat{P}_{P H}$ was estimated as follows:

$$
\hat{P}_{\mathrm{PH}}=\frac{\hat{N}_{\mathrm{PH}}}{\hat{N}_{\mathrm{PH}}+\hat{N}_{\mathrm{SP}}+\hat{N}_{\mathrm{TSW}}+N_{\mathrm{JBS}}}
$$




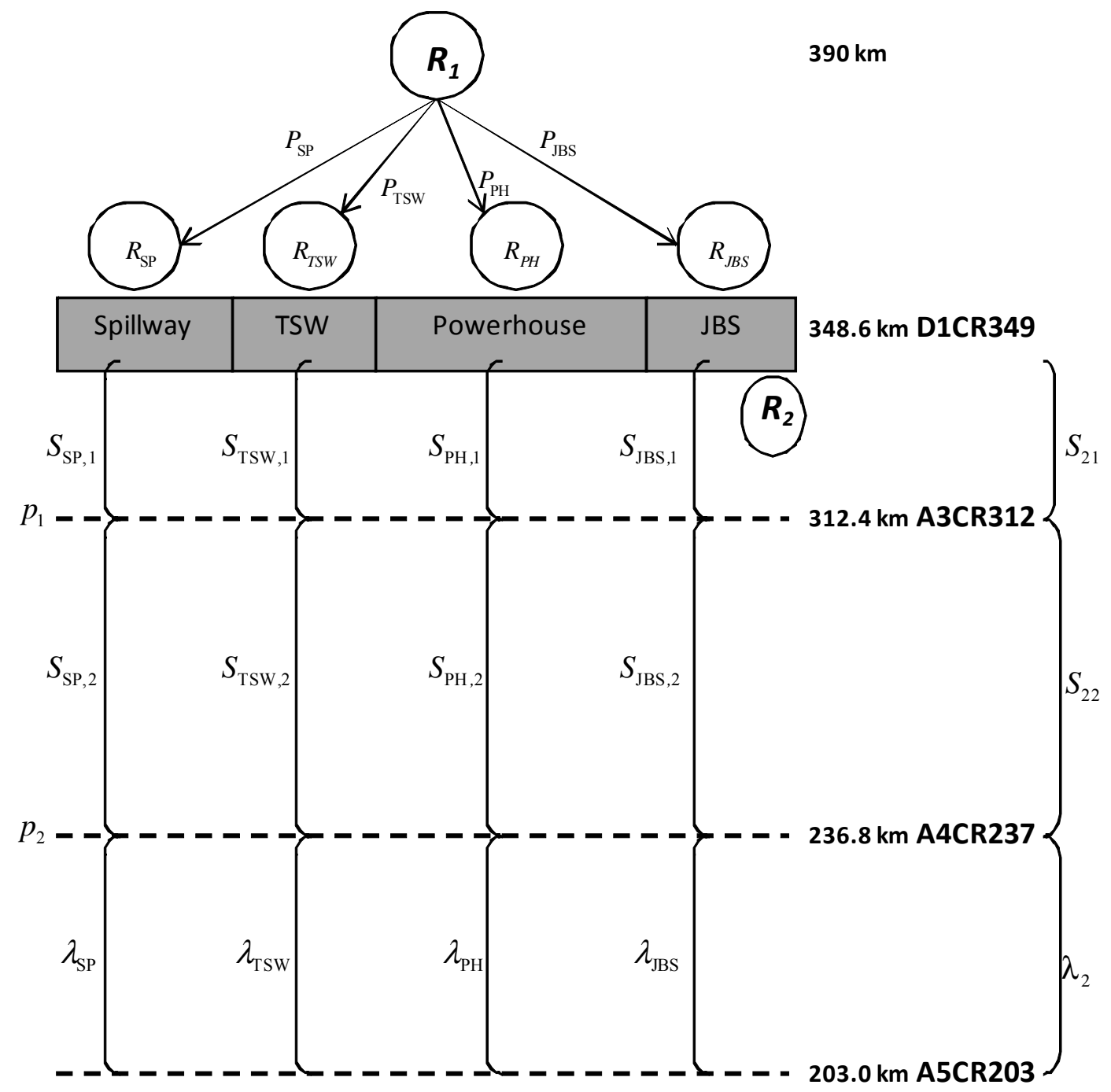

Figure 2.17. Schematic of route-specific passage and downstream recoveries for virtual releases at the spillway $\left(R_{\mathrm{SP}}\right)$, TSW $\left(R_{\mathrm{TSW}}\right)$, powerhouse $\left(R_{\mathrm{PH}}\right)$, and JBS $\left(R_{\mathrm{JBS}}\right)$

Using the delta method (Seber 1982:7-9), the variance of $\hat{P}_{P H}$ is approximated by

$$
\widehat{\operatorname{Var}}\left(\hat{P}_{\mathrm{PH}}\right)=\frac{\hat{P}_{\mathrm{PH}}\left(1-\hat{P}_{\mathrm{PH}}\right)}{\hat{N}}+\hat{P}_{\mathrm{PH}}^{2}\left(1-\hat{P}_{\mathrm{PH}}\right)^{2} \cdot\left[\frac{\widehat{\operatorname{Var}}\left(\hat{N}_{\mathrm{PH}}\right)}{\hat{N}_{\mathrm{PH}}^{2}}+\frac{\widehat{\operatorname{Var}}\left(\hat{N}_{\mathrm{SP}}\right)+\widehat{\operatorname{Var}}\left(\hat{N}_{\mathrm{TSW}}\right)+\widehat{\operatorname{Var}}\left(\hat{N}_{\mathrm{JBS}}\right)}{\left(\hat{N}_{\mathrm{SP}}+\hat{N}_{\mathrm{TSW}}+N_{\mathrm{JBS}}\right)^{2}}\right],
$$

where $\hat{N}=\hat{N}_{\mathrm{PH}}+\hat{N}_{\mathrm{SP}}+\hat{N}_{\mathrm{TSW}}+N_{\mathrm{JBS}}$. Values of $\hat{P}_{\mathrm{SP}}, \hat{P}_{\mathrm{TSW}}$, and $\hat{P}_{\mathrm{JBS}}$ were estimated analogously to Equation (2.18) and associated variances estimated analogously to Equation (2.19). Note for $N_{\text {JBS }}$ that $\operatorname{Var}\left(N_{J B S}\right)=0$. 


\subsubsection{Route-Specific Relative Survival Rates}

The 2D hydrophone array in the John Day Dam forebay was used to identify fish known to have passed through the spillway, powerhouse, and TSWs (spill bays 15-16).

Smolts known to have passed through the various routes at John Day Dam (Figure 2.17) were detected by listening devices on downstream arrays to obtain their capture histories. To estimate survival, it is first necessary to quantify the number of smolts passing by various routes, as follows:

- $R_{\mathrm{PH}}=$ number of smolts known to have passed through the powerhouse

- $n_{\mathrm{PH}}=$ number of smolts among $R_{\mathrm{PH}}$ detected downriver

- $R_{\mathrm{SP}}=$ number of smolts known to have passed through the spillway

- $n_{\mathrm{SP}}=$ number of smolts among $R_{\mathrm{SP}}$ detected downriver

- $R_{\mathrm{TSW}}=$ number of smolts known to have passed through the TSW

- $n_{\mathrm{TSW}}=$ number of smolts among $R_{\mathrm{TSW}}$ detected downriver

- $R_{\mathrm{JBS}}=$ number of smolts known to have passed through the JBS

- $n_{\mathrm{JBS}}=$ number of smolts among $R_{\mathrm{JBS}}$ detected downriver.

Using the relative recoveries of smolts through the various routes compared to the powerhouse, the relative route-specific survival probabilities can be estimated, e.g., the spill bay,

$$
R S_{\mathrm{SP} / \mathrm{PH}}=\frac{\left(\frac{n_{\mathrm{SP}}}{R_{\mathrm{SP}}}\right)}{\left(\frac{n_{\mathrm{PH}}}{R_{\mathrm{PH}}}\right)} .
$$

The variance of $R S_{\mathrm{SP} P \mathrm{PH}}$ is estimated by

$$
\widehat{\operatorname{Var}}\left(\widehat{R S}_{\mathrm{SP} / \mathrm{PH}}\right)=\widehat{R S}_{\mathrm{SP} / \mathrm{PH}}^{2}\left[\frac{1}{n_{\mathrm{PH}}}-\frac{1}{R_{\mathrm{PH}}}+\frac{1}{n_{\mathrm{SP}}}-\frac{1}{R_{\mathrm{SP}}}\right]
$$

The estimators of relative survival rates for the other three routes are analogous to Equation (2.20) and their variances analogous to Equation (2.21).

\subsubsection{Route-Specific Passage Survival Rates}

Using the smolts known to have passed through a specific route at the dam, absolute survival rates from the dam entrance to the tailrace release location were estimated using a paired release-recapture 
model analogous to Equation (2.2). The virtual release through a route was paired with the common tailrace release $\left(R_{2}\right)$ (Figure 2.14). All routes shared the same downstream control group.

It should be noted that pairing a virtual release with the tailrace group is pairing fish that have resided in river and previously tagged with newly tagged and released fish. Any post-release handling mortality among the $R_{2}$ smolts will positively bias the estimates of route-specific survival rates.

Route-specific survival rates for the powerhouse-passed fish were estimated by the quotient

$$
\hat{S}_{\mathrm{PH}}=\frac{\hat{S}_{\mathrm{PH}, 1}}{\hat{S}_{21}}
$$

with associated variance estimator

$$
\widehat{\operatorname{Var}}\left(\hat{S}_{\mathrm{PH}}\right)=\hat{S}_{\mathrm{PH}}^{2}\left[\frac{\widehat{\operatorname{Var}}\left(\hat{S}_{\mathrm{PH}, 1}\right)}{\hat{S}_{\mathrm{PH}, 1}^{2}}+\frac{\widehat{\operatorname{Var}}\left(\hat{S}_{21}\right)}{\hat{S}_{21}^{2}}\right]
$$

Route-specific passage survival rates through the spillway, TSW, or JBS were calculated analogously to Equation (2.22) with associated variance estimators analogous to Equation (2.23).

\subsubsection{Concrete-Passage Survival Rates}

Two approaches to estimating concrete-passage survival through John Day Dam were used. The first approach uses the estimated passage proportions (Equation [2.18]) and route-specific estimates of survival rates (Equation [2.22]), where

$$
\hat{S}_{\text {Concrete }}=\hat{P}_{\mathrm{PH}} \cdot \hat{S}_{\mathrm{PH}}+\hat{P}_{\mathrm{SP}} \cdot \hat{S}_{\mathrm{SP}}+\hat{P}_{\mathrm{TSW}} \cdot \hat{S}_{\mathrm{TSW}}+\hat{P}_{\mathrm{JBS}} \cdot \hat{S}_{\mathrm{JBS}}
$$

This first method reconstructs the dam-passage survival rate by summing the survival contributions through each route. The second approach uses a paired release (Figure 2.14) based on fish known to have arrived at the dam (i.e., a virtual release) with the tailrace release $R_{2}$. A paired release-recapture model analogous to Equation (2.2) was used to estimate the overall concrete-passage survival rate based on fish known to have arrived at the dam face and the common tailrace release $R_{2}$ (Figure 2.14).

Both of the above approaches are susceptible to positive bias due to the pairing of in-river, previously tagged fish with newly tagged and released smolts. If the passage proportions and route-specific survival rates are estimated properly, both estimation approaches should produce similar, albeit possibly biased, estimates of the total concrete-passage survival rate. 


\subsubsection{Lower Granite Dam Tagged Fish - John Day Dam Concrete-Passage Survival Rate}

Using tagged fish released at Lower Granite Dam $(R)$ and regrouped at the John Day Dam-face array $\left(R_{V}\right)$ and paired with John Day Dam $\left(R_{1}\right)$ tailrace released fish, paired release-recapture methods were used to estimate concrete-passage survival rates. The detection arrays at A3CR312, A4CR237, and A5CR203 provided $2^{3}=8$ possible capture histories for each release group. A sample-size weightedmean estimate of survival rate usually was estimated for the season because detection probabilities on the three downstream arrays rarely were homogeneous through time. When detection probabilities were homogeneous through time, as indicated by a nonsignificant chi-square test, virtual and tailrace release trials were pooled to estimate survival for the season.

In estimating the John Day Dam-passage survival rate for fish released at Lower Granite Dam, a fully parameterized paired release-recapture model can be written as follows:

$$
\begin{aligned}
L= & \left(\begin{array}{c}
R_{V} \\
\underset{\sim}{\sim}
\end{array}\right)\left(S_{11} p_{11} S_{12} p_{12}\right)^{n_{111}}\left(S_{11}\left(1-p_{11}\right) S_{12} p_{12} \lambda_{1}\right)^{n_{011}} \\
& \cdot\left(S_{11} p_{11} S_{12}\left(1-p_{12}\right) \lambda_{1}\right)^{n_{101}}\left(S_{11}\left(1-p_{11}\right) S_{12}\left(1-p_{12}\right) \lambda_{1}\right)^{n_{011}} \\
& \cdot\left(S_{11} p_{11} S_{12} p_{12}\left(1-\lambda_{1}\right)\right)^{n_{110}}\left(S_{11}\left(1-p_{11}\right) S_{12} p_{12}\left(1-\lambda_{1}\right)\right)^{n_{010}} \\
& \cdot\left(S_{11} p_{11}\left(\left(1-S_{12}\right)+S_{12}\left(1-p_{12}\right)\left(1-\lambda_{1}\right)\right)\right)^{n_{100}} \\
& \cdot\left(\left(1-S_{11}\right)+S_{11}\left(1-p_{11}\right)\left(\left(1-S_{12}\right)+S_{12}\left(1-p_{12}\right)\left(1-\lambda_{1}\right)\right)\right)^{n_{000}} \\
& \cdot\left(\begin{array}{l}
R_{1} \\
\underset{\sim}{m}
\end{array}\right)\left(S_{21} p_{21} S_{22} p_{22} \lambda_{2}\right)^{m_{111}}\left(S_{21}\left(1-p_{21}\right) S_{22} p_{22} \lambda_{2}\right)^{m_{011}} \\
& \cdot\left(S_{21} p_{21} S_{22}\left(1-p_{22}\right) \lambda_{2}\right)^{m_{101}}\left(S_{21}\left(1-p_{21}\right) S_{22}\left(1-p_{22}\right) \lambda_{2}\right)^{m_{011}} \\
& \cdot\left(S_{21} p_{21} S_{22} p_{22}\left(1-\lambda_{2}\right)\right)^{m_{110}}\left(S_{21}\left(1-p_{21}\right) S_{22} p_{22}\left(1-\lambda_{2}\right)\right)^{m_{010}} \\
& \cdot\left(S_{21} p_{21}\left(\left(1-S_{22}\right)+S_{22}\left(1-p_{22}\right)\left(1-\lambda_{2}\right)\right)\right)^{m_{100}} \\
& \cdot\left(\left(1-S_{21}\right)+S_{21}\left(1-p_{21}\right)\left(\left(1-S_{22}\right)+S_{22}\left(1-p_{22}\right)\left(1-\lambda_{2}\right)\right)\right)^{m_{000}},
\end{aligned}
$$

where $\underset{\sim}{n}$ and $\underset{\sim}{m}$ are the vector of counts associated with the downstream capture histories of releases $R_{V}$

and $R_{1}$, respectively. For example, $n_{101}$ is the number of $R_{V}$ fish detected at A3CR312, not detected at A4CR237, and subsequently detected at A5CR203.

The concrete-passage survival rate was estimated as the ratio

$$
\hat{S}_{L G R}=\frac{\hat{S}_{11}}{\hat{S}_{21}}
$$


with associated variance estimator

$$
\widehat{\operatorname{Var}}\left(\hat{S}_{L G R}\right)=\hat{S}_{L G R}^{2}\left[\frac{\widehat{\operatorname{Var}}\left(\hat{S}_{11}\right)}{\hat{S}_{11}^{2}}+\frac{\widehat{\operatorname{Var}}\left(\hat{S}_{21}\right)}{\hat{S}_{21}^{2}}\right] .
$$

Model selection procedures were used to find the most parsimonious model to describe the paired release-recapture data as described in Section 2.5.2 immediately after Equation (2.3).

\subsubsection{Dam-Passage Survival Rate for The Dalles Dam}

In spring, tagged fish were regrouped at The Dalles Dam forebay entrance array (A3CR312) to define virtual releases $R_{\mathrm{v}}$ and the dam-passage survival rate was estimated using a single release-recapture method. There were no releases of YC or STH in The Dalles Dam tailrace in spring so paired release estimates were not possible. In summer, tagged fish were regrouped at the same location $\left(R_{\mathrm{v}}\right)$ and virtually released and paired with fish released from The Dalles Dam tailrace $\left(R_{3}\right)$ to obtain dam-passage survival rates using the paired release-recapture method. The detection arrays at A4CR237, A5CR203, and A6CR192 provided $2^{3}=8$ possible capture histories for each release group. A sample-size weightedmean estimate of survival usually was estimated for the season because detection probabilities on the three downstream arrays rarely were homogeneous through time. When detection probabilities were homogeneous through time, trials were pooled throughout the season. In estimating The Dalles Dampassage survival rate for fish virtually released in The Dalles Dam forebay, the fully parameterized paired release-recapture model can be written as follows:

$$
\begin{aligned}
L= & \left(\begin{array}{c}
R_{V} \\
\underset{\sim}{\sim}
\end{array}\right)\left(S_{11} p_{11} S_{12} p_{12}\right)^{n_{111}}\left(S_{11}\left(1-p_{11}\right) S_{12} p_{12} \lambda_{1}\right)^{n_{011}} \\
& \cdot\left(S_{11} p_{11} S_{12}\left(1-p_{12}\right) \lambda_{1}\right)^{n_{101}}\left(S_{11}\left(1-p_{11}\right) S_{12}\left(1-p_{12}\right) \lambda_{1}\right)^{n_{011}} \\
& \cdot\left(S_{11} p_{11} S_{12} p_{12}\left(1-\lambda_{1}\right)\right)^{n_{110}}\left(S_{11}\left(1-p_{11}\right) S_{12} p_{12}\left(1-\lambda_{1}\right)\right)^{n_{010}} \\
& \cdot\left(S_{11} p_{11}\left(\left(1-S_{12}\right)+S_{12}\left(1-p_{12}\right)\left(1-\lambda_{1}\right)\right)\right)^{n_{100}} \\
& \cdot\left(\left(1-S_{11}\right)+S_{11}\left(1-p_{11}\right)\left(\left(1-S_{12}\right)+S_{12}\left(1-p_{12}\right)\left(1-\lambda_{1}\right)\right)\right)^{n_{000}} \\
& \cdot\left(\begin{array}{l}
R_{3} \\
\underset{\sim}{m}
\end{array}\right)\left(S_{21} p_{21} S_{22} p_{22} \lambda_{2}\right)^{m_{111}}\left(S_{21}\left(1-p_{21}\right) S_{22} p_{22} \lambda_{2}\right)^{m_{011}} \\
& \cdot\left(S_{21} p_{21} S_{22}\left(1-p_{22}\right) \lambda_{2}\right)^{m_{101}}\left(S_{21}\left(1-p_{21}\right) S_{22}\left(1-p_{22}\right) \lambda_{2}\right)^{m_{011}} \\
& \cdot\left(S_{21} p_{21} S_{22} p_{22}\left(1-\lambda_{2}\right)\right)^{m_{110}}\left(S_{21}\left(1-p_{21}\right) S_{22} p_{22}\left(1-\lambda_{2}\right)\right)^{m_{010}} \\
& \cdot\left(S_{21} p_{21}\left(\left(1-S_{22}\right)+S_{22}\left(1-p_{22}\right)\left(1-\lambda_{2}\right)\right)\right)^{m_{100}} \\
& \cdot\left(\left(1-S_{21}\right)+S_{21}\left(1-p_{21}\right)\left(\left(1-S_{22}\right)+S_{22}\left(1-p_{22}\right)\left(1-\lambda_{2}\right)\right)\right)^{m_{000}}
\end{aligned}
$$

where $\underset{\sim}{n}$ and $\underset{\sim}{m}$ are the vector of counts associated with the downstream capture histories of releases $R_{V}$ and $R_{3}$, respectively. For example, $n_{101}$ is the number of $R_{V}$ fish detected at A4CR237, not detected at A5CR203, and subsequently detected at A6CR192. 
The dam-passage survival rate was estimated as the ratio

$$
\hat{S}_{\mathrm{TDA}}=\frac{\hat{S}_{11}}{\hat{S}_{21}}
$$

with associated variance estimator

$$
\widehat{\operatorname{Var}}\left(\hat{S}_{\mathrm{TDA}}\right)=\hat{S}_{\mathrm{TDA}}^{2}\left[\frac{\widehat{\operatorname{Var}}\left(\hat{S}_{11}\right)}{\hat{S}_{11}^{2}}+\frac{\widehat{\operatorname{Var}}\left(\hat{S}_{21}\right)}{\hat{S}_{21}^{2}}\right] .
$$

\subsection{Statistical Methods - Fish Passage}

Fish passage was characterized by estimating various passage efficiencies (e.g., spillway-passage efficiency and TSW-passage efficiency). Spatial and temporal trends in passage and residence and egress times were also estimated, as described below.

\subsubsection{Fish Passage Characterization}

Fish-passage efficiency (FPE) is defined as the proportion of fish that pass through the dam through nonturbine routes (i.e., spill, TSW, or JBS). In this study, FPE was estimated by the sum of the proportions nonturbine passage proportions:

$$
\widehat{\mathrm{FPE}}=\hat{P}_{\mathrm{SP}}+\hat{P}_{\mathrm{TSW}}+\hat{P}_{\mathrm{JBS}}
$$

with associated variance estimator

$$
\begin{aligned}
\widehat{\operatorname{Var}}(\widehat{\mathrm{FPE}})= & \frac{\widehat{\mathrm{FPE}}(1-\widehat{\mathrm{FPE}})}{\hat{N}}+\widehat{\mathrm{FPE}}^{2}(1-\widehat{\mathrm{FPE}})^{2} \\
& \cdot\left[\frac{\widehat{\operatorname{Var}}\left(\hat{N}_{\mathrm{PH}}\right)}{\hat{N}_{\mathrm{PH}}^{2}}+\frac{\widehat{\operatorname{Var}}\left(\hat{N}_{\mathrm{SP}}\right)+\widehat{\operatorname{Var}}\left(\hat{N}_{\mathrm{TSW}}\right)+\widehat{\operatorname{Var}}\left(\hat{N}_{\mathrm{JBS}}\right)}{\left(\hat{N}_{\mathrm{SP}}+\hat{N}_{\mathrm{TSW}}+\hat{N}_{\mathrm{JBS}}\right)^{2}}\right] .
\end{aligned}
$$

Spillway-passage efficiency (SE) is defined as the proportion of fish that pass through the spillway (i.e., TSW and non-TSW spill bays). In the case of this study, SE refers to fish that pass through the spillway, or TSW. SE was estimated by the sum

$$
\widehat{\mathrm{SE}}=\hat{P}_{\mathrm{SP}}+\hat{P}_{\mathrm{TSW}}
$$


with associated variance estimator

$$
\begin{aligned}
\operatorname{Var}(\widehat{\mathrm{SE}})= & \frac{\widehat{\mathrm{SE}}(1-\widehat{\mathrm{SE}})}{\hat{N}}+\widehat{\mathrm{SE}}^{2}(1-\widehat{\mathrm{SE}})^{2} \\
& \cdot\left[\frac{\widehat{\operatorname{Var}}\left(\hat{N}_{\mathrm{SP}}\right)+\left(\hat{N}_{\mathrm{TSW}}\right)}{\left(\hat{N}_{\mathrm{SP}}+\hat{N}_{\mathrm{TSW}}\right)^{2}}+\frac{\widehat{\operatorname{Var}}\left(\hat{N}_{\mathrm{PH}}\right)+\widehat{\operatorname{Var}}\left(\hat{N}_{\mathrm{JBS}}\right)}{\left(\hat{N}_{\mathrm{PH}}+\hat{N}_{\mathrm{JBS}}\right)^{2}}\right]
\end{aligned}
$$

Spillway-passage effectiveness (SEF) is defined as the ratio of spillway-passage efficiency divided by the proportion of water passing the spillway relative to the total water discharge through the dam. In the case of this study, SEF was estimated as

$$
\widehat{\mathrm{SEF}}=\frac{\hat{P}_{\mathrm{SP}}+\hat{P}_{\mathrm{TSW}}}{\left(\frac{f_{\mathrm{SP}}}{F}\right)}=\widehat{\mathrm{SE}}\left(\frac{F}{f_{\mathrm{SP}}}\right)
$$

where $F=$ total water volume discharge at the dam and $f=$ total water volume discharge through the spillway and TSW. The variance of $\widehat{\mathrm{SEF}}$ was calculated as

$$
\widehat{\operatorname{Var}}(\widehat{\mathrm{SEF}})=\widehat{\operatorname{Var}}(\widehat{\mathrm{SE}})\left(\frac{F}{f}\right)^{2}
$$

Top spillway weir passage efficiency (TSWE) is defined as the proportion of smolts passing the dam through the TSW spill bays. For this study, the efficiency of TSW passage was expressed by

$$
\widehat{\mathrm{TSWE}}=\hat{P}_{\mathrm{TSW}}
$$

with associated variance estimator

$$
\begin{aligned}
\widehat{\operatorname{Var}}(\widehat{\mathrm{TSWE}})= & \frac{\hat{P}_{\mathrm{TSW}}\left(1-\hat{P}_{\mathrm{TSW}}\right)}{\hat{N}}+\hat{P}_{\mathrm{TSW}}{ }^{2}\left(1-\hat{P}_{\mathrm{TSW}}\right)^{2} \\
& \cdot\left[\frac{\widehat{\operatorname{Var}}\left(\hat{N}_{\mathrm{TSW}}\right)}{\hat{N}_{\mathrm{TSW}}^{2}}+\frac{\widehat{\operatorname{Var}}\left(\hat{N}_{\mathrm{SP}}\right)+\widehat{\operatorname{Var}}\left(\hat{N}_{\mathrm{PH}}\right)+\widehat{\operatorname{Var}}\left(\hat{N}_{\mathrm{JBS}}\right)}{\left(\hat{N}_{\mathrm{SP}}+\hat{N}_{\mathrm{PH}}+\hat{N}_{\mathrm{JBS}}\right)^{2}}\right] .
\end{aligned}
$$

The TSW passage effectiveness (TSWEF) is defined as TSW passage efficiency divided by the proportion of water discharge through the dam that passed through TSW spill bays. For this study, the effectiveness of TSW was expressed as the quotient

$$
\widehat{\mathrm{TSWEF}}=\frac{\hat{P}_{\mathrm{TSW}}}{\left(\frac{f_{\mathrm{TSW}}}{F}\right)}=\widehat{\mathrm{TSWE}}\left(\frac{F}{f_{\mathrm{TSW}}}\right)
$$


where $f_{\text {TSW }}=$ total water volume discharge through the TSW.

The variance of the $\widehat{\mathrm{TSWEF}}$ was estimated by the quantity

$$
\widehat{\operatorname{Var}}(\widehat{\mathrm{TSWEF}})=\widehat{\operatorname{Var}}(\widehat{\mathrm{TSWE}}) \cdot\left(\frac{F}{f_{\mathrm{TSW}}}\right)^{2}
$$

Fish-guidance efficiency (FGE) is the proportion of smolts entering turbines that were subsequently guided by in-turbine screens to the JBS. It was estimated by the proportion

$$
\widehat{\mathrm{FGE}}=\hat{P}_{\mathrm{JBS}}
$$

with the associated variance estimator

$$
\begin{aligned}
\widehat{\operatorname{Var}}(\widehat{\mathrm{FGE}})= & \frac{\widehat{\mathrm{FGE}}(1-\widehat{\mathrm{FGE}})}{\hat{N}}+\widehat{\mathrm{FGE}}^{2}(1-\widehat{\mathrm{FGE}})^{2} \\
& \cdot\left[\frac{\widehat{\operatorname{Var}}\left(\hat{N}_{\mathrm{JBS}}\right)}{\hat{N}_{\mathrm{JBS}}^{2}}+\frac{\widehat{\operatorname{Var}}\left(\hat{N}_{\mathrm{SP}}\right)+\widehat{\operatorname{Var}}\left(\hat{N}_{\mathrm{PH}}\right)+\widehat{\operatorname{Var}}\left(\hat{N}_{\mathrm{TSW}}\right)}{\left(\hat{N}_{\mathrm{SP}}+\hat{N}_{\mathrm{PH}}+\hat{N}_{\mathrm{TSW}}\right)^{2}}\right] .
\end{aligned}
$$

The passage efficiency of the JBS (JBSE) is the proportion of fish passing the dam through the JBS:

$$
\mathrm{JBSE}=\hat{P}_{\mathrm{JBS}}
$$

with the associated variance estimator

$$
\begin{aligned}
\widehat{\operatorname{Var}}(\widehat{\mathrm{JBSE}})= & \frac{\widehat{P}_{\mathrm{JBS}}\left(1-\widehat{P}_{\mathrm{JBS}}\right)}{\hat{N}}+\hat{P}_{\mathrm{JBS}}^{2}\left(1-\widehat{P}_{\mathrm{JBS}}\right)^{2} \\
& \cdot\left[\frac{\widehat{\operatorname{Var}}\left(\hat{N}_{\mathrm{JBS}}\right)}{\hat{N}_{\mathrm{JBS}}^{2}}+\frac{\widehat{\operatorname{Var}}\left(\hat{N}_{\mathrm{PH}}\right)+\widehat{\operatorname{Var}}\left(\hat{N}_{\mathrm{SP}}\right)+\widehat{\operatorname{Var}}\left(\hat{N}_{\mathrm{TSW}}\right)}{\left(\hat{N}_{\mathrm{PH}}+\hat{N}_{\mathrm{SP}}+\hat{N}_{\mathrm{TSW}}\right)^{2}}\right] .
\end{aligned}
$$

\subsubsection{Spatial Trends}

Based on detections on the dam-face array and 3D tracking, we were able to estimate the horizontal distribution of passage of each stock of fish at John Day Dam according to the individual turbine and spill bay of passage. The same 3D tracking data set allowed us to evaluate the vertical distribution of smolts within $75 \mathrm{~m}$ of the dam.

For a broader picture of fish behavior in the forebay, we compared the distribution of smolts detected on the forebay entrance array $2 \mathrm{~km}$ upstream of John Day Dam with the distribution of smolt passage at the dam. Smolt detections on the forebay array were assigned to horizontal blocks corresponding to locations upstream of dam structures, as follows (from south to north): PH1-8 = powerhouse units 1-8, 
PH9-16 = powerhouse units 9-16, skeleton bays, SW17-20 = spill bays 17-20, SW15-16 = spill bays 15-16 (each with a TSW), and SW1-14 = spill bays 1-14. Passage locations also were grouped into blocks of routes with the same names used to describe smolt arrivals, except that skeleton bays were dropped because they could not pass fish. This approach allowed us to examine how smolts behaviorally responded to the dam by avoiding or selecting blocks of passage routes. Similar arrival and passage distributions would suggest that smolt responses to forebay conditions and operations were limited, whereas substantial shifts in those distributions would indicate that smolts were responding to forebay conditions or operations by selecting preferred blocks of routes.

\subsubsection{Residence and Egress Times and Travel Rates}

As mentioned above, the John Day Dam forebay array was used to create a virtual release for fish as they enter the forebay $2 \mathrm{~km}$ upstream of John Day Dam. The John Day Dam-face array was used to create a virtual release for fish known to have passed John Day Dam and to estimate the route of passage at the dam using $3 \mathrm{D}$ tracking and last-detection data. The time of last detection by the dam-face array minus the time of first detection on the forebay array provide an estimate of forebay residence time. The time of first detection by the John Day Dam tailwater egress array minus the time of last detection on the dam-face array provided an estimate of relative egress time.

\subsection{Statistical Methods - Fish Tracking}

Fish behavior was assessed by 3D tracking of JSATS-tagged fish in the immediate forebay of John Day Dam.

\subsubsection{Tracking Algorithms}

Acoustic tracking is a common technique in bioacoustics based on TOA differences (TOADs) among different hydrophones. Usually, the process requires a three-hydrophone array for 2D tracking and a four-hydrophone array for 3D tracking. For this study, only 3D tracking was performed.

Consider a transmitting source (tag) in the range of a four-hydrophone array. The boldface letters indicate matrices or vectors. The source (S) and receiver (r) position vectors are defined as follows:

$$
\begin{aligned}
& \mathbf{S}=\left(s_{x}, s_{y}, s_{z}\right)^{\mathrm{T}} \\
& \mathbf{r}_{i}=\left(x_{i}, y_{i}, z_{i}\right)^{\mathrm{T}}
\end{aligned}
$$

The distance between transmitting source and receivers gives

$$
\left(s_{x}-x_{i}\right)^{2}+\left(s_{y}-y_{i}\right)^{2}+\left(s_{z}-z_{i}\right)^{2}=c^{2}\left(t_{i}+T_{0}\right)^{2}, \quad i=0,1,2,3
$$

where $\mathrm{c}$ is the speed of sound, $T_{0}$ is the time of travel from the source to the reference receiver (receiver 0 ), and $t_{\mathrm{i}}$ is the TOAD between receiver $i$ and the reference receiver. With $t_{\mathrm{i}}$ measured by the common clock, the source position vector and $T_{0}$ are the four unknowns to be solved by the four distance equations. 
There are several mathematical ways to obtain the exact solutions to the equations above (Watkins and Schevill 1972; Fang 1990; Spiesberger and Fristrup 1990; Juell and Westerberg 1993; Wahlberg et al. 2001). Wahlberg et al. (2001) applied a synthesis of the methods used by Watkins and Schevill (1972) and Spiesberger and Fristrup (1990). It has the advantage of giving the same mathematical form for 2D and $3 \mathrm{D}$ array systems, and for both minimum number of receivers arrays and over-determined arrays. Assuming that the first receiver is located at the origin of the coordinate system and subtracting Equation (2.49) for $i=0$ from Equation (2.49) for $i=1,2$ and 3, we obtain

$$
2 \mathbf{R}^{T} \mathbf{S}+2 c^{2} \mathbf{t} T_{0}=\mathbf{b}
$$

where

$$
\mathbf{R}=\left[\begin{array}{lll}
x_{1} & x_{2} & x_{3} \\
y_{1} & y_{2} & y_{3} \\
z_{1} & z_{2} & z_{3}
\end{array}\right], \mathbf{t}=\left(\begin{array}{l}
t_{1} \\
t_{2} \\
t_{3}
\end{array}\right), \mathbf{b}=\left(\begin{array}{l}
b_{1} \\
b_{2} \\
b_{3}
\end{array}\right) \text {, and } b_{i}=\left\|\mathbf{r}_{i}\right\|^{2}-c^{2} t_{i}^{2}
$$

From Equation (2.4),

$$
\mathbf{S}=\mathbf{R}^{-T}\left(\frac{1}{2} \mathbf{b}-c^{2} \mathbf{t} T_{0}\right)
$$

substituting Equation (2.5) to the relationship $\mathbf{S}^{T} \mathbf{S}=c^{2} T_{0}{ }^{2}$ gives

$$
T_{0}=\frac{-p \pm \sqrt{p^{2}-a q}}{a}
$$

where

$$
a=c^{4} \mathbf{t}^{T} \mathbf{R}^{-1} \mathbf{R}^{-T} \mathbf{t}-c^{2}, \quad p=-\frac{1}{2} c^{2} \mathbf{t}^{T} \mathbf{R}^{-1} \mathbf{R}^{-T} \mathbf{b}, \text { and } q=\frac{1}{4} \mathbf{b}^{T} \mathbf{R}^{-1} \mathbf{R}^{-T} \mathbf{b}
$$

After $T_{0}$ is determined, source position (S) is then obtained by Equation (2.52).

Note that there are two possible solutions for $T_{0}$. If they are both complex, then there is no exact solution for the given configuration and TOADs. A negative $T_{0}$ is nonphysical. When there are two real non-negative solutions, then both provide two possible locations for the source. In the John Day Dam 2008 study, all hydrophones were installed at the dam face and were oriented upstream to detect sound emanating from upstream sources only, so estimated source location downstream of the dam face could not be real.

However, an exact solution may not be available due to the nonlinearity of the four distance equations and the errors in sound speed, time measurements, and hydrophone location uncertainties. Therefore, we estimate the location of the sound source iteratively by minimizing the position errors. The most common methods are iterative Taylor-series methods or variant Newton-Gaussian methods, which linearize the 
equation using Taylor expansion and search for an approximate numerical solution iteratively by minimizing the least-square error (Foy 1976). Several other approaches have been developed: maximum likelihood algorithms (Chan 1994; Chan et al. 2006) that start from maximum likelihood functions instead of linearizing the equations first and derive a close-form approximation; the spherical interpolation approach (Torieri 1984); and linear-correction (Cheung et al. 2004). The codes for these approximation methods were developed but not applied to the John Day Dam 2008 study because of the high success rates of exact solvers.

After the source location was obtained from 3D tracking, a set of artificial TOADs $\left(t_{1}^{\prime}, t_{2}^{\prime}, t_{3}^{\prime}\right)$ and $T_{0}^{\prime}$ was computed directly using the 3D-tracked source location for the given hydrophone locations and the speed of sound. The total time error was then defined as

$$
\Delta T=\sqrt{\left(\mathrm{t}_{1}^{\prime}-\mathrm{t}_{1}\right)^{2}+\left(\mathrm{t}_{2}^{\prime}-\mathrm{t}_{2}\right)^{2}+\left(\mathrm{t}_{3}^{\prime}-\mathrm{t}_{3}\right)^{2}+\left(\mathrm{T}_{0}^{\prime}-\mathrm{T}_{0}\right)^{2}} .
$$

The detailed steps for 3D tracking are as follows:

- Pool together all detections of the same signal from different hydrophones. If more than four hydrophones detect the same tag signal, select the four with the best geometry configuration for 3D tracking (Wahlberg et al 2001; Ehrenberg and Steig 2002). Compute the TOAD directly from detection time because all hydrophones are synchronized to a universal GPS clock with accuracy within $0.4 \mu \mathrm{s}$.

- Apply tracking solvers to estimate 3D locations and output solutions that are physical and within the pre-specified $\Delta T$ (10 $\mu$ s for the John Day Dam 2008 study).

- Apply order 3 median filtering (Lim 1990) to remove spurious locations and smoothing fish tracks.

- Assign a route of passage based on the y component of the last tracked location.

- Assign another set of passage routes based on the detections on the last two hydrophones on different piers. For example, if the two hydrophones were at Pier 1 (numbering starting from the Oregon side) and Pier 2, then the passage route would be assigned to the first turbine unit.

- Compare the two sets of passage routes. If the difference for a fish is more than one bay, check its trajectory and detection history manually.

\subsubsection{Tracking Error Analysis}

To assess the accuracy of the deployed hydrophone arrays and validate tracking solvers, several tests were conducted with beacon tags fixed at various locations or drifting upstream of Turbine 9 intakes and spill bay 11. Two hydrophones were installed at each pier nose at two elevations throughout the dam and all of the systems had similar functional and geometric designs, so only one turbine unit and one spill bay were selected for model validation and error analysis. The locations of the acoustic tags were obtained through a Real Time Kinematic GPS system, which provided benchmark measurements for comparison 
with the 3D-tracked locations. The accuracy was assessed in terms of median and root mean square (RMS) values of the differences between GPS measurements and the locations computed from 3D tracking:

$$
\begin{aligned}
& \Delta x_{i}=\left|x_{i}^{3 D}-x_{i}^{G P S}\right|, \quad i=1, \ldots N \\
& \Delta y_{i}=\left|y_{i}^{3 D}-y_{i}^{G P S}\right|, \quad i=1, \ldots N \\
& \Delta z_{i}=\left|z_{i}^{3 D}-z_{i}^{G P S}\right|, \quad i=1, \ldots N \\
& \Delta d_{i}=\sqrt{\Delta x_{i}^{2}+\Delta y_{i}^{2}+\Delta z_{i}^{2}}, \quad i=1, \ldots N \\
& R M S_{x}=\sqrt{\frac{1}{N} \sum_{i=1}^{N} \Delta x_{i}^{2}} \\
& R M S_{y}=\sqrt{\frac{1}{N} \sum_{i=1}^{N} \Delta y_{i}^{2}} \\
& R M S_{z}=\sqrt{\frac{1}{N} \sum_{i=1}^{N} \Delta z_{i}^{2}} \\
& R M S_{d}=\sqrt{\frac{1}{N} \sum_{i=1}^{N} \Delta d_{i}^{2}}
\end{aligned}
$$

where, $\mathrm{N}$ was the number of estimated positions and $\mathrm{x}, \mathrm{y}, \mathrm{z}$ were the three components in the dam-face coordinate system. The dam-face coordinate system was defined as follows: the x-axis was perpendicular to the dam and looking straight into forebay. The y-axis was along the dam face from the Oregon to the Washington side. The z-axis was vertical, pointing upward.

The acoustic transmitters used for the error study had the same source power as JSATS acoustic tags i.e., $155 \mathrm{~dB}$ relative to $1 \mu \mathrm{Pa}$ at $1 \mathrm{~m}$. The $2008 \mathrm{JSATS}$ acoustic transmitters were attached at different water depths to a rope that was held steady by an anchor at the bottom of the forebay. For the fixed location tests, seven transmitters were suspended at 1,2, 3, 5, 10, 15, and $20 \mathrm{~m}$ below the water surface, respectively; and were held at various locations from $5 \mathrm{~m}$ to $100 \mathrm{~m}$ in the forebay (Figures 2.18 and 2.19). For the drogue drifts, six tags were held at 1, 2, 3, 5, 10, and $15 \mathrm{~m}$ below the water surface, respectively, and started drifting about $100 \mathrm{~m}$ away from the dam. The GPS measurement point was about $1 \mathrm{~m}$ above the water surface. Because of the windy conditions and underwater currents, the rope holding the beacons was not always straight or steady. There could be large uncertainties in the locations for the tags in deep water, so only beacons at 2,3, and $5 \mathrm{~m}$ below the water surface were used for the accuracy assessment. Detailed results for the 2-m tags are shown in Tables 2.4 and 2.5 and in Figures 2.20 and 2.21.

The $\mathrm{X}$ component was the distance to the dam face. At the spillway, the median errors ranged from 0.06 to $0.83 \mathrm{~m}$ for distances up to $75 \mathrm{~m}$, and ranged from 0.67 to $2.38 \mathrm{~m}$ at $100 \mathrm{~m}$. The RMS errors fell between 0.1 and $2.12 \mathrm{~m}$ for distances up to $75 \mathrm{~m}$, and between 1.18 and 5.24 at $100 \mathrm{~m}$. At the powerhouse, the median errors were within 0.82 to $2.00 \mathrm{~m}$ and the RMS errors were within 0.90 to $3.93 \mathrm{~m}$ throughout the test. However, for distances less than $30 \mathrm{~m}$, both median and RMS errors were within $1.72 \mathrm{~m}$. 


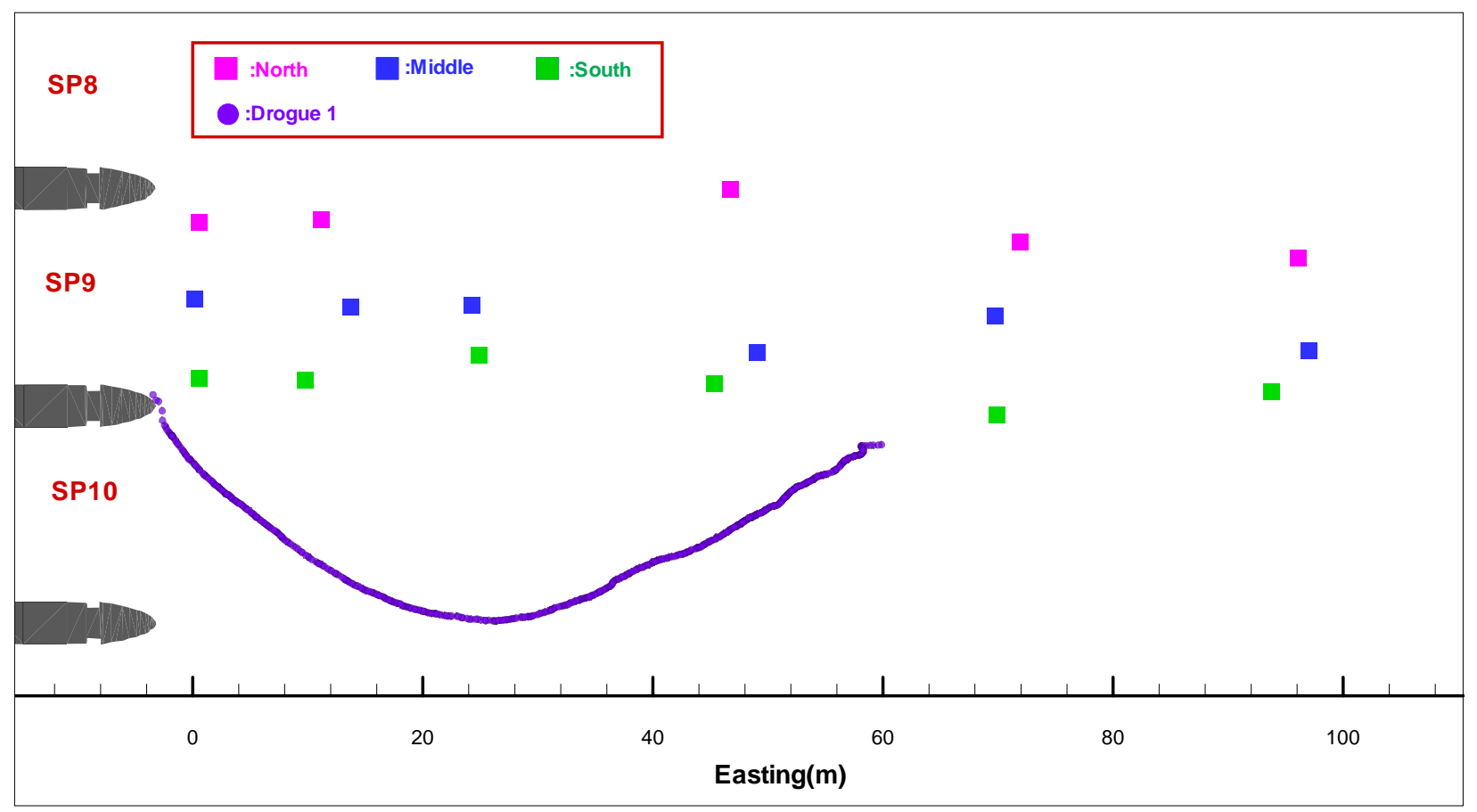

Figure 2.18. Test locations at the John Day Dam spillway for 3D-tracking error analysis

The Y component was used for the assignment of the route of fish passage and had the highest accuracy among the three components. At the spillway, median errors ranged from 0.06 to $0.27 \mathrm{~m}$ and RMS errors ranged from 0.05 to $0.58 \mathrm{~m}$. When the distance was less than $50 \mathrm{~m}$, the maximum median errors and RMS errors were within 0.2 to $0.26 \mathrm{~m}$. At the powerhouse, the median errors ranged from 0.03 to $0.48 \mathrm{~m}$ throughout the test. The RMS errors were within $0.5 \mathrm{~m}$ for distances up to $75 \mathrm{~m}$ and within $0.84 \mathrm{~m}$ for distances up to $100 \mathrm{~m}$ except for the $3-\mathrm{m}$ beacon at $50-\mathrm{m}$ distance in the middle section and 100-m distance in the south section.

The $\mathrm{Z}$ component was in the vertical plane. At the spillway, median errors ranged from 0.24 to $1.33 \mathrm{~m}$ for all distances. The RMS errors ranged from 0.24 to $2.78 \mathrm{~m}$ for distances up to $75 \mathrm{~m}$ and were within 0.99 to $4.61 \mathrm{~m}$ except the for 3-m-deep beacon tag $100 \mathrm{~m}$ toward the south. At the powerhouse, the median errors were within 0.1 to $2.1 \mathrm{~m}$ for distances up to $30 \mathrm{~m}$ and 1.48 to $8.78 \mathrm{~m}$ for distances from 50 to $100 \mathrm{~m}$. The RMS errors fell between 0.18 and $3.99 \mathrm{~m}$ for distances up to $30 \mathrm{~m}$ and between 2.41 and $8.63 \mathrm{~m}$ for distances from 50 to $100 \mathrm{~m}$. However at the $5-\mathrm{m}$ distance, the median errors fell to 0.03 to $0.45 \mathrm{~m}$ and RMS errors reduced to 0.04 to $0.65 \mathrm{~m}$ except for the $2-\mathrm{m}$ beacon at a $5-\mathrm{m}$ distance in the south section.

Both median and RMS errors were computed from 3D-tracked positions that were slightly smoothed by order 3 median filtering without removing outliers. If outliers were removed or additional smoothing (such as Kalman filtering) algorithms were applied, the RMS errors would be reduced significantly. In addition, windy conditions and underwater currents also could cause differences between GPS-estimated positions and true beacon-tag locations, resulting in an increase in RMS errors. 


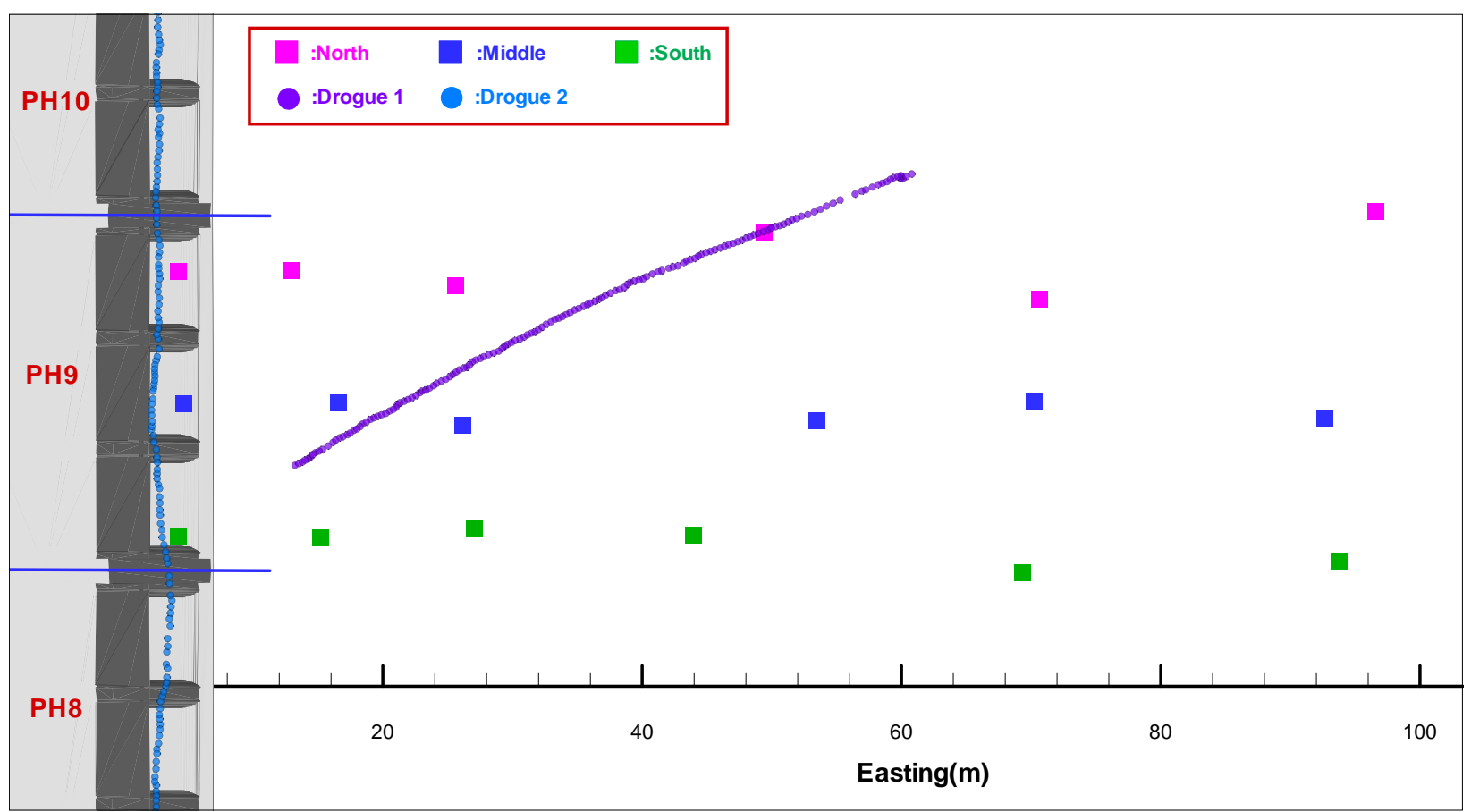

Figure 2.19. Test locations at John Day Dam powerhouse for 3D-tracking error analysis

Table 2.4. Median and route mean square errors in the position estimates of acoustic tags located $2 \mathrm{~m}$ below the water surface upstream of the John Day Dam spillway

\begin{tabular}{lccccccccc}
\hline Location & $\begin{array}{c}\text { Distance } \\
(\mathrm{m})\end{array}$ & $\begin{array}{c}\text { Median } \\
\left(\Delta \mathrm{x}_{\mathrm{i}}\right)\end{array}$ & $\begin{array}{c}\text { Median } \\
\left(\Delta \mathrm{y}_{\mathrm{i}}\right)\end{array}$ & $\begin{array}{c}\text { Median } \\
\left(\Delta \mathrm{z}_{\mathrm{i}}\right)\end{array}$ & $\begin{array}{c}\text { Median } \\
\left(\Delta \mathrm{d}_{\mathrm{i}}\right)\end{array}$ & $\mathrm{RMS}_{\mathrm{x}}$ & $\mathrm{RMS}_{\mathrm{y}}$ & $\mathrm{RMS}_{\mathrm{z}}$ & $\mathrm{RMS}_{\mathrm{d}}$ \\
\hline North & 5 & 0.06 & 0.06 & 0.39 & 0.40 & 0.10 & 0.08 & 0.39 & 0.41 \\
& 15 & 0.06 & 0.07 & 0.35 & 0.37 & 0.12 & 0.11 & 0.33 & 0.37 \\
& 50 & 0.22 & 0.07 & 0.57 & 0.64 & 0.38 & 0.12 & 2.13 & 2.16 \\
& 75 & 0.40 & 0.11 & 0.46 & 0.68 & 0.66 & 0.16 & 1.35 & 1.51 \\
Middle & 100 & 0.52 & 0.13 & 0.42 & 0.78 & 1.31 & 0.25 & 0.99 & 1.66 \\
& 5 & 0.34 & 0.05 & 0.31 & 0.69 & 0.97 & 0.08 & 0.93 & 1.35 \\
& 15 & 0.06 & 0.05 & 0.41 & 0.44 & 0.37 & 0.09 & 2.11 & 2.15 \\
& 30 & 0.21 & 0.02 & 0.87 & 0.94 & 0.37 & 0.16 & 1.82 & 1.86 \\
& 50 & 0.34 & 0.11 & 0.53 & 0.71 & 0.98 & 0.17 & 2.19 & 2.41 \\
& 75 & 0.51 & 0.11 & 0.58 & 0.99 & 0.86 & 0.16 & 1.80 & 2.00 \\
& 100 & 1.18 & 0.17 & 0.59 & 1.64 & 1.92 & 0.27 & 2.17 & 2.90 \\
& 5 & 0.07 & 0.06 & 0.40 & 0.42 & 0.13 & 0.08 & 0.43 & 0.45 \\
& 15 & 0.06 & 0.04 & 0.40 & 0.40 & 0.32 & 0.07 & 0.40 & 0.52 \\
& 30 & 0.11 & 0.05 & 0.53 & 0.56 & 0.21 & 0.09 & 0.54 & 0.59 \\
& 50 & 0.18 & 0.04 & 0.56 & 0.60 & 0.35 & 0.11 & 0.66 & 0.75 \\
& 75 & 0.55 & 0.18 & 0.57 & 0.95 & 0.79 & 0.24 & 1.78 & 1.96 \\
& 100 & 1.13 & 0.22 & 0.59 & 1.67 & 2.16 & 0.56 & 2.25 & 3.17 \\
\hline
\end{tabular}


Table 2.5. Median and route mean square errors in the position estimates of acoustic tags located $2 \mathrm{~m}$ below the water surface upstream of the John Day Dam powerhouse

\begin{tabular}{lccccccccc}
\hline \multirow{2}{*}{ Location } & $\begin{array}{c}\text { Distance } \\
(\mathrm{m})\end{array}$ & $\begin{array}{c}\text { Median } \\
\left(\Delta \mathrm{x}_{\mathrm{i}}\right)\end{array}$ & $\begin{array}{c}\text { Median } \\
\left(\Delta \mathrm{y}_{\mathrm{i}}\right)\end{array}$ & $\begin{array}{c}\text { Median } \\
\left(\Delta \mathrm{z}_{\mathrm{i}}\right)\end{array}$ & $\begin{array}{c}\text { Median } \\
\left(\Delta \mathrm{d}_{\mathrm{i}}\right)\end{array}$ & $\mathrm{RMS}_{\mathrm{x}}$ & $\mathrm{RMS}_{\mathrm{y}}$ & $\mathrm{RMS}_{\mathrm{z}}$ & $\mathrm{RMS}_{\mathrm{d}}$ \\
\hline North & 5 & 0.85 & 0.15 & 0.14 & 0.96 & 1.05 & 0.17 & 0.65 & 1.25 \\
& 15 & 0.87 & 0.08 & 0.73 & 1.16 & 1.23 & 0.22 & 1.50 & 1.95 \\
& 30 & 0.99 & 0.04 & 1.80 & 2.07 & 1.33 & 0.22 & 2.45 & 2.80 \\
& 50 & 1.00 & 0.06 & 3.97 & 4.11 & 1.36 & 0.66 & 3.91 & 4.19 \\
& 75 & 1.16 & 0.06 & 5.66 & 5.81 & 1.54 & 0.29 & 4.66 & 4.92 \\
Middle & 100 & 9.78 & 0.38 & 4.03 & 12.00 & 21.28 & 8.15 & 4.57 & 23.24 \\
& 5 & 1.17 & 0.03 & 0.14 & 1.18 & 1.65 & 0.16 & 0.48 & 1.73 \\
& 15 & 1.25 & 0.02 & 1.13 & 1.69 & 1.32 & 0.18 & 1.43 & 1.96 \\
& 30 & 1.09 & 0.02 & 1.92 & 2.22 & 1.14 & 0.14 & 2.05 & 2.35 \\
& 50 & 1.00 & 0.07 & 4.34 & 4.48 & 1.09 & 0.65 & 3.97 & 4.17 \\
& 75 & 1.10 & 0.10 & 4.26 & 4.66 & 1.46 & 0.34 & 4.54 & 4.78 \\
& 100 & 1.05 & 0.13 & 3.45 & 3.77 & 3.52 & 0.88 & 4.15 & 5.52 \\
& 5 & 0.92 & 0.12 & 0.45 & 1.17 & 1.31 & 0.31 & 1.50 & 2.01 \\
& 15 & 1.33 & 0.09 & 0.91 & 1.61 & 1.30 & 0.18 & 1.57 & 2.05 \\
& 30 & 0.85 & 0.11 & 1.97 & 2.16 & 1.02 & 0.30 & 2.12 & 2.38 \\
& 50 & 0.92 & 0.10 & 1.48 & 1.75 & 0.90 & 0.17 & 2.41 & 2.58 \\
& 75 & 1.07 & 0.11 & 1.40 & 2.03 & 1.49 & 0.41 & 3.61 & 3.93 \\
& 100 & 1.07 & 0.14 & 3.56 & 3.82 & 1.76 & 0.32 & 4.22 & 4.58 \\
\hline
\end{tabular}

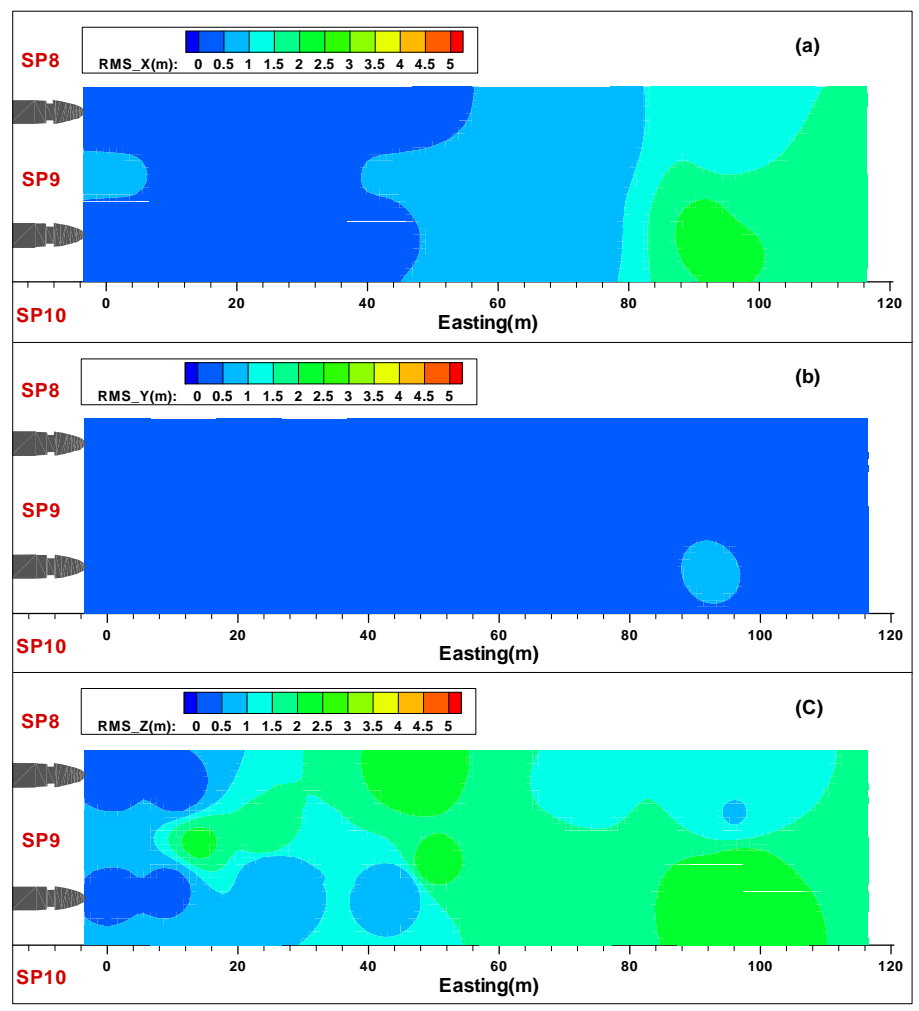

Figure 2.20. Contour plots of route mean square errors in the position estimation of acoustic tags located $2 \mathrm{~m}$ below the water surface upstream of the John Day Dam spillway (a) x, (b) y, (c) z 


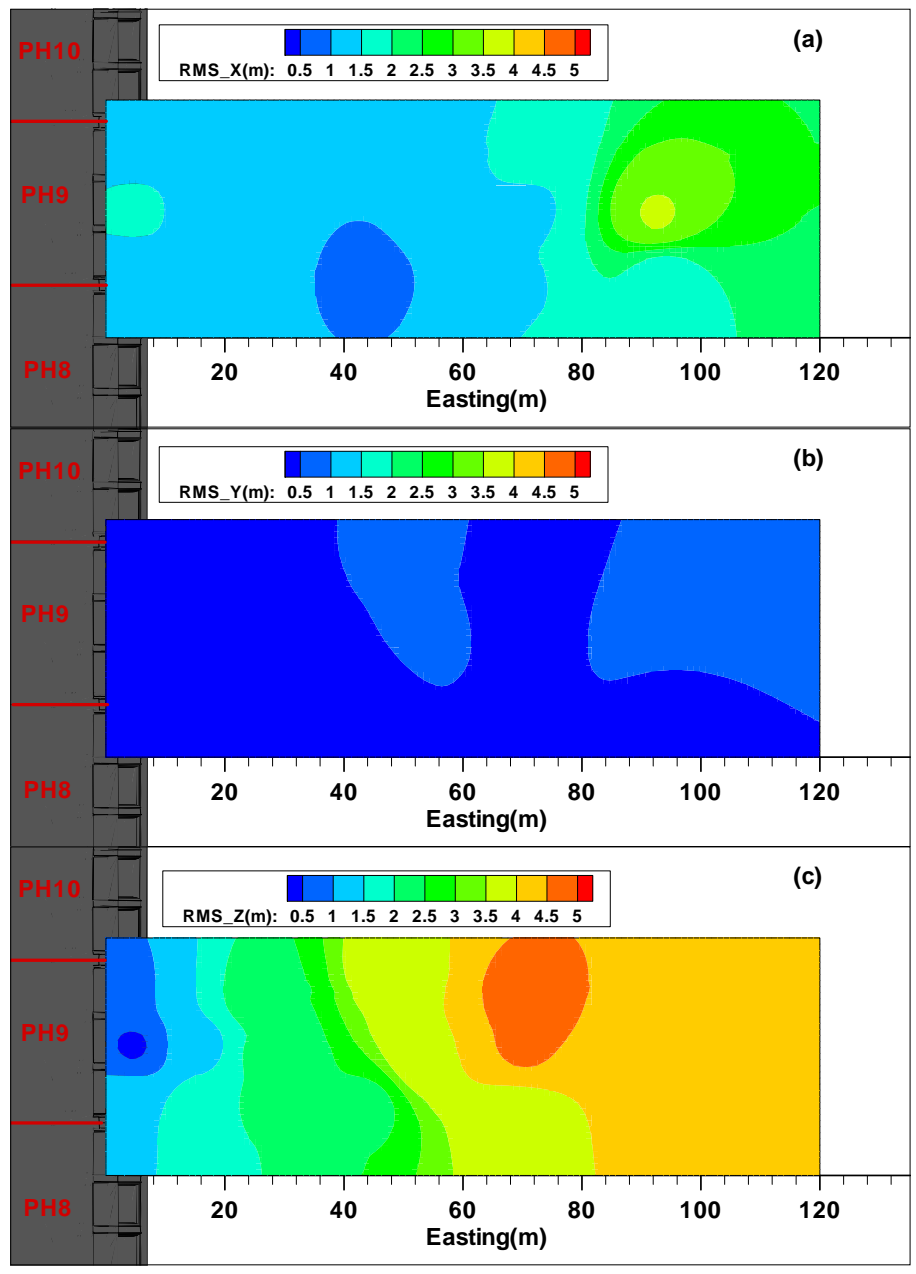

Figure 2.21. Contour plots of route mean square errors in the position estimation of acoustic tags located $2 \mathrm{~m}$ below the water surface upstream of the John Day Dam powerhouse (a) $\mathrm{x}$, (b) y, (c) $\mathrm{z}$ 


\subsection{Results}

The study results related to environmental conditions, validation of JSATS performance, various survival estimates, fish passage, and fish behavior are presented in the following sections.

\subsection{Environmental Conditions}

This section contains a description of environmental conditions during the 2008 study, including river discharge and temperature relative to the 10-year average, the length frequencies of tagged and untagged fish that were collected at the John Day Dam SMF, and results of the tag-life study.

\subsubsection{Dam Discharge and Temperature}

For the entire study period, from the first release of tagged fish to the retrieval of the last node (April 29 to August 20,2008), total daily discharge through the dam ranged from 81 to $353 \mathrm{kcfs}$ with a mean of $212 \mathrm{kcfs}$. Overall during this period, $31.6 \%$ of total discharge was spilled, including $9.5 \%$ TSW discharge. During the first half of the spring portion of the study, tagged fish were released when discharge was at or below the 10-year average (1998 to 2007; Figure 3.1). Discharge was higher than the 10 -year average during the second half of the spring season. Discharge exceeded the 10 -year average during the release of tagged fish in summer (Figure 3.1). Forebay water temperatures were below the 10-year average in both spring and summer (Figure 3.2).

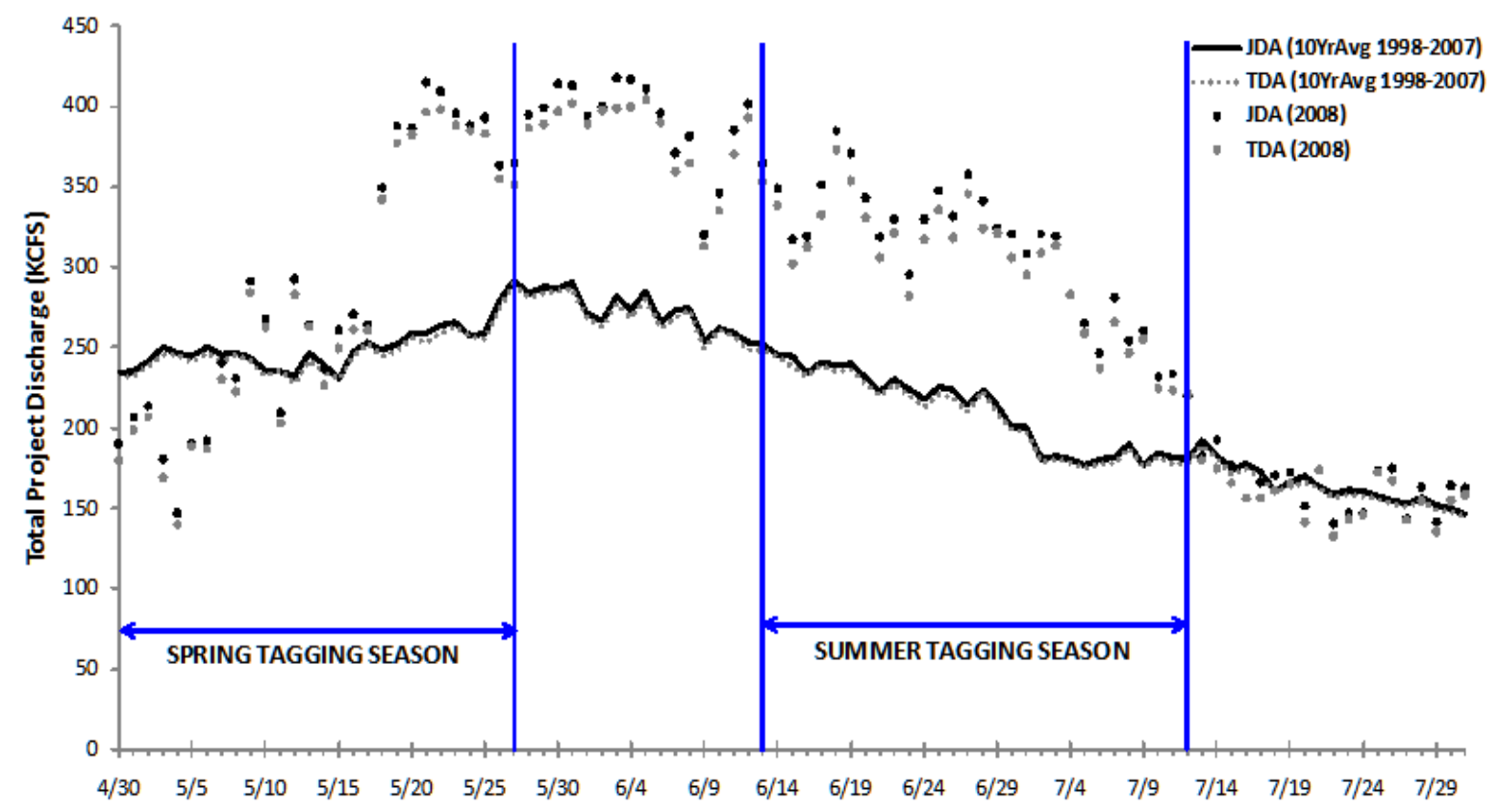

Figure 3.1. Average daily water discharge (kcfs) from John Day Dam and The Dalles Dam during the 2008 study and for the preceding 10 -year period. Fish releases lagged the tagging date by 1 day, and travel past all survival-detection arrays lagged the tagging date by 2.5 to 5 days depending on release location and travel time. 


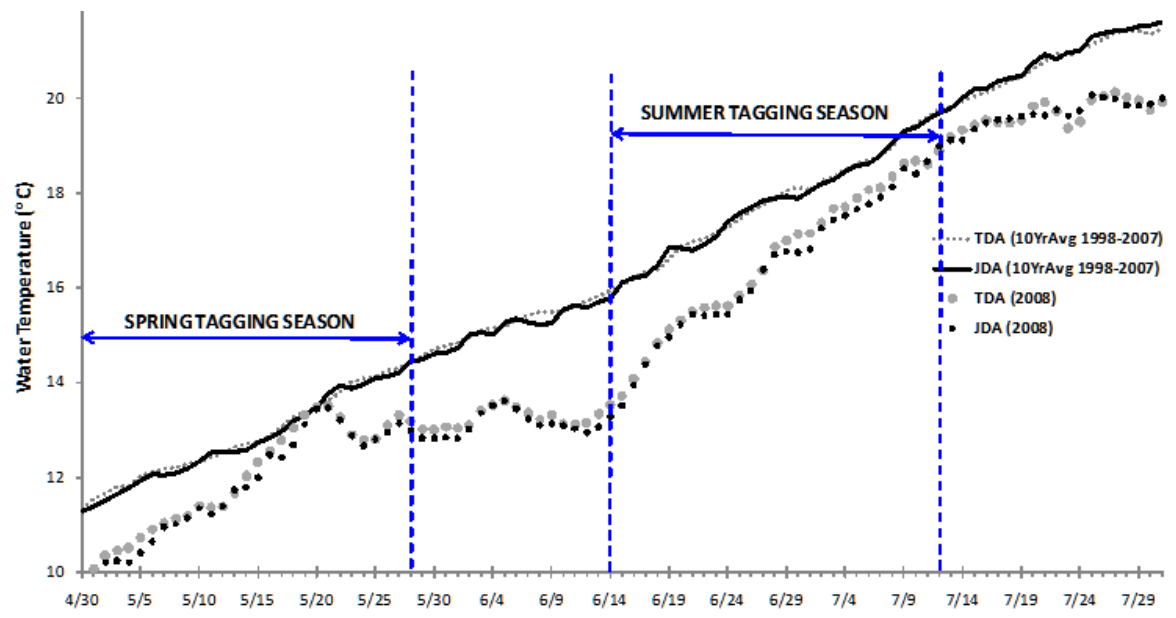

Figure 3.2. John Day Dam and The Dalles Dam average daily forebay water temperatures $\left({ }^{\circ} \mathrm{C}\right)$ during the 2008 study and for the preceding 10 -year period

\subsubsection{Realized Spill Treatment Conditions}

Treatment conditions were met for most of Blocks 1 through 3 during spring, but percent spill varied from prescribed treatment conditions for large parts of Blocks 4 through 7 (Figure 3.3). During summer, treatment conditions were not met for Blocks 1 through 5, but were met for most of Blocks 6 and 7 (Figure 3.4). Treatment conditions were not always met due to power-load issues and prevailing flow conditions. Except for Block 3 in summer, the dam operators were better able to meet prescribed conditions during $30 \%$ spill treatments than they did during $40 \%$ spill treatments.

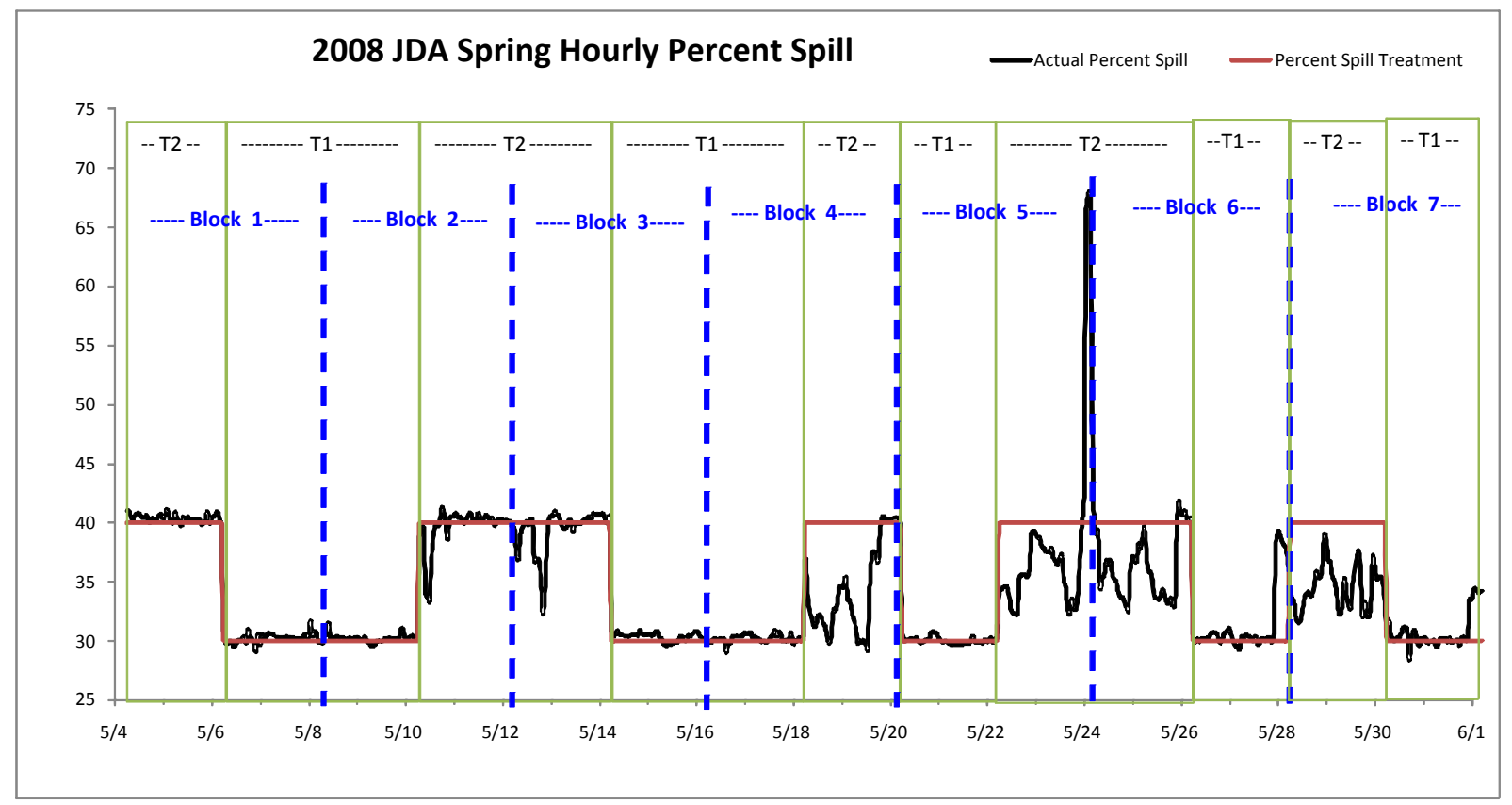

Figure 3.3. Spill treatments for the spring study at John Day Dam from May 4 through May 31, 2008. There were seven treatment blocks with two treatments per block. Treatment 1 (T1) was $30 \%$ spill and Treatment 2 (T2) was $40 \%$ spill. 


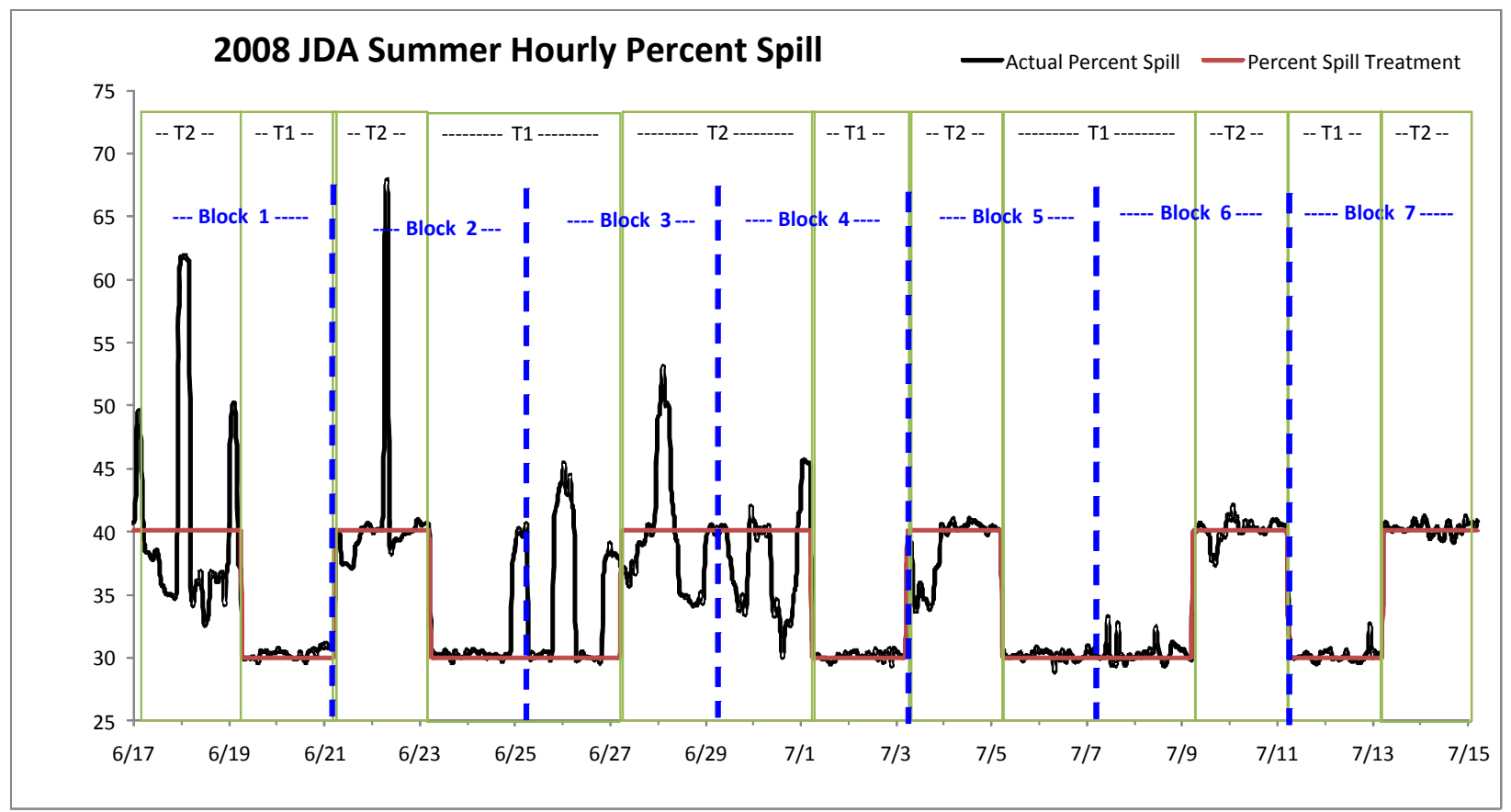

Figure 3.4. Spill treatments in summer at John Day Dam from June 14 through July 16, 2008. There were seven treatment blocks with two treatments per block. Treatment 1 (T1) was $30 \%$ spill and Treatment 2 (T2) was $40 \%$ spill.

\subsubsection{Run Timing}

The run timings of downstream migrating STH, YC, and SYC, as indicated by the smolt passage index from the John Day Dam Smolt Monitoring Program (SMP), were compared with the numbers of fish tagged at the John Day Dam SMF in 2008. The fish collection and tagging periods for spring and summer were from April 30 to May 28 and June 14 to July 12, 2008, respectively.

The goal was to tag the middle $80 \%$ of the run (10th to 90 th percentile) for each species. In spring, the tagging of STH and YC corresponded well with the run timing (Figure 3.5 and 3.6, respectively). With tagged fish being released about 24 hours after tagging and taking about 30 hours after release to reach John Day Dam, the arrival times of the run-of-river and tagged fish were very close to the targeted $80 \%$ middle of the run. In summer, tagging of SYC was somewhat early relative to the middle $80 \%$ of the run (Figure 3.7). We relied on the 10-year smolt index average as an indicator of run timing to determine the start date for tagging fish (Tables 3.1 to 3.3).

In summary (Table 3.4), we started tagging YC when about $8.2 \%$ of the run had passed the dam and finished when about $76.5 \%$ had passed. We started tagging STH when about $2.4 \%$ of the run had passed at John Day Dam and tagged the last STH when about $85 \%$ of the run had passed the dam. In summer, we started tagging SYC when $10 \%$ of the run had passed the dam and tagged the last fish when about $65.6 \%$ of the run had passed the dam. 


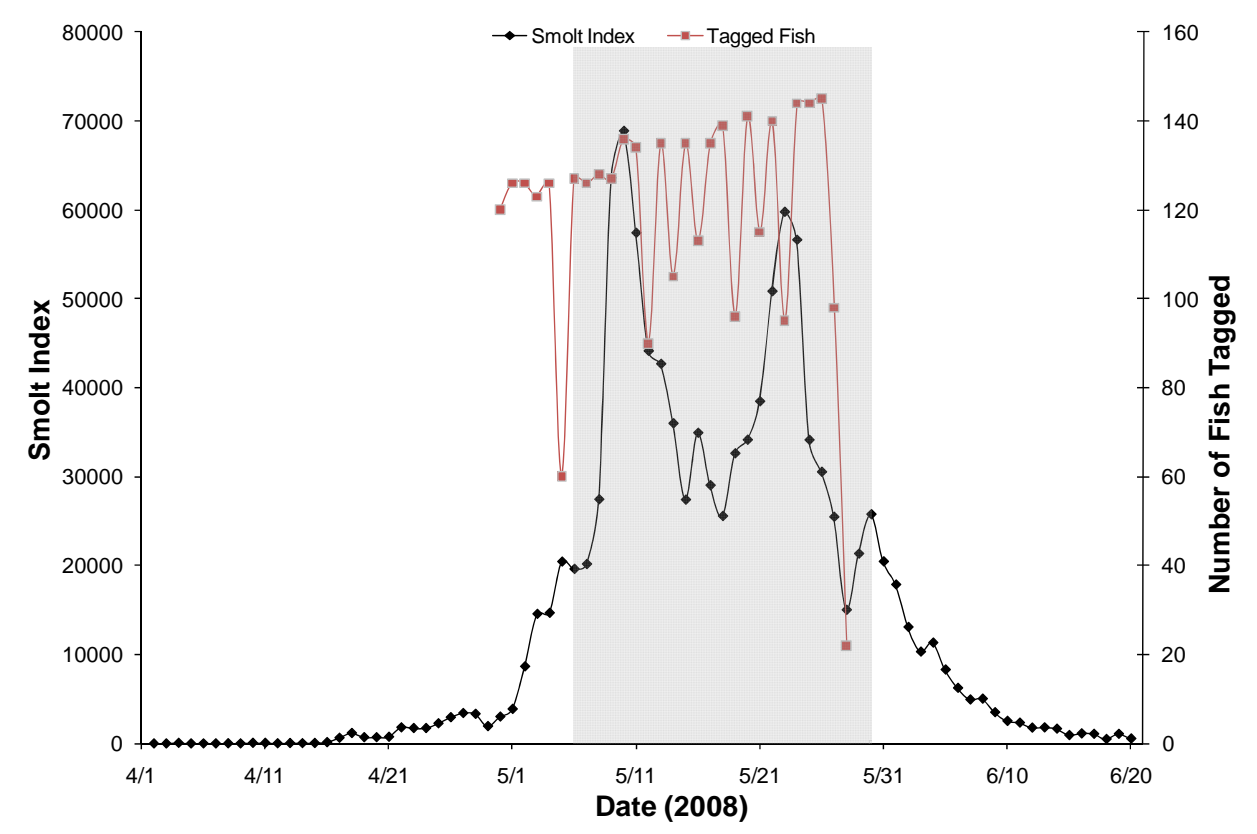

Figure 3.5. Smolt Monitoring Program passage index for April 2-June 20, 2008, and fish tagged per day for steelhead based upon data from the John Day Dam Smolt Monitoring Facility. Ten to 90 percent of the run passed John Day Dam within the region of the gray box. Data were obtained from the DART website (Data Access in Real Time; www.cbr.washington/dart/dart.html).

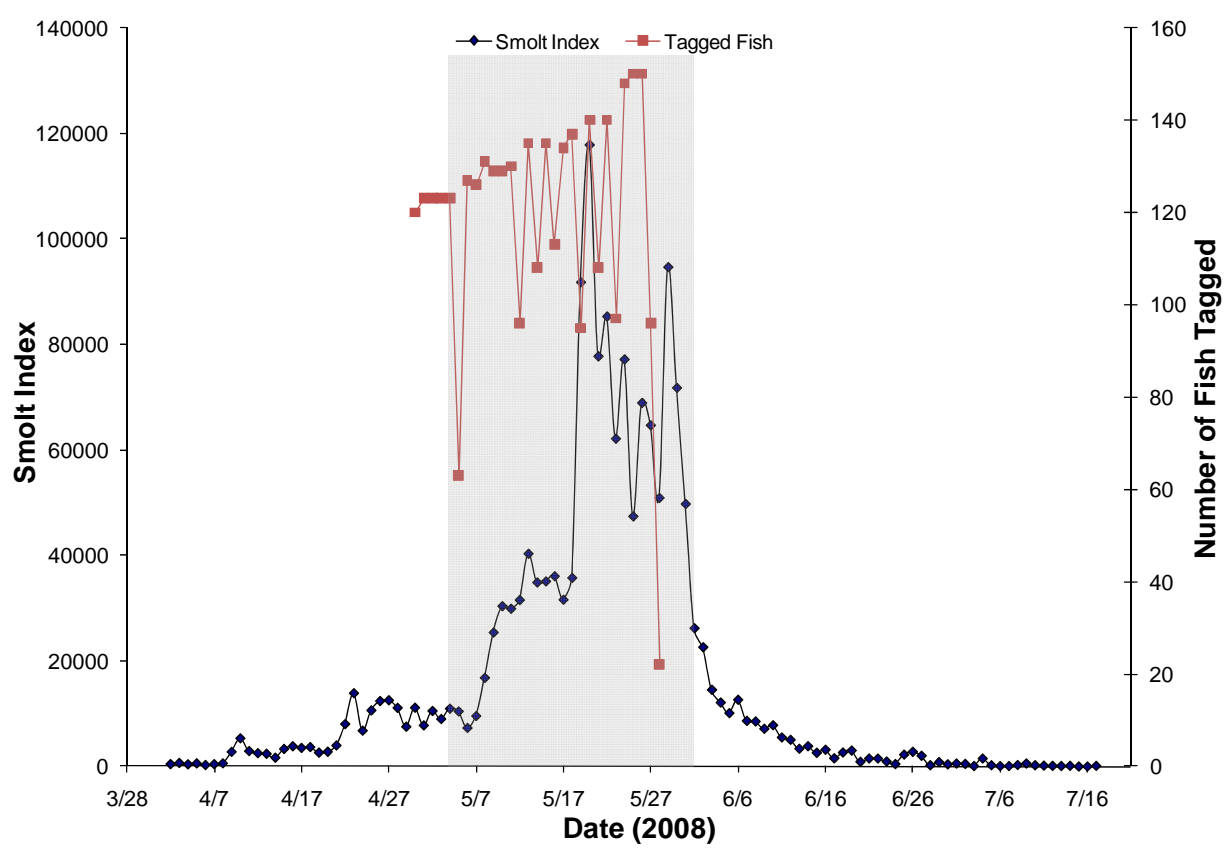

Figure 3.6. Smolt Monitoring Program passage index for April 2-July 16, 2008, and fish tagged per day for yearling Chinook salmon based upon data from the John Day Dam Smolt Monitoring Facility. Ten to 90 percent of the run passed John Day Dam within the region of the gray box. Data were obtained from the DART website (Data Access in Real Time; www.cbr.washington/dart/dart.html). 


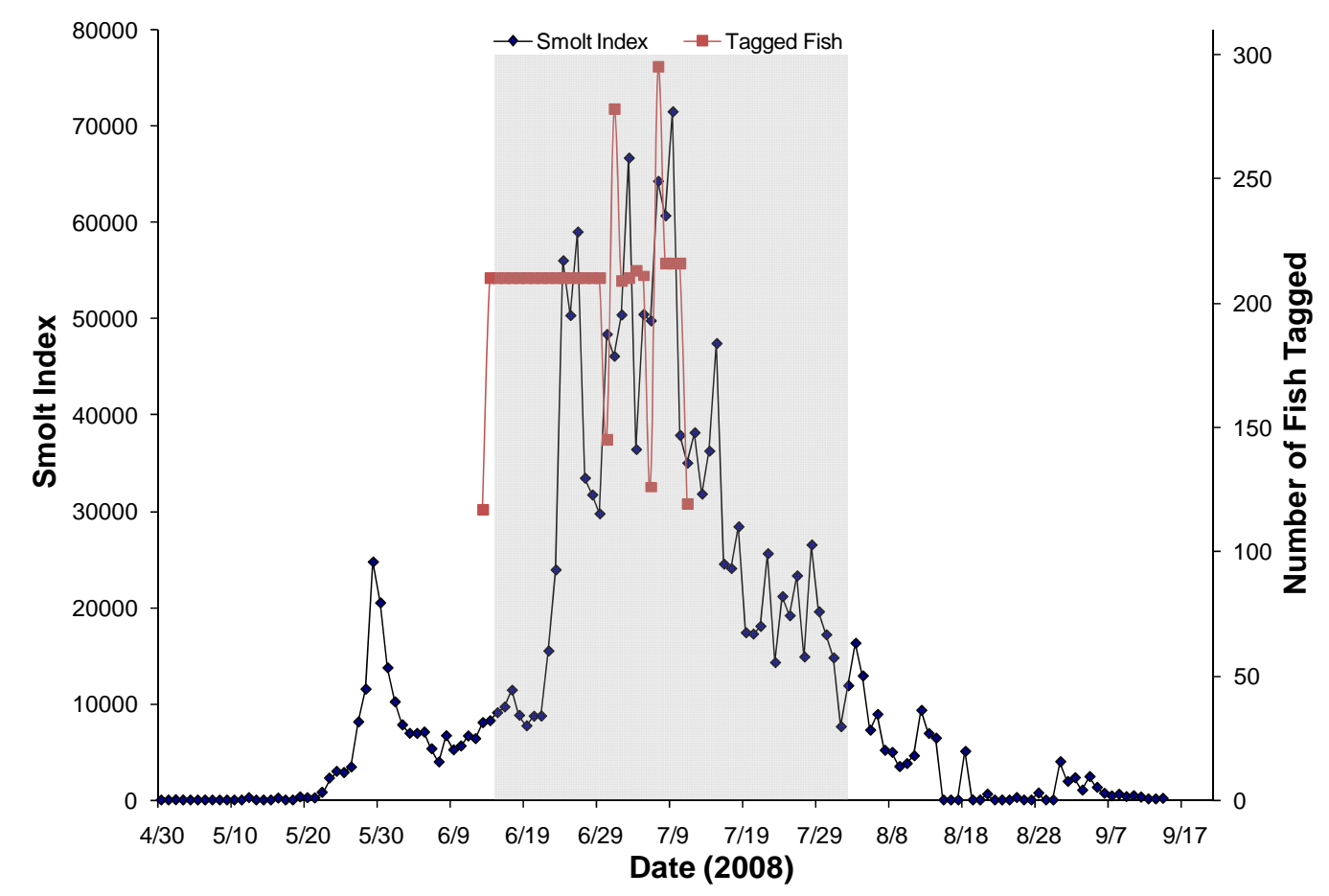

Figure 3.7. Smolt Monitoring Program passage index for June 1-July 31, 2008, and fish tagged per day for subyearling Chinook salmon based upon data from the John Day Dam Smolt Monitoring Facility. Ten to 90 percent of the run passed John Day Dam within the region of the gray box. Data were obtained from the DART website (Data Access in Real Time; www.cbr.washington/dart/dart.html).

Table 3.1. Ten-year average of percent of the run of yearling Chinook salmon passing at the John Day Dam SMF at percentiles of the passage index

\begin{tabular}{lccccccccc}
\hline \multicolumn{1}{c}{ Year } & First & $1 \%$ & $5 \%$ & $10 \%$ & $50 \%$ & $90 \%$ & $95 \%$ & Last & $80 \%$ Days \\
\hline 1998 & $4 / 2$ & $4 / 4$ & $4 / 18$ & $4 / 25$ & $5 / 12$ & $5 / 22$ & $5 / 30$ & $8 / 28$ & 28 \\
1999 & $4 / 1$ & $4 / 10$ & $4 / 18$ & $4 / 22$ & $5 / 13$ & $5 / 31$ & $6 / 6$ & $8 / 30$ & 40 \\
2000 & $4 / 4$ & $4 / 10$ & $4 / 16$ & $4 / 21$ & $5 / 09$ & $5 / 28$ & $6 / 5$ & $9 / 18$ & 38 \\
2001 & $3 / 30$ & $4 / 21$ & $5 / 01$ & $5 / 06$ & $5 / 27$ & $6 / 20$ & $6 / 27$ & $9 / 17$ & 46 \\
2002 & $3 / 19$ & $4 / 18$ & $4 / 25$ & $5 / 01$ & $5 / 17$ & $6 / 01$ & $6 / 05$ & $8 / 30$ & 32 \\
2003 & $4 / 01$ & $4 / 14$ & $4 / 27$ & $5 / 03$ & $5 / 19$ & $6 / 02$ & $6 / 04$ & $9 / 15$ & 31 \\
2004 & $4 / 02$ & $4 / 09$ & $4 / 20$ & $4 / 28$ & $5 / 16$ & $5 / 30$ & $6 / 06$ & $9 / 15$ & 33 \\
2005 & $4 / 02$ & $4 / 05$ & $4 / 18$ & $4 / 25$ & $5 / 12$ & $5 / 22$ & $5 / 30$ & $9 / 15$ & 28 \\
2006 & $4 / 4$ & $4 / 14$ & $4 / 22$ & $4 / 25$ & $5 / 11$ & $5 / 24$ & $5 / 27$ & $9 / 14$ & 30 \\
2007 & $4 / 3$ & $4 / 16$ & $4 / 26$ & $5 / 02$ & $5 / 13$ & $5 / 25$ & $5 / 30$ & $9 / 13$ & 24 \\
10 -y avg. & $3 / 31$ & $4 / 12$ & $4 / 22$ & $4 / 27$ & $5 / 14$ & $5 / 29$ & $6 / 04$ & $9 / 10$ & 33 \\
2008 & $4 / 02$ & $4 / 12$ & $4 / 26$ & $5 / 04$ & $5 / 22$ & $6 / 01$ & $6 / 06$ & $9 / 15$ & 29 \\
\hline
\end{tabular}


Table 3.2. Ten-year average of percent of the run of steelhead passing at the John Day Dam SMF at percentiles of the passage index

\begin{tabular}{lccccccccc}
\hline \multicolumn{1}{c}{ Year } & First & $1 \%$ & $5 \%$ & $10 \%$ & $50 \%$ & $90 \%$ & $95 \%$ & Last & Middle $80 \%$ \\
\hline 1998 & $3 / 31$ & $4 / 22$ & $4 / 26$ & $4 / 29$ & $5 / 13$ & $6 / 1$ & $6 / 3$ & $9 / 9$ & 34 \\
1999 & $4 / 1$ & $4 / 2$ & $4 / 22$ & $4 / 28$ & $5 / 26$ & $6 / 6$ & $6 / 11$ & $9 / 9$ & 40 \\
2000 & $4 / 4$ & $4 / 12$ & $4 / 15$ & $4 / 16$ & $5 / 4$ & $5 / 26$ & $6 / 2$ & $9 / 18$ & 41 \\
2001 & $3 / 30$ & $4 / 16$ & $4 / 25$ & $4 / 30$ & $5 / 12$ & $6 / 2$ & $6 / 20$ & $9 / 17$ & 34 \\
2002 & $3 / 20$ & $4 / 14$ & $4 / 19$ & $4 / 22$ & $5 / 16$ & $6 / 7$ & $6 / 12$ & $9 / 16$ & 47 \\
2003 & $4 / 1$ & $4 / 11$ & $4 / 26$ & $5 / 2$ & $5 / 29$ & $6 / 4$ & $6 / 6$ & $9 / 15$ & 34 \\
2004 & $4 / 2$ & $4 / 12$ & $4 / 25$ & $5 / 3$ & $5 / 21$ & $5 / 31$ & $6 / 5$ & $9 / 15$ & 29 \\
2005 & $4 / 2$ & $4 / 17$ & $44 / 30$ & $5 / 2$ & $5 / 18$ & $5 / 25$ & $5 / 28$ & $9 / 15$ & 24 \\
2006 & $4 / 4$ & $4 / 17$ & $4 / 24$ & $4 / 27$ & $5 / 11$ & $5 / 29$ & $6 / 1$ & $9 / 12$ & 33 \\
2007 & $4 / 3$ & $4 / 17$ & $5 / 1$ & $5 / 4$ & $5 / 12$ & $5 / 26$ & $6 / 2$ & $9 / 13$ & 23 \\
10 -y avg. & $3 / 31$ & $4 / 14$ & $4 / 23$ & $4 / 28$ & $5 / 16$ & $5 / 31$ & $6 / 5$ & $9 / 13$ & 34 \\
2008 & $4 / 2$ & $4 / 25$ & $5 / 4$ & $5 / 7$ & $5 / 18$ & $5 / 31$ & $6 / 4$ & $9 / 15$ & 25 \\
\hline
\end{tabular}

Table 3.3. Ten-year average of percent of the run of subyearling Chinook salmon passing at the John Day Dam SMF at percentiles of the passage index

\begin{tabular}{lccccccccc}
\hline \multicolumn{1}{c}{ Year } & First & $1 \%$ & $5 \%$ & $10 \%$ & $50 \%$ & $90 \%$ & $95 \%$ & Last & Middle $80 \%$ \\
\hline 1998 & $4 / 9$ & $6 / 2$ & $6 / 7$ & $6 / 11$ & $6 / 30$ & $7 / 29$ & $8 / 8$ & $10 / 29$ & 49 \\
1999 & $4 / 2$ & $6 / 3$ & $6 / 10$ & $6 / 18$ & $6 / 29$ & $7 / 25$ & $8 / 5$ & $10 / 26$ & 38 \\
2000 & $4 / 7$ & $6 / 1$ & $6 / 5$ & $6 / 6$ & $6 / 29$ & $8 / 3$ & $8 / 9$ & $9 / 18$ & 59 \\
2001 & $4 / 22$ & $6 / 10$ & $6 / 22$ & $6 / 27$ & $7 / 30$ & $8 / 22$ & $8 / 29$ & $9 / 17$ & 57 \\
2002 & $3 / 22$ & $6 / 3$ & $6 / 11$ & $6 / 20$ & $6 / 30$ & $7 / 21$ & $8 / 4$ & $9 / 16$ & 32 \\
2003 & $4 / 2$ & $5 / 30$ & $6 / 3$ & $6 / 6$ & $6 / 27$ & $7 / 30$ & $8 / 7$ & $9 / 15$ & 55 \\
2004 & $4 / 7$ & $5 / 30$ & $6 / 8$ & $6 / 14$ & $6 / 28$ & $7 / 23$ & $7 / 30$ & $9 / 15$ & 40 \\
2005 & $4 / 4$ & $5 / 25$ & $6 / 9$ & $6 / 19$ & $7 / 5$ & $7 / 27$ & $8 / 1$ & $9 / 15$ & 39 \\
2006 & $4 / 11$ & $5 / 25$ & $6 / 5$ & $6 / 12$ & $7 / 2$ & $7 / 17$ & $7 / 22$ & $9 / 14$ & 36 \\
2007 & $4 / 6$ & $5 / 28$ & $6 / 13$ & $6 / 25$ & $7 / 8$ & $7 / 17$ & $7 / 27$ & $9 / 13$ & 23 \\
10 -y avg. & $4 / 6$ & $5 / 31$ & $6 / 9$ & $6 / 15$ & $7 / 3$ & $7 / 27$ & $8 / 4$ & $9 / 23$ & 43 \\
2008 & $5 / 3$ & $5 / 28$ & $6 / 1$ & $6 / 14$ & $7 / 7$ & $7 / 30$ & $8 / 5$ & $9 / 15$ & 47 \\
\hline
\end{tabular}

Table 3.4. Percent of the run passing at the John Day Dam SMF on the first and last day of tagging and dates that 10, 25, 50, 75, and 90 percent of the run passed at the John Day Dam SMF

\begin{tabular}{lccccccc}
\hline & & \multicolumn{5}{c}{ Percent of Run Passage by Date } & \\
\cline { 3 - 6 } \multicolumn{1}{c}{ Stock } & First Tagging & $10 \%$ & $25 \%$ & $50 \%$ & $75 \%$ & $90 \%$ & Last Tagging \\
\hline Steelhead & $4 / 30(2.4 \%)$ & $5 / 6$ & $5 / 10$ & $5 / 17$ & $5 / 24$ & $5 / 30$ & $5 / 28(85.0 \%)$ \\
Yearling Chinook & $4 / 30(8.2 \%)$ & $5 / 4$ & $5 / 14$ & $5 / 21$ & $5 / 28$ & $6 / 1$ & $5 / 28(76.5 \%)$ \\
Subyearling Chinook & $6 / 14(10 \%)$ & $6 / 14$ & $6 / 27$ & $7 / 07$ & $7 / 17$ & $7 / 30$ & $7 / 12(65.6 \%)$ \\
\hline
\end{tabular}




\subsubsection{Length Frequency}

The lengths of tagged and untagged fish of each stock were grouped into 5-mm-length classes and plotted to compare length frequencies. The median length of tagged STH $(217 \mathrm{~mm})$ was $11 \mathrm{~mm}$ longer than that of untagged STH (206 mm; Figure 3.8). The median length of 3447 tagged YC was $8 \mathrm{~mm}$ longer than that of untagged YC (Figure 3.9), and the difference was greater for unclipped YC (21 mm) than it was for clipped YC $(7 \mathrm{~mm})$. The median length of 5931 tagged SYC $(115 \mathrm{~mm})$ was $6 \mathrm{~mm}$ longer than that of untagged SYC (109 mm) in routine SMF samples (Figure 3.10). The lower end of the distribution of length frequencies of 5931 tagged SYC was truncated at $95 \mathrm{~mm}$ relative to the length frequency distribution of run-of-river SYC handled at the John Day Dam SMF in summer due to a minimum size limit of $95 \mathrm{~mm}$ for using JSATS tags (Figure 3.10). Only about $9 \%$ of SYC in routine samples could not be tagged because they were too small. Of the SYC tagged, less than $1 \%$ were $99 \mathrm{~mm}$ or less; the majority of tagged SYC (76\%) were in the 105- to 125 -mm-length classes.

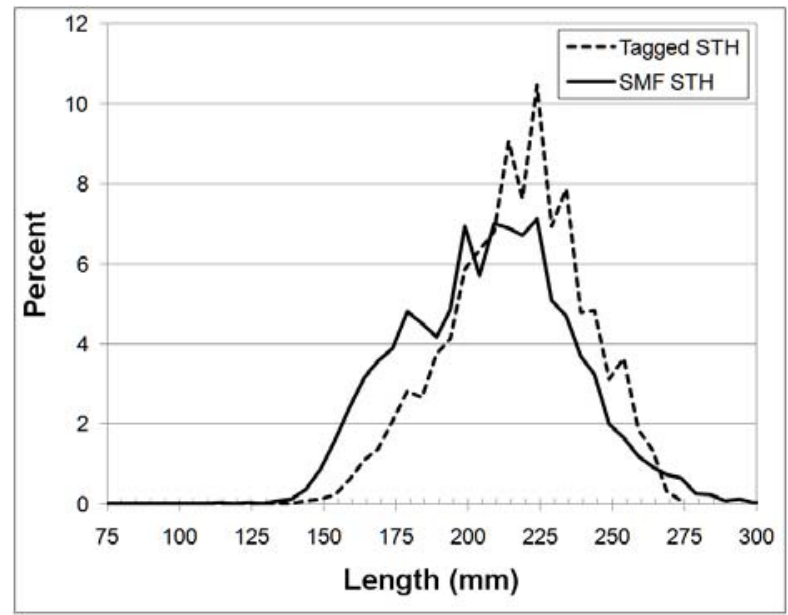

Figure 3.8. Length frequency of steelhead tagged and all steelhead collected at the John Day Dam SMF in spring 2008

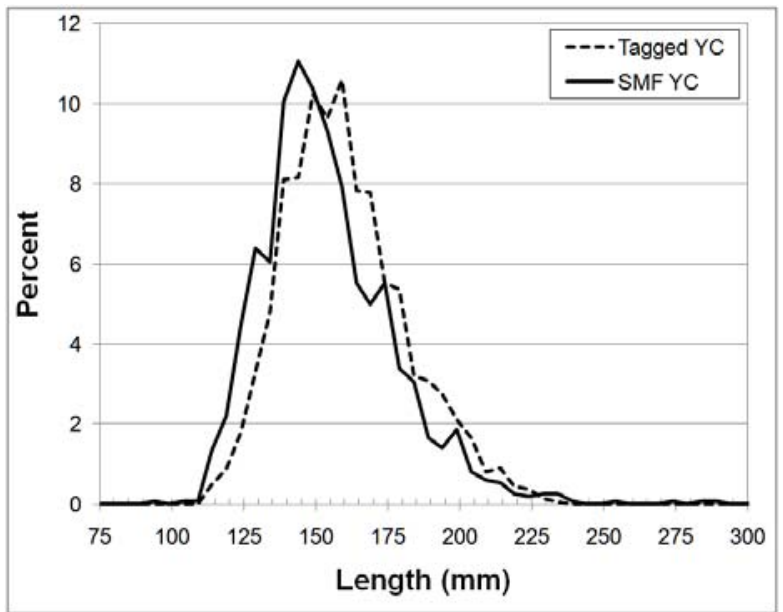

Figure 3.9. Length frequency of yearling Chinook salmon tagged and all yearling Chinook salmon collected at the John Day Dam SMF in spring 2008 


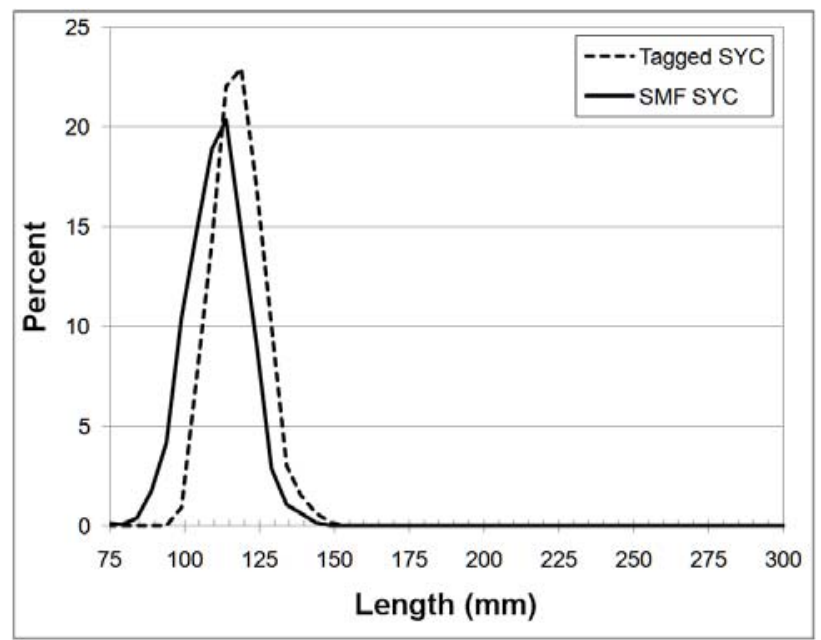

Figure 3.10. Length frequency of all subyearling Chinook salmon tagged and all subyearling Chinook salmon collected (by the John Day Dam SMF) by percent for summer

\subsection{JSATS Performance}

JSATS performance was evaluated in terms of the detection of dead fish, detection probabilities at dam-face arrays, detection probabilities and fish distribution at autonomous nodes, and probabilities of implanted tags still working by the time they passed the survival-detection arrays.

\subsubsection{Detection of Dead Fish}

A small subsample of the tagged fish was sacrificed and released dead at the release locations to make sure that if a fish died while passing through a dam it would not be detected on a downstream array and included as alive in the survival estimate. In spring, $14 \mathrm{YC}$ and $15 \mathrm{STH}$ were released with the reference group below John Day Dam. Another five STH and six YC also were released with the treatment fish near Arlington. No dead fish were detected on any of the autonomous or dam-face arrays. In summer, 6 SYC tagged with acoustic tags were sacrificed and released near Arlington, 14 were released with the reference group below John Day Dam, and 2 were released with the release group below The Dalles Dam. None of these tagged fish was detected on the autonomous or dam-face arrays.

\subsubsection{Detection Probabilities at Dam-Face Arrays}

Detection probabilities for each of three tagged fish populations were over $99 \%$ for both independent dam-face arrays, and the combined detection probability was essentially $100 \%$ (Table 3.5). Most tagged fish were detected by both arrays.

\subsubsection{Detection Probabilities and Fish Distributions at Autonomous Nodes}

Detection probabilities for survival-detection arrays composed of autonomous nodes were over $99 \%$ for arrays deployed upstream of Bonneville Dam each season, but probabilities fell $8 \%$ to $10 \%$ for the first survival-detection array below Bonneville Dam and another 10\% to $20 \%$ for the second array below Bonneville Dam (Figure 3.11). The first array below Bonneville Dam served as the tertiary array for John 
Day Dam survival estimates and as the secondary for The Dalles Dam survival estimates. The second array below Bonneville Dam served as the tertiary array for The Dalles Dam survival estimates.

Table 3.5. Detection probabilities for the dam-face arrays $(\mathrm{N} 11=$ detected on both arrays; $\mathrm{N} 10=$ detected on array 1 but not array 2; N01 = detected on array 2 but not array 1 )

\begin{tabular}{lccccccc}
\hline & $\begin{array}{c}\text { Number } \\
\text { Released }\end{array}$ & N11 & N10 & N01 & $\begin{array}{c}\text { Detection } \\
\text { Probability } \\
\text { Array 1 }\end{array}$ & $\begin{array}{c}\text { Detection } \\
\text { Probability } \\
\text { Array 2 }\end{array}$ & $\begin{array}{c}\text { Combined } \\
\text { Probability }\end{array}$ \\
\hline YC & 2445 & 2341 & 26 & 15 & 0.99363 & 0.98902 & 0.99993 \\
STH & 2448 & 2305 & 14 & 7 & 0.99697 & 0.99396 & 0.99999 \\
SYC & 2483 & 2351 & 3 & 5 & 0.99788 & 0.99873 & 0.99999 \\
\hline STH $=$ steelhead. \\
SYC $=$ subyearling Chinook salmon. \\
YC = yearling Chinook salmon.
\end{tabular}

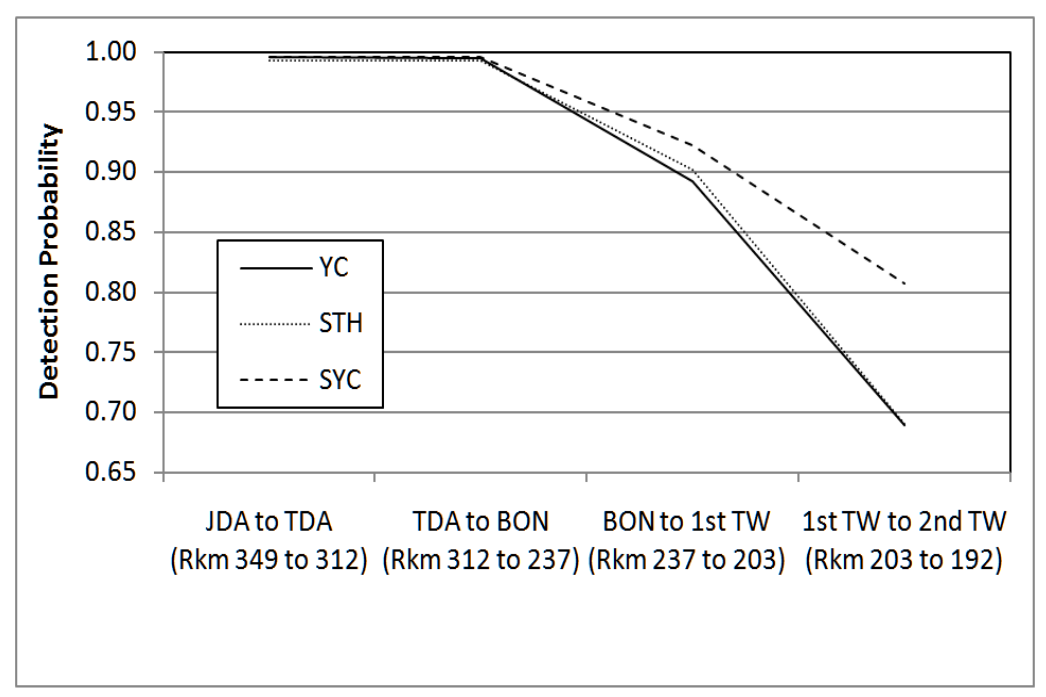

Figure 3.11. Detection probabilities by reach for the autonomous arrays

Most YC, STH, and SYC were detected approaching John Day Dam on the north side of the forebay channel (Figure 3.12). This was also apparent for YC and STH, but not for SYC, approaching Bonneville Dam. The lateral distribution of detections was less skewed at The Dalles Dam forebay entrance array (Figure 3.12). The center node in The Dalles Dam forebay was less effective than the two nodes on either side. The depth of the middle The Dalles Dam forebay node was $92 \mathrm{ft}$ compared to deployment depths of $59 \mathrm{ft}$ and $67 \mathrm{ft}$ for the adjacent nodes. On the Bonneville Dam tailwater arrays, a higher percentage of tagged fish of each stock was detected on nodes deployed in the main channel than in side channels behind islands (Figure 3.12). 


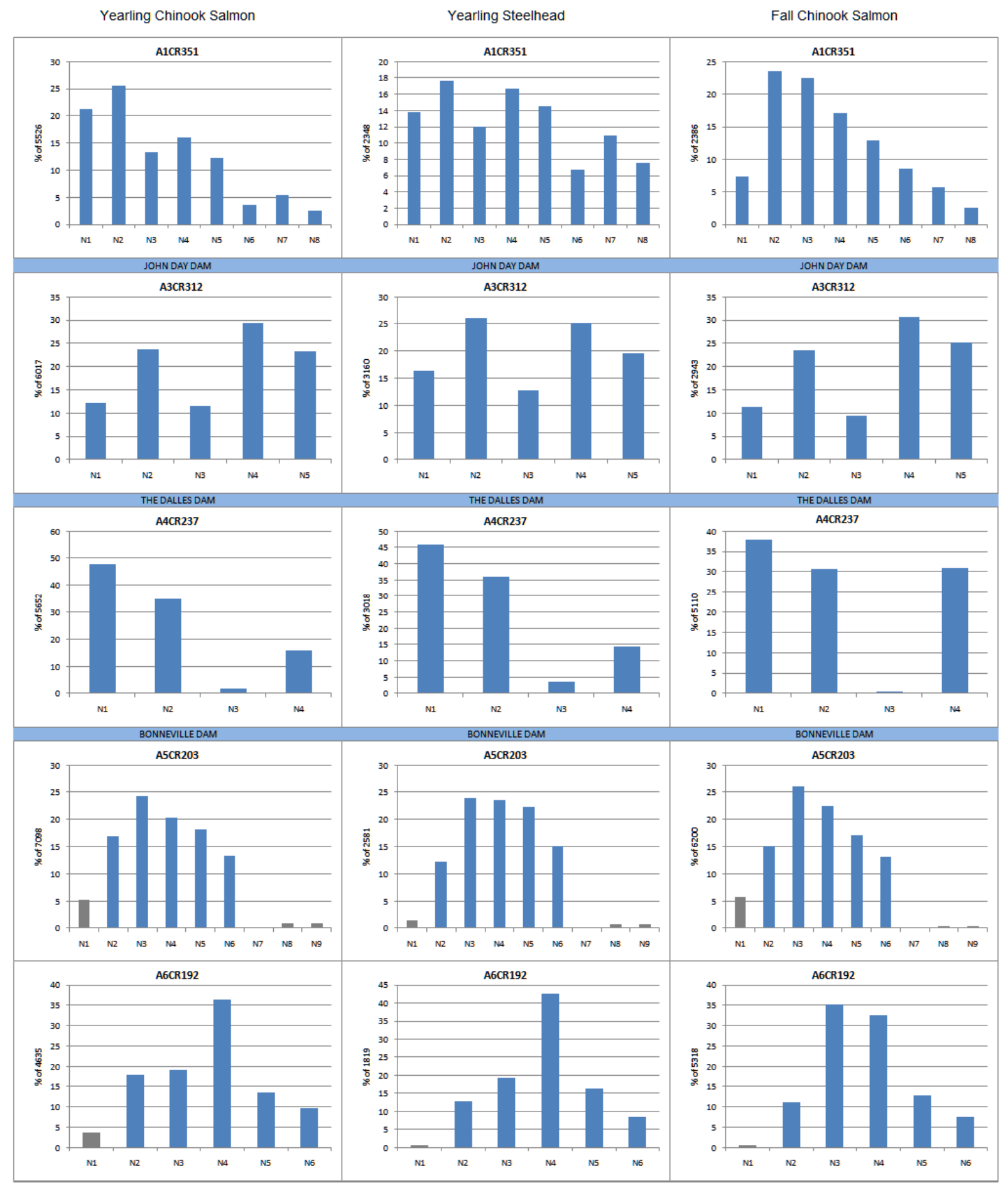

Figure 3.12. Percentage of acoustic tag detections by fish stock (columns) on autonomous nodes deployed in arrays in the John Day Dam forebay (1st row), The Dalles Dam forebay (2nd row), Bonneville Dam forebay (3rd row), Bonneville Dam tailwater near Reed Island (4th row), and Bonneville Dam tailwater near Lady Island and Camas, Washington (5th row). In general, the Washington shore is on the left side of each panel and the Oregon shore is on the right as if the reader were looking upstream. Gray bars represent nodes deployed in side channels outside of the main channel. 


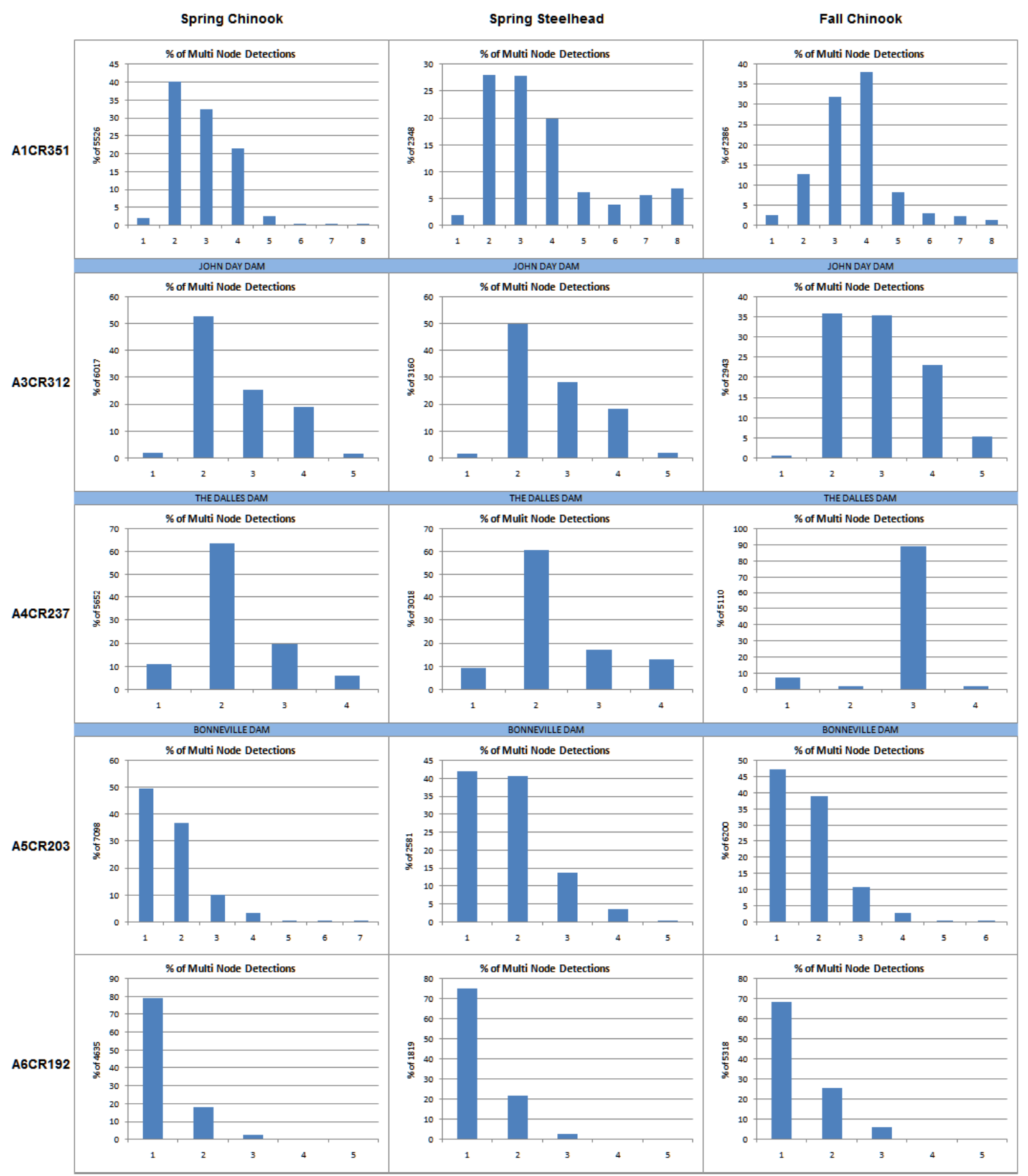

Figure 3.13. Frequency of detections on multiple autonomous nodes in arrays located in the John Day Dam forebay entrance (A1CR351), The Dalles Dam forebay entrance (A3CR312), Bonneville Dam forebay entrance (A4CR237), and Bonneville Dam tailwater (A5CR203 and A6CR192) 
Another indicator of performance is the frequency of simultaneous detections on multiple nodes within arrays, and the arrays upstream of Bonneville Dam clearly had more multi-node detections than did arrays downstream of Bonneville Dam (Figure 3.13). For example, the percent of simultaneous YC detections on two or more nodes was $96 \%$ on the John Day Dam forebay array, $98 \%$ on The Dalles Dam forebay array, and $89 \%$ on the Bonneville Dam forebay array. In contrast, the percent detection of YC on two or more nodes was just $50 \%$ on the first Bonneville Dam tailwater array and $21 \%$ for the second tailwater array. Similar trends were evident for STH and SYC (Figure 3.13), where the percent of multiple-node detections was higher on arrays upstream of Bonneville Dam than on downstream arrays.

Detection probabilities were so high for arrays in the John Day Dam, The Dalles Dam, and Bonneville Dam pools that there was not enough range in the data to correlate them with river discharge. However, for the two reaches below Bonneville Dam, correlations between river discharge and detection probability were readily apparent; as discharge increased, detectability decreased (Figure 3.14).

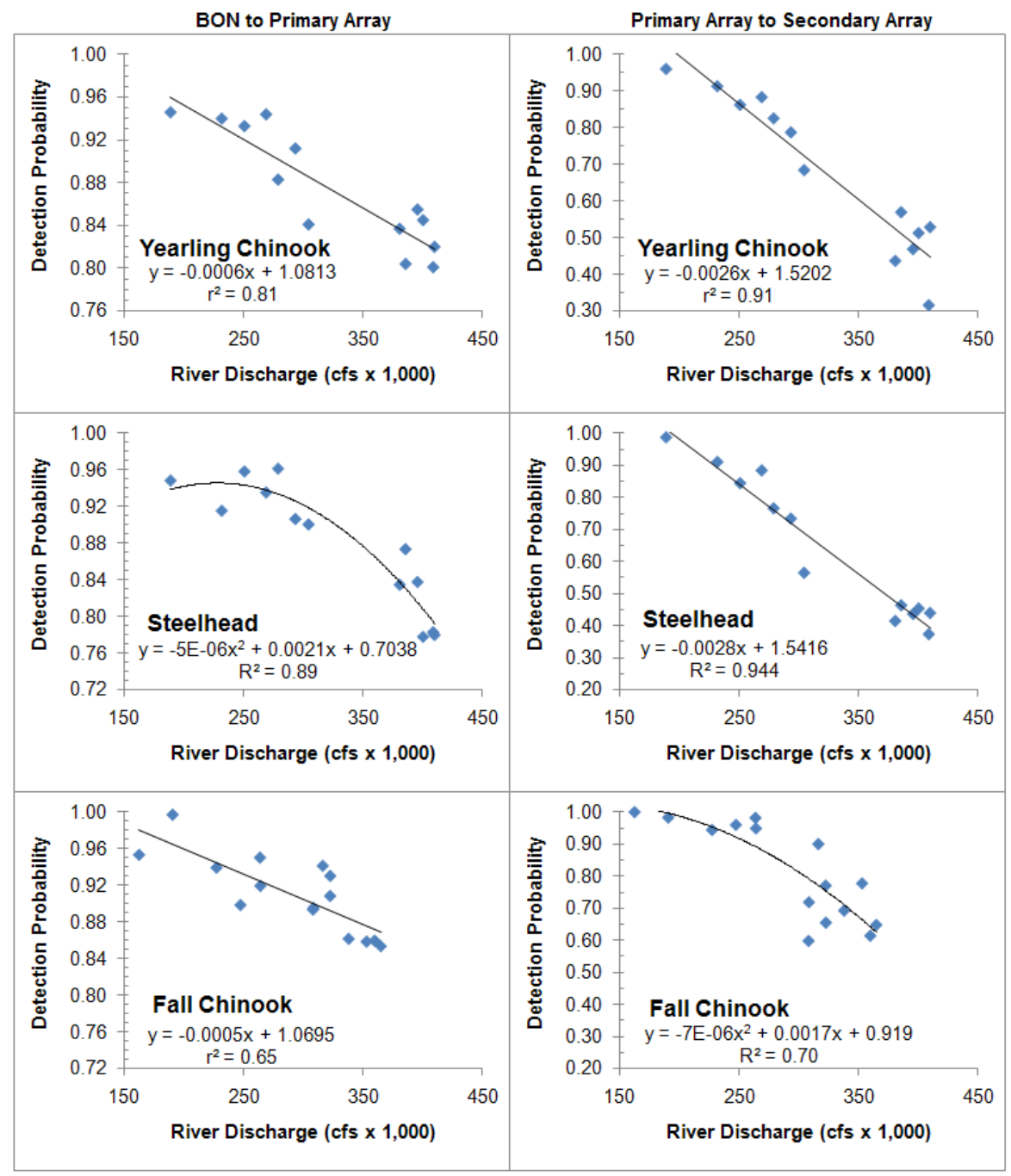

Figure 3.14. Detection probabilities as a function of water discharge in two river reaches below Bonneville Dam 


\subsubsection{Tag Life}

For all stocks of fish studied in 2008 , over $99 \%$ of the smolts passed the primary, secondary, and tertiary survival-detection arrays before there was any appreciable tag failure (Appendix C). The number of days required for over $99 \%$ of smolts to pass the tertiary survival-detection array for John Day Dam was 14 for YC, 16 for STH, and 10 for SYC. Appendix C also contains plots showing the probability of an implanted tag still working by the time it passed the Bonneville Dam survival-detection arrays. This probability exceeded $99 \%$ for a tag implanted in any of the three stocks of smolts tagged and released in the John Day Dam pool, John Day Dam tailwater, or The Dalles Dam tailwater. It was about $97 \%$ for a tag implanted in YC released on the Snake River below Lower Granite Dam.

\subsection{Survival Rates of Yearling Chinook in Spring}

The survival and detection history of YC in spring were studied at both John Day Dam and The Dalles Dam.

\subsubsection{John Day Dam Concrete-Passage Survival and Detection History}

Paired- and single-release results are described here.

\subsubsection{Paired Release}

Yearling Chinook salmon were released at Arlington, Oregon (rkm 390), and in the John Day Dam tailrace ( $\mathrm{rkm} 346)$ to provide paired release-recapture data. There was no relationship between survival rate and release date (Figure 3.15). The tag-life-corrected, paired-release, concrete-passage survival estimate was $0.957 \pm 0.013(1 / 295 \%$ confidence interval [CI]). It was similarly high for nonturbine routes; however, the turbine-passage survival rate at $0.855( \pm 0.034)$ was lower than survival rates for smolts passing through nonturbine routes (Table 3.6). Detailed capture history and survival results by release date are provided in Appendix E.

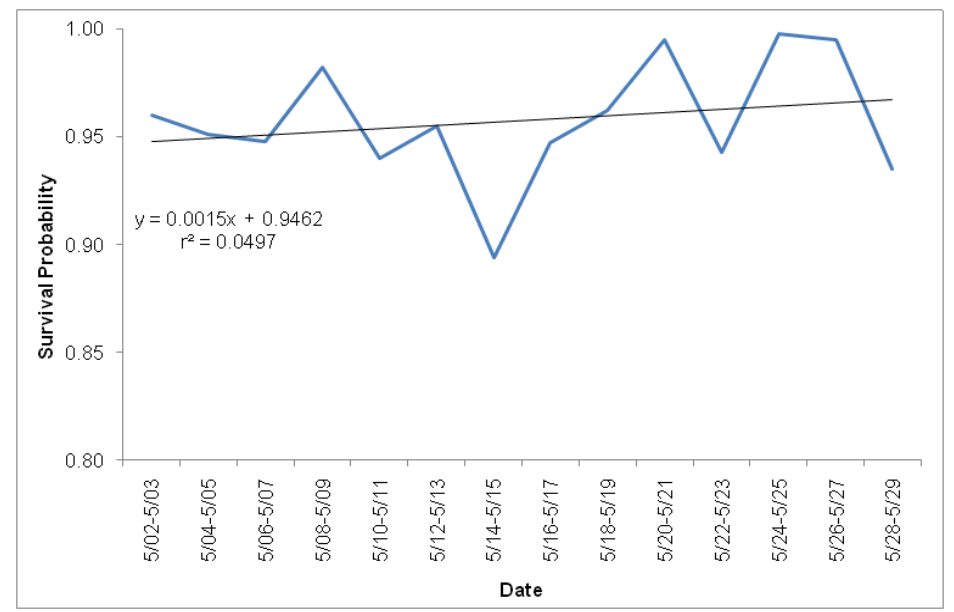

Figure 3.15. Survival rates by release period for yearling Chinook salmon. The black line is the linear regression line with a slope that did not differ significantly from zero. 
Table 3.6. Tag-life-corrected, paired-release estimates of survival rates for yearling Chinook salmon smolts regrouped at the corresponding routes at the dam to form virtual releases. Estimates of survival rate were based on pooled data when capture history probabilities were homogeneous and on sample-size-weighted means when probabilities were not homogeneous.

\begin{tabular}{lcc}
\hline \multicolumn{1}{c}{ Route } & Survival & $\pm 1 / 295 \%$ CI \\
\hline Concrete & 0.957 & 0.013 \\
Non-TSW & 0.966 & 0.011 \\
TSW & 0.961 & 0.020 \\
Turbine & 0.855 & 0.034 \\
JBS & 0.976 & 0.045 \\
\hline CI = confidence interval. \\
JBS = juvenile bypass system. \\
TSW = top-spill weir. \\
\hline
\end{tabular}

\subsubsection{Single Release}

Estimates of single-release survival rates [ $\hat{\mathrm{S}}( \pm 1 / 295 \% \mathrm{CI})]$ were calculated for YC released at Arlington, Oregon (rkm 390), and regrouped at the John Day Dam face to form virtual releases. The single-release, concrete-passage survival rate for John Day Dam was 0.944 ( \pm 0.011$)$. The highest routespecific survival rate was for TSW-passed fish $(0.990 \pm 0.006)$, whereas the lowest survival rate came from turbine-passed fish $(0.844 \pm 0.031$; Table 3.7). Detailed capture histories and survival estimates by release are in Appendix E.

Table 3.7. Tag-life-corrected, single-release estimates of route-specific survival rates for yearling Chinook salmon smolts in virtual releases at John Day Dam based on detections at three downstream arrays. Survival estimates were based on pooled data when capture history probabilities were homogeneous and on sample-size-weighted means when probabilities were not homogeneous.

\begin{tabular}{lcc}
\hline \multicolumn{1}{c}{ Route } & Survival & $\pm 1 / 295 \%$ CI \\
\hline Concrete & 0.944 & 0.011 \\
Non-TSW & 0.951 & 0.009 \\
TSW & 0.990 & 0.006 \\
Turbine & 0.844 & 0.031 \\
JBS & 0.963 & 0.044 \\
\hline CI $=$ confidence interval. \\
JBS = juvenile bypass system. \\
TSW = top-spill weir. \\
\hline
\end{tabular}

\subsubsection{The Dalles Dam Survival and Detection History}

Yearling Chinook salmon released at Arlington, Oregon (rkm 390), and in the John Day Dam tailrace (rkm 346) were regrouped on the The Dalles Dam forebay entrance array and used to estimate The Dalles 
Dam-passage survival rate based on subsequent detections on one array in the Bonneville Dam forebay and two in the Bonneville Dam tailwater. The estimate of the tag-life-corrected, single-release dampassage survival rate for YC smolts traveling from The Dalles Dam forebay entrance array to the Bonneville Dam forebay array was $0.947 \pm 0.007$ (1/2 95\% CI). Detailed capture history and survival results by release are in Appendix F.

\subsubsection{John Day Dam Concrete-Passage Survival Rate for Lower Granite Dam Yearling Chinook Salmon}

Yearling Chinook salmon were released at Lower Granite Dam and the survival rate was calculated for the fish that were detected passing John Day Dam. We compared the estimated paired-release survival rate of the Lower Granite Dam YC with the estimated paired-release survival rate based on YC released at Arlington, Oregon (rkm 390), and in the John Day Dam tailrace (rkm 346). We used the same downstream detection arrays (primary array at rkm 312.4, secondary array at rkm 237.5, and the tertiary array at rkm 204). There was no significant difference in the estimates of paired-release, concretepassage survival rates for smolts tagged and released at Lower Granite Dam $(0.938 \pm 0.028$ 1/2 95\% CI) or at Arlington, Orgeon $(0.957 \pm 0.0131 / 295 \% \mathrm{CI})$. Detailed capture history and survival results for Lower Granite Dam YC are in Appendix G.

\subsection{Survival Rates of Steelhead in Spring}

The survival rates of STH are reported in the following sections.

\subsubsection{John Day Dam Concrete-Passage Survival and Detection History}

Results related to estimates of paired-release and single-release survival rates for STH are described.

\subsubsection{Paired Release}

There was no relationship between paired-release survival estimates for STH smolts passing through John Day Dam and release date $\left(\mathrm{r}^{2}=0.0008\right.$; Figure 3.16). The estimate of tag-life-corrected, pairedrelease, concrete-passage survival rate for STH was $0.986 \pm 0.0191 / 295 \%$ CI (Table 3.8). Routespecific survival rates for STH were very high for smolts passing through the JBS (1.002 \pm 0.019$)$ and TSW (0.992 \pm 0.023$)$ and low for turbine-passed fish $(0.749 \pm 0.062$; Table 4.8). Detailed capture history and survival results by release date are in Appendix H. 


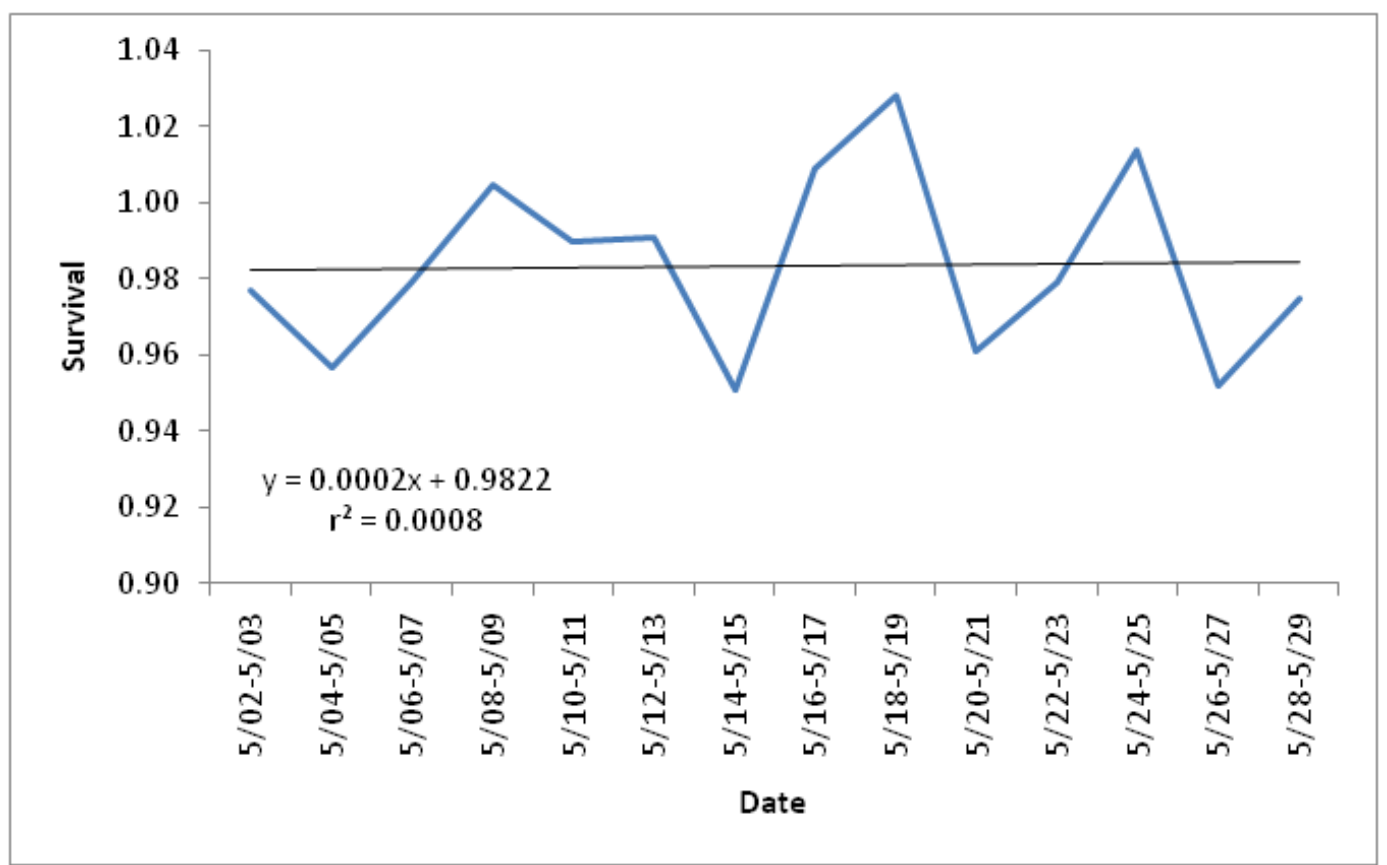

Figure 3.16. Survival rate by release period for yearling steelhead. The black line is the linear regression line with a slope that did not differ significantly from zero.

Table 3.8. Tag-life-corrected, paired-release estimates of survival rates for steelhead smolts regrouped at the corresponding routes at the dam to form virtual releases. Survival estimates were based on pooled data when capture history probabilities were homogeneous and on sample-sizeweighted means when probabilities were not homogeneous.

\begin{tabular}{lcc}
\hline \multicolumn{1}{c}{ Route } & Survival & $\pm 1 / 295 \% \mathrm{CI}$ \\
\hline Concrete & 0.986 & 0.019 \\
Non-TSW & 0.985 & 0.023 \\
TSW & 0.992 & 0.023 \\
Turbine & 0.749 & 0.062 \\
JBS & 1.002 & 0.019 \\
\hline CI $=$ confidence interval. \\
JBS = juvenile bypass system. \\
TSW = top-spill weir. \\
\hline
\end{tabular}

\subsubsection{Single Release}

Survival estimates were calculated from John Day Dam-face virtual releases of STH originally released at Arlington, Oregon ( $\mathrm{rkm} 390)$. The estimate of the tag-life-corrected survival rate $(\hat{\mathrm{S}} \pm 1 / 2$ 95\% CI) for John Day Dam was 0.959 \pm 0.011 . The single-release survival rate was highest for JBSpassed fish $(0.975 \pm 0.012)$, lower for TSW-passed fish $(0.965 \pm 0.017)$, and lowest for turbine-passed fish $(0.729 \pm 0.052$; Table 3.9). Detailed capture history and survival results by release date are in Appendix $\mathrm{H}$. 
Table 3.9. Cormack-Jolly-Seber, tag-life-corrected, single-release estimates of survival rates for steelhead smolts released near Arlington, Oregon. Survival estimates were based on pooled data when capture history probabilities were homogeneous and on sample-size-weighted means when probabilities were not homogeneous.

\begin{tabular}{lcc}
\hline \multicolumn{1}{c}{ Route } & Survival & $\pm 1 / 295 \% \mathrm{CI}$ \\
\hline Concrete & 0.959 & 0.011 \\
Non-TSW & 0.959 & 0.017 \\
TSW & 0.965 & 0.017 \\
Turbine & 0.729 & 0.052 \\
JBS & 0.975 & 0.012 \\
\hline CI = confidence interval. & \\
JBS = juvenile bypass system. & \\
TSW = top-spill weir. & \\
\hline
\end{tabular}

\subsubsection{The Dalles Dam Survival and Detection History}

Steelhead smolts were released near Arlington, Oregon (rkm 390), and in the John Day Dam tailrace (rkm 343.4), and regrouped on The Dalles Dam forebay entrance array to create virtual releases for estimating single-release dam-passage survival rates for The Dalles Dam. The tag-life-corrected survival rate from $2 \mathrm{~km}$ upstream of The Dalles Dam to the Bonneville Dam forebay was $0.959 \pm 0.009$ 1/2 95\% CI). Detailed capture history and survival results by release are in Appendix I.

\subsection{Survival Rates of Subyearling Chinook Salmon in Summer}

The John Day Dam and The Dalles Dam estimated survival rates and detection histories for SYC are described in the following sections.

\subsubsection{John Day Dam Concrete-Passage Survival Survival and Detection History}

Paired- and single-release results are discussed.

\subsubsection{Paired Release}

There was no relationship between the SYC paired-release survival rate and virtual release date $\left(\mathrm{r}^{2}=0.1383\right.$; Figure 3.17). The estimate of the tag-life-corrected, paired-release, concrete-passage survival rate $(\hat{\mathrm{S}} \pm 1 / 295 \% \mathrm{CI})$ for $\mathrm{SYC}$ was $0.861 \pm 0.017$. The lowest route-specific estimate was for turbinepassed fish and the highest was for JBS-passed fish (Table 3.10). The 1/2 95\% CI on the point estimate for TSW-passed smolts overlapped with that of the point estimate for JBS-passed fish. Survival of TSWpassed smolts was higher than that of smolts passing through non-TSW spill bays or turbines. Detailed capture history and survival results by release date are in Appendix $\mathrm{J}$. 


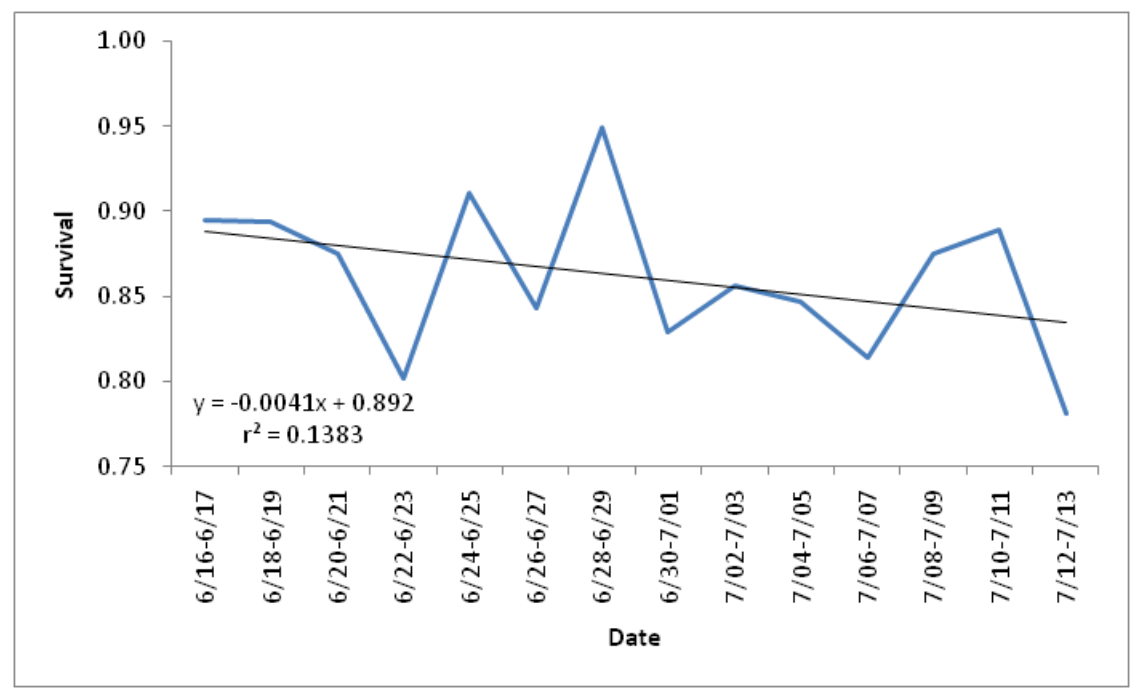

Figure 3.17. Paired-release estimates of concrete-passage survival rate by release date for subyearling Chinook salmon. The black line is the linear regression line with a slope that did not differ significantly from zero.

Table 3.10. Tag-life-corrected, paired-release estimates of survival rates for subyearling Chinook smolts regrouped at the corresponding routes at the dam to form virtual releases. Survival estimates were based on pooled data when capture history probabilities were homogeneous and on sample-size-weighted means when probabilities were not homogeneous.

\begin{tabular}{lcc}
\hline \multicolumn{1}{c}{ Route } & Survival & $\pm 1 / 295 \%$ CI \\
\hline Concrete & 0.861 & 0.017 \\
Non-TSW & 0.844 & 0.044 \\
TSW & 0.927 & 0.016 \\
Turbine & 0.728 & 0.056 \\
JBS & 0.973 & 0.057 \\
\hline CI = confidence interval. \\
JBS = juvenile bypass system. \\
TSW = top-spill weir. \\
\hline
\end{tabular}

\subsubsection{Single Release}

The single-release, tag-life-corrected estimate of the concrete-passage survival rate for SYC smolts was $0.844 \pm 0.023(1 / 295 \% \mathrm{CI})$. The highest tag-life-corrected, route-specific point estimate was for JBS-passed smolts $(0.954)$ followed by smolts passing through the TSW (0.910), non-TSW spill bays (0.827), and then turbines (0.714; Table 3.11). Detailed capture history and survival results by release date are in Appendix J. 
Table 3.11. Tag-life-corrected, single-release estimates of survival rates for subyearling Chinook smolts in virtual release at John Day Dam based on three downstream arrays. Survival estimates were based on pooled data when capture history probabilities were homogeneous and on sample-size-weighted means when probabilities were not homogeneous.

\begin{tabular}{lcc}
\hline \multicolumn{1}{c}{ Route } & Survival & $\pm 1 / 295 \%$ CI \\
\hline Concrete & 0.844 & 0.023 \\
Non-TSW & 0.827 & 0.039 \\
TSW & 0.910 & 0.012 \\
Turbine & 0.714 & 0.046 \\
JBS & 0.954 & 0.054 \\
\hline CI = confidence interval. \\
JBS = juvenile bypass system. \\
TSW = top-spill weir. \\
\hline
\end{tabular}

\subsubsection{The Dalles Dam Survival and Detection History}

Subyearling Chinook salmon smolts released at Arlington, Oregon (rkm 390), and in the John Day Dam tailrace (rkm 346) were regrouped to form virtual releases at The Dalles Dam forebay entrance array. There also were paired releases in The Dalles Dam tailrace. The tag-life-corrected, paired-release estimate of survival rate for SYC was $0.931( \pm 0.013)$. Detailed capture history and survival results by release date are in Appendix K.

\subsection{Spatial and Temporal Trends at John Day Dam and Spill- Condition Effects}

In this section, the spatial and temporal trends and spill-condition effects at John Day Dam are discussed for YC, STH, and SYC.

\subsubsection{Yearling Chinook Salmon}

Passage efficiency and effectiveness, horizontal passage distribution at the dam, powerhouse and spillway passage, the effect of spill conditions on dam-passage survival rate and passage proportions, and diel trends in survival rates and passage efficiencies relative to $\mathrm{YC}$ are described below.

\subsubsection{Passage Efficiency and Effectiveness}

For YC smolts in spring 2008, John Day Dam fish-passage efficiency was 92\%; spillway-passage efficiency was $76 \%$; and the two spill bays with TSWs passed $24 \%$ of all smolts in $6.9 \%$ of the water discharged through the dam (Table 3.12). The TSW was more effective than the entire spillway at passing YC smolts. Of the $24 \%$ of YC smolts passing into the powerhouse, $66 \%$ were diverted by the intake screens into the JBS, and JBS-passage efficiency, relative to total numbers passing through the dam, was $15.9 \%$. About $8 \%$ of all YC smolts passed through turbines. 
Table 3.12. Estimates of major passage metrics for yearling Chinook salmon during spring

\begin{tabular}{lc}
\hline \multicolumn{1}{c}{ Metric } & Spring $( \pm 1 / 295 \% \mathrm{CI})$ \\
\hline Fish-Passage Efficiency & $92.14 \pm 1.30 \%$ \\
Spillway-Passage Efficiency & $76.24 \pm 2.44 \%$ \\
Fish-Guidance Efficiency & $66.90 \pm 4.75 \%$ \\
TSW-Passage Efficiency & $23.55 \pm 2.81 \%$ \\
JBS-Passage Efficiency & $15.90 \pm 2.11 \%$ \\
Spillway-Passage Effectiveness & $2.32 \pm 0.07$ \\
TSW-Passage Effectiveness & $3.41 \pm 0.41$ \\
\hline CI = confidence interval. & \\
JBS = juvenile bypass system. & \\
TSW = top-spill weir. & \\
\hline
\end{tabular}

\subsubsection{Horizontal Passage Distribution at the Dam}

During spring, the number of tagged $\mathrm{YC}$ smolts passing through individual routes was very high at spill bays with TSWs (spill bays 15 and 16) and at nearby regular spill bays 17 and 18 even though 66\% of water discharge was through the powerhouse (Figure 3.18). Passage at spill bays 14 and 19 was less than $50 \%$ of passage at TSW bays and spill bays 17 and 18 , but passage was still two times higher than passage at most other individual routes.

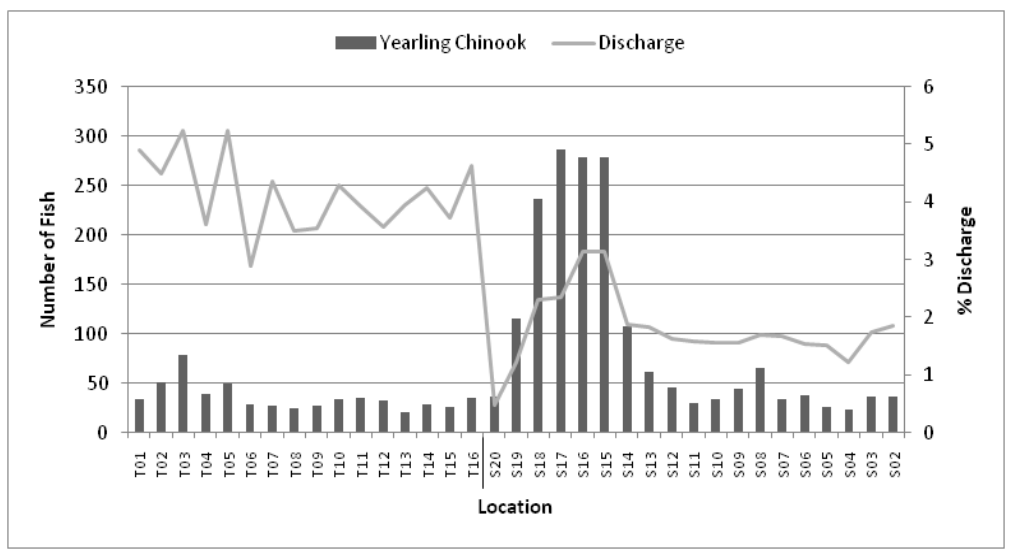

Figure 3.18. Yearling Chinook salmon smolt passage and discharge by individual passage route in spring 2008

\subsubsection{Powerhouse Passage}

During spring, $66.9 \%$ of the $\mathrm{YC}$ smolts that passed through the dam at the powerhouse were guided through the JBS, and the remaining one-third passed through the turbines (Figure 3.19). Turbine discharge was fairly uniform across the powerhouse, although $1 \%$ to $2 \%$ higher at turbine units $1,2,3$, and 5 than it was at most other units. 


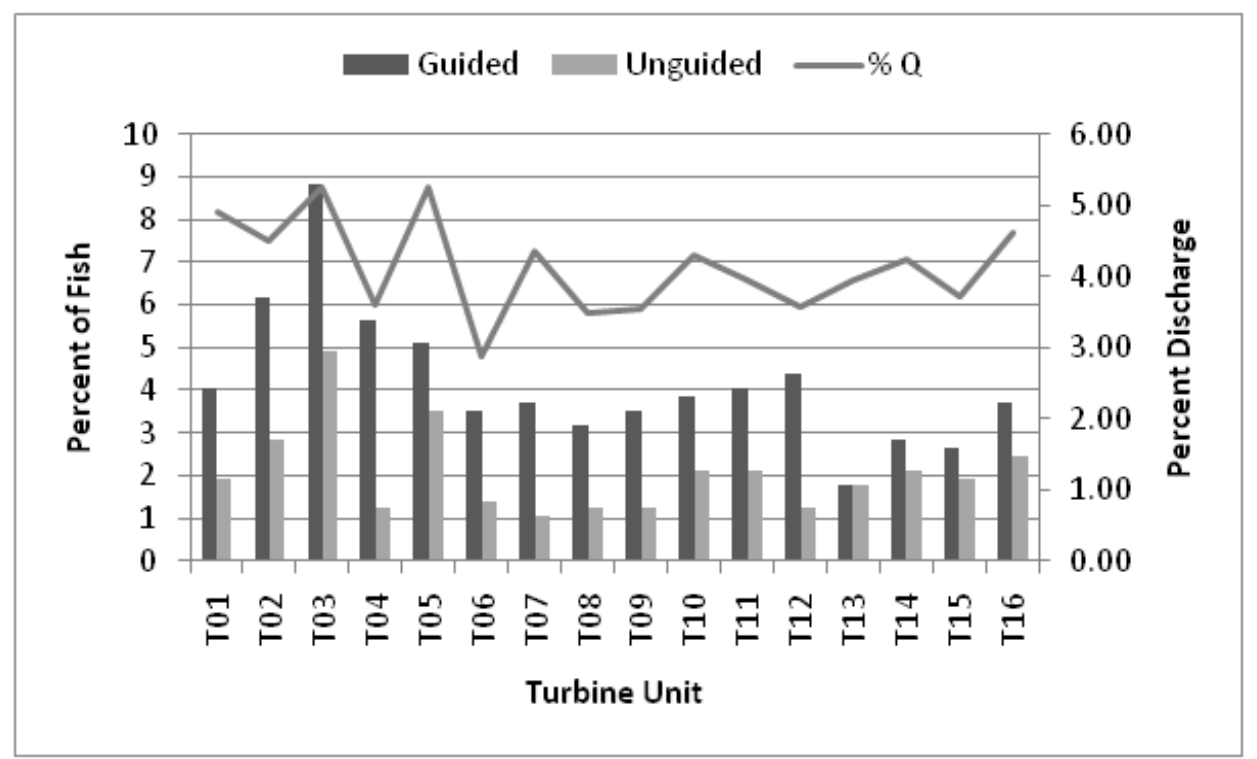

Figure 3.19. Guided and unguided passage of yearling Chinook salmon smolts and discharge $\left(\mathrm{m}^{3} \times 100\right)$ by turbine unit

\subsubsection{Spillway Passage}

Of the YC smolts passing through the spillway, 66\% passed through the TSW and adjacent spill bays, which also had the highest discharge (Figure 3.20). The average TSW spill bay passed 1.7 times more YC than the average bay from spill bays 17 to 20 and 7.1 times more smolts than the average bay from spill bays 1 to 14 (Figure 3.21).

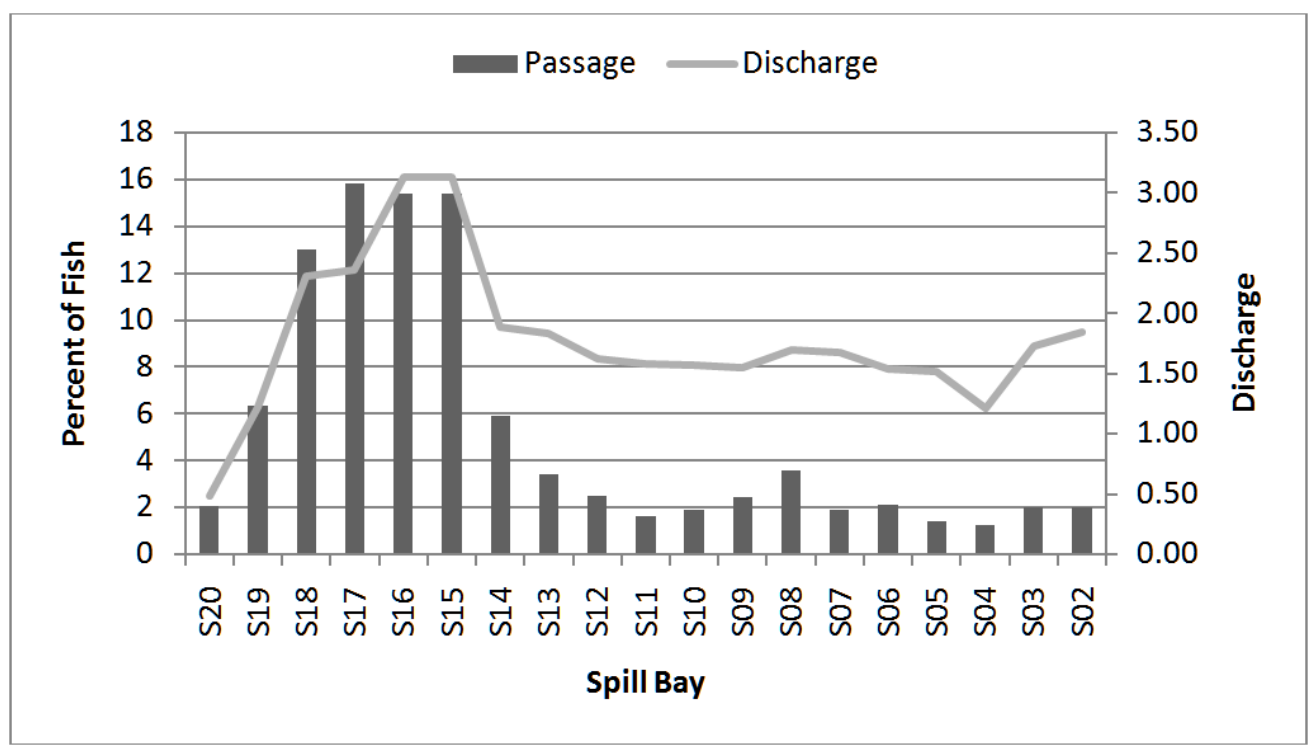

Figure 3.20. Yearling Chinook salmon passage and discharge (showing $\mathrm{m}^{3} \times 100$ ) by spill bay 


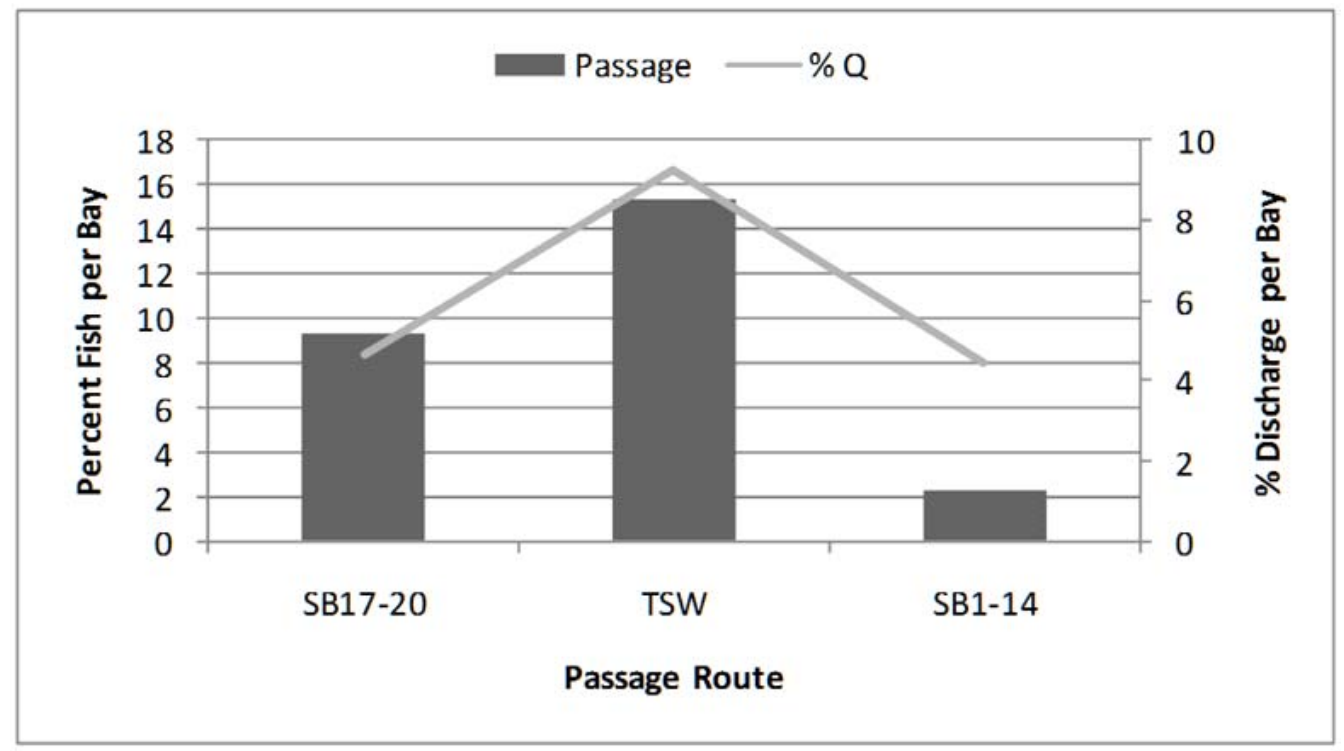

Figure 3.21. Average percent passage of yearling Chinook salmon smolts and percent discharge per spill bay within groups of bays

\subsubsection{Effect of Spill Condition on Dam Survival and Passage}

We defined post-hoc spill conditions to evaluate the effects of spill on dam-passage survival because mean hourly percent of spill discharge at John Day Dam during spring (Figure 3.22) was not similar to the prescribed spill treatments (Figure 2.1). During the middle of the spring season, higher than normal flows caused spill levels to deviate from the planned treatments. The post-hoc $30 \%$ spill condition was defined by passage when spill was $<35 \%$ and the post-hoc $40 \%$ spill condition was defined by passage when spill was between $35 \%$ and $45 \%$. The survival metric was paired-release dam-passage survival (i.e., survival of YC passing from the forebay entrance array to the tailrace release site).

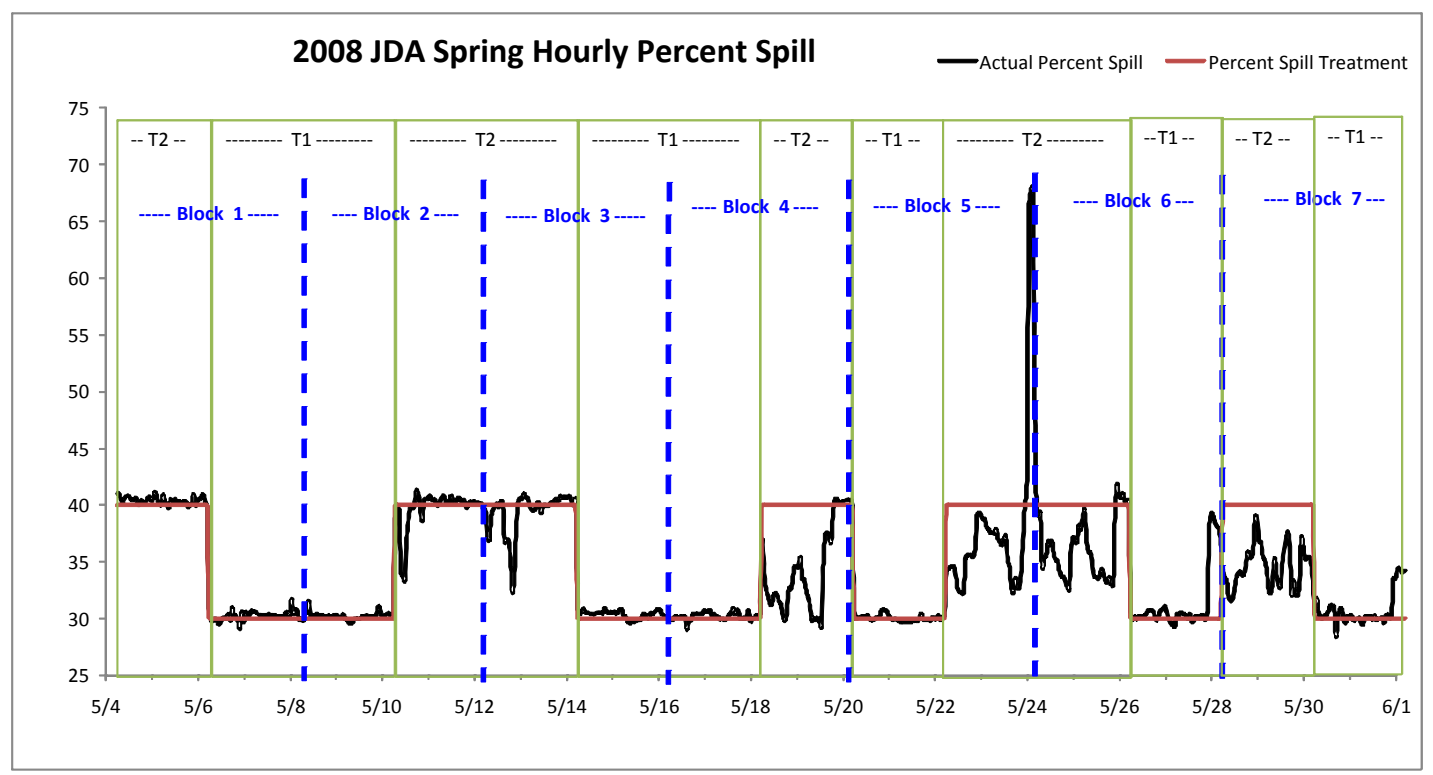

Figure 3.22. Spill treatments as prescribed (red line) and actual conditions (black line) in spring 
Paired-release estimates of dam-passage survival did not differ between the $30 \%$ and $40 \%$ spill conditions (Table 3.13) based on the overlap of 1/2 95\% CIs. Similarly, other fish-passage metrics did not differ between the $30 \%$ and $40 \%$ spill conditions (Table 3.14 ).

Table 3.13. Estimates of dam-passage survival rates by post-hoc spill condition for yearling Chinook salmon during spring

\begin{tabular}{lc}
\hline Condition & $\begin{array}{c}\text { Survival Rate }( \pm 1 / 2 \\
95 \% \mathrm{CI})\end{array}$ \\
\hline $30 \%$ Spill & $94.0 \pm 1.2 \%$ \\
$40 \%$ Spill & $94.2 \pm 1.6 \%$ \\
\hline $\mathrm{CI}=$ Confidence interval. \\
\hline
\end{tabular}

Table 3.14. Estimates of major passage metrics by spill treatment for yearling Chinook salmon during spring

\begin{tabular}{lc}
\hline \multicolumn{1}{c}{ Metric } & Spring $( \pm 1 / 295 \%$ CI $)$ \\
\hline FPE 30\% Spill & $92.85 \pm 1.85 \%$ \\
FPE 40\% Spill & $91.05 \pm 2.37 \%$ \\
\hline SE 30\% Spill & $75.89 \pm 3.93 \%$ \\
SE 40\% Spill & $76.76 \pm 4.06 \%$ \\
\hline FGE 30\% Spill & $70.35 \pm 6.87 \%$ \\
FGE 40\% Spill & $61.47 \pm 8.41 \%$ \\
\hline TSWE 30\% Spill & $25.02 \pm 4.75 \%$ \\
TSWE 40\% Spill & $21.32 \pm 4.88 \%$ \\
\hline JBSE 30\% Spill & $16.96 \pm 3.46 \%$ \\
JBSE 40\% Spill & $14.29 \pm 3.31 \%$ \\
\hline SEF 30\% Spill & $2.48 \pm 0.13$ \\
SEF 40\% Spill & $1.98 \pm 0.41$ \\
\hline TSWEF 30\% Spill & $3.68 \pm 0.70$ \\
TSWEF 40\% Spill & $2.97 \pm 0.68$ \\
\hline CI & $=$ confidence interval. \\
FGE & $=$ fish-guidance efficiency. \\
FPE & $=$ fish-passage efficiency. \\
JBSE & $=$ juvenile bypass system-passage \\
& efficiency. \\
SE & $=$ spillway-passage efficiency. \\
SEF & $=$ spillway-passage effectiveness. \\
TSW & $=$ top-spill weir. \\
TSWE & $=$ TSW-passage efficiency. \\
TSWEF $=$ TSW-passage effectiveness. & \\
\hline \multicolumn{3}{l}{}
\end{tabular}




\subsubsection{Diel Trends in Survival and Passage Efficiencies}

During spring, data were divided into day and night periods as follows: day $=0600$ to 2159 hours and night $=2200$ to 0559 hours. Most survival estimates did not differ greatly between day and night (Table 3.15). The point estimate of the turbine passage survival rate appeared to be higher at night than it was during the day, but this difference was not significant.

Table 3.15. Comparison of diel paired-release estimate of survival rates for yearling Chinook salmon during spring. These relative estimates were not corrected for tag life.

\begin{tabular}{lcc}
\hline \multicolumn{1}{c}{ Route } & Day $( \pm 1 / 295 \% \mathrm{CI})$ & Night $( \pm 1 / 295 \% \mathrm{CI})$ \\
\hline Concrete & $95.2 \pm 1.7 \%$ & $95.6 \pm 3.1 \%$ \\
Powerhouse & $90.6 \pm 4.8 \%$ & $92.8 \pm 7.3 \%$ \\
Turbine & $77.4 \pm 14.7 \%$ & $88.9 \pm 9.1 \%$ \\
JBS & $96.7 \pm 4.1 \%$ & $95.6 \pm 8.1 \%$ \\
Spillway & $95.6 \pm 1.6 \%$ & $97.0 \pm 2.2 \%$ \\
Spill bays 17-20 & $94.3 \pm 2.0 \%$ & $97.5 \pm 4.3 \%$ \\
TSW (spill bays 15 and 16) & $95.6 \pm 2.6 \%$ & $97.9 \pm 6.3 \%$ \\
Spill bays 1-14 & $96.9 \pm 3.5 \%$ & $95.9 \pm 5.5 \%$ \\
\hline CI = confidence interval. & & \\
JBS = juvenile bypass system. & & \\
TSW = top-spill weir. & & \\
\hline
\end{tabular}

Total passage and spillway passage were higher during the day than they were at night, but fish passage estimates for the powerhouse, turbines, and JBS were higher at night than during the day (Figure 3.23). The numbers of YC smolts passing through the dam were divided by total number of hours in "day" (464) and "night" (232) to come up with the number per hour. Passage rates through spill bays $1-14$, the TSW, and spill bays 17-20 were higher during the day than they were at night (Figure 3.24). Passage per bay and hour was higher for TSW bays than it was for other spill bays, and day rates were higher than night rates at the TSW bays but not at other spill bays (Figure 3.24).

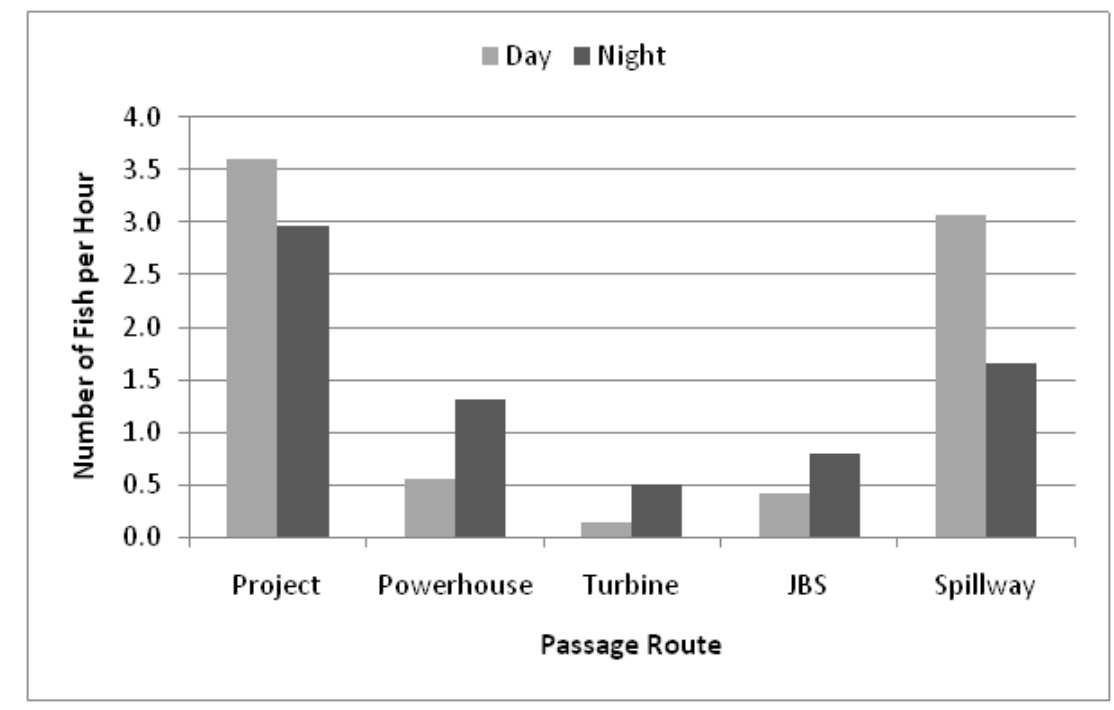

Figure 3.23. Day and night differences in passage rate for yearling Chinook salmon smolts 


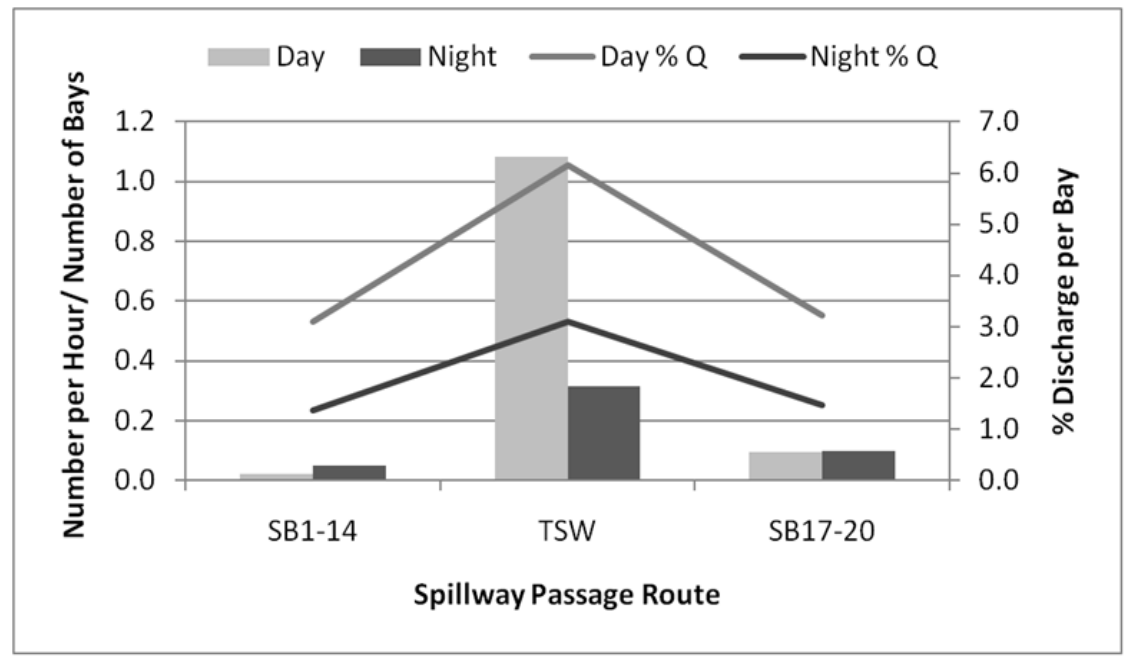

Figure 3.24. Diel passage rates (number/hour/bay) for yearling Chinook salmon smolts and percent of water discharge $(\mathrm{Q})$ for groups of spill bays

\subsubsection{Steelhead}

Passage efficiency and effectiveness, horizontal passage distribution at the dam, powerhouse and spillway passage, the effect of spill conditions on dam-passage survival rate and passage proportion among routes, and diel trends in survival rates and passage efficiencies relative to STH are described below.

\subsubsection{Passage Efficiency and Effectiveness}

During 2008, estimates of major passage metrics for STH smolts at John Day Dam show that the TSWs passed almost 50\% of all STH smolts (Table 3.16). Combining the TSW spill bays with non-TSW spill bays resulted in $74.4 \%$ of smolts passing through the spillway. Of the STH smolts passing into the powerhouse, about $89 \%$ were diverted by the intake screens into the JBS. Only about $3 \%$ of total fish passage was through turbines. The TSW spill bays were more than 3.2 times more effective than regular spill bays at passing STH (Table 3.16).

Table 3.16. Estimates of major passage metrics for yearling steelhead during spring

\begin{tabular}{lc}
\hline \multicolumn{1}{c}{ Metric } & Spring $( \pm 1 / 295 \% \mathrm{CI})$ \\
\hline Fish-Passage Efficiency & $97.2 \pm 0.7 \%$ \\
Spillway-Passage Efficiency & $74.4 \pm 2.6 \%$ \\
Fish-Guidance Efficiency & $88.9 \pm 2.7 \%$ \\
TSW-Passage Efficiency & $49.6 \pm 3.3 \%$ \\
JBS-Passage Efficiency & $22.7 \pm 2.5 \%$ \\
Spillway-Passage Effectiveness & $2.25 \pm 0.08$ \\
TSW-Passage Effectiveness & $7.21 \pm 0.48$ \\
\hline CI = confidence interval. & \\
JBS = juvenile bypass system. & \\
TSW = top-spill weir. & \\
\hline
\end{tabular}




\subsubsection{Horizontal Passage Distribution at the Dam}

The passage of STH smolts at TSW spill bays was more than six times higher than it was at any other route at John Day Dam in spring, except for adjacent spill bay 17 where TSW bay passage was only 3.3 times higher (Figure 3.25). The majority of STH (75\%) used the spillway to pass through the dam even though $66 \%$ of water discharge was through the powerhouse (Figure 3.25).

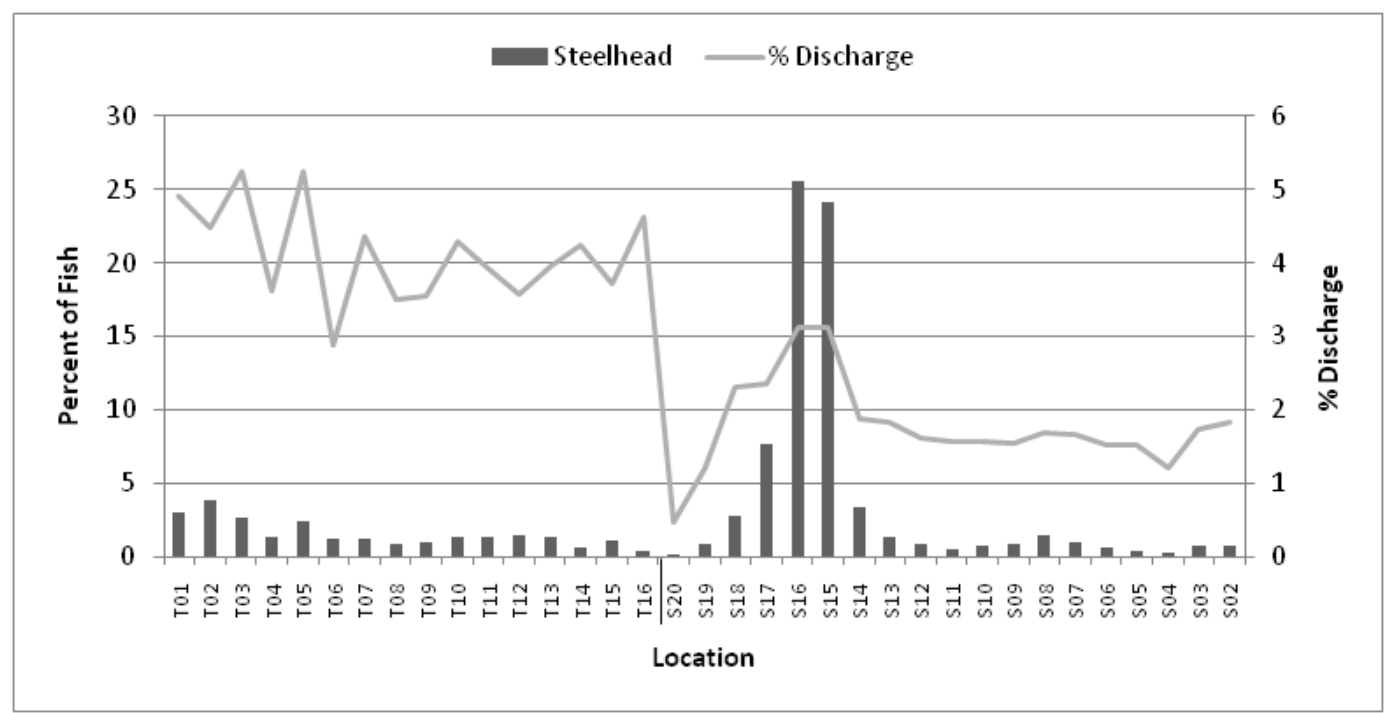

Figure 3.25. Steelhead smolt passage and percent discharge by individual passage route in spring 2008

\subsubsection{Powerhouse Passage}

During spring, $25 \%$ of STH smolts passed into the powerhouse; of these, $89 \%$ were guided by screens into the JBS (Figure 3.26).

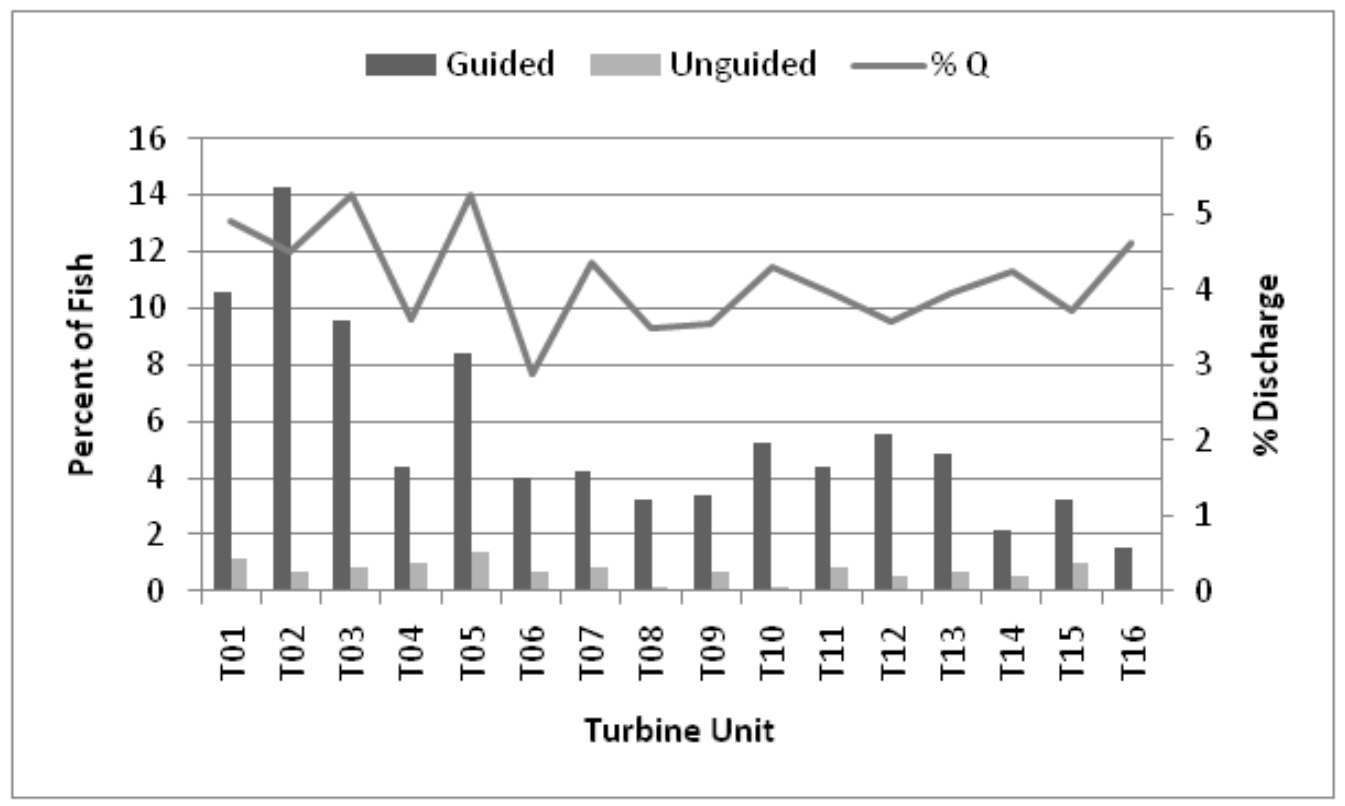

Figure 3.26. Guided and unguided passage of steelhead smolts in spring 


\subsubsection{Spillway Passage}

Among routes through the spillway (Figure 3.27), TSW spill bays 15 and 16 passed $66.6 \%$ of STH smolts (Figure 3.27). On a per-bay basis, percent passage through an average TSW bay was 22 times higher than that through an average spill bay from spill bays 2 through 14 and 8.3 times higher than that through an average bay from spill bays 17 through 20 (Figure 3.28).

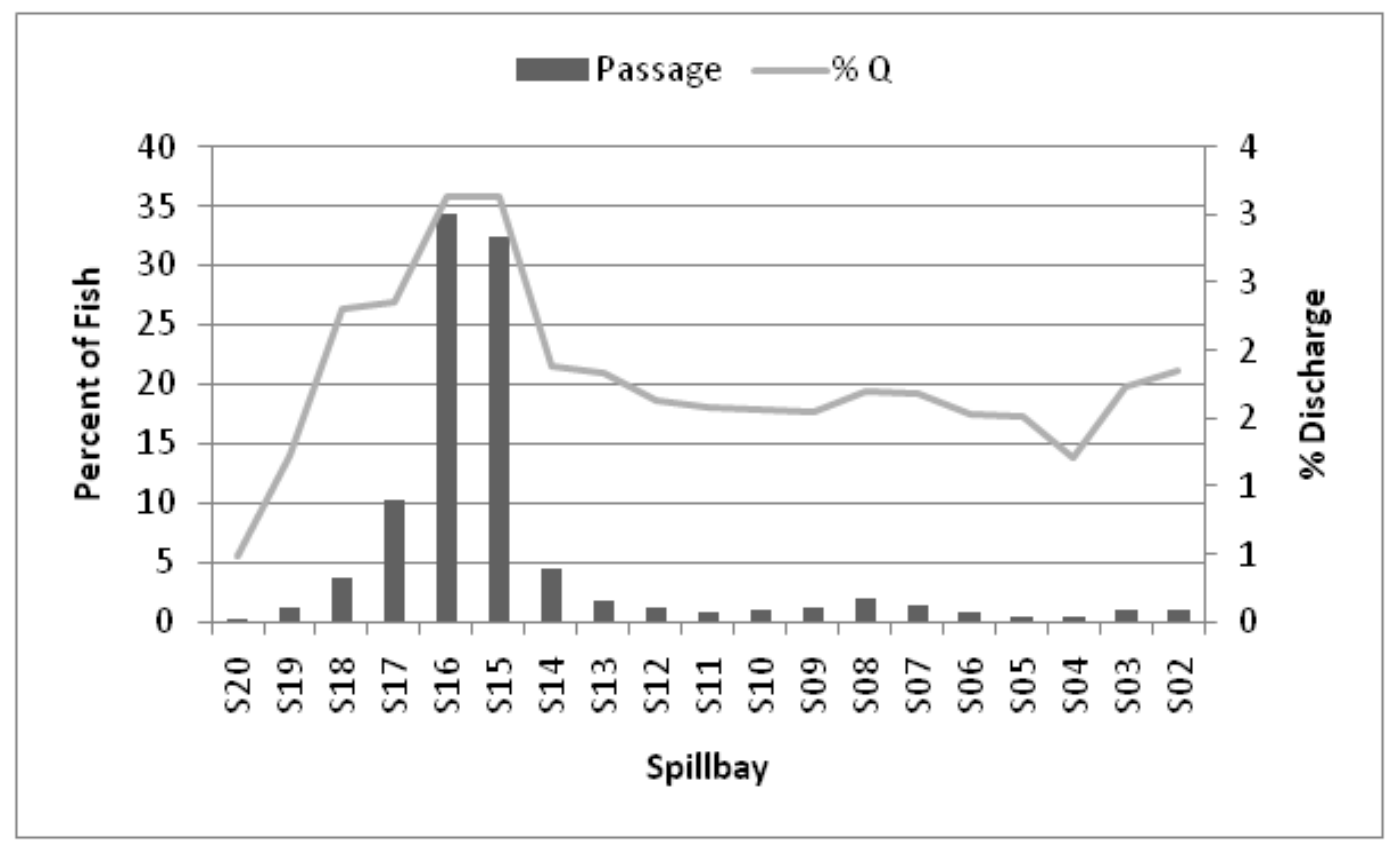

Figure 3.27. Steelhead smolt passage and percent discharge by spill bay

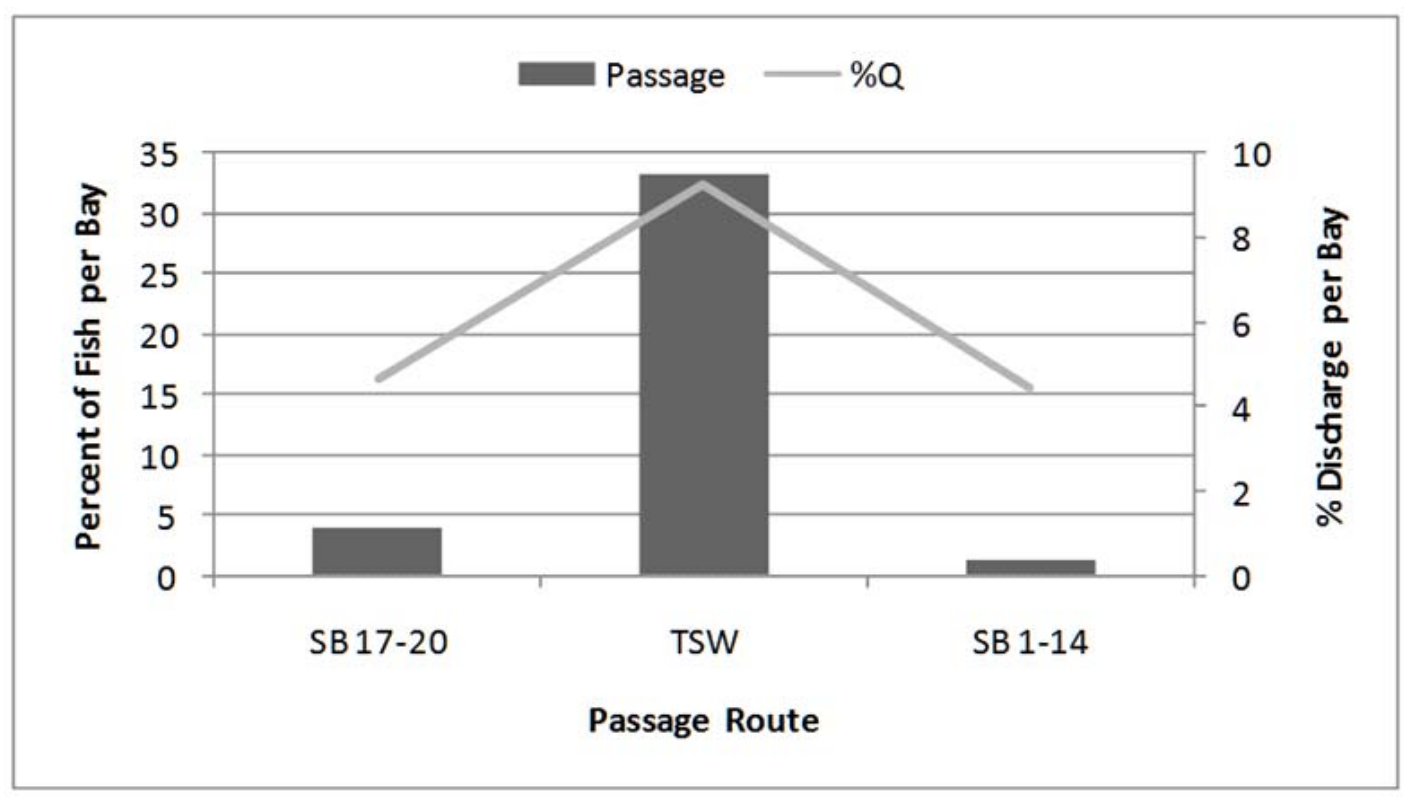

Figure 3.28. Percent passage of steelhead smolts and discharge for an average spill bay within groups of bays 


\subsubsection{Effect of Spill Condition on Dam Survival and Passage}

As for YC, we defined post-hoc spill conditions to evaluate the effects of spill on STH dam-passage survival because mean hourly percent spill discharge at John Day Dam during spring (Figure 3.29) was not similar to prescribed spill treatments (Figure 2.1). Higher than normal flows during mid-spring caused spill levels to deviate from planned treatments. The post-hoc $30 \%$ spill condition was defined by passage when spill was $<35 \%$ and the post-hoc $40 \%$ spill condition was defined by passage when spill was between $35 \%$ and $45 \%$. The survival metric was the paired-release dam-passage survival rate (i.e., survival rate of STH passing from the forebay entrance array to the tailrace release site).

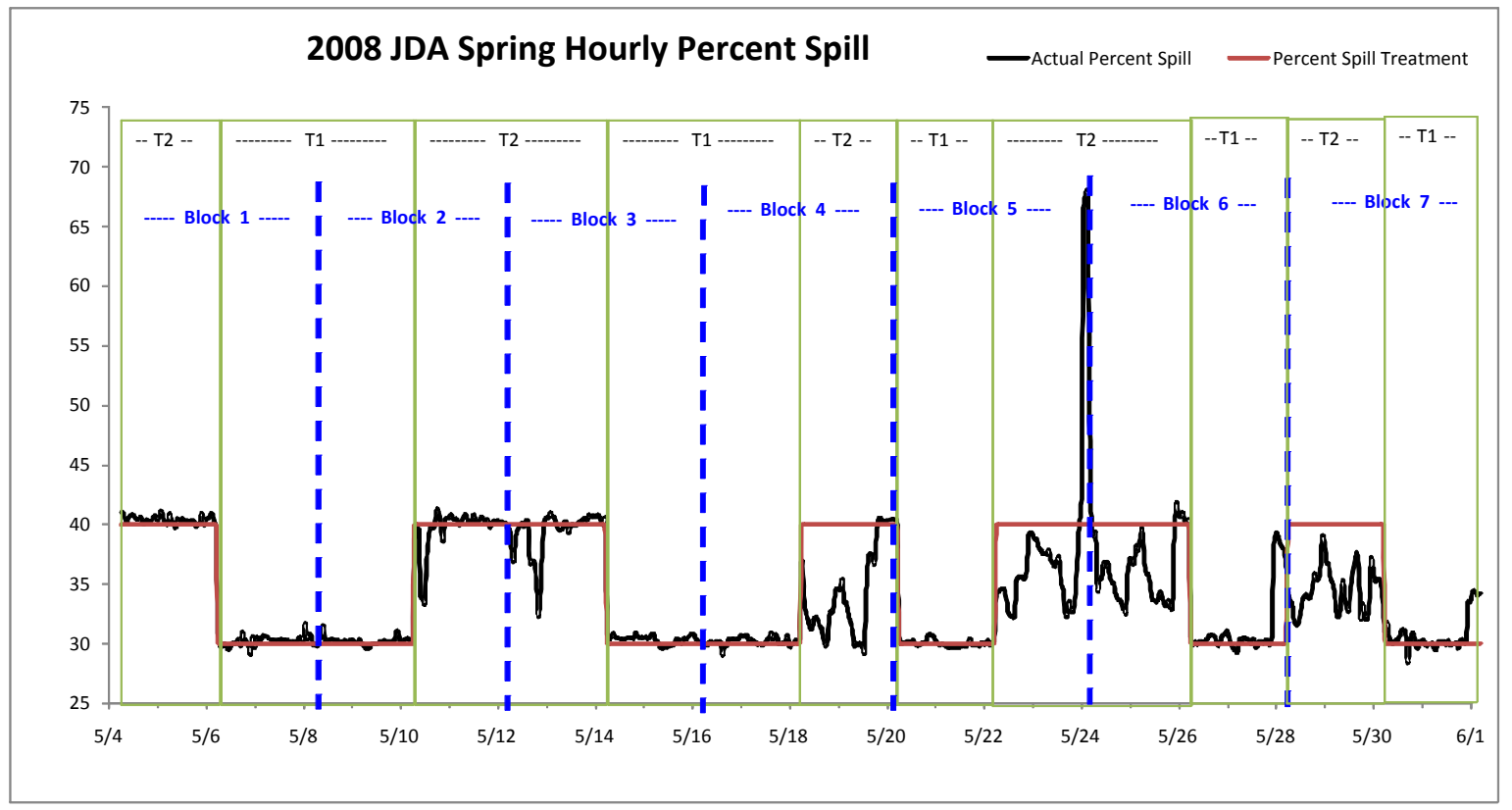

Figure 3.29. Spill treatments as prescribed (red line) and actual conditions (black line) in spring (repeated from Figure 3.22 for ease of reference)

Paired-release estimates of STH dam-passage survival rate did not differ between the $30 \%$ and $40 \%$ spill conditions based on overlap of $1 / 295 \%$ CIs (Table 3.17). Most fish-passage metrics were similar under the $30 \%$ and $40 \%$ spill conditions (Table 3.18). The single exception was spill-passage effectiveness, which was higher under the $30 \%$ spill condition than under the $40 \%$ spill condition $(\mathrm{t}=2.17 ; \mathrm{n}=8$; one-tailed $\mathrm{P}=0.0293$ ). The TSW-passage efficiency was $10 \%$ higher under the $30 \%$ spill condition than it was under the $40 \%$ spill condition, but this difference was not significant $(\mathrm{t}=1.22 ; \mathrm{n}=8$; one tailed $\mathrm{P}=$ 0.1308). The null hypothesis that TSW-passage efficiency under the $30 \%$ spill condition was higher than TSW-passage efficiency under the $40 \%$ spill condition could not be rejected.

Table 3.17. Estimates of dam-passage survival rates by post-hoc spill condition for steelhead smolts during spring

\begin{tabular}{lc}
\hline Condition & Survival $( \pm 1 / 295 \% \mathrm{CI})$ \\
\hline $30 \%$ Spill & $99.1 \pm 2.8 \%$ \\
$40 \%$ Spill & $97.2 \pm 3.7 \%$ \\
\hline $\mathrm{CI}=$ confidence interval. \\
\hline
\end{tabular}


Table 3.18. Estimates of major passage metrics by post-hoc spill condition for steelhead smolts during spring. Only spillway-passage effectiveness differed between the post-hoc definitions of spill condition.

\begin{tabular}{lc}
\hline \multicolumn{1}{c}{ Metric } & Spring $( \pm 1 / 295 \%$ CI $)$ \\
\hline FPE 30\% Spill & $97.4 \pm 0.9 \%$ \\
FPE 40\% Spill & $96.7 \pm 1.3 \%$ \\
\hline SE 30\% Spill & $75.8 \pm 3.7 \%$ \\
SE 40\% Spill & $72.4 \pm 5.0 \%$ \\
\hline FGE 30\% Spill & $89.4 \pm 3.8 \%$ \\
FGE 40\% Spill & $88.1 \pm 4.6 \%$ \\
\hline TSWE 30\% Spill & $53.8 \pm 4.8 \%$ \\
TSWE 40\% Spill & $43.9 \pm 6.7 \%$ \\
\hline JBSE 30\% Spill & $21.6 \pm 3.6 \%$ \\
JBSE 40\% Spill & $24.7 \pm 4.9 \%$ \\
\hline SEF 30\% Spill & $2.48 \pm 0.12^{(\mathrm{a})}$ \\
SEF 40\% Spill & $1.87 \pm 0.13^{(\mathrm{a})}$ \\
\hline TSWEF 30\% Spill & $7.92 \pm 0.71$ \\
TSWEF 40\% Spill & $6.13 \pm 0.93$ \\
\hline
\end{tabular}

(a) Spillway-passage effectiveness was higher under the $30 \%$ spill condition $(\mathrm{t}=2.17 ; \mathrm{n}=$ 8 ; one-tailed $\mathrm{P}=0.0293$ ).

$\mathrm{CI}=$ confidence interval.

FGE = fish-guidance efficiency.

FPE = fish-passage efficiency.

JBSE = juvenile bypass system-passage efficiency.

$\mathrm{SE} \quad=$ spillway-passage efficiency.

SEF = spillway-passage effectiveness.

TSW $=$ top-spill weir.

TSWE $=$ TSW-passage efficiency.

TSWEF $=$ TSW-passage effectiveness.

\subsubsection{Diel Trends in Survival and Passage Efficiencies}

Survival estimates did not differ much between day and night, except for powerhouse survival, which was higher at night than it was during the day (Table 3.19). The day and night difference in powerhouse survival was entirely due to turbine passage survival because it was higher at night (78.9\%) than it was during the day (67.1\%), whereas JBS survival was similar during day and night (Table 3.19).

The rates of passage of STH smolts were higher at night than during the day at the powerhouse, turbines, and JBS, whereas day passage rates were higher than night passage rates for the entire spillway (Figure 3.30). On a per-bay basis, the TSW had a higher passage rate than did other locations within the spillway, and the rate was much higher during the day than it was at night (Figure 3.31). The night passage rate was slightly higher than the day passage rate at non-TSW bays, and differences in day-night trends for TSW and non-TSW spill bays indicate that the predominance of day passage for the entire spillway (Figure 3.30) was mostly due to high daytime passage at TSW bays (Figure 3.31). 
Table 3.19. Comparison of diel non-tag-life-corrected paired-release survival rate trends for steelhead smolts during spring

\begin{tabular}{lcc}
\hline \multicolumn{1}{c}{ Metric } & Day $( \pm 1 / 295 \% \mathrm{CI})$ & Night $( \pm 1 / 295 \% \mathrm{CI})$ \\
\hline Concrete & $97.5 \pm 1.6 \%$ & $98.7 \pm 2.0 \%$ \\
Powerhouse & $90.9 \pm 4.7 \%$ & $98.0 \pm 2.7 \%$ \\
JBS & $99.0 \pm 0.6 \%$ & $99.7 \pm 2.1 \%$ \\
Spillway & $97.9 \pm 1.7 \%$ & $98.5 \pm 1.7 \%$ \\
Spill bays 17-20 & $97.3 \pm 2.1 \%$ & $96.7 \pm 3.3 \%$ \\
TSW (spill bays 15 and 16) & $98.5 \pm 2.0 \%$ & $96.2 \pm 0.3 \%$ \\
Spill bays 1-14 & $95.3 \pm 3.7 \%$ & $101.4 \pm 1.6 \%$ \\
\hline CI = confidence interval. & & \\
JBS = juvenile bypass system. & & \\
TSW = top-spill weir. & & \\
\hline
\end{tabular}

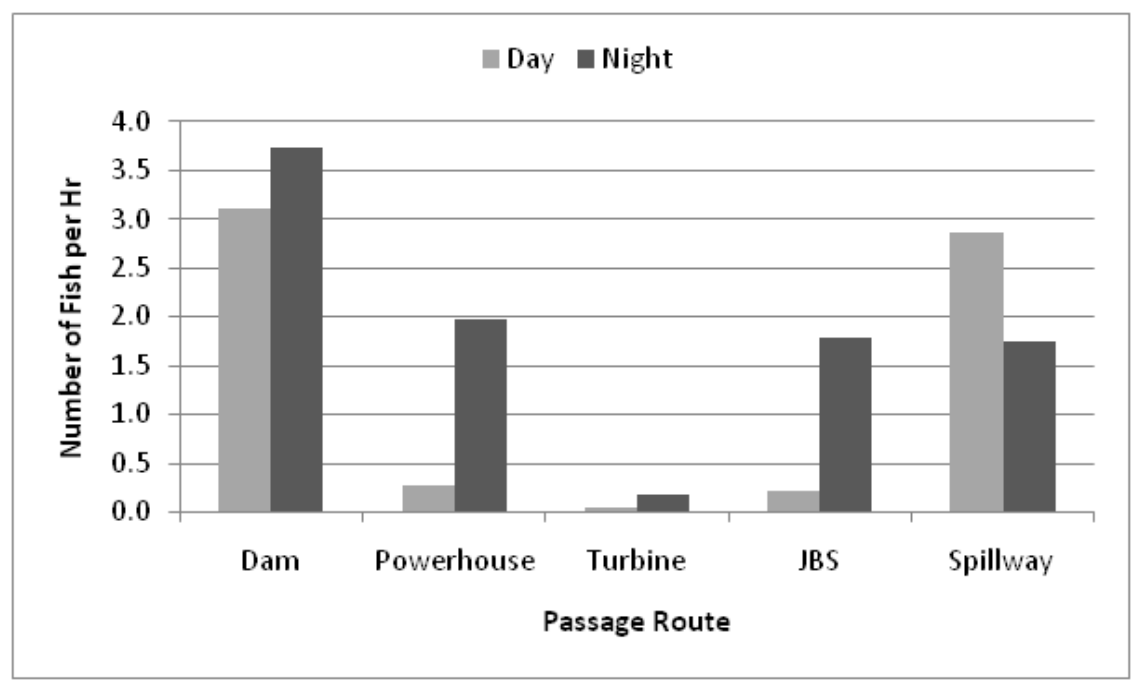

Figure 3.30. Hourly rate of steelhead passage by passage route

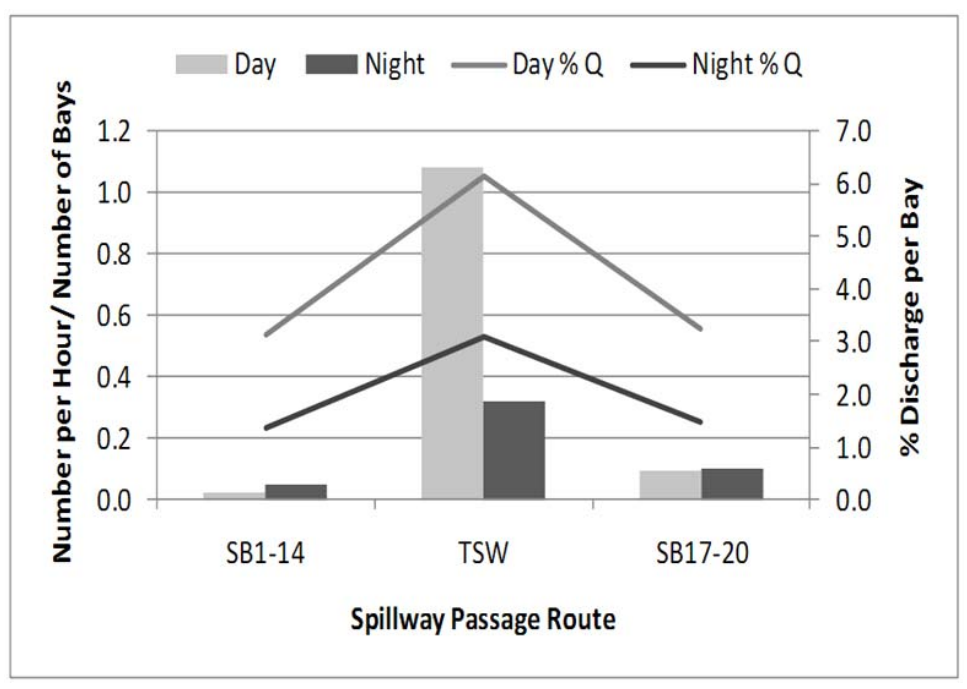

Figure 3.31. Diel passage rates (number/hour/bay) for steelhead and percent discharge for groups of bays 


\subsubsection{Subyearling Chinook Salmon}

Passage efficiency and effectiveness, horizontal passage distribution at the dam, powerhouse and spillway passage, the effect of spill conditions on dam-passage survival rate and fish passage proportions among routes, and diel trends in survival rates and passage efficiencies relative to SYC are described below.

\subsubsection{Passage Efficiency and Effectiveness}

During 2008, the FPE of SYC smolts was $83.3 \%$, with $14.7 \%$ guided by in-turbine screens to the JBS and $68.6 \%$ passing through the spillway (Table 3.20 ). The passage efficiency of the TSW bays was $20.6 \%$ relative to the numbers passing through the dam and $30 \%$ relative to numbers passing through the spillway. About $17 \%$ of total fish passage was through turbines (1-FPE), and the FGE of powerhouse screens was $46.8 \%$ (Table 3.20). The TSW was more effective than the entire spillway for passing SYC smolts (Table 3.20).

\subsubsection{Horizontal Passage Distribution at the Dam}

The passage of tagged SYC smolts at TSW bays was higher than passage at any other individual passage route at John Day Dam (Figure 3.32). On average, each TSW bay passed five times more smolts than individual turbines or spill bays from 2 to 13. Passage also was high at spill bays near TSW bays (i.e., at spill bays $14,17,18$, and 19). The majority (69\%) of smolts passed at the spillway despite $65 \%$ of water discharge passing through the powerhouse, and the two TSW bays passed $30 \%$ of the total number of SYC passing through the spillway (Figure 3.32).

Table 3.20. Estimates of major passage metrics for subyearling Chinook salmon smolts

\begin{tabular}{lc}
\hline \multicolumn{1}{c}{ Metric } & Estimate $\pm 1 / 295 \%$ CI \\
\hline Fish-Passage Efficiency & $83.30 \pm 1.86 \%$ \\
Spillway-Passage Efficiency & $68.60 \pm 2.37 \%$ \\
Fish-Guidance Efficiency & $46.80 \pm 4.41 \%$ \\
TSW-Passage Efficiency & $20.60 \pm 2.13 \%$ \\
JBS-Passage Efficiency & $14.70 \pm 1.79 \%$ \\
Spillway-Passage Effectiveness & $1.94 \pm 0.07$ \\
TSW-Passage Effectiveness & $3.14 \pm 0.32$ \\
\hline CI = confidence interval. & \\
JBS = juvenile bypass system. & \\
TSW = top-spill weir. & \\
\hline
\end{tabular}




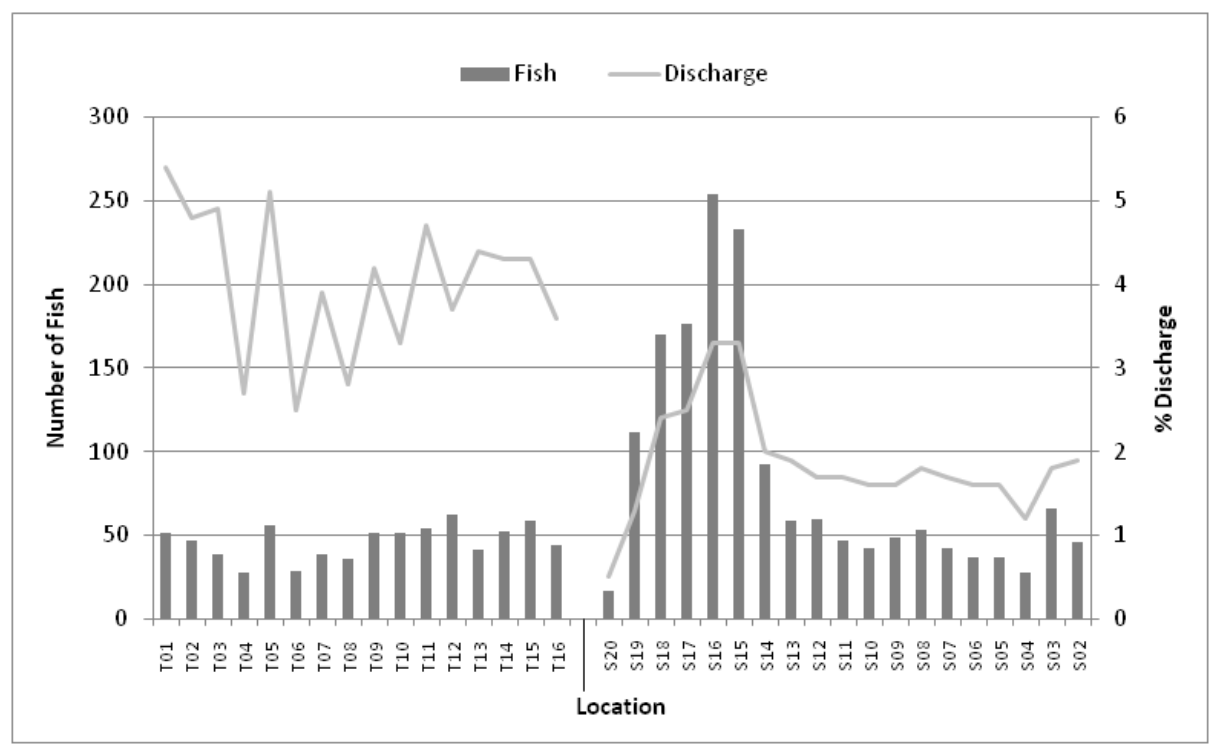

Figure 3.32. Subyearling Chinook salmon passage and discharge by individual passage route in spring 2008

\subsubsection{Powerhouse Passage}

During summer, only $46.8 \%$ of the fish that passed through the dam at the powerhouse were guided through the JBS, and the remaining 53.2\% passed through turbines (Figure 3.33). Guided passage exceeded unguided passage at turbine units $1,5,6,8$, and 10, but was less than unguided passage at the other 11 units.

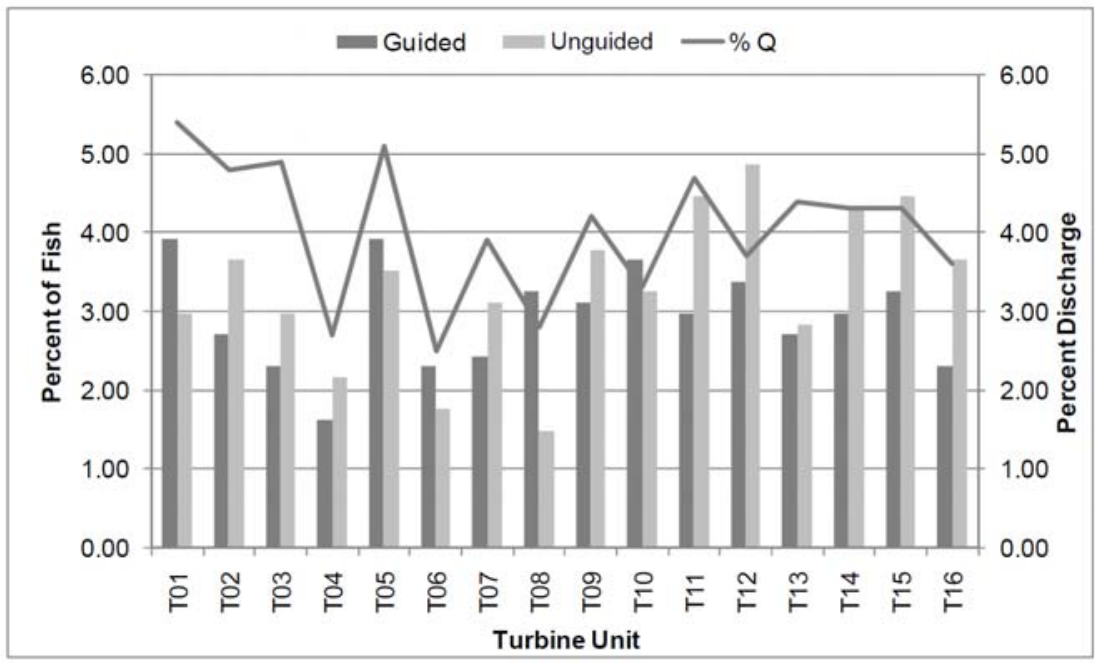

Figure 3.33. Guided and unguided passage of subyearling Chinook salmon in summer

\subsubsection{Spillway Passage}

The highest percent passage and discharge within the spillway occurred at TSW spill bays 15 and 16 and nearby non-TSW spill bays 14, 17, and 18 (Figure 3.34). On a per-bay basis, an average TSW bay 
passed 1.6 times more fish than an average non-TSW bay to the south (spill bays 17-20) and 4.3 times more fish than an average bay to the north (spill bays 2-14; Figure 3.35).

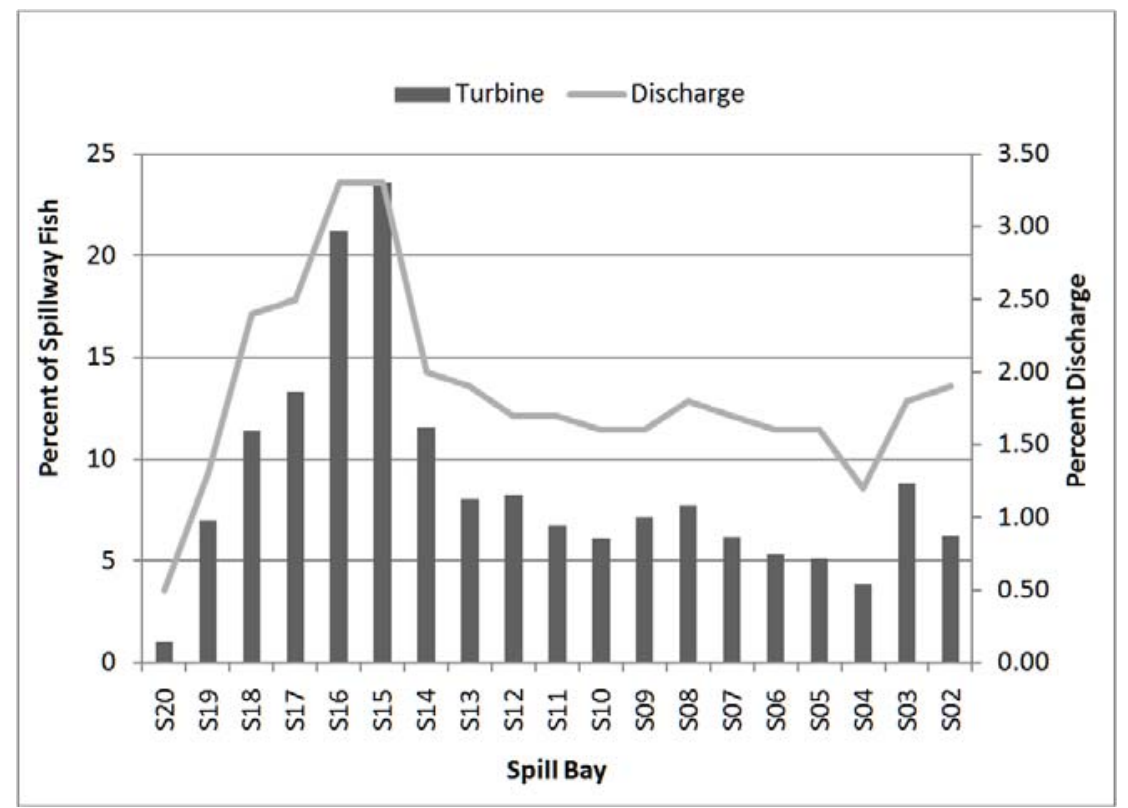

Figure 3.34. Percent discharge and passage of subyearling Chinook salmon smolts by spill bay

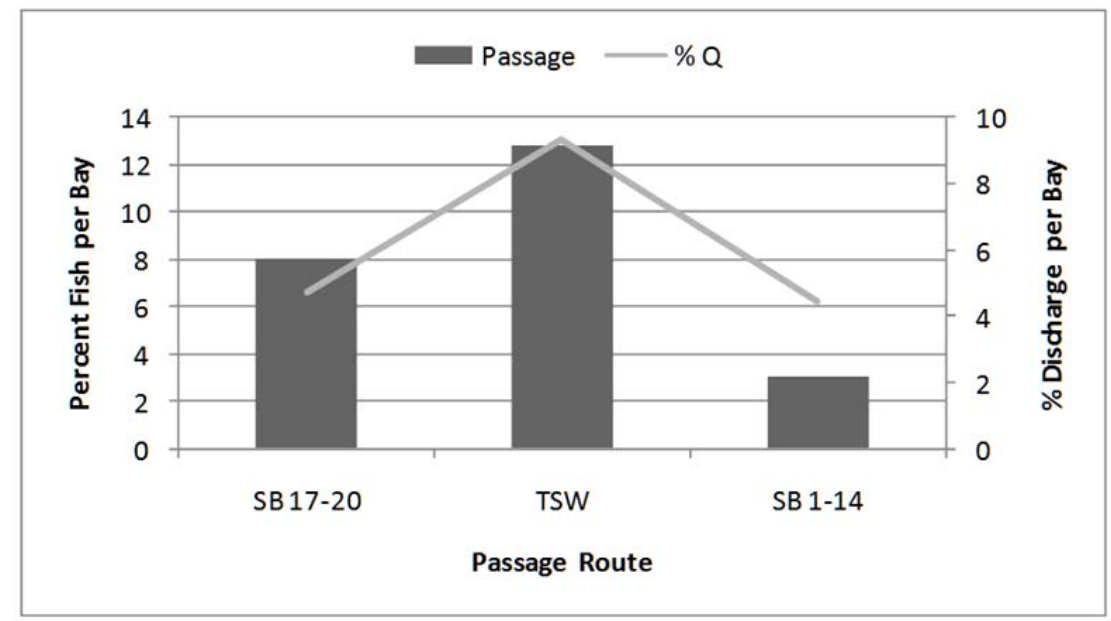

Figure 3.35. Percent discharge and passage for subyearling Chinook salmon per individual spill bay within groups of bays

\subsubsection{Effect of Spill Condition on Dam Survival and Passage}

We defined post-hoc spill conditions because mean hourly percent spill discharge at John Day Dam during the summer deviated a lot from some of the prescribed treatments (Figure 3.26). During the 30\% treatments, spill ranged from $29 \%$ to $68 \%$, with a mean of $36 \%$, and during the $40 \%$ treatments, spill ranged from $29 \%$ to $58 \%$, with a mean of $35 \%$. Spill bay discharge ranged from 37 to $240 \mathrm{kcfs}$ during the summer study period. The post-hoc $30 \%$ spill condition was defined by passage when spill was $<35 \%$ and the post-hoc $40 \%$ spill condition was defined by passage when spill was between $35 \%$ and $45 \%$. The 
survival metric was the paired-release dam-passage survival rate (i.e., the survival rate of SYC passing from the forebay entrance array to the tailrace release site).

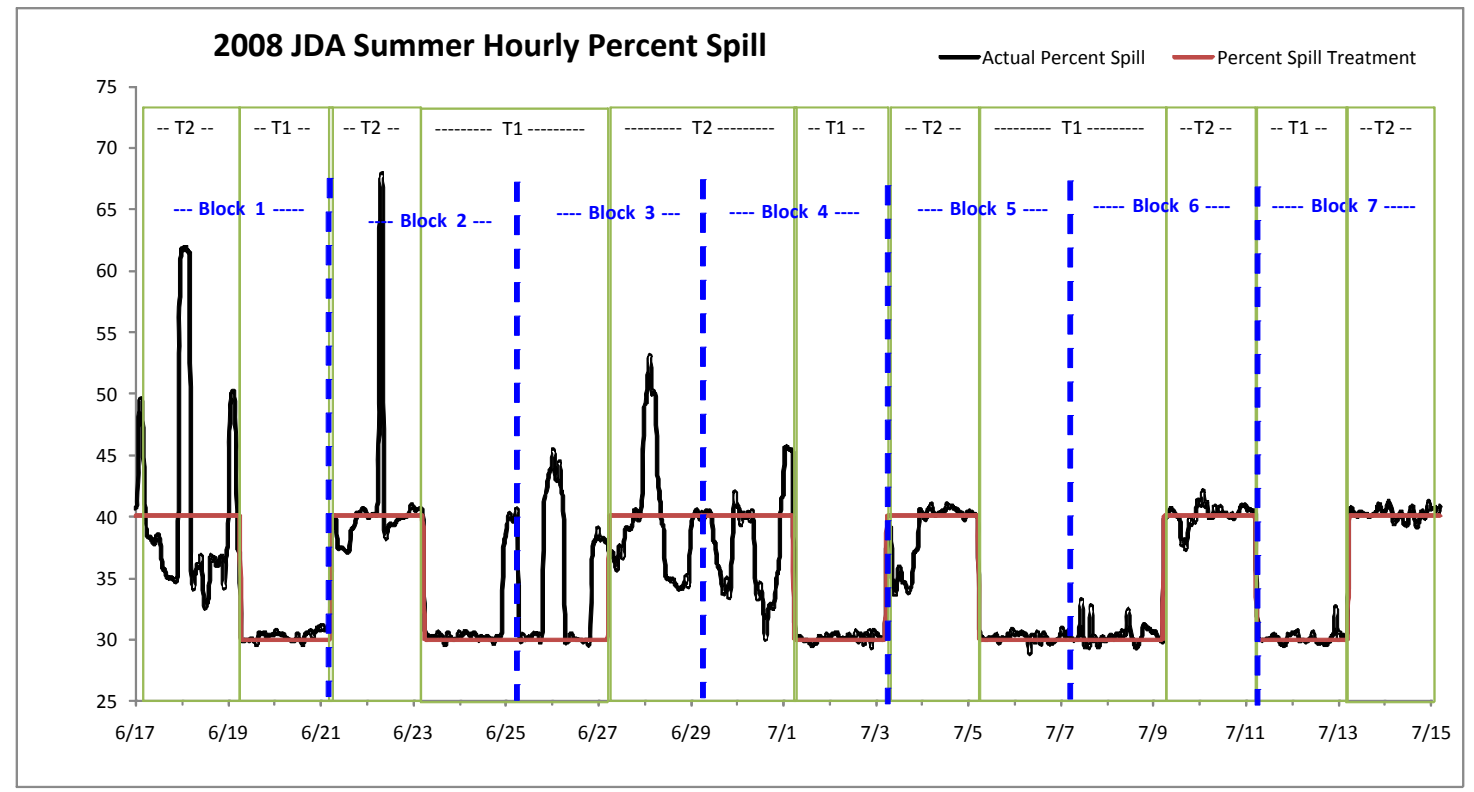

Figure 3.36. Spill conditions during summer

Paired-release estimates of dam-passage survival rate did not differ between the $30 \%$ and $40 \%$ spill conditions (Table 3.21) based on the overlap of $1 / 295 \% \mathrm{CIs}$ and on a one-tailed t-test $(\mathrm{P}=0.4027)$. The null hypothesis for the one-tailed test was that the dam-passage survival rate during $40 \%$ spill conditions was not significantly greater than the dam-passage survival rate during $30 \%$ spill conditions. Other fishpassage metrics (Table 3.22) also showed no significant difference between $30 \%$ and $40 \%$ spill conditions, except for spill-passage effectiveness, which was significantly higher under the $30 \%$ spill condition than it was under the $40 \%$ spill condition $(\mathrm{t}=3.545 ; \mathrm{n}=8 ; \mathrm{P}=0.0020)$.

Table 3.21. Paired-release estimates of dam-passage survival rates by post-hoc spill condition for subyearling Chinook salmon during summer

\begin{tabular}{lc}
\hline \multicolumn{1}{c}{ Spill Condition } & Survival $( \pm 1 / 295 \% \mathrm{CI})$ \\
\hline $30 \%$ Spill & $0.852 \pm 0.024$ \\
$40 \%$ Spill & $0.866 \pm 0.024$ \\
\hline $\mathrm{CI}=$ confidence interval. \\
\hline
\end{tabular}


Table 3.22. Estimates of major passage metrics by spill treatment for subyearling Chinook salmon

\begin{tabular}{lc}
\hline \multicolumn{1}{c}{ Metric } & \multicolumn{1}{c}{ Summer $( \pm 1 / 295 \% \mathrm{CI})$} \\
\hline FPE 30\% Spill & $82.03 \pm 2.96 \%$ \\
FPE 40\% Spill & $84.43 \pm 2.92 \%$ \\
\hline SE 30\% Spill & $65.71 \pm 3.80 \%$ \\
SE 40\% Spill & $71.08 \pm 3.79 \%$ \\
\hline FGE 30\% Spill & $47.61 \pm 6.61 \%$ \\
FGE 40\% Spill & $46.15 \pm 7.39 \%$ \\
TSWE 30\% Spill & $21.41 \pm 3.36 \%$ \\
TSWE 40\% Spill & $20.79 \pm 3.52 \%$ \\
\hline JBSE 30\% Spill & $16.33 \pm 2.95 \%$ \\
JBSE 40\% Spill & $13.35 \pm 2.79 \%$ \\
\hline SEF 30\% Spill & $2.14 \pm 0.12$ \\
SEF 40\% Spill & $1.81 \pm 0.10$ \\
\hline TSWEF 30\% Spill & $3.38 \pm 0.52$ \\
TSWEF 40\% Spill & $3.00 \pm 0.52$ \\
\hline CI & $=$ confidence interval. \\
FGE & $=$ fish-guidance efficiency. \\
FPE & $=$ fish-passage efficiency. \\
JBSE & $=$ juvenile bypass system-passage \\
\multicolumn{3}{l}{ SE } & efficiency. \\
SEF & $=$ spillway-passage efficiency. \\
TSW & $=$ top-spillway-passage effectiveness. \\
TSWE & $=$ TSW-passage efficiency. \\
TSWEF & $=$ TSW-passage effectiveness. \\
\hline &
\end{tabular}

\subsubsection{Diel Trends in Survival and Passage Efficiencies}

The survival rate of SYC was higher at night than it was during the day for smolts passing through the dam, powerhouse, turbines, spillway, and spill bays 17-20 (Table 3.23). Day and night estimates of survival rate were similar for SYC passing through the JBS, TSW, and spill bays 1-14.

Table 3.23. Comparison of diel non-tag-life-corrected paired-release survival trends for subyearling Chinook salmon during summer

\begin{tabular}{lcc}
\hline \multicolumn{1}{c}{ Route } & Day $( \pm 1 / 295 \% \mathrm{CI})$ & Night $( \pm 1 / 295 \% \mathrm{CI})$ \\
\hline Dam & $82.3 \pm 3.3 \%$ & $93.8 \pm 2.3 \%$ \\
Powerhouse & $75.1 \pm 10.3 \%$ & $91.9 \pm 2.9 \%$ \\
Turbine & $60.8 \pm 14.1 \%$ & $86.5 \pm 5.0 \%$ \\
JBS & $93.5 \pm 8.9 \%$ & $99.0 \pm 5.1 \%$ \\
Spillway & $84.2 \pm 3.4 \%$ & $96.4 \pm 2.8 \%$ \\
Spill bays 17-20 & $60.6 \pm 12.2 \%$ & $97.5 \pm 6.1 \%$ \\
TSW (spill bays 15 and 16) & $91.8 \pm 2.4 \%$ & $97.2 \pm 1.1 \%$ \\
Spill bays 1-14 & $96.4 \pm 2.5 \%$ & $93.0 \pm 8.1 \%$ \\
\hline CI = confidence interval. & & \\
JBS = juvenile bypass system. & & \\
TSW = top-spill weir. & & \\
\hline
\end{tabular}


The hourly rate of passage of SYC through the dam, powerhouse, turbines, and JBS was slightly higher at night than it was during the day (Figure 3.37). Only the spillway passed more SYC during the day ( $2.2 \mathrm{fish} / \mathrm{hr}$ ) than it did at night (1.9 fish/hr). On a per-bay hourly basis, the passage rate through the TSW bay was higher than the passage rate through other spill bays within day and night periods, and passage rates per bay were higher during the day than they were at night for all groups of spill bays (Figure 3.38).

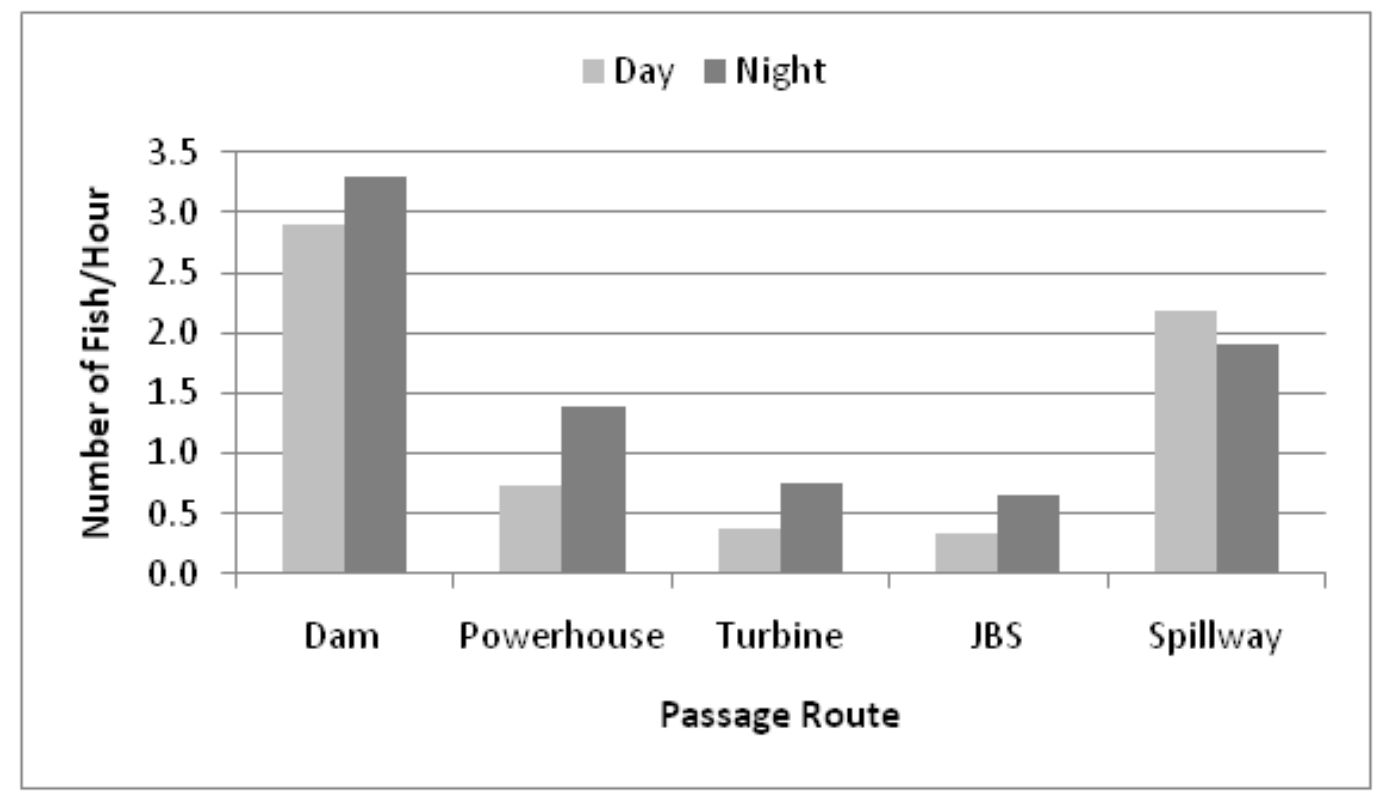

Figure 3.37. Day and night passage rates by route for subyearling Chinook salmon smolts

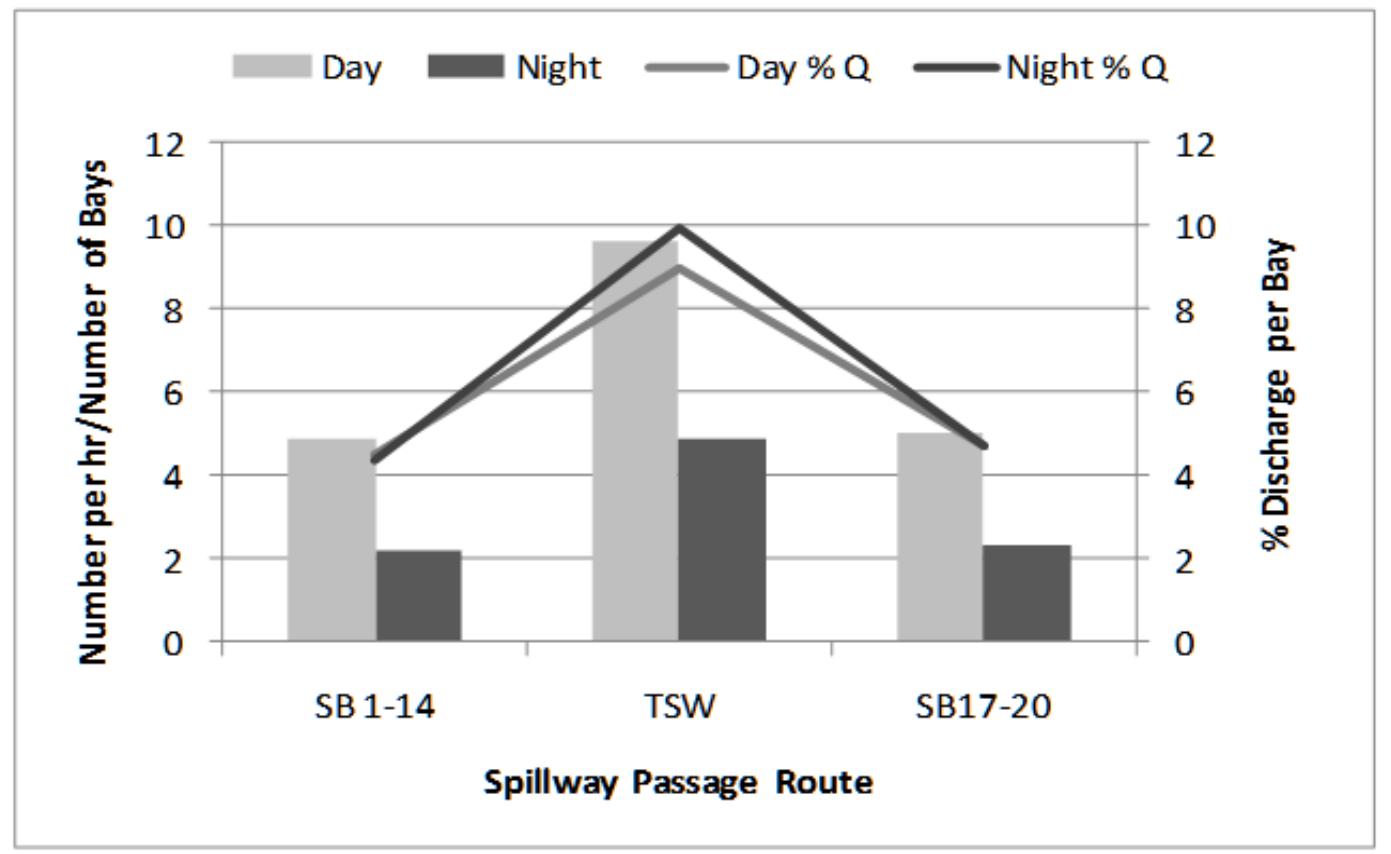

Figure 3.38. Hourly passage rates and percent discharge per bay for subyearling Chinook salmon within groups of spill bays 


\subsubsection{Travel Times}

In spring, $2384 \mathrm{YC}$ smolts were released from Arlington, Oregon, and subsequently detected on the John Day Dam forebay array; median travel time was 25.4 hours (Table 3.24). For tagged smolts detected on the forebay array (2370 fish), the median travel time until passage through John Day Dam was 2.2 hours. Median travel time from the John Day Dam face to the tailrace egress array $10 \mathrm{~km}$ downstream of the dam was 1.5 hours. Median travel time for 3179 YC from the John Day Dam egress array to The Dalles Dam forebay array was 10.7 hours. These fish $(n=5628)$ had a median travel time of 24.4 hours to reach the Bonneville Dam forebay array.

For STH, 2348 fish were released at Arlington, Oregon, and detected on the John Day Dam forebay node array with a median travel time of 1 day (Table 3.25). Of these, 2325 were detected and passed the dam with a median passage time of 4.3 hours. Of the STH passing John Day Dam, 2240 were detected on the egress array with a median travel time of 1.2 hours for all passage routes pooled. Median travel time for steelhead from the John Day Dam egress array to The Dalles Dam forebay array was 7.6 hours. Median travel time for these fish $(n=2995)$ to reach the Bonneville Dam forebay array was 22 hours.

Table 3.24. Distance of travel and median travel time $( \pm 1 / 295 \% \mathrm{CI})$ for yearling Chinook salmon smolts passing through specific river reaches between Arlington, Oregon, and the Bonneville Dam forebay

\begin{tabular}{lcc}
\hline \multicolumn{1}{c}{ Reach } & Distance (km) & Time (hr) \\
\hline Arlington to John Day Dam Forebay & 38.9 & $25.4 \pm 14.0$ \\
John Day Dam Forebay to John Day Dam Passage & 2.0 & \\
Dam & & $2.2 \pm 1.0$ \\
JBS & & $2.7 \pm 1.2$ \\
Turbine & & $2.7 \pm 1.2$ \\
TSW & 5.2 & $2.1 \pm 0.9$ \\
John Day Dam Passage to John Day Dam Egress & & \\
Dam & & $1.5 \pm 1.0$ \\
JBS & & $3.6 \pm 1.9$ \\
Turbine & & $1.6 \pm 1.1$ \\
TSW & 5.2 & $1.6 \pm 1.0$ \\
John Day Dam Passage to John Day Dam Egress 30\% Spill & & $1.4 \pm 1.0$ \\
Dam & & $5.4 \pm 2.2$ \\
JBS & & $1.6 \pm 1.2$ \\
Turbine & & $1.5 \pm 1.0$ \\
TSW & 5.2 & \\
John Day Dam Passage to John Day Dam Egress 40\% Spill & & $1.5 \pm 1.0$ \\
Dam & & $2.9 \pm 3.7$ \\
JBS & & $1.5 \pm 1.1$ \\
Turbine & & $1.8 \pm 1.1$ \\
TSW & & $10.7 \pm 7.0$ \\
John Day Dam Egress to The Dalles Dam Forebay & 31.0 & \\
The Dalles Dam Forebay to Bonneville Dam Forebay & 74.9 & $24.4 \pm 0.52$ \\
\hline JBS = juvenile bypass system. & & \\
TSW top-spill weir. & & \\
\hline & & \\
\hline
\end{tabular}


Table 3.25. Distance of travel and median travel time $( \pm 1 / 295 \% \mathrm{CI})$ for steelhead smolts passing through specific river reaches between Arlington, Oregon, and the Bonneville Dam forebay

\begin{tabular}{lcc}
\hline \multicolumn{1}{c}{ Reach } & Distance (km) & Time (hr) \\
\hline Arlington to John Day Dam Forebay & 38.9 & $24.1 \pm 15.1$ \\
John Day Dam Forebay to John Day Dam Passage & 2.0 & \\
Dam & & $4.3 \pm 1.0$ \\
JBS & & $5.9 \pm 1.7$ \\
Turbine & & $4.0 \pm 1.5$ \\
TSW & 5.2 & $3.7 \pm 0.9$ \\
John Day Dam Passage to John Day Dam Egress & & \\
Dam & & $1.2 \pm 0.9$ \\
JBS & & $3.9 \pm 2.3$ \\
Turbine & & $1.8 \pm 1.1$ \\
TSW & 5.2 & $1.2 \pm 0.9$ \\
John Day Dam Passage to John Day Dam Egress 30\% Spill & & \\
Dam & & $1.2 \pm 0.9$ \\
JBS & & $3.7 \pm 3.1$ \\
Turbine & & $1.6 \pm 1.1$ \\
TSW & 5.2 & $1.2 \pm 0.9$ \\
John Day Dam Passage to John Day Dam Egress 40\% Spill & & \\
Dam & & $1.3 \pm 1.0$ \\
JBS & & $3.9 \pm 3.5$ \\
Turbine & & $2.2 \pm 1.3$ \\
TSW & & $1.3 \pm 1.0$ \\
John Day Dam Egress to The Dalles Dam Forebay & & $7.6 \pm 5.4$ \\
The Dalles Dam Forebay to Bonneville Dam Forebay & 74.9 & $21.7 \pm 0.45$ \\
\hline JBS = juvenile bypass system. & & \\
TSW = top-spill weir. & & \\
\hline & & \\
\hline & & \\
\hline
\end{tabular}

The median travel time of the 2386 SYC released at Arlington, Oregon, to the John Day Dam forebay array was 22.6 hours (Table 3.26). Of these, 2360 passed through the John Day Dam with a median passage time of 2.2 hours. This time used the last detection time at the dam face. Based on a sample size of 2029 fish, the median travel time from the dam to the tailrace egress array was 1.5 hours. Released fish at Arlington were timed with the John Day Dam tailwater releases to ensure that adequate mixing would occur for John Day Dam passage. The median travel time for 2934 SYC from the John Day Dam egress array to The Dalles Dam forebay was 11.2 hours. The median travel time for these fish $(n=2694)$ to reach the Bonneville Dam forebay was 30 hours. Table 3.26 shows travel times from Arlington, Oregon, to the Bonneville Dam forebay including the reach, subroutes, and spill treatments as they passed John Day Dam. 
Table 3.26. Distance of travel and median travel time $( \pm 1 / 295 \% \mathrm{CI})$ for subyearling Chinook salmon smolts passing through specific river reaches between Arlington, Oregon, and the Bonneville Dam forebay

\begin{tabular}{lcc}
\hline \multicolumn{1}{c}{ Reach } & Distance $(\mathrm{km})$ & Time $(\mathrm{hr})$ \\
\hline Arlington to John Day Dam Forebay & 38.9 & $22.6 \pm 14.9$ \\
John Day Dam Forebay to John Day Dam Passage & 2.0 & \\
Dam & & $2.2 \pm 0.9$ \\
JBS & & $2.4 \pm 1.0$ \\
Turbine & & $2.5 \pm 1.1$ \\
TSW & 5.2 & $2.1 \pm 0.8$ \\
John Day Dam Passage to John Day Dam Egress & & \\
Dam & & $1.5 \pm 1.1$ \\
JBS & & $6.5 \pm 1.6$ \\
Turbine & 5.2 & $1.7 \pm 1.3$ \\
TSW & & $1.5 \pm 1.1$ \\
John Day Dam Passage to John Day Dam Egress 30\% & & \\
Spill & & $1.5 \pm 1.1$ \\
Dam & & $6.9 \pm 2.0$ \\
JBS & & $1.7 \pm 1.2$ \\
Turbine & 5.2 & $1.5 \pm 1.1$ \\
TSW & & \\
John Day Dam Passage to John Day Dam Egress 40\% & & \\
Spill & & \\
Dam & & $1.4 \pm 1.1$ \\
JBS & & $6.4 \pm 2.9$ \\
Turbine & & $1.6 \pm 1.3$ \\
TSW & & $1.5 \pm 1.1$ \\
John Day Dam Egress to The Dalles Dam Forebay & & \\
The Dalles Dam Forebay to Bonneville Dam Forebay & 74.9 & \\
\hline JBS = juvenile bypass system. & & \\
TSW = top-spill weir. & & \\
\hline & & \\
\hline
\end{tabular}

\subsection{Fish Behavior}

This section contains a description of the arrival and passage distributions, day and night differences in behavior, vertical distributions, and horizontal distributions of tagged fish released upstream of and approaching John Day Dam. The autonomous node array located 2 rkm upstream of John Day Dam was used to assign approach locations and dam-mounted hydrophones were used to assign passage locations. Forebay residence times are described by passage route and for combinations of arrival and passage location. 


\subsubsection{Yearling Chinook}

\subsubsection{Approach and Route of Passage}

The approach of YC smolts at John Day Dam was skewed toward first detections at the powerhouse (46\%) and then the spillway (37\%; Figure 3.39). Smolts first detected at the powerhouse or skeleton bays made up $62 \%$ of all fish arriving at John Day Dam. Of those fish, $60 \%$ would eventually pass through the spillway. Fish detected in the spillway were much more likely to pass through the dam at the spillway $(37 \%)$ than they were to be pass through the dam at the powerhouse $(<1 \%)$.

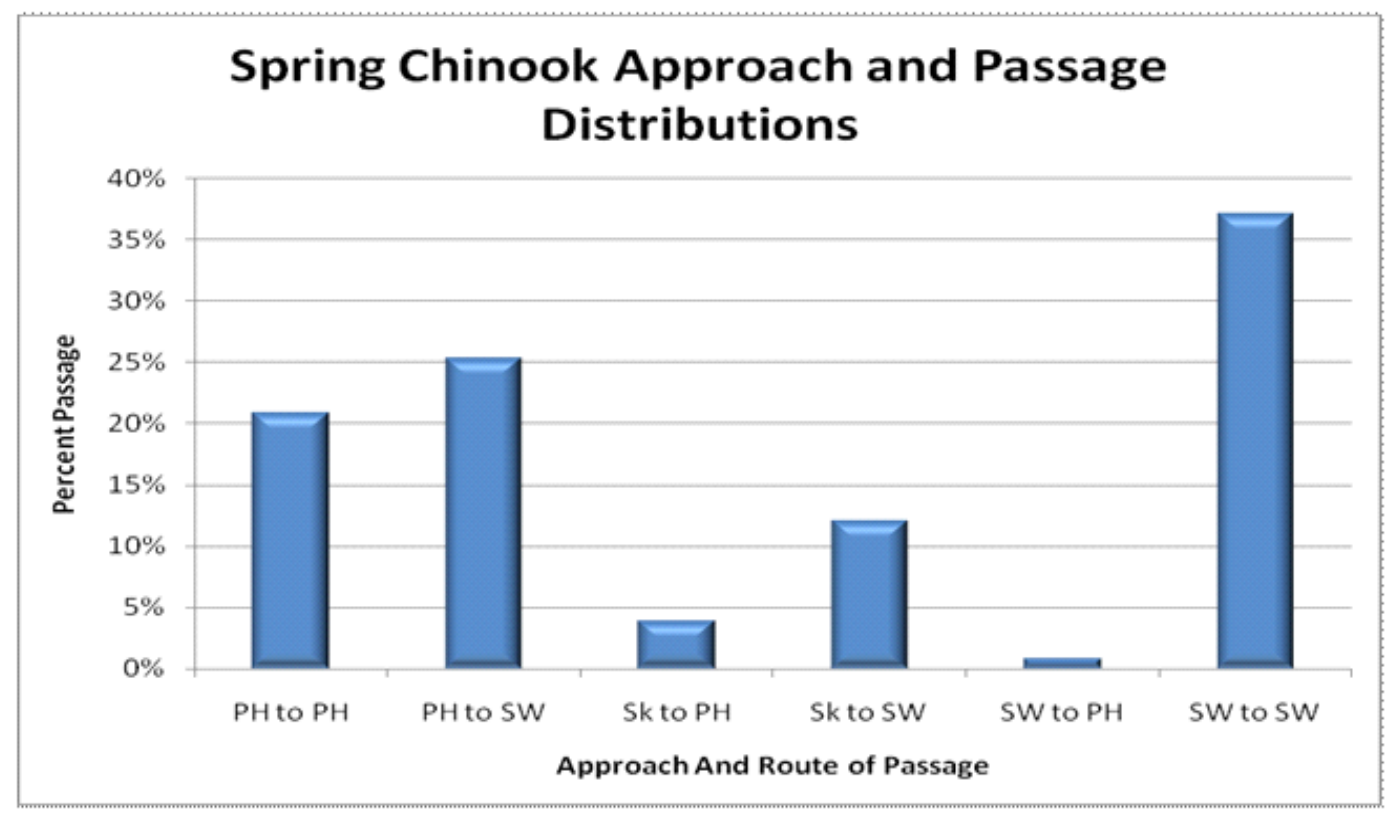

Figure 3.39. Yearling Chinook salmon approach and passage distributions at John Day Dam. The first abbreviation is for the approach location and the second is for the passage location.

Abbreviations are as follows: $\mathrm{PH}=$ powerhouse; $\mathrm{Sk}=$ skeleton bay; $\mathrm{SW}=$ spillway.

Fish arriving at John Day Dam were grouped into arrival blocks and passage-route blocks. The arrival blocks were assigned from autonomous nodes located in the John Day Dam forebay, and passageroute blocks were assigned from detections on the dam-face arrays. These blocks included powerhouse units 1-8, 9-16, skeleton bays 17-20, spill bays 1-14, 15-16 (TSW), and spill bays 17-20 (Figure 4.40). Yearling Chinook arriving at the powerhouse in spring made up $62 \%$ of all fish released upstream at Arlington, Oregon. Of these, only 11\% would eventually pass through spillway block (SW) 15-16 in which the TSW was installed. A greater number of powerhouse-arrived fish, 22\%, were eventually passed through SW 17-20, which is located near the transition of the powerhouse to the spillway. More than half of the powerhouse-arrived YC were attracted to the spillway. 


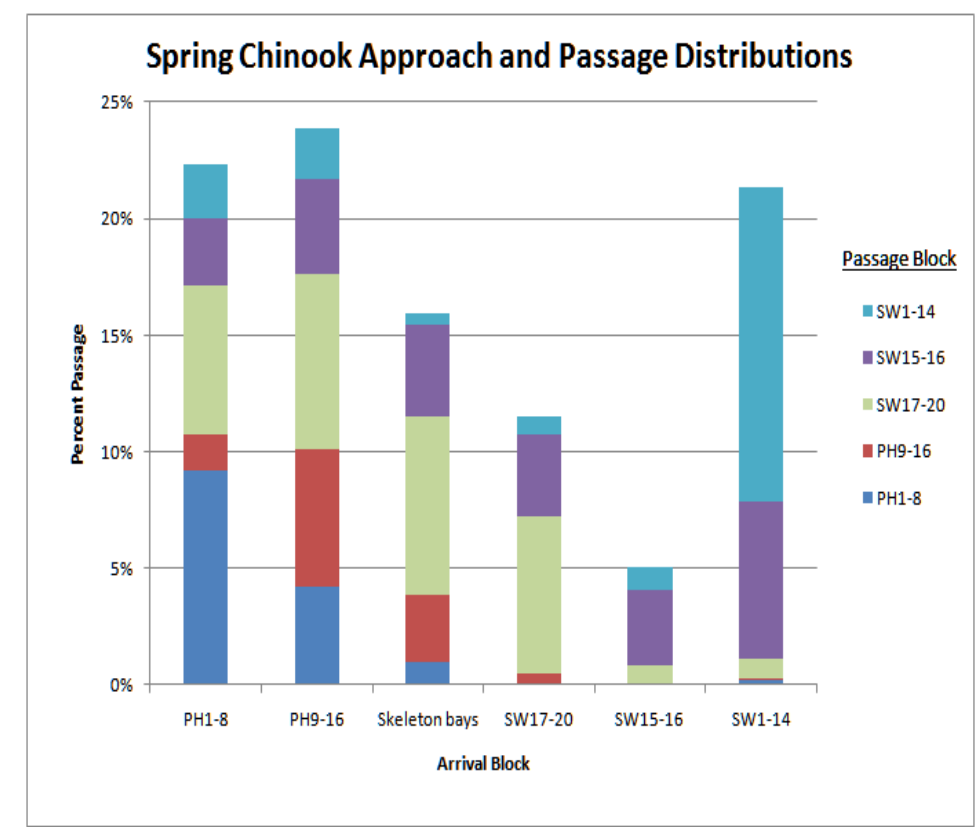

Figure 3.40. Yearling Chinook salmon approach and passage distributions by passage blocks at John Day Dam

\subsubsection{Diel Behavior Patterns}

About 68\% of YC smolts passed through John Day Dam during the day primarily because daytime spillway passage predominated, but powerhouse passage, regardless of approach location, was higher at night than it was during the day (Figure 3.41). The spillway was more effective at attracting fish approaching the powerhouse during the day than at night. Smolts approaching the powerhouse at night tended to pass through the powerhouse rather than move to the spillway.

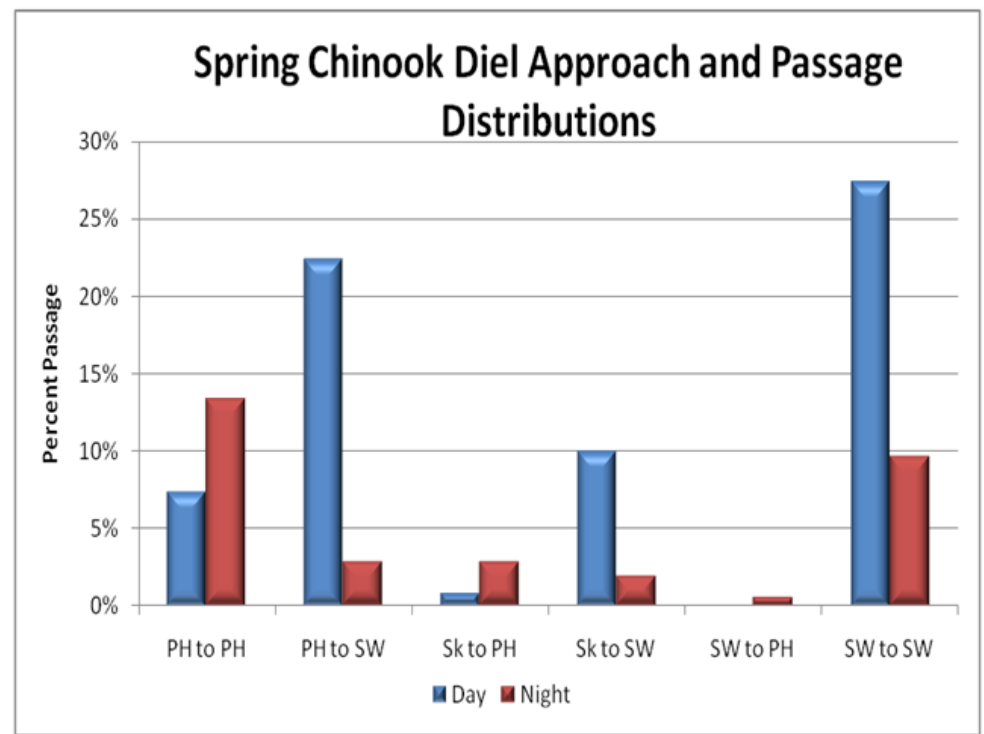

Figure 3.41. Yearling Chinook salmon smolt approach and passage distributions during day and night 
Passage distributions during the day were similar to pooled distributions for day and night periods. Most YC arriving at the powerhouse during the day eventually passed through spill bays 17-20

(Figure 3.42). This was not the case at night when most YC arriving at the powerhouse also passed there (Figure 3.43). Night detections of YC at the powerhouse (67\%) were much greater than night detections at the spillway (33\%; Figure 3.43).

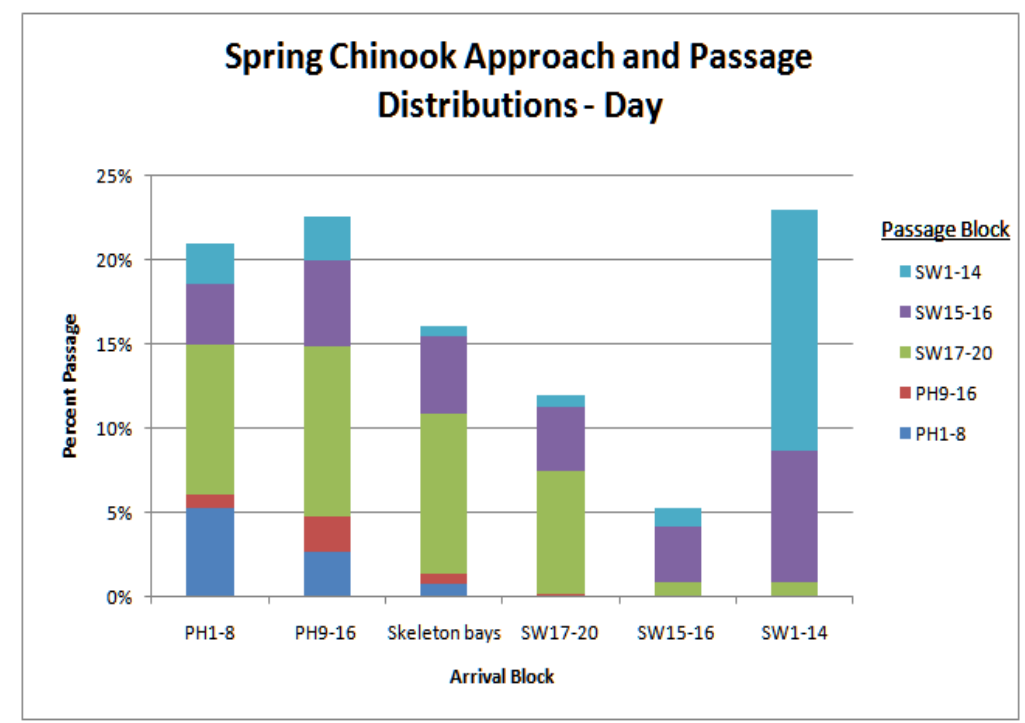

Figure 3.42. Approach and passage distributions for yearling Chinook salmon during daytime at John Day Dam

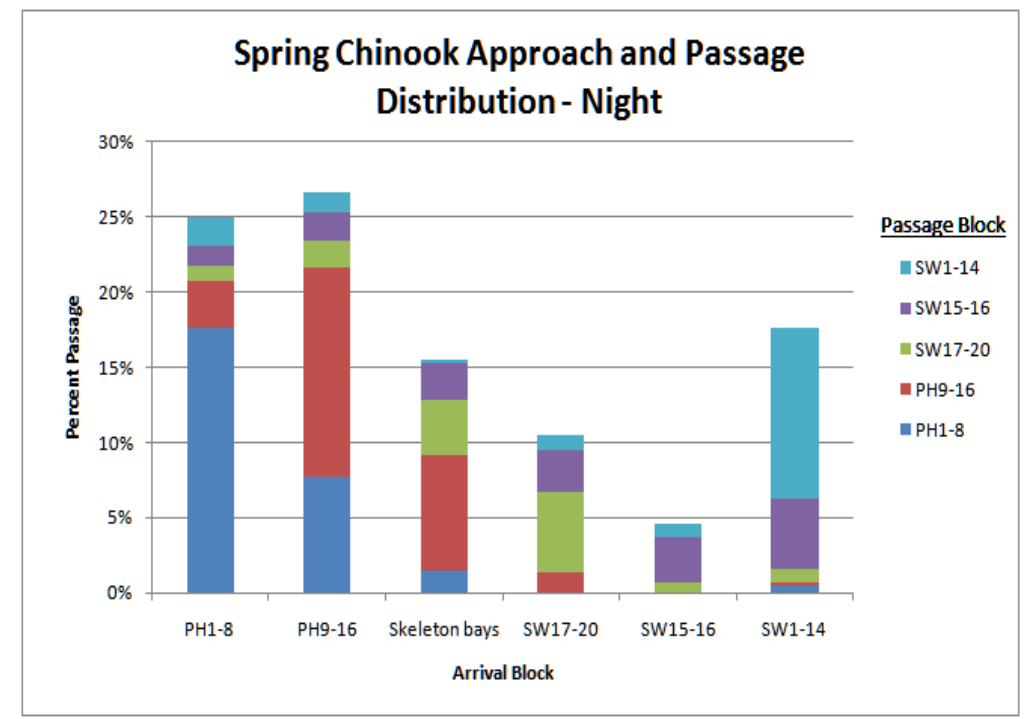

Figure 3.43. Approach and passage distributions for yearling Chinook salmon passing John Day Dam at night

The number of YC passing through the powerhouse was slightly higher at night than it was during the day, whereas the opposite was true for the spillway, particularly at the TSW, where daytime passage predominated (Figure 3.44). Most YC passed evenly at the TSW and nearby bays during the day, but passage was highest at TSW bay 16 at night. 


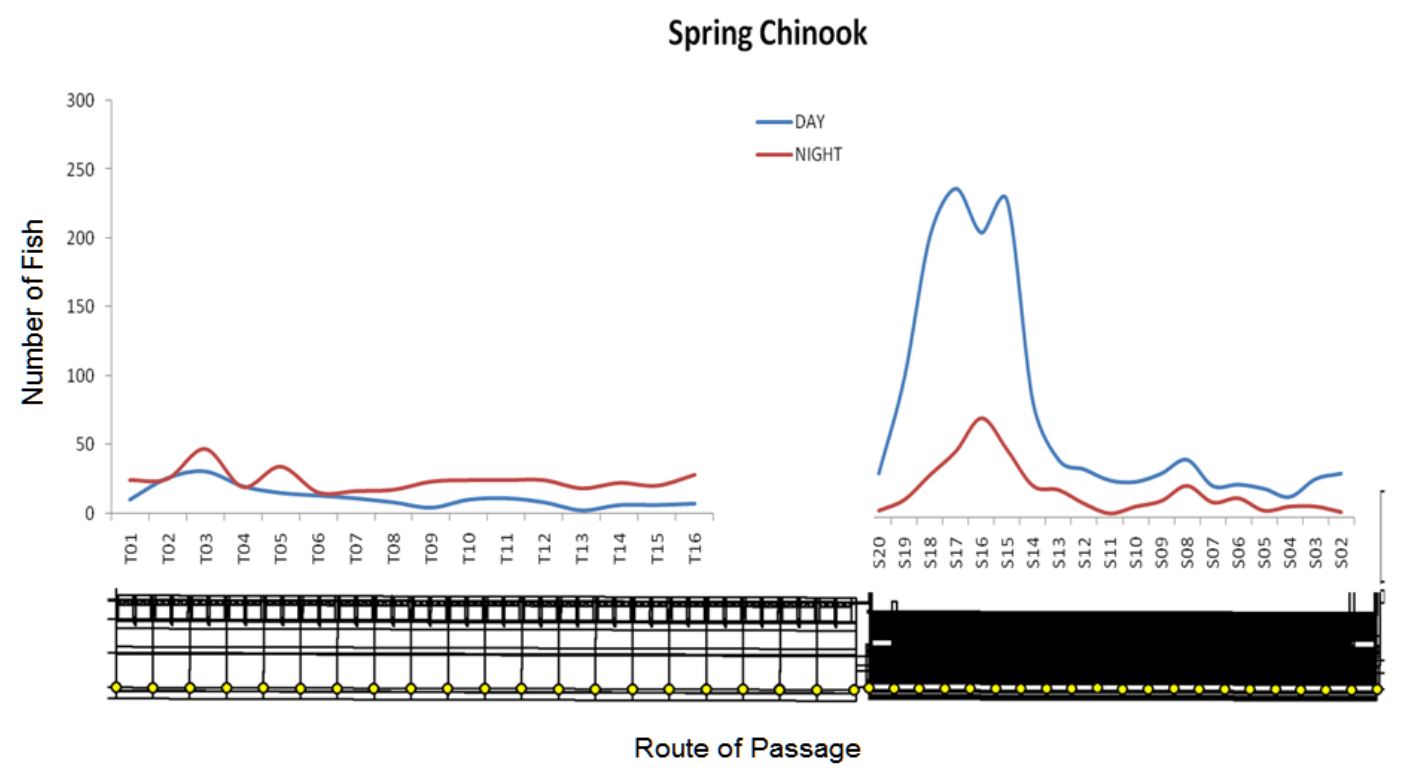

Figure 3.44. Day and night passage of acoustic tagged juvenile yearling Chinook salmon at each passage route at John Day Dam. The powerhouse is on the left and the spillway is on the right as if viewed from the forebay looking downstream. The blank space indicates the location of the skeleton bays, through which fish cannot pass.

\subsubsection{Vertical Distributions}

As arriving fish moved from 75 to $10 \mathrm{~m}$ from the face of the powerhouse, travel depth gradually decreased, but at $<5 \mathrm{~m}$ from the dam face, detection depths increased to over $20 \mathrm{~m}$ (Figure 3.45). This was expected because turbine- and JBS-passed fish must pass at much greater depths than spillwaypassed fish. The YC smolts approaching the spillway also move up slightly in the water column. However, sudden increases in depth associated with passage under tainter gates was not detected because hydrophones were mounted on piers well upstream of the spill gates. There were no day and night differences in vertical distributions for powerhouse- or spillway-passed fish.

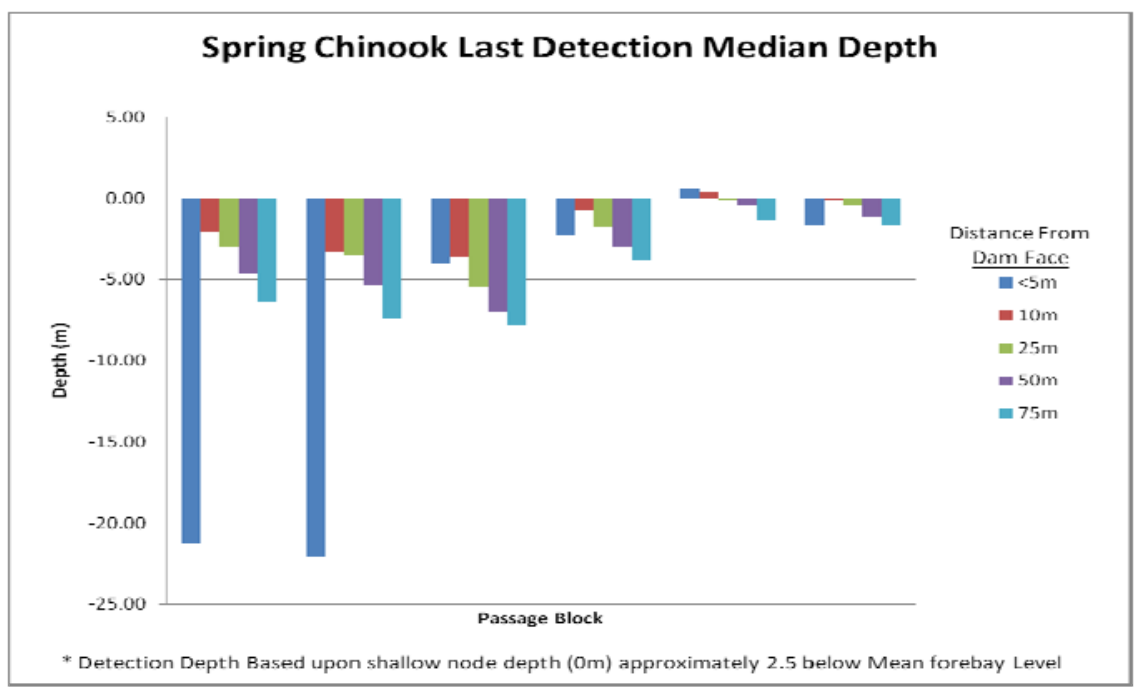

Figure 3.45. Median depths of last detection of tagged yearling Chinook salmon smolts at John Day Dam 
Turbine- and JBS-passed YC smolts had median last-detection depths of $25 \mathrm{~m}$ and $20 \mathrm{~m}$, respectively (Figure 3.46). Fish that pass into the JBS at John Day Dam are intercepted by screens in the upper part of the turbines whereas deeper fish are not intercepted and pass into turbines. The difference in median lastdetection depths of these two routes is consistent with the depths of submerged traveling screens.

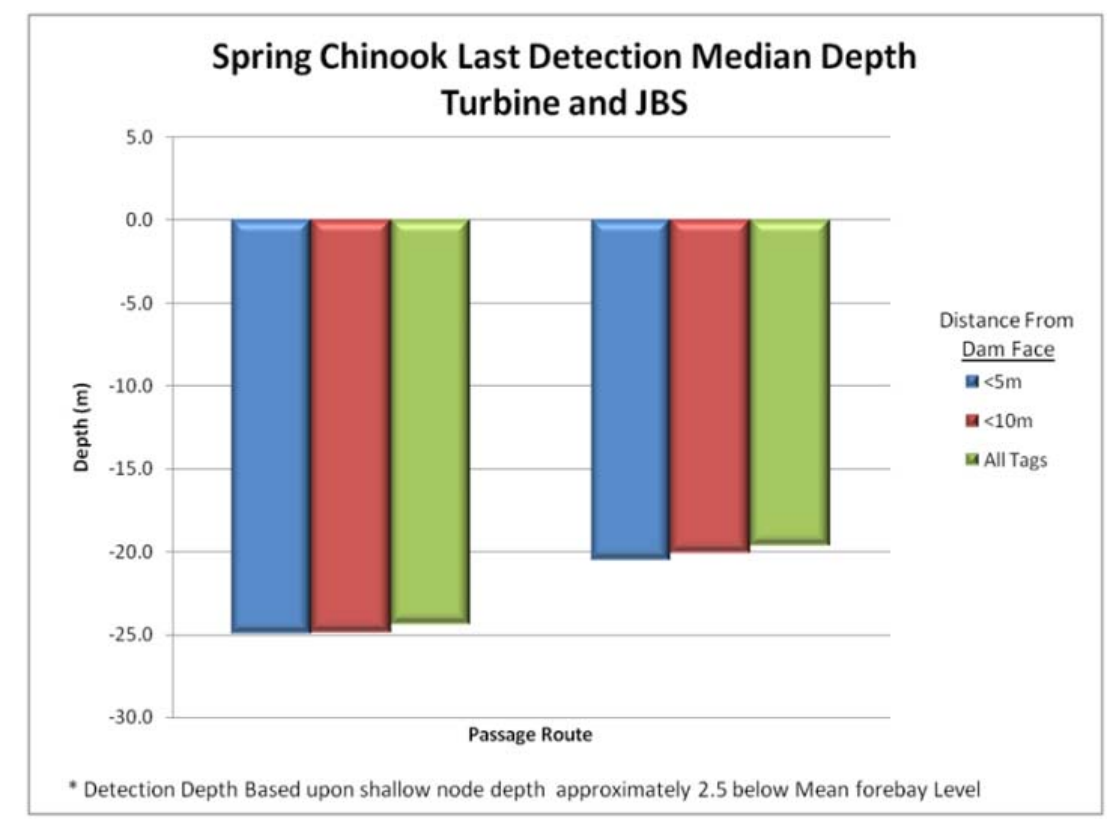

Figure 3.46. Differences in the median depths of the last detection of yearling Chinook salmon smolts that passed into the JBS and turbines

\subsubsection{Residence Times}

The YC arriving and passing at the spillway had a median residence time of 4 minutes, whereas fish arriving and passing through the powerhouse had a median residence time that was 8 -fold higher (Figure 3.47). Fish arriving at the powerhouse and later passing through the spillway had a median residence time of over 2 hours, while fish approaching the spillway and passing through the powerhouse had median residence times of 49 minutes.

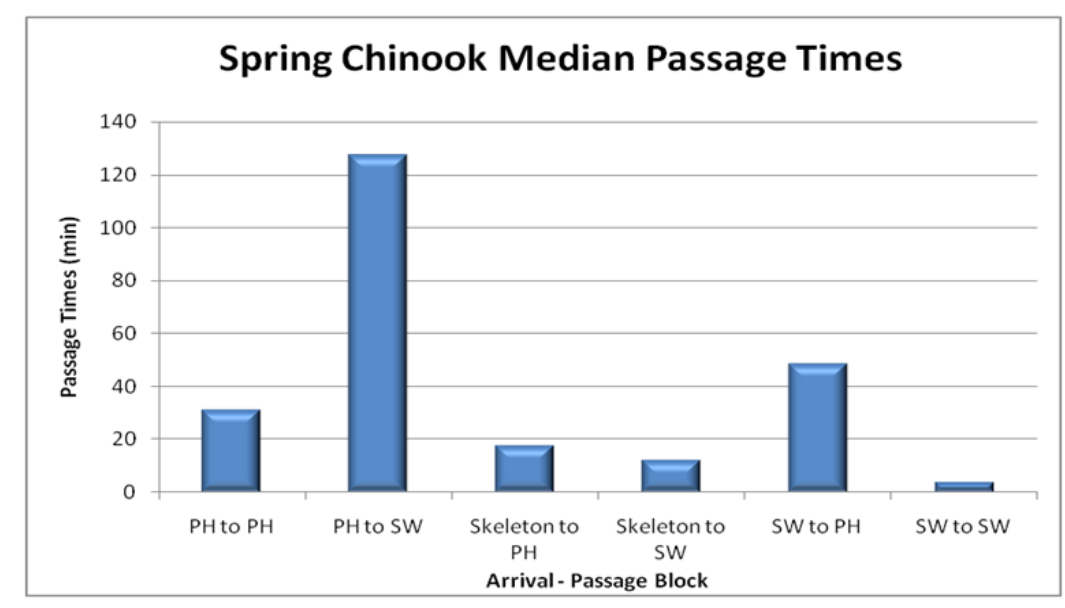

Figure 3.47. Spring Chinook salmon median passage times 
For YC approaching the powerhouse and passing the spillway, residence times were three times greater at night than during the day (Figure 3.48). In contrast, YC approaching the spillway and passing there had a median residence time of just 4 minutes.

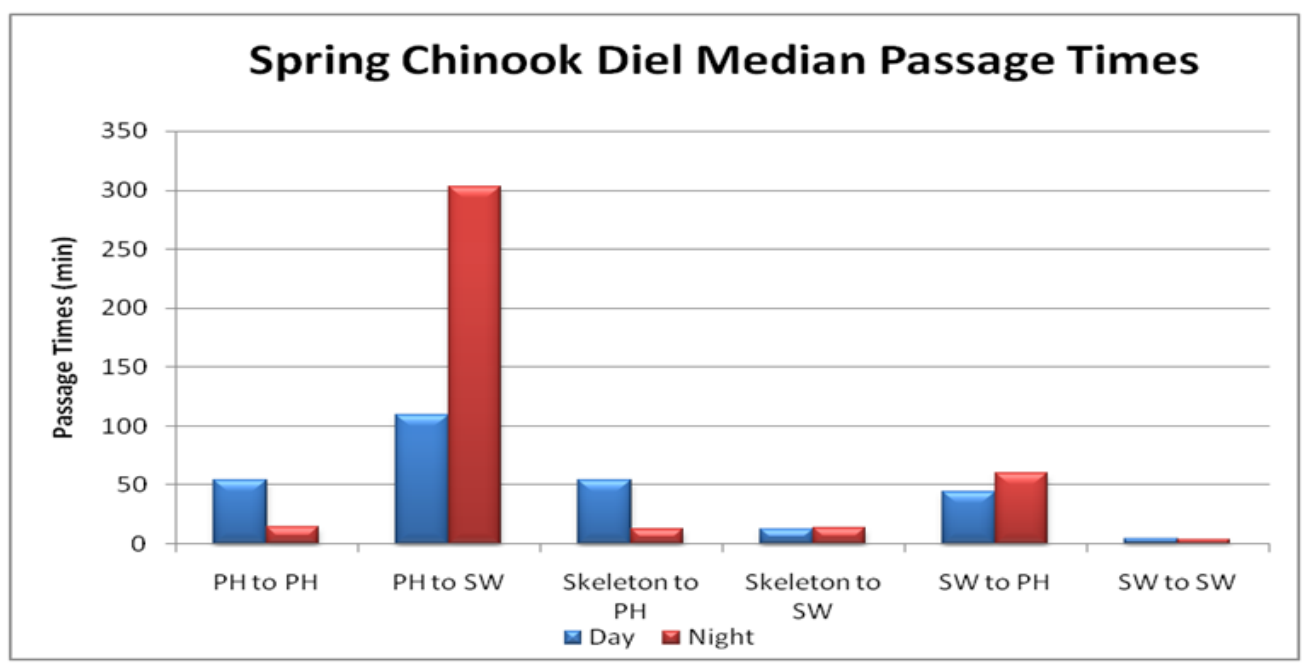

Figure 3.48. Spring Chinook salmon diel median passage times by approach and passage blocks at John Day Dam

\subsubsection{Steelhead}

\subsubsection{Approach and Route of Passage}

The STH approach to John Day Dam was similar to that of YC with 64\% of fish approaching at the powerhouse and 34\% approaching at the spillway. However, 32\% of the STH that approached the powerhouse eventually passed through the dam at the spillway (Figure 3.49). Most STH approaching the spillway passed there; only $3 \%$ of the STH approaching the spillway passed at the powerhouse.

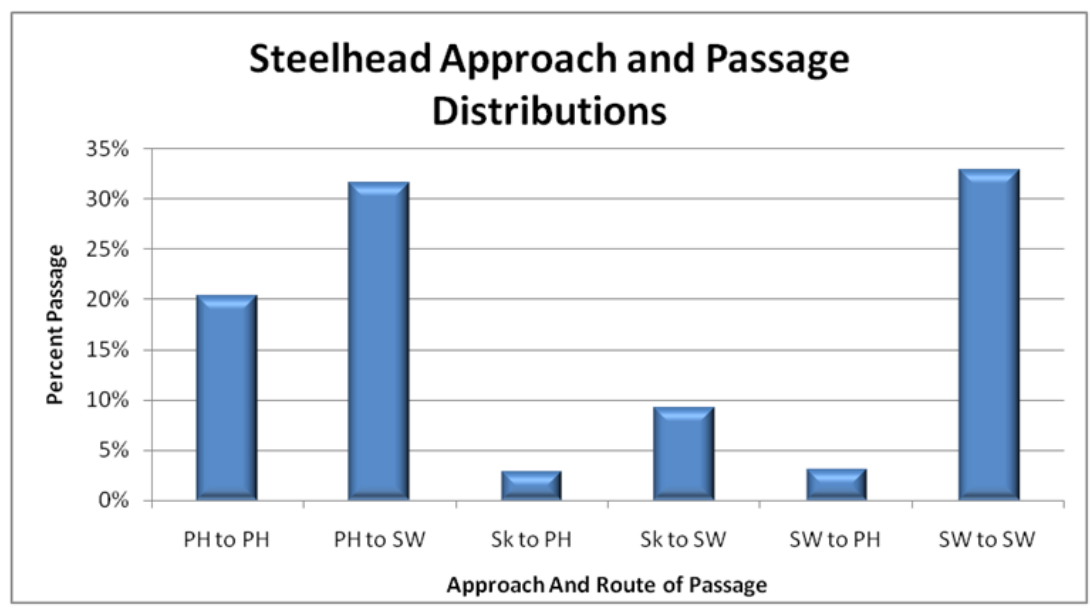

Figure 3.49. Steelhead percent passage by approach and passage blocks at John Day Dam.

Abbreviations are as follows: $\mathrm{PH}=$ powerhouse; $\mathrm{Sk}=$ skeleton bay; $\mathrm{SW}=$ spillway. 
Of the $64 \%$ of STH approaching on the powerhouse side in spring, $29 \%$ would eventually pass the TSW in spill bays 15 and 16 (Figure 3.50). In contrast, only 7.7\% of the STH approaching on the powerhouse side passed at spill bays 17-20 even though spill bays 17-20 were between the powerhouse and TSW. Most STH approaching the spillway side passed there. Again, only 3\% of STH approaching the spillway passed at the powerhouse.

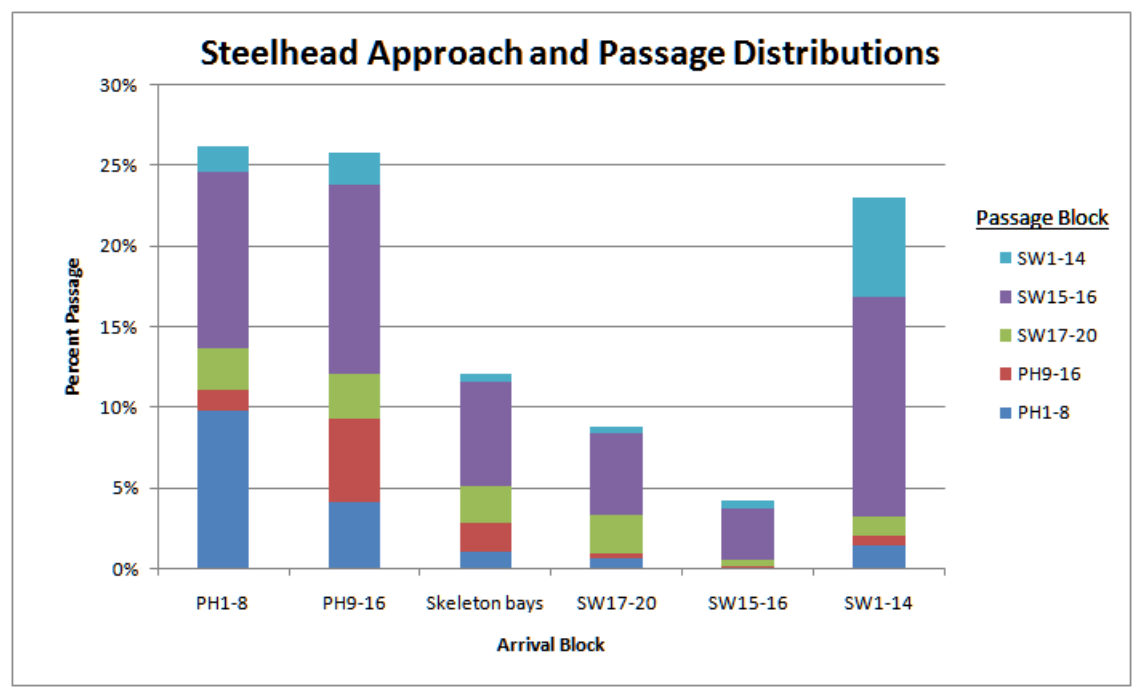

Figure 3.50. Steelhead approach and passage distributions by approach and passage blocks at John Day Dam

\subsubsection{Diel Behavior Patterns}

Steelhead approaching the powerhouse during the day had a much greater tendency to pass the spillway than they did at night; 55\% during day and 18\% at night (Figure 3.51). The powerhouse was much more effective at passing STH that arrived at night, as seen previously with YC. The spillway was more effective at retaining approaching STH with 38\% passage during the day and 25\% passage at night.

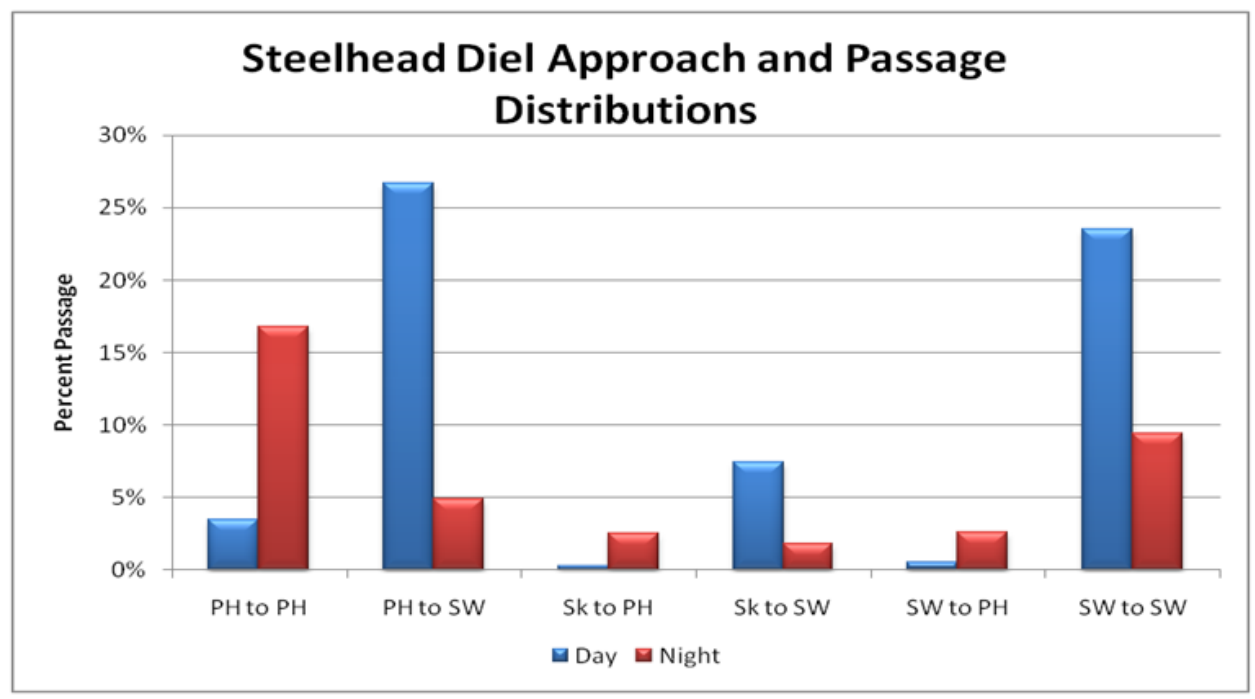

Figure 3.51. Steelhead approach and passage distributions during day and night 
During the day, the spillway was effective at attracting powerhouse-arrived fish, whereas at night the powerhouse was more effective at passing arriving STH (Figures 3.52 and 3.53). Passage SW 15-16 (TSW bays) was overwhelmingly effective at passing arriving STH, regardless of how fish approached the dam. About $74 \%$ of all fish arriving at John Day Dam during the day passed at the TSW bays (SW 15-16).

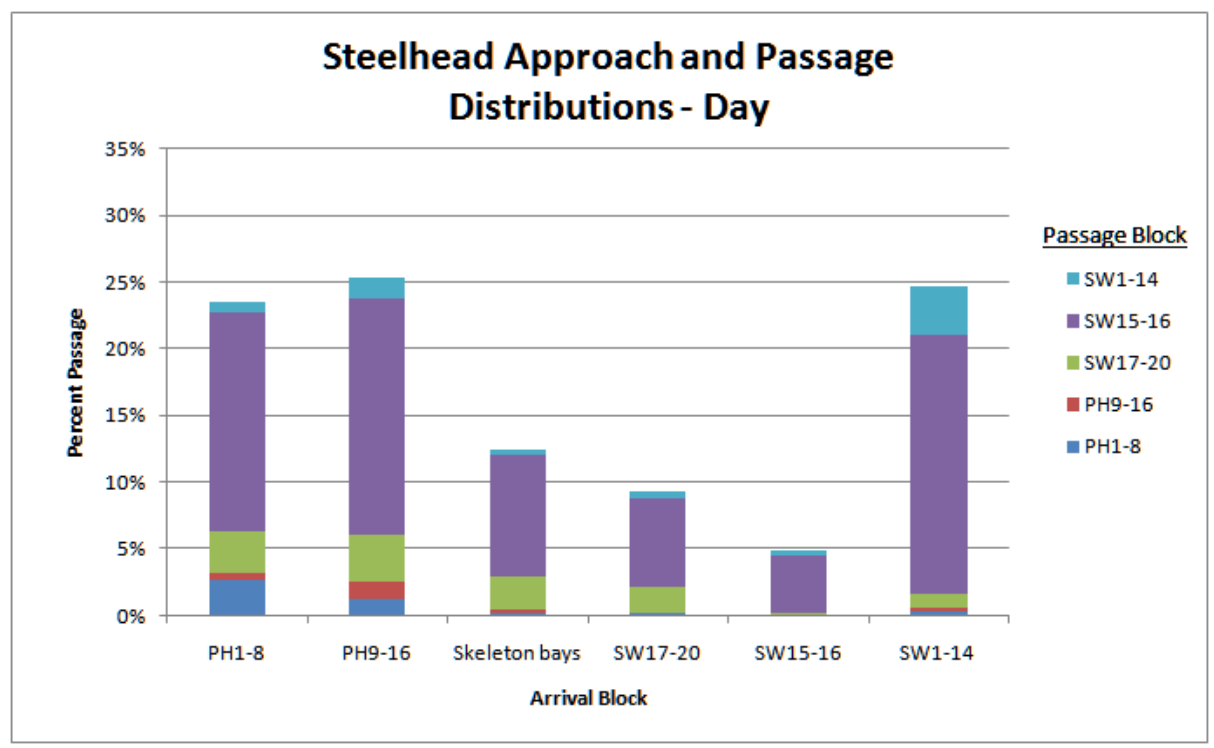

Figure 3.52. Steelhead day passage behaviors by blocks at John Day Dam

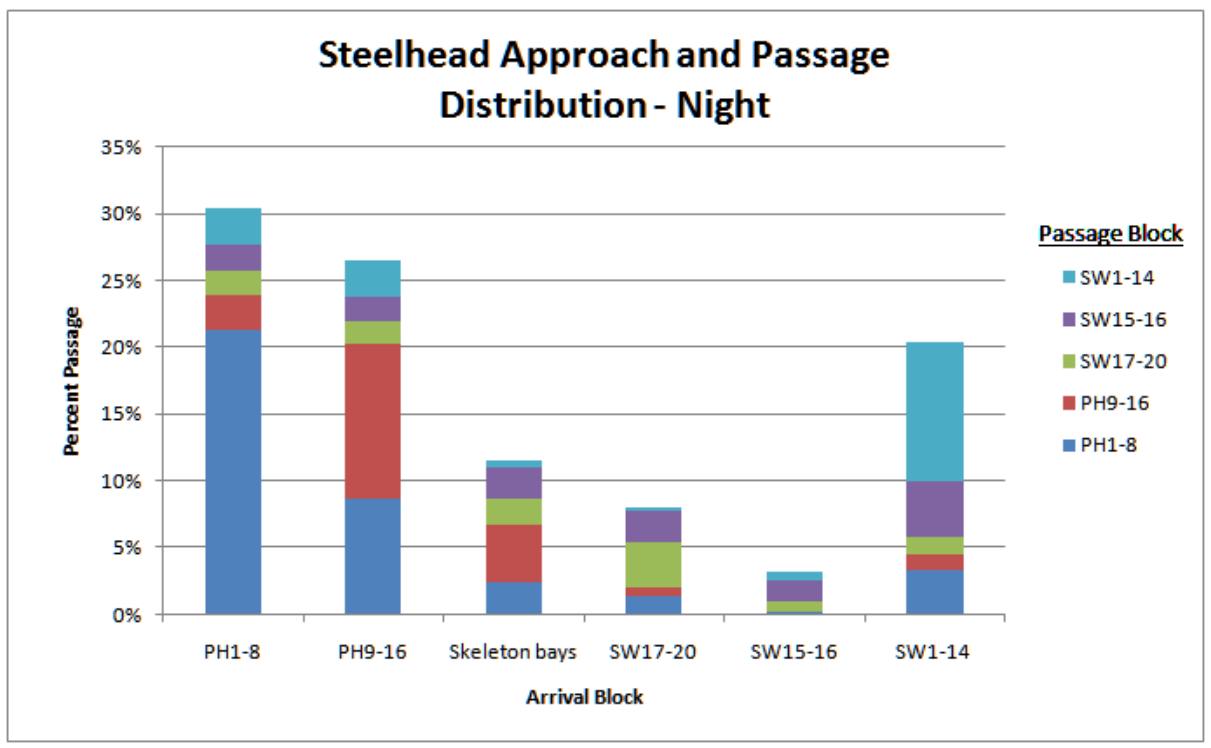

Figure 3.53. Steelhead night passage behaviors by blocks at John Day Dam

The horizontal distribution of STH passage was much higher at the TSW and adjacent bays than any other locations during the day, whereas nighttime passage was only slightly higher at the TSW and turbine units 1 and 2 than at other locations (Figure 3.54). Tagged STH passed in greater numbers at more locations at night than during the day, particularly at the powerhouse, except at the TSW and adjacent bays where daytime passage was much higher than nighttime passage. 


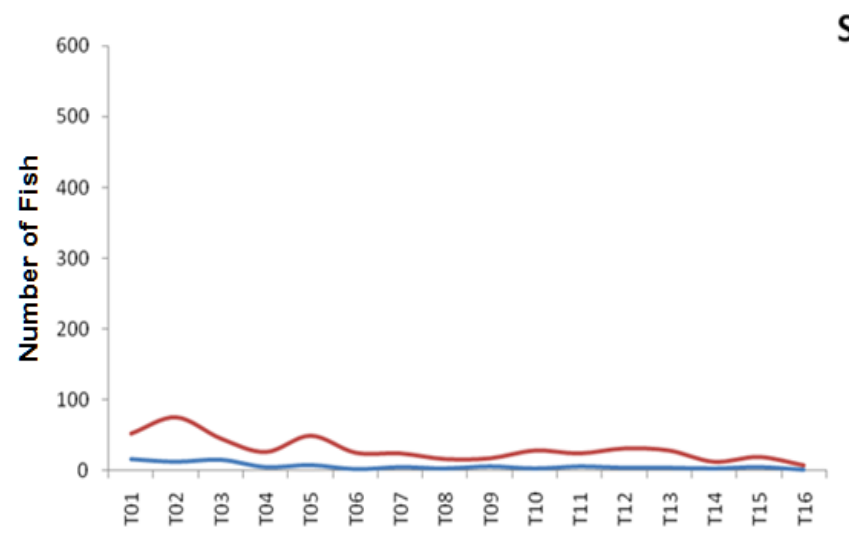

\section{Steelhead}
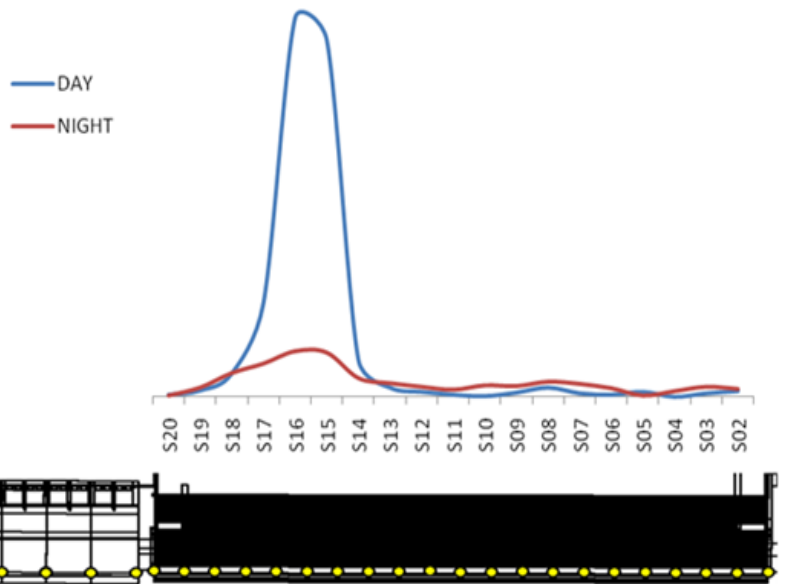

Route of Passage

Figure 3.54. Day and night passage of acoustic-tagged steelhead smolts at each passage route at John Day Dam. The powerhouse is on the left and the spillway is on the right as if viewed from the forebay looking downstream. The blank space indicates the location of the skeleton bays, through which fish cannot pass.

\subsubsection{Vertical Distributions}

The median depths of smolts approaching within $10 \mathrm{~m}$ of the powerhouse or spillway were $<5 \mathrm{~m}$, which is typical for STH (Figure 3.55). The median depths of detection at TSW and conventional spill bays remained shallow to within $5 \mathrm{~m}$ of the piers, and increasing depths associated with passing under tainter gates were not detected because hydrophones were mounted on piers well upstream of the gates. The median last-detection depths at the powerhouse at distances $<5$ m were much deeper and this is consistent with passage into turbines and the ability of hydrophones on piers very near the dam face to detect such activity.

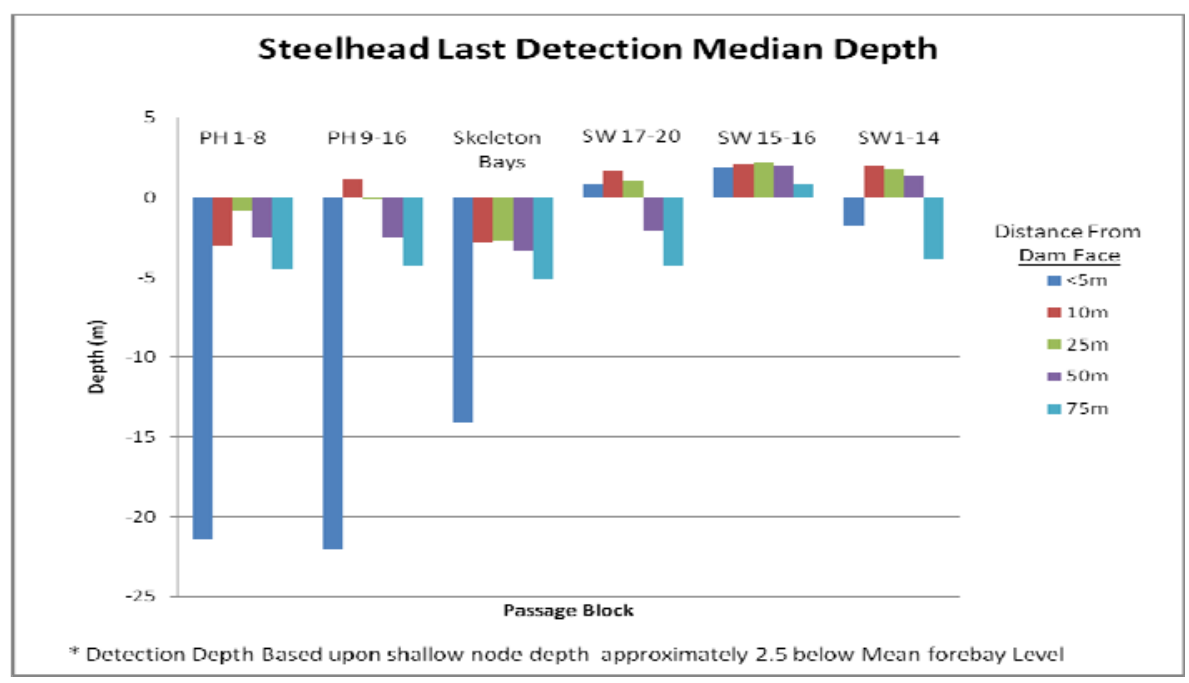

Figure 3.55. Median depths of last detection of tagged steelhead smolts at John Day Dam 
Trends in vertical distributions of passage during the day (Figure 3.56) and night (Figure 3.57) were similar, although depths of fish $>5 \mathrm{~m}$ from the dam were slightly greater at night than they were during the day, regardless of the final route of passage. The depths of STH ultimately passing through turbines was about $5 \mathrm{~m}$ greater than the depth of STH routed into the JBS (Figure 3.58).

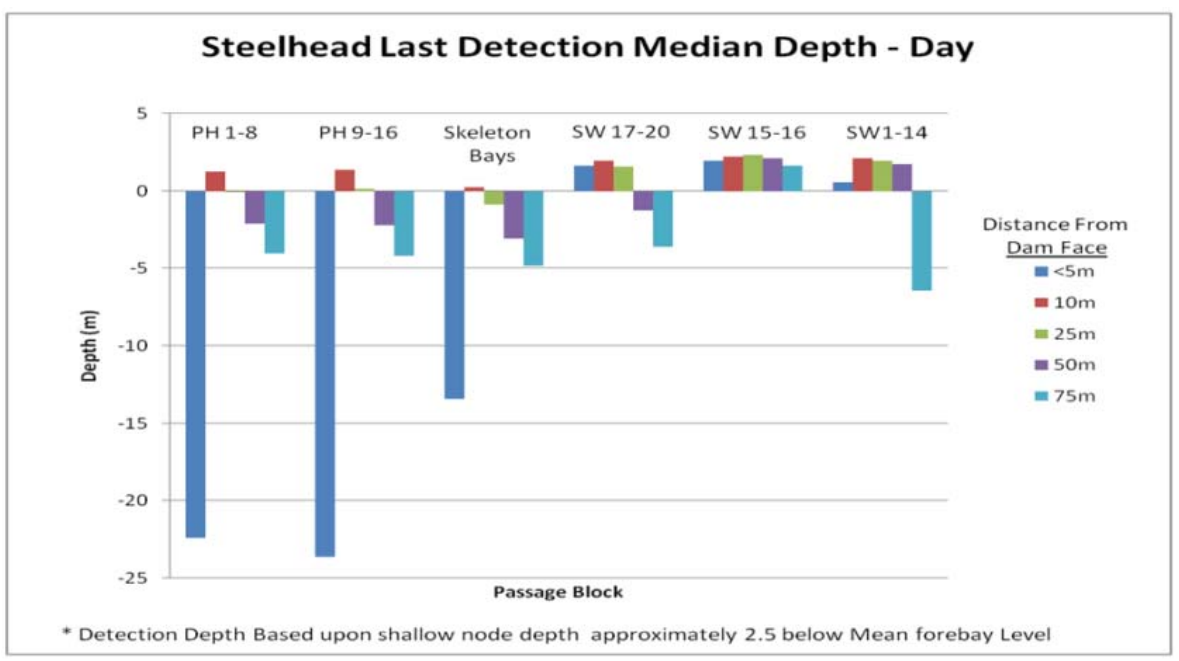

Figure 3.56. Median depths of last detection of tagged steelhead smolts at John Day Dam during the day

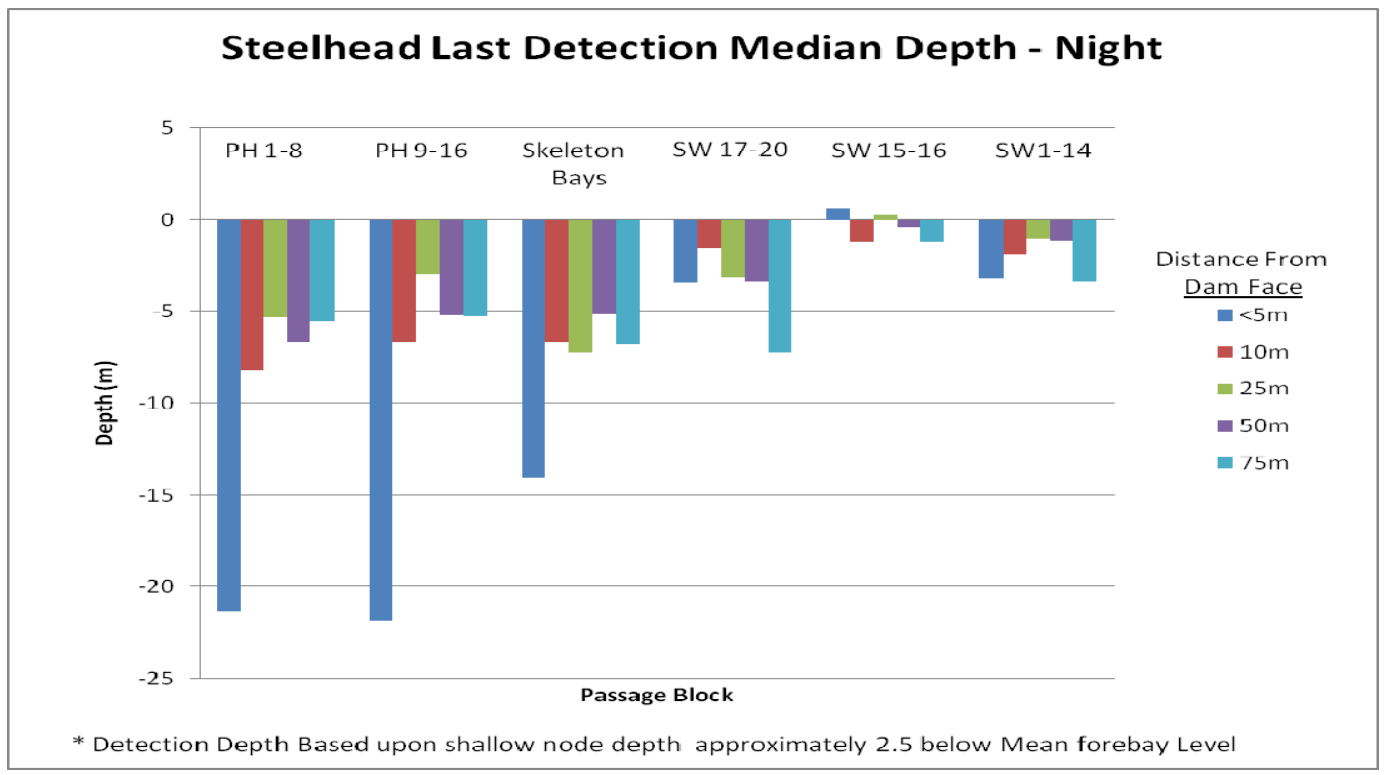

Figure 3.57. Median depths of last detection of tagged steelhead smolts at John Day Dam at night 


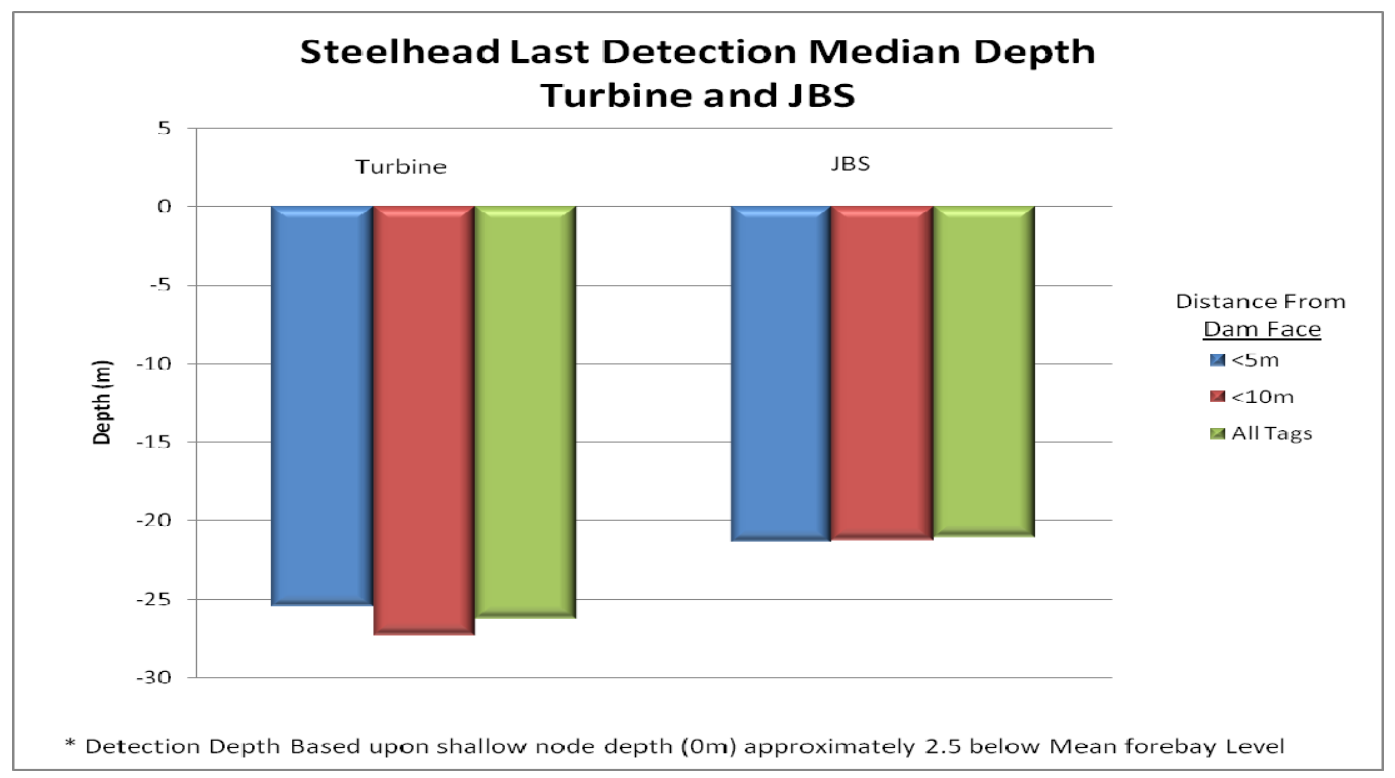

Figure 3.58. Steelhead median last-detection depths for turbine and JBS-passed fish

\subsubsection{Residence Times}

Steelhead approaching the spillway but eventually passing through the dam at the powerhouse had a median residence time that was slightly less than 7 hours, whereas fish approaching the powerhouse and passing at the spillway had a median residence time of 3 hours (Figure 3.59). The opposite trend was observed for YC. The STH approaching the spillway and passing there had the lowest residence time ( 8 minutes), and this was similar to the forebay residence time observed for tagged YC exhibiting the same behavior.

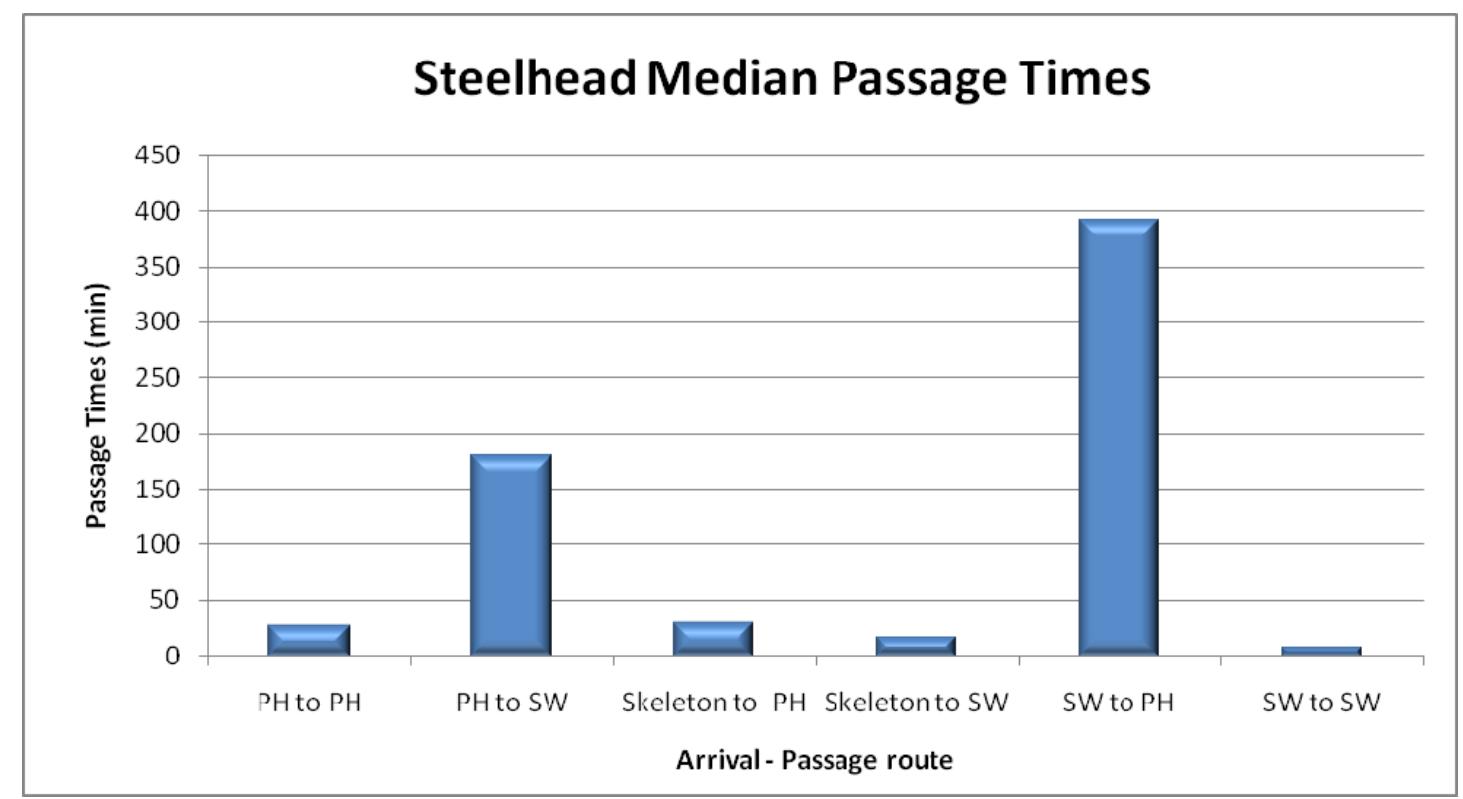

Figure 3.59. Steelhead median passage times by approach and passage routes at John Day Dam 
As evident for YC, STH that approached either the powerhouse or spillway and subsequently passed by the other route showed the highest median residence times (Figure 3.60). This was especially true for STH approaching the spillway during the day but eventually passing the powerhouse a median 16 hours later.

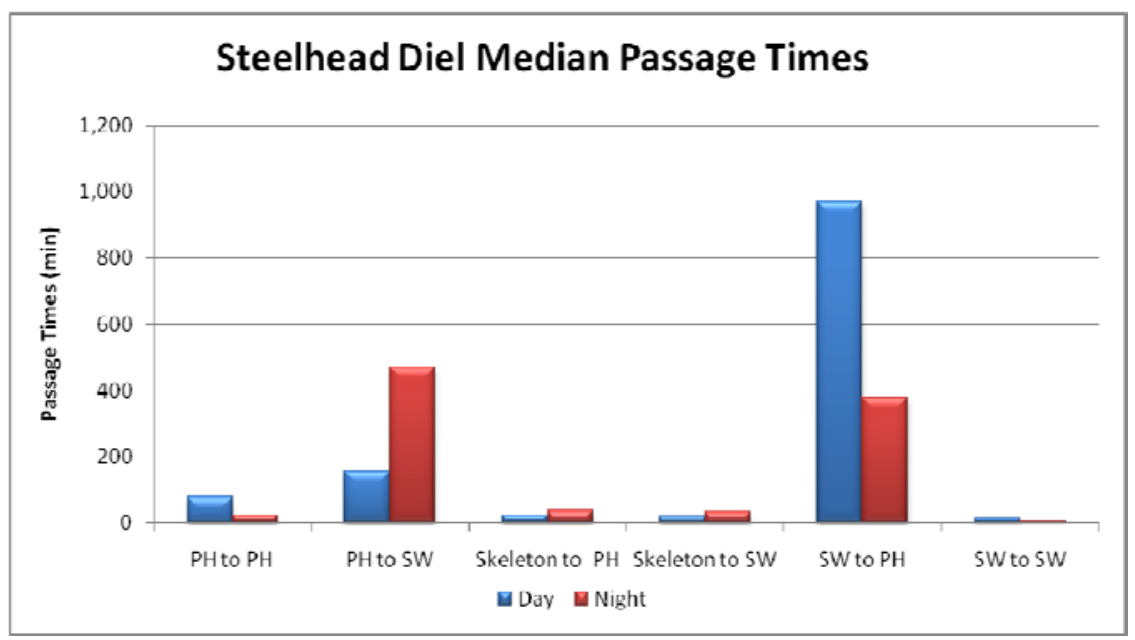

Figure 3.60. Steelhead diel median passage times at John Day Dam

\subsubsection{Subyearling Chinook Salmon}

\subsubsection{Approach and Route of Passage}

The SYC approach to John Day Dam was similar to spring with $60 \%$ of first detections at the powerhouse and skeleton bays (Figure 3.61). Of the SYC first detected at the powerhouse, nearly $47 \%$ would eventually pass the through the dam at the spillway, showing a similar trend to that observed for spring stocks. The SYC approaching the spillway were more likely to pass at the spillway than at the powerhouse.

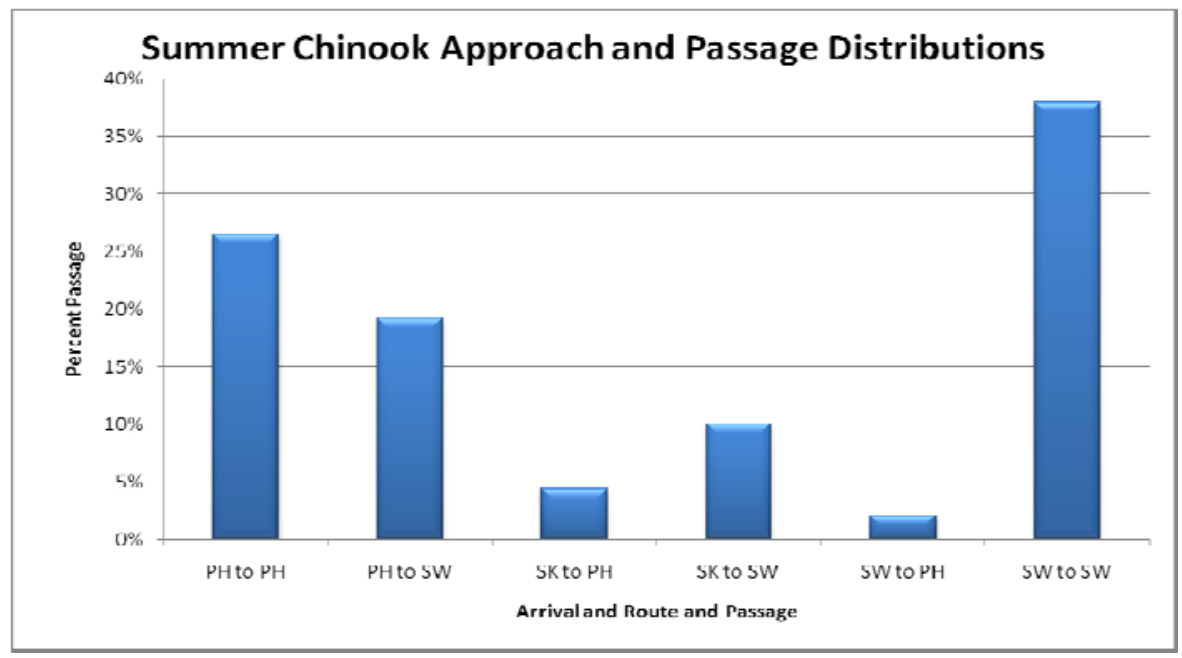

Figure 3.61. Subyearling Chinook salmon approach and passage behaviors at John Day Dam. Abbreviations are as follows: $\mathrm{PH}=$ powerhouse; $\mathrm{Sk}=$ skeleton bay; $\mathrm{SW}=$ spillway. 
The SYC arriving at the powerhouse in summer composed $60 \%$ of all fish released upstream at Arlington, Oregon, and of these, 30\% passed at the spillway (13\% at spill bays $17-20,9 \%$ at the TSW, and $8 \%$ at spill bays 1-14; Figure 3.62). This again illustrates the tendency of smolts approaching the powerhouse to travel along it until they reach the spillway.

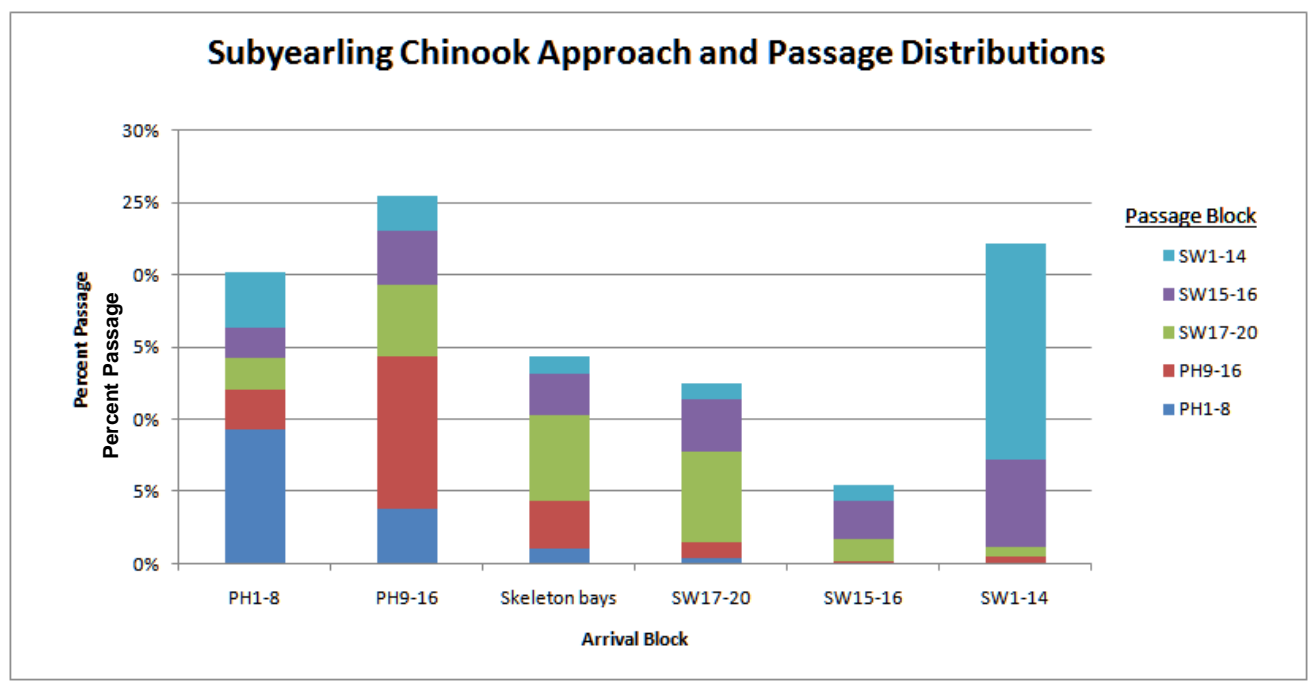

Figure 3.62. Subyearling Chinook salmon approach and passage distributions by blocks at John Day Dam

\subsubsection{Diel Behavior Patterns}

Of the SYC that approached the powerhouse during the day, 15\% would eventually pass through the dam at the spillway (Figure 3.63). At night, only 3\% of SYC approaching on the powerhouse side ended up passing at the spillway. The percentage of SYC approaching the powerhouse or spillway and eventually passing at the other location was higher during the day than it was at night (Figure 3.63).

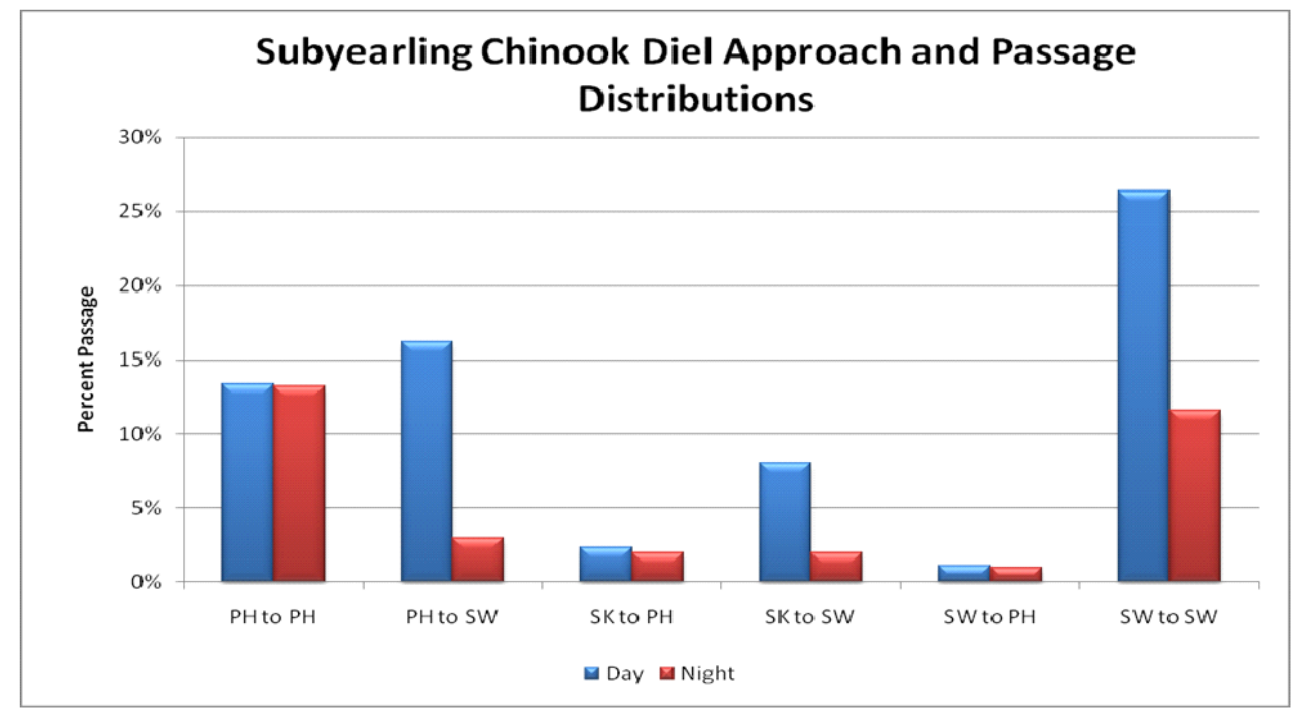

Figure 3.63. Subyearling Chinook salmon smolt approach and passage distributions at John Day Dam during day and night 
Passage distributions for SYC during the day were similar to the pooled distributions for day and night periods, with a tendency for powerhouse-arriving fish to move laterally along the powerhouse and pass at the spillway (Figure 3.64). This trend does not seem as evident at night (Figure 3.65). At night, SYC tended to pass through the same block that they first approached. A majority of fish arriving at the powerhouse passed there while fish arriving at the spillway passed at the spillway. Fish arriving at the skeleton bays favored the spillway over the powerhouse.

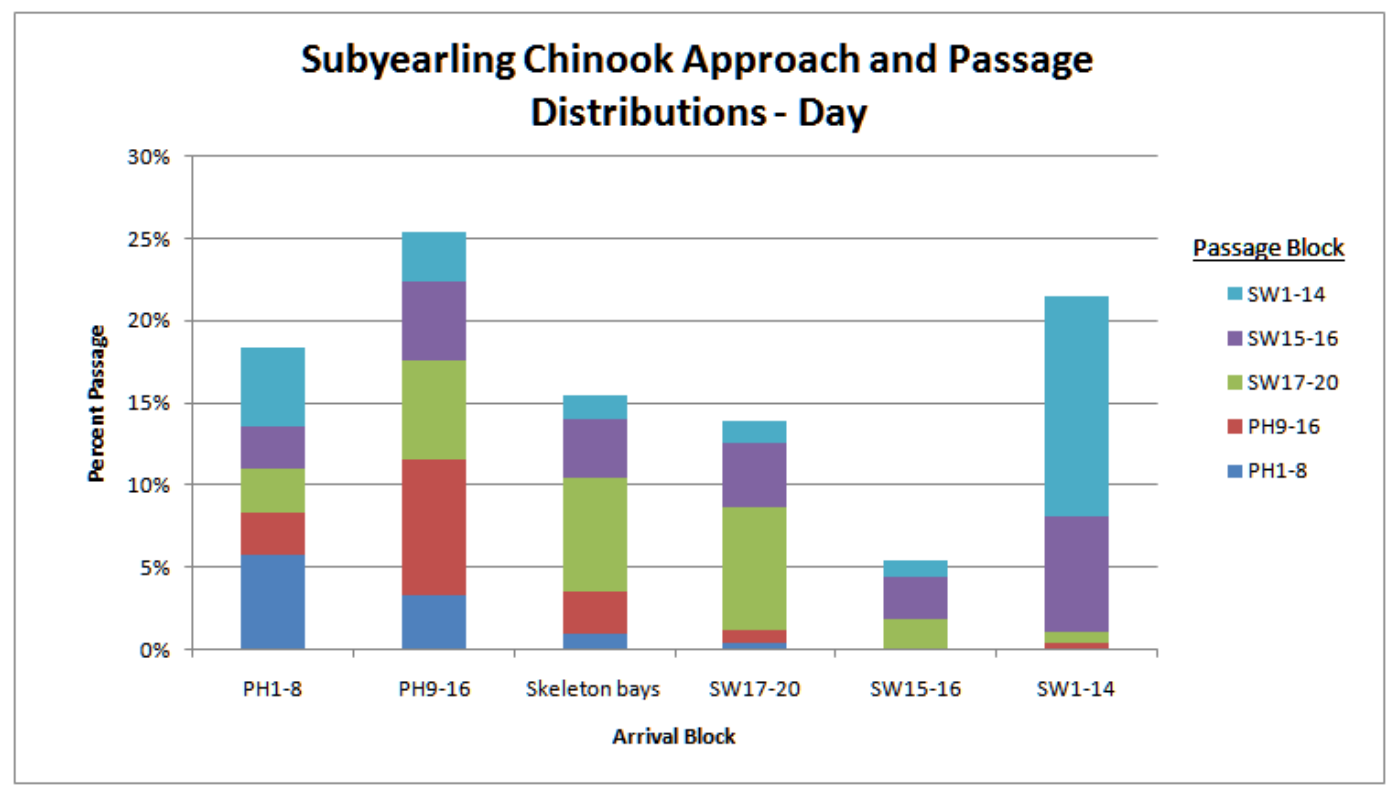

Figure 3.64. Subyearling Chinook salmon day approach and passage distributions at John Day Dam

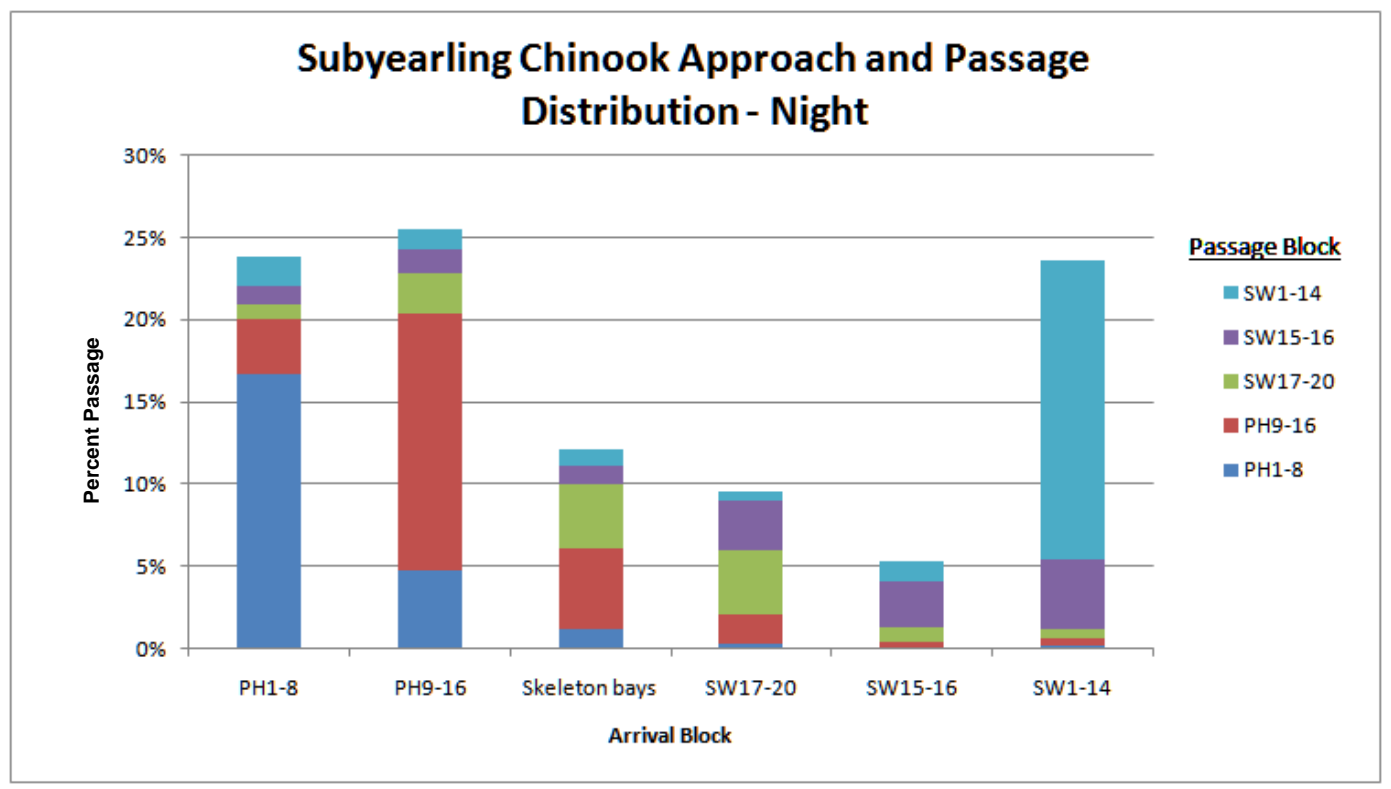

Figure 3.65. Subyearling Chinook salmon night approach and passage distributions at John Day Dam

Day and night passage rates were similar at the powerhouse, much higher during the day than at night for at TSW bays 15 and 16 and nearby bays (17-19) than at other spill bays, and slightly higher during 
the day at bays 2-14 (Figure 3.66). Passage distributions were relatively uniform at night compared to the daytime when the TSW and nearby bays passed very high numbers of SYC.

\section{Fall Chinook}
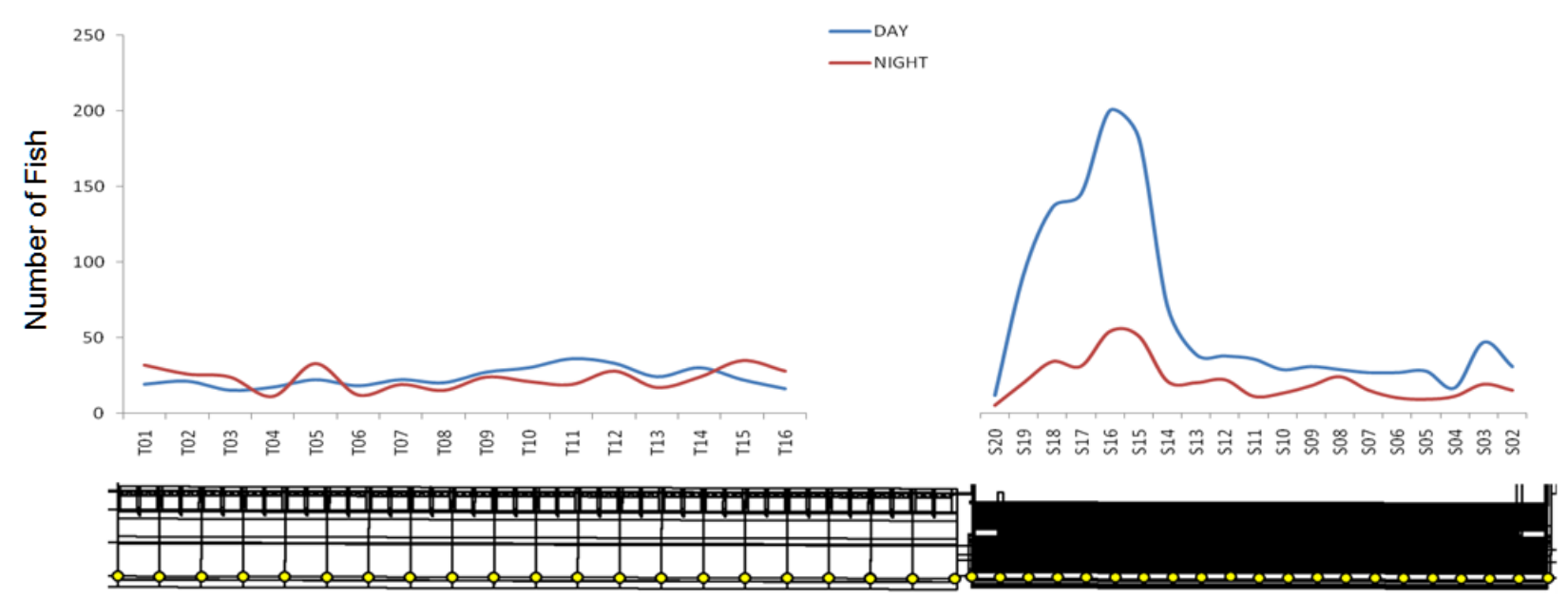

Route of Passage

Figure 3.66. Day and night passage of acoustic-tagged subyearling Chinook salmon smolts at each passage route at John Day Dam. The powerhouse is on the left and the spillway is on the right as if viewed from the forebay looking downstream. The blank space indicates the location of the skeleton bays, through which fish cannot pass.

\subsubsection{Vertical Distributions}

Most SYC > $5 \mathrm{~m}$ upstream from the powerhouse and skeleton bays traveled at depths between 5 and $11 \mathrm{~m}$, while the median depths of smolts within $5 \mathrm{~m}$ of the powerhouse or skeleton bays were detected to be between depths of 20 and 25 m (Figure 3.67). Turbine intake depths at John Day Dam are deep (>20 m). In contrast, the last-detection depths were relatively shallow at the spillway. As SYC approached the TSW, they migrated up in the water column, but this trend was not evident for smolts approaching other spill bays. There were few obvious differences between vertical distributions of approach between day and night periods. The SYC that passed turbines were approximately $5 \mathrm{~m}$ deeper than those that were screened into the JBS (Figure 3.68). 


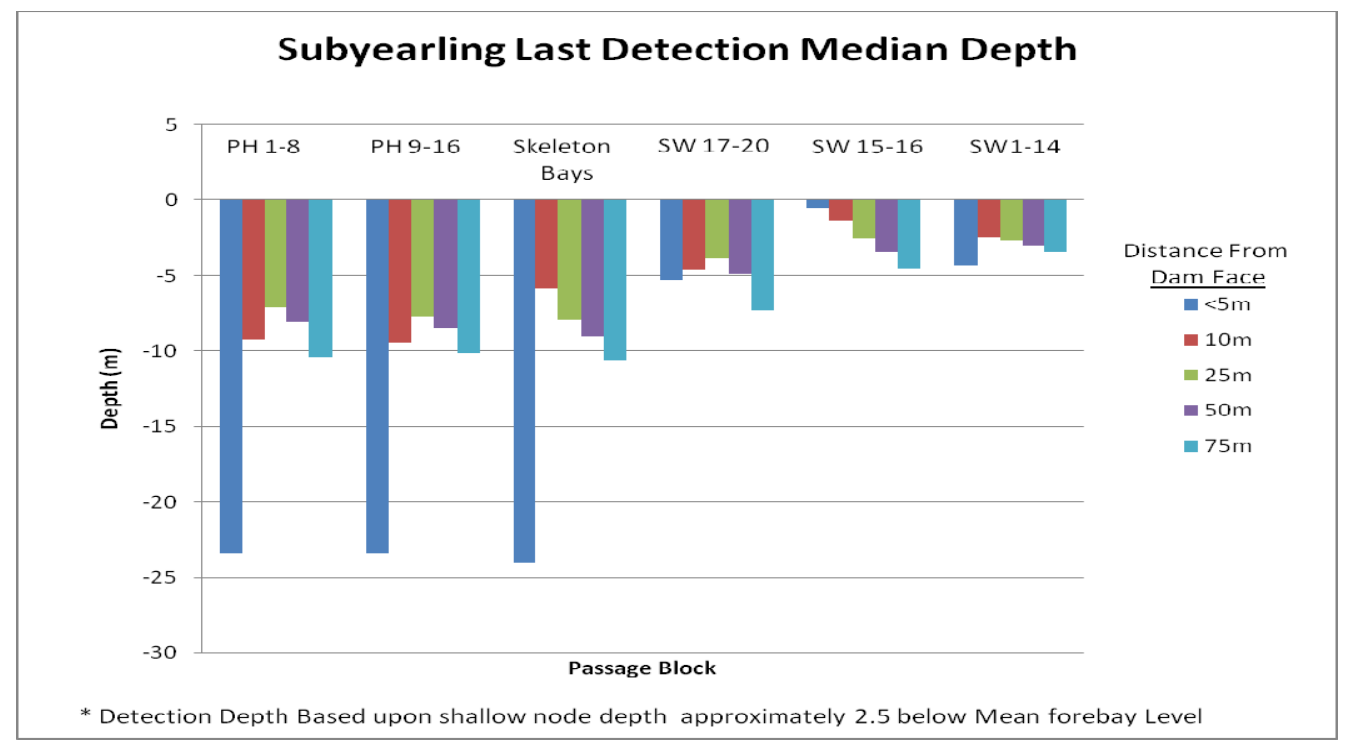

Figure 3.67. Median depths of the last detection of tagged subyearling Chinook salmon smolts at John Day Dam

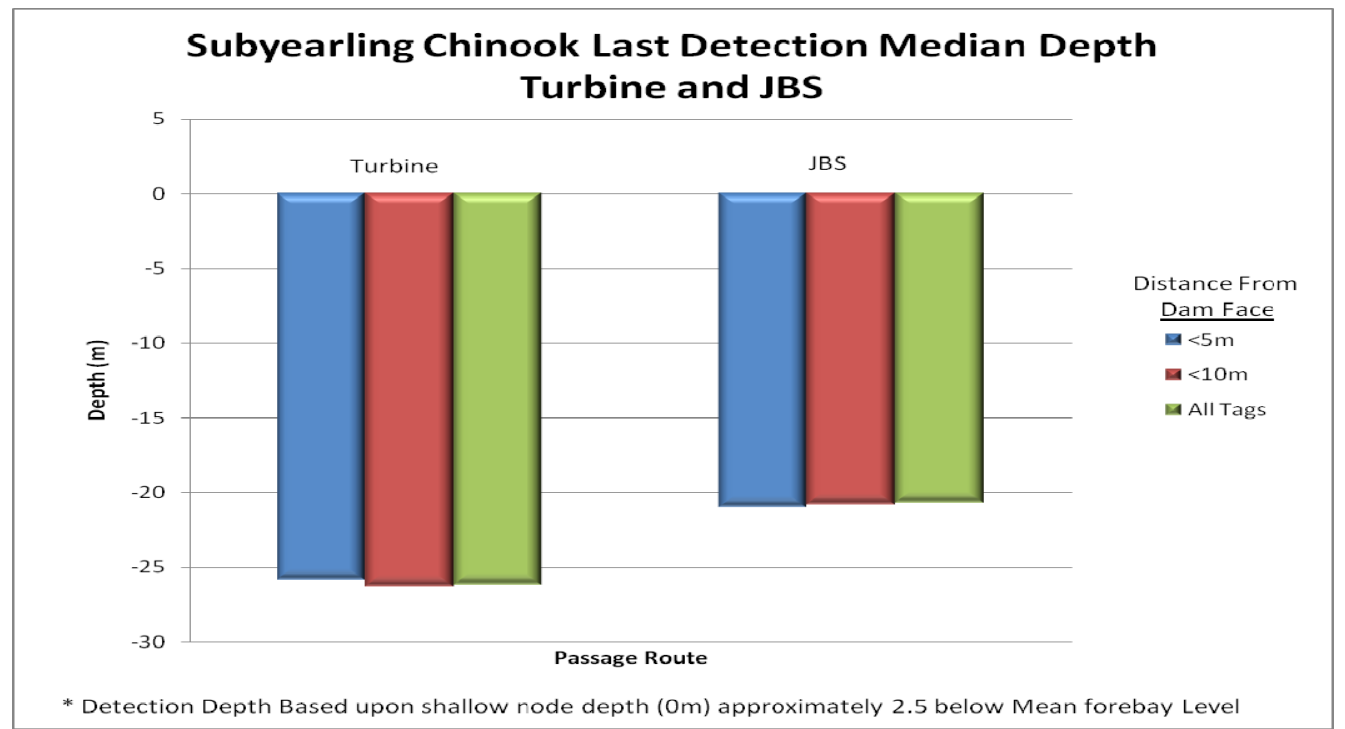

Figure 3.68. Subyearling Chinook salmon median last-detection depths for turbine- and JBS-passed fish

\subsubsection{Residence Times}

The median residence times of SYC were similar to those of YC and STH. Fish approaching and passing through the dam at the spillway had the shortest residence times ( $<5$ minutes), whereas fish approaching the powerhouse but passing at the spillway had a 90-minute residence time (Figure 3.69). Fish approaching the spillway and passing through the powerhouse had a median residence time of 25 minutes. 


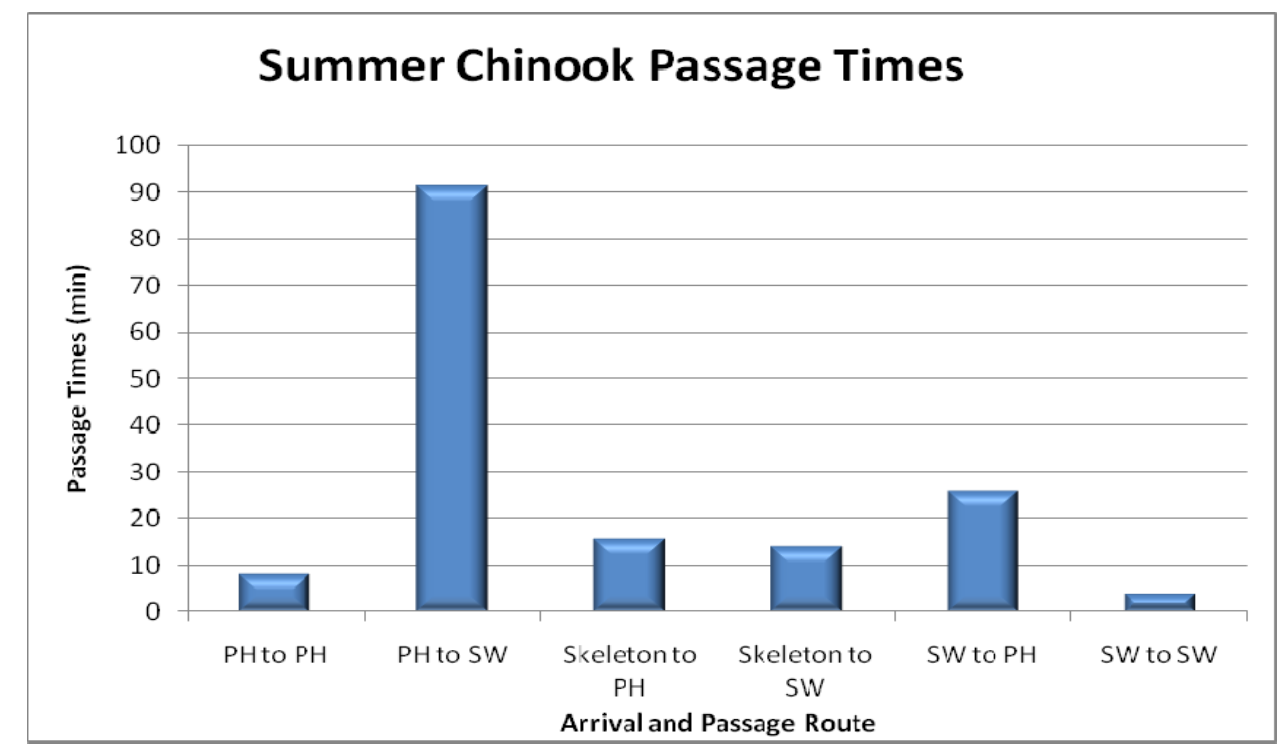

Figure 3.69. Median residence times of subyearling Chinook salmon smolts at John Day Dam

The median residence time of smolts arriving at the powerhouse but passing through the dam at the spillway at night was nearly 2.8 times longer than that of smolts exhibiting the same behavior during the day (Figure 3.70). This trend also was observed for YC in spring.

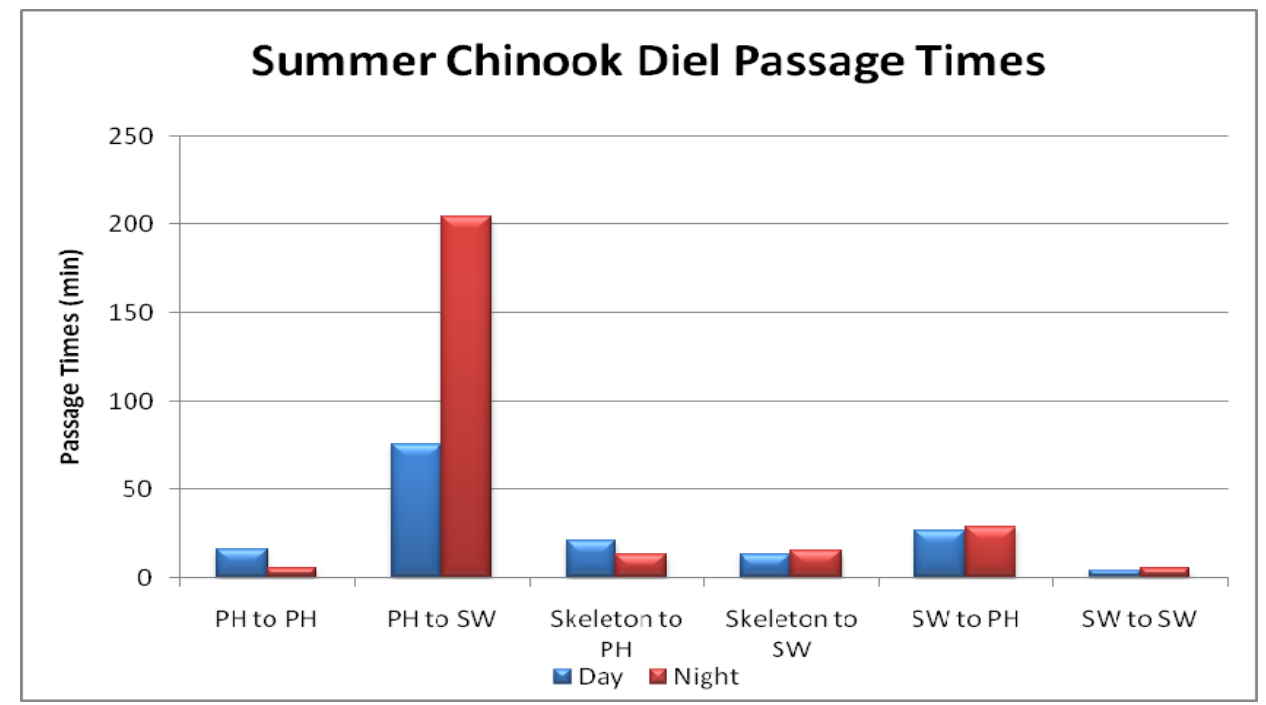

Figure 3.70. Subyearling Chinook salmon diel median passage times at John Day Dam. Abbreviations are as follows: $\mathrm{PH}=$ powerhouse; $\mathrm{SW}=$ spillway; Skeleton $=$ skeleton bays.

\subsection{Detailed Data on Tagging, Release, Virtual Releases, and Dam Operations}

Appendix L describes the large comma-separated variable files that are on a CD that accompanies the hard-copy version of this report. These data sets combine all data on fish tagging, fish releases, and 
virtual releases at John Day Dam with hourly dam operations data and subsequent capture history data on downstream survival-detection arrays. The date and hour that each fish was last detected on the dam-face array is the key to linking forebay detections with hourly dam operations and subsequent capture history data (i.e., the date and time of detection on the dam-face and downstream survival-detection arrays). These data are provided to allow for multi-year post-hoc analyses of the effects of dam operations on the dam and route-specific survival after several years of similar data have been acquired.

\subsection{Tests of Survival-Model Assumptions}

We already compared the length frequencies of tagged and untagged fish of each stock in Section 3.1.4 to help assess whether tagged fish were reasonably representative of the run at large.

In the following sections, we describe the results of two types of model assumption tests:

- Burnham et al. (1987) Test 2 and Test 3 to assess the assumption that upstream and downstream detection and survival probabilities are independent

- Comparison of the TOAs of tagged smolts at the primary survival-detection array to verify that the releases mixed reasonably well in the common tailwater below a dam. The assumption is that treatment and reference releases of fish passed through the common tailwater at similar times of day and likely experienced similar survival processes.

\subsubsection{Burnham Test Results}

A major assumption of the survival models used in this study is that upstream detections do not affect downstream detection or survival probabilities, and this can be tested using Burnham Test 2 and Test 3 . Appendix $\mathrm{M}$ tables probabilities of chi square tests on $2 \times 2$ contingency tables for every release by fish stock and survival metric reported in this study.

A majority of the Burnham test could not be calculated because of exceptionally high detection probabilities on John Day Dam survival-detection arrays, and of those that could be calculated, none were significant at $\alpha=0.1$ (Appendix $M$ ).

\subsubsection{Arrival Distribution Tests}

We examined the cumulative frequency of arrivals of tagged fish in virtual and reference releases at the primary survival-detection arrays for John Day Dam and The Dalles Dam to determine whether the model assumption of mixing of fish in the common tailwater was violated. For all stocks of tagged fish, cumulative frequencies of arrivals were very similar and no consistent large deviation of arrival times of the two releases was evident for any stock of fish or either dam (Appendix N). Scatter plots of arrival hour at the primary array showed that arrivals of virtually released fish were relatively uniform throughout each day. Arrivals of smolts released in the John Day tailrace at The Dalles Dam forebay array were loosely clustered around three times of day, although some reference smolts could be found passing through The Dalles Dam pool during any hour of the day. Arrivals of SYC smolts released in The Dalles tailrace at the Bonneville Dam forebay array were relatively uniform, and it was much harder to discern that there were three releases in The Dalles Dam tailrace each day in summer (Appendix N; Table N.4). 


\subsection{Discussion and Conclusions}

In this section, we discuss study integrity, a comparison of 2008 results with previous survival and passage studies at John Day Dam, and the performance of the prototype TSW SFOs. The section closes with study conclusions.

\subsection{Study Integrity}

The JSATS acoustic telemetry study at John Day Dam during 2008 provided reliable data on fish survival rates, passage rates, and behavior, as indicated by the following evidence.

The tagged fish population reasonably represented the run-at-large for each run of smolts. The goal of tagging the middle $80 \%$ of each of the YC, STH, and SYC runs was reasonably well met. The start and end times, respectively, for tagging relative to the percentage of passage according to the smoltmonitoring index of passage were $8.2 \%$ and $76.5 \%$ for $\mathrm{YC}, 2.4 \%$ and $85.0 \%$ for STH, and $10 \%$ and $65.6 \%$ for SYC. The median length of tagged fish was from 6 to $11 \mathrm{~mm}$ longer than that of untagged fish of the same stock (11 mm for STH, $8 \mathrm{~mm}$ for YC, and $6 \mathrm{~mm}$ for SYC), and this shift was observed over most length classes, reflecting a small but consistent bias in fish selection. We believe that this slight bias could have resulted from a preference for clipped hatchery fish over unclipped fish of unknown origin. Clipped fish tend to be slightly larger than unclipped fish of the same stock. It is also possible that smaller smolts were unintentionally sampled less frequently because they were not as visible to collectors as were larger individuals. We recommend that survival-study managers emphasize the importance of random sampling of smolts from all length classes without regard to fin clip status (clipped or unclipped). The $>95$-mm-length requirement on candidate fish for tagging did not restrict the lengths of fish that could be tagged in the spring and only excluded about $9 \%$ of the run-of-river subyearlings from tagging in 2008 (Figure 4.1). In 2007, 40\% of subyearlings could not be tagged because they were too small (Ploskey et al. 2008), presumably because growth was slower that year. Tagging must include 80- to 95-mm smolts to be fully representative of the run-of-river population in summer, but only the production of smaller lighter tags than those available in 2008 will make that possible.

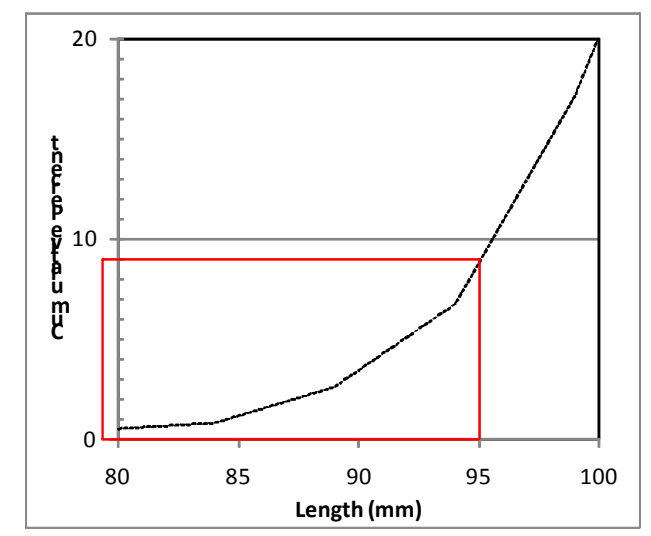

Figure 4.1. Plot of the lower end of the cumulative length frequency distribution of subyearlings in routine SMF samples. The red box highlights the $9 \%$ of smolts that could not be tagged because of a $>95$-mm-length requirement in 2008 . 
Zero detection rates for acoustic-tagged dead fish verified that tailwater detection arrays were placed far enough downstream. Small subsamples of fish were sacrificed and released during the season to help determine if detection arrays were far enough downstream. This was done to determine if a fish would be detected on a downstream array if it died from passing through a previous dam. For spring and summer, a combined total of 62 tagged dead fish were released at either Arlington, below John Day Dam, or below The Dalles Dam. None of these fish was detected on downstream arrays.

Detection probabilities at the dam-face cable array exceeded expectations. The combined probability of detection for the two independent arrays exceeded $99.99 \%$ for every stock of fish in the study. The detection ability of the JSATS cable array, when deployed and maintained properly, is exceptional.

Detection performance for arrays above Bonneville Dam was excellent, and it was acceptable for those below Bonneville Dam. Detection rates were $99 \%$ for both the spring and summer tagging season above Bonneville Dam, but $8 \%$ to 10\% lower for those arrays below Bonneville Dam. Multi-node detections in the Bonneville Dam tailrace arrays were 50\% for the first array and $21 \%$ for the second. Possible reasons for poor performance on the Bonneville Dam tailwater arrays include the structure of the river in that particular reach, including depth, bathymetry, and location of islands and sandbars that interfere with sound reception. We recommend increasing node densities in arrays downstream of Bonneville Dam in future studies to improve detection performance.

Two other testable assumptions of the survival models were met. There were no significant results of Burnham et al. (1987) Test 2 or Test 3. In fact, a majority of the Burnham test could not be calculated because of exceptionally high detection probabilities on John Day Dam survival-detection arrays, and of those that could be calculated, none were significant at $\alpha=0.1$. The cumulative frequencies of arrivals of tagged fish of each stock in virtual and reference releases at the primary survival-detection arrays for John Day Dam and The Dalles Dam were very similar, and this demonstrates that the model assumption of mixing of fish in the common tailwater was not violated.

\subsection{Comparison with Previous Survival and Passage Studies at John Day Dam}

\subsubsection{Yearling Chinook Salmon}

The FPE estimate of $92.14 \pm 1.30 \%$ for YC in spring was among the highest values of FPE observed at John Day Dam (Table 4.1). Higher than normal FPE could be explained by the addition of the two TSWs in spill bays 15 and 16 that increased non-turbine passage in 2008. Estimates of FPE ranged from $82.4 \%$ to $93.8 \%$ from 1999 to 2008 . Five FPE values were different from the values observed in 2008; of these values only one had a similar spill pattern (2002 RT 24 h 30/30). Spill-passage efficiency can vary considerably from one year to the next. The highest estimate of SE was observed in 2000 at $86.2 \%$, while the lowest (21\%) was estimated in 1985. Spillway passage efficiency in 2008 was on the higher side of all estimates at $76 \%$. The high percent SE could be attributed to the TSWs in spill bays 15 and 16 and the increase in flow through the TSWs and surrounding spill bays. In 2002, a hydroacoustics study recorded FGE estimates of $69.5 \%$ and 55\%, and these were similar to FGE in 2008. In 2002 and 2003, radiotelemetry studies estimated JBSE between $25 \%$ and $36 \%$. In 2008, JBSE estimates ranged from $14 \%$ to $17 \%$. The difference in JBSE between radio-telemetry and acoustic telemetry was significant. The low 
JBSE in 2008 could be associated with the installation of the two TSW surface passage routes at the spillway. Spillway passage effectiveness was calculated in most years with the highest being observed in 1995 at 6.3 while the lowest SEF was recorded in 1985 at 0.75 . A majority of the estimates of SEF fall between 1.5 and 3. Estimates in 2008 were no different, with estimates of SEF ranging from 1.98 (40\% spill) to 2.48 (30\% spill) with an overall average of 2.32 . There were also two estimates used at John Day Dam that were not used in previous studies. Surface outlet efficiency (TSWE) and surface outlet effectiveness (TSWEF) were estimated for the new TSWs installed in spill bays 15 and 16. The TSWE for John Day Dam in 2008 was 23.55\% with a TSWEF of 3.41. The estimates at John Day Dam in 2008 were very similar to the results observed at McNary Dam in 2007 (Adams and Counihan 2008).

Table 4.1. Estimates of major fish passage metrics for yearling Chinook salmon smolts from previous radio-telemetry studies relative to estimates from this 2008 acoustic telemetry study. We also show estimates from previous hydroacoustic studies, although they would represent composite estimates for all stocks of juvenile salmon because hydroacoustic sampling cannot differentiate between species. Studies prior to 2002 were summarized by Anglea et al. (2001) and subsequent references are footnoted in the table.

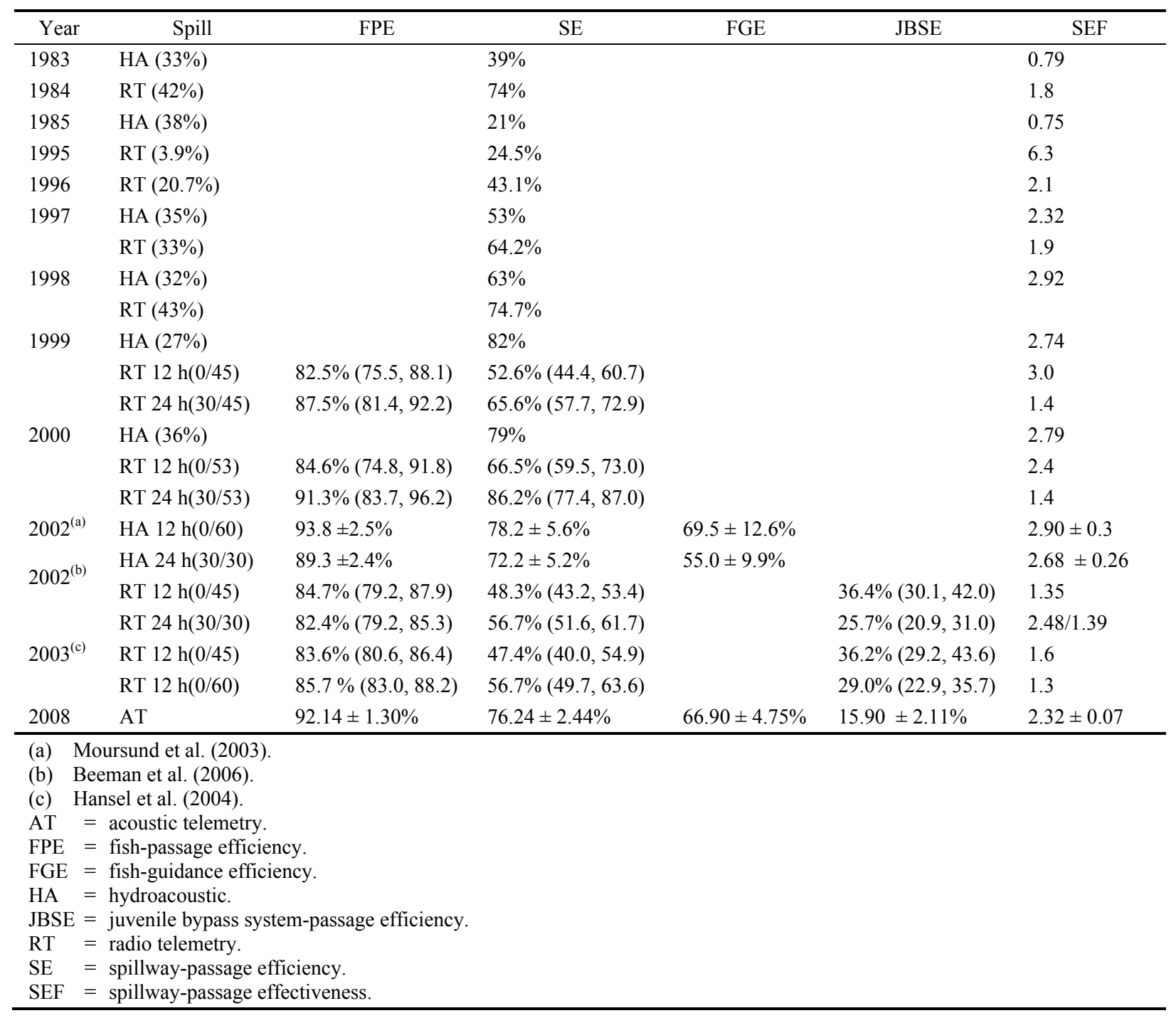




\subsubsection{Steelhead}

In 2008, we recorded the highest FPE for STH passing at John Day Dam (97.2\%; Table 4.2). The next highest FPE was observed with radio telemetry in 1999 at $94.2 \%$. As with YC, and particularly for STH, we attribute high FPE to the TSW installations, which provided an ideal route of passage. Steelhead smolts typically migrate at shallow depths, prefer surface passage routes, and in 2008 passed in high numbers at TSW spill bays during the day (Figure 3.54). The SE for 2008 was similar to estimates in 1999, 2000, and 2002. The FGE of in-turbine screens also was very high in 2008 (88.9\%) and considerably higher than estimates ranging from 55\% to $70 \%$ in a 2002 hydroacoustics report. Of course, the hydroacoustic estimates would have been based on a mix of spring stocks most of which are less guidable than STH. JBSE and SEF showed similar results to past studies with values for JBSE near 25\% and SPS values of around 2.0 (Table 4.2).

Table 4.2. Estimates of major fish passage metrics for steelhead smolts from previous radio-telemetry studies relative to estimates from this 2008 acoustic telemetry study. We also show estimates from previous hydroacoustic studies, although they would represent composite estimates for all stocks of juvenile salmon because hydroacoustic sampling cannot differentiate between species. Studies prior to 2002 were summarized by Anglea et al. (2001) and subsequent references are footnoted in the table.

\begin{tabular}{|c|c|c|c|c|c|c|}
\hline Year & Spill Condition & FPE & $\mathrm{SE}$ & FGE & JBSE & SEF \\
\hline 1983 & HA (33\%) & & $39 \%$ & & & 0.79 \\
\hline 1985 & HA $(38 \%)$ & & $21 \%$ & & & 0.75 \\
\hline \multirow{2}{*}{1997} & HA $(35 \%)$ & & $53 \%$ & & & 2.32 \\
\hline & RT $(33 \%)$ & & $54.6 \%$ & & & 1.7 \\
\hline \multirow[t]{2}{*}{1998} & HA $(32 \%)$ & & $63 \%$ & & & 2.92 \\
\hline & RT $(43 \%)$ & & $52.3 \%$ & & & 1.2 \\
\hline \multirow[t]{3}{*}{1999} & HA $(27 \%)$ & & $82 \%$ & & & 2.74 \\
\hline & RT $12 \mathrm{~h}(0 / 45)$ & $94.2 \%(88.9 .97 .5)$ & $44.9 \%(36.5 .53 .6)$ & & & 1.6 \\
\hline & RT $24 \mathrm{~h}(30 / 45)$ & $90.4 \%(84.6,94.5)$ & $52.6 \%(44.4,60.6)$ & & & 1.1 \\
\hline \multirow[t]{3}{*}{2000} & HA $(36 \%)$ & & $79 \%$ & & & 2.79 \\
\hline & RT 12 h(0/53) & $93.0 \%(89.0,96.0)$ & $68.6 \%(61.8 .74 .9)$ & & & 2.3 \\
\hline & RT $24 \mathrm{~h}(30 / 53)$ & $91.3 \%(87.2 .94 .5)$ & $73.4 \%(67.3 .78 .9)$ & & & 1.4 \\
\hline \multirow[t]{4}{*}{$2002^{(a)}$} & HA $12 \mathrm{~h}(0 / 60)$ & $93.8 \pm 2.5 \%$ & $78.2 \pm 5.6 \%$ & $69.5 \pm 12.6 \%$ & & $2.90 \pm 0.3$ \\
\hline & HA $24 \mathrm{~h}(30 / 30)$ & $89.3 \pm 2.4 \%$ & $72.2 \pm 5.2 \%$ & $55.0 \pm 9.9 \%$ & & $2.68 \pm 0.26$ \\
\hline & RT $12 \mathrm{~h}(0 / 54)$ & $91.0 \%(86.9,94.1)$ & $64.2 \%(53.4 .74 .1)$ & & $26.8 \%(17.1,38.2)$ & 1.34 \\
\hline & RT $24 \mathrm{~h}(30 / 30)$ & $88.4 \%(83.1 .92 .6)$ & $54.3 \%(41.5 .66 .8)$ & & $34.1 \%(21.7 .48 .3)$ & 1.55 \\
\hline 2008 & $\mathrm{AT}$ & $97.2 \pm 0.7 \%$ & $74.4 \pm 2.6 \%$ & $88.9 \pm 2.7 \%$ & $22.7 \pm 2.5 \%$ & $2.25 \pm 0.08$ \\
\hline $\begin{array}{l}\text { (a) Bee } \\
\mathrm{AT}= \\
\mathrm{FPE}= \\
\mathrm{FGE}= \\
\mathrm{HA}= \\
\mathrm{JBSE}= \\
\mathrm{RT}= \\
\mathrm{SE}= \\
\mathrm{SEF}=\end{array}$ & $\begin{array}{l}\text { man et al. (2006). } \\
\text { acoustic telemetry. } \\
\text { fish-passage efficie } \\
\text { fish-guidance effic } \\
\text { hydroacoustic. } \\
\text { juvenile bypass sys } \\
\text { radio telemetry. } \\
\text { spillway-passage e } \\
\text { spillway-passage e }\end{array}$ & $\begin{array}{l}\text { ncy. } \\
\text { ency. } \\
\text { tem-passage efficiency } \\
\text { ficiency. } \\
\text { fectiveness. }\end{array}$ & & & & \\
\hline
\end{tabular}

\subsubsection{Subyearling Chinook Salmon}

Data collected in 2008 using acoustic telemetry were compared to past metrics with data collected using hydroacoustics and radio telemetry (Table 4.3). Fish-passage efficiency for $30 \%$ spill conditions in 
$2008(82.7 \%)$ was higher than the same treatment in $2002(70.4 \%)$ and $2003(74.8 \%)$ as determined by radio telemetry, but was lower than an estimate in a 2002 hydroacoustics study (88.0\%). Spillwaypassage efficiency in 2008 (68.6\%) was much higher than during the 1980s and comparable to estimates from within the last 10 years. Fish-guidance efficiency in 2008 was much lower than that reported 1996, but higher than estimates reported for 2000. Direct comparisons of current estimates with estimates from past studies were difficult because many previous spill treatments only had a 12-hour monitoring period and $0 \%$ daytime spill, whereas 2008 treatments consisted of 24 -hour spill at a $30 \%$ or $40 \%$ level. The JBS-passage efficiency for SYC in 2008 was only comparable to an estimate made in a 2003 radiotelemetry study (Beeman et al. 2006).

Table 4.3. Estimates of major fish passage metrics for subyearling Chinook salmon smolts from previous radio-telemetry studies relative to estimates from this 2008 acoustic telemetry study. We also show estimates from previous hydroacoustic studies, which should reasonably represent subyearling metrics because subyearlings are the only outmigrating juvenile salmonids passing the dam in summer. Studies prior to 2002 were summarized by Anglea et al. (2001) and subsequent references are footnoted in the table.

\begin{tabular}{|c|c|c|c|c|c|c|}
\hline Year & Spill Condition & FPE & $\mathrm{SE}$ & FGE & JBSE & SEF \\
\hline 1983 & HA $(33 \%)$ & & $40 \%$ & & & 1.04 \\
\hline 1984 & HA $(30 \%)$ & & $38 \%$ & & & 0.76 \\
\hline 1986 & HA $(30 \%)$ & & $32 \%$ & & & 1.04 \\
\hline 1987 & HA (18\%) & & $23 \%$ & & & 1.30 \\
\hline 1988 & HA (18\%) & & $19 \%$ & & & 1.10 \\
\hline 1989 & HA $(21 \%)$ & & $28 \%$ & & & 1.40 \\
\hline \multirow[t]{2}{*}{1996} & RT (18.4\%) & & $39.50 \%$ & & & $2.1: 1$ \\
\hline & HA $(21 \%)$ & & NA & $75 \%$ & & \\
\hline \multirow[t]{2}{*}{1997} & HA $(35 \%)$ & & $85 \%$ & & & 3.92 \\
\hline & RT (19.9\%) & & $49.60 \%$ & & & $2.5: 1$ \\
\hline \multirow[t]{2}{*}{1998} & HA $(32 \%)$ & & $49 \%$ & & & 1.89 \\
\hline & RT (53.2\%) & & $76.50 \%$ & & & $1.4: 1$ \\
\hline \multirow{2}{*}{1999} & HA $24 \mathrm{~h}(0 / 30 \%)$ & & $63 \%$ & & & 4.75 \\
\hline & HA $24 \mathrm{~h}(30 / 30 \%)$ & & $93 \%$ & & & 2.76 \\
\hline \multirow[t]{5}{*}{2000} & RT $12 \mathrm{~h}(0 / 30 \%)$ & $78.70 \%(71.5-84.9)$ & $53.90 \%(45.7-62.0)$ & & & $1.14-1.58$ \\
\hline & RT $24 \mathrm{~h}(30 / 30 \%)$ & $91.10 \%$ & $81.50 \%$ & & & $2.57-3.01$ day \\
\hline & & $75.0-87.1$ & $75.0-87.1$ & & & $1.29-1.56 \mathrm{night}$ \\
\hline & HA $12 \mathrm{~h}(0 / 60)$ & $72.00 \%$ & $61.00 \%$ & $28 \%$ & & 28.36 \\
\hline & HA $24 \mathrm{~h}(30 / 60)$ & $91.30 \%$ & $87.00 \%$ & $30 \%$ & & 2.25 \\
\hline \multirow[t]{2}{*}{$2002^{(\mathrm{a})}$} & RT $12 \mathrm{~h}(0 / 60 \%)$ & $71.8(67.8,75.6)$ & $41.6(34.6,48.9)$ & & & \\
\hline & RT $24 \mathrm{~h}(30 / 30 \%)$ & $70.4(6.66,74.1)$ & $57.8(51.0,64.4)$ & & & \\
\hline \multirow{2}{*}{$2002^{(\mathrm{b})}$} & HA $12 \mathrm{~h}(0 / 60 \%)$ & $91.60( \pm 1.0)$ & $58.40( \pm 11.0)$ & & & $2.10 \quad( \pm 0.30)$ \\
\hline & HA $24 \mathrm{~h}(30 / 30 \%)$ & $88.00( \pm 0.9)$ & $60.90( \pm 11.5)$ & & & $2.30 \quad( \pm 0.32)$ \\
\hline \multirow[t]{2}{*}{$2003^{(\mathrm{c})}$} & RT $12 \mathrm{~h}(0 / 60)$ & $70.70(64.7-76.4)$ & $48.10(38.7,57.6)$ & & $22.6(17.8-28.0$ & 1.3 \\
\hline & RT $24 \mathrm{~h}(30 / 30)$ & $74.80(69.5,79.7)$ & $61.70(53.1-69.9)$ & & $13.1(9.6-17.1)$ & $1.6-2.3$ \\
\hline \multirow[t]{3}{*}{2008} & $\mathrm{AT}$ & $83.30 \pm 1.86 \%$ & $68.60( \pm 2.37)$ & $46.80( \pm .41)$ & $14.70 \pm 1.79 \%$ & $1.94( \pm 0.07)$ \\
\hline & AT $30 \%$ & $82.03 \pm 2.96 \%$ & $65.71 \pm 3.80 \%$ & $47.61 \pm 6.61 \%$ & $16.33 \pm 2.95 \%$ & $2.14 \pm 0.12$ \\
\hline & AT $40 \%$ & $84.43 \pm 2.92 \%$ & $71.08 \pm 3.79 \%$ & $46.15 \pm 7.39 \%$ & $13.35 \pm 2.79 \%$ & $1.81 \pm 0.10$ \\
\hline \multicolumn{3}{|c|}{ (a) Beeman et al. (2006). } & \multicolumn{4}{|c|}{ HA $=$ hydroacoustic. } \\
\hline \multicolumn{3}{|c|}{ (b) Moursund et al. 2003 . } & \multicolumn{4}{|c|}{ JBSE $=$ juvenile bypass system-passage efficiency. } \\
\hline \multicolumn{3}{|c|}{ (c) Hansel et al. (2004). } & \multicolumn{4}{|c|}{$\mathrm{NA}=$ not applicable. } \\
\hline \multicolumn{3}{|c|}{$\mathrm{AT}=$ acoustic telemetry. } & \multicolumn{2}{|c|}{$\mathrm{RT}=$ radio telemetry. } & & \\
\hline \multicolumn{3}{|c|}{ FPE = fish-passage efficiency. } & $\mathrm{SE}=$ & spillway-passage & ficiency. & \\
\hline \multicolumn{3}{|c|}{ FGE = fish-guidance efficiency. } & \multicolumn{3}{|c|}{$\mathrm{SEF}=$ spillway-passage effectiveness. } & \\
\hline
\end{tabular}




\subsection{Performance of the Prototype TSW Surface Flow Outlets}

The prototype TSW SFO tested for the first time at John Day Dam during 2008 performed comparably to other SFOs on the main stem Columbia and Snake rivers (Table 4.4). In fact, SFO passage efficiency and effectiveness for the John Day Dam TSW were similar to its cousin, the McNary TSW. Neither SFO, though, performed as well as the SFOs at Wells Dam or the Bonneville Dam second powerhouse (B2). The John Day Dam TSW out-performed the Lower Granite Dam and Ice Harbor Dam removable spillway weirs for STH, but not for YC or SYC. The SFOs at Wells Dam and B2 benefit from a pronounced horizontal concentration of juvenile salmonid emigrants due to physical features of the dam structure and forebay circulation patterns (Sweeney et al. 2007). Lower Granite and Ice Harbor dams have a horizontal concentrating mechanism due to relatively small forebay widths in the Snake River compared to main stem dams downstream in the Columbia River.

Table 4.4. Comparison of performance for various surface-flow outlets

\begin{tabular}{ccllccccc}
\hline & & & \multicolumn{3}{c}{ SFO Efficiency } & \multicolumn{3}{c}{ SFO Effectiveness } \\
Year & Dam & \multicolumn{1}{c}{ SFO Type } & YC & STH & SYC & YC & STH & SYC \\
\hline $1990-1992^{(\mathrm{a})}$ & WEL & Retrofit baffle & $0.89^{(\mathrm{b})}$ & & 0.89 & $17.9^{(\mathrm{b})}$ & & 17.8 \\
$2004-2005^{(\mathrm{c})}$ & B2 & Sluice Chute & 0.33 & 0.70 & 0.39 & $6.5^{(\mathrm{d})}$ & $13.7^{(\mathrm{d})}$ & $5.8^{(\mathrm{d})}$ \\
$2006^{(\mathrm{e})}$ & LGR & RSW & 0.30 & 0.26 & 0.57 & 6.0 & 5.4 & 4.6 \\
$2006^{(\mathrm{f})}$ & IHR & RSW & 0.42 & 0.34 & 0.68 & 6.9 & 5.6 & 4.6 \\
$2007^{(\mathrm{g})}$ & MCN & Temp. SW & 0.25 & 0.66 & 0.28 & 3.4 & 8.9 & 3.1 \\
$2008^{(\mathrm{h})}$ & JDA & Top SW & 0.24 & 0.50 & 0.21 & 3.4 & 7.2 & 3.1 \\
\hline
\end{tabular}

(a) Skalski et al. (1996).

(b) Run-at-large in spring comprised of yearling Chinook salmon and steelhead.

(c) Counihan et al. (2006a, 2006b).

(d) Re: Total B2 Q, not the entire Bonneville complex.

(e) Beeman et al. (2007); the two values are for spring and summer periods.

(f) Data for spring are from Axel et al. (2007); values are averages of data for the BiOp and $30 \% / 40 \%$ spill treatments. Data for summer are from Ogden et al. (2008).

(g) Adams and Counihan (2009); the two values are for spring and summer periods.

(h) This study.

B2 = Bonneville Dam second powerhouse.

IHR $=$ Ice Harbor Dam.

JDA $=$ John Day Dam.

LGR $=$ Lower Granite Dam.

$\mathrm{MCN}=$ McNary Dam.

$\mathrm{SFO}=$ surface-flow outlet.

STH $=$ steelhead

$\mathrm{SYC}=$ subyearling Chinook salmon.

$\mathrm{WEL}=$ Wells Dam

$\mathrm{YC}=$ yearling Chinook salmon.

Because John Day Dam does not have a pre-existing mechanism to concentrate fish horizontally, the SFO design relied on relatively high SFO discharge and a correspondingly large flow net in the forebay to attract or intercept downstream migrants, which are naturally surface-oriented and reluctant to sound during emigration (Andrew and Geen 1960). Accordingly, the intent of the John Day Dam TSW and associated spill operation was to pass fish that approached the spillway at the spillway and pass an appreciable number of fish approaching the powerhouse at the spillway. Researchers wanted to know 
whether fish approaching the powerhouse would move to the north to pass through the spillway. The forebay behavior data showed that this was indeed the case for about one-half to two-thirds of the tagged fish. This is an important finding given the huge size of the John Day Dam powerhouse. This effect possibly could be enhanced by locating the TSW closer to the powerhouse.

Besides efficient and effective collection of fish in a dam forebay, SFO performance must also be assessed in terms of survival rates (Johnson and Dauble 2006; Sweeney et al. 2007). Route-specific survivals (dam face through the tailrace) for the TSW were high ( $92 \%$ to $99 \%$, depending on stock), indicating that conveyance and outfall conditions for the TSW were satisfactory. Non-TSW spill improves tailrace passage conditions for TSW-passed fish by inhibiting eddy formation and providing fast water velocities to deter predation. The survival and passage-efficiency data, however, did not reveal a benefit of $40 \%$ spill over $30 \%$ spill. Future evaluations might consider a lower spill level as a study treatment. Regardless of spill level, the prototype TSW SFO at John Day Dam during 2008 performed very well.

\subsection{Predation}

Mortality associated with route-specific dam passage is direct or indirect. Direct mortality is immediate and results from mechanical injury from fish contacting structure, hydraulic injury from shear or cavitation, or barotrama associated with rapid pressure changes. Indirect mortality results from disease or predation because smolts are weakened by passage injuries or loss of equilibrium. In 2009, piscivorous birds arrived in large numbers during smolt runs (Figure 4.2), and bird counts were correlated with the number of smolt passing the dam (Figure 4.3). Despite the obvious correlation between gull numbers and smolt numbers, we found no significant correlations between concrete-passage survival estimates or route-specific survival estimates and the number of gulls counted per day in the tailrace area for any run of fish. Nevertheless, nighttime survival estimates were significantly higher than daytime estimates for steelhead passing through turbines and for SYC passing through the dam, powerhouse, turbines, the spillway, and spill bays 17-20. These day-and-night differences likely result from bird predation, which is intense during the day and minimal at night.

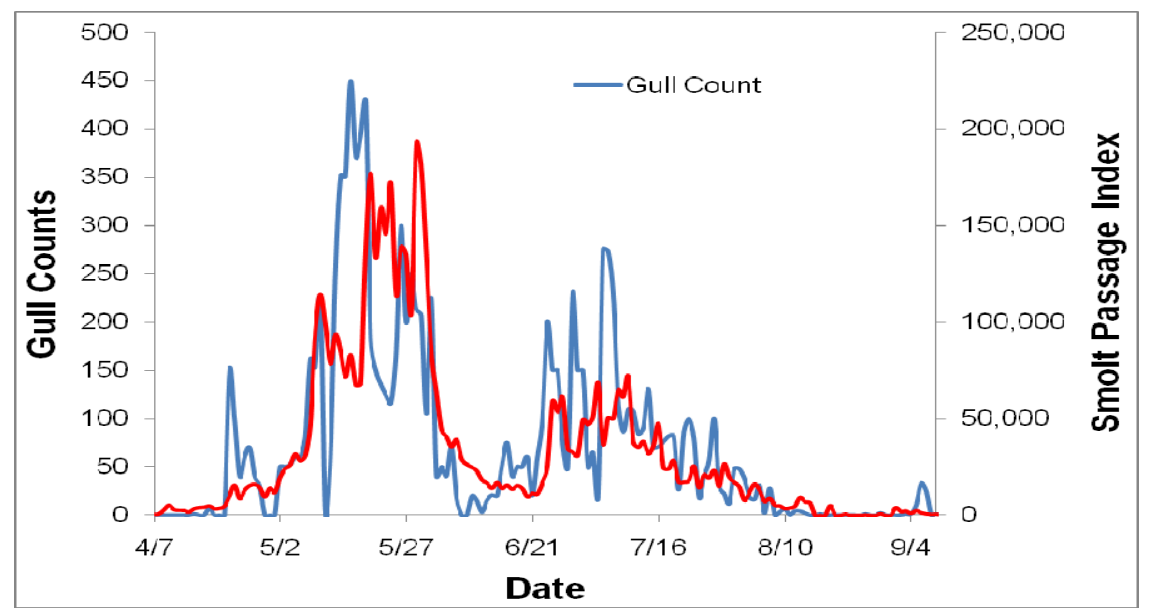

Figure 4.2. Plot of seasonal trends in the smolt index and the number of gulls counted in the John Day tailrace in 2009. Smolt index estimates were obtained from the Fish Passage Center and gull counts were provided by Jim Dillon, Biological Technician for the U.S. Army Corps of Engineers at The Dalles/John Day Projects. 


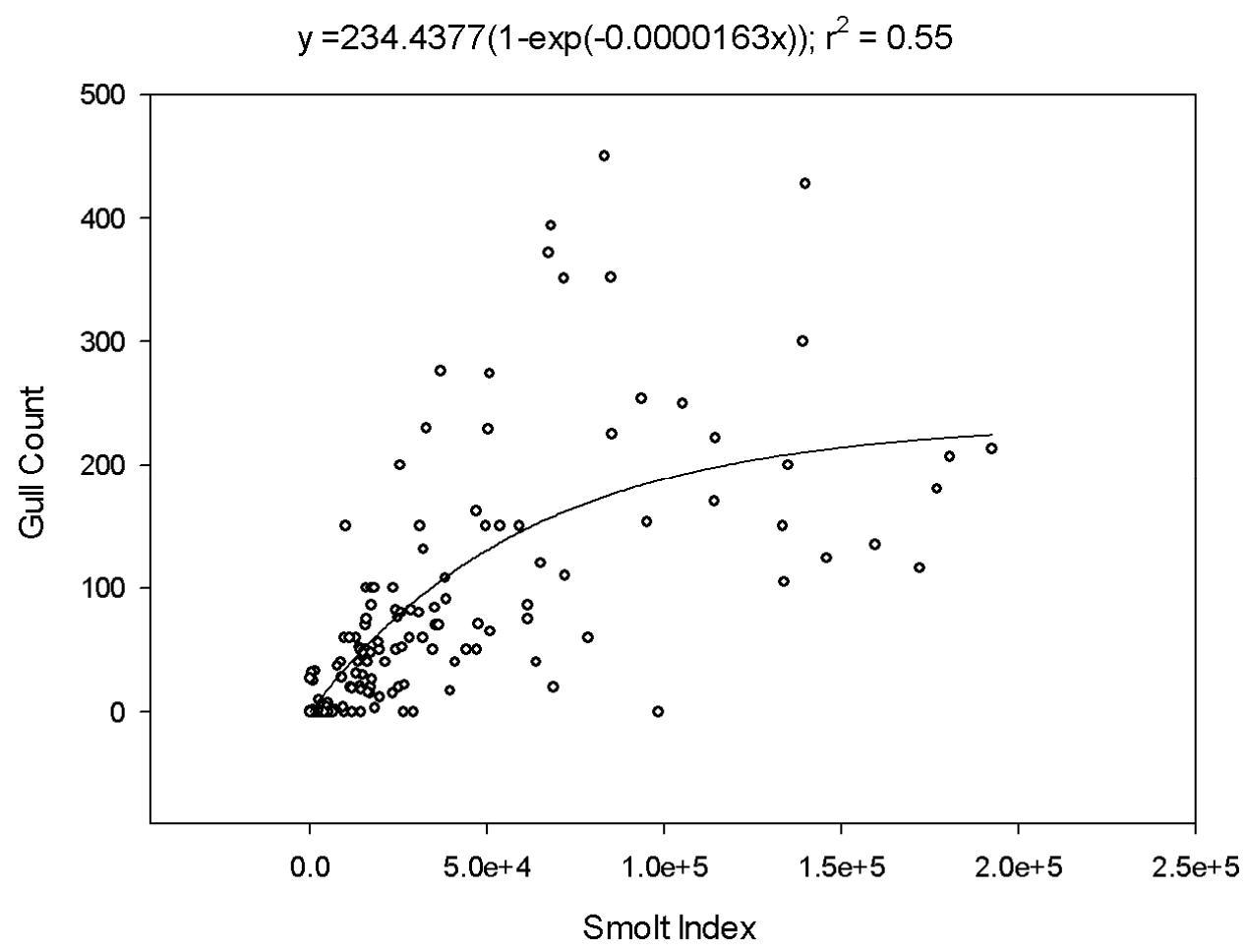

Figure 4.3. Regression line fit to daily gull counts and smolt indices by date. Smolt index estimates were obtained from the Fish Passage Center and gull counts were provided by Jim Dillon, The Dalles / John Day Project Biological Technician.

\subsection{Conclusions}

During the 2008 evaluation of juvenile salmonids at John Day Dam, the JSATS provided reliable data about survival, fish passage, and fish behavior.

Tag-life-corrected paired-release estimates of concrete-passage survival rates for $\mathrm{YC}[0.957 \pm 0.013$ $(1 / 295 \% \mathrm{CI})]$ and STH $[0.986 \pm 0.019(1 / 295 \% \mathrm{CI}]$ were high and close to the $96 \%$ performance standard set forth in the $2008 \mathrm{BiOp}$. Similar estimates for SYC, however, were about $86 \%$, which would be 7\% below the BiOp standard of 93\%. The highest route-specific survival rates were for the JBS and TSW ( 97\%); fish passing through turbines had the lowest survival rates (73\% to $86 \%$ ).

Fish-passage metrics were generally highest for STH and lowest for SYC. Proportionately more SYC than YC or STH passed through the dam via turbines.

The comparison of $30 \%$ versus $40 \%$ post-hoc spill conditions was inconsequential. Stock-specific survival estimates, passage efficiencies, and fish behaviors were similar between the two spill conditions. The increase in spill discharge from $30 \%$ to $40 \%$ of total water discharge through the dam basically served to pass incrementally more fish at non-TSW bays and incrementally fewer fish at the TSW bays. Spillway-passage effectiveness was significantly higher at 30\% spill than it was at $40 \%$ spill for STH smolts (one tailed $\mathrm{P}=0.0293)$ and for SYC smolts $(\mathrm{P}=0.0020)$.

Spill and TSW operations attracted downstream migrant juvenile salmonids. About half of the tagged fish arriving in the forebay of the powerhouse and skeleton bays moved toward and passed at the 
spillway. In contrast, few smolts approaching the spillway passed at the powerhouse, and fish approaching the spillway had the shortest median residence time. The longest residence time was for fish approaching the powerhouse and then passing through the dam at the spillway or vice versa.

Tagged fish were surface-oriented, being distributed in the upper portion of the water column on approach to the dam. The median depths of smolts last detected within $5 \mathrm{~m}$ of the powerhouse ranged from 21 to $24 \mathrm{~m}$ depending on the stock of fish, and turbine-passed fish had median depths that were about $5 \mathrm{~m}$ deeper than the median depth of JBS-passed fish. Most fish approaching the spillway piers were high in the water column.

The prototype TSWs performed well. Using about $20 \mathrm{kcfs}$, the TSW bays passed half of the STH, a quarter of the YC, and a fifth of the SYC of the respective totals passing through John Day Dam. As was the intent of the design, the TSW surface flows appeared to attract, or at the least provide a surface outlet opportunity, for fish that had originally arrived at the dam in the powerhouse forebay. Passage at the TSW bays was much higher during the day than it was at night, which is consistent with observations at many other SFOs (Johnson and Dauble 2006; Sweeney et al. 2007). 


\subsection{References}

Adams NS and TD Counihan. 2008. Survival and Migration Behavior of Juvenile Salmonids at McNary Dam, 2007. Draft Report of Research prepared by the U.S. Geological Survey, Cook, Washington, for the U.S. Army Corps of Engineers, Walla Walla, Washington.

Adams NS and TD Counihan (eds.). 2009. Survival and Migration Behavior of Juvenile Salmonids at McNary Dam, 2007. U.S. Geological Survey Report to the U.S. Army Corps of Engineers, Contract W68SBV70178419, Walla Walla, Washington.

Andrew FJ and GH Geen. 1960. Sockeye and Pink Salmon Production in Relation to Proposed Dams in the Fraser River System. International Pacific Salmon Fisheries Commission Bulletin, XI, New Westminster, British Columbia, Canada.

Anglea S, T Poe, and A Giorgi. 2001. Synthesis of Radio Telemetry, Hydroacoustic, and Survival Studies of Juvenile Salmon at John Day Dam (1980-2000). Prepared for the U.S. Army Corps of Engineers District, Portland, Oregon by Pacific Northwest National Laboratory, Richland, Washington.

Axel GA, EE Hockersmith, DA Ogden, BJ Burke, KE Frick, BP Sandford, and WD Muir. 2007. Passage Behavior and Survival of Radio-Tagged Yearling Chinook Salmon and Steelhead at Ice Harbor Dam, 2006. Report of research by Northwest Fisheries Science Center, National Marine Fisheries Service submitted to the U.S. Army Corps of Engineers, Walla Walla District.

Beeman JW, HC Hansel, PV Haner, K Hardiman, D Hardiman, and J Hardiman. 2003. Estimates of Fish and Spill Passage Efficiency of Radio-Tagged Juvenile Steelhead, and Yearling and Subyearling Chinook Salmon at John Day Dam, 2000. Final Report of Research prepared by the U.S. Geological Survey, Cook, Washington, for the U.S. Army Corps of Engineers, Portland, Oregon.

Beeman JW, L Dingmon, S Juhnke, HC Hansel, B Hausmann, and P Haner. 2006. Estimates of Fish, Spill, and Juvenile Fish Bypass Passage Efficiencies of Radio-Tagged Juvenile Salmonids Relative to Spring and Summer Spill Treatments at John Day Dam in 2002. Final Report of Research prepared by the U.S. Geological Survey, Cook, Washington, for the U.S. Army Corps of Engineers, Portland, Oregon.

Beeman JW, SD Fielding, AC Braatz, TS Wilkerson, AC Pope, CE Walker, JM Hardiman, RW Perry, and TD Counihan. 2007. Survival and Migration Behavior of Juvenile Salmonids at Lower Granite Dam, 2006. Final Report of Research by the U.S. Geological Survey to the U.S. Army Corps of Engineers, Walla Walla District, Contract W68SBV60378208, Walla Walla, Washington.

BioSonics, Inc. 1999. Hydroacoustic Evaluation and Studies at the John Day Dam, 1997. Final Report. BioSonics, Inc., Seattle, Washington.

Burnham KP, DR Anderson, GC White, C Brownie, and KH Pollock. 1987. "Design and Analysis Methods for Fish Survival Estimates Based on Release-Recapture." American Fisheries Society Monograph No. 5. 
Cash KM, DM Faber, TW Hatton, EC Jones, RJ Magie, NM Swyers, RK Burns, MD Sholtis, SA Zimmerman, JS Hughes, TL Gilbride, NS Adams, and DW Rondorf. 2005. Three Dimensional Behavior and Passage of Juvenile Salmonids at The Dalles Dam, 2004. Final Report of Research prepared by the U.S. Geological Survey and Pacific Northwest National Laboratory to the U.S. Army Corps of Engineers, Portland, Oregon.

Chan YT and KC Ho. 1994. "A Simple and Efficient Estimator for Hyperbolic Location." IEEE Trans. Signal Process. 42(8):1905-1915.

Chan YT, HYC Hang, and P-C Ching. 2006. "Exact and Approximate Maximum Likelihood Localization Algorithms." IEEE Transactions on Vehicular Technology 55(1).

Cheung KW, HC So, WK Ma, and YT Chan. 2004. "Least Squares Algorithms for Time-of-ArrivalBased Mobile Location.” IEEE Trans. Signal Process. 52:1121-1128.

Counihan TD, JH Petersen, NS Adams, RS Shively, and HC Hansel. 2002a. Feasibility of Extracting Survival Information from Radio-Telemetry Studies at the John Day Dam, 1999. Final Report of Research prepared by the U.S. Geological Survey, Cook, Washington, for the U.S. Army Corps of Engineers, Portland District, Portland, Oregon.

Counihan T D, JH Petersen, and KJ Felton. 2002b. Survival Estimates of Migrant Juvenile Salmonids in the Columbia River from John Day Dam through Bonneville Dam using Radio-Telemetry, 2000. Final Report of Research prepared by the U.S. Geological Survey, Cook, Washington, for the U.S. Army Corps of Engineers, Portland, Oregon.

Counihan TD, AL Puls, CE Walker, JM Hardiman, and GS Holmberg. 2006a. Survival Estimates of Migrant Juvenile Salmonids through The Dalles Dam Using Radiotelemetry, 2004. Final Report of Research prepared by the U.S. Geological Survey, Cook, Washington, for the U.S. Army Corps of Engineers, Portland, Oregon.

Counihan TD, AL Puls, CE Walker, JM Hardiman, and GS Holmberg. 2006b. Survival Estimates of Migrant Juvenile Salmonids through The Dalles Dam Using Radiotelemetry, 2005. Final Report of Research prepared by the U.S. Geological Survey, Cook, Washington, for the U.S. Army Corps of Engineers, Portland, Oregon.

Counihan TD, GS Holmberg, and JH Peterson. 2006c. Survival Estimates of Migrant Juvenile Salmonids in the Columbia River through John Day Dam using Radio Telemetry, 2002. Final Report of Research prepared by the U.S. Geological Survey, Columbia River Research Laboratory, Cook, Washington, for the U.S. Army Engineer District, Portland, Oregon.

Counihan TD, GS Holmberg, CE Walker, and JM Hardiman. 2006d. Survival Estimates of Migrant Juvenile Salmonids in the Columbia River through John Day Dam using Radio- Telemetry, 2003. Final Report of Research prepared by the U.S. Geological Survey, Columbia River Research Laboratory, Cook, Washington, for the U.S. Army Engineer District, Portland, Oregon.

Efron B and RJ Tibshirani. 1993. An Introduction to the Bootstrap. Chapman \& Hall, New York. 
Ehgrenberg JE and TW Steig. 2002. "A Method for Estimating the Position Accuracy of Acoustic Fish Tags.” ICES Journal of Marine Science 59:140-149.

Endangered Species Act of 1973. 1973. Public Law 93-205, as amended, 16 USC 1531 et seq.

Hansel, HC, JW Beeman, TD Counihan, BD Liedtke, MS Novick, and JM Plumb. 2000. Estimates of Fish and Spill Passage Efficiency for Radio-Tagged Juvenile Steelhead and Yearling Chinook Salmon at John Day Dam, 1999. Annual report of research to U.S. Army Corps of Engineers, Portland District, Portland, Oregon. U.S. Geological Survey, Biological Resources Division, 5501A Cook-Underwood Rd., Cook, Washington

Faber DM, MA Weiland, RA Moursund, TJ Carlson, N Adams, and D. Rhondorf. 2001. Evaluation of the Fish Passage Effectiveness of the Bonneville I Prototype Surface Collector using Three-Dimensional Ultrasonic Fish Tracking. Final Report, PNNL-13526, prepared by Pacific Northwest National Laboratory and U.S. Geological Survey, Biological Resources Division, for the U.S. Army Corps of Engineers, Portland District, Portland, Oregon.

Fang BT. 1990. "Simple Solutions for Hyperbolic and Related Position Fixes." IEEE Trans. Aerosp. Electron. Syst. 26:748-753.

Foy WH. 1976. "Position-Location Solutions by Taylor-Series Estimation.” IEEE Trans. Aerosp. Electron. Syst. AES-12:187-194.

Giorgi AE and JR Stevenson. 1995. A Review of Biological Investigations Describing Smolt Passage Behavior at Portland District Corps of Engineer Projects: Implications to Surface Collection Systems. Draft, Don Chapman Consultants, Inc., Boise, Idaho.

Hansel HC, JW Beeman, BJ Hausmann, SD Juhnke, PV Haner, and JL Phelps. 2004. Estimates of Fish, Spill, and Juvenile Fish Bypass Passage Efficiencies of Radio-Tagged Juvenile Salmonids Relative to Spring and Summer Spill Treatments at John Day Dam in 2003. Final Report of Research prepared by the U.S. Geological Survey, Cook, Washington, for the U.S. Army Corps of Engineers, Portland, Oregon.

Hansel HC, NS Adams, TD Counihan, BD Liedtke, MS Novick, JM Plumb, and TP Poe. 2000. Independent Scientific Group. Return to the River 2000: Restoration of Salmonid Fishes in the Columbia River Ecosystem. NWPPC 2000-12, Northwest Power Planning Council, Portland, Oregon.

Johnson GE and DD Dauble. 2006. "Surface Flow Outlets to Protect Juvenile Salmonids Passing Through Hydropower Dams." Reviews in Fisheries Science 14:213-244.

Juell J-E and H Westerberg. 1993. "An Ultrasonic Telemetric System for Automatic Positioning of Individual Fish Used to Track Atlantic Salmon (Salmo salar L.) in a Sea Cage." Aquacultural Eng. 12:1-18.

Lim JS. 1990. Two-Dimensional Signal and Image Processing. Prentice Hall, Englewood Cliffs, New Jersey, pp. 469-476. 
McComas RL, JW Ferguson, SG Smith, GA McMichael, TJ Carlson, JA Vucelick, and KD Ham. 2005. "A Study to Estimate Salmonid Survival Through the Columbia River Estuary Using Acoustic Tags." Abstract in the 2005 Anadromous Fish Evaluation Program, U.S. Army Corps of Engineer District, Portland, Oregon.

McComas RL, JW Ferguson, SG Smith, GA McMichael, and TJ Carlson. 2004. "A Study to Estimate Salmonid Survival Through the Columbia River Estuary Using Acoustic Tags." Abstract in the 2004 Anadromous Fish Evaluation Program, U.S. Army Corps of Engineer District, Portland, Oregon.

McComas RL, L Gilbreath, E Hockersmith, SG Smith, GA McMichael, TJ Carlson, JA Vucelick, and KD Ham. 2006. "A Study to Estimate Salmonid Survival Through the Columbia River Estuary Using Acoustic Tags, 2006." Abstract in the 2006 Anadromous Fish Evaluation Program, U.S. Army Corps of Engineer District, Portland, Oregon.

McComas RL, JP Everett, GA McMichael, GE Johnson, GM Matthews, and JW Ferguson. 2007. "Field Evaluation of a Three-Dimensional Mobile System for Tracking Acoustically-Tagged Smolts in the Columbia River and Estuary." Abstract in the 2007 Anadromous Fish Evaluation Program, U.S. Army Corps of Engineers District, Portland, Oregon.

McComas RL, JP Everett, GA McMichael, and J Carter. 2008. "A Study to Estimate Salmonid Survival Through the Columbia River Estuary Using Acoustic Tags, Mobile Tracking Efforts." Abstract in the 2008 Anadromous Fish Evaluation Program, U.S. Army Corps of Engineers District, Portland, Oregon.

Montgomery Watson, NHC, Glosten Associates, and I. Civil Tech. 2000. John Day Dam Surface Bypass Removable Spillway Weir Physical Model Alternatives Report. Technical report prepared for the U.S. Army Corps of Engineer District, Portland, Oregon.

Moursund RA, KD Ham, and PS Titzler. 2003. Hydroacoustic Evaluation of Downstream Fish Passage at John Day Dam in 2002. PNWD-3236, prepared for U.S. Army Corps of Engineers District, Portland, Oregon, by Pacific Northwest National Laboratory, Richland, Washington.

National Marine Fisheries Service (NMFS). 2008. Biological Opinion - Consultation on Remand for Operation of the Federal Columbia River Power System, 11 Bureau of Reclamation Projects in the Columbia Basin and ESA Section 10(a)(1)(A) Permit for Juvenile Fish Transportation Program. National Oceanic and Atmospheric Administration Fisheries, Northwest Region, Seattle, Washington.

Ogden DA, EE Hockersmith, GA Axel, BJ Burke, KE Frick, RF Absolon, and BP Sandford. 2008. Passage Behavior and Survival for River-run Subyearling Chinook Salmon at Ice Harbor Dam, 2006. Report of research by Northwest Fisheries Science Center, National Marine Fisheries Service, submitted the U.S. Army Corps of Engineers, Walla Walla District.

Peven C, A Giorgi, J Skalski, M Langeslay, A Grassell, SG Smith, T Counihan, R Perry, and S Bickford. 2005. Guidelines and Recommended Protocols for Conducting, Analyzing, and Reporting Juvenile Salmonid Survival Studies in the Columbia River Basin. Published electronically; available in PDF electronic format from chuckp@chelanpud.org. 
Ploskey GR, MA Weiland, JS Hughes, SR Zimmerman, RE Durham, ES Fischer, J Kim, RL Townsend, JR Skalski, and RL McComas. 2007. Acoustic Telemetry Studies of Juvenile Chinook Salmon Survival at the Lower Columbia Projects in 2006. PNNL-16560, prepared for U.S. Army Corps of Engineers District, Portland, Oregon, by Pacific Northwest National Laboratory, Richland, Washington.

Ploskey GR, MA Weiland, JS Hughes, SR Zimmerman, RE Durham, ES Fischer, J Kim, RL Townsend, JR Skalski, RA Buchanan, and RL McComas. 2008. Survival of Juvenile Chinook Salmon Passing the Bonneville Dam Spillway in 2007. PNNL-18113, prepared for U.S. Army Corps of Engineers District, Portland, Oregon, by Pacific Northwest National Laboratory, Richland, Washington.

Seber GAF. 1982. The Estimation of Animal Abundance. MacMillan, New York.

Skalski JR, GE Johnson, CM Sullivan, EA Kudera, and MW Erho. 1996. "Statistical Evaluation of Turbine Bypass Efficiency at Wells Dam on the Columbia River, Washington. Can. J. Fish. Aquat. Sci. 53:2188-2198.

Skalski JR, SG Smith, RN Iwamoto, JF Williams, and A Hoffmann. 1998. "Use of PIT-Tags to Estimate Survival of Migrating Juvenile Salmonids in the Snake and Columbia Rivers." Canadian Journal of Fisheries and Aquatic Sciences 55:1484-1493.

Spiesberger JL and KM Fristrup. 1990. "Passive Location of Calling Animals and Sensing of Their Acoustic Environment Using Acoustic Tomography.” Am. Nat. 135:107-153.

Sweeney CE, R Hall, AE Giorgi, M Miller, and GE Johnson. 2007. Surface Bypass Program Comprehensive Review Report. ENSR Document No. 09000-399-0409, prepared for the U.S. Army Corps of Engineers, Portland District, Portland, Oregon, by ENSR/AECOM, BioAnalysts, Inc, and Pacific Northwest National Laboratory, published by ENSR, Redmond, Washington.

Torieri DJ. 1984. "Statistical Theory of Passive Location Systems." IEEE Trans. Aerospace Electronic Systems 20:183-198.

Townsend RL, JR Skalski, P Dillingham, and TW Steig. 2006. "Correcting Bias in Survival Estimation Resulting from Tag Failure in Acoustic and Radiotelemetry Studies." Journal of Agricultural Biology and Environmental Statistics 11(2):183-196.

U.S. Army Corps of Engineers (USACE). 1995. "Lower Snake and Columbia Rivers Surface Bypass and Collection Systems Prototype Development Program." Portland and Walla Walla Districts, USACE, Walla Walla, Washington.

U.S. Army Corps of Engineers (USACE) Portland District. 2007. John Day Lock and Dam Configuration and Operation Plan. USACE, Portland District, Portland, Oregon.

Wahlberg M, B Mohl, and PT Madsen. 2001. "Estimating Source Position Accuracy of a LargeAperture Hydrophone Array for Bioacoustics.” Jour. Acoust. Soc. Am. 109(1):397-406.

Watkins WA and WE Schevill. 1972. "Sound Source Location by Arrival-Times on a Non-Rigid ThreeDimensional Hydrophone Array.” Deep-Sea Res. 19:691-706. 
Appendix A

\section{Tagging Tables}


Table A.1. 2008 spring tagging at John Day Dam

\begin{tabular}{|c|c|c|c|c|c|c|}
\hline Tag Date & $\begin{array}{l}\text { Release } \\
\text { Date }\end{array}$ & $\begin{array}{c}\text { Number } \\
\text { Tagged }\end{array}$ & Release Location & Species & $\begin{array}{l}\text { Number } \\
\text { Released }\end{array}$ & Mortalities \\
\hline \multirow[t]{2}{*}{$4 / 30 / 2008$} & $5 / 1 / 2008$ & 240 & Arlington & Steelhead & 120 & 1 \\
\hline & & & & Yearling Chinook & 120 & 1 \\
\hline \multirow[t]{4}{*}{$5 / 1 / 2008$} & $5 / 2 / 2008$ & 249 & Arlington & Steelhead & 90 & 0 \\
\hline & & & & Yearling Chinook & 87 & 0 \\
\hline & & & JDA Tailwaters & Steelhead & 36 & 0 \\
\hline & & & & Yearling Chinook & 36 & 0 \\
\hline \multirow[t]{4}{*}{$5 / 2 / 2008$} & $5 / 3 / 2008$ & 249 & Arlington & Steelhead & 90 & 0 \\
\hline & & & & Yearling Chinook & 87 & 0 \\
\hline & & & JDA Tailwaters & Steelhead & 36 & 0 \\
\hline & & & & Yearling Chinook & 36 & 0 \\
\hline \multirow[t]{4}{*}{$5 / 3 / 2007$} & $5 / 4 / 2008$ & 246 & Arlington & Steelhead & 87 & 0 \\
\hline & & & & Yearling Chinook & 87 & 0 \\
\hline & & & JDA Tailwaters & Steelhead & 36 & 0 \\
\hline & & & & Yearling Chinook & 36 & 0 \\
\hline \multirow[t]{4}{*}{$5 / 4 / 2008$} & $5 / 5 / 2008$ & 249 & Arlington & Steelhead & 90 & 0 \\
\hline & & & & Yearling Chinook & 87 & 0 \\
\hline & & & JDA Tailwaters & Steelhead & 36 & 1 \\
\hline & & & & Yearling Chinook & 36 & 1 \\
\hline \multirow[t]{4}{*}{$5 / 5 / 2008$} & $5 / 6 / 2008$ & 123 & Arlington & Steelhead & 45 & 0 \\
\hline & & & & Yearling Chinook & 48 & 1 \\
\hline & & & JDA Tailwaters ${ }^{(8)}$ & Steelhead & 15 & 0 \\
\hline & & & & Yearling Chinook & 15 & 0 \\
\hline \multirow[t]{4}{*}{$5 / 6 / 2008$} & $5 / 7 / 2008$ & 254 & Arlington $^{(2)}$ & Steelhead & 90 & 0 \\
\hline & & & & Yearling Chinook & 90 & 0 \\
\hline & & & JDA Tailwaters ${ }^{(12)}$ & Steelhead & 37 & 0 \\
\hline & & & & Yearling Chinook & 37 & 0 \\
\hline \multirow[t]{4}{*}{ 5/7/2008 } & $5 / 8 / 2008$ & 252 & Arlington $^{(6)}$ & Steelhead & 90 & 0 \\
\hline & & & & Yearling Chinook & 89 & 0 \\
\hline & & & JDA Tailwaters ${ }^{(9)}$ & Steelhead & 36 & 0 \\
\hline & & & & Yearling Chinook & 37 & 0 \\
\hline \multirow[t]{4}{*}{$5 / 8 / 2008$} & $5 / 9 / 2008$ & 259 & Arlington & Steelhead & 89 & 0 \\
\hline & & & & Yearling Chinook & 92 & 1 \\
\hline & & & JDA Tailwaters & Steelhead & 39 & 0 \\
\hline & & & & Yearling Chinook & 39 & 0 \\
\hline \multirow[t]{4}{*}{$5 / 9 / 2008$} & $5 / 10 / 2008$ & 256 & Arlington & Steelhead & 88 & 0 \\
\hline & & & & Yearling Chinook & 90 & 0 \\
\hline & & & JDA Tailwaters & Steelhead & 39 & 0 \\
\hline & & & & Yearling Chinook & 39 & 0 \\
\hline
\end{tabular}


Table A.1. (contd)

\begin{tabular}{|c|c|c|c|c|c|c|}
\hline Tag Date & $\begin{array}{l}\text { Release } \\
\text { Date }\end{array}$ & $\begin{array}{c}\text { Number } \\
\text { Tagged }\end{array}$ & Release Location & Species & $\begin{array}{l}\text { Number } \\
\text { Released }\end{array}$ & Mortalities \\
\hline \multirow[t]{4}{*}{$5 / 10 / 2008$} & $5 / 11 / 2008$ & 265 & Arlington $^{(4)}$ & Steelhead & 97 & 0 \\
\hline & & & & Yearling Chinook & 90 & 2 \\
\hline & & & JDA Tailwaters $^{(9)}$ & Steelhead & 39 & 0 \\
\hline & & & & Yearling Chinook & 39 & 0 \\
\hline \multirow[t]{4}{*}{$5 / 11 / 2008$} & $5 / 12 / 2008$ & 264 & Arlington $^{(4)}$ & Steelhead & 95 & 0 \\
\hline & & & & Yearling Chinook & 91 & 0 \\
\hline & & & JDA Tailwaters $^{(7)}$ & Steelhead & 39 & 0 \\
\hline & & & & Yearling Chinook & 39 & 0 \\
\hline \multirow[t]{4}{*}{$5 / 12 / 2008$} & $5 / 13 / 2008$ & 186 & Arlington & Steelhead & 63 & 0 \\
\hline & & & & Yearling Chinook & 63 & 0 \\
\hline & & & JDA Tailwaters & Steelhead & 27 & 0 \\
\hline & & & & Yearling Chinook & 33 & 0 \\
\hline \multirow[t]{4}{*}{$5 / 13 / 2008$} & $5 / 14 / 2008$ & 270 & Arlington & Steelhead & 96 & 0 \\
\hline & & & & Yearling Chinook & 96 & 0 \\
\hline & & & JDA Tailwaters & Steelhead & 39 & 0 \\
\hline & & & & Yearling Chinook & 39 & 1 \\
\hline \multirow[t]{4}{*}{$5 / 14 / 2008$} & $5 / 15 / 2008$ & 213 & Arlington & Steelhead & 72 & 0 \\
\hline & & & & Yearling Chinook & 72 & 0 \\
\hline & & & JDA Tailwaters & Steelhead & 33 & 0 \\
\hline & & & & Yearling Chinook & 36 & 0 \\
\hline \multirow[t]{4}{*}{$5 / 15 / 2008$} & $5 / 16 / 2008$ & 270 & Arlington & Steelhead & 96 & 0 \\
\hline & & & & Yearling Chinook & 96 & 0 \\
\hline & & & JDA Tailwaters & Steelhead & 39 & 0 \\
\hline & & & & Yearling Chinook & 39 & 0 \\
\hline \multirow[t]{4}{*}{$5 / 16 / 2008$} & $5 / 17 / 2008$ & 226 & Arlington $^{(1)}$ & Steelhead & 78 & 0 \\
\hline & & & & Yearling Chinook & 78 & 0 \\
\hline & & & JDA Tailwaters & Steelhead & 35 & 0 \\
\hline & & & & Yearling Chinook & 35 & 0 \\
\hline \multirow[t]{4}{*}{$5 / 17 / 2008$} & $5 / 18 / 2008$ & 269 & Arlington & Steelhead & 96 & 0 \\
\hline & & & & Yearling Chinook & 96 & 0 \\
\hline & & & JDA Tailwaters ${ }^{(3)}$ & Steelhead & 39 & 0 \\
\hline & & & & Yearling Chinook & 38 & 0 \\
\hline \multirow[t]{4}{*}{$5 / 18 / 2008$} & $5 / 19 / 2008$ & 276 & Arlington $^{(2)}$ & Steelhead & 96 & 0 \\
\hline & & & & Yearling Chinook & 96 & 0 \\
\hline & & & JDA Tailwaters ${ }^{(11)}$ & Steelhead & 43 & 1 \\
\hline & & & & Yearling Chinook & 41 & 0 \\
\hline
\end{tabular}


Table A.1. (contd)

\begin{tabular}{|c|c|c|c|c|c|c|}
\hline Tag Date & $\begin{array}{l}\text { Release } \\
\text { Date }\end{array}$ & $\begin{array}{c}\text { Number } \\
\text { Tagged }\end{array}$ & Release Location & Species & $\begin{array}{l}\text { Number } \\
\text { Released }\end{array}$ & Mortalities \\
\hline \multirow[t]{4}{*}{$5 / 19 / 2008$} & $5 / 20 / 2008$ & 191 & Arlington $^{(6)}$ & Steelhead & 69 & 0 \\
\hline & & & & Yearling Chinook & 66 & 0 \\
\hline & & & JDA Tailwaters ${ }^{(10)}$ & Steelhead & 27 & 0 \\
\hline & & & & Yearling Chinook & 29 & 0 \\
\hline \multirow[t]{4}{*}{$5 / 20 / 2008$} & $5 / 21 / 2008$ & 281 & Arlington $^{(4)}$ & Steelhead & 98 & $2 *$ \\
\hline & & & & Yearling Chinook & 99 & 0 \\
\hline & & & JDA Tailwaters $^{(10)}$ & Steelhead & 43 & 0 \\
\hline & & & & Yearling Chinook & 41 & $3 *$ \\
\hline \multirow[t]{4}{*}{$5 / 21 / 2008$} & $5 / 22 / 2008$ & 223 & Arlington $^{(5)}$ & Steelhead & 78 & 0 \\
\hline & & & & Yearling Chinook & 74 & 0 \\
\hline & & & JDA Tailwaters ${ }^{(10)}$ & Steelhead & 37 & 0 \\
\hline & & & & Yearling Chinook & 34 & 0 \\
\hline \multirow[t]{4}{*}{$5 / 22 / 2008$} & $5 / 23 / 208$ & 280 & Arlington $^{(4)}$ & Steelhead & 104 & 0 \\
\hline & & & & Yearling Chinook & 104 & 0 \\
\hline & & & JDA Tailwaters $^{(10)}$ & Steelhead & 36 & 0 \\
\hline & & & & Yearling Chinook & 36 & 0 \\
\hline \multirow[t]{4}{*}{$5 / 23 / 2008$} & $5 / 24 / 2008$ & 192 & Arlington & Steelhead & 68 & 1 \\
\hline & & & & Yearling Chinook & 72 & 0 \\
\hline & & & JDA Tailwaters & Steelhead & 27 & 0 \\
\hline & & & & Yearling Chinook & 25 & 0 \\
\hline \multirow[t]{4}{*}{$5 / 24 / 2008$} & $5 / 25 / 2008$ & 292 & Arlington & Steelhead & 100 & 0 \\
\hline & & & & Yearling Chinook & 106 & 0 \\
\hline & & & JDA Tailwaters & Steelhead & 44 & 0 \\
\hline & & & & Yearling Chinook & 42 & 0 \\
\hline \multirow[t]{4}{*}{$5 / 25 / 2008$} & $5 / 26 / 2008$ & 294 & Arlington & Steelhead & 104 & 1 \\
\hline & & & & Yearling Chinook & 107 & 0 \\
\hline & & & JDA Tailwaters ${ }^{(11)}$ & Steelhead & 40 & 0 \\
\hline & & & & Yearling Chinook & 43 & 0 \\
\hline \multirow[t]{4}{*}{$5 / 26 / 2008$} & $5 / 27 / 2008$ & 295 & Arlington & Steelhead & 108 & 0 \\
\hline & & & & Yearling Chinook & 108 & 1 \\
\hline & & & JDA Tailwaters & Steelhead & 37 & $4^{*}$ \\
\hline & & & & Yearling Chinook & 42 & $4^{*}$ \\
\hline \multirow[t]{4}{*}{$5 / 27 / 2008$} & $5 / 28 / 2008$ & 194 & Arlington & Steelhead & 56 & 0 \\
\hline & & & & Yearling Chinook & 60 & 0 \\
\hline & & & JDA Tailwaters & Steelhead & 42 & $5^{*}$ \\
\hline & & & & Yearling Chinook & 36 & $3 *$ \\
\hline
\end{tabular}


Table A.1. (contd)

\begin{tabular}{lccllcc}
\hline \multirow{2}{*}{ Tag Date } & $\begin{array}{c}\text { Release } \\
\text { Date }\end{array}$ & $\begin{array}{c}\text { Number } \\
\text { Tagged }\end{array}$ & Release Location & \multicolumn{1}{c}{ Species } & Number \\
Released & Mortalities \\
\hline $5 / 28 / 2008$ & $5 / 29 / 2008$ & \multirow{2}{*}{36} & JDA Tailwaters & Steelhead & 19 & $4^{*}$ \\
& & & & Yearling Chinook & 17 & $2^{*}$ \\
\multirow{2}{*}{ Totals } & \multirow{2}{*}{ Totals } & \multirow{2}{*}{6894} & \multirow{2}{*}{ Arlington } & Steelhead & 2453 & $5^{(\text {a) }}$ \\
& & & & Yearling Chinook & 2451 & 6 \\
& & & \multirow{2}{*}{ JDA Tailwaters } & Steelhead & 995 & $15^{(\mathrm{b})}$ \\
& & & & Yearling Chinook & 995 & $14^{(\mathrm{c})}$ \\
\hline
\end{tabular}

*Sacrificed to reach a goal of tagging and releasing 40 dead fish in spring.

(a) 2 of these fish were intentionally sacrificed to reach a goal of tagging and releasing 40 dead fish in spring.

(b) 13 of these fish were intentionally sacrificed to reach a goal of tagging and releasing 40 dead fish in spring.

(c) 12 of these fish were intentionally sacrificed to reach a goal of tagging and releasing 40 dead fish in spring.

(1) Fish were released at grain elevator due to weather condition for 6 AM release.

(2) Fish were released at grain elevator due to weather condition for 6 PM release.

(3) Fish were released at the dock due to weather condition for 1 AM release.

(4) Fish were released at grain elevator due to weather condition for all releases.

(5) Fish were released at grain elevator for $6 \mathrm{AM}$ and $6 \mathrm{PM}$ releases and at the shore for $12 \mathrm{PM}$ release due to weather condition.

(6) Fish were released at grain elevator due to weather condition for $12 \mathrm{PM}$ and $6 \mathrm{PM}$ releases.

(7) Fish were released at the dock due to weather condition for all releases.

(8) Fish were released at the dock due to weather condition for 7 PM and 1 AM releases.

(9) Fish were released at the dock for 7 PM and 1 AM releases and at the shore for 1 PM release due to weather condition.

(10) Fish were released at JDA_SMF due to weather condition for all releases.

(11) Fish were released at JDA_SMF due to weather condition for 7 PM and 1 AM releases.

(12) Fish were released at the shore due to weather condition for 7 PM and 1 AM releases. 
Table A.2. 2008 summer steelhead tagging at John Day Dam

\begin{tabular}{|c|c|c|c|c|c|}
\hline Tag Date & $\begin{array}{l}\text { Release } \\
\text { Date }\end{array}$ & $\begin{array}{l}\text { Number } \\
\text { Tagged }\end{array}$ & Release Location & $\begin{array}{l}\text { Number } \\
\text { Released }\end{array}$ & Mortalities \\
\hline $6 / 14 / 2008$ & $6 / 15 / 2008$ & 117 & Arlington & 117 & 1 \\
\hline \multirow[t]{3}{*}{$6 / 15 / 2008$} & $6 / 16 / 2008$ & 210 & Arlington $^{(3)}$ & 87 & 0 \\
\hline & & & JDA Tailwaters $^{(7)}$ & 37 & $1^{*}$ \\
\hline & & & TDA Tailwaters ${ }^{(11)}$ & 86 & 0 \\
\hline \multirow[t]{3}{*}{$6 / 16 / 2008$} & $6 / 17 / 2008$ & 210 & Arlington $^{(4)}$ & 87 & 1 \\
\hline & & & JDA Tailwaters ${ }^{(7)}$ & 35 & 0 \\
\hline & & & TDA Tailwaters & 88 & 0 \\
\hline \multirow[t]{3}{*}{$6 / 17 / 2008$} & $6 / 18 / 2008$ & 210 & Arlington & 87 & 0 \\
\hline & & & JDA Tailwaters & 36 & 0 \\
\hline & & & TDA Tailwaters & 87 & 0 \\
\hline \multirow[t]{3}{*}{$6 / 18 / 2008$} & $6 / 19 / 2008$ & 210 & Arlington & 87 & 0 \\
\hline & & & JDA Tailwaters & 36 & 0 \\
\hline & & & TDA Tailwaters & 87 & 0 \\
\hline \multirow[t]{3}{*}{$6 / 19 / 2008$} & $6 / 20 / 2008$ & 210 & Arlington & 87 & 0 \\
\hline & & & JDA Tailwaters & 38 & $2^{*}$ \\
\hline & & & TDA Tailwaters & 85 & 0 \\
\hline \multirow[t]{3}{*}{$6 / 20 / 2008$} & $6 / 21 / 2008$ & 210 & Arlington & 87 & 2 \\
\hline & & & JDA Tailwaters $^{(7)}$ & 34 & 0 \\
\hline & & & TDA Tailwaters ${ }^{(11)}$ & 89 & 0 \\
\hline \multirow[t]{3}{*}{$6 / 21 / 2008$} & $6 / 22 / 2008$ & 210 & Arlington $^{(3)}$ & 87 & 0 \\
\hline & & & JDA Tailwaters ${ }^{(8)}$ & 36 & 0 \\
\hline & & & $\begin{array}{l}\text { TDA } \\
\text { Tailwaters } \\
(10,11)\end{array}$ & 87 & 0 \\
\hline \multirow[t]{3}{*}{$6 / 22 / 2008$} & $6 / 23 / 2008$ & 210 & Arlington $^{(3)}$ & 87 & 1 \\
\hline & & & JDA Tailwaters ${ }^{(7)}$ & 36 & 0 \\
\hline & & & TDA Tailwaters ${ }^{(11)}$ & 87 & 1 \\
\hline \multirow[t]{3}{*}{$6 / 23 / 2008$} & $6 / 24 / 2008$ & 210 & Arlington & 86 & 0 \\
\hline & & & JDA Tailwaters ${ }^{(7)}$ & 37 & 1 \\
\hline & & & TDA Tailwaters ${ }^{(11)}$ & 87 & 0 \\
\hline \multirow[t]{3}{*}{$6 / 24 / 2008$} & $6 / 25 / 2008$ & 210 & Arlington $^{(2,3)}$ & 87 & 0 \\
\hline & & & JDA Tailwaters ${ }^{(8)}$ & 36 & 0 \\
\hline & & & TDA Tailwaters ${ }^{(12)}$ & 87 & 0 \\
\hline \multirow[t]{3}{*}{$6 / 25 / 2008$} & $6 / 26 / 2008$ & 210 & Arlington $^{(1,2)}$ & 88 & 0 \\
\hline & & & JDA Tailwaters ${ }^{(8)}$ & 35 & 0 \\
\hline & & & TDA Tailwaters ${ }^{(9,10)}$ & 87 & 0 \\
\hline \multirow[t]{3}{*}{$6 / 26 / 2008$} & $6 / 27 / 2008$ & 210 & Arlington & 86 & 0 \\
\hline & & & JDA Tailwaters & 37 & 1 \\
\hline & & & TDA Tailwaters & 87 & 0 \\
\hline \multirow[t]{3}{*}{$6 / 27 / 2008$} & $6 / 28 / 2008$ & 210 & Arlington & 87 & 0 \\
\hline & & & JDA Tailwaters $^{(7)}$ & 36 & 0 \\
\hline & & & TDA Tailwaters & 87 & 0 \\
\hline
\end{tabular}


Table A.2. (contd)

\begin{tabular}{|c|c|c|c|c|c|c|}
\hline Tag Date & $\begin{array}{c}\text { Release } \\
\text { Date }\end{array}$ & $\begin{array}{c}\text { Number } \\
\text { Tagged }\end{array}$ & Release Location & Species & $\begin{array}{l}\text { Number } \\
\text { Released }\end{array}$ & Mortalities \\
\hline \multirow[t]{3}{*}{$6 / 28 / 2008$} & $6 / 29 / 2008$ & 210 & Arlington $^{(3)}$ & Subyearling & 87 & 0 \\
\hline & & & JDA Tailwaters $^{(6,7)}$ & Subyearling & 36 & 0 \\
\hline & & & TDA Tailwaters ${ }^{(11)}$ & Subyearling & 87 & 0 \\
\hline \multirow[t]{3}{*}{$6 / 29 / 2008$} & $6 / 30 / 2008$ & 210 & Arlington $^{(3)}$ & Subyearling & 88 & 0 \\
\hline & & & JDA Tailwaters $^{(7)}$ & Subyearling & 35 & 0 \\
\hline & & & TDA Tailwaters ${ }^{(11)}$ & Subyearling & 87 & 0 \\
\hline \multirow[t]{3}{*}{$6 / 30 / 2008$} & $7 / 1 / 2008$ & 210 & Arlington & Subyearling & 86 & 0 \\
\hline & & & JDA Tailwaters & Subyearling & 37 & 1 \\
\hline & & & TDA Tailwaters ${ }^{(9)}$ & Subyearling & 87 & 0 \\
\hline \multirow[t]{3}{*}{$7 / 1 / 2008$} & $7 / 2 / 2008$ & 145 & Arlington & Subyearling & 57 & 0 \\
\hline & & & JDA Tailwaters $^{(7)}$ & Subyearling & 27 & 0 \\
\hline & & & TDA Tailwaters ${ }^{(11)}$ & Subyearling & 61 & 0 \\
\hline \multirow[t]{3}{*}{$7 / 2 / 2008$} & $7 / 3 / 2008$ & 278 & Arlington $^{(3)}$ & Subyearling & 119 & 0 \\
\hline & & & JDA Tailwaters $^{(7)}$ & Subyearling & 45 & 1 \\
\hline & & & TDA Tailwaters ${ }^{(11)}$ & Subyearling & 114 & 0 \\
\hline \multirow[t]{3}{*}{$7 / 3 / 2008$} & $7 / 4 / 2008$ & 209 & Arlington $^{(4)}$ & Subyearling & 90 & 0 \\
\hline & & & JDA Tailwaters $^{(7)}$ & Subyearling & 32 & 0 \\
\hline & & & TDA Tailwaters & Subyearling & 87 & 0 \\
\hline \multirow[t]{3}{*}{$7 / 4 / 2008$} & $7 / 5 / 2008$ & 210 & Arlington $^{(3)}$ & Subyearling & 90 & 0 \\
\hline & & & JDA Tailwaters $^{(7)}$ & Subyearling & 33 & 0 \\
\hline & & & TDA Tailwaters & Subyearling & 87 & 0 \\
\hline \multirow[t]{3}{*}{$7 / 5 / 2008$} & $7 / 6 / 2008$ & 213 & Arlington $^{(3)}$ & Subyearling & 92 & 0 \\
\hline & & & JDA Tailwaters ${ }^{(7)}$ & Subyearling & 34 & 1 \\
\hline & & & TDA Tailwaters ${ }^{(11)}$ & Subyearling & 87 & 0 \\
\hline \multirow[t]{3}{*}{$7 / 6 / 2008$} & 7/7/2008 & 211 & Arlington & Subyearling & 88 & 0 \\
\hline & & & JDA Tailwaters $^{(7)}$ & Subyearling & 36 & $2 *$ \\
\hline & & & TDA Tailwaters & Subyearling & 87 & 0 \\
\hline \multirow[t]{3}{*}{$7 / 7 / 2008$} & $7 / 8 / 2008$ & 126 & Arlington $^{(1)}$ & Subyearling & 53 & 0 \\
\hline & & & JDA Tailwaters ${ }^{(7)}$ & Subyearling & 22 & 0 \\
\hline & & & TDA Tailwaters & Subyearling & 51 & 0 \\
\hline \multirow[t]{3}{*}{$7 / 8 / 2008$} & $7 / 9 / 2008$ & 295 & Arlington $^{(3)}$ & Subyearling & 122 & 0 \\
\hline & & & JDA Tailwaters $^{(7)}$ & Subyearling & 51 & 2 \\
\hline & & & TDA Tailwaters $^{(11)}$ & Subyearling & 122 & 0 \\
\hline \multirow[t]{3}{*}{$7 / 9 / 2008$} & $7 / 10 / 2008$ & 216 & Arlington ${ }^{(2,3)}$ & Subyearling & 90 & 0 \\
\hline & & & JDA Tailwaters ${ }^{(5,6)}$ & Subyearling & 36 & 0 \\
\hline & & & TDA Tailwaters & Subyearling & 90 & 0 \\
\hline \multirow[t]{3}{*}{$7 / 10 / 2008$} & $7 / 11 / 2008$ & 216 & Arlington & Subyearling & 90 & 0 \\
\hline & & & JDA Tailwaters & Subyearling & 36 & 0 \\
\hline & & & TDA Tailwaters & Subyearling & 90 & 1 \\
\hline
\end{tabular}


Table A.2. (contd)

\begin{tabular}{|c|c|c|c|c|c|c|}
\hline Tag Date & $\begin{array}{c}\text { Release } \\
\text { Date }\end{array}$ & $\begin{array}{c}\text { Number } \\
\text { Tagged }\end{array}$ & Release Location & Species & $\begin{array}{l}\text { Number } \\
\text { Released }\end{array}$ & Mortalities \\
\hline \multirow[t]{3}{*}{$7 / 11 / 2008$} & $7 / 12 / 2008$ & 216 & Arlington & Subyearling & 90 & 1 \\
\hline & & & JDA Tailwaters ${ }^{(7)}$ & Subyearling & 36 & 1 \\
\hline & & & TDA Tailwaters & Subyearling & 90 & 0 \\
\hline \multirow[t]{2}{*}{$7 / 12 / 2008$} & $7 / 13 / 2008$ & 119 & JDA Tailwaters & Subyearling & 31 & $1^{*}$ \\
\hline & & & TDA Tailwaters & Subyearling & 88 & 0 \\
\hline \multirow[t]{3}{*}{ Totals } & Totals & 5931 & Arlington & Subyearling & 2489 & 6 \\
\hline & & & JDA Tailwaters & Subyearling & 996 & $14^{(\mathrm{a})}$ \\
\hline & & & TDA Tailwaters & Subyearling & 2446 & 2 \\
\hline
\end{tabular}

*Sacrificed to reach a goal of tagging and releasing 40 dead fish in summer.

(a) 6 of these fish were intentionally sacrificed to reach a goal of tagging and releasing 20 dead fish in summer.

(1) Fish were released at grain elevator due to weather condition for 6 AM release.

(2) Fish were released at grain elevator due to weather condition for $12 \mathrm{PM}$ release.

(3) Fish were released at grain elevator due to weather condition for 9 PM release.

(4) Fish were released at grain elevator due to weather condition for all releases.

(5) Fish were released at JDA_SMF due to weather condition for 1 PM release.

(6) Fish were released at JDA_SMF due to weather condition for 7 PM release.

(7) Fish were released at JDA_SMF due to weather condition for 1 AM release.

(8) Fish were released at JDA_SMF due to weather condition for all releases.

(9) Fish were released at the boat dock due to weather condition for 7 AM release.

(10) Fish were released at the boat dock due to weather condition for 2 PM release.

(11) Fish were released at the boat dock due to weather condition for $12 \mathrm{AM}$ release.

(12) Fish were released at the boat dock due to weather condition for all releases. 
Appendix B

Hydrophone and Autonomous Node Deployment Tables 
Table B.1. 2008 John Day Dam-face hydrophone deployment table

\begin{tabular}{|c|c|c|c|c|c|c|c|c|c|c|c|c|c|}
\hline System & Pier Nose & $\begin{array}{l}\text { Elevation } \\
\text { Category }\end{array}$ & Trailer & $\begin{array}{l}\text { Y-Block } \\
\text { Color }\end{array}$ & Channel & $\begin{array}{l}\text { Y-Block } \\
\text { Location }\end{array}$ & $\begin{array}{l}\text { Beldon Cable } \\
\text { Length (ft) }\end{array}$ & $\begin{array}{l}\text { Deck Cable } \\
\text { Length (ft) }\end{array}$ & $\begin{array}{l}\text { Node } \\
\text { Type }\end{array}$ & $\begin{array}{l}\text { Node } \\
\text { SN }\end{array}$ & Northing & Easting & $\begin{array}{c}\text { Elevation } \\
\text { (MSL) }\end{array}$ \\
\hline \multirow[t]{4}{*}{$\mathrm{P} 1$} & $0-1$ & $S$ & PH South & Red & 4 & $0-1$ & 100 & 250 & $\mathrm{D}$ & 107 & 745814.842 & 8153758.415 & 255.480 \\
\hline & & $\mathrm{D}$ & & Yellow & 3 & & 250 & & $\mathrm{C}$ & 117 & 745819.012 & 8153763.507 & 169.423 \\
\hline & $1-2$ & S & & Blue & 2 & & 150 & & $\mathrm{D}$ & 108 & 745886.286 & 8153706.834 & 255.593 \\
\hline & & $\mathrm{D}$ & & Green & 1 & & 250 & & $\mathrm{C}$ & 115 & 745890.456 & 8153711.927 & 169.536 \\
\hline \multirow[t]{4}{*}{ P2 } & $2-3$ & $\mathrm{~S}$ & PH South & Red & 4 & $2-3$ & 100 & 250 & D & 105 & 745959.263 & 8153654.155 & 255.592 \\
\hline & & $\mathrm{D}$ & & Yellow & 3 & & 250 & & $\mathrm{C}$ & 118 & 745963.433 & 8153659.248 & 169.535 \\
\hline & $3-4$ & S & & Blue & 2 & & 150 & & D & 106 & 746032.140 & 8153601.580 & 255.521 \\
\hline & & $\mathrm{D}$ & & Green & 1 & & 250 & & $\mathrm{C}$ & 121 & 746036.309 & 8153606.673 & 169.464 \\
\hline \multirow[t]{4}{*}{ P3 } & $4-5$ & S & PH South & Red & 4 & $4-5$ & 100 & 500 & $\mathrm{D}$ & 100 & 746104.930 & 8153548.783 & 255.506 \\
\hline & & $\mathrm{D}$ & & Yellow & 3 & & 250 & & $\mathrm{C}$ & 109 & 746109.100 & 8153553.875 & 169.449 \\
\hline & $5-6$ & S & & Blue & 2 & & 150 & & $\mathrm{D}$ & 101 & 746178.072 & 8153496.125 & 255.459 \\
\hline & & $\mathrm{D}$ & & Green & 1 & & 250 & & $\mathrm{C}$ & 125 & 746182.241 & 8153501.217 & 169.402 \\
\hline \multirow[t]{4}{*}{ P4 } & $6-7$ & S & PH Unit 8 & Red & 4 & $7-8$ & 150 & 250 & $\mathrm{D}$ & 102 & 746251.006 & 8153443.515 & 255.618 \\
\hline & & $\mathrm{D}$ & & Yellow & 3 & & 250 & & $\mathrm{C}$ & 116 & 746255.176 & 8153448.607 & 169.561 \\
\hline & $7-8$ & S & & Blue & 2 & & 100 & & $\mathrm{D}$ & 103 & 746324.071 & 8153390.801 & 255.485 \\
\hline & & $\mathrm{D}$ & & Green & 1 & & 250 & & $\mathrm{C}$ & 112 & 746328.240 & 8153395.894 & 169.428 \\
\hline \multirow[t]{4}{*}{ P5 } & $8-9$ & S & PH Unit 8 & Red & 4 & $8-9$ & 100 & 250 & D & 104 & 746397.006 & 8153338.144 & 255.391 \\
\hline & & $\mathrm{D}$ & & Yellow & 3 & & 250 & & $\mathrm{C}$ & 29 & 746401.175 & 8153343.236 & 169.334 \\
\hline & $9-10$ & S & & Blue & 2 & & 150 & & $\mathrm{D}$ & 96 & 746469.786 & 8153285.298 & 255.542 \\
\hline & & $\mathrm{D}$ & & Green & 1 & & 250 & & $\mathrm{C}$ & 128 & 746473.956 & 8153290.391 & 169.485 \\
\hline \multirow[t]{4}{*}{ P6 } & $10-11$ & S & PH Unit 8 & Red & 4 & $10-11$ & 100 & 500 & $\mathrm{D}$ & 97 & 746542.776 & 8153232.562 & 255.558 \\
\hline & & $\mathrm{D}$ & & Yellow & 3 & & 250 & & $\mathrm{C}$ & 127 & 746546.945 & 8153237.655 & 169.501 \\
\hline & $11-12$ & S & & Blue & 2 & & 150 & & $\mathrm{D}$ & 98 & 746615.964 & 8153179.896 & 255.513 \\
\hline & & $\mathrm{D}$ & & Green & 1 & & 250 & & $\mathrm{C}$ & 130 & 746620.134 & 8153184.988 & 169.456 \\
\hline \multirow[t]{4}{*}{ P7 } & $12-13$ & S & PH Unit 8 & Red & 4 & $12-13$ & 100 & 500 & $\mathrm{D}$ & 95 & 746688.829 & 8153127.264 & 255.588 \\
\hline & & $\mathrm{D}$ & & Yellow & 3 & & 250 & & $\mathrm{C}$ & 126 & 746692.998 & 8153132.356 & 169.531 \\
\hline & $13-14$ & $\mathrm{~S}$ & & Blue & 2 & & 150 & & D & 99 & 746761.826 & 8153074.494 & 255.402 \\
\hline & & $\mathrm{D}$ & & Green & 1 & & 250 & & $\mathrm{C}$ & 135 & 746765.995 & 8153079.586 & 169.345 \\
\hline \multirow[t]{4}{*}{ P8 } & $14-15$ & $\mathrm{~S}$ & PH Unit 8 & Red & 4 & $14-15$ & 150 & 750 & D & 94 & 746834.781 & 8153022.149 & 255.412 \\
\hline & & $\mathrm{D}$ & & Yellow & 3 & & 250 & & $\mathrm{C}$ & 131 & 746838.950 & 8153027.242 & 169.355 \\
\hline & $15-16$ & $\mathrm{~S}$ & & Blue & 2 & & 150 & & D & 93 & 746907.727 & 8152969.353 & 255.491 \\
\hline & & $\mathrm{D}$ & & Green & 1 & & 250 & & $\mathrm{C}$ & 134 & 746911.896 & 8152974.445 & 169.434 \\
\hline
\end{tabular}


Table B.1. (contd)

\begin{tabular}{|c|c|c|c|c|c|c|c|c|c|c|c|c|c|}
\hline System & Pier Nose & $\begin{array}{l}\text { Elevation } \\
\text { Category }\end{array}$ & Trailer & $\begin{array}{c}\text { Y-Block } \\
\text { Color }\end{array}$ & Channel & $\begin{array}{l}\text { Y-Block } \\
\text { Location }\end{array}$ & $\begin{array}{c}\text { Beldon Cable } \\
\text { Length (ft) }\end{array}$ & $\begin{array}{l}\text { Deck Cable } \\
\text { Length (ft) }\end{array}$ & $\begin{array}{l}\text { Node } \\
\text { Type }\end{array}$ & $\begin{array}{c}\text { Node } \\
\text { SN }\end{array}$ & Northing & Easting & $\begin{array}{c}\text { Elevation } \\
\text { (MSL) }\end{array}$ \\
\hline \multirow[t]{4}{*}{ P9 } & $16-17$ & $\mathrm{~S}$ & $\begin{array}{c}\text { PH } \\
\text { Unit } 19\end{array}$ & Red & 4 & $17-18$ & 150 & 500 & $\mathrm{D}$ & 109 & 746980.621 & 8152916.494 & 255.601 \\
\hline & & $\mathrm{D}$ & & Yellow & 3 & & 250 & & $\mathrm{C}$ & 140 & 746984.790 & 8152921.587 & 169.544 \\
\hline & $17-18$ & $\mathrm{~S}$ & & Blue & 2 & & 150 & & $\mathrm{D}$ & 107 & 747053.519 & 8152863.773 & 255.417 \\
\hline & & $\mathrm{D}$ & & Green & 1 & & 250 & & $\mathrm{C}$ & 133 & 747057.688 & 8152868.865 & 169.360 \\
\hline \multirow[t]{4}{*}{ P10 } & $18-19$ & S & $\begin{array}{c}\text { PH } \\
\text { Unit } 19\end{array}$ & Red & 4 & $19-20$ & 150 & 500 & $\mathrm{D}$ & 52 & 747126.386 & 8152811.128 & 255.468 \\
\hline & & $\mathrm{D}$ & & Yellow & 3 & & 250 & & $\mathrm{C}$ & 132 & 747130.555 & 8152816.220 & 169.411 \\
\hline & $19-20$ & S & & Blue & 2 & & 150 & & $\mathrm{D}$ & 70 & 747199.333 & 8152758.451 & 255.521 \\
\hline & & $\mathrm{D}$ & & Green & 1 & & 250 & & $\mathrm{C}$ & 138 & 747203.502 & 8152763.544 & 169.464 \\
\hline \multirow[t]{4}{*}{ P11 } & 20-0 PH & S & $\begin{array}{c}\text { PH } \\
\text { Unit } 19\end{array}$ & Red & 4 & $20-0$ & 150 & 250 & $\mathrm{D}$ & 110 & 747273.236 & 8152705.030 & 255.521 \\
\hline & 20-0 PH & $\mathrm{D}$ & & Yellow & 3 & & 250 & & $\mathrm{C}$ & 136 & 747277.406 & 8152710.123 & 169.464 \\
\hline & 20-0 SP & $\mathrm{S}$ & & Blue & 2 & & 150 & 250 & $\mathrm{C}$ & 74 & 747297.216 & 8152677.926 & 259.699 \\
\hline & 20-0 SP & $\mathrm{D}$ & & Green & 1 & & 150 & & $\mathrm{C}$ & 40 & 747297.216 & 8152677.926 & 232.529 \\
\hline \multirow[t]{2}{*}{ S11 } & $1-2$ & S & SP North & Blue & 2 & $1-2$ & 150 & & $\mathrm{D}$ & 53 & 748251.896 & 8151988.454 & 259.899 \\
\hline & & $\mathrm{D}$ & & Green & 1 & & 150 & & $\mathrm{C}$ & 13 & 748251.896 & 8151988.454 & 232.729 \\
\hline \multirow[t]{4}{*}{$\mathrm{S} 12$} & $2-3$ & $\mathrm{~S}$ & SP North & Red & 4 & $2-3$ & 100 & 500 & $\mathrm{D}$ & 54 & 748201.453 & 8152024.735 & 259.554 \\
\hline & & $\mathrm{D}$ & & Yellow & 3 & & 100 & & $\mathrm{C}$ & 14 & 748201.453 & 8152024.735 & 232.384 \\
\hline & $3-4$ & $\mathrm{~S}$ & & Blue & 2 & & 150 & & $\mathrm{D}$ & 55 & 748151.050 & 8152060.869 & 259.757 \\
\hline & & $\mathrm{D}$ & & Green & 1 & & 150 & & $\mathrm{C}$ & 15 & 748151.050 & 8152060.869 & 232.587 \\
\hline \multirow[t]{4}{*}{ S13 } & $4-5$ & $\mathrm{~S}$ & SP North & Red & 4 & $4-5$ & 100 & 500 & $\mathrm{D}$ & 56 & 748101.134 & 8152097.002 & 259.470 \\
\hline & & $\mathrm{D}$ & & Yellow & 3 & & 100 & & $\mathrm{C}$ & 16 & 748101.134 & 8152097.002 & 232.300 \\
\hline & $5-6$ & $\mathrm{~S}$ & & Blue & 2 & & 150 & & $\mathrm{D}$ & 57 & 748050.729 & 8152133.202 & 259.810 \\
\hline & & $\mathrm{D}$ & & Green & 1 & & 150 & & $\mathrm{C}$ & 17 & 748050.729 & 8152133.202 & 232.640 \\
\hline \multirow[t]{4}{*}{ S14 } & $6-7$ & S & SP North & Red & 4 & $6-7$ & 100 & 750 & $\mathrm{D}$ & 58 & 748000.695 & 8152169.330 & 259.792 \\
\hline & & $\mathrm{D}$ & & Yellow & 3 & & 100 & & $\mathrm{C}$ & 18 & 748000.695 & 8152169.330 & 232.622 \\
\hline & $7-8$ & S & & Blue & 2 & & 150 & & $\mathrm{D}$ & 59 & 747949.842 & 8152205.888 & 259.862 \\
\hline & & $\mathrm{D}$ & & Green & 1 & & 150 & & $\mathrm{C}$ & 19 & 747949.842 & 8152205.888 & 232.692 \\
\hline \multirow[t]{4}{*}{ S15 } & $8-9$ & $\mathrm{~S}$ & SP North & Red & 4 & $8-9$ & 150 & 750 & $\mathrm{D}$ & 60 & 747899.708 & 8152242.057 & 259.867 \\
\hline & & D & & Yellow & 3 & & 150 & & $\mathrm{C}$ & 20 & 747899.708 & 8152242.057 & 232.697 \\
\hline & $9-10$ & S & & Blue & 2 & & 100 & & $\mathrm{D}$ & 61 & 747849.496 & 8152278.533 & 259.807 \\
\hline & & $\mathrm{D}$ & & Green & 1 & & 100 & & $\mathrm{C}$ & 21 & 747849.496 & 8152278.533 & 232.637 \\
\hline
\end{tabular}


Table B.1. (contd)

\begin{tabular}{|c|c|c|c|c|c|c|c|c|c|c|c|c|c|}
\hline System & Pier Nose & $\begin{array}{l}\text { Elevation } \\
\text { Category }\end{array}$ & Trailer & $\begin{array}{l}\text { Y-Block } \\
\text { Color }\end{array}$ & Channel & $\begin{array}{l}\text { Y-Block } \\
\text { Location }\end{array}$ & $\begin{array}{l}\text { Beldon Cable } \\
\text { Length (ft) }\end{array}$ & $\begin{array}{l}\text { Deck Cable } \\
\text { Length (ft) }\end{array}$ & $\begin{array}{l}\text { Node } \\
\text { Type }\end{array}$ & $\begin{array}{l}\text { Node } \\
\text { SN }\end{array}$ & Northing & Easting & $\begin{array}{c}\text { Elevation } \\
\text { (MSL) }\end{array}$ \\
\hline \multirow[t]{4}{*}{ S16 } & $10-11$ & $\mathrm{~S}$ & $\begin{array}{c}\text { PH } \\
\text { Unit } 19\end{array}$ & Red & 4 & $11-12$ & 150 & 1000 & $\mathrm{D}$ & 62 & 747799.155 & 8152314.604 & 259.547 \\
\hline & & $\mathrm{D}$ & & Yellow & 3 & & 150 & & $\mathrm{C}$ & 22 & 747799.155 & 8152314.604 & 232.377 \\
\hline & $11-12$ & S & & Blue & 2 & & 100 & & $\mathrm{D}$ & 63 & 747748.826 & 8152350.942 & 259.866 \\
\hline & & $\mathrm{D}$ & & Green & 1 & & 100 & & $\mathrm{C}$ & 23 & 747748.826 & 8152350.942 & 232.696 \\
\hline \multirow[t]{4}{*}{ S17 } & $12-13$ & S & $\begin{array}{c}\text { PH } \\
\text { Unit } 19\end{array}$ & Red & 4 & $12-13$ & 150 & 750 & D & 64 & 747698.843 & 8152387.293 & 259.612 \\
\hline & & $\mathrm{D}$ & & Yellow & 3 & & 150 & & $\mathrm{C}$ & 24 & 747698.843 & 8152387.293 & 232.442 \\
\hline & $13-14$ & S & & Blue & 2 & & 100 & & D & 65 & 747648.471 & 8152423.584 & 259.705 \\
\hline & & $\mathrm{D}$ & & Green & 1 & & 100 & & $\mathrm{C}$ & 25 & 747648.471 & 8152423.584 & 232.535 \\
\hline \multirow[t]{4}{*}{ S18 } & $14-15$ & S & $\begin{array}{c}\text { PH } \\
\text { Unit } 19\end{array}$ & Red & 4 & $14-15$ & 150 & 750 & D & 66 & 747598.238 & 8152459.904 & 259.524 \\
\hline & & D & & Yellow & 3 & & 150 & & $\mathrm{C}$ & 26 & 747598.238 & 8152459.904 & 232.354 \\
\hline & $15-16$ & S & & Blue & 2 & & 100 & & D & 67 & 747548.010 & 8152496.251 & 259.345 \\
\hline & & $\mathrm{D}$ & & Green & 1 & & 100 & & $\mathrm{C}$ & 27 & 747548.010 & 8152496.251 & 232.175 \\
\hline \multirow[t]{4}{*}{ S19 } & $16-17$ & S & $\begin{array}{c}\text { PH } \\
\text { Unit } 19\end{array}$ & Red & 4 & $16-17$ & 150 & 500 & $\mathrm{D}$ & 68 & 747497.645 & 8152532.546 & 259.622 \\
\hline & & D & & Yellow & 3 & & 150 & & $\mathrm{C}$ & 28 & 747497.645 & 8152532.546 & 232.452 \\
\hline & $17-18$ & S & & Blue & 2 & & 100 & & D & 71 & 747447.224 & 8152568.918 & 259.927 \\
\hline & & $\mathrm{D}$ & & Green & 1 & & 100 & & $\mathrm{C}$ & 29 & 747447.224 & 8152568.918 & 232.757 \\
\hline \multirow[t]{4}{*}{$\mathrm{S} 20$} & $18-19$ & S & $\begin{array}{c}\text { PH } \\
\text { Unit } 19\end{array}$ & Red & 4 & $18-19$ & 150 & 500 & $\mathrm{D}$ & 72 & 747397.018 & 8152605.211 & 259.781 \\
\hline & & $\mathrm{D}$ & & Yellow & 3 & & 150 & & $\mathrm{C}$ & 30 & 747397.018 & 8152605.211 & 232.611 \\
\hline & $19-20$ & S & & Blue & 2 & & 100 & & $\mathrm{D}$ & 73 & 747346.707 & 8152641.527 & 259.779 \\
\hline & & $\mathrm{D}$ & & Green & 1 & & 100 & & $\mathrm{C}$ & 31 & 747346.707 & 8152641.527 & 232.609 \\
\hline
\end{tabular}


Table B.2. Approximate global positioning system coordinates of autonomous nodes deployed in 2008 by array. Array_Node is a concatenation of the array name and autonomous node number, which incremented with increasing distance from the Washington shore toward Oregon. Array name is a concatenation of "A" for autonomous, a single digit indicating the successive array number from Arlington, Oregon, downstream to Oak Point, Washington, and "CR" for Columbia River.

\begin{tabular}{|c|c|c|c|c|}
\hline Array_Node & Array Function & $\begin{array}{l}\text { Latitude in Decimal } \\
\text { Deg. (neg. is south) }\end{array}$ & $\begin{array}{l}\text { Longitude in Decimal } \\
\text { Deg. (neg. is west) }\end{array}$ & $\begin{array}{l}\text { Approximate } \\
\text { Depth }(\mathrm{m})\end{array}$ \\
\hline A1CR351_01 & JDA Forebay Entrance & 45.731319 & -120.677188 & 36.6 \\
\hline A1CR351_02 & & 45.730279 & -120.675845 & 41.1 \\
\hline A1CR351_03 & & 45.729167 & -120.674787 & 30.5 \\
\hline A1CR351_04 & & 45.728181 & -120.673703 & 34.7 \\
\hline A1CR351_05 & & 45.727194 & -120.672516 & 36.0 \\
\hline A1CR351_06 & & 45.726136 & -120.671329 & 34.1 \\
\hline A1CR351_07 & & 45.725114 & -120.670038 & 40.8 \\
\hline A1CR351_08 & & 45.724074 & -120.668877 & 23.2 \\
\hline A2CR346_01 & JDA Tailwater Egress & 45.690151 & -120.785139 & 22.6 \\
\hline A2CR346_02 & & 45.689271 & -120.784493 & 17.0 \\
\hline A2CR346_03 & & 45.688517 & -120.783898 & 15.8 \\
\hline A2CR346_04 & & 45.687690 & -120.783303 & 11.7 \\
\hline A3CR312_01 & $\begin{array}{l}\text { TDA Forebay Entrance \& } \\
\text { JDA Primary }\end{array}$ & 45.634858 & -121.106748 & 7.5 \\
\hline A3CR312_02 & & 45.634300 & -121.105223 & 18.0 \\
\hline A3CR312_03 & & 45.633795 & -121.103775 & 28.0 \\
\hline A3CR312_04 & & 45.633381 & -121.102328 & 20.4 \\
\hline A3CR312_05 & & 45.633075 & -121.101062 & 12.8 \\
\hline A4CR237_01 & $\begin{array}{l}\text { BON Forebay Entrance \& } \\
\text { JDA Secondary; TDA } \\
\text { Primary }\end{array}$ & 45.652628 & -121.914020 & 19.8 \\
\hline A4CR237_02 & & 45.652196 & -121.913659 & 28.2 \\
\hline A4CR237_03 & & 45.651764 & -121.913299 & 22.9 \\
\hline A4CR237_04 & & 45.651405 & -121.912939 & 16.4 \\
\hline A5CR203_01 & $\begin{array}{l}\text { JDA Tertiary; TDA } \\
\text { Secondary; BON Primary }\end{array}$ & 45.558905 & -122.333054 & 6.0 \\
\hline A5CR203_02 & & 45.549664 & -122.316765 & 12.8 \\
\hline A5CR203_03 & & 45.544965 & -122.288452 & 15.9 \\
\hline A5CR203_04 & & 45.544139 & -122.288503 & 18.1 \\
\hline A5CR203_05 & & 45.543406 & -122.288460 & 19.4 \\
\hline A5CR203_06 & & 45.542718 & -122.288513 & 20.8 \\
\hline A5CR203_07 & & 45.547699 & -122.342397 & 9.8 \\
\hline A5CR203_08 & & 45.550893 & -122.345255 & 10.0 \\
\hline A5CR203_09 & & 45.553001 & -122.348805 & 8.3 \\
\hline A6CR192_01 & $\begin{array}{l}\text { TDA Tertiary; BON } \\
\text { Secondary }\end{array}$ & 45.575009 & -122.435287 & 11.1 \\
\hline
\end{tabular}


Table B.2. (contd)

\begin{tabular}{|c|c|c|c|c|}
\hline Array_Node & Array Function & $\begin{array}{l}\text { Latitude in Decimal } \\
\text { Deg. (neg. is south) }\end{array}$ & $\begin{array}{l}\text { Longitude in Decimal } \\
\text { Deg. (neg. is west) }\end{array}$ & $\begin{array}{l}\text { Approximate } \\
\text { Depth (m) }\end{array}$ \\
\hline A6CR192_02 & & 45.568794 & -122.420568 & 21.9 \\
\hline A6CR192_03 & & 45.567852 & -122.420311 & 19.8 \\
\hline A6CR192_04 & & 45.566947 & -122.420055 & 17.2 \\
\hline A6CR192_05 & & 45.565824 & -122.419696 & 10.4 \\
\hline A6CR192_06 & & 45.564955 & -122.419440 & 11.5 \\
\hline A7CR086_01 & BON Tertiary & 46.185928 & -123.180278 & 21.3 \\
\hline A7CR086_02 & & 46.184991 & -123.179601 & 20.8 \\
\hline A7CR086_03 & & 46.184127 & -123.179132 & 15.8 \\
\hline A7CR086_04 & & 46.183370 & -123.178715 & 20.6 \\
\hline
\end{tabular}


Appendix C

\section{Tag-Life Plots}




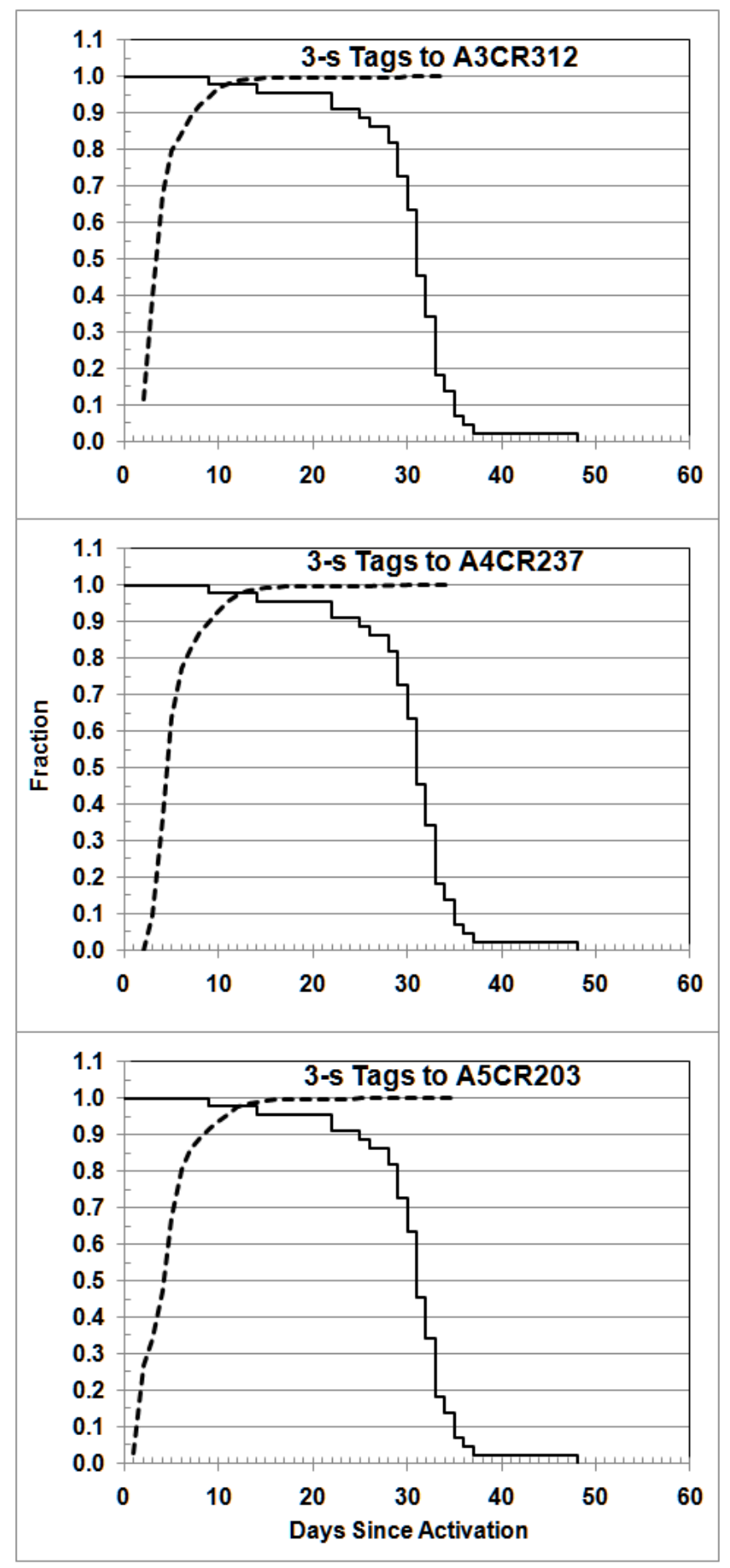

Figure C.1. Fraction of tag-life study tags transmitting (solid lines) and the cumulative fraction of tagged yearling Chinook salmon smolts arriving at three John Day Dam survival-detection arrays (dashed lines) as a function of days since tag activation. Arrays included A3CR312 (the John Day Dam primary array in The Dalles Dam forebay), A4CR237 (the secondary in the Bonneville Dam forebay), and A5CR203 (the tertiary in the Bonneville Dam tailwater). 


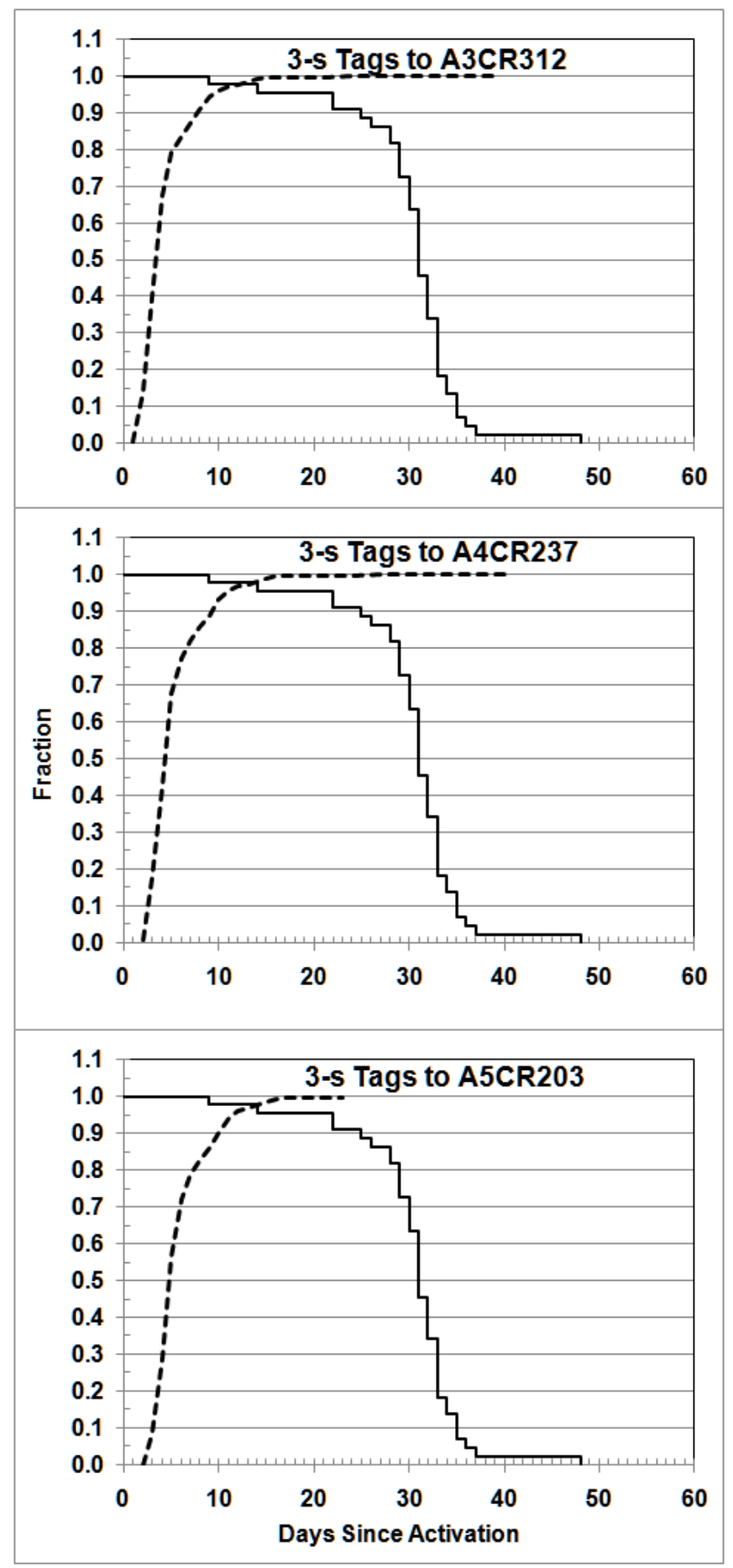

Figure C.2. Fraction of tag-life study tags transmitting (solid lines) and the cumulative fraction of tagged steelhead smolts arriving at three John Day Dam survival-detection arrays (dashed lines) as a function of days since tag activation. Arrays included A3CR312 (the John Day Dam primary array in The Dalles Dam forebay), A4CR237 (the secondary in the Bonneville Dam forebay), and A5CR203 (the tertiary in the Bonneville Dam tailwater). 

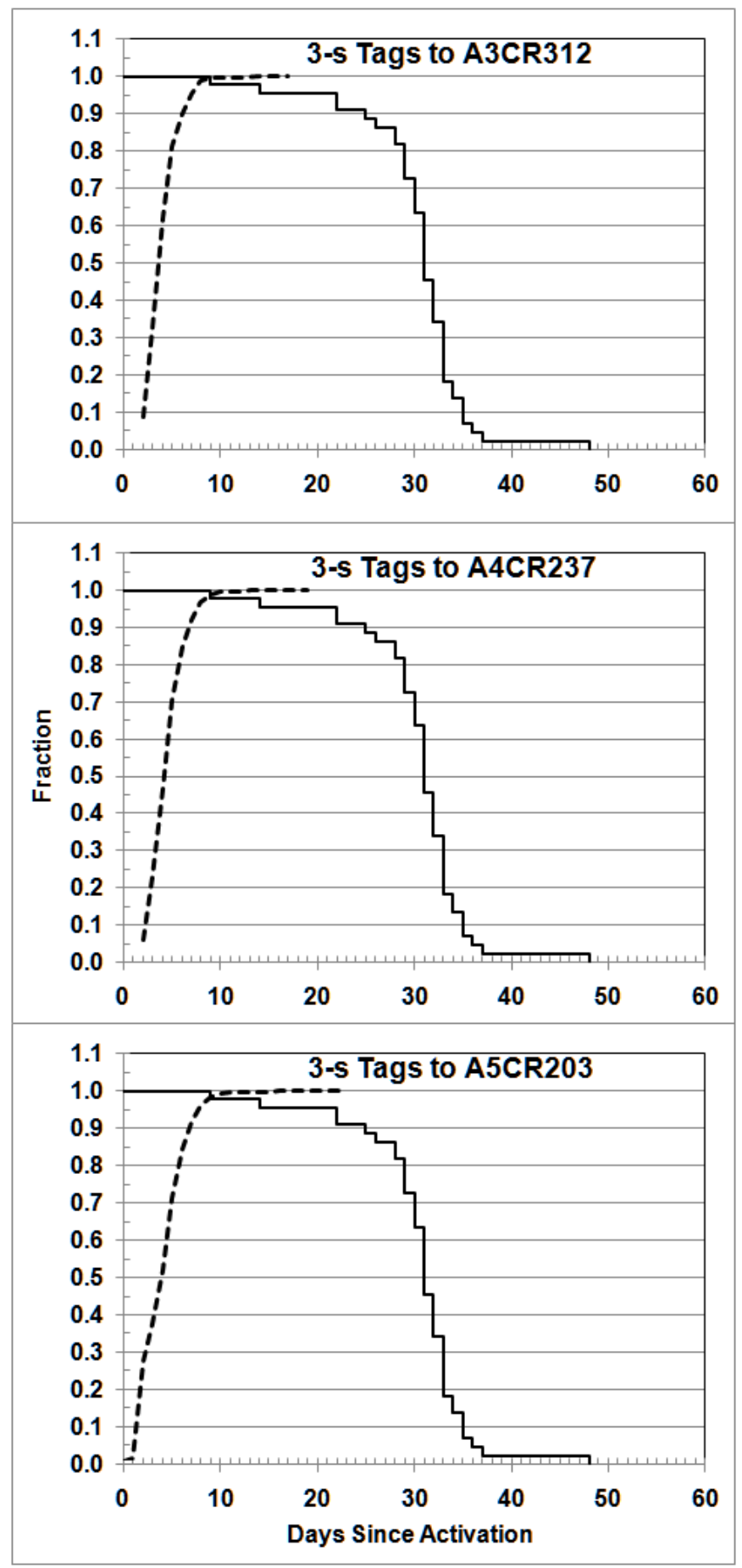

Figure C.3. Fraction of tag-life study tags transmitting (solid lines) and the cumulative fraction of tagged subyearling Chinook salmon smolts arriving at three John Day Dam survival-detection arrays (dashed lines) as a function of days since tag activation. Arrays included A3CR312 (the John Day Dam primary array in The Dalles Dam forebay), A4CR237 (the secondary in the Bonneville Dam forebay), and A5CR203 (the tertiary in the Bonneville Dam tailwater). 


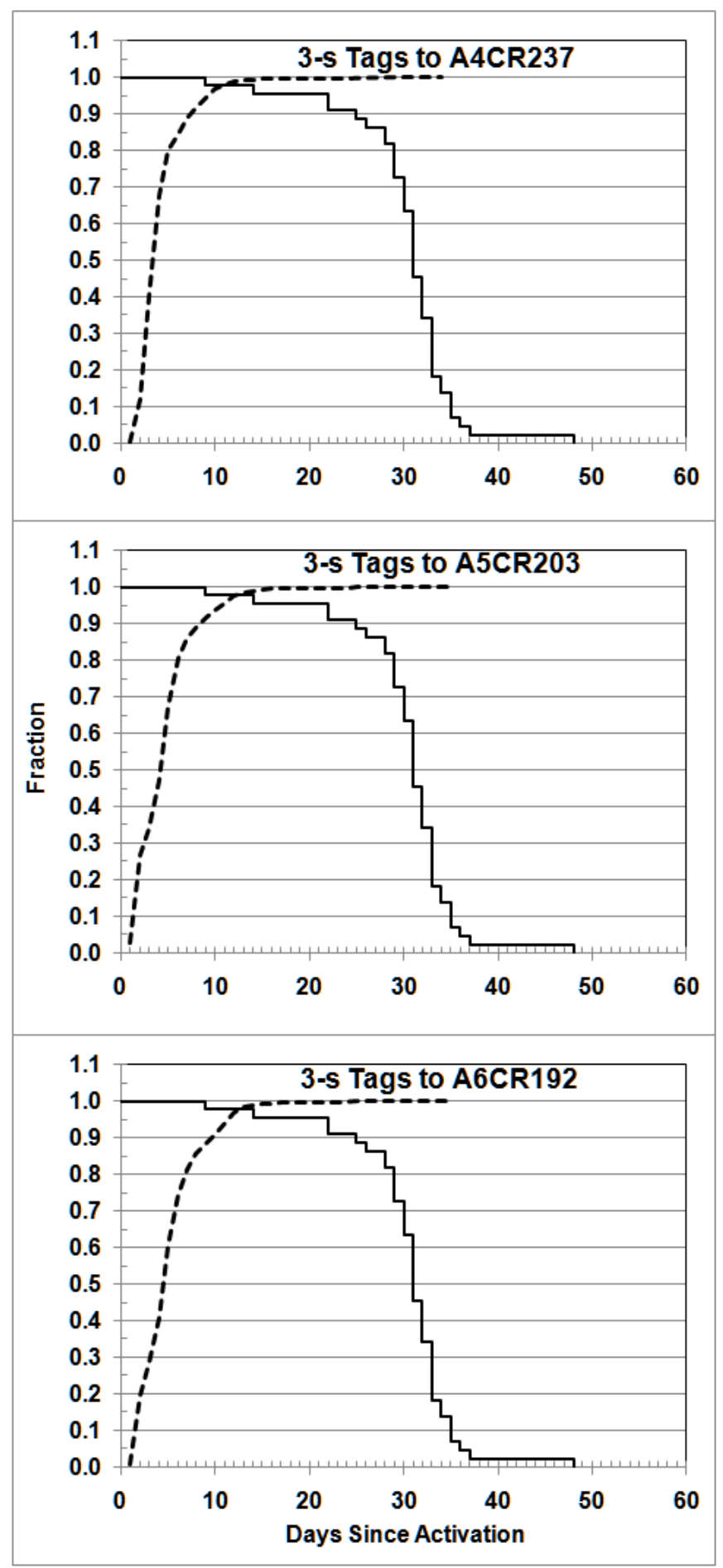

Figure C.4. Fraction of tag-life study tags transmitting (solid lines) and the cumulative fraction of tagged yearling Chinook salmon smolts arriving at three survival-detection arrays at The Dalles Dam (dashed lines) as a function of days since tag activation. Arrays included A4CR237 (The Dalles Dam primary array in the Bonneville Dam forebay), A5CR203 (the secondary in the Bonneville Dam tailwater), and A6CR192 (the tertiary in the Bonneville Dam tailwater). 


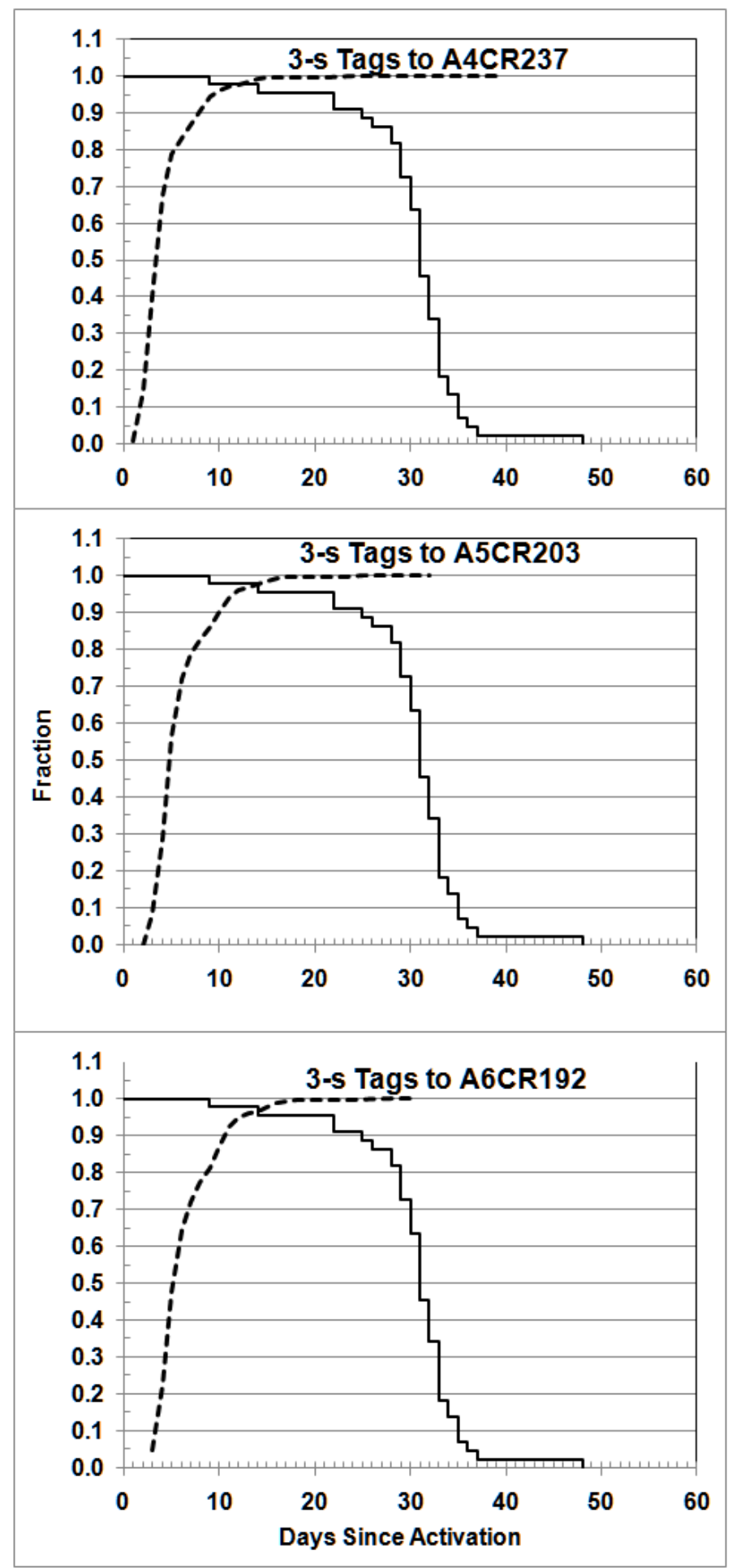

Figure C.5. Fraction of tag-life study tags transmitting (solid lines) and the cumulative fraction of tagged steelhead smolts arriving at three survival-detection arrays at The Dalles Dam (dashed lines) as a function of days since tag activation. Arrays included A4CR237 (The Dalles Dam primary array in the Bonneville Dam forebay), A5CR203 (the secondary in the Bonneville Dam tailwater), and A6CR192 (the tertiary in the Bonneville Dam tailwater). 

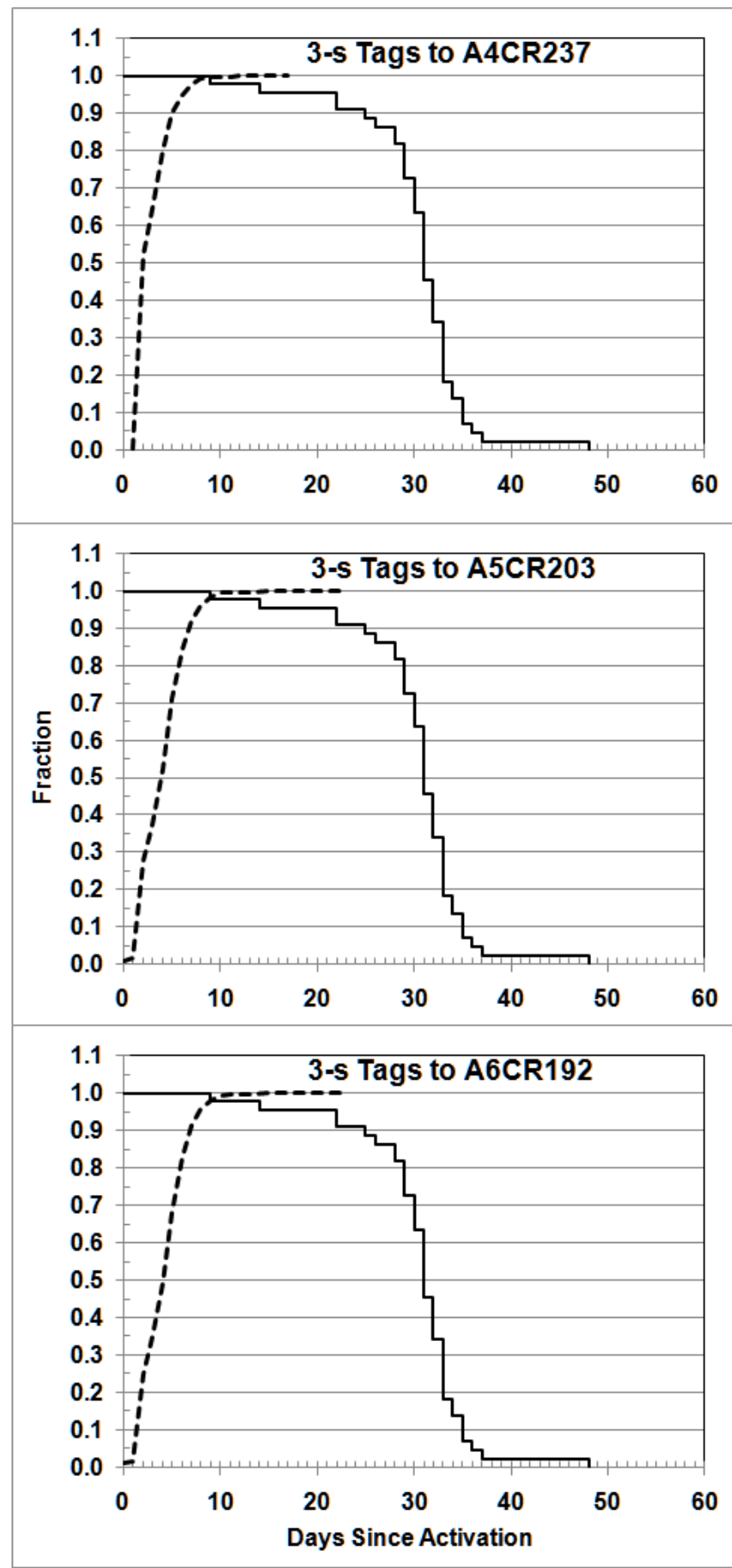

Figure C.6. Fraction of tag-life study tags transmitting (solid lines) and the cumulative fraction of tagged subyearling Chinook salmon smolts arriving at three survival-detection arrays at The Dalles Dam (dashed lines) as a function of days since tag activation. Arrays included A4CR237 (The Dalles Dam primary array in the Bonneville Dam forebay), A5CR203 (the secondary in the Bonneville Dam tailwater), and A6CR192 (the tertiary in the Bonneville Dam tailwater). 


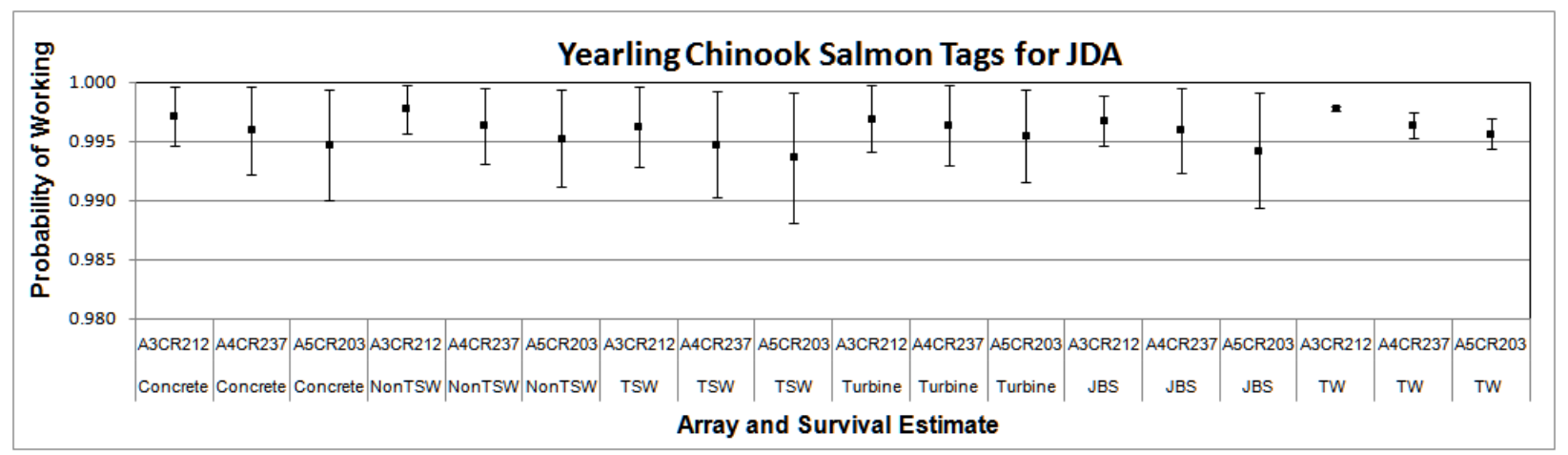

Figure C.7. Plot of the probability of a tag implanted in yearling Chinook salmon smolts working by the time fish arrived at survival-detection arrays for John Day Dam by array and survival estimate. Fish passing all dam-passage routes indicated below the array name on the $\mathrm{x}$ axis were released at Arlington, Oregon, except for those indicated by TW, which were released in the John Day tailrace.

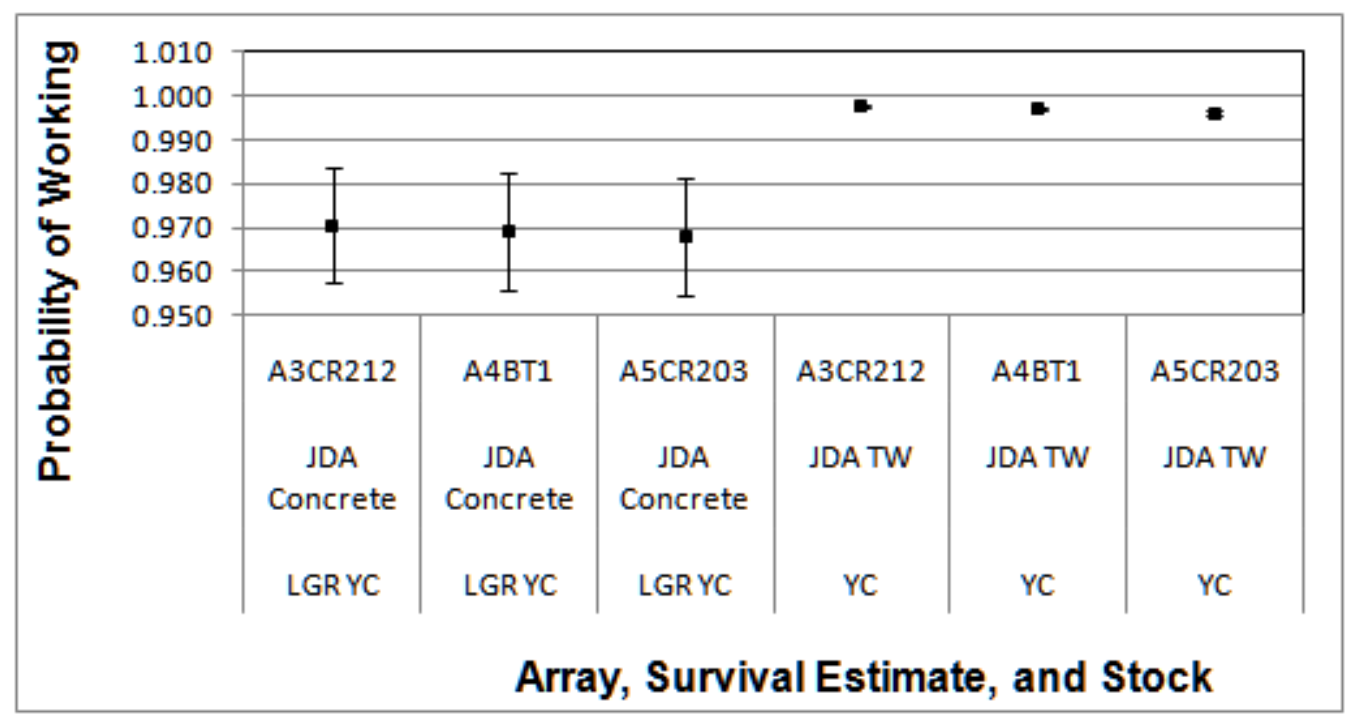

Figure C.8. Plot of the probability of a tag implanted in yearling Chinook salmon smolts released in the Lower Granite Dam tailrace (LGR YC) or in the John Day Tailwater (JDA TW) working by the time fish arrived at survival-detection arrays for John Day Dam by array, survival estimate, and stock. Array abbreviations are as follows: A3CR312 = The Dalles Dam forebay (primary), A4CR237 = Bonneville Dam forebay array (secondary), A4BT1 = Bonneville Dam tailwater 1 (tertiary). 


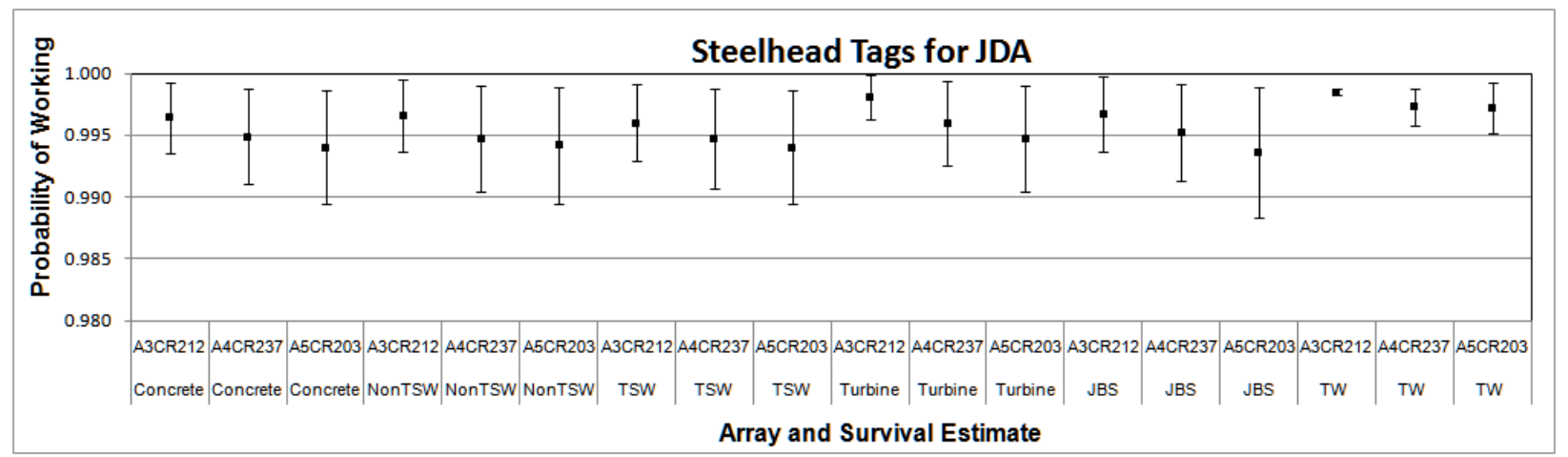

Figure C.9. Plot of the probability of a tag implanted in steelhead smolts working by the time fish arrived at survival-detection arrays for John Day Dam by array and survival estimate. Fish passing all dam-passage routes indicated below the array name on the $\mathrm{x}$ axis were released at Arlington, Oregon, except for those indicated by TW, which were released in the John Day tailrace.

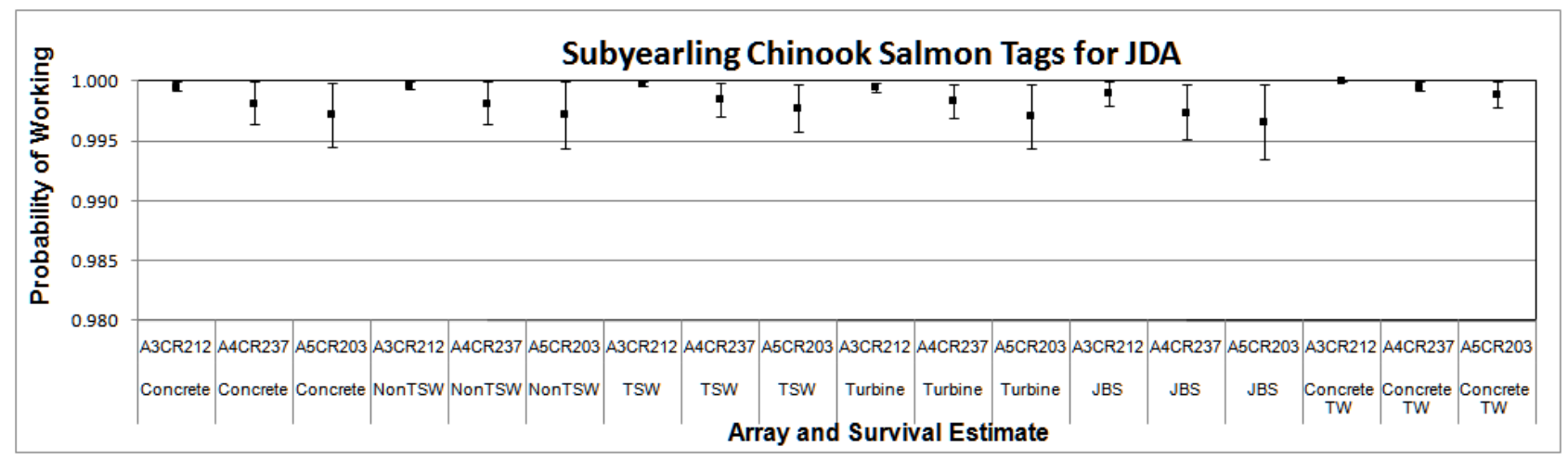

Figure C.10. Plot of the probability of a tag implanted in subyearling Chinook salmon smolts working by the time fish arrived at survival-detection arrays for John Day Dam by array and survival estimate. Fish passing all dam-passage routes indicated below the array name on the $\mathrm{x}$ axis were released at Arlington, Oregon, except for those indicated by TW, which were released in the John Day tailrace.

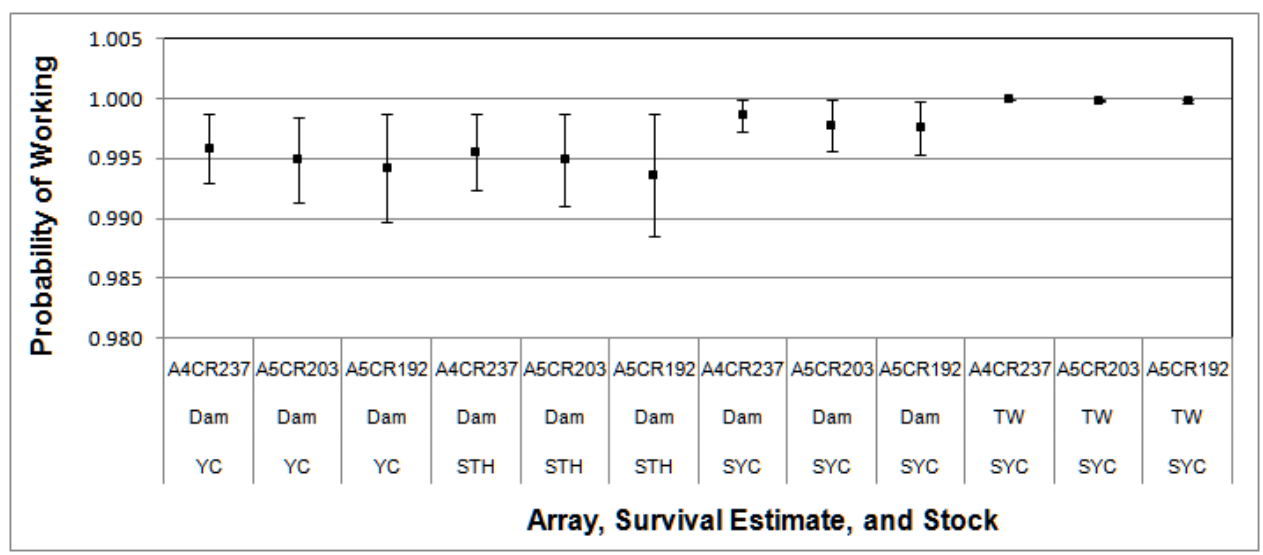

Figure C.11. Plot of the probability of a tag implanted in yearling Chinook salmon smolts released near Arlington, Oregon (Dam) or in the John Day tailwater (TW) working by the time fish arrived at survival-detection arrays for The Dalles Dam by array, survival estimate, and stock 


\section{Appendix D}

Survival and Detection Probabilities for Single- and PairedReleases without Tag-Life Corrections 
Table D.1. List of Excel files on an accompanying compact disc ${ }^{(a)}$

\begin{tabular}{|c|c|}
\hline File & Description \\
\hline Appendix D1.xls & $\begin{array}{l}\text { Yearling Chinook Single and Paired Release Survival and Detection Probabilities without } \\
\text { Tag-Life Corrections }\end{array}$ \\
\hline Appendix D2.xls & $\begin{array}{l}\text { Steelhead Single and Paired Release Survival and Detection Probabilities without Tag- } \\
\text { Life Corrections }\end{array}$ \\
\hline Appendix D3.xls & $\begin{array}{l}\text { Subyearling Chinook Single and Paired Release Survival and Detection Probabilities } \\
\text { without Tag-Life Corrections }\end{array}$ \\
\hline \multicolumn{2}{|c|}{$\begin{array}{l}\text { A compact disc accompanying the report has nine files: A Portable Document Format (PDF) file of this } \\
\text { report, three Excel files with non-tag-life-corrected survival and detection probabilities, and five Excel files } \\
\text { with tagging, release, virtual release, capture-history, and dam operations data. }\end{array}$} \\
\hline
\end{tabular}

Table D.2. Variable names and definitions in Appendix D.xls files

\begin{tabular}{|c|c|}
\hline Variable & Definition \\
\hline $\mathrm{S}$ & Survival probabilities \\
\hline $\mathrm{CI}$ & Confidence interval \\
\hline Lambda & The product of survival and detection probabilities for the third array \\
\hline N-Wt Mean & $\begin{array}{l}\text { The N-Wt Mean (weighted by numbers of fish in virtual releases) is preferred over the pooled } \\
\text { estimate when capture histories are not homogeneous and some variance estimates approach zero } \\
\text { and would overly weight high survival estimates. }\end{array}$ \\
\hline $\begin{array}{l}\text { Capture History } \\
\text { Headings }\end{array}$ & $\begin{array}{l}\text { Headings of columns } 2 \text { through } 9 \text { on detection histories have three digits and each digit } \\
\text { represents a detection (1) or non-detection ( } 0 \text { ) at three successive survival-detection arrays (The } \\
\text { Dalles Dam forebay array, Bonneville [BON] forebay array, and BON tailwater1 array, } \\
\text { respectively). }\end{array}$ \\
\hline Virtual Releases & $\begin{array}{l}\text { Smolts detected and regrouped to form virtual releases at the dam-face array except for the } \\
\text { forebay survival (regrouped at the John Day Dam forebay array). }\end{array}$ \\
\hline
\end{tabular}




\section{Appendix E}

Tag-Life-Corrected John Day Concrete-Passage and RouteSpecific Survival Rates for John Day Dam Yearling Chinook Salmon 
Table E.1. Detection histories for yearling Chinook salmon smolts detected and regrouped to form virtual releases at John Day Dam in spring for estimating dam survival. Headings of columns 2 through 9 have three digits and each digit represents a detection (1) or non-detection (0) at three successive survival-detection arrays (TDA_FB, BON_FB, and BTW1, respectively). A chi-square test for homogeneity, excluding pooled estimates, columns with $<5$ pooled detections, and totals, was not significant $(\mathrm{P}=0.3880)$.

\begin{tabular}{crrrrrrrrr}
\hline Date & P_111 & P_011 & P_101 & P_001 & P_110 & P_010 & P_100 & P_000 & Total \\
\hline $5 / 02-5 / 03$ & 38 & 0 & 1 & 0 & 9 & 0 & 6 & 4 & 58 \\
$5 / 04-5 / 05$ & 83 & 0 & 5 & 0 & 31 & 0 & 16 & 10 & 145 \\
$5 / 06-5 / 07$ & 118 & 0 & 27 & 0 & 39 & 0 & 30 & 17 & 231 \\
$5 / 08-5 / 09$ & 86 & 2 & 11 & 0 & 34 & 0 & 16 & 8 & 157 \\
$5 / 10-5 / 11$ & 89 & 0 & 21 & 0 & 28 & 0 & 31 & 13 & 182 \\
$5 / 12-5 / 13$ & 108 & 0 & 14 & 0 & 45 & 0 & 20 & 9 & 196 \\
$5 / 14-5 / 15$ & 70 & 0 & 15 & 0 & 26 & 1 & 19 & 17 & 148 \\
$5 / 16-5 / 17$ & 53 & 0 & 42 & 0 & 22 & 0 & 43 & 11 & 171 \\
$5 / 18-5 / 19$ & 48 & 0 & 55 & 0 & 39 & 0 & 63 & 15 & 220 \\
$5 / 20-5 / 21$ & 32 & 0 & 37 & 0 & 36 & 0 & 63 & 4 & 172 \\
$5 / 22-5 / 23$ & 28 & 2 & 35 & 1 & 33 & 2 & 50 & 14 & 165 \\
$5 / 24-5 / 25$ & 42 & 0 & 35 & 0 & 37 & 0 & 58 & 6 & 178 \\
$5 / 26-5 / 27$ & 35 & 0 & 60 & 0 & 43 & 0 & 60 & 6 & 204 \\
$5 / 28-5 / 29$ & 23 & 0 & 47 & 0 & 19 & 0 & 55 & 10 & 154 \\
Pooled & 853 & 4 & 405 & 1 & 441 & 3 & 530 & 144 & 2381 \\
\hline
\end{tabular}

Table E.2. Tag-life-corrected, single-release estimates of dam survival (S) and detection probabilities for yearling Chinook salmon smolts in virtual releases at John Day Dam based on three downstream arrays. Lambda is the product of survival and detection probabilities for the third array, and $\mathrm{CI}=$ confidence interval.

\begin{tabular}{|c|c|c|c|c|c|c|c|c|c|c|}
\hline $\begin{array}{c}\text { Virtual } \\
\text { Release } \\
\text { Dates }\end{array}$ & $\begin{array}{c}\text { S to } 1 \text { st } \\
\text { Array }\end{array}$ & $\begin{array}{c}1 / 2 \\
95 \% \mathrm{CI} \\
\end{array}$ & $\begin{array}{l}\text { S from } \\
1 \text { st to } \\
2 \text { nd } \\
\text { Array }\end{array}$ & $\begin{array}{c}1 / 2 \\
95 \% \mathrm{CI} \\
\end{array}$ & $\begin{array}{c}\text { Detect. } \\
\text { Prob. To } \\
\text { 1st Array }\end{array}$ & $\begin{array}{c}1 / 2 \\
95 \% \mathrm{CI} \\
\end{array}$ & $\begin{array}{l}\text { Detect. } \\
\text { Prob. } \\
\text { from } 1 \mathrm{st} \\
\text { to } 2 \mathrm{nd} \\
\text { Array }\end{array}$ & $\begin{array}{c}1 / 2 \\
95 \% \mathrm{CI} \\
\end{array}$ & Lambda & $\begin{array}{c}1 / 2 \\
95 \% \mathrm{CI} \\
\end{array}$ \\
\hline $5 / 02-5 / 03$ & 0.934 & 0.065 & 0.964 & 0.069 & 1.000 & 0.065 & 1.000 & 0.069 & 0.863 & 0.094 \\
\hline $5 / 04-5 / 05$ & 0.951 & 0.052 & 0.956 & 0.035 & 1.000 & 0.052 & 1.000 & 0.035 & 0.900 & 0.052 \\
\hline $5 / 06-5 / 07$ & 0.933 & 0.036 & 0.948 & 0.032 & 1.000 & 0.036 & 1.000 & 0.032 & 0.892 & 0.044 \\
\hline $5 / 08-5 / 09$ & 0.954 & 0.035 & 0.962 & 0.032 & 0.986 & 0.035 & 1.000 & 0.032 & 0.875 & 0.054 \\
\hline $5 / 10-5 / 11$ & 0.930 & 0.038 & 0.917 & 0.042 & 1.000 & 0.038 & 1.000 & 0.042 & 0.884 & 0.050 \\
\hline $5 / 12-5 / 13$ & 0.955 & 0.029 & 0.941 & 0.034 & 1.000 & 0.029 & 1.000 & 0.034 & 0.910 & 0.043 \\
\hline $5 / 14-5 / 15$ & 0.894 & 0.050 & 0.946 & 0.039 & 0.984 & 0.050 & 1.000 & 0.039 & 0.864 & 0.060 \\
\hline $5 / 16-5 / 17$ & 0.937 & 0.037 & 0.963 & 0.029 & 1.000 & 0.037 & 1.000 & 0.029 & 0.760 & 0.067 \\
\hline $5 / 18-5 / 19$ & 0.937 & 0.032 & 0.942 & 0.032 & 0.995 & 0.032 & 1.000 & 0.032 & 0.810 & 0.055 \\
\hline $5 / 20-5 / 21$ & 0.977 & 0.023 & 0.983 & 0.020 & 1.000 & 0.023 & 1.000 & 0.020 & 0.770 & 0.064 \\
\hline $5 / 22-5 / 23$ & 0.930 & 0.040 & 0.968 & 0.030 & 0.953 & 0.040 & 0.992 & 0.030 & 0.838 & 0.060 \\
\hline $5 / 24-5 / 25$ & 0.969 & 0.027 & 0.903 & 0.045 & 1.000 & 0.027 & 0.983 & 0.045 & 0.772 & 0.067 \\
\hline $5 / 26-5 / 27$ & 0.971 & 0.023 & 0.956 & 0.029 & 1.000 & 0.023 & 0.993 & 0.029 & 0.793 & 0.058 \\
\hline $5 / 28-5 / 29$ & 0.935 & 0.039 & 0.919 & 0.048 & 1.000 & 0.039 & 0.953 & 0.048 & 0.802 & 0.070 \\
\hline Pooled & 0.944 & 0.011 & 0.946 & 0.010 & 0.994 & 0.011 & 0.995 & 0.010 & 0.836 & 0.016 \\
\hline
\end{tabular}


Table E.3. Detection histories for yearling Chinook salmon smolts released in the upper John Day Dam tailwater as reference releases for dam survival and non-TSW survival. Headings of columns 2 through 9 have three digits and each digit represents a detection (1) or nondetection (0) at three successive survival-detection arrays (TDA_FB, BON_FB, and BTW1, respectively). A chi-square test for homogeneity, excluding pooled estimates, columns with $<5$ pooled detections, and totals, was not significant $(\mathrm{P}=0.3880)$.

\begin{tabular}{cccccccccc}
\hline Date & P_111 & P_011 & P_101 & P_001 & P_110 & P_010 & P_100 & P_000 & Total \\
\hline $5 / 02-5 / 03$ & 60 & 0 & 0 & 0 & 6 & 0 & 4 & 2 & 72 \\
$5 / 04-5 / 05$ & 51 & 0 & 0 & 0 & 4 & 0 & 4 & 0 & 59 \\
$5 / 06-5 / 07$ & 51 & 0 & 0 & 0 & 7 & 0 & 4 & 1 & 63 \\
$5 / 08-5 / 09$ & 54 & 0 & 0 & 0 & 8 & 0 & 4 & 2 & 68 \\
$5 / 10-5 / 11$ & 69 & 0 & 1 & 0 & 7 & 1 & 7 & 1 & 86 \\
$5 / 12-5 / 13$ & 49 & 0 & 0 & 0 & 6 & 0 & 4 & 0 & 59 \\
$5 / 14-5 / 15$ & 61 & 2 & 0 & 0 & 8 & 0 & 3 & 0 & 74 \\
$5 / 16-5 / 17$ & 64 & 0 & 0 & 0 & 16 & 0 & 6 & 1 & 87 \\
$5 / 18-5 / 19$ & 61 & 0 & 0 & 0 & 11 & 0 & 5 & 2 & 79 \\
$5 / 20-5 / 21$ & 44 & 0 & 0 & 0 & 8 & 0 & 3 & 1 & 56 \\
$5 / 22-5 / 23$ & 52 & 0 & 0 & 0 & 10 & 0 & 6 & 1 & 69 \\
$5 / 24-5 / 25$ & 45 & 0 & 0 & 0 & 15 & 0 & 5 & 2 & 67 \\
$5 / 26-5 / 27$ & 54 & 0 & 0 & 0 & 23 & 0 & 4 & 2 & 83 \\
$5 / 28-5 / 29$ & 42 & 0 & 3 & 0 & 12 & 0 & 1 & 0 & 58 \\
Pooled & 757 & 2 & 4 & 0 & 141 & 1 & 60 & 15 & 980 \\
\hline
\end{tabular}

Table E.4. Tag-life-corrected, single-release estimates of survival (S) and detection probabilities for yearling Chinook salmon smolts in reference releases for dam and non-TSW survival. Releases were in the upper John Day Dam tailwater. Lambda is the product of survival and detection probabilities for the third array, and $\mathrm{CI}=$ confidence interval.

\begin{tabular}{|c|c|c|c|c|c|c|c|c|c|c|}
\hline $\begin{array}{c}\text { Virtual } \\
\text { Release } \\
\text { Dates }\end{array}$ & $\begin{array}{c}\mathrm{S} \text { to } 1 \mathrm{st} \\
\text { Array }\end{array}$ & $\begin{array}{c}1 / 2 \\
95 \% \mathrm{CI}\end{array}$ & $\begin{array}{l}\text { S from } \\
1 \text { st to } \\
\text { 2nd } \\
\text { Array }\end{array}$ & $\begin{array}{c}1 / 2 \\
95 \% \mathrm{CI}\end{array}$ & $\begin{array}{c}\text { Detect. } \\
\text { Prob. To } \\
\text { 1st } \\
\text { Array }\end{array}$ & $\begin{array}{c}1 / 2 \\
95 \% \mathrm{CI}\end{array}$ & $\begin{array}{l}\text { Detect. } \\
\text { Prob. } \\
\text { from 1st } \\
\text { to } 2 \text { nd } \\
\text { Array }\end{array}$ & $\begin{array}{c}1 / 2 \\
95 \% \mathrm{CI}\end{array}$ & Lambda & $\begin{array}{c}1 / 2 \\
95 \% \\
\text { CI }\end{array}$ \\
\hline $5 / 02-5 / 03$ & 0.973 & 0.038 & 0.954 & 0.060 & 1.000 & 0.038 & 1.000 & 0.060 & 0.909 & 0.069 \\
\hline $5 / 04-5 / 05$ & 1.000 & 0.011 & 0.932 & 0.064 & 1.000 & 0.011 & 1.000 & 0.064 & 0.928 & 0.069 \\
\hline $5 / 06-5 / 07$ & 0.984 & 0.031 & 0.938 & 0.061 & 1.000 & 0.031 & 1.000 & 0.061 & 0.881 & 0.084 \\
\hline $5 / 08-5 / 09$ & 0.971 & 0.040 & 0.940 & 0.058 & 1.000 & 0.040 & 1.000 & 0.058 & 0.870 & 0.083 \\
\hline $5 / 10-5 / 11$ & 0.989 & 0.023 & 0.918 & 0.059 & 0.987 & 0.023 & 0.986 & 0.059 & 0.896 & 0.068 \\
\hline $5 / 12-5 / 13$ & 1.000 & 0.011 & 0.932 & 0.064 & 1.000 & 0.011 & 1.000 & 0.064 & 0.891 & 0.083 \\
\hline $5 / 14-5 / 15$ & 1.000 & 0.010 & 0.960 & 0.045 & 0.973 & 0.010 & 1.000 & 0.045 & 0.887 & 0.074 \\
\hline $5 / 16-5 / 17$ & 0.989 & 0.022 & 0.930 & 0.054 & 1.000 & 0.022 & 1.000 & 0.054 & 0.800 & 0.088 \\
\hline $5 / 18-5 / 19$ & 0.975 & 0.035 & 0.935 & 0.055 & 1.000 & 0.035 & 1.000 & 0.055 & 0.847 & 0.083 \\
\hline $5 / 20-5 / 21$ & 0.982 & 0.035 & 0.946 & 0.060 & 1.000 & 0.035 & 1.000 & 0.060 & 0.846 & 0.098 \\
\hline $5 / 22-5 / 23$ & 0.986 & 0.028 & 0.912 & 0.067 & 1.000 & 0.028 & 1.000 & 0.067 & 0.839 & 0.092 \\
\hline $5 / 24-5 / 25$ & 0.970 & 0.041 & 0.923 & 0.065 & 1.000 & 0.041 & 1.000 & 0.065 & 0.750 & 0.110 \\
\hline $5 / 26-5 / 27$ & 0.976 & 0.033 & 0.951 & 0.047 & 1.000 & 0.033 & 1.000 & 0.047 & 0.702 & 0.102 \\
\hline $5 / 28-5 / 29$ & 1.000 & 0.012 & 1.000 & 0.027 & 1.000 & 0.012 & 0.936 & 0.027 & 0.788 & 0.109 \\
\hline Pooled & 0.987 & 0.008 & 0.940 & 0.015 & 0.997 & 0.008 & 0.995 & 0.015 & 0.843 & 0.024 \\
\hline
\end{tabular}


Table E.5. Tag-life-corrected, paired-release estimates of dam survival (S) for yearling Chinook salmon smolts in virtual releases from the forebay to the upper John Day Dam tailwater

\begin{tabular}{lcc}
\hline Paired Release & S to Upper Tailwater & $1 / 295 \%$ CI \\
\hline $5 / 02-5 / 03$ & 0.960 & 0.077 \\
$5 / 04-5 / 05$ & 0.951 & 0.053 \\
$5 / 06-5 / 07$ & 0.948 & 0.047 \\
$5 / 08-5 / 09$ & 0.982 & 0.055 \\
$5 / 10-5 / 11$ & 0.940 & 0.044 \\
$5 / 12-5 / 13$ & 0.955 & 0.031 \\
$5 / 14-5 / 15$ & 0.894 & 0.051 \\
$5 / 16-5 / 17$ & 0.947 & 0.043 \\
$5 / 18-5 / 19$ & 0.962 & 0.048 \\
$5 / 20-5 / 21$ & 0.995 & 0.042 \\
$5 / 22-5 / 23$ & 0.943 & 0.049 \\
$5 / 24-5 / 25$ & 0.998 & 0.050 \\
$5 / 26-5 / 27$ & 0.995 & 0.041 \\
$5 / 28-5 / 29$ & 0.935 & 0.040 \\
Pooled & 0.957 & 0.013 \\
\hline
\end{tabular}

Table E.6. Detection histories for yearling Chinook salmon smolts detected and regrouped to form virtual releases at non-TSW spill bays in spring. Headings of columns 2 through 9 have three digits and each digit represents a detection (1) or non-detection (0) at three successive survivaldetection arrays (TDA_FB, BON_FB, and BTW1, respectively). A chi-square test for homogeneity, excluding pooled estimates, columns with $<5$ pooled detections, and totals, was significant $(\mathrm{P}<0.0010)$.

\begin{tabular}{ccrrrrrrrr}
\hline Date & P_111 & P_011 & P_101 & P_001 & P_110 & P_010 & P_100 & P_000 & Total \\
\hline $5 / 02-5 / 03$ & 27 & 0 & 1 & 0 & 8 & 0 & 4 & 2 & 42 \\
$5 / 04-5 / 05$ & 35 & 0 & 2 & 0 & 17 & 0 & 11 & 3 & 68 \\
$5 / 06-5 / 07$ & 53 & 0 & 11 & 0 & 20 & 0 & 13 & 5 & 102 \\
$5 / 08-5 / 09$ & 34 & 0 & 4 & 0 & 18 & 0 & 8 & 2 & 66 \\
$5 / 10-5 / 11$ & 49 & 0 & 13 & 0 & 14 & 0 & 14 & 6 & 96 \\
$5 / 12-5 / 13$ & 65 & 0 & 9 & 0 & 26 & 0 & 12 & 4 & 116 \\
$5 / 14-5 / 15$ & 25 & 0 & 8 & 0 & 7 & 0 & 5 & 7 & 52 \\
$5 / 16-5 / 17$ & 28 & 0 & 19 & 0 & 11 & 0 & 16 & 4 & 78 \\
$5 / 18-5 / 19$ & 34 & 0 & 37 & 0 & 23 & 0 & 39 & 8 & 141 \\
$5 / 20-5 / 21$ & 19 & 0 & 17 & 0 & 19 & 0 & 32 & 3 & 90 \\
$5 / 22-5 / 23$ & 19 & 1 & 21 & 0 & 22 & 0 & 28 & 7 & 98 \\
$5 / 24-5 / 25$ & 32 & 0 & 25 & 0 & 24 & 0 & 34 & 6 & 121 \\
$5 / 26-5 / 27$ & 17 & 0 & 29 & 0 & 24 & 0 & 34 & 5 & 109 \\
$5 / 28-5 / 29$ & 8 & 0 & 28 & 0 & 11 & 0 & 25 & 4 & 76 \\
Pooled & 445 & 1 & 224 & 0 & 244 & 0 & 275 & 66 & 1255 \\
\hline
\end{tabular}


Table E.7. Tag-life-corrected, single-release estimates of non-TSW spill bay passage survival (S) and detection probabilities for yearling Chinook salmon smolts in virtual releases at John Day Dam based on detections at three downstream arrays. Lambda is the product of survival and detection probabilities for the third array, and $\mathrm{CI}=$ confidence interval. The $\mathrm{N}-\mathrm{Wt}$ Mean (weighted by numbers of fish in virtual releases) is preferred over the pooled estimate when capture histories are not homogeneous.

\begin{tabular}{|c|c|c|c|c|c|c|c|c|c|c|}
\hline $\begin{array}{c}\text { Virtual } \\
\text { Release } \\
\text { Dates }\end{array}$ & $\begin{array}{c}\text { S to } 1 \text { st } \\
\text { Array }\end{array}$ & $\begin{array}{c}1 / 2 \\
95 \% \mathrm{CI}\end{array}$ & $\begin{array}{l}\text { S from } \\
\text { 1st to } \\
2 \text { nd } \\
\text { Array }\end{array}$ & $\begin{array}{c}1 / 2 \\
95 \% \mathrm{CI}\end{array}$ & $\begin{array}{c}\text { Detect. } \\
\text { Prob. To } \\
\text { 1st } \\
\text { Array } \\
\end{array}$ & $\begin{array}{c}1 / 2 \\
95 \% \mathrm{CI} \\
\end{array}$ & $\begin{array}{l}\text { Detect. } \\
\text { Prob. } \\
\text { from } 1 \mathrm{st} \\
\text { to } 2 \mathrm{nd} \\
\text { Array }\end{array}$ & $\begin{array}{c}1 / 2 \\
95 \% \mathrm{CI}\end{array}$ & Lambda & $\begin{array}{c}1 / 2 \\
95 \% \mathrm{CI} \\
\end{array}$ \\
\hline $5 / 02-5 / 03$ & 0.955 & 0.065 & 0.995 & 0.053 & 1.000 & 0.065 & 1.000 & 0.053 & 0.846 & 0.113 \\
\hline $5 / 04-5 / 05$ & 0.976 & 0.059 & 0.939 & 0.058 & 1.000 & 0.059 & 1.000 & 0.058 & 0.836 & 0.093 \\
\hline $5 / 06-5 / 07$ & 0.956 & 0.043 & 0.951 & 0.044 & 1.000 & 0.043 & 1.000 & 0.044 & 0.865 & 0.072 \\
\hline $5 / 08-5 / 09$ & 0.974 & 0.042 & 0.958 & 0.053 & 1.000 & 0.042 & 1.000 & 0.053 & 0.869 & 0.085 \\
\hline $5 / 10-5 / 11$ & 0.938 & 0.048 & 0.911 & 0.059 & 1.000 & 0.048 & 1.000 & 0.059 & 0.878 & 0.071 \\
\hline $5 / 12-5 / 13$ & 0.967 & 0.033 & 0.938 & 0.045 & 1.000 & 0.033 & 1.000 & 0.045 & 0.896 & 0.059 \\
\hline $5 / 14-5 / 15$ & 0.887 & 0.087 & 0.933 & 0.073 & 0.977 & 0.087 & 1.000 & 0.073 & 0.861 & 0.104 \\
\hline $5 / 16-5 / 17$ & 0.949 & 0.049 & 0.973 & 0.037 & 1.000 & 0.049 & 1.000 & 0.037 & 0.764 & 0.098 \\
\hline $5 / 18-5 / 19$ & 0.944 & 0.038 & 0.955 & 0.035 & 1.000 & 0.038 & 1.000 & 0.035 & 0.820 & 0.067 \\
\hline $5 / 20-5 / 21$ & 0.967 & 0.037 & 1.000 & 0.000 & 1.000 & 0.037 & 1.000 & 0.000 & 0.805 & 0.083 \\
\hline $5 / 22-5 / 23$ & 0.941 & 0.048 & 0.959 & 0.043 & 0.977 & 0.048 & 0.986 & 0.043 & 0.829 & 0.080 \\
\hline $5 / 24-5 / 25$ & 0.951 & 0.039 & 0.961 & 0.038 & 1.000 & 0.039 & 0.977 & 0.038 & 0.787 & 0.077 \\
\hline $5 / 26-5 / 27$ & 0.954 & 0.039 & 0.962 & 0.037 & 1.000 & 0.039 & 1.000 & 0.037 & 0.710 & 0.089 \\
\hline $5 / 28-5 / 29$ & 0.947 & 0.050 & 0.949 & 0.054 & 1.000 & 0.050 & 0.981 & 0.054 & 0.761 & 0.102 \\
\hline Pooled & 0.951 & 0.013 & 0.955 & 0.012 & 0.997 & 0.013 & 0.996 & 0.012 & 0.821 & 0.022 \\
\hline N-Wt Mean & 0.951 & 0.009 & 0.955 & 0.011 & & & & & & \\
\hline
\end{tabular}

Table E.8. Tag-life-corrected, paired-release estimates of survival (S) for yearling Chinook salmon smolts in virtual releases at non-TSW spill bays to the upper John Day Dam tailwater. Treatment virtual release data were from Tables E.6 and E.7, and reference release data were from Table E.4.

\begin{tabular}{lrr}
\hline Paired Release & S to Tailrace & $1 / 295 \%$ CI \\
\hline $5 / 02-5 / 03$ & 0.982 & 0.077 \\
$5 / 04-5 / 05$ & 0.976 & 0.060 \\
$5 / 06-5 / 07$ & 0.972 & 0.053 \\
$5 / 08-5 / 09$ & 1.003 & 0.060 \\
$5 / 10-5 / 11$ & 0.948 & 0.054 \\
$5 / 12-5 / 13$ & 0.967 & 0.035 \\
$5 / 14-5 / 15$ & 0.887 & 0.087 \\
$5 / 16-5 / 17$ & 0.960 & 0.054 \\
$5 / 18-5 / 19$ & 0.969 & 0.052 \\
$5 / 20-5 / 21$ & 0.985 & 0.051 \\
$5 / 22-5 / 23$ & 0.955 & 0.056 \\
$5 / 24-5 / 25$ & 0.980 & 0.057 \\
$5 / 26-5 / 27$ & 0.978 & 0.052 \\
$5 / 28-5 / 29$ & 0.947 & 0.051 \\
N-Wt Mean & 0.966 & 0.011 \\
\hline
\end{tabular}


Table E.9. Detection histories for yearling Chinook salmon smolts detected and regrouped to form virtual releases at TSW spill bays in spring. Headings of columns 2 through 9 have three digits and each digit represents a detection (1) or non-detection (0) at three successive survival-detection arrays (TDA_FB, BON_FB, and BTW1, respectively). A chi-square test for homogeneity, excluding pooled estimates, columns with $<5$ pooled detections, and totals, was significant $(\mathrm{P}<0.0001)$.

\begin{tabular}{lrrrrrrrrr}
\hline \multicolumn{1}{c}{ Date } & P_111 & P_011 & P_101 & P_001 & P_110 & P_010 & P_100 & P_000 & Total \\
\hline $5 / 02-5 / 05$ & 44 & 0 & 3 & 0 & 10 & 0 & 4 & 5 & 66 \\
$5 / 06-5 / 09$ & 56 & 0 & 10 & 0 & 17 & 0 & 17 & 8 & 108 \\
$5 / 10-5 / 13$ & 49 & 0 & 10 & 0 & 24 & 0 & 16 & 3 & 102 \\
$5 / 14-5 / 17$ & 54 & 0 & 20 & 0 & 22 & 0 & 27 & 9 & 132 \\
$5 / 18-5 / 21$ & 5 & 0 & 7 & 0 & 9 & 0 & 13 & 3 & 37 \\
$5 / 22-5 / 25$ & 7 & 0 & 4 & 1 & 10 & 0 & 10 & 2 & 34 \\
$5 / 26-5 / 29$ & 17 & 0 & 18 & 0 & 12 & 0 & 31 & 1 & 79 \\
Pooled & 232 & 0 & 72 & 1 & 104 & 0 & 118 & 31 & 558 \\
\hline
\end{tabular}

Table E.10. Tag-life-corrected, single-release estimates of TSW survival (S) and detection probabilities for yearling Chinook salmon smolts in virtual releases at John Day Dam based on detections at three downstream arrays. Lambda is the product of survival and detection probabilities for the third array, and CI = confidence interval. The N-Wt Mean (weighted by numbers of fish in virtual releases) is preferred over the pooled estimate when capture histories are not homogeneous.

\begin{tabular}{|c|c|c|c|c|c|c|c|c|c|c|}
\hline $\begin{array}{c}\text { Virtual } \\
\text { Release } \\
\text { Dates }\end{array}$ & $\begin{array}{c}\mathrm{S} \text { to } 1 \mathrm{st} \\
\text { Array }\end{array}$ & $\begin{array}{c}1 / 2 \\
95 \% \mathrm{CI}\end{array}$ & $\begin{array}{l}\text { S from } \\
1 \text { st to } \\
2 \text { nd } \\
\text { Array }\end{array}$ & $\begin{array}{c}1 / 2 \\
95 \% \mathrm{CI}\end{array}$ & $\begin{array}{c}\text { Detect. } \\
\text { Prob. To } \\
\text { 1st } \\
\text { Array }\end{array}$ & $\begin{array}{c}1 / 2 \\
95 \% \mathrm{CI}\end{array}$ & $\begin{array}{l}\text { Detect. } \\
\text { Prob. from } \\
\text { 1st to } 2 \text { nd } \\
\text { Array }\end{array}$ & $\begin{array}{c}1 / 2 \\
95 \% \mathrm{CI}\end{array}$ & Lambda & $\begin{array}{c}1 / 2 \\
95 \% \mathrm{CI}\end{array}$ \\
\hline $5 / 02-5 / 05$ & 0.985 & 0.021 & 0.944 & 0.044 & 1.000 & 0.021 & 1.000 & 0.044 & 0.917 & 0.049 \\
\hline $5 / 06-5 / 09$ & 0.977 & 0.026 & 0.939 & 0.042 & 1.000 & 0.026 & 1.000 & 0.042 & 0.876 & 0.059 \\
\hline $5 / 10-5 / 13$ & 0.994 & 0.013 & 0.924 & 0.044 & 0.993 & 0.013 & 0.992 & 0.044 & 0.894 & 0.053 \\
\hline $5 / 14-5 / 17$ & 0.995 & 0.012 & 0.943 & 0.036 & 0.987 & 0.012 & 1.000 & 0.036 & 0.841 & 0.058 \\
\hline $5 / 18-5 / 21$ & 0.978 & 0.025 & 0.939 & 0.041 & 1.000 & 0.025 & 1.000 & 0.041 & 0.847 & 0.063 \\
\hline $5 / 22-5 / 25$ & 0.978 & 0.025 & 0.917 & 0.047 & 1.000 & 0.025 & 1.000 & 0.047 & 0.795 & 0.072 \\
\hline $5 / 26-5 / 29$ & 1.000 & 0.023 & 0.974 & 0.033 & 1.000 & 0.023 & 0.970 & 0.033 & 0.737 & 0.076 \\
\hline Pooled & 0.987 & 0.008 & 0.940 & 0.015 & 0.997 & 0.008 & 0.995 & 0.015 & 0.843 & 0.024 \\
\hline N-Wt Mean & 0.987 & 0.007 & 0.940 & 0.013 & & & & & & \\
\hline
\end{tabular}


Table E.11. Detection histories for yearling Chinook salmon smolts in TSW reference releases in the upper John Day Dam tailwater based on three downstream arrays. Headings of columns 2 through 9 have three digits and each digit represents a detection (1) or non-detection (0) at three successive survival-detection arrays (TDA_FB, BON_FB, and BTW1, respectively). A chi-square test for homogeneity, excluding pooled estimates, columns with $<5$ pooled detections, and totals, was significant $(\mathrm{P}=0.0096)$.

\begin{tabular}{lcrrrrrrrr}
\hline \multicolumn{1}{c}{ Date } & P_111 & P_011 & P_101 & P_001 & P_110 & P_010 & P_100 & P_000 & Total \\
\hline 5/02-5/05 & 111 & 0 & 0 & 0 & 10 & 0 & 8 & 2 & 131 \\
$5 / 06-5 / 09$ & 105 & 0 & 0 & 0 & 15 & 0 & 8 & 3 & 131 \\
$5 / 10-5 / 13$ & 118 & 0 & 1 & 0 & 13 & 1 & 11 & 1 & 145 \\
$5 / 14-5 / 17$ & 125 & 2 & 0 & 0 & 24 & 0 & 9 & 1 & 161 \\
$5 / 18-5 / 21$ & 105 & 0 & 0 & 0 & 19 & 0 & 8 & 3 & 135 \\
$5 / 22-5 / 25$ & 97 & 0 & 0 & 0 & 25 & 0 & 11 & 3 & 136 \\
$5 / 26-5 / 29$ & 96 & 0 & 3 & 0 & 35 & 0 & 5 & 2 & 141 \\
Pooled & 757 & 2 & 4 & 0 & 141 & 1 & 60 & 15 & 980 \\
\hline
\end{tabular}

Table E.12. Tag-life-corrected, single-release survival estimates for yearling Chinook salmon smolts in TSW reference releases based on detections at three downstream arrays. Lambda is the product of survival and detection probabilities for the third array, and CI = confidence interval. The N-Wt Mean (weighted by numbers of fish in virtual releases) is preferred over the pooled estimate when capture histories are not homogeneous.

\begin{tabular}{|c|c|c|c|c|c|c|c|c|c|c|}
\hline $\begin{array}{c}\text { Virtual } \\
\text { Release } \\
\text { Dates }\end{array}$ & $\begin{array}{c}\text { S to } 1 \text { st } \\
\text { Array }\end{array}$ & $\begin{array}{c}1 / 2 \\
95 \% \mathrm{CI}\end{array}$ & $\begin{array}{l}\text { S from } \\
\text { 1st to } \\
\text { 2nd } \\
\text { Array }\end{array}$ & $\begin{array}{c}1 / 2 \\
95 \% \text { CI }\end{array}$ & $\begin{array}{c}\text { Detect. } \\
\text { Prob. To } \\
\text { 1st } \\
\text { Array }\end{array}$ & $\begin{array}{c}1 / 2 \\
95 \% \text { CI }\end{array}$ & $\begin{array}{l}\text { Detect. } \\
\text { Prob. } \\
\text { from 1st } \\
\text { to } 2 \text { nd } \\
\text { Array }\end{array}$ & $\begin{array}{c}1 / 2 \\
95 \% \text { CI }\end{array}$ & Lambda & $\begin{array}{c}1 / 2 \\
95 \% \mathrm{CI}\end{array}$ \\
\hline $5 / 02-5 / 05$ & 0.985 & 0.021 & 0.944 & 0.044 & 1.000 & 0.021 & 1.000 & 0.044 & 0.917 & 0.049 \\
\hline 5/06-5/09 & 0.977 & 0.026 & 0.939 & 0.042 & 1.000 & 0.026 & 1.000 & 0.042 & 0.876 & 0.059 \\
\hline $5 / 10-5 / 13$ & 0.994 & 0.013 & 0.924 & 0.044 & 0.993 & 0.013 & 0.992 & 0.044 & 0.894 & 0.053 \\
\hline $5 / 14-5 / 17$ & 0.995 & 0.012 & 0.943 & 0.036 & 0.987 & 0.012 & 1.000 & 0.036 & 0.841 & 0.058 \\
\hline $5 / 18-5 / 21$ & 0.978 & 0.025 & 0.939 & 0.041 & 1.000 & 0.025 & 1.000 & 0.041 & 0.847 & 0.063 \\
\hline $5 / 22-5 / 25$ & 0.978 & 0.025 & 0.917 & 0.047 & 1.000 & 0.025 & 1.000 & 0.047 & 0.795 & 0.072 \\
\hline $5 / 26-5 / 29$ & 1.000 & 0.023 & 0.974 & 0.033 & 1.000 & 0.023 & 0.970 & 0.033 & 0.737 & 0.076 \\
\hline Pooled & 0.987 & 0.008 & 0.940 & 0.015 & 0.997 & 0.008 & 0.995 & 0.015 & 0.843 & 0.024 \\
\hline N-Wt Mean & 0.987 & 0.007 & 0.940 & 0.013 & & & & & & \\
\hline
\end{tabular}


Table E.13. Tag-life-corrected, paired-release estimates of TSW spill bay (15 and 16) passage survival (S) for yearling Chinook salmon smolts

\begin{tabular}{lcc}
\hline \multicolumn{1}{c}{ Paired Release } & S to Tailrace & $1 / 295 \%$ CI \\
\hline $5 / 02-5 / 05$ & 0.956 & 0.071 \\
$5 / 06-5 / 09$ & 0.952 & 0.057 \\
$5 / 10-5 / 13$ & 0.979 & 0.036 \\
$5 / 14-5 / 17$ & 0.938 & 0.045 \\
$5 / 18-5 / 21$ & 0.940 & 0.093 \\
$5 / 22-5 / 25$ & 0.966 & 0.085 \\
$5 / 26-5 / 29$ & 0.987 & 0.033 \\
Pooled & 0.961 & 0.022 \\
N-Wt Mean & 0.961 & 0.020 \\
\hline
\end{tabular}

Table E.14. Detection histories for yearling Chinook salmon smolts detected and regrouped to form virtual releases for John Day Dam turbines in spring. Headings of columns 2 through 9 have three digits and each digit represents a detection (1) or non-detection (0) at three successive survival-detection arrays (TDA_FB, BON_FB, and BTW1, respectively). A chi-square test for homogeneity, excluding pooled estimates, columns with $<5$ pooled detections, and totals, was significant $(\mathrm{P}<0.001)$.

\begin{tabular}{lccccccccc}
\hline \multicolumn{1}{c}{ Date } & P_111 & P_011 & P_101 & P_001 & P_110 & P_010 & P_100 & P_000 & Total \\
\hline $5 / 02-5 / 06$ & 10 & 0 & 0 & 0 & 6 & 0 & 3 & 6 & 25 \\
$5 / 07-5 / 12$ & 19 & 0 & 3 & 0 & 6 & 0 & 3 & 6 & 37 \\
$5 / 13-5 / 18$ & 7 & 0 & 5 & 0 & 5 & 1 & 6 & 5 & 29 \\
$5 / 19-5 / 24$ & 7 & 0 & 11 & 0 & 7 & 1 & 19 & 7 & 52 \\
$5 / 25-5 / 29$ & 8 & 0 & 18 & 0 & 4 & 0 & 9 & 6 & 45 \\
Pooled & 51 & 0 & 37 & 0 & 28 & 2 & 40 & 30 & 188 \\
\hline
\end{tabular}

Table E.15. Tag-life-corrected, single-release estimates of survival (S) and detection probabilities for yearling Chinook salmon smolts in virtual releases at John Day Dam turbines based on three downstream arrays. Lambda is the product of survival and detection probabilities for the third array, and CI = confidence interval. The N-Wt Mean (weighted by numbers of fish in virtual releases) is preferred over the pooled estimate when capture histories are not homogeneous.

\begin{tabular}{|c|c|c|c|c|c|c|c|c|c|c|}
\hline $\begin{array}{c}\text { Virtual } \\
\text { Release } \\
\text { Dates }\end{array}$ & $\begin{array}{l}\mathrm{S} \text { to } 1 \mathrm{st} \\
\text { Array }\end{array}$ & $\begin{array}{c}1 / 2 \\
95 \% \mathrm{CI}\end{array}$ & $\begin{array}{l}\text { S from } \\
1 \text { st to } \\
\text { 2nd } \\
\text { Array }\end{array}$ & $\begin{array}{c}1 / 2 \\
95 \% \mathrm{CI}\end{array}$ & $\begin{array}{c}\text { Detect. } \\
\text { Prob. To } \\
1 \text { st } \\
\text { Array }\end{array}$ & $\begin{array}{c}1 / 2 \\
95 \% \mathrm{CI}\end{array}$ & $\begin{array}{l}\text { Detect. } \\
\text { Prob. } \\
\text { from } 1 \text { st } \\
\text { to } 2 \text { nd } \\
\text { Array }\end{array}$ & $\begin{array}{c}1 / 2 \\
95 \% \mathrm{CI}\end{array}$ & Lambda & $\begin{array}{c}1 / 2 \\
95 \% \mathrm{CI}\end{array}$ \\
\hline $5 / 02-5 / 06$ & 0.771 & 0.172 & 0.895 & 0.138 & 1.000 & 0.172 & 1.000 & 0.138 & 0.825 & 0.181 \\
\hline $5 / 07-5 / 12$ & 0.843 & 0.120 & 0.938 & 0.087 & 1.000 & 0.120 & 1.000 & 0.087 & 0.865 & 0.126 \\
\hline $5 / 13-5 / 18$ & 0.835 & 0.140 & 0.826 & 0.155 & 0.950 & 0.140 & 1.000 & 0.155 & 0.900 & 0.132 \\
\hline $5 / 19-5 / 24$ & 0.866 & 0.093 & 0.955 & 0.062 & 0.977 & 0.093 & 1.000 & 0.062 & 0.698 & 0.137 \\
\hline $5 / 25-5 / 29$ & 0.867 & 0.099 & 0.903 & 0.096 & 1.000 & 0.099 & 0.938 & 0.096 & 0.909 & 0.098 \\
\hline Pooled & 0.844 & 0.053 & 0.914 & 0.045 & 0.986 & 0.053 & 0.983 & 0.045 & 0.825 & 0.063 \\
\hline N-Wt Mean & 0.844 & 0.031 & 0.911 & 0.042 & & & & & & \\
\hline
\end{tabular}


Table E.16. Detection histories for yearling Chinook salmon smolts released in the upper John Day Dam tailwater as reference releases for turbine survival. Headings of columns 2 through 9 have three digits and each digit represents a detection (1) or non-detection (0) at three successive survival-detection arrays (TDA_FB, BON_FB, and BTW1, respectively). A chi-square test for homogeneity, excluding pooled estimates, columns with $<5$ pooled detections, and totals, was significant $(\mathrm{P}=0.0040)$.

\begin{tabular}{lccccccccc}
\hline \multicolumn{1}{c}{ Date } & P_111 & P_011 & P_101 & P_001 & P_110 & P_010 & P_100 & P_000 & Total \\
\hline $5 / 02-5 / 06$ & 131 & 0 & 0 & 0 & 10 & 0 & 9 & 2 & 152 \\
$5 / 07-5 / 12$ & 177 & 0 & 1 & 0 & 22 & 1 & 17 & 4 & 222 \\
$5 / 13-5 / 18$ & 173 & 2 & 0 & 0 & 32 & 0 & 11 & 2 & 220 \\
$5 / 19-5 / 24$ & 157 & 0 & 0 & 0 & 37 & 0 & 16 & 5 & 215 \\
$5 / 25-5 / 29$ & 119 & 0 & 3 & 0 & 40 & 0 & 7 & 2 & 171 \\
Pooled & 757 & 2 & 4 & 0 & 141 & 1 & 60 & 15 & 980 \\
\hline
\end{tabular}

Table E.17. Tag-life-corrected, single-release estimates of survival (S) and detection probabilities for yearling Chinook salmon smolts in turbine reference releases in the upper John Day Dam tailwater based on three downstream arrays. Lambda is the product of survival and detection probabilities for the third array, and CI = confidence interval. The N-Wt Mean (weighted by numbers of fish in virtual releases) is preferred over the pooled estimate when capture histories are not homogeneous.

\begin{tabular}{|c|c|c|c|c|c|c|c|c|c|c|}
\hline $\begin{array}{l}\text { Virtual } \\
\text { Release } \\
\text { Dates }\end{array}$ & $\begin{array}{l}S \text { to } 1 \text { st } \\
\text { Array }\end{array}$ & $\begin{array}{c}1 / 2 \\
95 \% \mathrm{CI}\end{array}$ & $\begin{array}{c}S \text { from } \\
1 \text { st to } \\
2 \text { nd } \\
\text { Array }\end{array}$ & $\begin{array}{c}1 / 2 \\
95 \% \mathrm{CI}\end{array}$ & $\begin{array}{l}\text { Detect. } \\
\text { Prob. To } \\
\text { 1st Array }\end{array}$ & $\begin{array}{c}1 / 2 \\
95 \% \mathrm{CI}\end{array}$ & $\begin{array}{l}\text { Detect. } \\
\text { Prob. } \\
\text { from 1st } \\
\text { to 2nd } \\
\text { Array }\end{array}$ & $\begin{array}{c}1 / 2 \\
95 \% \mathrm{CI}\end{array}$ & Lambda & $\begin{array}{c}1 / 2 \\
95 \% \mathrm{CI}\end{array}$ \\
\hline $5 / 02-5 / 06$ & 0.987 & 0.018 & 0.946 & 0.04 & 1.000 & 0.018 & 1.000 & 0.04 & 0.9295 & 0.042 \\
\hline $5 / 07-5 / 12$ & 0.982 & 0.017 & 0.923 & 0.036 & 0.995 & 0.017 & 0.994 & 0.036 & 0.8851 & 0.044 \\
\hline $5 / 13-5 / 18$ & 0.992 & 0.013 & 0.949 & 0.029 & 0.990 & 0.013 & 1.000 & 0.029 & 0.8453 & 0.049 \\
\hline $5 / 19-5 / 24$ & 0.977 & 0.02 & 0.924 & 0.036 & 1.000 & 0.02 & 1.000 & 0.036 & 0.8093 & 0.055 \\
\hline $5 / 25-5 / 29$ & 1.000 & 0.02 & 0.967 & 0.031 & 1.000 & 0.02 & 0.975 & 0.031 & 0.752 & 0.068 \\
\hline Pooled & 0.987 & 0.008 & 0.940 & 0.015 & 0.997 & 0.008 & 0.995 & 0.015 & 0.843 & 0.024 \\
\hline N-Wt Mean & 0.987 & 0.008 & 0.94 & 0.016 & & & & & & \\
\hline
\end{tabular}

Table E.18. Tag-life-corrected, paired-release estimates of turbine-passage survival (S) for yearling Chinook salmon smolts in virtual releases into John Day Dam turbines to the upper John Day Dam tailwater

\begin{tabular}{lcc}
\hline Paired Release & S to Tailrace & $1 / 295 \%$ CI \\
\hline $5 / 02-5 / 06$ & 0.781 & 0.174 \\
$5 / 07-5 / 12$ & 0.859 & 0.123 \\
$5 / 13-5 / 18$ & 0.842 & 0.141 \\
$5 / 19-5 / 24$ & 0.887 & 0.097 \\
$5 / 25-5 / 29$ & 0.867 & 0.101 \\
Pooled & 0.855 & 0.054 \\
N-Wt Mean & 0.855 & 0.034 \\
\hline
\end{tabular}


Table E.19. Detection histories for yearling Chinook salmon smolts detected and regrouped to form virtual releases for the John Day Dam JBS in spring. Headings of columns 2 through 9 have three digits and each digit represents a detection (1) or non-detection (0) at three successive survival-detection arrays (TDA_FB, BON_FB, and BTW1, respectively). A chi-square test for homogeneity, excluding pooled estimates, columns with $<5$ pooled detections, and totals, was significant $(\mathrm{P}<0.0010)$.

\begin{tabular}{lccccccccc}
\hline \multicolumn{1}{c}{ Date } & P_111 & P_011 & P_101 & P_001 & P_110 & P_010 & P_100 & P_000 & Total \\
\hline $5 / 02-5 / 07$ & 30 & 0 & 6 & 0 & 7 & 0 & 5 & 5 & 53 \\
$5 / 08-5 / 11$ & 37 & 2 & 6 & 0 & 7 & 0 & 7 & 1 & 60 \\
$5 / 12-5 / 15$ & 20 & 0 & 6 & 0 & 10 & 0 & 3 & 7 & 46 \\
$5 / 16-5 / 19$ & 13 & 0 & 12 & 0 & 9 & 0 & 20 & 2 & 56 \\
$5 / 20-5 / 23$ & 9 & 1 & 20 & 0 & 16 & 1 & 29 & 2 & 78 \\
$5 / 24-5 / 29$ & 16 & 0 & 22 & 0 & 16 & 0 & 33 & 0 & 87 \\
Pooled & 125 & 3 & 72 & 0 & 65 & 1 & 97 & 17 & 380 \\
\hline
\end{tabular}

Table E.20. Tag-life-corrected, single-release estimates of JBS passage survival (S) and detection probabilities for yearling Chinook salmon smolts in virtual releases at John Day Dam based on detections at three downstream arrays. Lambda is the product of survival and detection probabilities for the third array, and CI = confidence interval. The N-Wt Mean (weighted by numbers of fish in virtual releases) is preferred over the pooled estimate when capture histories are not homogeneous.

\begin{tabular}{|c|c|c|c|c|c|c|c|c|c|c|}
\hline $\begin{array}{c}\text { Virtual } \\
\text { Release } \\
\text { Dates }\end{array}$ & $\begin{array}{c}\text { S to } \\
1 \text { st } \\
\text { Array }\end{array}$ & $\begin{array}{c}1 / 2 \\
95 \% \mathrm{CI}\end{array}$ & $\begin{array}{l}\text { S from } \\
1 \text { st to } \\
\text { 2nd } \\
\text { Array }\end{array}$ & $\begin{array}{c}1 / 2 \\
95 \% \mathrm{CI}\end{array}$ & $\begin{array}{l}\text { Detect. } \\
\text { Prob. To } \\
\text { 1st Array }\end{array}$ & $\begin{array}{c}1 / 2 \\
95 \% \mathrm{CI}\end{array}$ & $\begin{array}{l}\text { Detect. } \\
\text { Prob. } \\
\text { from } 1 \mathrm{st} \\
\text { to } 2 \mathrm{nd} \\
\text { Array }\end{array}$ & $\begin{array}{c}1 / 2 \\
95 \% \mathrm{CI}\end{array}$ & Lambda & $\begin{array}{c}1 / 2 \\
95 \% \\
\text { CI }\end{array}$ \\
\hline $5 / 02-5 / 07$ & 0.915 & 0.080 & 0.947 & 0.070 & 1.000 & 0.080 & 1.000 & 0.070 & 0.981 & 0.043 \\
\hline $5 / 08-5 / 11$ & 0.988 & 0.033 & 0.967 & 0.048 & 0.965 & 0.033 & 1.000 & 0.048 & 0.861 & 0.090 \\
\hline $5 / 12-5 / 15$ & 0.849 & 0.104 & 0.974 & 0.050 & 1.000 & 0.104 & 1.000 & 0.050 & 0.844 & 0.116 \\
\hline $5 / 16-5 / 19$ & 0.984 & 0.035 & 0.926 & 0.070 & 0.980 & 0.035 & 1.000 & 0.070 & 0.863 & 0.094 \\
\hline $5 / 20-5 / 23$ & 0.989 & 0.025 & 0.960 & 0.045 & 0.960 & 0.025 & 1.000 & 0.045 & 0.771 & 0.096 \\
\hline $5 / 24-5 / 29$ & 1.000 & 0.009 & 0.875 & 0.070 & 1.000 & 0.009 & 0.968 & 0.070 & 0.824 & 0.087 \\
\hline Pooled & 0.965 & 0.020 & 0.935 & 0.026 & 0.982 & 0.020 & 0.993 & 0.026 & 0.848 & 0.038 \\
\hline N-Wt Mean & 0.963 & 0.044 & 0.937 & 0.032 & & & & & & \\
\hline
\end{tabular}


Table E.21. Detection histories for yearling Chinook salmon smolts released in the upper John Day Dam tailwater as reference releases for JBS passage survival. Headings of columns 2 through 9 have three digits and each digit represents a detection (1) or non-detection (0) at three successive survival-detection arrays (TDA_FB, BON_FB, and BTW1, respectively). A chisquare test for homogeneity, excluding pooled estimates, columns with $<5$ pooled detections, and totals, was significant $(\mathrm{P}=0.0090)$.

\begin{tabular}{lccccccccc}
\hline \multicolumn{1}{c}{ Date } & P_111 & P_011 & P_101 & P_001 & P_110 & P_010 & P_100 & P_000 & Total \\
\hline $5 / 02-5 / 07$ & 162 & 0 & 0 & 0 & 17 & 0 & 12 & 3 & 194 \\
$5 / 08-5 / 11$ & 123 & 0 & 1 & 0 & 15 & 1 & 11 & 3 & 154 \\
$5 / 12-5 / 15$ & 110 & 2 & 0 & 0 & 14 & 0 & 7 & 0 & 133 \\
$5 / 16-5 / 19$ & 125 & 0 & 0 & 0 & 27 & 0 & 11 & 3 & 166 \\
$5 / 20-5 / 23$ & 96 & 0 & 0 & 0 & 18 & 0 & 9 & 2 & 125 \\
$5 / 24-5 / 29$ & 141 & 0 & 3 & 0 & 50 & 0 & 10 & 4 & 208 \\
Pooled & 757 & 2 & 4 & 0 & 141 & 1 & 60 & 15 & 980 \\
\hline
\end{tabular}

Table E.22. Tag-life-corrected, single-release estimates of survival (S) and detection probabilities for yearling Chinook salmon smolts in JBS reference releases in the upper John Day Dam tailwater based on detections at three downstream arrays. Lambda is the product of survival and detection probabilities for the third array, and $\mathrm{CI}=$ confidence interval. The $\mathrm{N}-\mathrm{Wt}$ mean and confidence interval (weighted by numbers of fish in virtual releases) is preferred over the pooled estimate when capture histories are not homogeneous and some variance estimates approach zero and would overly weight high survival estimates.

\begin{tabular}{|c|c|c|c|c|c|c|c|c|c|c|}
\hline $\begin{array}{c}\text { Virtual } \\
\text { Release Dates }\end{array}$ & $\begin{array}{c}\text { S to } \\
1 \text { st } \\
\text { Array }\end{array}$ & $\begin{array}{c}1 / 2 \\
95 \% \\
\text { CI }\end{array}$ & $\begin{array}{l}\text { S from } \\
1 \text { st to } \\
2 \text { nd } \\
\text { Array }\end{array}$ & $\begin{array}{c}1 / 2 \\
95 \% \\
\text { CI }\end{array}$ & $\begin{array}{c}\text { Detect. } \\
\text { Prob. To } \\
\text { 1st } \\
\text { Array }\end{array}$ & $\begin{array}{c}1 / 2 \\
95 \% \\
\text { CI }\end{array}$ & $\begin{array}{l}\text { Detect. } \\
\text { Prob. from } \\
\text { 1st to 2nd } \\
\text { Array }\end{array}$ & $\begin{array}{c}1 / 2 \\
95 \% \\
\text { CI }\end{array}$ & Lambda & $\begin{array}{c}1 / 295 \% \\
\mathrm{CI}\end{array}$ \\
\hline $5 / 02-5 / 07$ & 0.985 & 0.017 & 0.942 & 0.036 & 1.000 & 0.017 & 1.000 & 0.036 & 0.906 & 0.043 \\
\hline $5 / 08-5 / 11$ & 0.981 & 0.022 & 0.928 & 0.042 & 0.993 & 0.022 & 0.992 & 0.042 & 0.885 & 0.053 \\
\hline $5 / 12-5 / 15$ & 1.000 & 0.008 & 0.947 & 0.038 & 0.985 & 0.008 & 1.000 & 0.038 & 0.889 & 0.055 \\
\hline $5 / 16-5 / 19$ & 0.982 & 0.020 & 0.933 & 0.039 & 1.000 & 0.020 & 1.000 & 0.039 & 0.822 & 0.061 \\
\hline $5 / 20-5 / 23$ & 0.984 & 0.022 & 0.927 & 0.046 & 1.000 & 0.022 & 1.000 & 0.046 & 0.842 & 0.067 \\
\hline $5 / 24-5 / 29$ & 0.991 & 0.019 & 0.958 & 0.030 & 1.000 & 0.019 & 0.979 & 0.030 & 0.741 & 0.063 \\
\hline Pooled & 0.987 & 0.008 & 0.940 & 0.015 & 0.997 & 0.008 & 0.995 & 0.015 & 0.843 & 0.024 \\
\hline N-Wt Mean & 0.987 & 0.005 & 0.940 & 0.010 & & & & & & \\
\hline
\end{tabular}

Table E.23. Tag-life-corrected, paired-release estimates of JBS-passage survival (S) for yearling Chinook salmon smolts in virtual releases from the JBS to the upper John Day Dam tailwater

\begin{tabular}{lcc}
\hline \multicolumn{1}{c}{ Paired Release } & S to Tailrace & $1 / 295 \%$ CI \\
\hline $5 / 02-5 / 07$ & 0.929 & 0.083 \\
$5 / 08-5 / 11$ & 1.007 & 0.040 \\
$5 / 12-5 / 15$ & 0.849 & 0.104 \\
$5 / 16-5 / 19$ & 1.002 & 0.041 \\
$5 / 20-5 / 23$ & 1.005 & 0.034 \\
$5 / 24-5 / 29$ & 1.009 & 0.021 \\
Pooled & 0.977 & 0.022 \\
N-Wt Mean & 0.976 & 0.045 \\
\hline
\end{tabular}




\section{Appendix F}

\section{Tag-Life-Corrected Survival Rates for Yearling Chinook at The Dalles Dam}


Table F.1. Detection histories for yearling Chinook salmon smolts detected and regrouped to form virtual releases at The Dalles Dam in spring for estimating dam survival. Headings of columns 2 through 9 have three digits and each digit represents a detection (1) or non-detection (0) at three successive survival-detection arrays (BON_FB, BTW1, and BTW2). A chi-square test for homogeneity, excluding pooled estimates, columns with $<5$ pooled detections, and totals, was significant $(\mathrm{P}<0.0010)$.

\begin{tabular}{|c|c|c|c|c|c|c|c|c|c|}
\hline Date & P_111 & P_011 & P_101 & P_001 & P_110 & P_010 & P_100 & P_000 & Total \\
\hline $5 / 4 / 2008$ & 71 & 6 & 2 & 1 & 19 & 0 & 1 & 10 & 110 \\
\hline $5 / 5 / 2008$ & 57 & 3 & 1 & 1 & 27 & 0 & 3 & 10 & 102 \\
\hline $5 / 6 / 2008$ & 70 & 4 & 8 & 0 & 27 & 2 & 3 & 11 & 125 \\
\hline $5 / 7 / 2008$ & 73 & 4 & 9 & 1 & 22 & 2 & 4 & 15 & 130 \\
\hline $5 / 8 / 2008$ & 51 & 6 & 20 & 2 & 20 & 1 & 7 & 14 & 121 \\
\hline $5 / 9 / 2008$ & 66 & 7 & 9 & 2 & 22 & 2 & 4 & 13 & 125 \\
\hline $5 / 10 / 2008$ & 84 & 8 & 10 & 2 & 23 & 1 & 5 & 5 & 138 \\
\hline $5 / 11 / 2008$ & 57 & 3 & 13 & 0 & 14 & 1 & 8 & 13 & 109 \\
\hline $5 / 12 / 2008$ & 70 & 8 & 13 & 2 & 26 & 0 & 3 & 18 & 140 \\
\hline $5 / 13 / 2008$ & 71 & 2 & 11 & 1 & 38 & 0 & 4 & 13 & 140 \\
\hline $5 / 14 / 2008$ & 48 & 8 & 10 & 1 & 15 & 4 & 4 & 13 & 103 \\
\hline $5 / 15 / 2008$ & 53 & 7 & 9 & 1 & 21 & 3 & 4 & 6 & 104 \\
\hline $5 / 16 / 2008$ & 49 & 13 & 16 & 3 & 20 & 2 & 10 & 7 & 120 \\
\hline $5 / 17 / 2008$ & 27 & 6 & 29 & 4 & 11 & 2 & 17 & 13 & 109 \\
\hline $5 / 18 / 2008$ & 37 & 6 & 28 & 4 & 18 & 5 & 26 & 23 & 147 \\
\hline $5 / 19 / 2008$ & 25 & 5 & 38 & 5 & 24 & 3 & 22 & 14 & 136 \\
\hline $5 / 20 / 2008$ & 31 & 3 & 21 & 5 & 21 & 6 & 30 & 21 & 138 \\
\hline $5 / 21 / 2008$ & 14 & 6 & 18 & 5 & 19 & 4 & 32 & 17 & 115 \\
\hline $5 / 22 / 2008$ & 17 & 4 & 17 & 5 & 32 & 3 & 28 & 14 & 120 \\
\hline $5 / 23 / 2008$ & 22 & 2 & 22 & 3 & 21 & 7 & 22 & 12 & 111 \\
\hline $5 / 24 / 2008$ & 17 & 8 & 11 & 6 & 30 & 2 & 25 & 15 & 114 \\
\hline $5 / 25 / 2008$ & 25 & 3 & 20 & 8 & 15 & 3 & 14 & 16 & 104 \\
\hline $5 / 26 / 2008$ & 18 & 4 & 32 & 6 & 21 & 4 & 22 & 21 & 128 \\
\hline $5 / 27 / 2008$ & 25 & 5 & 36 & 9 & 28 & 4 & 25 & 21 & 153 \\
\hline $5 / 28 / 2008$ & 13 & 4 & 30 & 7 & 17 & 1 & 20 & 21 & 113 \\
\hline $5 / 29 / 2008$ & 17 & 4 & 44 & 11 & 17 & 2 & 34 & 18 & 147 \\
\hline Pooled & 1108 & 139 & 477 & 95 & 568 & 64 & 377 & 374 & 3202 \\
\hline
\end{tabular}


Table F.2. Tag-life-corrected, single-release estimates of dam survival (S) and detection probabilities for yearling Chinook salmon smolts in virtual releases at The Dalles Dam based on detections at three downstream arrays. Lambda is the product of survival and detection probabilities for the third array, and $\mathrm{CI}=$ confidence interval.

\begin{tabular}{|c|c|c|c|c|c|c|c|c|c|c|}
\hline $\begin{array}{c}\text { Virtual } \\
\text { Release } \\
\text { Dates }\end{array}$ & $\begin{array}{c}\text { S to } 1 \text { st } \\
\text { Array }\end{array}$ & $\begin{array}{c}1 / 2 \\
95 \% \mathrm{CI}\end{array}$ & $\begin{array}{l}\text { S from } \\
1 \text { st to } \\
\text { 2nd } \\
\text { Array }\end{array}$ & $\begin{array}{c}1 / 2 \\
95 \% \mathrm{CI}\end{array}$ & $\begin{array}{c}\text { Detect. } \\
\text { Prob. To } \\
\text { 1st } \\
\text { Array }\end{array}$ & $\begin{array}{c}1 / 2 \\
95 \% \text { CI }\end{array}$ & $\begin{array}{l}\text { Detect. } \\
\text { Prob. } \\
\text { from } 1 \text { st } \\
\text { to } 2 \text { nd } \\
\text { Array }\end{array}$ & $\begin{array}{c}1 / 2 \\
95 \% \mathrm{CI}\end{array}$ & Lambda & $\begin{array}{c}1 / 2 \\
95 \% \mathrm{CI}\end{array}$ \\
\hline $5 / 4 / 2008$ & 0.972 & 0.049 & 0.945 & 0.047 & 1.000 & 0.049 & 0.938 & 0.047 & 0.968 & 0.036 \\
\hline $5 / 5 / 2008$ & 0.956 & 0.054 & 0.949 & 0.047 & 1.000 & 0.054 & 0.966 & 0.047 & 0.955 & 0.044 \\
\hline $5 / 6 / 2008$ & 0.956 & 0.047 & 0.972 & 0.036 & 1.000 & 0.047 & 0.942 & 0.036 & 0.899 & 0.057 \\
\hline $5 / 7 / 2008$ & 0.937 & 0.045 & 0.953 & 0.043 & 1.000 & 0.045 & 0.941 & 0.043 & 0.881 & 0.062 \\
\hline $5 / 8 / 2008$ & 0.960 & 0.042 & 0.944 & 0.059 & 1.000 & 0.042 & 0.910 & 0.059 & 0.725 & 0.089 \\
\hline $5 / 9 / 2008$ & 0.953 & 0.043 & 0.944 & 0.047 & 1.000 & 0.043 & 0.907 & 0.047 & 0.870 & 0.065 \\
\hline $5 / 10 / 2008$ & 0.974 & 0.028 & 0.987 & 0.026 & 1.000 & 0.028 & 0.922 & 0.026 & 0.877 & 0.058 \\
\hline $5 / 11 / 2008$ & 0.938 & 0.046 & 0.953 & 0.048 & 0.990 & 0.046 & 0.947 & 0.048 & 0.772 & 0.086 \\
\hline $5 / 12 / 2008$ & 0.894 & 0.051 & 0.971 & 0.036 & 1.000 & 0.051 & 0.923 & 0.036 & 0.857 & 0.065 \\
\hline $5 / 13 / 2008$ & 0.937 & 0.041 & 0.965 & 0.033 & 1.000 & 0.041 & 0.982 & 0.033 & 0.879 & 0.057 \\
\hline $5 / 14 / 2008$ & 0.923 & 0.052 & 0.965 & 0.055 & 1.000 & 0.052 & 0.840 & 0.055 & 0.818 & 0.086 \\
\hline $5 / 15 / 2008$ & 0.963 & 0.037 & 0.988 & 0.037 & 1.000 & 0.037 & 0.881 & 0.037 & 0.851 & 0.075 \\
\hline $5 / 16 / 2008$ & 0.959 & 0.036 & 1.000 & 0.000 & 1.000 & 0.036 & 0.827 & 0.000 & 0.731 & 0.081 \\
\hline $5 / 17 / 2008$ & 0.955 & 0.039 & 0.978 & 0.100 & 1.000 & 0.039 & 0.826 & 0.100 & 0.452 & 0.106 \\
\hline $5 / 18 / 2008$ & 0.954 & 0.034 & 0.934 & 0.082 & 1.000 & 0.034 & 0.833 & 0.082 & 0.506 & 0.094 \\
\hline $5 / 19 / 2008$ & 0.964 & 0.032 & 0.969 & 0.081 & 1.000 & 0.032 & 0.860 & 0.081 & 0.449 & 0.093 \\
\hline $5 / 20 / 2008$ & 0.921 & 0.045 & 0.952 & 0.079 & 1.000 & 0.045 & 0.853 & 0.079 & 0.504 & 0.096 \\
\hline $5 / 21 / 2008$ & 0.957 & 0.037 & 0.983 & 0.128 & 1.000 & 0.037 & 0.768 & 0.128 & 0.398 & 0.105 \\
\hline $5 / 22 / 2008$ & 0.969 & 0.032 & 0.925 & 0.080 & 0.990 & 0.032 & 0.875 & 0.080 & 0.522 & 0.101 \\
\hline $5 / 23 / 2008$ & 0.947 & 0.042 & 1.000 & 0.056 & 1.000 & 0.042 & 0.830 & 0.056 & 0.496 & 0.097 \\
\hline $5 / 24 / 2008$ & 0.932 & 0.047 & 0.949 & 0.086 & 0.989 & 0.047 & 0.825 & 0.086 & 0.566 & 0.107 \\
\hline $5 / 25 / 2008$ & 0.925 & 0.052 & 0.885 & 0.093 & 0.988 & 0.052 & 0.870 & 0.093 & 0.540 & 0.113 \\
\hline $5 / 26 / 2008$ & 0.930 & 0.044 & 0.942 & 0.102 & 1.000 & 0.044 & 0.830 & 0.102 & 0.419 & 0.100 \\
\hline $5 / 27 / 2008$ & 0.949 & 0.035 & 0.919 & 0.082 & 0.992 & 0.035 & 0.855 & 0.082 & 0.465 & 0.092 \\
\hline $5 / 28 / 2008$ & 0.952 & 0.042 & 0.868 & 0.113 & 0.977 & 0.042 & 0.857 & 0.113 & 0.375 & 0.106 \\
\hline $5 / 29 / 2008$ & 0.957 & 0.043 & 0.957 & 0.111 & 0.941 & 0.043 & 0.850 & 0.111 & 0.304 & 0.085 \\
\hline Pooled & 0.947 & 0.010 & 0.940 & 0.012 & 0.995 & 0.010 & 0.892 & 0.012 & 0.663 & 0.018 \\
\hline N-Wt Mean & 0.947 & 0.007 & 0.954 & 0.012 & & & & & & \\
\hline
\end{tabular}




\section{Appendix G}

\section{Tag-Life-Corrected Survival Rates for Lower Granite Dam Yearling Chinook at John Day Dam}


Table G.1. Detection histories for yearling Chinook salmon smolts released at Lower Granite Dam and detected and regrouped to form virtual releases at John Day Dam in spring for estimating dam survival. Headings of columns 2 through 9 have three digits and each digit represents a detection (1) or non-detection (0) at three successive survival-detection arrays (A3CR311, A4CR236, and A5CR203, respectively). A chi-square test for homogeneity, excluding pooled estimates, columns with $<5$ pooled detections, and totals, was significant $(\mathrm{P}<0.01)$.

\begin{tabular}{rrrrrrrrrrr}
\hline Date & P_111 & P_011 & P_101 & P_001 & P_110 & P_010 & P_100 & P_000 & Total \\
\hline $5 / 04-5 / 11$ & 20 & 0 & 9 & 0 & 10 & 0 & 11 & 7 & 57 \\
$5 / 12-5 / 13$ & 75 & 0 & 23 & 0 & 36 & 0 & 59 & 13 & 206 \\
$5 / 14-5 / 15$ & 78 & 1 & 34 & 0 & 29 & 1 & 39 & 24 & 206 \\
$5 / 16-5 / 17$ & 48 & 0 & 71 & 0 & 32 & 0 & 99 & 27 & 277 \\
$5 / 18-5 / 19$ & 48 & 0 & 95 & 0 & 58 & 0 & 176 & 32 & 409 \\
$5 / 20-5 / 21$ & 32 & 0 & 86 & 0 & 45 & 0 & 168 & 28 & 359 \\
$5 / 22-5 / 23$ & 39 & 1 & 60 & 1 & 60 & 1 & 143 & 60 & 365 \\
$5 / 24-5 / 25$ & 100 & 0 & 174 & 0 & 129 & 0 & 302 & 64 & 769 \\
$5 / 26-5 / 27$ & 20 & 1 & 56 & 0 & 29 & 0 & 100 & 24 & 230 \\
$5 / 28-5 / 29$ & 8 & 0 & 41 & 0 & 8 & 0 & 55 & 34 & 146 \\
Pooled & 468 & 3 & 649 & 1 & 436 & 2 & 1152 & 313 & 3024 \\
\hline
\end{tabular}

Table G.2. Tag-life-corrected, single-release estimates of dam survival (S) and detection probabilities for yearling Chinook salmon smolts released at Lower Granite Dam and regrouped to form virtual releases at John Day Dam based on three downstream arrays. Lambda is the product of survival and detection probabilities for the third array, and CI = confidence interval.

\begin{tabular}{|c|c|c|c|c|c|c|c|c|c|c|}
\hline $\begin{array}{c}\text { Virtual } \\
\text { Release } \\
\text { Dates }\end{array}$ & $\begin{array}{c}\mathrm{S} \text { to } 1 \mathrm{st} \\
\text { Array }\end{array}$ & $\begin{array}{c}1 / 2 \\
95 \% \\
\text { CI }\end{array}$ & $\begin{array}{l}\text { S from } \\
\text { 1st to } \\
\text { 2nd } \\
\text { Array }\end{array}$ & $\begin{array}{c}1 / 2 \\
95 \% \\
\text { CI }\end{array}$ & $\begin{array}{l}\text { Detect. } \\
\text { Prob. To } \\
\text { 1st Array }\end{array}$ & $\begin{array}{c}1 / 2 \\
95 \% \\
\text { CI }\end{array}$ & $\begin{array}{l}\text { Detect. } \\
\text { Prob. } \\
\text { from 1st } \\
\text { to } 2 \text { nd } \\
\text { Array }\end{array}$ & $\begin{array}{c}1 / 2 \\
95 \% \\
\text { CI }\end{array}$ & Lambda & $\begin{array}{c}1 / 2 \\
95 \% \\
\text { CI }\end{array}$ \\
\hline $5 / 04-5 / 11$ & 0.905 & 0.089 & 0.962 & 0.054 & 1.000 & 0.089 & 1.000 & 0.054 & 0.876 & 0.094 \\
\hline $5 / 12-5 / 13$ & 0.967 & 0.044 & 0.927 & 0.038 & 1.000 & 0.044 & 0.993 & 0.038 & 0.770 & 0.062 \\
\hline $5 / 14-5 / 15$ & 0.919 & 0.052 & 0.959 & 0.030 & 0.983 & 0.052 & 0.993 & 0.030 & 0.835 & 0.055 \\
\hline $5 / 16-5 / 17$ & 0.938 & 0.045 & 0.964 & 0.025 & 0.996 & 0.045 & 0.994 & 0.025 & 0.747 & 0.055 \\
\hline $5 / 18-5 / 19$ & 0.953 & 0.032 & 0.960 & 0.020 & 1.000 & 0.032 & 1.000 & 0.020 & 0.783 & 0.043 \\
\hline $5 / 20-5 / 21$ & 0.951 & 0.034 & 0.953 & 0.023 & 1.000 & 0.034 & 1.000 & 0.023 & 0.728 & 0.049 \\
\hline $5 / 22-5 / 23$ & 0.867 & 0.045 & 0.938 & 0.028 & 0.983 & 0.045 & 0.990 & 0.028 & 0.727 & 0.052 \\
\hline $5 / 24-5 / 25$ & 0.941 & 0.032 & 0.943 & 0.017 & 0.999 & 0.032 & 0.994 & 0.017 & 0.772 & 0.032 \\
\hline $5 / 26-5 / 27$ & 0.914 & 0.046 & 0.938 & 0.035 & 1.000 & 0.046 & 0.974 & 0.035 & 0.813 & 0.056 \\
\hline $5 / 28-5 / 29$ & 0.795 & 0.074 & 1.000 & 0.044 & 1.000 & 0.074 & 0.864 & 0.044 & 0.757 & 0.079 \\
\hline Pooled & 0.925 & 0.027 & 0.949 & 0.009 & 0.996 & 0.027 & 0.989 & 0.009 & 0.770 & 0.016 \\
\hline N-Wt Mean & 0.925 & 0.026 & 0.951 & 0.010 & & & & & & \\
\hline
\end{tabular}


Table G.3. Detection histories for yearling Chinook salmon smolts released in the upper John Day Dam tailwater as reference releases for virtual releases of yearling Chinook salmon from Lower Granite Dam. Headings of columns 2 through 9 have three digits and each digit represents a detection (1) or non-detection (0) at three successive survival-detection arrays (TDA_FB, BON_FB, and BTW1, respectively). A chi-square test for homogeneity, excluding pooled estimates, columns with $<5$ pooled detections, and totals, was not significant $(\mathrm{P}=0.1630)$.

\begin{tabular}{ccccccccccc}
\hline \multicolumn{1}{c}{ Date } & P_111 & P_011 & P_101 & P_001 & P_110 & P_010 & P_100 & P_000 & Total \\
\hline $5 / 04-5 / 11$ & 225 & 0 & 1 & 0 & 26 & 1 & 19 & 4 & 276 \\
$5 / 12-5 / 13$ & 49 & 0 & 0 & 0 & 6 & 0 & 4 & 0 & 59 \\
$5 / 14-5 / 15$ & 61 & 2 & 0 & 0 & 8 & 0 & 3 & 0 & 74 \\
$5 / 16-5 / 17$ & 64 & 0 & 0 & 0 & 16 & 0 & 6 & 1 & 87 \\
$5 / 18-5 / 19$ & 61 & 0 & 0 & 0 & 11 & 0 & 5 & 2 & 79 \\
$5 / 20-5 / 21$ & 44 & 0 & 0 & 0 & 8 & 0 & 3 & 1 & 56 \\
$5 / 22-5 / 23$ & 52 & 0 & 0 & 0 & 10 & 0 & 6 & 1 & 69 \\
$5 / 24-5 / 25$ & 45 & 0 & 0 & 0 & 15 & 0 & 5 & 2 & 67 \\
$5 / 26-5 / 27$ & 54 & 0 & 0 & 0 & 23 & 0 & 4 & 2 & 83 \\
$5 / 28-5 / 29$ & 42 & 0 & 3 & 0 & 12 & 0 & 1 & 0 & 58 \\
Pooled & 697 & 2 & 4 & 0 & 135 & 1 & 56 & 13 & 908 \\
\hline
\end{tabular}

Table G.4. Tag-life-corrected, single-release estimates of survival (S) and detection probabilities for yearling Chinook salmon smolts in reference releases for dam and non-TSW survival. Releases were in the upper John Day Dam tailwater. Lambda is the product of survival and detection probabilities for the third array, and $\mathrm{CI}=$ confidence interval.

\begin{tabular}{|c|c|c|c|c|c|c|c|c|c|c|}
\hline $\begin{array}{l}\text { Virtual } \\
\text { Release } \\
\text { Dates }\end{array}$ & $\begin{array}{c}\mathrm{S} \text { to } 1 \mathrm{st} \\
\text { Array }\end{array}$ & $\begin{array}{c}1 / 2 \\
95 \% \mathrm{CI}\end{array}$ & $\begin{array}{c}\text { S from } 1 \text { st } \\
\text { to } 2 \text { nd } \\
\text { Array }\end{array}$ & $\begin{array}{c}1 / 2 \\
95 \% \\
\text { CI }\end{array}$ & $\begin{array}{l}\text { Detect. } \\
\text { Prob. To } \\
\text { 1st Array }\end{array}$ & $\begin{array}{c}1 / 2 \\
95 \% \\
\text { CI }\end{array}$ & $\begin{array}{l}\text { Detect. } \\
\text { Prob. } \\
\text { from } 1 \text { st } \\
\text { to } 2 \text { nd } \\
\text { Array }\end{array}$ & $\begin{array}{c}1 / 2 \\
95 \% \mathrm{CI}\end{array}$ & Lambda & $\begin{array}{c}1 / 2 \\
95 \% \\
\text { CI }\end{array}$ \\
\hline $5 / 04-5 / 11$ & 0.986 & 0.014 & 0.931 & 0.030 & 0.996 & 0.014 & 0.996 & 0.030 & 0.893 & 0.038 \\
\hline $5 / 12-5 / 13$ & 1.000 & 0.011 & 0.932 & 0.064 & 1.000 & 0.011 & 1.000 & 0.064 & 0.891 & 0.083 \\
\hline $5 / 14-5 / 15$ & 1.000 & 0.010 & 0.960 & 0.045 & 0.973 & 0.010 & 1.000 & 0.045 & 0.887 & 0.074 \\
\hline $5 / 16-5 / 17$ & 0.989 & 0.022 & 0.930 & 0.054 & 1.000 & 0.022 & 1.000 & 0.054 & 0.800 & 0.088 \\
\hline $5 / 18-5 / 19$ & 0.975 & 0.035 & 0.935 & 0.055 & 1.000 & 0.035 & 1.000 & 0.055 & 0.847 & 0.083 \\
\hline $5 / 20-5 / 21$ & 0.982 & 0.035 & 0.946 & 0.060 & 1.000 & 0.035 & 1.000 & 0.060 & 0.846 & 0.098 \\
\hline $5 / 22-5 / 23$ & 0.986 & 0.028 & 0.912 & 0.067 & 1.000 & 0.028 & 1.000 & 0.067 & 0.839 & 0.092 \\
\hline $5 / 24-5 / 25$ & 0.970 & 0.041 & 0.923 & 0.065 & 1.000 & 0.041 & 1.000 & 0.065 & 0.750 & 0.110 \\
\hline $5 / 26-5 / 27$ & 0.976 & 0.033 & 0.951 & 0.047 & 1.000 & 0.033 & 1.000 & 0.047 & 0.702 & 0.102 \\
\hline $5 / 28-5 / 29$ & 1.000 & 0.012 & 1.000 & 0.027 & 1.000 & 0.012 & 0.936 & 0.027 & 0.788 & 0.109 \\
\hline Pooled & 0.988 & 0.008 & 0.939 & 0.016 & 0.996 & 0.008 & 0.994 & 0.016 & 0.8377 & 0.025 \\
\hline
\end{tabular}


Table G.5. Tag-life-corrected, paired-release estimates of dam survival (S) for yearling Chinook salmon smolts released from Lower Granite Dam, regrouped in virtual releases, and traveling from the forebay to the upper John Day Dam tailwater

\begin{tabular}{lcc}
\hline \multicolumn{1}{c}{ Paired Release } & S to Tailrace & $1 / 295 \% \mathrm{CI}$ \\
\hline $5 / 04-5 / 11$ & 0.918 & 0.092 \\
$5 / 12-5 / 13$ & 0.967 & 0.045 \\
$5 / 14-5 / 15$ & 0.919 & 0.053 \\
$5 / 16-5 / 17$ & 0.949 & 0.050 \\
$5 / 18-5 / 19$ & 0.978 & 0.048 \\
$5 / 20-5 / 21$ & 0.968 & 0.049 \\
$5 / 22-5 / 23$ & 0.880 & 0.052 \\
$5 / 24-5 / 25$ & 0.970 & 0.052 \\
$5 / 26-5 / 27$ & 0.936 & 0.057 \\
$5 / 28-5 / 29$ & 0.795 & 0.074 \\
Pooled & 0.936 & 0.029 \\
N-Wt Mean & 0.938 & 0.028 \\
\hline
\end{tabular}




\section{Appendix $\mathrm{H}$}

\section{Tag-Life-Corrected Survival Rates for Steelhead at John Day Dam}


Table H.1. Detection histories for steelhead smolts detected and regrouped to form virtual releases at John Day Dam in spring for estimating dam survival. Headings of columns 2 through 9 have three digits and each digit represents a detection (1) or non-detection (0) at three successive survival-detection arrays (TDA_FB, BON_FB, and BTW1, respectively). A chi-square test for homogeneity, excluding pooled estimates, columns with $\leq 5$ pooled detections, and totals, was significant $(\mathrm{P}<0.0010)$.

\begin{tabular}{cccccccccc}
\hline \multicolumn{1}{c}{ Date } & P_111 & P_011 & P_101 & P_001 & P_110 & P_010 & P_100 & P_000 & Total \\
\hline $5 / 02-5 / 03$ & 38 & 0 & 0 & 0 & 17 & 0 & 3 & 4 & 62 \\
$5 / 04-5 / 05$ & 89 & 0 & 4 & 0 & 45 & 0 & 5 & 10 & 153 \\
$5 / 06-5 / 07$ & 77 & 0 & 13 & 0 & 47 & 0 & 16 & 5 & 158 \\
$5 / 08-5 / 09$ & 144 & 2 & 39 & 0 & 43 & 2 & 22 & 5 & 257 \\
$5 / 10-5 / 11$ & 72 & 0 & 25 & 0 & 44 & 0 & 21 & 6 & 168 \\
$5 / 12-5 / 13$ & 85 & 0 & 11 & 0 & 54 & 0 & 26 & 15 & 191 \\
$5 / 14-5 / 15$ & 49 & 3 & 19 & 0 & 42 & 1 & 30 & 13 & 157 \\
$5 / 16-5 / 17$ & 35 & 0 & 27 & 0 & 27 & 0 & 44 & 9 & 142 \\
$5 / 18-5 / 19$ & 29 & 0 & 41 & 0 & 37 & 0 & 86 & 11 & 204 \\
$5 / 20-5 / 21$ & 19 & 0 & 26 & 0 & 39 & 0 & 65 & 6 & 155 \\
$5 / 22-5 / 23$ & 16 & 0 & 23 & 0 & 51 & 1 & 77 & 8 & 176 \\
$5 / 24-5 / 25$ & 23 & 0 & 34 & 0 & 41 & 0 & 64 & 5 & 167 \\
$5 / 26-5 / 27$ & 28 & 0 & 32 & 0 & 37 & 0 & 80 & 9 & 186 \\
$5 / 28-5 / 29$ & 18 & 0 & 24 & 0 & 33 & 0 & 77 & 4 & 156 \\
Pooled & 722 & 5 & 318 & 0 & 557 & 4 & 616 & 110 & 2332 \\
\hline
\end{tabular}

H.1 
Table H.2. Tag-life-corrected, single-release estimates of dam survival (S) and detection probabilities for steelhead smolts in virtual releases at John Day Dam based on three downstream arrays. Lambda is the product of survival and detection probabilities for the third array, and $\mathrm{CI}=$ confidence interval. The N-Wt mean and confidence interval (weighted by numbers of fish in virtual releases) is preferred over the pooled estimate when capture histories are not homogeneous and some variance estimates approach zero and would overly weight high survival estimates.

\begin{tabular}{|c|c|c|c|c|c|c|c|c|c|c|}
\hline $\begin{array}{c}\text { Virtual } \\
\text { Release } \\
\text { Dates }\end{array}$ & $\begin{array}{c}\mathrm{S} \text { to } 1 \mathrm{st} \\
\text { Array }\end{array}$ & $\begin{array}{c}1 / 2 \\
95 \% \mathrm{CI}\end{array}$ & $\begin{array}{l}\text { S from } \\
1 \text { st to } \\
2 \text { nd } \\
\text { Array }\end{array}$ & $\begin{array}{c}1 / 2 \\
95 \% \mathrm{CI}\end{array}$ & $\begin{array}{c}\text { Detect. } \\
\text { Prob. To } \\
\text { 1st } \\
\text { Array }\end{array}$ & $\begin{array}{c}1 / 2 \\
95 \% \\
\text { CI } \\
\end{array}$ & $\begin{array}{l}\text { Detect. } \\
\text { Prob. from } \\
\text { 1st to 2nd } \\
\text { Array }\end{array}$ & $\begin{array}{c}1 / 2 \\
95 \% \mathrm{CI} \\
\end{array}$ & Lambda & $\begin{array}{c}1 / 2 \\
95 \% \mathrm{CI} \\
\end{array}$ \\
\hline $5 / 02-5 / 03$ & 0.951 & 0.062 & 1.000 & 0.000 & 1.000 & 0.062 & 1.000 & 0.000 & 0.932 & 0.065 \\
\hline $5 / 04-5 / 05$ & 0.957 & 0.040 & 1.000 & 0.000 & 1.000 & 0.040 & 1.000 & 0.000 & 0.887 & 0.052 \\
\hline $5 / 06-5 / 07$ & 0.979 & 0.030 & 0.968 & 0.028 & 1.000 & 0.030 & 1.000 & 0.028 & 0.902 & 0.049 \\
\hline $5 / 08-5 / 09$ & 0.994 & 0.015 & 0.981 & 0.022 & 0.976 & 0.015 & 1.000 & 0.022 & 0.921 & 0.034 \\
\hline $5 / 10-5 / 11$ & 0.967 & 0.028 & 0.970 & 0.027 & 1.000 & 0.028 & 1.000 & 0.027 & 0.898 & 0.047 \\
\hline $5 / 12-5 / 13$ & 0.922 & 0.038 & 0.921 & 0.040 & 1.000 & 0.038 & 1.000 & 0.040 & 0.914 & 0.043 \\
\hline $5 / 14-5 / 15$ & 0.926 & 0.042 & 0.943 & 0.038 & 0.964 & 0.042 & 1.000 & 0.038 & 0.884 & 0.054 \\
\hline $5 / 16-5 / 17$ & 0.938 & 0.040 & 0.947 & 0.038 & 1.000 & 0.040 & 1.000 & 0.038 & 0.856 & 0.061 \\
\hline $5 / 18-5 / 19$ & 0.951 & 0.030 & 0.943 & 0.033 & 0.995 & 0.030 & 1.000 & 0.033 & 0.814 & 0.056 \\
\hline $5 / 20-5 / 21$ & 0.961 & 0.030 & 0.947 & 0.036 & 1.000 & 0.030 & 1.000 & 0.036 & 0.759 & 0.071 \\
\hline $5 / 22-5 / 23$ & 0.967 & 0.027 & 0.952 & 0.032 & 0.982 & 0.027 & 1.000 & 0.032 & 0.828 & 0.058 \\
\hline $5 / 24-5 / 25$ & 0.970 & 0.026 & 0.963 & 0.029 & 1.000 & 0.026 & 1.000 & 0.029 & 0.814 & 0.061 \\
\hline $5 / 26-5 / 27$ & 0.952 & 0.031 & 0.956 & 0.031 & 1.000 & 0.031 & 0.993 & 0.031 & 0.816 & 0.059 \\
\hline $5 / 28-5 / 29$ & 0.975 & 0.025 & 0.981 & 0.035 & 1.000 & 0.025 & 0.912 & 0.035 & 0.765 & 0.071 \\
\hline Pooled & 0.959 & 0.010 & 0.960 & 0.009 & 0.993 & 0.010 & 0.994 & 0.009 & 0.856 & 0.015 \\
\hline N-Wt Mean & 0.959 & 0.011 & 0.960 & 0.011 & & & & & & \\
\hline
\end{tabular}


Table H.3. Detection histories for steelhead smolts released in the upper John Day Dam tailwater as reference releases for estimating dam passage survival and TSW passage survival. Headings of columns 2 through 9 have three digits and each digit represents a detection (1) or nondetection (0) at three successive survival-detection arrays (TDA_FB, BON_FB, and BTW1, respectively). A chi-square test for homogeneity, excluding pooled estimates, columns with $\leq 5$ pooled detections, and totals, was significant $(\mathrm{P}<0.0010)$.

\begin{tabular}{cccccccccc}
\hline Date & P_111 & P_011 & P_101 & P_001 & P_110 & P_010 & P_100 & P_000 & Total \\
\hline $5 / 02-5 / 03$ & 60 & 0 & 0 & 0 & 6 & 0 & 4 & 2 & 72 \\
$5 / 04-5 / 05$ & 54 & 0 & 0 & 0 & 4 & 0 & 1 & 0 & 59 \\
$5 / 06-5 / 07$ & 48 & 0 & 0 & 0 & 9 & 0 & 6 & 0 & 63 \\
$5 / 08-5 / 09$ & 50 & 3 & 0 & 0 & 8 & 0 & 5 & 1 & 67 \\
$5 / 10-5 / 11$ & 68 & 0 & 0 & 0 & 8 & 0 & 8 & 2 & 86 \\
$5 / 12-5 / 13$ & 46 & 0 & 0 & 0 & 6 & 0 & 1 & 4 & 57 \\
$5 / 14-5 / 15$ & 54 & 1 & 1 & 0 & 5 & 0 & 7 & 2 & 70 \\
$5 / 16-5 / 17$ & 61 & 0 & 0 & 0 & 14 & 0 & 4 & 6 & 85 \\
$5 / 18-5 / 19$ & 51 & 0 & 0 & 0 & 19 & 0 & 5 & 6 & 81 \\
$5 / 20-5 / 21$ & 43 & 0 & 0 & 0 & 12 & 0 & 2 & 0 & 57 \\
$5 / 22-5 / 23$ & 49 & 3 & 1 & 0 & 18 & 0 & 2 & 1 & 74 \\
$5 / 24-5 / 25$ & 52 & 0 & 0 & 0 & 12 & 0 & 2 & 3 & 69 \\
$5 / 26-5 / 27$ & 60 & 0 & 0 & 0 & 13 & 0 & 5 & 0 & 78 \\
$5 / 28-5 / 29$ & 41 & 0 & 3 & 0 & 12 & 0 & 4 & 1 & 61 \\
Pooled & 737 & 7 & 5 & 0 & 146 & 0 & 56 & 28 & 979 \\
\hline
\end{tabular}


Table H.4. Tag-life-corrected, single-release estimates of survival (S) and detection probabilities for steelhead smolts in reference releases for dam passage survival and TSW passage survival. Releases were in the upper John Day Dam tailwater. Lambda is the product of survival and detection probabilities for the third array, and $\mathrm{CI}=$ confidence interval. The $\mathrm{N}-\mathrm{Wt}$ mean and confidence interval (weighted by numbers of fish in virtual releases) is preferred over the pooled estimate when capture histories are not homogeneous and some variance estimates approach zero and would overly weight high survival estimates.

\begin{tabular}{|c|c|c|c|c|c|c|c|c|c|c|}
\hline $\begin{array}{c}\text { Release } \\
\text { Dates }\end{array}$ & $\begin{array}{c}\text { S to } 1 \text { st } \\
\text { Array }\end{array}$ & $\begin{array}{c}1 / 2 \\
95 \% \mathrm{CI}\end{array}$ & $\begin{array}{l}\text { S from } \\
\text { 1st to } \\
2 \text { nd } \\
\text { Array }\end{array}$ & $\begin{array}{c}1 / 2 \\
95 \% \mathrm{CI}\end{array}$ & $\begin{array}{c}\text { Detect. } \\
\text { Prob. To } \\
\text { 1st } \\
\text { Array }\end{array}$ & $\begin{array}{c}1 / 2 \\
95 \% \mathrm{CI}\end{array}$ & $\begin{array}{l}\text { Detect. } \\
\text { Prob. } \\
\text { from } 1 \mathrm{st} \\
\text { to } 2 \mathrm{nd} \\
\text { Array }\end{array}$ & $\begin{array}{c}1 / 2 \\
95 \% \mathrm{CI}\end{array}$ & Lambda & $\begin{array}{c}1 / 2 \\
95 \% \mathrm{CI}\end{array}$ \\
\hline $5 / 02-5 / 03$ & 0.974 & 0.038 & 0.960 & 0.061 & 1.000 & 0.038 & 1.000 & 0.061 & 0.913 & 0.070 \\
\hline $5 / 04-5 / 05$ & 1.000 & 0.011 & 0.983 & 0.033 & 1.000 & 0.011 & 1.000 & 0.033 & 0.932 & 0.065 \\
\hline $5 / 06-5 / 07$ & 1.000 & 0.011 & 0.905 & 0.073 & 1.000 & 0.011 & 1.000 & 0.073 & 0.842 & 0.095 \\
\hline $5 / 08-5 / 09$ & 0.989 & 0.030 & 0.921 & 0.067 & 0.951 & 0.030 & 1.000 & 0.067 & 0.869 & 0.085 \\
\hline $5 / 10-5 / 11$ & 0.977 & 0.032 & 0.905 & 0.063 & 1.000 & 0.032 & 1.000 & 0.063 & 0.895 & 0.069 \\
\hline $5 / 12-5 / 13$ & 0.930 & 0.066 & 0.981 & 0.037 & 1.000 & 0.066 & 1.000 & 0.037 & 0.885 & 0.087 \\
\hline $5 / 14-5 / 15$ & 0.973 & 0.039 & 0.897 & 0.074 & 0.984 & 0.039 & 0.982 & 0.074 & 0.917 & 0.070 \\
\hline $5 / 16-5 / 17$ & 0.929 & 0.054 & 0.949 & 0.048 & 1.000 & 0.054 & 1.000 & 0.048 & 0.814 & 0.088 \\
\hline $5 / 18-5 / 19$ & 0.926 & 0.057 & 0.933 & 0.056 & 1.000 & 0.057 & 1.000 & 0.056 & 0.729 & 0.104 \\
\hline $5 / 20-5 / 21$ & 1.000 & 0.012 & 0.965 & 0.048 & 1.000 & 0.012 & 1.000 & 0.048 & 0.782 & 0.109 \\
\hline $5 / 22-5 / 23$ & 0.988 & 0.026 & 0.976 & 0.040 & 0.958 & 0.026 & 0.981 & 0.040 & 0.743 & 0.102 \\
\hline $5 / 24-5 / 25$ & 0.957 & 0.048 & 0.970 & 0.041 & 1.000 & 0.048 & 1.000 & 0.041 & 0.814 & 0.096 \\
\hline $5 / 26-5 / 27$ & 1.000 & 0.000 & 0.936 & 0.054 & 1.000 & 0.000 & 1.000 & 0.054 & 0.822 & 0.088 \\
\hline $5 / 28-5 / 29$ & 1.000 & 0.023 & 0.946 & 0.067 & 1.000 & 0.023 & 0.932 & 0.067 & 0.766 & 0.112 \\
\hline Pooled & 0.973 & 0.010 & 0.943 & 0.015 & 0.992 & 0.010 & 0.993 & 0.015 & 0.836 & 0.024 \\
\hline N-Wt Mean & 0.973 & 0.015 & 0.943 & 0.015 & & & & & & \\
\hline
\end{tabular}


Table H.5. Tag-life-corrected, paired-release estimates of dam survival (S) for steelhead smolts in virtual releases from the John Day Dam face to the upper John Day Dam tailwater

\begin{tabular}{lcc}
\hline Paired Release & S to Tailrace & $1 / 295 \%$ CI \\
\hline $5 / 02-5 / 03$ & 0.977 & 0.074 \\
$5 / 04-5 / 05$ & 0.957 & 0.042 \\
$5 / 06-5 / 07$ & 0.979 & 0.032 \\
$5 / 08-5 / 09$ & 1.005 & 0.034 \\
$5 / 10-5 / 11$ & 0.990 & 0.043 \\
$5 / 12-5 / 13$ & 0.991 & 0.082 \\
$5 / 14-5 / 15$ & 0.951 & 0.058 \\
$5 / 16-5 / 17$ & 1.009 & 0.073 \\
$5 / 18-5 / 19$ & 1.028 & 0.071 \\
$5 / 20-5 / 21$ & 0.961 & 0.032 \\
$5 / 22-5 / 23$ & 0.979 & 0.038 \\
$5 / 24-5 / 25$ & 1.014 & 0.058 \\
$5 / 26-5 / 27$ & 0.952 & 0.031 \\
$5 / 28-5 / 29$ & 0.975 & 0.033 \\
Pooled & 0.986 & 0.015 \\
N-Wt Mean & 0.986 & 0.019 \\
\hline
\end{tabular}

Table H.6. Detection histories for steelhead smolts detected and regrouped to form virtual releases at non-TSW spill bays in spring. Headings of columns 2 through 9 have three digits and each digit represents a detection (1) or non-detection (0) at three successive survival-detection arrays (TDA_FB, BON_FB, and BTW1, respectively). A chi-square test for homogeneity, excluding pooled estimates, columns with $<5$ pooled detections, and totals, was significant $(\mathrm{P}<0.0010)$.

\begin{tabular}{lccccccccc}
\hline \multicolumn{1}{c}{ Date } & P_111 & P_011 & P_101 & P_001 & P_110 & P_010 & P_100 & P_000 & Total \\
\hline $5 / 02-5 / 05$ & 46 & 0 & 1 & 0 & 19 & 0 & 2 & 5 & 73 \\
$5 / 06-5 / 09$ & 30 & 0 & 8 & 0 & 18 & 1 & 6 & 2 & 65 \\
$5 / 10-5 / 13$ & 30 & 0 & 8 & 0 & 24 & 0 & 13 & 3 & 78 \\
$5 / 14-5 / 17$ & 11 & 0 & 9 & 0 & 14 & 0 & 9 & 5 & 48 \\
$5 / 18-5 / 21$ & 12 & 0 & 19 & 0 & 25 & 0 & 46 & 7 & 109 \\
$5 / 22-5 / 25$ & 15 & 0 & 18 & 0 & 27 & 0 & 38 & 5 & 103 \\
$5 / 26-5 / 29$ & 11 & 0 & 17 & 0 & 19 & 0 & 55 & 2 & 104 \\
Pooled & 155 & 0 & 80 & 0 & 146 & 1 & 169 & 29 & 580 \\
\hline
\end{tabular}


Table H.7. Tag-life-corrected, single-release estimates of non-TSW spill bay passage survival (S) and detection probabilities for steelhead smolts in virtual releases at John Day Dam based on detections at three downstream arrays. Lambda is the product of survival and detection probabilities for the third array, and $\mathrm{CI}=$ confidence interval. The N-Wt Mean (weighted by numbers of fish in virtual releases) is preferred over the pooled estimate when capture histories are not homogeneous and some variance estimates approach zero and would overly weight high survival estimates.

\begin{tabular}{|c|c|c|c|c|c|c|c|c|c|c|}
\hline $\begin{array}{c}\text { Virtual } \\
\text { Release } \\
\text { Dates }\end{array}$ & $\begin{array}{c}\mathrm{S} \text { to } 1 \mathrm{st} \\
\text { Array }\end{array}$ & $\begin{array}{c}1 / 2 \\
95 \% \mathrm{CI}\end{array}$ & $\begin{array}{c}\text { S from } \\
1 \text { st to } \\
\text { 2nd } \\
\text { Array }\end{array}$ & $\begin{array}{c}1 / 2 \\
95 \% \mathrm{CI}\end{array}$ & $\begin{array}{c}\text { Detect. } \\
\text { Prob. To } \\
1 \text { st } \\
\text { Array } \\
\end{array}$ & $\begin{array}{c}1 / 2 \\
95 \% \mathrm{CI}\end{array}$ & $\begin{array}{l}\text { Detect. } \\
\text { Prob. } \\
\text { from 1st } \\
\text { to } 2 \mathrm{nd} \\
\text { Array }\end{array}$ & $\begin{array}{c}1 / 2 \\
95 \% \\
\mathrm{CI} \\
\end{array}$ & Lambda & $\begin{array}{c}1 / 2 \\
95 \% \mathrm{CI}\end{array}$ \\
\hline $5 / 02-5 / 05$ & 0.951 & 0.059 & 1.000 & 0.011 & 1.000 & 0.059 & 1.000 & 0.011 & 0.927 & 0.062 \\
\hline $5 / 06-5 / 09$ & 0.991 & 0.031 & 0.955 & 0.054 & 0.967 & 0.031 & 1.000 & 0.054 & 0.969 & 0.045 \\
\hline $5 / 10-5 / 13$ & 0.964 & 0.043 & 0.934 & 0.056 & 1.000 & 0.043 & 1.000 & 0.056 & 0.928 & 0.060 \\
\hline $5 / 14-5 / 17$ & 0.917 & 0.078 & 0.977 & 0.045 & 0.977 & 0.078 & 1.000 & 0.045 & 0.907 & 0.087 \\
\hline $5 / 18-5 / 21$ & 0.936 & 0.046 & 0.922 & 0.052 & 1.000 & 0.046 & 1.000 & 0.052 & 0.798 & 0.081 \\
\hline $5 / 22-5 / 25$ & 0.962 & 0.037 & 0.959 & 0.039 & 0.990 & 0.037 & 1.000 & 0.039 & 0.811 & 0.079 \\
\hline $5 / 26-5 / 29$ & 0.981 & 0.026 & 0.966 & 0.038 & 1.000 & 0.026 & 0.954 & 0.038 & 0.884 & 0.065 \\
\hline Pooled & 0.959 & 0.018 & 0.957 & 0.018 & 0.992 & 0.018 & 0.991 & 0.018 & 0.879 & 0.028 \\
\hline N-Wt Mean & 0.959 & 0.017 & 0.956 & 0.019 & & & & & & \\
\hline
\end{tabular}

Table H.8. Detection histories for steelhead smolts released in the upper John Day Dam tailwater as reference releases for fish passing non-TSW spill bays in spring. Headings of columns 2 through 9 have three digits and each digit represents a detection (1) or non-detection (0) at three successive survival-detection arrays (TDA_FB, BON_FB, and BTW1, respectively). A chi-square test for homogeneity, excluding pooled estimates, columns with $<5$ pooled detections, and totals, was significant $(\mathrm{P}<0.0010)$.

\begin{tabular}{lcrrrrrrrc}
\hline \multicolumn{1}{c}{ Date } & P_111 & P_011 & P_101 & P_001 & P_110 & P_010 & P_100 & P_000 & Total \\
\hline $5 / 02-5 / 05$ & 85 & 0 & 7 & 0 & 25 & 0 & 12 & 2 & 131 \\
$5 / 06-5 / 09$ & 55 & 2 & 24 & 0 & 30 & 1 & 17 & 1 & 130 \\
$5 / 10-5 / 13$ & 69 & 0 & 8 & 0 & 38 & 0 & 22 & 6 & 143 \\
$5 / 14-5 / 17$ & 35 & 0 & 25 & 1 & 33 & 0 & 53 & 8 & 155 \\
$5 / 18-5 / 21$ & 18 & 0 & 25 & 0 & 32 & 0 & 57 & 6 & 138 \\
$5 / 22-5 / 25$ & 29 & 0 & 26 & 1 & 32 & 1 & 49 & 5 & 143 \\
$5 / 26-5 / 29$ & 14 & 0 & 30 & 0 & 30 & 0 & 64 & 1 & 139 \\
Pooled & 305 & 2 & 145 & 2 & 220 & 2 & 274 & 29 & 979 \\
\hline
\end{tabular}


Table H.9. Tag-life-corrected, paired-release estimates of survival (S) for steelhead smolts in reference releases in the upper John Day Dam tailwater for fish passing non-TSW bays in spring. The $\mathrm{N}-\mathrm{Wt}$ mean and confidence interval (weighted by numbers of fish in releases) is preferred over the pooled estimate when capture histories are not homogeneous and some variance estimates approach zero and would overly weight high survival estimates.

\begin{tabular}{|c|c|c|c|c|c|c|c|c|c|c|}
\hline $\begin{array}{c}\text { Release } \\
\text { Dates }\end{array}$ & $\begin{array}{c}\mathrm{S} \text { to } 1 \text { st } \\
\text { Array }\end{array}$ & $\begin{array}{c}1 / 2 \\
95 \% \mathrm{CI}\end{array}$ & $\begin{array}{l}\text { S from } \\
\text { 1st to } \\
2 \text { nd } \\
\text { Array }\end{array}$ & $\begin{array}{c}1 / 2 \\
95 \% \mathrm{CI}\end{array}$ & $\begin{array}{l}\text { Detect. } \\
\text { Prob. To } \\
\text { 1st Array }\end{array}$ & $\begin{array}{c}1 / 2 \\
95 \% \mathrm{CI}\end{array}$ & $\begin{array}{l}\text { Detect. } \\
\text { Prob. } \\
\text { from } 1 \text { st } \\
\text { to } 2 \text { nd } \\
\text { Array }\end{array}$ & $\begin{array}{c}1 / 2 \\
95 \% \mathrm{CI}\end{array}$ & Lambda & $\begin{array}{c}1 / 2 \\
95 \% \mathrm{CI}\end{array}$ \\
\hline $5 / 02-5 / 05$ & 0.986 & 0.021 & 0.971 & 0.038 & 1.000 & 0.021 & 1.000 & 0.038 & 0.922 & 0.048 \\
\hline $5 / 06-5 / 09$ & 0.995 & 0.015 & 0.913 & 0.049 & 0.975 & 0.015 & 1.000 & 0.049 & 0.856 & 0.063 \\
\hline $5 / 10-5 / 13$ & 0.958 & 0.033 & 0.935 & 0.042 & 1.000 & 0.033 & 1.000 & 0.042 & 0.891 & 0.054 \\
\hline $5 / 14-5 / 17$ & 0.949 & 0.035 & 0.926 & 0.043 & 0.993 & 0.035 & 0.992 & 0.043 & 0.860 & 0.059 \\
\hline $5 / 18-5 / 21$ & 0.957 & 0.034 & 0.947 & 0.038 & 1.000 & 0.034 & 1.000 & 0.038 & 0.752 & 0.076 \\
\hline $5 / 22-5 / 25$ & 0.973 & 0.027 & 0.973 & 0.029 & 0.978 & 0.027 & 0.991 & 0.029 & 0.777 & 0.071 \\
\hline $5 / 26-5 / 29$ & 1.000 & 0.014 & 0.939 & 0.042 & 1.000 & 0.014 & 0.971 & 0.042 & 0.798 & 0.069 \\
\hline Pooled & 0.973 & 0.010 & 0.943 & 0.015 & 0.992 & 0.010 & 0.993 & 0.015 & 0.836 & 0.024 \\
\hline N-Wt Mean & 0.973 & 0.015 & 0.943 & 0.016 & & & & & & \\
\hline
\end{tabular}

Table H.10. Tag-life-corrected, paired-release estimates of dam survival (S) for steelhead smolts in virtual releases from non-TSW spill bays to the upper John Day Dam tailwater

\begin{tabular}{lcc}
\hline Paired Release & S to Tailrace & $1 / 295 \%$ CI \\
\hline $5 / 02-5 / 05$ & 0.965 & 0.063 \\
$5 / 06-5 / 09$ & 0.996 & 0.035 \\
$5 / 10-5 / 13$ & 1.006 & 0.057 \\
$5 / 14-5 / 17$ & 0.967 & 0.090 \\
$5 / 18-5 / 21$ & 0.979 & 0.059 \\
$5 / 22-5 / 25$ & 0.988 & 0.047 \\
$5 / 26-5 / 29$ & 0.981 & 0.030 \\
Pooled & 0.985 & 0.021 \\
N-Wt Mean & 0.985 & 0.023 \\
\hline
\end{tabular}


Table H.11. Detection histories for steelhead smolts detected and regrouped to form virtual releases at TSW spill bays in spring. Headings of columns 2 through 9 have three digits and each digit represents a detection (1) or non-detection (0) at three successive survival-detection arrays (TDA_FB, BON_FB, and BTW1, respectively). A chi-square test for homogeneity, excluding pooled estimates, columns with $<5$ pooled detections, and totals, was significant $(\mathrm{P}<0.0010)$.

\begin{tabular}{cccrrrrrrr}
\hline Date & P_111 & P_011 & P_101 & P_001 & P_110 & P_010 & P_100 & P_000 & Total \\
\hline $5 / 02-5 / 03$ & 11 & 0 & 0 & 0 & 5 & 0 & 2 & 2 & 20 \\
$5 / 04-5 / 05$ & 45 & 0 & 2 & 0 & 24 & 0 & 3 & 2 & 76 \\
$5 / 06-5 / 07$ & 43 & 0 & 8 & 0 & 32 & 0 & 11 & 1 & 95 \\
$5 / 08-5 / 09$ & 85 & 1 & 24 & 0 & 24 & 1 & 11 & 1 & 147 \\
$5 / 10-5 / 11$ & 48 & 0 & 12 & 0 & 26 & 0 & 9 & 4 & 99 \\
$5 / 12-5 / 13$ & 53 & 0 & 7 & 0 & 25 & 0 & 14 & 11 & 110 \\
$5 / 14-5 / 15$ & 31 & 2 & 8 & 0 & 23 & 1 & 16 & 5 & 86 \\
$5 / 16-5 / 17$ & 25 & 0 & 16 & 0 & 17 & 0 & 30 & 5 & 93 \\
$5 / 18-5 / 19$ & 17 & 0 & 18 & 0 & 10 & 0 & 32 & 4 & 81 \\
$5 / 20-5 / 21$ & 10 & 0 & 8 & 0 & 21 & 0 & 25 & 1 & 65 \\
$5 / 22-5 / 23$ & 3 & 0 & 7 & 0 & 20 & 0 & 29 & 3 & 62 \\
$5 / 24-5 / 25$ & 12 & 0 & 14 & 0 & 13 & 0 & 27 & 3 & 69 \\
$5 / 26-5 / 27$ & 16 & 0 & 18 & 0 & 22 & 0 & 38 & 5 & 99 \\
$5 / 28-5 / 29$ & 7 & 0 & 11 & 0 & 9 & 0 & 28 & 0 & 55 \\
Pooled & 406 & 3 & 153 & 0 & 271 & 2 & 275 & 47 & 1157 \\
\hline
\end{tabular}


Table H.12. Tag-life-corrected, single-release estimates of TSW survival (S) and detection probabilities for steelhead smolts in virtual releases at John Day Dam based on detections at three downstream arrays. Lambda is the product of survival and detection probabilities for the third array, and $\mathrm{CI}=$ confidence interval. The N-Wt mean and confidence interval (weighted by numbers of fish in releases) is preferred over the pooled estimate when capture histories are not homogeneous and some variance estimates approach zero and would overly weight high survival estimates.

\begin{tabular}{|c|c|c|c|c|c|c|c|c|c|c|}
\hline $\begin{array}{c}\text { Virtual } \\
\text { Release } \\
\text { Dates }\end{array}$ & $\begin{array}{c}\text { S to } 1 \text { st } \\
\text { Array }\end{array}$ & $\begin{array}{c}1 / 2 \\
95 \% \mathrm{CI}\end{array}$ & $\begin{array}{c}\text { S from } \\
1 \text { st to } \\
\text { 2nd } \\
\text { Array }\end{array}$ & $\begin{array}{c}1 / 2 \\
95 \% \mathrm{CI}\end{array}$ & $\begin{array}{c}\text { Detect. } \\
\text { Prob. To } \\
\text { 1st } \\
\text { Array }\end{array}$ & $\begin{array}{c}1 / 2 \\
95 \% \mathrm{CI}\end{array}$ & $\begin{array}{l}\text { Detect. } \\
\text { Prob. } \\
\text { from } 1 \mathrm{st} \\
\text { to } 2 \mathrm{nd} \\
\text { Array }\end{array}$ & $\begin{array}{c}1 / 2 \\
95 \% \mathrm{CI}\end{array}$ & Lambda & $\begin{array}{c}1 / 2 \\
95 \% \mathrm{CI}\end{array}$ \\
\hline $5 / 02-5 / 03$ & 0.914 & 0.133 & 1.000 & 0.021 & 1.000 & 0.133 & 1.000 & 0.021 & 0.944 & 0.106 \\
\hline $5 / 04-5 / 05$ & 1.000 & 0.005 & 0.988 & 0.026 & 1.000 & 0.005 & 1.000 & 0.026 & 0.836 & 0.085 \\
\hline $5 / 06-5 / 07$ & 1.000 & 0.002 & 0.980 & 0.029 & 1.000 & 0.002 & 1.000 & 0.029 & 0.895 & 0.064 \\
\hline $5 / 08-5 / 09$ & 0.998 & 0.014 & 0.998 & 0.015 & 0.987 & 0.014 & 1.000 & 0.015 & 0.905 & 0.047 \\
\hline $5 / 10-5 / 11$ & 0.961 & 0.039 & 0.979 & 0.029 & 1.000 & 0.039 & 1.000 & 0.029 & 0.893 & 0.063 \\
\hline $5 / 12-5 / 13$ & 0.900 & 0.056 & 0.909 & 0.057 & 1.000 & 0.056 & 1.000 & 0.057 & 0.923 & 0.055 \\
\hline $5 / 14-5 / 15$ & 0.943 & 0.050 & 0.962 & 0.043 & 0.962 & 0.050 & 1.000 & 0.043 & 0.898 & 0.067 \\
\hline $5 / 16-5 / 17$ & 0.948 & 0.046 & 0.943 & 0.048 & 1.000 & 0.046 & 1.000 & 0.048 & 0.878 & 0.070 \\
\hline $5 / 18-5 / 19$ & 0.964 & 0.041 & 0.948 & 0.050 & 0.987 & 0.041 & 1.000 & 0.050 & 0.824 & 0.087 \\
\hline $5 / 20-5 / 21$ & 0.985 & 0.030 & 0.954 & 0.052 & 1.000 & 0.030 & 1.000 & 0.052 & 0.836 & 0.093 \\
\hline $5 / 22-5 / 23$ & 0.968 & 0.044 & 0.967 & 0.046 & 0.983 & 0.044 & 1.000 & 0.046 & 0.810 & 0.101 \\
\hline $5 / 24-5 / 25$ & 0.957 & 0.048 & 0.970 & 0.041 & 1.000 & 0.048 & 1.000 & 0.041 & 0.891 & 0.076 \\
\hline $5 / 26-5 / 27$ & 0.950 & 0.043 & 0.950 & 0.046 & 1.000 & 0.043 & 0.986 & 0.046 & 0.796 & 0.084 \\
\hline $5 / 28-5 / 29$ & 1.000 & 0.012 & 0.962 & 0.065 & 1.000 & 0.012 & 0.946 & 0.065 & 0.700 & 0.127 \\
\hline Pooled & 0.965 & 0.013 & 0.964 & 0.011 & 0.994 & 0.013 & 0.997 & 0.011 & 0.863 & 0.021 \\
\hline N-Wt Mean & 0.965 & 0.017 & 0.963 & 0.013 & & & & & & \\
\hline
\end{tabular}


Table H.13. Tag-life-corrected, paired-release estimates of TSW spill bay (15 and 16) passage survival (S) for steelhead smolts

\begin{tabular}{lcc}
\hline Paired Release & S to Tailrace & $1 / 295 \%$ CI \\
\hline $5 / 02-5 / 03$ & 0.938 & 0.142 \\
$5 / 04-5 / 05$ & 1.000 & 0.013 \\
$5 / 06-5 / 07$ & 1.000 & 0.011 \\
$5 / 08-5 / 09$ & 1.009 & 0.033 \\
$5 / 10-5 / 11$ & 0.984 & 0.051 \\
$5 / 12-5 / 13$ & 0.968 & 0.092 \\
$5 / 14-5 / 15$ & 0.969 & 0.064 \\
$5 / 16-5 / 17$ & 1.020 & 0.078 \\
$5 / 18-5 / 19$ & 1.041 & 0.078 \\
$5 / 20-5 / 21$ & 0.985 & 0.032 \\
$5 / 22-5 / 23$ & 0.980 & 0.052 \\
$5 / 24-5 / 25$ & 1.000 & 0.071 \\
$5 / 26-5 / 27$ & 0.950 & 0.043 \\
$5 / 28-5 / 29$ & 1.000 & 0.025 \\
Pooled & 0.992 & 0.017 \\
N-Wt Mean & 0.992 & 0.023 \\
\hline
\end{tabular}

Table H.14. Detection histories for steelhead smolts detected and regrouped to form virtual releases for John Day Dam turbines in spring. Headings of columns 2 through 9 have three digits and each digit represents a detection (1) or non-detection (0) at three successive survivaldetection arrays (TDA_FB, BON_FB, and BTW1, respectively). A chi-square test for homogeneity, excluding pooled estimates, columns with $<5$ pooled detections, and totals, was significant $(\mathrm{P}=0.041)$.

\begin{tabular}{lccccccccc}
\hline \multicolumn{1}{c}{ Date } & P_111 & P_011 & P_101 & P_001 & P_110 & P_010 & P_100 & P_000 & Total \\
\hline 5/02-5/15 & 7 & 0 & 3 & 0 & 5 & 0 & 3 & 8 & 26 \\
5/16-5/29 & 2 & 0 & 8 & 0 & 6 & 0 & 14 & 10 & 40 \\
Pooled & 9 & 0 & 11 & 0 & 11 & 0 & 17 & 18 & 66 \\
\hline
\end{tabular}

Table H.15. Tag-life-corrected, single-release estimates of survival (S) and detection probabilities for steelhead smolts in virtual releases at John Day Dam turbines based on three downstream arrays. Lambda is the product of survival and detection probabilities for the third array, and $\mathrm{CI}=$ confidence interval. The $\mathrm{N}-\mathrm{Wt}$ mean and confidence interval (weighted by numbers of fish in releases) is preferred over the pooled estimate when capture histories are not homogeneous and some variance estimates approach zero and would overly weight high survival estimates.

\begin{tabular}{|c|c|c|c|c|c|c|c|c|c|c|}
\hline $\begin{array}{c}\text { Virtual } \\
\text { Release } \\
\text { Dates }\end{array}$ & $\begin{array}{c}\mathrm{S} \text { to } 1 \mathrm{st} \\
\text { Array }\end{array}$ & $\begin{array}{c}1 / 2 \\
95 \% \mathrm{CI}\end{array}$ & $\begin{array}{l}\text { S from } \\
1 \text { st to } \\
2 \text { nd } \\
\text { Array }\end{array}$ & $\begin{array}{c}1 / 2 \\
95 \% \text { CI }\end{array}$ & $\begin{array}{c}\text { Detect. } \\
\text { Prob. To } \\
\text { 1st } \\
\text { Array }\end{array}$ & $\begin{array}{c}1 / 2 \\
95 \% \mathrm{CI}\end{array}$ & $\begin{array}{l}\text { Detect. } \\
\text { Prob. } \\
\text { from } 1 \text { st } \\
\text { to } 2 \text { nd } \\
\text { Array }\end{array}$ & $\begin{array}{c}1 / 2 \\
95 \% \mathrm{CI}\end{array}$ & Lambda & $\begin{array}{c}1 / 2 \\
95 \% \mathrm{CI}\end{array}$ \\
\hline $5 / 02-5 / 15$ & 0.696 & 0.178 & 0.950 & 0.107 & 1.000 & 0.178 & 1.000 & 0.107 & 0.824 & 0.181 \\
\hline $5 / 16-5 / 29$ & 0.750 & 0.134 & 0.933 & 0.089 & 1.000 & 0.134 & 1.000 & 0.089 & 0.571 & 0.183 \\
\hline Pooled & 0.729 & 0.108 & 0.940 & 0.069 & 1.000 & 0.108 & 1.000 & 0.069 & 0.668 & 0.138 \\
\hline N-Wt Mean & 0.729 & 0.052 & 0.940 & 0.016 & & & & & & \\
\hline
\end{tabular}


Table H.16. Detection histories for steelhead smolts released in the upper John Day Dam tailwater as reference releases for turbine survival. Headings of columns 2 through 9 have three digits and each digit represents a detection (1) or non-detection (0) at three successive survivaldetection arrays (TDA_FB, BON_FB, and BTW1, respectively). A chi-square test for homogeneity, excluding pooled estimates, columns with $<5$ pooled detections, and totals, was significant $(\mathrm{P}<0.0010)$.

\begin{tabular}{lccccccccc}
\hline \multicolumn{1}{c}{ Date } & P_111 & P_011 & P_101 & P_001 & P_110 & P_010 & P_100 & P_000 & Total \\
\hline 5/02-5/15 & 380 & 4 & 1 & 0 & 46 & 0 & 32 & 11 & 474 \\
5/16-5/29 & 357 & 3 & 4 & 0 & 100 & 0 & 24 & 17 & 505 \\
Pooled & 737 & 7 & 5 & 0 & 146 & 0 & 56 & 28 & 979 \\
\hline
\end{tabular}

Table H.17. Tag-life-corrected, single-release estimates of survival (S) and detection probabilities for steelhead smolts in turbine reference releases in the upper John Day Dam tailwater based on three downstream arrays. Lambda is the product of survival and detection probabilities for the third array, and $\mathrm{CI}=$ confidence interval. The $\mathrm{N}-\mathrm{Wt}$ mean and confidence interval (weighted by numbers of fish in releases) is preferred over the pooled estimate when capture histories are not homogeneous and some variance estimates approach zero and would overly weight high survival estimates.

\begin{tabular}{|c|c|c|c|c|c|c|c|c|c|c|}
\hline $\begin{array}{c}\text { Release } \\
\text { Dates }\end{array}$ & $\begin{array}{c}\mathrm{S} \text { to } 1 \mathrm{st} \\
\text { Array }\end{array}$ & $\begin{array}{c}1 / 2 \\
95 \% \mathrm{CI}\end{array}$ & $\begin{array}{c}\text { S from } \\
1 \text { st to } \\
\text { 2nd } \\
\text { Array }\end{array}$ & $\begin{array}{c}1 / 2 \\
95 \% \mathrm{CI}\end{array}$ & $\begin{array}{l}\text { Detect. } \\
\text { Prob. To } \\
\text { 1st Array }\end{array}$ & $\begin{array}{c}1 / 2 \\
95 \% \mathrm{CI}\end{array}$ & $\begin{array}{l}\text { Detect. } \\
\text { Prob. } \\
\text { from } 1 \mathrm{st} \\
\text { to } 2 \text { nd } \\
\text { Array }\end{array}$ & $\begin{array}{c}1 / 2 \\
95 \% \mathrm{CI}\end{array}$ & Lambda & $\begin{array}{c}1 / 2 \\
95 \% \mathrm{CI}\end{array}$ \\
\hline $5 / 02-5 / 15$ & 0.978 & 0.014 & 0.933 & 0.024 & 0.991 & 0.014 & 0.997 & 0.024 & 0.8939 & 0.029 \\
\hline $5 / 16-5 / 29$ & 0.969 & 0.016 & 0.953 & 0.019 & 0.994 & 0.016 & 0.989 & 0.019 & 0.7819 & 0.038 \\
\hline Pooled & 0.973 & 0.01 & 0.943 & 0.015 & 0.992 & 0.01 & 0.993 & 0.015 & 0.836 & 0.024 \\
\hline N-Wt Mean & 0.973 & 0.008 & 0.943 & 0.019 & & & & & & \\
\hline
\end{tabular}

Table H.18. Tag-life-corrected, paired-release estimates of turbine-passage survival (S) for steelhead smolts in virtual releases into John Day Dam turbines to the upper John Day Dam tailwater

\begin{tabular}{lcc}
\hline Paired Release & S to Tailrace & $1 / 295 \%$ CI \\
\hline $5 / 02-5 / 15$ & 0.712 & 0.183 \\
$5 / 16-5 / 29$ & 0.774 & 0.139 \\
Pooled & 0.749 & 0.111 \\
N-Wt Mean & 0.749 & 0.062 \\
\hline
\end{tabular}


Table H.19. Detection histories for steelhead smolts detected and regrouped to form virtual releases for the John Day Dam JBS in spring. Headings of columns 2 through 9 have three digits and each digit represents a detection (1) or non-detection (0) at three successive survivaldetection arrays (TDA_FB, BON_FB, and BTW1, respectively). A chi-square test for homogeneity, excluding pooled estimates, columns with $<5$ pooled detections, and totals, was significant $(\mathrm{P}<0.0010)$.

\begin{tabular}{crcrrrrrrr}
\hline Date & P_111 & P_011 & P__101 & P_001 & P_110 & P_010 & P_100 & P_000 & Total \\
\hline $5 / 02-5 / 04$ & 15 & 0 & 0 & 0 & 7 & 0 & 1 & 1 & 24 \\
$5 / 05-5 / 06$ & 13 & 0 & 2 & 0 & 6 & 0 & 3 & 2 & 26 \\
$5 / 07-5 / 08$ & 28 & 0 & 4 & 0 & 10 & 0 & 0 & 1 & 43 \\
$5 / 09-5 / 10$ & 39 & 1 & 9 & 0 & 9 & 0 & 9 & 2 & 69 \\
$5 / 11-5 / 12$ & 7 & 0 & 2 & 0 & 12 & 0 & 4 & 0 & 25 \\
$5 / 13-5 / 14$ & 10 & 0 & 3 & 0 & 8 & 0 & 5 & 1 & 27 \\
$5 / 15-5 / 16$ & 12 & 1 & 10 & 0 & 8 & 0 & 10 & 3 & 44 \\
$5 / 17-5 / 18$ & 3 & 0 & 3 & 0 & 6 & 0 & 17 & 1 & 30 \\
$5 / 19-5 / 20$ & 2 & 0 & 12 & 0 & 14 & 0 & 23 & 1 & 52 \\
$5 / 21-5 / 22$ & 5 & 0 & 11 & 0 & 15 & 0 & 25 & 0 & 56 \\
$5 / 23-5 / 24$ & 6 & 0 & 6 & 0 & 13 & 1 & 19 & 1 & 46 \\
$5 / 25-5 / 26$ & 8 & 0 & 5 & 0 & 3 & 0 & 10 & 0 & 26 \\
$5 / 27-5 / 29$ & 4 & 0 & 7 & 0 & 18 & 0 & 29 & 3 & 61 \\
Pooled & 152 & 2 & 74 & 0 & 129 & 1 & 155 & 16 & 529 \\
\hline
\end{tabular}

Table H.20. Tag-life-corrected, single-release estimates of JBS passage survival (S) and detection probabilities for steelhead smolts in virtual releases at John Day Dam based on detections at three downstream arrays. Lambda is the product of survival and detection probabilities for the third array, and CI = confidence interval. The N-Wt Mean (weighted by numbers of fish in virtual releases) is preferred over the pooled estimate when capture histories are not homogeneous and some variance estimates approach zero and would overly weight high survival estimates.

\begin{tabular}{|c|c|c|c|c|c|c|c|c|c|c|}
\hline $\begin{array}{c}\text { Virtual } \\
\text { Release } \\
\text { Dates }\end{array}$ & $\begin{array}{c}\mathrm{S} \text { to } 1 \mathrm{st} \\
\text { Array }\end{array}$ & $\begin{array}{c}1 / 2 \\
95 \% \mathrm{CI}\end{array}$ & $\begin{array}{l}\text { S from } \\
1 \text { st to } \\
2 \text { nd } \\
\text { Array }\end{array}$ & $\begin{array}{c}1 / 2 \\
95 \% \mathrm{CI}\end{array}$ & $\begin{array}{c}\text { Detect. } \\
\text { Prob. To } \\
\text { 1st } \\
\text { Array }\end{array}$ & $\begin{array}{c}1 / 2 \\
95 \% \mathrm{CI}\end{array}$ & $\begin{array}{l}\text { Detect. } \\
\text { Prob. } \\
\text { from 1st } \\
\text { to } 2 \text { nd } \\
\text { Array }\end{array}$ & $\begin{array}{c}1 / 2 \\
95 \% \mathrm{CI}\end{array}$ & Lambda & $\begin{array}{c}1 / 2 \\
95 \% \mathrm{CI}\end{array}$ \\
\hline $5 / 02-5 / 04$ & 0.978 & 0.082 & 1.000 & 0.018 & 1.000 & 0.082 & 1.000 & 0.018 & 0.958 & 0.083 \\
\hline $5 / 05-5 / 06$ & 0.940 & 0.108 & 0.917 & 0.111 & 1.000 & 0.108 & 1.000 & 0.111 & 0.911 & 0.120 \\
\hline $5 / 07-5 / 08$ & 0.982 & 0.045 & 1.000 & 0.000 & 1.000 & 0.045 & 1.000 & 0.000 & 0.959 & 0.065 \\
\hline $5 / 09-5 / 10$ & 0.993 & 0.030 & 0.942 & 0.058 & 0.969 & 0.030 & 1.000 & 0.058 & 0.906 & 0.071 \\
\hline $5 / 11-5 / 12$ & 1.000 & 0.017 & 0.963 & 0.077 & 1.000 & 0.017 & 1.000 & 0.077 & 0.833 & 0.149 \\
\hline $5 / 13-5 / 14$ & 0.963 & 0.071 & 0.962 & 0.074 & 1.000 & 0.071 & 1.000 & 0.074 & 0.920 & 0.106 \\
\hline $5 / 15-5 / 16$ & 0.935 & 0.075 & 0.901 & 0.093 & 0.973 & 0.075 & 1.000 & 0.093 & 0.785 & 0.133 \\
\hline $5 / 17-5 / 18$ & 0.968 & 0.064 & 0.897 & 0.111 & 1.000 & 0.064 & 1.000 & 0.111 & 0.846 & 0.139 \\
\hline $5 / 19-5 / 20$ & 0.981 & 0.037 & 0.980 & 0.038 & 1.000 & 0.037 & 1.000 & 0.038 & 0.760 & 0.118 \\
\hline $5 / 21-5 / 22$ & 1.000 & 0.000 & 0.929 & 0.067 & 1.000 & 0.000 & 1.000 & 0.067 & 0.770 & 0.115 \\
\hline $5 / 23-5 / 24$ & 0.979 & 0.042 & 1.000 & 0.000 & 0.978 & 0.042 & 1.000 & 0.000 & 0.778 & 0.122 \\
\hline $5 / 25-5 / 26$ & 1.000 & 0.017 & 0.962 & 0.074 & 1.000 & 0.017 & 1.000 & 0.074 & 0.802 & 0.157 \\
\hline $5 / 27-5 / 29$ & 0.952 & 0.054 & 0.989 & 0.055 & 1.000 & 0.054 & 0.907 & 0.055 & 0.751 & 0.118 \\
\hline Pooled & 0.975 & 0.015 & 0.958 & 0.018 & 0.992 & 0.015 & 0.990 & 0.018 & 0.835 & 0.033 \\
\hline N-Wt Mean & 0.975 & 0.012 & 0.958 & 0.020 & & & & & & \\
\hline
\end{tabular}


Table H.21. Detection histories for steelhead smolts released in the upper John Day Dam tailwater as reference releases for JBS passage survival. Headings of columns 2 through 9 have three digits and each digit represents a detection (1) or non-detection (0) at three successive survival-detection arrays (TDA_FB, BON_FB, and BTW1, respectively). A chi-square test for homogeneity, excluding pooled estimates, columns with $<5$ pooled detections, and totals, was significant $(\mathrm{P}=0.0090)$.

\begin{tabular}{crcccccccc}
\hline Date & P_111 & P_011 & P_101 & P_001 & P_110 & P_010 & P_100 & P_000 & Total \\
\hline $5 / 02-5 / 04$ & 81 & 0 & 0 & 0 & 9 & 0 & 4 & 2 & 96 \\
$5 / 05-5 / 06$ & 52 & 0 & 0 & 0 & 3 & 0 & 1 & 0 & 56 \\
$5 / 07-5 / 08$ & 55 & 3 & 0 & 0 & 10 & 0 & 9 & 1 & 78 \\
$5 / 09-5 / 10$ & 61 & 0 & 0 & 0 & 10 & 0 & 7 & 0 & 78 \\
$5 / 11-5 / 12$ & 52 & 0 & 0 & 0 & 6 & 0 & 3 & 4 & 65 \\
$5 / 13-5 / 14$ & 54 & 0 & 0 & 0 & 6 & 0 & 3 & 3 & 66 \\
$5 / 15-5 / 16$ & 65 & 1 & 1 & 0 & 8 & 0 & 6 & 4 & 85 \\
$5 / 17-5 / 18$ & 42 & 0 & 0 & 0 & 14 & 0 & 4 & 4 & 64 \\
$5 / 19-5 / 20$ & 51 & 0 & 0 & 0 & 18 & 0 & 5 & 5 & 79 \\
$5 / 21-5 / 22$ & 48 & 0 & 1 & 0 & 16 & 0 & 3 & 0 & 68 \\
$5 / 23-5 / 24$ & 48 & 3 & 0 & 0 & 19 & 0 & 2 & 3 & 75 \\
$5 / 25-5 / 26$ & 58 & 0 & 0 & 0 & 8 & 0 & 3 & 1 & 70 \\
$5 / 27-5 / 29$ & 70 & 0 & 3 & 0 & 19 & 0 & 6 & 1 & 99 \\
Pooled & 737 & 7 & 5 & 0 & 146 & 0 & 56 & 28 & 979 \\
\hline
\end{tabular}

Table H.22. Tag-life-corrected, single-release estimates of survival (S) and detection probabilities for steelhead smolts in JBS reference releases in the upper John Day Dam tailwater based on detections at three downstream arrays. Lambda is the product of survival and detection probabilities for the third array, and CI = confidence interval. The N-Wt Mean (weighted by numbers of fish in virtual releases) is preferred over the pooled estimate when capture histories are not homogeneous and some variance estimates approach zero and would overly weight high survival estimates.

\begin{tabular}{|c|c|c|c|c|c|c|c|c|c|c|}
\hline $\begin{array}{c}\text { Virtual } \\
\text { Release } \\
\text { Dates } \\
\end{array}$ & $\begin{array}{c}\mathrm{S} \text { to } \\
1 \mathrm{st} \\
\text { Array }\end{array}$ & $\begin{array}{c}1 / 2 \\
95 \% \mathrm{CI}\end{array}$ & $\begin{array}{l}\mathrm{S} \text { from } \\
1 \mathrm{st} \text { to } \\
2 \text { nd } \\
\text { Array } \\
\end{array}$ & $\begin{array}{c}1 / 2 \\
95 \% \mathrm{CI} \\
\end{array}$ & $\begin{array}{c}\text { Detect. } \\
\text { Prob. To } \\
1 \text { st } \\
\text { Array } \\
\end{array}$ & $\begin{array}{c}1 / 2 \\
95 \% \mathrm{CI} \\
\end{array}$ & $\begin{array}{l}\text { Detect. } \\
\text { Prob. from } \\
\text { 1st to } 2 \text { nd } \\
\text { Array }\end{array}$ & $\begin{array}{c}1 / 2 \\
95 \% \mathrm{CI}\end{array}$ & Lambda & $\begin{array}{c}1 / 2 \\
95 \% \mathrm{CI}\end{array}$ \\
\hline $5 / 02-5 / 04$ & 0.981 & 0.029 & 0.970 & 0.046 & 1.000 & 0.029 & 1.000 & 0.046 & 0.903 & 0.062 \\
\hline $5 / 05-5 / 06$ & 1.000 & 0.012 & 0.982 & 0.035 & 1.000 & 0.012 & 1.000 & 0.035 & 0.946 & 0.060 \\
\hline $5 / 07-5 / 08$ & 0.993 & 0.026 & 0.878 & 0.074 & 0.956 & 0.026 & 1.000 & 0.074 & 0.853 & 0.084 \\
\hline $5 / 09-5 / 10$ & 1.000 & 0.000 & 0.911 & 0.064 & 1.000 & 0.000 & 1.000 & 0.064 & 0.859 & 0.081 \\
\hline $5 / 11-5 / 12$ & 0.939 & 0.058 & 0.951 & 0.054 & 1.000 & 0.058 & 1.000 & 0.054 & 0.897 & 0.078 \\
\hline $5 / 13-5 / 14$ & 0.955 & 0.050 & 0.952 & 0.053 & 1.000 & 0.050 & 1.000 & 0.053 & 0.900 & 0.076 \\
\hline $5 / 15-5 / 16$ & 0.954 & 0.045 & 0.927 & 0.058 & 0.987 & 0.045 & 0.985 & 0.058 & 0.893 & 0.071 \\
\hline $5 / 17-5 / 18$ & 0.938 & 0.059 & 0.933 & 0.063 & 1.000 & 0.059 & 1.000 & 0.063 & 0.750 & 0.113 \\
\hline $5 / 19-5 / 20$ & 0.937 & 0.054 & 0.932 & 0.057 & 1.000 & 0.054 & 1.000 & 0.057 & 0.739 & 0.104 \\
\hline $5 / 21-5 / 22$ & 1.000 & 0.011 & 0.961 & 0.050 & 1.000 & 0.011 & 0.980 & 0.050 & 0.750 & 0.106 \\
\hline $5 / 23-5 / 24$ & 0.962 & 0.044 & 0.971 & 0.040 & 0.957 & 0.044 & 1.000 & 0.040 & 0.729 & 0.104 \\
\hline $5 / 25-5 / 26$ & 0.986 & 0.028 & 0.957 & 0.048 & 1.000 & 0.028 & 1.000 & 0.048 & 0.879 & 0.079 \\
\hline $5 / 27-5 / 29$ & 1.000 & 0.017 & 0.946 & 0.049 & 1.000 & 0.017 & 0.959 & 0.049 & 0.782 & 0.085 \\
\hline Pooled & 0.973 & 0.010 & 0.943 & 0.015 & 0.992 & 0.010 & 0.993 & 0.015 & 0.836 & 0.024 \\
\hline N-Wt Mean & 0.973 & 0.014 & 0.943 & 0.015 & & & & & & \\
\hline
\end{tabular}


Table H.23. Tag-life-corrected, paired-release estimates of JBS-passage survival (S) for steelhead smolts in virtual releases from the JBS to the upper John Day Dam tailwater

\begin{tabular}{lcc}
\hline Paired Release & S to Tailrace & $1 / 295 \%$ CI \\
\hline $5 / 02-5 / 04$ & 0.997 & 0.088 \\
$5 / 05-5 / 06$ & 0.940 & 0.109 \\
$5 / 07-5 / 08$ & 0.989 & 0.052 \\
$5 / 09-5 / 10$ & 0.993 & 0.030 \\
$5 / 11-5 / 12$ & 1.066 & 0.069 \\
$5 / 13-5 / 14$ & 1.009 & 0.091 \\
$5 / 15-5 / 16$ & 0.980 & 0.091 \\
$5 / 17-5 / 18$ & 1.033 & 0.095 \\
$5 / 19-5 / 20$ & 1.047 & 0.072 \\
$5 / 21-5 / 22$ & 1.000 & 0.011 \\
$5 / 23-5 / 24$ & 1.018 & 0.064 \\
$5 / 25-5 / 26$ & 1.015 & 0.033 \\
$5 / 27-5 / 29$ & 0.952 & 0.057 \\
Pooled & 1.002 & 0.019 \\
N-Wt Mean & 1.002 & 0.019 \\
\hline
\end{tabular}




\section{Appendix I}

\section{Tag-Life-Corrected Survival Rates for Steelhead at The Dalles}

Dam 
Table I.1. Detection histories for steelhead smolts detected and regrouped to form virtual releases at The Dalles Dam in spring for estimating dam survival. Headings of columns 2 through 9 have three digits and each digit represents a detection (1) or non-detection (0) at three successive survival-detection arrays (BON_FB, BTW1, and BTW2, respectively). A chi-square test for homogeneity, excluding pooled estimates and totals, was significant $(\mathrm{P}<0.0010)$.

\begin{tabular}{|c|c|c|c|c|c|c|c|c|c|}
\hline Date & P_111 & P_011 & P_101 & P_001 & P_110 & P_010 & P_100 & P_000 & Total \\
\hline $05 / 03 / 2008$ & 48 & 1 & 1 & 0 & 10 & 0 & 0 & 4 & 64 \\
\hline $05 / 04 / 2008$ & 52 & 6 & 1 & 0 & 15 & 2 & 1 & 4 & 81 \\
\hline $05 / 05 / 2008$ & 71 & 10 & 3 & 0 & 50 & 1 & 2 & 7 & 144 \\
\hline 05/06/2008 & 45 & 0 & 7 & 0 & 26 & 0 & 1 & 3 & 82 \\
\hline 05/07/2008 & 53 & 5 & 4 & 1 & 27 & 5 & 2 & 10 & 107 \\
\hline 05/08/2008 & 40 & 4 & 33 & 2 & 24 & 3 & 5 & 15 & 126 \\
\hline 05/09/2008 & 81 & 6 & 21 & 3 & 25 & 2 & 4 & 5 & 147 \\
\hline $05 / 10 / 2008$ & 96 & 5 & 11 & 2 & 37 & 1 & 5 & 11 & 168 \\
\hline $05 / 11 / 2008$ & 49 & 3 & 14 & 0 & 26 & 1 & 4 & 15 & 112 \\
\hline $05 / 12 / 2008$ & 52 & 4 & 18 & 0 & 34 & 3 & 6 & 10 & 127 \\
\hline $05 / 13 / 2008$ & 64 & 5 & 3 & 0 & 35 & 2 & 3 & 15 & 127 \\
\hline $05 / 14 / 2008$ & 32 & 1 & 10 & 1 & 25 & 0 & 9 & 11 & 89 \\
\hline $05 / 15 / 2008$ & 26 & 2 & 10 & 0 & 33 & 1 & 6 & 11 & 89 \\
\hline $05 / 16 / 2008$ & 40 & 3 & 16 & 5 & 28 & 2 & 24 & 12 & 130 \\
\hline $05 / 17 / 2008$ & 20 & 0 & 21 & 4 & 16 & 2 & 27 & 12 & 102 \\
\hline $05 / 18 / 2008$ & 19 & 3 & 20 & 3 & 16 & 1 & 29 & 22 & 113 \\
\hline 05/19/2008 & 17 & 1 & 19 & 7 & 19 & 5 & 45 & 18 & 131 \\
\hline $05 / 20 / 2008$ & 14 & 5 & 20 & 5 & 28 & 8 & 33 & 21 & 134 \\
\hline $05 / 21 / 2008$ & 7 & 5 & 15 & 7 & 30 & 3 & 31 & 15 & 113 \\
\hline $05 / 22 / 2008$ & 7 & 4 & 10 & 7 & 32 & 4 & 37 & 17 & 118 \\
\hline $05 / 23 / 2008$ & 12 & 4 & 13 & 3 & 24 & 5 & 31 & 15 & 107 \\
\hline $05 / 24 / 2008$ & 20 & 2 & 14 & 5 & 33 & 7 & 39 & 12 & 132 \\
\hline $05 / 25 / 2008$ & 15 & 5 & 22 & 0 & 20 & 2 & 20 & 17 & 101 \\
\hline $05 / 26 / 2008$ & 16 & 1 & 25 & 1 & 22 & 3 & 37 & 20 & 125 \\
\hline $05 / 27 / 2008$ & 15 & 4 & 27 & 2 & 20 & 8 & 39 & 13 & 128 \\
\hline $05 / 28 / 2008$ & 11 & 0 & 19 & 7 & 13 & 6 & 47 & 15 & 118 \\
\hline 05/29-6/01 & 14 & 3 & 15 & 7 & 24 & 8 & 51 & 22 & 144 \\
\hline Pooled & 936 & 92 & 392 & 72 & 692 & 85 & 538 & 352 & 3159 \\
\hline
\end{tabular}


Table I.2. Tag-life-corrected, single-release estimates of dam survival (S) and detection probabilities for steelhead smolts in virtual releases at The Dalles Dam based on detections at three downstream arrays. Lambda is the product of survival and detection probabilities for the third array, and $\mathrm{CI}=$ confidence interval. The $\mathrm{N}-\mathrm{Wt}$ mean and confidence interval (weighted by numbers of fish in virtual releases) is preferred over the pooled estimate when capture histories are not homogeneous and some variance estimates approach zero and would overly weight high survival estimates.

\begin{tabular}{|c|c|c|c|c|c|c|c|c|c|c|}
\hline $\begin{array}{c}\text { Virtual } \\
\text { Release } \\
\text { Dates }\end{array}$ & $\begin{array}{c}\mathrm{S} \text { to } 1 \mathrm{st} \\
\text { Array }\end{array}$ & $\begin{array}{c}1 / 2 \\
95 \% \mathrm{CI}\end{array}$ & $\begin{array}{c}\text { S from } \\
1 \text { st to } \\
\text { 2nd } \\
\text { Array }\end{array}$ & $\begin{array}{c}1 / 2 \\
95 \% \mathrm{CI}\end{array}$ & $\begin{array}{c}\text { Detect. } \\
\text { Prob. To } \\
\text { 1st } \\
\text { Array }\end{array}$ & $\begin{array}{c}1 / 2 \\
95 \% \mathrm{CI}\end{array}$ & $\begin{array}{l}\text { Detect. } \\
\text { Prob. } \\
\text { from } 1 \mathrm{st} \\
\text { to } 2 \text { nd } \\
\text { Array }\end{array}$ & $\begin{array}{c}1 / 2 \\
95 \% \mathrm{CI}\end{array}$ & Lambda & $\begin{array}{c}1 / 2 \\
95 \% \mathrm{CI}\end{array}$ \\
\hline $5 / 3 / 2008$ & 1.000 & 0.011 & 0.957 & 0.063 & 1.000 & 0.011 & 0.983 & 0.063 & 0.984 & 0.033 \\
\hline $5 / 4 / 2008$ & 0.989 & 0.051 & 1.000 & 0.008 & 1.000 & 0.051 & 0.885 & 0.008 & 0.962 & 0.043 \\
\hline $5 / 5 / 2008$ & 1.000 & 0.012 & 0.968 & 0.041 & 1.000 & 0.012 & 0.917 & 0.041 & 0.961 & 0.034 \\
\hline $5 / 6 / 2008$ & 1.000 & 0.000 & 0.964 & 0.041 & 1.000 & 0.000 & 1.000 & 0.041 & 0.898 & 0.066 \\
\hline $5 / 7 / 2008$ & 0.949 & 0.045 & 0.959 & 0.043 & 1.000 & 0.045 & 0.889 & 0.043 & 0.930 & 0.054 \\
\hline $5 / 8 / 2008$ & 0.934 & 0.046 & 0.975 & 0.059 & 1.000 & 0.046 & 0.901 & 0.059 & 0.628 & 0.094 \\
\hline $5 / 9 / 2008$ & 0.988 & 0.026 & 0.978 & 0.033 & 1.000 & 0.026 & 0.930 & 0.033 & 0.809 & 0.067 \\
\hline $5 / 10 / 2008$ & 0.975 & 0.027 & 0.955 & 0.034 & 0.994 & 0.027 & 0.957 & 0.034 & 0.893 & 0.050 \\
\hline $5 / 11 / 2008$ & 0.931 & 0.048 & 0.942 & 0.050 & 1.000 & 0.048 & 0.949 & 0.050 & 0.807 & 0.080 \\
\hline $5 / 12 / 2008$ & 0.946 & 0.040 & 0.991 & 0.032 & 1.000 & 0.040 & 0.925 & 0.032 & 0.782 & 0.077 \\
\hline $5 / 13 / 2008$ & 0.930 & 0.045 & 0.953 & 0.040 & 1.000 & 0.045 & 0.934 & 0.040 & 0.943 & 0.044 \\
\hline $5 / 14 / 2008$ & 0.944 & 0.048 & 0.921 & 0.060 & 1.000 & 0.048 & 0.983 & 0.060 & 0.750 & 0.097 \\
\hline $5 / 15 / 2008$ & 0.923 & 0.056 & 0.961 & 0.049 & 0.987 & 0.056 & 0.952 & 0.049 & 0.786 & 0.093 \\
\hline $5 / 16 / 2008$ & 0.947 & 0.039 & 0.942 & 0.054 & 1.000 & 0.039 & 0.932 & 0.054 & 0.631 & 0.091 \\
\hline $5 / 17 / 2008$ & 0.952 & 0.042 & 0.915 & 0.076 & 1.000 & 0.042 & 0.947 & 0.076 & 0.429 & 0.106 \\
\hline $5 / 18 / 2008$ & 0.921 & 0.050 & 0.900 & 0.093 & 1.000 & 0.050 & 0.897 & 0.093 & 0.416 & 0.105 \\
\hline $5 / 19 / 2008$ & 0.939 & 0.041 & 0.949 & 0.102 & 1.000 & 0.041 & 0.857 & 0.102 & 0.360 & 0.094 \\
\hline $5 / 20 / 2008$ & 0.963 & 0.032 & 0.965 & 0.111 & 1.000 & 0.032 & 0.764 & 0.111 & 0.442 & 0.100 \\
\hline $5 / 21 / 2008$ & 0.944 & 0.045 & 0.954 & 0.105 & 1.000 & 0.045 & 0.822 & 0.105 & 0.442 & 0.106 \\
\hline $5 / 22 / 2008$ & 0.968 & 0.033 & 0.908 & 0.102 & 0.989 & 0.033 & 0.830 & 0.102 & 0.454 & 0.105 \\
\hline $5 / 23 / 2008$ & 0.944 & 0.044 & 0.990 & 0.109 & 1.000 & 0.044 & 0.800 & 0.109 & 0.450 & 0.109 \\
\hline $5 / 24 / 2008$ & 0.985 & 0.021 & 0.954 & 0.078 & 1.000 & 0.021 & 0.855 & 0.078 & 0.500 & 0.095 \\
\hline $5 / 25 / 2008$ & 0.970 & 0.033 & 0.944 & 0.105 & 1.000 & 0.033 & 0.833 & 0.105 & 0.455 & 0.111 \\
\hline $5 / 26 / 2008$ & 0.936 & 0.043 & 0.945 & 0.084 & 1.000 & 0.043 & 0.905 & 0.084 & 0.380 & 0.095 \\
\hline $5 / 27 / 2008$ & 0.954 & 0.037 & 1.000 & 0.000 & 0.991 & 0.037 & 0.828 & 0.000 & 0.385 & 0.086 \\
\hline $5 / 28 / 2008$ & 0.959 & 0.041 & 0.996 & 0.154 & 0.938 & 0.041 & 0.800 & 0.154 & 0.267 & 0.091 \\
\hline 05/29-6/01 & 0.988 & 0.033 & 0.947 & 0.121 & 0.922 & 0.033 & 0.776 & 0.121 & 0.366 & 0.093 \\
\hline Pooled & 0.959 & 0.010 & 0.941 & 0.012 & 0.993 & 0.010 & 0.902 & 0.012 & 0.637 & 0.019 \\
\hline N-Wt Mean & 0.959 & 0.009 & 0.957 & 0.010 & & & & & & \\
\hline
\end{tabular}




\section{Appendix J}

\section{Tag-Life-Corrected Survival Rates at John Day Dam for John Day Dam Subyearling Chinook}


Table J.1. Detection histories for subyearling Chinook salmon smolts detected and regrouped to form virtual releases at John Day Dam in summer for estimating dam survival. Headings of columns 2 through 9 have three digits and each digit represents a detection (1) or nondetection (0) at three successive survival-detection arrays (TDA_FB, BON_FB, and BTW1, respectively). A chi-square test for homogeneity, excluding pooled estimates, columns with $\leq 5$ pooled detections, and totals, was significant $(\mathrm{P}<0.0010)$.

\begin{tabular}{crrrrrrrrr}
\hline Date & P_111 & P_011 & P_101 & P_001 & P_110 & P_010 & P_100 & P_000 & Total \\
\hline $6 / 16-6 / 17$ & 64 & 1 & 29 & 0 & 30 & 0 & 22 & 22 & 168 \\
$6 / 18-6 / 19$ & 73 & 2 & 45 & 1 & 14 & 0 & 24 & 19 & 178 \\
$6 / 20-6 / 21$ & 63 & 0 & 22 & 0 & 14 & 0 & 20 & 19 & 138 \\
$6 / 22-6 / 23$ & 73 & 0 & 42 & 0 & 21 & 0 & 28 & 43 & 207 \\
$6 / 24-6 / 25$ & 89 & 0 & 30 & 0 & 21 & 0 & 22 & 19 & 181 \\
$6 / 26-6 / 27$ & 69 & 2 & 19 & 0 & 30 & 0 & 22 & 27 & 169 \\
$6 / 28-6 / 29$ & 52 & 0 & 17 & 0 & 26 & 0 & 23 & 11 & 129 \\
$6 / 30-7 / 01$ & 67 & 0 & 22 & 0 & 23 & 0 & 30 & 32 & 174 \\
$7 / 02-7 / 03$ & 92 & 0 & 3 & 0 & 23 & 0 & 15 & 27 & 160 \\
$7 / 04-7 / 05$ & 98 & 0 & 3 & 0 & 18 & 0 & 21 & 28 & 168 \\
$7 / 06-7 / 07$ & 108 & 2 & 3 & 0 & 18 & 0 & 29 & 40 & 200 \\
$7 / 08-7 / 09$ & 73 & 0 & 3 & 0 & 4 & 0 & 22 & 22 & 124 \\
$7 / 10-7 / 11$ & 121 & 0 & 6 & 0 & 13 & 0 & 36 & 22 & 198 \\
$7 / 12-7 / 13$ & 76 & 0 & 0 & 0 & 17 & 0 & 35 & 38 & 166 \\
Pooled & 1118 & 7 & 244 & 1 & 272 & 0 & 349 & 369 & 2360 \\
\hline
\end{tabular}

Table J.2. Tag-life-corrected, single-release estimates of dam survival (S) and detection probabilities for subyearling Chinook salmon smolts in virtual releases at John Day Dam based on three downstream arrays. Lambda is the product of survival and detection probabilities for the third array, and $\mathrm{CI}=$ confidence interval. The $\mathrm{N}-\mathrm{Wt}$ mean and confidence interval (weighted by numbers of fish in each virtual release) is preferred over the pooled estimate when capture histories are not homogeneous.

\begin{tabular}{|c|c|c|c|c|c|c|c|c|c|c|}
\hline $\begin{array}{c}\text { Virtual } \\
\text { Release } \\
\text { Dates }\end{array}$ & $\begin{array}{c}\mathrm{S} \text { to } 1 \mathrm{st} \\
\text { Array }\end{array}$ & $\begin{array}{c}1 / 2 \\
95 \% \mathrm{CI}\end{array}$ & $\begin{array}{l}\text { S from } \\
1 \text { st to } \\
\text { 2nd } \\
\text { Array }\end{array}$ & $\begin{array}{c}1 / 2 \\
95 \% \mathrm{CI}\end{array}$ & $\begin{array}{c}\text { Detect. } \\
\text { Prob. To } \\
\text { 1st } \\
\text { Array }\end{array}$ & $\begin{array}{c}1 / 2 \\
95 \% \mathrm{CI}\end{array}$ & $\begin{array}{l}\text { Detect. } \\
\text { Prob. } \\
\text { from } 1 \mathrm{st} \\
\text { to } 2 \mathrm{nd} \\
\text { Array }\end{array}$ & $\begin{array}{c}1 / 2 \\
95 \% \mathrm{CI}\end{array}$ & Lambda & $\begin{array}{c}1 / 2 \\
95 \% \mathrm{CI}\end{array}$ \\
\hline $6 / 16-6 / 17$ & 0.870 & 0.051 & 0.921 & 0.045 & 0.993 & 0.051 & 0.974 & 0.045 & 0.840 & 0.063 \\
\hline $6 / 18-6 / 19$ & 0.894 & 0.045 & 0.955 & 0.033 & 0.980 & 0.045 & 1.000 & 0.033 & 0.857 & 0.056 \\
\hline $6 / 20-6 / 21$ & 0.863 & 0.058 & 0.917 & 0.050 & 1.000 & 0.058 & 1.000 & 0.050 & 0.881 & 0.061 \\
\hline $6 / 22-6 / 23$ & 0.793 & 0.055 & 0.910 & 0.044 & 1.000 & 0.055 & 1.000 & 0.044 & 0.881 & 0.053 \\
\hline $6 / 24-6 / 25$ & 0.895 & 0.045 & 0.965 & 0.029 & 1.000 & 0.045 & 0.992 & 0.029 & 0.841 & 0.058 \\
\hline $6 / 26-6 / 27$ & 0.843 & 0.055 & 0.928 & 0.047 & 0.985 & 0.055 & 1.000 & 0.047 & 0.893 & 0.053 \\
\hline $6 / 28-6 / 29$ & 0.915 & 0.048 & 0.950 & 0.040 & 1.000 & 0.048 & 1.000 & 0.040 & 0.841 & 0.068 \\
\hline $6 / 30-7 / 01$ & 0.817 & 0.058 & 0.928 & 0.045 & 1.000 & 0.058 & 1.000 & 0.045 & 0.880 & 0.056 \\
\hline $7 / 02-7 / 03$ & 0.832 & 0.058 & 0.940 & 0.040 & 1.000 & 0.058 & 1.000 & 0.040 & 0.904 & 0.052 \\
\hline $7 / 04-7 / 05$ & 0.834 & 0.056 & 0.907 & 0.048 & 1.000 & 0.056 & 1.000 & 0.048 & 0.882 & 0.056 \\
\hline $7 / 06-7 / 07$ & 0.801 & 0.055 & 0.925 & 0.041 & 0.987 & 0.055 & 0.992 & 0.041 & 0.858 & 0.057 \\
\hline 7/08-7/09 & 0.823 & 0.067 & 0.892 & 0.060 & 1.000 & 0.067 & 1.000 & 0.060 & 0.759 & 0.088 \\
\hline $7 / 10-7 / 11$ & 0.889 & 0.044 & 0.904 & 0.044 & 1.000 & 0.044 & 1.000 & 0.044 & 0.875 & 0.052 \\
\hline $7 / 12-7 / 13$ & 0.771 & 0.064 & 0.838 & 0.064 & 1.000 & 0.064 & 0.989 & 0.064 & 0.868 & 0.064 \\
\hline Pooled & 0.844 & 0.015 & 0.921 & 0.012 & 0.996 & 0.015 & 0.996 & 0.012 & 0.863 & 0.016 \\
\hline N-Wt Mean & 0.844 & 0.023 & 0.920 & 0.016 & & & & & & \\
\hline
\end{tabular}


Table J.3. Detection histories for subyearling Chinook salmon smolts released in the upper John Day Dam tailwater as reference releases for estimating dam passage survival and non-TSW passage survival. Headings of columns 2 through 9 have three digits and each digit represents a detection (1) or non-detection (0) at three successive survival-detection arrays (TDA_FB, BON_FB, and BTW1, respectively). A chi-square test for homogeneity, excluding pooled estimates, columns with $\leq 5$ pooled detections, and totals, was not significant $(\mathrm{P}=0.480)$.

\begin{tabular}{cccccccccc}
\hline Date & P_111 & P_011 & P__101 & P_001 & P_110 & P_010 & P_100 & P_000 & Total \\
\hline $6 / 16-6 / 17$ & 50 & 0 & 2 & 0 & 11 & 0 & 6 & 2 & 71 \\
$6 / 18-6 / 19$ & 43 & 2 & 0 & 0 & 7 & 0 & 8 & 0 & 60 \\
$6 / 20-6 / 21$ & 57 & 0 & 0 & 0 & 7 & 0 & 5 & 1 & 70 \\
$6 / 22-6 / 23$ & 67 & 0 & 0 & 0 & 11 & 0 & 5 & 1 & 84 \\
$6 / 24-6 / 25$ & 43 & 0 & 1 & 0 & 10 & 0 & 5 & 1 & 60 \\
$6 / 26-6 / 27$ & 56 & 1 & 0 & 0 & 11 & 0 & 3 & 0 & 71 \\
$6 / 28-6 / 29$ & 68 & 0 & 0 & 0 & 8 & 0 & 5 & 3 & 84 \\
$6 / 30-7 / 01$ & 54 & 0 & 0 & 0 & 12 & 0 & 4 & 1 & 71 \\
$7 / 02-7 / 03$ & 60 & 0 & 0 & 0 & 4 & 0 & 5 & 2 & 71 \\
$7 / 04-7 / 05$ & 53 & 0 & 0 & 0 & 6 & 0 & 5 & 1 & 65 \\
$7 / 06-7 / 07$ & 44 & 1 & 0 & 0 & 5 & 0 & 4 & 1 & 55 \\
$7 / 08-7 / 09$ & 62 & 0 & 0 & 0 & 8 & 0 & 8 & 5 & 83 \\
$7 / 10-7 / 11$ & 48 & 0 & 0 & 0 & 3 & 0 & 9 & 0 & 60 \\
$7 / 12-7 / 13$ & 64 & 0 & 0 & 0 & 4 & 0 & 8 & 1 & 77 \\
Pooled & 769 & 4 & 3 & 0 & 107 & 0 & 80 & 19 & 982 \\
\hline
\end{tabular}

Table J.4. Tag-life-corrected, single-release estimates of survival (S) and detection probabilities for subyearling Chinook salmon smolts in reference releases for dam-passage survival and nonTSW-passage survival. Releases were in the upper John Day Dam tailwater. Lambda is the product of survival and detection probabilities for the third array, and CI = confidence interval. The N-Wt mean and confidence interval (weighted by numbers of fish in virtual releases) is preferred over the pooled estimate when capture histories are not homogeneous and some variance estimates approach zero and would overly weight high survival estimates.

\begin{tabular}{|c|c|c|c|c|c|c|c|c|c|c|}
\hline $\begin{array}{c}\text { Virtual } \\
\text { Release } \\
\text { Dates }\end{array}$ & $\begin{array}{c}\mathrm{S} \text { to } 1 \mathrm{st} \\
\text { Array }\end{array}$ & $\begin{array}{c}1 / 2 \\
95 \% \mathrm{CI}\end{array}$ & $\begin{array}{l}\text { S from } \\
1 \text { st to } \\
2 \text { nd } \\
\text { Array }\end{array}$ & $\begin{array}{c}1 / 2 \\
95 \% \mathrm{CI}\end{array}$ & $\begin{array}{l}\text { Detect. } \\
\text { Prob. } \\
\text { To 1st } \\
\text { Array }\end{array}$ & $\begin{array}{c}1 / 2 \\
95 \% \mathrm{CI}\end{array}$ & $\begin{array}{l}\text { Detect. } \\
\text { Prob. } \\
\text { from } 1 \text { st } \\
\text { to } 2 \text { nd } \\
\text { Array }\end{array}$ & $\begin{array}{c}1 / 2 \\
95 \% \mathrm{CI}\end{array}$ & Lambda & $\begin{array}{c}1 / 2 \\
95 \% \mathrm{CI}\end{array}$ \\
\hline $6 / 16-6 / 17$ & 0.972 & 0.038 & 0.919 & 0.068 & 1.000 & 0.038 & 0.962 & 0.068 & 0.820 & 0.096 \\
\hline $6 / 18-6 / 19$ & 1.000 & 0.011 & 0.867 & 0.086 & 0.967 & 0.011 & 1.000 & 0.086 & 0.865 & 0.093 \\
\hline $6 / 20-6 / 21$ & 0.986 & 0.028 & 0.928 & 0.061 & 1.000 & 0.028 & 1.000 & 0.061 & 0.892 & 0.077 \\
\hline $6 / 22-6 / 23$ & 0.988 & 0.023 & 0.940 & 0.051 & 1.000 & 0.023 & 1.000 & 0.051 & 0.860 & 0.077 \\
\hline $6 / 24-6 / 25$ & 0.983 & 0.032 & 0.920 & 0.072 & 1.000 & 0.032 & 0.977 & 0.072 & 0.815 & 0.106 \\
\hline $6 / 26-6 / 27$ & 1.000 & 0.010 & 0.961 & 0.047 & 0.986 & 0.010 & 1.000 & 0.047 & 0.839 & 0.088 \\
\hline $6 / 28-6 / 29$ & 0.964 & 0.040 & 0.938 & 0.052 & 1.000 & 0.040 & 1.000 & 0.052 & 0.896 & 0.069 \\
\hline $6 / 30-7 / 01$ & 0.986 & 0.027 & 0.943 & 0.054 & 1.000 & 0.027 & 1.000 & 0.054 & 0.818 & 0.093 \\
\hline $7 / 02-7 / 03$ & 0.972 & 0.038 & 0.928 & 0.061 & 1.000 & 0.038 & 1.000 & 0.061 & 0.938 & 0.059 \\
\hline $7 / 04-7 / 05$ & 0.985 & 0.030 & 0.922 & 0.066 & 1.000 & 0.030 & 1.000 & 0.066 & 0.898 & 0.077 \\
\hline $7 / 06-7 / 07$ & 0.983 & 0.035 & 0.925 & 0.071 & 0.980 & 0.035 & 1.000 & 0.071 & 0.900 & 0.083 \\
\hline 7/08-7/09 & 0.940 & 0.051 & 0.897 & 0.067 & 1.000 & 0.051 & 1.000 & 0.067 & 0.886 & 0.074 \\
\hline $7 / 10-7 / 11$ & 1.000 & 0.011 & 0.850 & 0.090 & 1.000 & 0.011 & 1.000 & 0.090 & 0.941 & 0.064 \\
\hline $7 / 12-7 / 13$ & 0.988 & 0.025 & 0.895 & 0.069 & 1.000 & 0.025 & 1.000 & 0.069 & 0.941 & 0.056 \\
\hline Pooled & 0.981 & 0.009 & 0.917 & 0.017 & 0.996 & 0.009 & 0.996 & 0.017 & 0.879 & 0.022 \\
\hline
\end{tabular}


Table J.5. Tag-life-corrected, paired-release estimates of dam survival (S) for subyearling Chinook salmon smolts in virtual releases from the John Day Dam face to the upper John Day Dam tailwater

\begin{tabular}{lcc}
\hline Paired Release & S to Tailrace & $1 / 295 \%$ CI \\
\hline $6 / 16-6 / 17$ & 0.895 & 0.063 \\
$6 / 18-6 / 19$ & 0.894 & 0.047 \\
$6 / 20-6 / 21$ & 0.875 & 0.063 \\
$6 / 22-6 / 23$ & 0.802 & 0.059 \\
$6 / 24-6 / 25$ & 0.911 & 0.054 \\
$6 / 26-6 / 27$ & 0.843 & 0.056 \\
$6 / 28-6 / 29$ & 0.949 & 0.063 \\
$6 / 30-7 / 01$ & 0.829 & 0.063 \\
$7 / 02-7 / 03$ & 0.856 & 0.069 \\
$7 / 04-7 / 05$ & 0.847 & 0.063 \\
$7 / 06-7 / 07$ & 0.814 & 0.064 \\
$7 / 08-7 / 09$ & 0.875 & 0.086 \\
$7 / 10-7 / 11$ & 0.889 & 0.045 \\
$7 / 12-7 / 13$ & 0.781 & 0.068 \\
Pooled & 0.861 & 0.017 \\
\hline
\end{tabular}

Table J.6. Detection histories for subyearling Chinook salmon smolts detected and regrouped to form virtual releases at non-TSW spill bays in summer. Headings of columns 2 through 9 have three digits and each digit represents a detection (1) or non-detection (0) at three successive survival-detection arrays (TDA_FB, BON_FB, and BTW1, respectively). A chi-square test for homogeneity, excluding pooled estimates, columns with $<5$ pooled detections, and totals, was significant $(\mathrm{P}<0.0010)$.

\begin{tabular}{cccrrrrrrr}
\hline Date & P_111 & P_011 & P_101 & P_001 & P_110 & P_010 & P_100 & P_000 & Total \\
\hline $6 / 16-6 / 17$ & 29 & 1 & 24 & 0 & 15 & 0 & 13 & 13 & 95 \\
$6 / 18-6 / 19$ & 38 & 1 & 26 & 1 & 11 & 0 & 16 & 7 & 100 \\
$6 / 20-6 / 21$ & 24 & 0 & 6 & 0 & 6 & 0 & 3 & 7 & 46 \\
$6 / 22-6 / 23$ & 34 & 0 & 19 & 0 & 9 & 0 & 14 & 33 & 109 \\
$6 / 24-6 / 25$ & 46 & 0 & 17 & 0 & 11 & 0 & 13 & 14 & 101 \\
$6 / 26-6 / 27$ & 43 & 1 & 11 & 0 & 18 & 0 & 9 & 17 & 99 \\
$6 / 28-6 / 29$ & 26 & 0 & 10 & 0 & 13 & 0 & 13 & 5 & 67 \\
$6 / 30-7 / 01$ & 29 & 0 & 9 & 0 & 9 & 0 & 13 & 19 & 79 \\
$7 / 02-7 / 03$ & 40 & 0 & 1 & 0 & 14 & 0 & 8 & 10 & 73 \\
$7 / 04-7 / 05$ & 49 & 0 & 3 & 0 & 7 & 0 & 11 & 16 & 86 \\
$7 / 06-7 / 07$ & 37 & 1 & 0 & 0 & 8 & 0 & 8 & 20 & 74 \\
$7 / 08-7 / 09$ & 27 & 0 & 1 & 0 & 0 & 0 & 11 & 14 & 53 \\
$7 / 10-7 / 11$ & 51 & 0 & 2 & 0 & 8 & 0 & 19 & 10 & 90 \\
$7 / 12-7 / 13$ & 27 & 0 & 0 & 0 & 8 & 0 & 15 & 11 & 61 \\
Pooled & 500 & 4 & 129 & 1 & 137 & 0 & 166 & 196 & 1133 \\
\hline
\end{tabular}


Table J.7. Tag-life-corrected, single-release estimates of non-TSW spill bay passage survival (S) and detection probabilities for subyearling Chinook salmon smolts in virtual releases at John Day Dam based on detections at three downstream arrays. Lambda is the product of survival and detection probabilities for the third array, and $\mathrm{CI}=$ confidence interval. The N-Wt Mean (weighted by numbers of fish in virtual releases) is preferred over the pooled estimate when capture histories are not homogeneous and some variance estimates approach zero and would overly weight high survival estimates.

\begin{tabular}{|c|c|c|c|c|c|c|c|c|c|c|}
\hline $\begin{array}{c}\text { Virtual } \\
\text { Release } \\
\text { Dates }\end{array}$ & $\begin{array}{l}\mathrm{S} \text { to } 1 \mathrm{st} \\
\text { Array }\end{array}$ & $\begin{array}{c}1 / 2 \\
95 \% \mathrm{CI}\end{array}$ & $\begin{array}{l}\text { S from } \\
\text { 1st to } \\
\text { 2nd } \\
\text { Array }\end{array}$ & $\begin{array}{c}1 / 2 \\
95 \% \mathrm{CI}\end{array}$ & $\begin{array}{c}\text { Detect. } \\
\text { Prob. To } \\
\text { 1st } \\
\text { Array }\end{array}$ & $\begin{array}{c}1 / 2 \\
95 \% \mathrm{CI}\end{array}$ & $\begin{array}{l}\text { Detect. } \\
\text { Prob. from } \\
\text { 1st to 2nd } \\
\text { Array }\end{array}$ & $\begin{array}{c}1 / 2 \\
95 \% \mathrm{CI}\end{array}$ & Lambda & $\begin{array}{c}1 / 2 \\
95 \% \mathrm{CI}\end{array}$ \\
\hline $6 / 16-6 / 17$ & 0.864 & 0.069 & 0.904 & 0.065 & 0.987 & 0.069 & 0.983 & 0.065 & 0.808 & 0.090 \\
\hline $6 / 18-6 / 19$ & 0.931 & 0.050 & 0.956 & 0.042 & 0.978 & 0.050 & 1.000 & 0.042 & 0.844 & 0.076 \\
\hline $6 / 20-6 / 21$ & 0.848 & 0.104 & 0.949 & 0.069 & 1.000 & 0.104 & 1.000 & 0.069 & 0.893 & 0.100 \\
\hline $6 / 22-6 / 23$ & 0.698 & 0.086 & 0.897 & 0.069 & 1.000 & 0.086 & 1.000 & 0.069 & 0.899 & 0.072 \\
\hline $6 / 24-6 / 25$ & 0.861 & 0.067 & 0.967 & 0.038 & 1.000 & 0.067 & 1.000 & 0.038 & 0.882 & 0.069 \\
\hline $6 / 26-6 / 27$ & 0.830 & 0.074 & 0.970 & 0.044 & 0.987 & 0.074 & 1.000 & 0.044 & 0.887 & 0.070 \\
\hline $6 / 28-6 / 29$ & 0.926 & 0.063 & 0.937 & 0.061 & 1.000 & 0.063 & 1.000 & 0.061 & 0.864 & 0.089 \\
\hline $6 / 30-7 / 01$ & 0.760 & 0.094 & 0.937 & 0.064 & 1.000 & 0.094 & 1.000 & 0.064 & 0.913 & 0.075 \\
\hline $7 / 02-7 / 03$ & 0.864 & 0.079 & 0.905 & 0.073 & 1.000 & 0.079 & 1.000 & 0.073 & 0.930 & 0.066 \\
\hline $7 / 04-7 / 05$ & 0.814 & 0.082 & 0.900 & 0.070 & 1.000 & 0.082 & 1.000 & 0.070 & 0.857 & 0.086 \\
\hline $7 / 06-7 / 07$ & 0.731 & 0.101 & 0.943 & 0.062 & 0.980 & 0.101 & 1.000 & 0.062 & 0.923 & 0.074 \\
\hline 7/08-7/09 & 0.736 & 0.119 & 0.898 & 0.095 & 1.000 & 0.119 & 1.000 & 0.095 & 0.743 & 0.145 \\
\hline $7 / 10-7 / 11$ & 0.889 & 0.065 & 0.864 & 0.076 & 1.000 & 0.065 & 1.000 & 0.076 & 0.841 & 0.086 \\
\hline $7 / 12-7 / 13$ & 0.820 & 0.096 & 0.840 & 0.102 & 1.000 & 0.096 & 1.000 & 0.102 & 0.857 & 0.106 \\
\hline Pooled & 0.828 & 0.022 & 0.921 & 0.018 & 0.994 & 0.022 & 0.999 & 0.018 & 0.869 & 0.023 \\
\hline N-Wt Mean & 0.827 & 0.039 & 0.921 & 0.020 & & & & & & \\
\hline
\end{tabular}

Table J.8. Tag-life-corrected, paired-release estimates of survival (S) for subyearling Chinook salmon smolts in virtual releases from non-TSW spill bays to the upper John Day Dam tailwater

\begin{tabular}{lcc}
\hline \multicolumn{1}{c}{ Paired Release } & S to Tailrace & $1 / 295 \%$ CI \\
\hline $6 / 16-6 / 17$ & 0.889 & 0.079 \\
$6 / 18-6 / 19$ & 0.931 & 0.051 \\
$6 / 20-6 / 21$ & 0.860 & 0.108 \\
$6 / 22-6 / 23$ & 0.706 & 0.089 \\
$6 / 24-6 / 25$ & 0.876 & 0.074 \\
$6 / 26-6 / 27$ & 0.830 & 0.075 \\
$6 / 28-6 / 29$ & 0.960 & 0.076 \\
$6 / 30-7 / 01$ & 0.771 & 0.098 \\
$7 / 02-7 / 03$ & 0.889 & 0.089 \\
$7 / 04-7 / 05$ & 0.827 & 0.087 \\
$7 / 06-7 / 07$ & 0.743 & 0.106 \\
$7 / 08-7 / 09$ & 0.783 & 0.133 \\
$7 / 10-7 / 11$ & 0.889 & 0.066 \\
$7 / 12-7 / 13$ & 0.830 & 0.100 \\
Pooled & 0.844 & 0.024 \\
N-Wt Mean & 0.844 & 0.044 \\
\hline
\end{tabular}


Table J.9. Detection histories for subyearling Chinook salmon smolts detected and regrouped to form virtual releases at TSW spill bays in summer. Headings of columns 2 through 9 have three digits and each digit represents a detection (1) or non-detection (0) at three successive survival-detection arrays (TDA_FB, BON_FB, and BTW1, respectively). A chi-square test for homogeneity, excluding pooled estimates, columns with $<5$ pooled detections, and totals, was significant $(\mathrm{P}<0.0010)$.

\begin{tabular}{lccrrrrrrr}
\hline \multicolumn{1}{c}{ Date } & P_111 & P_011 & P_101 & P_001 & P_110 & P_010 & P_100 & P_000 & Total \\
\hline $6 / 16-6 / 19$ & 17 & 0 & 10 & 0 & 8 & 0 & 5 & 4 & 44 \\
$6 / 20-6 / 23$ & 26 & 0 & 13 & 0 & 8 & 0 & 9 & 5 & 61 \\
$6 / 24-6 / 27$ & 26 & 1 & 11 & 0 & 10 & 0 & 4 & 6 & 58 \\
$6 / 28-7 / 01$ & 11 & 0 & 6 & 0 & 6 & 0 & 9 & 3 & 35 \\
$7 / 02-7 / 05$ & 44 & 0 & 0 & 0 & 10 & 0 & 9 & 4 & 67 \\
$7 / 06-7 / 09$ & 60 & 0 & 5 & 0 & 9 & 0 & 16 & 9 & 99 \\
$7 / 10-7 / 13$ & 71 & 0 & 3 & 0 & 11 & 0 & 25 & 13 & 123 \\
Pooled & 255 & 1 & 48 & 0 & 62 & 0 & 77 & 44 & 487 \\
\hline
\end{tabular}

Table J.10. Tag-life-corrected, single-release estimates of TSW survival (S) and detection probabilities for subyearling Chinook salmon smolts in virtual releases at John Day Dam based on detections at three downstream arrays. Lambda is the product of survival and detection probabilities for the third array, and $\mathrm{CI}=$ confidence interval. The N-Wt mean and confidence interval (weighted by numbers of fish in releases) is preferred over the pooled estimate when capture histories are not homogeneous and some variance estimates approach zero and would overly weight high survival estimates.

\begin{tabular}{|c|c|c|c|c|c|c|c|c|c|c|}
\hline $\begin{array}{c}\text { Virtual } \\
\text { Release } \\
\text { Dates }\end{array}$ & $\begin{array}{c}\mathrm{S} \text { to } 1 \mathrm{st} \\
\text { Array }\end{array}$ & $\begin{array}{c}1 / 2 \\
95 \% \mathrm{CI}\end{array}$ & $\begin{array}{l}\text { S from } \\
1 \text { st to } \\
\text { 2nd } \\
\text { Array }\end{array}$ & $\begin{array}{c}1 / 2 \\
95 \% \mathrm{CI}\end{array}$ & $\begin{array}{c}\text { Detect. } \\
\text { Prob. To } \\
\text { 1st } \\
\text { Array }\end{array}$ & $\begin{array}{c}1 / 2 \\
95 \% \mathrm{CI}\end{array}$ & $\begin{array}{l}\text { Detect. } \\
\text { Prob. } \\
\text { from } 1 \mathrm{st} \\
\text { to } 2 \text { nd } \\
\text { Array }\end{array}$ & $\begin{array}{c}1 / 2 \\
95 \% \mathrm{CI}\end{array}$ & Lambda & $\begin{array}{c}1 / 2 \\
95 \% \mathrm{CI}\end{array}$ \\
\hline $6 / 16-6 / 19$ & 0.909 & 0.085 & 0.925 & 0.082 & 1.000 & 0.085 & 1.000 & 0.082 & 0.893 & 0.100 \\
\hline $6 / 20-6 / 23$ & 0.918 & 0.069 & 0.965 & 0.049 & 1.000 & 0.069 & 1.000 & 0.049 & 0.871 & 0.090 \\
\hline $6 / 24-6 / 27$ & 0.898 & 0.078 & 0.966 & 0.054 & 0.980 & 0.078 & 1.000 & 0.054 & 0.840 & 0.102 \\
\hline $6 / 28-7 / 01$ & 0.914 & 0.093 & 0.911 & 0.102 & 1.000 & 0.093 & 1.000 & 0.102 & 0.932 & 0.092 \\
\hline $7 / 02-7 / 05$ & 0.941 & 0.057 & 0.953 & 0.053 & 1.000 & 0.057 & 1.000 & 0.053 & 0.900 & 0.076 \\
\hline 7/06-7/09 & 0.909 & 0.057 & 0.891 & 0.065 & 1.000 & 0.057 & 0.985 & 0.065 & 0.849 & 0.079 \\
\hline $7 / 10-7 / 13$ & 0.894 & 0.054 & 0.865 & 0.064 & 1.000 & 0.054 & 0.988 & 0.064 & 0.905 & 0.060 \\
\hline Pooled & 0.910 & 0.025 & 0.916 & 0.026 & 0.998 & 0.025 & 0.994 & 0.026 & 0.882 & 0.032 \\
\hline N-Wt Mean & 0.910 & 0.012 & 0.916 & 0.032 & & & & & & \\
\hline
\end{tabular}


Table J.11. Detection histories for subyearling Chinook salmon smolts released into the upper John Day Dam tailwater as reference releases for fish passing the John Day Dam TSW, turbines, and JBS in summer. Headings of columns 2 through 9 have three digits and each digit represents a detection (1) or non-detection (0) at three successive survival-detection arrays (TDA_FB, BON_FB, and BTW1, respectively). A chi-square test for homogeneity, excluding pooled estimates, columns with $<5$ pooled detections, and totals, was not significant $(\mathrm{P}=0.1010)$.

\begin{tabular}{lccccccccc}
\hline \multicolumn{1}{c}{ Date } & P_111 & P_011 & P_101 & P_001 & P_110 & P_010 & P_100 & P_000 & Total \\
\hline $6 / 16-6 / 19$ & 93 & 2 & 2 & 0 & 18 & 0 & 14 & 2 & 131 \\
$6 / 20-6 / 23$ & 124 & 0 & 0 & 0 & 18 & 0 & 10 & 2 & 154 \\
$6 / 24-6 / 27$ & 99 & 1 & 1 & 0 & 21 & 0 & 8 & 1 & 131 \\
$6 / 28-7 / 01$ & 122 & 0 & 0 & 0 & 20 & 0 & 9 & 4 & 155 \\
$7 / 02-7 / 05$ & 113 & 0 & 0 & 0 & 10 & 0 & 10 & 3 & 136 \\
$7 / 06-7 / 09$ & 106 & 1 & 0 & 0 & 13 & 0 & 12 & 6 & 138 \\
$7 / 10-7 / 13$ & 112 & 0 & 0 & 0 & 7 & 0 & 17 & 1 & 137 \\
Pooled & 769 & 4 & 3 & 0 & 107 & 0 & 80 & 19 & 982 \\
\hline
\end{tabular}

Table J.12. Tag-life-corrected, single-release estimates of survival of upper tailwater releases of reference fish for TSW-, turbine-, and JBS-passed subyearling Chinook salmon in summer based on detections at three downstream arrays. Lambda is the product of survival and detection probabilities for the third array, and $\mathrm{CI}=$ confidence interval.

\begin{tabular}{|c|c|c|c|c|c|c|c|c|c|c|}
\hline $\begin{array}{c}\text { Virtual } \\
\text { Release } \\
\text { Dates }\end{array}$ & $\begin{array}{c}\mathrm{S} \text { to } 1 \mathrm{st} \\
\text { Array }\end{array}$ & $\begin{array}{c}1 / 2 \\
95 \% \mathrm{CI}\end{array}$ & $\begin{array}{l}\text { S from } \\
1 \text { st to } \\
2 \text { nd } \\
\text { Array }\end{array}$ & $\begin{array}{c}1 / 2 \\
95 \% \mathrm{CI}\end{array}$ & $\begin{array}{c}\text { Detect. } \\
\text { Prob. To } \\
1 \text { st } \\
\text { Array }\end{array}$ & $\begin{array}{c}1 / 2 \\
95 \% \mathrm{CI}\end{array}$ & $\begin{array}{l}\text { Detect. } \\
\text { Prob. } \\
\text { from } 1 \mathrm{st} \\
\text { to } 2 \mathrm{nd} \\
\text { Array }\end{array}$ & $\begin{array}{c}1 / 2 \\
95 \% \\
\text { CI } \\
\end{array}$ & Lambda & $\begin{array}{c}1 / 2 \\
95 \% \mathrm{CI}\end{array}$ \\
\hline $6 / 16-6 / 19$ & 0.987 & 0.021 & 0.893 & 0.055 & 0.983 & 0.021 & 0.979 & 0.055 & 0.841 & 0.067 \\
\hline $6 / 20-6 / 23$ & 0.987 & 0.018 & 0.934 & 0.039 & 1.000 & 0.018 & 1.000 & 0.039 & 0.874 & 0.055 \\
\hline $6 / 24-6 / 27$ & 0.993 & 0.015 & 0.942 & 0.042 & 0.992 & 0.015 & 0.990 & 0.042 & 0.829 & 0.068 \\
\hline $6 / 28-7 / 01$ & 0.974 & 0.025 & 0.941 & 0.038 & 1.000 & 0.025 & 1.000 & 0.038 & 0.860 & 0.057 \\
\hline $7 / 02-7 / 05$ & 0.978 & 0.025 & 0.925 & 0.045 & 1.000 & 0.025 & 1.000 & 0.045 & 0.919 & 0.048 \\
\hline 7/06-7/09 & 0.957 & 0.034 & 0.908 & 0.049 & 0.992 & 0.034 & 1.000 & 0.049 & 0.892 & 0.056 \\
\hline $7 / 10-7 / 13$ & 0.993 & 0.014 & 0.875 & 0.056 & 1.000 & 0.014 & 1.000 & 0.056 & 0.941 & 0.042 \\
\hline Pooled & 0.981 & 0.009 & 0.917 & 0.017 & 0.996 & 0.009 & 0.996 & 0.017 & 0.879 & 0.022 \\
\hline
\end{tabular}

Table J.13. Tag-life-corrected, paired-release estimates of TSW spill bay (15 and 16) passage survival (S) for subyearling Chinook salmon smolts

\begin{tabular}{lcc}
\hline \multicolumn{1}{c}{ Paired Release } & S to Tailrace & $1 / 295 \%$ CI \\
\hline $6 / 16-6 / 19$ & 0.921 & 0.088 \\
$6 / 20-6 / 23$ & 0.931 & 0.072 \\
$6 / 24-6 / 27$ & 0.904 & 0.080 \\
$6 / 28-7 / 01$ & 0.939 & 0.098 \\
$7 / 02-7 / 05$ & 0.962 & 0.063 \\
$7 / 06-7 / 09$ & 0.950 & 0.068 \\
$7 / 10-7 / 13$ & 0.901 & 0.056 \\
Pooled & 0.928 & 0.027 \\
N-Wt Mean & 0.927 & 0.016 \\
\hline
\end{tabular}


Table J.14. Detection histories for subyearling Chinook salmon smolts detected and regrouped to form virtual releases for John Day Dam turbines in summer. Headings of columns 2 through 9 have three digits and each digit represents a detection (1) or non-detection (0) at three successive survival-detection arrays (TDA_FB, BON_FB, and BTW1, respectively). A chisquare test for homogeneity, excluding pooled estimates, columns with $<5$ pooled detections, and totals, was significant $(\mathrm{P}<0.0010)$.

\begin{tabular}{lcrrrrrrrr}
\hline \multicolumn{1}{c}{ Date } & P_111 & P_011 & P_101 & P_001 & P_110 & P_010 & P_100 & P_000 & Total \\
\hline $6 / 16-6 / 19$ & 21 & 0 & 2 & 0 & 3 & 0 & 9 & 17 & 52 \\
$6 / 20-6 / 23$ & 23 & 0 & 13 & 0 & 4 & 0 & 10 & 16 & 66 \\
$6 / 24-6 / 27$ & 24 & 0 & 2 & 0 & 6 & 0 & 7 & 9 & 48 \\
$6 / 28-7 / 01$ & 22 & 0 & 3 & 0 & 13 & 0 & 8 & 15 & 61 \\
$7 / 02-7 / 05$ & 27 & 0 & 2 & 0 & 6 & 0 & 2 & 22 & 59 \\
$7 / 06-7 / 09$ & 26 & 1 & 0 & 0 & 4 & 0 & 5 & 16 & 52 \\
$7 / 10-7 / 13$ & 28 & 0 & 1 & 0 & 2 & 0 & 7 & 18 & 56 \\
Pooled & 171 & 1 & 23 & 0 & 38 & 0 & 48 & 113 & 394 \\
\hline
\end{tabular}

Table J.15. Tag-life-corrected, single-release estimates of survival (S) and detection probabilities for subyearling Chinook salmon smolts in virtual releases at John Day Dam turbines based on three downstream arrays. Lambda is the product of survival and detection probabilities for the third array, and CI = confidence interval. The N-Wt mean and confidence interval (weighted by numbers of fish in releases) is preferred over the pooled estimate when capture histories are not homogeneous and some variance estimates approach zero and would overly weight high survival estimates.

\begin{tabular}{|c|c|c|c|c|c|c|c|c|c|c|}
\hline $\begin{array}{c}\text { Virtual } \\
\text { Release } \\
\text { Dates }\end{array}$ & $\begin{array}{l}\mathrm{S} \text { to } 1 \mathrm{st} \\
\text { Array }\end{array}$ & $\begin{array}{c}1 / 2 \\
95 \% \mathrm{CI}\end{array}$ & $\begin{array}{l}\text { S from } \\
1 \text { st to } \\
\text { 2nd } \\
\text { Array }\end{array}$ & $\begin{array}{c}1 / 2 \\
95 \% \mathrm{CI}\end{array}$ & $\begin{array}{c}\text { Detect. } \\
\text { Prob. To } \\
\text { 1st } \\
\text { Array }\end{array}$ & $\begin{array}{c}1 / 2 \\
95 \% \mathrm{CI}\end{array}$ & $\begin{array}{l}\text { Detect. } \\
\text { Prob. } \\
\text { from } 1 \text { st } \\
\text { to } 2 \text { nd } \\
\text { Array }\end{array}$ & $\begin{array}{c}1 / 2 \\
95 \% \mathrm{CI}\end{array}$ & Lambda & $\begin{array}{c}1 / 2 \\
95 \% \mathrm{CI}\end{array}$ \\
\hline $6 / 16-6 / 19$ & 0.673 & 0.128 & 0.915 & 0.093 & 1.000 & 0.128 & 1.000 & 0.093 & 0.813 & 0.135 \\
\hline $6 / 20-6 / 23$ & 0.758 & 0.103 & 0.881 & 0.090 & 1.000 & 0.103 & 1.000 & 0.090 & 0.888 & 0.094 \\
\hline $6 / 24-6 / 27$ & 0.813 & 0.111 & 0.927 & 0.084 & 1.000 & 0.111 & 1.000 & 0.084 & 0.864 & 0.113 \\
\hline $6 / 28-7 / 01$ & 0.755 & 0.108 & 0.915 & 0.082 & 1.000 & 0.108 & 1.000 & 0.082 & 0.835 & 0.113 \\
\hline $7 / 02-7 / 05$ & 0.628 & 0.123 & 0.946 & 0.073 & 1.000 & 0.123 & 1.000 & 0.073 & 0.914 & 0.093 \\
\hline 7/06-7/09 & 0.694 & 0.126 & 0.915 & 0.093 & 0.970 & 0.126 & 1.000 & 0.093 & 0.818 & 0.132 \\
\hline $7 / 10-7 / 13$ & 0.679 & 0.122 & 0.947 & 0.071 & 1.000 & 0.122 & 1.000 & 0.071 & 0.834 & 0.122 \\
\hline Pooled & 0.714 & 0.045 & 0.919 & 0.032 & 0.996 & 0.045 & 1.000 & 0.032 & 0.854 & 0.043 \\
\hline N-Wt Mean & 0.714 & 0.046 & 0.920 & 0.018 & & & & & & \\
\hline
\end{tabular}


Table J.16. Tag-life-corrected, paired-release estimates of turbine-passage survival (S) for subyearling Chinook salmon smolts in virtual releases into John Day Dam turbines to the upper John Day Dam tailwater

\begin{tabular}{lcc}
\hline \multicolumn{1}{c}{ Paired Release } & S to Tailrace & $1 / 295 \% \mathrm{CI}$ \\
\hline $6 / 16-6 / 19$ & 0.682 & 0.130 \\
$6 / 20-6 / 23$ & 0.768 & 0.106 \\
$6 / 24-6 / 27$ & 0.819 & 0.112 \\
$6 / 28-7 / 01$ & 0.775 & 0.113 \\
$7 / 02-7 / 05$ & 0.642 & 0.127 \\
$7 / 06-7 / 09$ & 0.725 & 0.134 \\
$7 / 10-7 / 13$ & 0.683 & 0.124 \\
Pooled & 0.728 & 0.046 \\
N-Wt Mean & 0.728 & 0.056 \\
\hline
\end{tabular}

Table J.17. Detection histories for subyearling Chinook salmon smolts detected and regrouped to form virtual releases for the John Day Dam JBS in summer. Headings of columns 2 through 9 have three digits and each digit represents a detection (1) or non-detection (0) at three successive survival-detection arrays (TDA_FB, BON_FB, and BTW1, respectively). A chisquare test for homogeneity, excluding pooled estimates, columns with $<5$ pooled detections, and totals, was significant $(\mathrm{P}<0.0010)$.

\begin{tabular}{lrrrrrrrrr}
\hline \multicolumn{1}{c}{ Date } & P_111 & P_011 & P_101 & P_001 & P_110 & P_010 & P_100 & P_000 & Total \\
\hline $6 / 16-6 / 19$ & 32 & 1 & 12 & 0 & 7 & 0 & 3 & 0 & 55 \\
$6 / 20-6 / 23$ & 29 & 0 & 13 & 0 & 8 & 0 & 12 & 1 & 63 \\
$6 / 24-6 / 27$ & 19 & 0 & 8 & 0 & 6 & 0 & 11 & 0 & 44 \\
$6 / 28-7 / 01$ & 31 & 0 & 11 & 0 & 8 & 0 & 10 & 1 & 61 \\
$7 / 02-7 / 05$ & 30 & 0 & 0 & 0 & 4 & 0 & 6 & 3 & 43 \\
$7 / 06-7 / 09$ & 31 & 0 & 0 & 0 & 1 & 0 & 11 & 3 & 46 \\
$7 / 10-7 / 13$ & 20 & 0 & 0 & 0 & 1 & 0 & 5 & 8 & 34 \\
Pooled & 192 & 1 & 44 & 0 & 35 & 0 & 58 & 16 & 346 \\
\hline
\end{tabular}


Table J.18. Tag-life-corrected, single-release estimates of JBS passage survival (S) and detection probabilities for subyearling Chinook salmon smolts in virtual releases at John Day Dam based on detections at three downstream arrays. Lambda is the product of survival and detection probabilities for the third array, and $\mathrm{CI}=$ confidence interval. The N-Wt Mean (weighted by numbers of fish in virtual releases) is preferred over the pooled estimate when capture histories are not homogeneous and some variance estimates approach zero and would overly weight high survival estimates.

\begin{tabular}{|c|c|c|c|c|c|c|c|c|c|c|}
\hline $\begin{array}{c}\text { Virtual } \\
\text { Release } \\
\text { Dates }\end{array}$ & $\begin{array}{c}\text { S to } 1 \mathrm{st} \\
\text { Array }\end{array}$ & $\begin{array}{c}1 / 2 \\
95 \% \mathrm{CI}\end{array}$ & $\begin{array}{l}\mathrm{S} \text { from } \\
\text { 1st to } \\
\text { 2nd } \\
\text { Array }\end{array}$ & $\begin{array}{c}1 / 2 \\
95 \% \mathrm{CI}\end{array}$ & $\begin{array}{c}\text { Detect. } \\
\text { Prob. To } \\
\text { 1st } \\
\text { Array }\end{array}$ & $\begin{array}{c}1 / 2 \\
95 \% \mathrm{CI}\end{array}$ & $\begin{array}{l}\text { Detect. } \\
\text { Prob. } \\
\text { from } 1 \mathrm{st} \\
\text { to } 2 \text { nd } \\
\text { Array }\end{array}$ & $\begin{array}{c}1 / 2 \\
95 \% \mathrm{CI}\end{array}$ & Lambda & $\begin{array}{c}1 / 2 \\
95 \% \mathrm{CI} \\
\end{array}$ \\
\hline $6 / 16-6 / 19$ & 1.000 & 0.000 & 0.986 & 0.036 & 0.982 & 0.000 & 0.959 & 0.036 & 0.904 & 0.080 \\
\hline $6 / 20-6 / 23$ & 0.986 & 0.031 & 0.889 & 0.079 & 1.000 & 0.031 & 1.000 & 0.079 & 0.855 & 0.093 \\
\hline $6 / 24-6 / 27$ & 1.000 & 0.013 & 0.871 & 0.103 & 1.000 & 0.013 & 0.968 & 0.103 & 0.813 & 0.126 \\
\hline $6 / 28-7 / 01$ & 0.985 & 0.032 & 0.971 & 0.046 & 1.000 & 0.032 & 1.000 & 0.046 & 0.794 & 0.104 \\
\hline $7 / 02-7 / 05$ & 0.930 & 0.076 & 0.925 & 0.082 & 1.000 & 0.076 & 1.000 & 0.082 & 0.866 & 0.110 \\
\hline 7/06-7/09 & 0.935 & 0.071 & 0.930 & 0.076 & 1.000 & 0.071 & 1.000 & 0.076 & 0.701 & 0.142 \\
\hline $7 / 10-7 / 13$ & 0.765 & 0.143 & 0.924 & 0.103 & 1.000 & 0.143 & 1.000 & 0.103 & 0.917 & 0.111 \\
\hline Pooled & 0.955 & 0.022 & 0.930 & 0.028 & 0.997 & 0.022 & 0.988 & 0.028 & 0.832 & 0.042 \\
\hline N-Wt Mean & 0.954 & 0.054 & 0.930 & 0.032 & & & & & & \\
\hline
\end{tabular}

Table J.19. Tag-life-corrected, paired-release estimates of JBS-passage survival (S) for subyearling Chinook salmon smolts in virtual releases from the JBS to the upper John Day Dam tailwater

\begin{tabular}{lcc}
\hline Paired Release & S to Tailrace & $1 / 295 \% \mathrm{CI}$ \\
\hline $6 / 16-6 / 19$ & 1.014 & 0.022 \\
$6 / 20-6 / 23$ & 0.999 & 0.036 \\
$6 / 24-6 / 27$ & 1.007 & 0.020 \\
$6 / 28-7 / 01$ & 1.011 & 0.042 \\
$7 / 02-7 / 05$ & 0.951 & 0.081 \\
$7 / 06-7 / 09$ & 0.977 & 0.082 \\
$7 / 10-7 / 13$ & 0.771 & 0.144 \\
Pooled & 0.973 & 0.024 \\
N-Wt Mean & 0.973 & 0.057 \\
\hline
\end{tabular}




\section{Appendix K}

Tag-Life-Corrected Survival Rates at The Dalles Dam for Subyearling Chinook Salmon 
Table K.1. Detection histories for subyearling Chinook salmon smolts detected and regrouped to form virtual releases at The Dalles Dam in summer for estimating dam survival. Headings of columns 2 through 9 have three digits and each digit represents a detection (1) or nondetection (0) at three successive survival-detection arrays (BON_FB, BTW1, and BTW2, respectively). A chi-square test for homogeneity, excluding pooled estimates, columns with $\leq 5$ pooled detections, and totals, was significant $(\mathrm{P}<0.0010)$.

\begin{tabular}{|c|c|c|c|c|c|c|c|c|c|}
\hline Date & $P \_111$ & P_011 & P_101 & P_001 & P_110 & P_010 & P_100 & P_000 & Total \\
\hline $06 / 16-6 / 17$ & 54 & 4 & 24 & 5 & 19 & 6 & 7 & 16 & 135 \\
\hline $06 / 18 / 2008$ & 43 & 6 & 20 & 7 & 23 & 4 & 10 & 12 & 125 \\
\hline 06/19/2008 & 43 & 4 & 30 & 3 & 12 & 1 & 6 & 13 & 112 \\
\hline 06/20/2008 & 46 & 2 & 21 & 2 & 8 & 0 & 2 & 10 & 91 \\
\hline $06 / 21 / 2008$ & 50 & 5 & 15 & 1 & 7 & 1 & 3 & 12 & 94 \\
\hline $06 / 22 / 2008$ & 43 & 3 & 25 & 2 & 13 & 0 & 6 & 13 & 105 \\
\hline $06 / 23 / 2008$ & 47 & 4 & 27 & 6 & 20 & 4 & 13 & 14 & 135 \\
\hline $06 / 24 / 2008$ & 48 & 10 & 24 & 2 & 10 & 1 & 7 & 12 & 114 \\
\hline $06 / 25 / 2008$ & 55 & 11 & 14 & 4 & 18 & 1 & 5 & 9 & 117 \\
\hline 06/26/2008 & 40 & 5 & 12 & 3 & 16 & 2 & 9 & 11 & 98 \\
\hline 06/27/2008 & 56 & 6 & 14 & 2 & 20 & 4 & 6 & 10 & 118 \\
\hline $06 / 28 / 2008$ & 34 & 5 & 13 & 2 & 19 & 1 & 4 & 14 & 92 \\
\hline 06/29/2008 & 43 & 2 & 15 & 2 & 23 & 1 & 5 & 11 & 102 \\
\hline 06/30/2008 & 37 & 5 & 16 & 3 & 14 & 0 & 9 & 4 & 88 \\
\hline 07/01/2008 & 38 & 5 & 16 & 3 & 20 & 1 & 7 & 15 & 105 \\
\hline 07/02/2008 & 70 & 5 & 9 & 0 & 14 & 2 & 5 & 13 & 118 \\
\hline 07/03/2008 & 58 & 1 & 1 & 0 & 14 & 1 & 2 & 8 & 85 \\
\hline 07/04/2008 & 76 & 3 & 1 & 0 & 18 & 1 & 1 & 11 & 111 \\
\hline 07/05/2008 & 62 & 4 & 2 & 1 & 13 & 3 & 1 & 16 & 102 \\
\hline $07 / 06 / 2008$ & 60 & 5 & 3 & 0 & 14 & 0 & 0 & 12 & 94 \\
\hline 07/07/2008 & 74 & 4 & 3 & 0 & 15 & 0 & 3 & 13 & 112 \\
\hline 07/08/2008 & 69 & 11 & 3 & 0 & 4 & 1 & 1 & 17 & 106 \\
\hline 07/09/2008 & 39 & 5 & 2 & 0 & 4 & 1 & 1 & 16 & 68 \\
\hline $07 / 10 / 2008$ & 69 & 5 & 2 & 2 & 12 & 0 & 1 & 21 & 112 \\
\hline $07 / 11 / 2008$ & 84 & 2 & 6 & 0 & 11 & 0 & 2 & 26 & 131 \\
\hline $07 / 12 / 2008$ & 72 & 0 & 2 & 0 & 7 & 0 & 1 & 18 & 100 \\
\hline 07/13/2008 & 65 & 1 & 0 & 0 & 14 & 0 & 2 & 19 & 101 \\
\hline Pooled & 1475 & 123 & 320 & 50 & 382 & 36 & 119 & 366 & 2871 \\
\hline
\end{tabular}


Table K.2. Tag-life-corrected, single-release estimates of dam survival (S) and detection probabilities for subyearling Chinook salmon smolts in virtual releases at The Dalles Dam based on detections at three downstream arrays. Lambda is the product of survival and detection probabilities for the third array, and $\mathrm{CI}=$ confidence interval. The $\mathrm{N}-\mathrm{Wt}$ mean and confidence interval (weighted by numbers of fish in each virtual release) is preferred over the pooled estimate when capture histories are not homogeneous.

\begin{tabular}{|c|c|c|c|c|c|c|c|c|c|c|}
\hline $\begin{array}{c}\text { Virtual } \\
\text { Release } \\
\text { Dates }\end{array}$ & $\begin{array}{c}\mathrm{S} \text { to } 1 \mathrm{st} \\
\text { Array }\end{array}$ & $\begin{array}{c}1 / 2 \\
95 \% \mathrm{CI}\end{array}$ & $\begin{array}{c}\text { S from } \\
1 \text { st to } \\
\text { 2nd } \\
\text { Array }\end{array}$ & $\begin{array}{c}1 / 2 \\
95 \% \mathrm{CI}\end{array}$ & $\begin{array}{c}\text { Detect. } \\
\text { Prob. To } \\
\text { 1st } \\
\text { Array }\end{array}$ & $\begin{array}{c}1 / 2 \\
95 \% \mathrm{CI}\end{array}$ & $\begin{array}{l}\text { Detect. } \\
\text { Prob. } \\
\text { from } 1 \mathrm{st} \\
\text { to } 2 \text { nd } \\
\text { Array }\end{array}$ & $\begin{array}{c}1 / 2 \\
95 \% \mathrm{CI}\end{array}$ & Lambda & $\begin{array}{c}1 / 2 \\
95 \% \mathrm{CI}\end{array}$ \\
\hline $06 / 16-6 / 17$ & 0.911 & 0.048 & 0.961 & 0.054 & 1.000 & 0.048 & 0.880 & 0.054 & 0.702 & 0.088 \\
\hline $06 / 18 / 2008$ & 0.957 & 0.038 & 0.924 & 0.067 & 0.953 & 0.038 & 0.868 & 0.067 & 0.687 & 0.093 \\
\hline 06/19/2008 & 0.911 & 0.053 & 0.975 & 0.056 & 1.000 & 0.053 & 0.917 & 0.056 & 0.605 & 0.101 \\
\hline $06 / 20 / 2008$ & 0.945 & 0.047 & 0.930 & 0.060 & 1.000 & 0.047 & 0.964 & 0.060 & 0.702 & 0.102 \\
\hline $06 / 21 / 2008$ & 0.904 & 0.059 & 0.976 & 0.051 & 1.000 & 0.059 & 0.905 & 0.051 & 0.760 & 0.097 \\
\hline $06 / 22 / 2008$ & 0.906 & 0.056 & 0.966 & 0.050 & 1.000 & 0.056 & 0.949 & 0.050 & 0.644 & 0.101 \\
\hline $06 / 23 / 2008$ & 0.912 & 0.048 & 0.976 & 0.055 & 1.000 & 0.048 & 0.893 & 0.055 & 0.627 & 0.092 \\
\hline $06 / 24 / 2008$ & 0.940 & 0.044 & 0.990 & 0.063 & 1.000 & 0.044 & 0.841 & 0.063 & 0.652 & 0.099 \\
\hline $06 / 25 / 2008$ & 0.967 & 0.033 & 0.950 & 0.055 & 1.000 & 0.033 & 0.859 & 0.055 & 0.794 & 0.083 \\
\hline $06 / 26 / 2008$ & 0.929 & 0.058 & 0.965 & 0.064 & 0.976 & 0.058 & 0.889 & 0.064 & 0.728 & 0.100 \\
\hline $06 / 27 / 2008$ & 0.964 & 0.039 & 0.962 & 0.049 & 1.000 & 0.039 & 0.884 & 0.049 & 0.792 & 0.081 \\
\hline $06 / 28 / 2008$ & 0.892 & 0.064 & 0.950 & 0.062 & 1.000 & 0.064 & 0.898 & 0.062 & 0.757 & 0.100 \\
\hline $06 / 29 / 2008$ & 0.942 & 0.046 & 0.938 & 0.054 & 1.000 & 0.046 & 0.957 & 0.054 & 0.768 & 0.089 \\
\hline $06 / 30 / 2008$ & 0.979 & 0.031 & 0.972 & 0.058 & 1.000 & 0.031 & 0.911 & 0.058 & 0.672 & 0.106 \\
\hline $07 / 01 / 2008$ & 0.930 & 0.052 & 0.923 & 0.066 & 1.000 & 0.052 & 0.906 & 0.066 & 0.716 & 0.098 \\
\hline $07 / 02 / 2008$ & 0.934 & 0.046 & 0.965 & 0.041 & 1.000 & 0.046 & 0.923 & 0.041 & 0.858 & 0.069 \\
\hline 07/03/2008 & 0.954 & 0.045 & 0.952 & 0.047 & 1.000 & 0.045 & 0.973 & 0.047 & 0.959 & 0.044 \\
\hline $07 / 04 / 2008$ & 0.928 & 0.048 & 0.972 & 0.033 & 1.000 & 0.048 & 0.959 & 0.033 & 0.979 & 0.029 \\
\hline $07 / 05 / 2008$ & 0.902 & 0.058 & 0.927 & 0.054 & 1.000 & 0.058 & 0.915 & 0.054 & 0.962 & 0.043 \\
\hline $07 / 06 / 2008$ & 0.916 & 0.056 & 0.956 & 0.045 & 0.988 & 0.056 & 0.937 & 0.045 & 0.961 & 0.043 \\
\hline 07/07/2008 & 0.947 & 0.042 & 0.937 & 0.048 & 1.000 & 0.042 & 0.957 & 0.048 & 0.938 & 0.049 \\
\hline $07 / 08 / 2008$ & 0.915 & 0.053 & 0.925 & 0.056 & 1.000 & 0.053 & 0.859 & 0.056 & 0.948 & 0.050 \\
\hline 07/09/2008 & 0.897 & 0.072 & 0.859 & 0.090 & 1.000 & 0.072 & 0.878 & 0.090 & 0.935 & 0.071 \\
\hline $07 / 10 / 2008$ & 0.875 & 0.061 & 0.911 & 0.057 & 1.000 & 0.061 & 0.942 & 0.057 & 0.965 & 0.040 \\
\hline $07 / 11 / 2008$ & 0.879 & 0.056 & 0.915 & 0.052 & 1.000 & 0.056 & 0.979 & 0.052 & 0.922 & 0.052 \\
\hline $07 / 12 / 2008$ & 0.900 & 0.059 & 0.911 & 0.059 & 1.000 & 0.059 & 1.000 & 0.059 & 0.963 & 0.041 \\
\hline $07 / 13 / 2008$ & 0.862 & 0.067 & 0.943 & 0.049 & 1.000 & 0.067 & 0.988 & 0.049 & 0.975 & 0.034 \\
\hline Pooled & 0.920 & 0.010 & 0.943 & 0.010 & 0.996 & 0.010 & 0.922 & 0.010 & 0.813 & 0.016 \\
\hline N-Wt Mean & 0.922 & 0.011 & 0.947 & 0.010 & & & & & & \\
\hline
\end{tabular}


Table K.3. Detection histories for subyearling Chinook salmon smolts released in the upper The Dalles Dam tailwater as reference releases for estimating The Dalles Dam passage survival.

Headings of columns 2 through 9 have three digits and each digit represents a detection (1) or non-detection (0) at three successive survival-detection arrays (BON_FB, BTW1, and BTW2, respectively). A chi-square test for homogeneity, excluding pooled estimates, columns with $\leq 5$ pooled detections, and totals, was not significant $(\mathrm{P}=0.480)$.

\begin{tabular}{|c|c|c|c|c|c|c|c|c|c|}
\hline Date & P_111 & P_011 & P_101 & P_001 & P_110 & P_010 & P_100 & P_000 & Total \\
\hline 06/16-6/17 & 82 & 0 & 14 & 0 & 61 & 1 & 16 & 0 & 174 \\
\hline 06/18/2008 & 37 & 3 & 5 & 0 & 31 & 1 & 8 & 2 & 87 \\
\hline 06/19/2008 & 47 & 0 & 8 & 0 & 28 & 0 & 3 & 1 & 87 \\
\hline 06/20/2008 & 47 & 0 & 3 & 0 & 28 & 0 & 7 & 0 & 85 \\
\hline 06/21/2008 & 49 & 0 & 5 & 0 & 28 & 0 & 7 & 0 & 89 \\
\hline 06/22/2008 & 41 & 0 & 3 & 0 & 38 & 0 & 5 & 0 & 87 \\
\hline 06/23/2008 & 31 & 0 & 6 & 0 & 34 & 0 & 15 & 0 & 86 \\
\hline 06/24/2008 & 42 & 0 & 8 & 0 & 32 & 0 & 4 & 1 & 87 \\
\hline 06/25/2008 & 60 & 0 & 13 & 0 & 6 & 0 & 7 & 1 & 87 \\
\hline 06/26/2008 & 47 & 2 & 9 & 0 & 20 & 1 & 7 & 1 & 87 \\
\hline 06/27/2008 & 54 & 0 & 8 & 0 & 19 & 0 & 6 & 0 & 87 \\
\hline 06/28/2008 & 61 & 0 & 5 & 0 & 13 & 0 & 7 & 1 & 87 \\
\hline 06/29/2008 & 64 & 0 & 7 & 0 & 11 & 0 & 5 & 0 & 87 \\
\hline 06/30/2008 & 56 & 0 & 7 & 0 & 20 & 0 & 4 & 0 & 87 \\
\hline 07/01/2008 & 57 & 0 & 3 & 0 & 14 & 0 & 9 & 4 & 87 \\
\hline 07/02/2008 & 47 & 0 & 1 & 0 & 7 & 0 & 6 & 0 & 61 \\
\hline 07/03/2008 & 90 & 0 & 10 & 0 & 9 & 0 & 4 & 1 & 114 \\
\hline 07/04/2008 & 74 & 0 & 5 & 0 & 3 & 0 & 5 & 0 & 87 \\
\hline 07/05/2008 & 76 & 0 & 5 & 0 & 0 & 0 & 4 & 2 & 87 \\
\hline 07/06/2008 & 65 & 6 & 6 & 1 & 3 & 0 & 6 & 0 & 87 \\
\hline 07/07/2008 & 67 & 0 & 10 & 0 & 4 & 0 & 4 & 2 & 87 \\
\hline 07/08/2008 & 40 & 0 & 3 & 0 & 2 & 0 & 6 & 0 & 51 \\
\hline 07/09/2008 & 102 & 0 & 4 & 0 & 5 & 0 & 10 & 1 & 122 \\
\hline 07/10/2008 & 73 & 0 & 7 & 0 & 4 & 0 & 6 & 0 & 90 \\
\hline $07 / 11 / 2008$ & 75 & 0 & 2 & 0 & 3 & 0 & 8 & 1 & 89 \\
\hline $07 / 12 / 2008$ & 81 & 0 & 0 & 0 & 1 & 0 & 4 & 4 & 90 \\
\hline 07/13/2008 & 75 & 0 & 1 & 0 & 2 & 0 & 7 & 3 & 88 \\
\hline Pooled & 1640 & 11 & 158 & 1 & 426 & 3 & 180 & 25 & 2444 \\
\hline
\end{tabular}


Table K.4. Tag-life-corrected, single-release estimates of survival (S) and detection probabilities for subyearling Chinook salmon smolts in reference releases for dam passage survival. Releases were in the upper The Dalles Dam tailwater. Lambda is the product of survival and detection probabilities for the third array, and $\mathrm{CI}=$ confidence interval. The $\mathrm{N}-\mathrm{Wt}$ mean and confidence interval (weighted by numbers of fish in virtual releases) is preferred over the pooled estimate when capture histories are not homogeneous and some variance estimates approach zero and would overly weight high survival estimates.

\begin{tabular}{|c|c|c|c|c|c|c|c|c|c|c|}
\hline $\begin{array}{c}\text { Virtual } \\
\text { Release } \\
\text { Dates }\end{array}$ & $\begin{array}{l}\mathrm{S} \text { to } 1 \mathrm{st} \\
\text { Array }\end{array}$ & $\begin{array}{c}1 / 2 \\
95 \% \mathrm{CI}\end{array}$ & $\begin{array}{l}\text { S from } \\
1 \text { st to } \\
2 \text { nd } \\
\text { Array }\end{array}$ & $\begin{array}{c}1 / 2 \\
95 \% \mathrm{CI}\end{array}$ & $\begin{array}{l}\text { Detect. } \\
\text { Prob. To } \\
\text { 1st } \\
\text { Array }\end{array}$ & $\begin{array}{c}1 / 2 \\
95 \% \mathrm{CI}\end{array}$ & $\begin{array}{l}\text { Detect. } \\
\text { Prob. } \\
\text { from 1st } \\
\text { to } 2 \text { nd } \\
\text { Array }\end{array}$ & $\begin{array}{c}1 / 2 \\
95 \% \mathrm{CI}\end{array}$ & Lambda & $\begin{array}{c}1 / 2 \\
95 \% \mathrm{CI}\end{array}$ \\
\hline $06 / 16-6 / 17$ & 1.000 & 0.000 & 0.969 & 0.059 & 0.994 & 0.000 & 0.854 & 0.059 & 0.569 & 0.080 \\
\hline 06/18/2008 & 0.982 & 0.032 & 0.948 & 0.082 & 0.948 & 0.032 & 0.889 & 0.082 & 0.556 & 0.110 \\
\hline 06/19/2008 & 0.989 & 0.022 & 1.000 & 0.000 & 1.000 & 0.022 & 0.872 & 0.000 & 0.640 & 0.100 \\
\hline 06/20/2008 & 1.000 & 0.009 & 0.939 & 0.065 & 1.000 & 0.009 & 0.940 & 0.065 & 0.627 & 0.110 \\
\hline $06 / 21 / 2008$ & 1.000 & 0.009 & 0.954 & 0.066 & 1.000 & 0.009 & 0.907 & 0.066 & 0.636 & 0.100 \\
\hline $06 / 22 / 2008$ & 1.000 & 0.009 & 0.975 & 0.063 & 1.000 & 0.009 & 0.932 & 0.063 & 0.519 & 0.110 \\
\hline 06/23/2008 & 1.000 & 0.009 & 0.902 & 0.112 & 1.000 & 0.009 & 0.838 & 0.112 & 0.477 & 0.120 \\
\hline 06/24/2008 & 0.989 & 0.022 & 1.000 & 0.020 & 1.000 & 0.022 & 0.861 & 0.020 & 0.581 & 0.100 \\
\hline $06 / 25 / 2008$ & 0.989 & 0.022 & 0.936 & 0.061 & 1.000 & 0.022 & 0.822 & 0.061 & 0.911 & 0.070 \\
\hline 06/26/2008 & 0.992 & 0.023 & 0.960 & 0.072 & 0.962 & 0.023 & 0.845 & 0.072 & 0.700 & 0.100 \\
\hline 06/27/2008 & 1.000 & 0.009 & 0.963 & 0.061 & 1.000 & 0.009 & 0.871 & 0.061 & 0.740 & 0.100 \\
\hline 06/28/2008 & 0.989 & 0.022 & 0.931 & 0.060 & 1.000 & 0.022 & 0.924 & 0.060 & 0.824 & 0.080 \\
\hline 06/29/2008 & 1.000 & 0.009 & 0.956 & 0.051 & 1.000 & 0.009 & 0.901 & 0.051 & 0.853 & 0.080 \\
\hline $06 / 30 / 2008$ & 1.000 & 0.009 & 0.983 & 0.052 & 1.000 & 0.009 & 0.889 & 0.052 & 0.737 & 0.090 \\
\hline $07 / 01 / 2008$ & 0.954 & 0.044 & 0.900 & 0.068 & 1.000 & 0.044 & 0.950 & 0.068 & 0.803 & 0.090 \\
\hline 07/02/2008 & 1.000 & 0.011 & 0.904 & 0.075 & 1.000 & 0.011 & 0.979 & 0.075 & 0.870 & 0.090 \\
\hline 07/03/2008 & 0.991 & 0.017 & 0.974 & 0.035 & 1.000 & 0.017 & 0.900 & 0.035 & 0.909 & 0.050 \\
\hline 07/04/2008 & 1.000 & 0.009 & 0.945 & 0.049 & 1.000 & 0.009 & 0.937 & 0.049 & 0.961 & 0.040 \\
\hline $07 / 05 / 2008$ & 0.977 & 0.032 & 0.953 & 0.045 & 1.000 & 0.032 & 0.938 & 0.045 & 1.000 & 0.010 \\
\hline 07/06/2008 & 1.000 & 0.009 & 0.934 & 0.054 & 0.920 & 0.009 & 0.910 & 0.054 & 0.960 & 0.040 \\
\hline 07/07/2008 & 0.977 & 0.032 & 0.960 & 0.046 & 1.000 & 0.032 & 0.870 & 0.046 & 0.944 & 0.050 \\
\hline 07/08/2008 & 1.000 & 0.012 & 0.885 & 0.089 & 1.000 & 0.012 & 0.930 & 0.089 & 0.952 & 0.060 \\
\hline 07/09/2008 & 0.992 & 0.016 & 0.919 & 0.049 & 1.000 & 0.016 & 0.962 & 0.049 & 0.953 & 0.040 \\
\hline $07 / 10 / 2008$ & 1.000 & 0.000 & 0.938 & 0.052 & 1.000 & 0.000 & 0.913 & 0.052 & 0.948 & 0.050 \\
\hline $07 / 11 / 2008$ & 0.989 & 0.022 & 0.910 & 0.060 & 1.000 & 0.022 & 0.974 & 0.060 & 0.962 & 0.040 \\
\hline $07 / 12 / 2008$ & 0.956 & 0.043 & 0.954 & 0.044 & 1.000 & 0.043 & 1.000 & 0.044 & 0.988 & 0.020 \\
\hline 07/13/2008 & 0.966 & 0.038 & 0.918 & 0.058 & 1.000 & 0.038 & 0.987 & 0.058 & 0.974 & 0.030 \\
\hline Pooled & 0.990 & 0.004 & 0.942 & 0.011 & 0.993 & 0.004 & 0.912 & 0.011 & 0.794 & 0.010 \\
\hline N-Wt Mean & 0.990 & 0.005 & 0.947 & 0.011 & & & & & & \\
\hline
\end{tabular}


Table K.5. Tag-life-corrected, paired-release estimates of dam survival (S) for subyearling Chinook salmon smolts in virtual releases from the The Dalles Dam forebay entrance array to the upper end of the The Dalles Dam tailwater. Treatment virtual release data were from Tables K.1 and K.2, and reference release data were from Tables K.3 and K.4.

\begin{tabular}{lcc}
\hline Paired Release & S to Tailrace & $1 / 295 \%$ CI \\
\hline $06 / 16-6 / 17$ & 0.911 & 0.048 \\
$06 / 18 / 2008$ & 0.975 & 0.050 \\
$06 / 19 / 2008$ & 0.921 & 0.057 \\
$06 / 20 / 2008$ & 0.945 & 0.048 \\
$06 / 21 / 2008$ & 0.904 & 0.060 \\
$06 / 22 / 2008$ & 0.906 & 0.057 \\
$06 / 23 / 2008$ & 0.912 & 0.049 \\
$06 / 24 / 2008$ & 0.951 & 0.050 \\
$06 / 25 / 2008$ & 0.977 & 0.040 \\
$06 / 26 / 2008$ & 0.937 & 0.062 \\
$06 / 27 / 2008$ & 0.964 & 0.040 \\
$06 / 28 / 2008$ & 0.902 & 0.068 \\
$06 / 29 / 2008$ & 0.942 & 0.047 \\
$06 / 30 / 2008$ & 0.979 & 0.033 \\
$07 / 01 / 2008$ & 0.975 & 0.071 \\
$07 / 02 / 2008$ & 0.934 & 0.047 \\
$07 / 03 / 2008$ & 0.962 & 0.048 \\
$07 / 04 / 2008$ & 0.928 & 0.049 \\
$07 / 05 / 2008$ & 0.923 & 0.066 \\
$07 / 06 / 2008$ & 0.916 & 0.057 \\
$07 / 07 / 2008$ & 0.969 & 0.053 \\
$07 / 08 / 2008$ & 0.915 & 0.054 \\
$07 / 09 / 2008$ & 0.905 & 0.074 \\
$07 / 10 / 2008$ & 0.875 & 0.061 \\
$07 / 11 / 2008$ & 0.889 & 0.060 \\
$07 / 12 / 2008$ & 0.942 & 0.074 \\
$07 / 13 / 2008$ & 0.892 & 0.078 \\
Pooled & 0.929 & 0.011 \\
N-Wt Mean & 0.931 & 0.013 \\
\hline
\end{tabular}




\section{Appendix L}

Tables on Tagging, John Day Dam Tailwater Releases, John Day Dam Virtual Releases, John Day Dam Operations Data, and Capture History Data at John Day Dam or Downstream 
Table L.1. List of comma-separated-variable files on an accompanying compact disc. ${ }^{\text {(a) }}$ Variables in the first row of comma-separated-variable files are defined in Tables L. 2 through L.6 below.

\begin{tabular}{cc}
\hline \multicolumn{1}{c}{ File } & Description \\
\hline Appendix L1.xls & $\begin{array}{c}\text { John Day Dam virtual releases, reference releases, hourly dam operations data, } \\
\text { and capture history data at John Day Dam or at the primary, secondary, and } \\
\text { tertiary arrays downstreamA (all species) }\end{array}$ \\
Appendix L2.xls & $\begin{array}{c}\text { Tagging, release, and capture history data for steelhead } \\
\text { Tagging, release, and capture history data for spring Chinook salmon released in } \\
\text { the John Day Dam and The Dalles Dam pools }\end{array}$ \\
Appendix L4.xls & $\begin{array}{c}\text { Tagging, release, and capture history data for fall Chinook salmon released in the } \\
\text { John DayDam, The Dalles Dam, and Bonneville Dam pools }\end{array}$ \\
Appendix L5.xls & $\begin{array}{c}\text { Tagging, release, and capture history data for spring Chinook salmon released in } \\
\text { the Lower Granite Dam tailrace }\end{array}$ \\
\hline (a) $\quad \begin{array}{l}\text { A compact disc accompanying the report has nine files: A Portable Document Format (PDF) file of this } \\
\text { report, three Excel files with non-tag-life-corrected survival and detection probabilities, and five Excel files } \\
\text { with tagging, release, virtual release, capture-history, and dam operations data. }\end{array}$ \\
\hline
\end{tabular}


Table L.2. Variable names and definitions in Appendix L1.xls

\begin{tabular}{|c|c|}
\hline Variable & Definition \\
\hline SEASON & Spring or Summer \\
\hline TAGGER & Name of surgeon implanting tags \\
\hline SP & Species name \\
\hline SPP & PTAGIS species code \\
\hline LENGTH & Fork length $(\mathrm{mm})$ \\
\hline WEIGHT & Fish weight $(\mathrm{g})$ \\
\hline MORT & $0=$ Alive $;>0=$ Dead \\
\hline ACTAGCODE & Acoustic tag code \\
\hline PRI & Pulse repetition interval of acoustic tag \\
\hline PIT & PIT tag code \\
\hline ADATETIME & Acoustic tag activation date and time (mm/dd/yyyy hh:mm) \\
\hline TDATETIME & Tagging date and time (mm/dd/yyyy hh:mm) \\
\hline RDATETIME & Release date and time (mm/dd/yyyy hh:mm) \\
\hline REL_LOC & Release location \\
\hline $\mathrm{Rkm}$ & Release river kilometer $(\mathrm{km})$ \\
\hline JDA_ARRAY & Regrouped at John Day Dam face array $(1=$ yes or $0=$ no $)$ \\
\hline DATE & $\begin{array}{l}\text { Date released (if REL_LOC }=\text { JDA_TW) or date of dam-face virtual release (if } \\
\text { JDA_ARRAY=1). Routes are indicated by JROUTE, JSUB_ROUTE, or JHOLE below. }\end{array}$ \\
\hline HOUR & $\begin{array}{l}\text { Hour released (if REL_LOC=JDA_TW) or hour of dam-face virtual release (if } \\
\text { JDA_ARRAY=1). Routes are indicated by JROUTE, JSUB_ROUTE, or JHOLE below. }\end{array}$ \\
\hline A $3 C R 312$ & $\begin{array}{l}\text { Detected (1) or not detected (0) on The Dalles Dam forebay entrance array (primary survival- } \\
\text { detection array) }\end{array}$ \\
\hline A4CR237 & $\begin{array}{l}\text { Detected (1) or not detected (0) on the Bonneville Dam forebay entrance array (secondary } \\
\text { survival-detection array) }\end{array}$ \\
\hline A5CR203 & $\begin{array}{l}\text { Detected (1) or not detected (0) on the tertiary survival-detection array in the Bonneville Dam } \\
\text { tailwater near Reed Island }\end{array}$ \\
\hline A3CR312_TIME & Time of arrival at The Dalles Dam forebay entrance array \\
\hline A4CR237_TIME & Time of arrival at the Bonneville Dam forebay entrance array \\
\hline A5CR203_TIME & $\begin{array}{l}\text { Time of arrival at the tertiary survival-detection array in the Bonneville Dam tailwater near } \\
\text { Reed Island }\end{array}$ \\
\hline JROUTE & Route of passage through John Day Dam (powerhouse or spillway) \\
\hline JSUB_ROUTE & Sub-route of passage through John Day Dam (turbine, JBS, TSW, non-TSW) \\
\hline JHOLE & Specific route of passage exiting the forebay (turbine $=\mathrm{T} 01-\mathrm{T} 16$; spill bay $=\mathrm{S} 01-\mathrm{S} 20$ \\
\hline $\mathrm{J}$ & Assigned pool of dates for virtual releases at John Day Dam for estimating dam survival \\
\hline J_TW & $\begin{array}{l}\text { Assigned pool of dates for reference releases in the upper John Day Dam tailwater for pairing } \\
\text { with variable J above }\end{array}$ \\
\hline J_TSW & $\begin{array}{l}\text { Assigned pool of dates for virtual releases at John Day Dam TSW spill bays (spill bays } 15 \text { and } \\
16 \text { in 2008) }\end{array}$ \\
\hline $\mathrm{J}_{-} \mathrm{TSW} \mathrm{TW}_{-}$ & $\begin{array}{l}\text { Assigned pool of dates for reference releases in the upper John Day Dam tailwater for pairing } \\
\text { with J_TSW above }\end{array}$ \\
\hline
\end{tabular}


Table L.2. (contd)

\begin{tabular}{|c|c|}
\hline Variable & Definition \\
\hline J_NON_TSW & Assigned pool of dates for virtual releases at non-TSW spill bays at John Day Dam \\
\hline J_NON_TSW_TW & $\begin{array}{l}\text { Assigned pool of dates for reference releases in the upper John Day Dam tailwater for pairing } \\
\text { with J_NON_TSW above }\end{array}$ \\
\hline J_TUR & Assigned pool of dates for virtual releases at John Day Dam turbines \\
\hline J_TUR_TW & $\begin{array}{l}\text { Assigned pool of dates for reference releases in the upper John Day Dam tailwater for pairing } \\
\text { with J_TUR above }\end{array}$ \\
\hline J_JBS & Assigned pool of dates for virtual releases at the John Day Dam JBS \\
\hline J_JBS_TW & $\begin{array}{l}\text { Assigned pool of dates for reference releases in the upper John Day Dam tailwater for pairing } \\
\text { with J_JBS above }\end{array}$ \\
\hline $\mathrm{T} 1$ & Turbine 1 discharge $(\mathrm{cfs} \times 1000)$ \\
\hline $\mathrm{T} 2$ & Turbine 2 discharge $(\mathrm{cfs} \times 1000)$ \\
\hline $\mathrm{T} 3$ & Turbine 3 discharge $(\mathrm{cfs} \times 1000)$ \\
\hline $\mathrm{T} 4$ & Turbine 4 discharge $(\mathrm{cfs} \times 1000)$ \\
\hline T5 & Turbine 5 discharge $(\mathrm{cfs} \times 1000)$ \\
\hline T6 & Turbine 6 discharge $(\mathrm{cfs} \times 1000)$ \\
\hline $\mathrm{T} 7$ & Turbine 7 discharge $(\mathrm{cfs} \times 1000)$ \\
\hline $\mathrm{T} 8$ & Turbine 8 discharge $(\mathrm{cfs} \times 1000)$ \\
\hline T9 & Turbine 9 discharge $(\mathrm{cfs} \times 1000)$ \\
\hline $\mathrm{T} 10$ & Turbine 10 discharge $(\mathrm{cfs} \times 1000)$ \\
\hline T11 & Turbine 11 discharge $(\mathrm{cfs} \times 1000)$ \\
\hline $\mathrm{T} 12$ & Turbine 12 discharge $(\mathrm{cfs} \times 1000)$ \\
\hline $\mathrm{T} 13$ & Turbine 13 discharge $(\mathrm{cfs} \times 1000)$ \\
\hline T14 & Turbine 14 discharge $(\mathrm{cfs} \times 1000)$ \\
\hline $\mathrm{T} 15$ & Turbine 15 discharge $(\mathrm{cfs} \times 1000)$ \\
\hline T16 & Turbine 16 discharge $(\mathrm{cfs} \times 1000)$ \\
\hline SB1 & Spill bay 1 discharge $(\mathrm{cfs} \times 1000)$ \\
\hline SB2 & Spill bay 2 discharge $(\mathrm{cfs} \times 1000)$ \\
\hline SB3 & Spill bay 3 discharge $(\mathrm{cfs} \times 1000)$ \\
\hline SB4 & Spill bay 4 discharge $(\mathrm{cfs} \times 1000)$ \\
\hline SB5 & Spill bay 5 discharge $(\mathrm{cfs} \times 1000)$ \\
\hline SB6 & Spill bay 6 discharge $(\mathrm{cfs} \times 1000)$ \\
\hline SB7 & Spill bay 7 discharge $(\mathrm{cfs} \times 1000)$ \\
\hline SB8 & Spill bay 8 discharge $(\mathrm{cfs} \times 1000)$ \\
\hline SB9 & Spill bay 9 discharge $(\mathrm{cfs} \times 1000)$ \\
\hline SB10 & Spill bay 10 discharge $(\mathrm{cfs} \times 1000)$ \\
\hline SB11 & Spill bay 11 discharge $(\mathrm{cfs} \times 1000)$ \\
\hline SB12 & Spill bay 12 discharge $(\mathrm{cfs} \times 1000)$ \\
\hline SB13 & Spill bay 13 discharge $(\mathrm{cfs} \times 1000)$ \\
\hline SB14 & Spill bay 14 discharge $(\mathrm{cfs} \times 1000)$ \\
\hline
\end{tabular}


Table L.2. (contd)

\begin{tabular}{ll}
\hline \multicolumn{1}{c}{ Variable } & \multicolumn{1}{c}{ Definition } \\
\hline SB15 & Spill bay 15 discharge $(\mathrm{cfs} \times 1000)-$ TSW route in 2008 \\
SB16 & Spill bay 16 discharge $(\mathrm{cfs} \times 1000)-$ TSW route in 2008 \\
SB17 & Spill bay 17 discharge $(\mathrm{cfs} \times 1000)$ \\
SB18 & Spill bay 18 discharge $(\mathrm{cfs} \times 1000)$ \\
SB19 & Spill bay 19 discharge $(\mathrm{cfs} \times 1000)$ \\
SB20 & Spill bay 20 discharge $(\mathrm{cfs} \times 1000)$ \\
JDA_Q & John Day Dam project discharge $(\mathrm{cfs} \times 1000)$ \\
PH_Q & John Day Dam powerhouse discharge $(\mathrm{cfs} \times 1000)$ \\
SPILL_Q & John Day Dam spill discharge $(\mathrm{cfs} \times 1000)$ \\
TSW_Q & TSW discharge $(\mathrm{cfs} \times 1000)$ \\
NON_TSW_Q & Non-TSW discharge $(\mathrm{cfs} \times 1000)$ \\
P_SPILL & Percent spill at John Day Dam \\
\hline
\end{tabular}


Table L.3. Variable names and definitions in Appendix L2.xls

\begin{tabular}{|c|c|}
\hline Variable Name & Definition \\
\hline SEASON & Spring or summer outmigration season defined by type of fish and release date \\
\hline SP & Species or run of juvenile salmon (SPR_STH = steelhead) \\
\hline REL_LOC & $\begin{array}{l}\text { Release location (ARLINGTON=Arlington, OR; JDA_TW = upper end of the John Day } \\
\text { Dam tailwater) }\end{array}$ \\
\hline RDATETIME & Release date and time (mm/dd/yyyy hh:mm) \\
\hline ADATETIME & Acoustic tag activation date and time (mm/dd/yyyy hh:mm) \\
\hline PIT & Passive integrated transponder tag code \\
\hline ACTAGCODE & Acoustic tag code \\
\hline A1CR351 & $\begin{array}{l}\text { Detection indicator for the John Day Dam forebay entrance array }(1=\text { detected; } 0=\text { not } \\
\text { detected; blank = missing) }\end{array}$ \\
\hline JDA_ARRAY & $\begin{array}{l}\text { Detection indicator for the John Day Dam-face array }(1=\text { detected; } 0=\text { not detected; } \\
\text { blank = missing })\end{array}$ \\
\hline A2CR339 & $\begin{array}{l}\text { Detection indicator for the John Day Dam tailwater array }(1=\text { detected; } 0=\text { not detected; } \\
\text { blank }=\text { missing })\end{array}$ \\
\hline A $3 \mathrm{CR} 312$ & $\begin{array}{l}\text { Detection indicator for The Dalles Dam forebay entrance array }(1=\text { detected; } 0=\text { not } \\
\text { detected; blank }=\text { missing })\end{array}$ \\
\hline A4CR237 & $\begin{array}{l}\text { Detection indicator for the Bonneville Dam forebay entrance array }(1=\text { detected; } 0=\text { not } \\
\text { detected; blank = missing) }\end{array}$ \\
\hline B2_ARRAY & $\begin{array}{l}\text { Detection indicator for the Bonneville Dam Powerhouse } 2 \text { dam-face array }(1=\text { detected; } \\
0=\text { not detected; blank = missing })\end{array}$ \\
\hline BSPILL_ARRAY & $\begin{array}{l}\text { Detection indicator for the Bonneville Dam spillway array }(1=\text { detected; } 0=\text { not detected; } \\
\text { blank }=\text { missing })\end{array}$ \\
\hline A5CR203 & $\begin{array}{l}\text { Detection indicator for the first Bonneville Dam tailwater array at Reed Island }(1= \\
\text { detected; } 0=\text { not detected; blank = missing) }\end{array}$ \\
\hline A6CR192 & $\begin{array}{l}\text { Detection indicator for the second Bonneville Dam tailwater array at Lady Island }(1= \\
\text { detected; } 0=\text { not detected; blank = missing) }\end{array}$ \\
\hline A7CR086 & $\begin{array}{l}\text { Detection indicator for the third Bonneville Dam tailwater array at Oak Point }(1= \\
\text { detected; } 0=\text { not detected; blank = missing) }\end{array}$ \\
\hline A1CR351_TIME & Date and time of arrival at the John Day Dam forebay entrance array \\
\hline JDATETIME & Date and time of arrival at the John Day Dam-face array \\
\hline A2CR339_TIME & Date and time of arrival at the John Day Dam tailwater array \\
\hline A3CR312_TIME & Date and time of arrival at The Dalles Dam forebay entrance array \\
\hline A4CR237_TIME & Date and time of arrival at the Bonneville Dam forebay entrance array \\
\hline B2DATETIME & Date and time of last detection on the Bonneville Dam Powerhouse 2 array \\
\hline BSDATETIME & Date and time of last detection on the Bonneville Dam spillway array \\
\hline A5CR203_TIME & Date and time of arrival at the first Bonneville Dam tailwater array at Reed Island \\
\hline A6CR192_TIME & Date and time of arrival at the second Bonneville Dam tailwater array at Lady Island \\
\hline A7CR086_TIME & Date and time of arrival at the third Bonneville Dam tailwater array at Oak Point \\
\hline JROUTE & Route of passage through John Day Dam (powerhouse or spillway) \\
\hline JSUB_ROUTE & $\begin{array}{l}\text { Sub-route of passage through John Day Dam [TSW (spill), non-TSW (spill), turbine, } \\
\text { JBS] }\end{array}$ \\
\hline
\end{tabular}


Table L.3. (contd)

\begin{tabular}{|c|c|}
\hline Variable Name & Definition \\
\hline JHOLE & Specific route of passage (spill bays S1-S20; turbines T1-T16; blank = missing) \\
\hline BROUTE & Route of passage through Bonneville Dam (B2 or SPILL) \\
\hline BSUB_ROUTE & $\begin{array}{l}\text { Sub-route of passage through Bonneville } \mathrm{Dam}(\mathrm{SP} \mathrm{MID}=\text { spill bays } 4-15 ; \mathrm{SP} E N D= \\
\text { spill bays } 1-3 \text { or } 16-18 ; \mathrm{BCC}=\mathrm{B} 2 \mathrm{CC} \text {; turbine }=\mathrm{B} 2 \text { turbines; JBS = juvenile bypass } \\
\text { system) }\end{array}$ \\
\hline BHOLE & $\begin{array}{l}\text { Specific route of passage through Bonneville Dam }(\text { spill bays }=\text { SB1-SB18; Turbines }= \\
\text { TU11-TU18 or Unknown Turbine = UnkTurb; B2CC=BCC; Juvenile Bypass System }= \\
\text { JBS) }\end{array}$ \\
\hline $\mathrm{J}$ & Assigned pool of dates for virtual releases at John Day Dam for estimating dam survival \\
\hline J_TW & $\begin{array}{l}\text { Assigned pool of dates for reference releases in the upper John Day Dam tailwater for } \\
\text { pairing with variable J above }\end{array}$ \\
\hline J_NON_TSW & Assigned pool of dates for virtual releases at non-TSW spill bays at John Day Dam \\
\hline J_NON_TSW_TW & $\begin{array}{l}\text { Assigned pool of dates for reference releases in the upper John Day Dam tailwater for } \\
\text { pairing with J_NON_TSW above }\end{array}$ \\
\hline J_TSW & $\begin{array}{l}\text { Assigned pool of dates for virtual releases at John Day Dam TSW spill bays (spill bays } \\
15 \text { and } 16 \text { in 2008) }\end{array}$ \\
\hline J_TSW_TW & $\begin{array}{l}\text { Assigned pool of dates for reference releases in the upper John Day Dam tailwater for } \\
\text { pairing with J_TSW above }\end{array}$ \\
\hline J_TUR & Assigned pool of dates for virtual releases at John Day Dam turbines \\
\hline J_TUR_TW & $\begin{array}{l}\text { Assigned pool of dates for reference releases in the upper John Day Dam tailwater for } \\
\text { pairing with J_TUR above }\end{array}$ \\
\hline J_JBS & Assigned pool of dates for virtual releases at the John Day Dam JBS \\
\hline J_JBS_TW & $\begin{array}{l}\text { Assigned pool of dates for reference releases in the upper John Day Dam tailwater for } \\
\text { pairing with J_JBS above }\end{array}$ \\
\hline T_FB & Assigned pool of dates for virtual releases at The Dalles Dam forebay entrance array \\
\hline B_FB & $\begin{array}{l}\text { Assigned pool of dates for reference releases in the upper John Day Dam tailwater for } \\
\text { pairing with J_TUR above }\end{array}$ \\
\hline B2 & Assigned pool of dates for virtual releases at Bonneville Dam Powerhouse 2 \\
\hline $\mathrm{B} 2 \mathrm{CC}$ & Assigned pool of dates for virtual releases at the Bonneville Dam B2CC \\
\hline B2_JBS & Assigned pool of dates for virtual releases at the Bonneville Dam B2 JBS \\
\hline B2_TUR & Assigned pool of dates for virtual releases at Bonneville Dam B2 turbines \\
\hline BSPILL & Assigned pool of dates for virtual releases at the Bonneville Dam spillway \\
\hline BS_END & $\begin{array}{l}\text { Assigned pool of dates for virtual releases at end bays (1-3 and 16-18) at the Bonneville } \\
\text { Dam spillway }\end{array}$ \\
\hline BS_MID & $\begin{array}{l}\text { Assigned pool of dates for virtual releases at middle spill bays at the Bonneville Dam } \\
\text { spillway }\end{array}$ \\
\hline
\end{tabular}


Table L.4. Variable names and definitions in Appendix L3.xls

\begin{tabular}{|c|c|}
\hline Variable Name & Definition \\
\hline SEASON & Spring or summer outmigration season defined by type of fish and release date \\
\hline SP & Species or run of juvenile salmon $($ SPR_CHN $=$ spring Chinook salmon) \\
\hline REL_LOC & $\begin{array}{l}\text { Release location (ARLINGTON=Arlington, OR; JDA_TW }=\text { upper end of the John Day } \\
\text { Dam tailwater; BON_T }=\text { the upper end of the Bonneville Dam tailwater) }\end{array}$ \\
\hline RDATETIME & Release date and time (mm/dd/yyyy hh:mm) \\
\hline ADATETIME & Acoustic tag activation date and time (mm/dd/yyyy hh:mm) \\
\hline PIT & Passive integrated transponder tag code \\
\hline ACTAGCODE & Acoustic tag code \\
\hline A1CR351 & $\begin{array}{l}\text { Detection indicator for the John Day Dam forebay entrance array }(1=\text { detected; } 0=\text { not } \\
\text { detected; blank = missing) }\end{array}$ \\
\hline JDA_ARRAY & $\begin{array}{l}\text { Detection indicator for the John Day Dam-face array }(1=\text { detected; } 0=\text { not detected; } \\
\text { blank }=\text { missing })\end{array}$ \\
\hline A2CR339 & $\begin{array}{l}\text { Detection indicator for the John Day Dam tailwater array }(1=\text { detected; } 0=\text { not detected; } \\
\text { blank = missing })\end{array}$ \\
\hline A3CR312 & $\begin{array}{l}\text { Detection indicator for The Dalles Dam forebay entrance array }(1=\text { detected; } 0=\text { not } \\
\text { detected; blank }=\text { missing })\end{array}$ \\
\hline A4CR237 & $\begin{array}{l}\text { Detection indicator for the Bonneville Dam forebay entrance array }(1=\text { detected; } 0=\text { not } \\
\text { detected; blank = missing) }\end{array}$ \\
\hline B2_ARRAY & $\begin{array}{l}\text { Detection indicator for the Bonneville Dam Powerhouse } 2 \text { dam-face array }(1=\text { detected; } \\
\quad 0=\text { not detected; blank = missing) }\end{array}$ \\
\hline BSPILL_ARRAY & $\begin{array}{l}\text { Detection indicator for the Bonneville Dam spillway array }(1=\text { detected; } 0=\text { not detected; } \\
\text { blank = missing) }\end{array}$ \\
\hline A5CR203 & $\begin{array}{l}\text { Detection indicator for the first Bonneville Dam tailwater array at Reed Island }(1= \\
\text { detected; } 0=\text { not detected; blank = missing) }\end{array}$ \\
\hline A6CR192 & $\begin{array}{l}\text { Detection indicator for the second Bonneville Dam tailwater array at Lady Island }(1= \\
\text { detected; } 0=\text { not detected; blank = missing) }\end{array}$ \\
\hline A7CR086 & $\begin{array}{l}\text { Detection indicator for the third Bonneville Dam tailwater array at Oak Point }(1=\text { detected; } \\
\quad 0=\text { not detected; blank = missing })\end{array}$ \\
\hline A1CR351_TIME & Date and time of arrival at the John Day Dam forebay entrance array \\
\hline JDATETIME & Date and time of arrival at the John Day Dam-face array \\
\hline A2CR339_TIME & Date and time of arrival at the John Day Dam tailwater array \\
\hline A3CR312_TIME & Date and time of arrival at The Dalles Dam forebay entrance array \\
\hline A4CR237_TIME & Date and time of arrival at the Bonneville Dam forebay entrance array \\
\hline B2DATETIME & Date and time of last detection on the Bonneville Dam Powerhouse 2 array \\
\hline BSDATETIME & Date and time of last detection on the Bonneville Dam spillway array \\
\hline A5CR203_TIME & Date and time of arrival at the first Bonneville Dam tailwater array at Reed Island \\
\hline A6CR192_TIME & Date and time of arrival at the second Bonneville Dam tailwater array at Lady Island \\
\hline A7CR086_TIME & Date and time of arrival at the third Bonneville Dam tailwater array at Oak Point \\
\hline JROUTE & Route of passage through John Day Dam (powerhouse or spillway) \\
\hline JSUB_ROUTE & Sub-route of passage through John Day Dam [TSW (spill), non-TSW (spill), Turbine, JBS] \\
\hline
\end{tabular}


Table L.4. (contd)

\begin{tabular}{|c|c|}
\hline Variable Name & Definition \\
\hline JHOLE & Specific route of passage (spill bays S1-S20; Turbines T1-T16; blank = missing) \\
\hline BROUTE & Route of passage through Bonneville Dam (B2 or SPILL) \\
\hline BSUB_ROUTE & $\begin{array}{l}\text { Sub-route of passage through Bonneville Dam }(\mathrm{SP} \text { MID }=\text { spill bays } 4-15 ; \mathrm{SP} \text { END }=\text { spill } \\
\text { bays } 1-3 \text { or } 16-18 ; \mathrm{BCC}=\mathrm{B} 2 \mathrm{CC} ; \text { Turbine = } \mathrm{B} 2 \text { turbines; JBS = juvenile bypass system })\end{array}$ \\
\hline BHOLE & $\begin{array}{l}\text { Specific route of passage through Bonneville Dam }(\text { spill bays }=\text { SB1-SB18; Turbines }= \\
\text { TU11-TU18 or Unknown Turbine = UnkTurb; B2CC=BCC; Juvenile Bypass System = } \\
\text { JBS) }\end{array}$ \\
\hline $\mathrm{J}$ & Assigned pool of dates for virtual releases at John Day Dam for estimating dam survival \\
\hline J_TW & $\begin{array}{l}\text { Assigned pool of dates for reference releases in the upper John Day Dam tailwater for } \\
\text { pairing with variable J above }\end{array}$ \\
\hline J_NON_TSW & Assigned pool of dates for virtual releases at non-TSW spill bays at John Day Dam \\
\hline J_NON_TSW_TW & $\begin{array}{l}\text { Assigned pool of dates for reference releases in the upper John Day Dam tailwater for } \\
\text { pairing with J_NON_TSW above }\end{array}$ \\
\hline J_TSW & $\begin{array}{l}\text { Assigned pool of dates for virtual releases at John Day Dam TSW spill bays (spill bays } 15 \\
\text { and } 16 \text { in 2008) }\end{array}$ \\
\hline J_TSW_TW & $\begin{array}{l}\text { Assigned pool of dates for reference releases in the upper John Day Dam tailwater for } \\
\text { pairing with J_TSW above }\end{array}$ \\
\hline J_TUR & Assigned pool of dates for virtual releases at John Day Dam turbines \\
\hline J_TUR_TW & $\begin{array}{l}\text { Assigned pool of dates for reference releases in the upper John Day Dam tailwater for } \\
\text { pairing with J_TUR above }\end{array}$ \\
\hline J_JBS & Assigned pool of dates for virtual releases at the John Day Dam JBS \\
\hline J_JBS_TW & $\begin{array}{l}\text { Assigned pool of dates for reference releases in the upper John Day Dam tailwater for } \\
\text { pairing with J_JBS above }\end{array}$ \\
\hline T_FB & Assigned pool of dates for virtual releases at The Dalles Dam forebay entrance array \\
\hline B_FB & $\begin{array}{l}\text { Assigned pool of dates for virtual releases at the Bonneville Dam forebay entrance array for } \\
\text { estimating Bonneville Dam survival }\end{array}$ \\
\hline B_FB_TW & Assigned pool of date for reference releases for pairing with B_FB above \\
\hline B2 & Assigned pool of dates for virtual releases at Bonneville Dam Powerhouse 2 \\
\hline B2_TW & Assigned pool of dates for reference releases for pairing with B2 above \\
\hline $\mathrm{B} 2 \mathrm{CC}$ & Assigned pool of dates for virtual releases at the Bonneville Dam B2CC \\
\hline B2CC_TW & Assigned pool of dates for reference releases for pairing with B2 above \\
\hline B2CC_R & Assigned pool of dates for releases directly into the $\mathrm{B} 2 \mathrm{CC}$ \\
\hline B2CC_R_TW & $\begin{array}{l}\text { Assigned pool of dates for reference releases in the Bonneville Dam tailwater for pairing } \\
\text { with B2CC_R }\end{array}$ \\
\hline B2_JBS & Assigned pool of dates for virtual releases at the Bonneville Dam B2 JBS \\
\hline B2_JBS_TW & $\begin{array}{l}\text { Assigned pool of dates for reference releases in the Bonneville Dam tailwater for pairing } \\
\text { with B2_JBS above }\end{array}$ \\
\hline B2_TUR & Assigned pool of dates for virtual releases at Bonneville Dam B2 Turbines \\
\hline B2_TUR_TW & $\begin{array}{l}\text { Assigned pool of dates for reference releases in the Bonneville Dam tailwater for pairing } \\
\text { with B2_TUR above }\end{array}$ \\
\hline BSPILL & Assigned pool of dates for virtual releases at the Bonneville Dam spillway \\
\hline
\end{tabular}


Table L.4. (contd)

\begin{tabular}{|c|c|}
\hline Variable Name & Definition \\
\hline BSPILL_TW & $\begin{array}{l}\text { Assigned pool of dates for references releases in the Bonneville Dam tailwater for pairing } \\
\text { with BSPILL above }\end{array}$ \\
\hline BS_END & $\begin{array}{l}\text { Assigned pool of dates for virtual releases at end bays (1-3 and 16-18) at the Bonneville } \\
\text { Dam spillway }\end{array}$ \\
\hline BS_END_TW & $\begin{array}{l}\text { Assigned pool of dates for references releases in the Bonneville Dam tailwater for pairing } \\
\text { with BS_END above }\end{array}$ \\
\hline BS_MID & $\begin{array}{l}\text { Assigned pool of dates for virtual releases at middle spill bays at the Bonneville Dam } \\
\text { spillway }\end{array}$ \\
\hline BS_MID_TW & $\begin{array}{l}\text { Assigned pool of dates for references releases in the Bonneville Dam tailwater for pairing } \\
\text { with BS MID above }\end{array}$ \\
\hline
\end{tabular}


Table L.5. Variable names and definitions in Appendix L4.xls

\begin{tabular}{|c|c|}
\hline Variable Name & Definition \\
\hline SEASON & Spring or summer outmigration season defined by type of fish and release date \\
\hline SP & Species or run of juvenile salmon $($ FALL_CHN $=$ fall Chinook salmon $)$ \\
\hline REL_LOC & $\begin{array}{l}\text { Release location (ARLINGTON=Arlington, OR; JDA_TW }=\text { upper end of the John Day } \\
\text { Dam tailwater; TDA_TW }=\text { the upper end of The Dalles Dam tailwater; BON_T }=\text { the } \\
\text { upper end of the Bonneville Dam tailwater) }\end{array}$ \\
\hline RDATETIME & Release date and time (mm/dd/yyyy hh:mm) \\
\hline ADATETIME & Acoustic tag activation date and time (mm/dd/yyyy hh:mm) \\
\hline PIT & Passive integrated transponder tag code \\
\hline ACTAGCODE & Acoustic tag code \\
\hline A1CR351 & $\begin{array}{l}\text { Detection indicator for the John Day Dam forebay entrance array }(1=\text { detected; } 0=\text { not } \\
\text { detected; blank = missing) }\end{array}$ \\
\hline JDA_ARRAY & $\begin{array}{l}\text { Detection indicator for the John Day Dam-face array }(1=\text { detected; } 0=\text { not detected; } \\
\text { blank = missing })\end{array}$ \\
\hline A2CR339 & $\begin{array}{l}\text { Detection indicator for the John Day Dam tailwater array }(1=\text { detected; } 0=\text { not detected; } \\
\text { blank = missing) }\end{array}$ \\
\hline $\mathrm{A} 3 \mathrm{CR} 312$ & $\begin{array}{l}\text { Detection indicator for The Dalles Dam forebay entrance array }(1=\text { detected; } 0=\text { not } \\
\text { detected; blank = missing })\end{array}$ \\
\hline A4CR237 & $\begin{array}{l}\text { Detection indicator for the Bonneville Dam forebay entrance array }(1=\text { detected; } 0=\text { not } \\
\text { detected; blank = missing })\end{array}$ \\
\hline B2_ARRAY & $\begin{array}{l}\text { Detection indicator for the Bonneville Dam Powerhouse } 2 \text { dam-face array }(1=\text { detected; } \\
0=\text { not detected; blank = missing })\end{array}$ \\
\hline BSPILL_ARRAY & $\begin{array}{l}\text { Detection indicator for the Bonneville Dam spillway array }(1=\text { detected; } 0=\text { not detected; } \\
\text { blank = missing })\end{array}$ \\
\hline A5CR203 & $\begin{array}{l}\text { Detection indicator for the first Bonneville Dam tailwater array at Reed Island }(1= \\
\text { detected; } 0=\text { not detected; blank = missing })\end{array}$ \\
\hline A6CR192 & $\begin{array}{l}\text { Detection indicator for the second Bonneville Dam tailwater array at Lady Island }(1= \\
\text { detected; } 0 \text { = not detected; blank = missing) }\end{array}$ \\
\hline A7CR086 & $\begin{array}{l}\text { Detection indicator for the third Bonneville Dam tailwater array at Oak Point }(1=\text { detected; } \\
0=\text { not detected; blank = missing })\end{array}$ \\
\hline A1CR351_TIME & Date and time of arrival at the John Day Dam forebay entrance array \\
\hline JDATETIME & Date and time of arrival at the John Day Dam-face array \\
\hline A2CR339_TIME & Date and time of arrival at the John Day Dam tailwater array \\
\hline A3CR312_TIME & Date and time of arrival at The Dalles Dam forebay entrance array \\
\hline A4CR237_TIME & Date and time of arrival at the Bonneville Dam forebay entrance array \\
\hline B2DATETIME & Date and time of last detection on the Bonneville Dam Powerhouse 2 array \\
\hline BSDATETIME & Date and time of last detection on the Bonneville Dam spillway array \\
\hline A5CR203_TIME & Date and time of arrival at the first Bonneville Dam tailwater array at Reed Island \\
\hline A6CR192_TIME & Date and time of arrival at the second Bonneville Dam tailwater array at Lady Island \\
\hline A7CR086_TIME & Date and time of arrival at the third Bonneville Dam tailwater array at Oak Point \\
\hline JROUTE & Route of passage through John Day Dam (powerhouse or spillway) \\
\hline
\end{tabular}


Table L.5. (contd)

\begin{tabular}{|c|c|}
\hline Variable Name & Definition \\
\hline JSUB_ROUTE & Sub-route of passage through John Day Dam [TSW (spill), non-TSW (spill), turbine, JBS] \\
\hline JHOLE & Specific route of passage (spill bays S1-S20; Turbines T1-T16; blank = missing) \\
\hline BROUTE & Route of passage through Bonneville Dam (B2 or SPILL) \\
\hline BSUB_ROUTE & $\begin{array}{l}\text { Sub-route of passage through Bonneville Dam }\left(\mathrm{SP}_{-} \mathrm{MID}=\text { spill bays } 4-15 ; \mathrm{SP} \_\mathrm{END}=\text { spill }\right. \\
\text { bays } 1-3 \text { or } 16-18 ; \mathrm{BCC}=\mathrm{B} 2 \mathrm{CC} \text {; turbine = } \mathrm{B} 2 \text { turbines; JBS }=\text { juvenile bypass system })\end{array}$ \\
\hline BHOLE & $\begin{array}{l}\text { Specific route of passage through Bonneville Dam }(\text { spill bays }=\text { SB1-SB18; turbines }= \\
\text { TU11-TU18 or Unknown Turbine = UnkTurb; B2CC=BCC; Juvenile Bypass System = } \\
\text { JBS) }\end{array}$ \\
\hline $\mathrm{J}$ & Assigned pool of dates for virtual releases at John Day Dam for estimating dam survival \\
\hline J_TW & $\begin{array}{l}\text { Assigned pool of dates for reference releases in the upper John Day Dam tailwater for } \\
\text { pairing with variable J above }\end{array}$ \\
\hline J_NON_TSW & Assigned pool of dates for virtual releases at non-TSW spill bays at John Day Dam \\
\hline J_NON_TSW_TW & $\begin{array}{l}\text { Assigned pool of dates for reference releases in the upper John Day Dam tailwater for } \\
\text { pairing with J_NON_TSW above }\end{array}$ \\
\hline J_TSW & $\begin{array}{l}\text { Assigned pool of dates for virtual releases at John Day Dam TSW spill bays (spill bays } 15 \\
\text { and } 16 \text { in 2008) }\end{array}$ \\
\hline J_TSW_TW & $\begin{array}{l}\text { Assigned pool of dates for reference releases in the upper John Day Dam tailwater for } \\
\text { pairing with J_TSW above }\end{array}$ \\
\hline J_TUR & Assigned pool of dates for virtual releases at John Day Dam turbines \\
\hline J_TUR_TW & $\begin{array}{l}\text { Assigned pool of dates for reference releases in the upper John Day Dam tailwater for } \\
\text { pairing with J_TUR above }\end{array}$ \\
\hline J_JBS & Assigned pool of dates for virtual releases at the John Day Dam JBS \\
\hline J_JBS_TW & $\begin{array}{l}\text { Assigned pool of dates for reference releases in the upper John Day Dam tailwater for } \\
\text { pairing with J_JBS above }\end{array}$ \\
\hline T_FB & Assigned pool of dates for virtual releases at The Dalles Dam forebay entrance array \\
\hline T_FB & Assigned pool of dates for reference releases in the upper tailwater of The Dalles Dam \\
\hline B_FB & $\begin{array}{l}\text { Assigned pool of dates for virtual releases at the Bonneville Dam forebay entrance array for } \\
\text { estimating Bonneville Dam survival }\end{array}$ \\
\hline B_FB_TW & Assigned pool of date for reference releases for pairing with B_FB above \\
\hline B2 & Assigned pool of dates for virtual releases at Bonneville Dam Powerhouse 2 \\
\hline B2_TW & Assigned pool of dates for reference releases for pairing with $\mathrm{B} 2$ above \\
\hline $\mathrm{B} 2 \mathrm{CC}$ & Assigned pool of dates for virtual releases at the Bonneville Dam B2CC \\
\hline B2CC_TW & Assigned pool of dates for reference releases for pairing with B2 above \\
\hline B2CC_R & Assigned pool of dates for releases directly into the $\mathrm{B} 2 \mathrm{CC}$ \\
\hline B2CC_R_TW & $\begin{array}{l}\text { Assigned pool of dates for reference releases in the Bonneville Dam tailwater for pairing } \\
\text { with B2CC_R }\end{array}$ \\
\hline B2_JBS & Assigned pool of dates for virtual releases at the Bonneville Dam B2 JBS \\
\hline B2_JBS_TW & $\begin{array}{l}\text { Assigned pool of dates for reference releases in the Bonneville Dam tailwater for pairing } \\
\text { with B2_JBS above }\end{array}$ \\
\hline B2_TUR & Assigned pool of dates for virtual releases at Bonneville Dam B2 Turbines \\
\hline B2_TUR_TW & $\begin{array}{l}\text { Assigned pool of dates for reference releases in the Bonneville Dam tailwater for pairing } \\
\text { with B2_TUR above }\end{array}$ \\
\hline
\end{tabular}


Table L.5. (contd)

\begin{tabular}{|c|c|}
\hline Variable Name & Definition \\
\hline BSPILL & Assigned pool of dates for virtual releases at the Bonneville Dam spillway \\
\hline BSPILL_TW & $\begin{array}{l}\text { Assigned pool of dates for references releases in the Bonneville Dam tailwater for pairing } \\
\text { with BSPILL above }\end{array}$ \\
\hline BS_END & $\begin{array}{l}\text { Assigned pool of dates for virtual releases at end bays (1-3 and 16-18) at the Bonneville } \\
\text { Dam spillway }\end{array}$ \\
\hline BS_END_TW & $\begin{array}{l}\text { Assigned pool of dates for references releases in the Bonneville Dam tailwater for pairing } \\
\text { with BS_END above }\end{array}$ \\
\hline BS_MID & $\begin{array}{l}\text { Assigned pool of dates for virtual releases at middle spill bays at the Bonneville Dam } \\
\text { spillway }\end{array}$ \\
\hline BS_MID_TW & $\begin{array}{l}\text { Assigned pool of dates for references releases in the Bonneville Dam tailwater for pairing } \\
\text { with BS MID above }\end{array}$ \\
\hline
\end{tabular}


Table L.6. Variable Names and definitions in Appendix L5.xls

\begin{tabular}{|c|c|}
\hline Variable Name & Definition \\
\hline SEASON & Spring or summer outmigration season defined by type of fish and release date \\
\hline SP & Species or run of juvenile salmon (SPR_CHN = spring Chinook salmon) \\
\hline REL_LOC & $\begin{array}{l}\text { Release Location (LGR=Lower Granite Tailwater; JDA_TW }=\text { upper end of the John Day } \\
\text { Dam tailwater; BON_T }=\text { the upper end of the Bonneville Dam tailwater) }\end{array}$ \\
\hline RDATETIME & Release date and time (mm/dd/yyyy hh:mm) \\
\hline ADATETIME & Acoustic tag activation date and time (mm/dd/yyyy hh:mm) \\
\hline PIT & Passive integrated transponder tag code \\
\hline ACTAGCODE & Acoustic tag code \\
\hline A1CR351 & $\begin{array}{l}\text { Detection indicator for the John Day Dam forebay entrance array }(1=\text { detected; } 0=\text { not } \\
\text { detected; blank = missing) }\end{array}$ \\
\hline JDA_ARRAY & $\begin{array}{l}\text { Detection indicator for the John Day Dam-face array }(1=\text { detected; } 0=\text { not detected; blank }= \\
\text { missing) }\end{array}$ \\
\hline A2CR339 & $\begin{array}{l}\text { Detection indicator for the John Day Dam tailwater array }(1=\text { detected; } 0=\text { not detected; } \\
\text { blank = missing })\end{array}$ \\
\hline $\mathrm{A} 3 \mathrm{CR} 312$ & $\begin{array}{l}\text { Detection indicator for The Dalles Dam forebay entrance array }(1=\text { detected; } 0=\text { not } \\
\text { detected; blank = missing) }\end{array}$ \\
\hline A4CR237 & $\begin{array}{l}\text { Detection indicator for the Bonneville Dam forebay entrance array }(1=\text { detected; } 0=\text { not } \\
\text { detected; blank = missing) }\end{array}$ \\
\hline B2_ARRAY & $\begin{array}{l}\text { Detection indicator for the Bonneville Dam Powerhouse } 2 \text { dam-face array }(1=\text { detected; } 0= \\
\text { not detected; blank = missing })\end{array}$ \\
\hline BSPILL_ARRAY & $\begin{array}{l}\text { Detection indicator for the Bonneville Dam spillway array }(1=\text { detected; } 0=\text { not detected; } \\
\text { blank = missing })\end{array}$ \\
\hline A5CR203 & $\begin{array}{l}\text { Detection indicator for the first Bonneville Dam tailwater array at Reed Island }(1=\text { detected; } \\
0=\text { not detected; blank = missing) }\end{array}$ \\
\hline A6CR192 & $\begin{array}{l}\text { Detection indicator for the second Bonneville Dam tailwater array at Lady Island }(1= \\
\text { detected; } 0=\text { not detected; blank = missing })\end{array}$ \\
\hline A7CR086 & $\begin{array}{l}\text { Detection indicator for the third Bonneville Dam tailwater array at Oak Point }(1=\text { detected; } \\
0=\text { not detected; blank = missing) }\end{array}$ \\
\hline A1CR351_TIME & Date and time of arrival at the John Day Dam forebay entrance array \\
\hline JDATETIME & Date and time of arrival at the John Day Dam-face array \\
\hline A2CR339_TIME & Date and time of arrival at the John Day Dam tailwater array \\
\hline A3CR312_TIME & Date and time of arrival at The Dalles Dam forebay entrance array \\
\hline A4CR237_TIME & Date and time of arrival at the Bonneville Dam forebay entrance array \\
\hline B2DATETIME & Date and time of last detection on the Bonneville Dam Powerhouse 2 array \\
\hline BSDATETIME & Date and time of last detection on the Bonneville Dam spillway array \\
\hline A5CR203_TIME & Date and time of arrival at the first Bonneville Dam tailwater array at Reed Island \\
\hline A6CR192_TIME & Date and time of arrival at the second Bonneville Dam tailwater array at Lady Island \\
\hline A7CR086_TIME & Date and time of arrival at the third Bonneville Dam tailwater array at Oak Point \\
\hline JROUTE & Route of passage through John Day Dam (powerhouse or spillway) \\
\hline JSUB_ROUTE & Sub-route of passage through John Day Dam [TSW (spill), non-TSW (spill), turbine, JBS] \\
\hline
\end{tabular}


Table L.6. (contd)

\begin{tabular}{|c|c|}
\hline Variable Name & Definition \\
\hline JHOLE & Specific route of passage (spill bays S1-S20; Turbines T1-T16; blank = missing) \\
\hline BROUTE & Route of passage through Bonneville Dam (B2 or SPILL) \\
\hline BSUB_ROUTE & $\begin{array}{l}\text { Sub-route of passage through Bonneville Dam }(\mathrm{SP} \text { MID }=\text { spill bays } 4-15 ; \mathrm{SP} \text { END }=\text { spill } \\
\text { bays } 1-3 \text { or } 16-18 ; \mathrm{BCC}=\mathrm{B} 2 \mathrm{CC} \text {; Turbine }=\mathrm{B} 2 \text { turbines; JBS }=\text { juvenile bypass system })\end{array}$ \\
\hline BHOLE & $\begin{array}{l}\text { Specific route of passage through Bonneville Dam }(\text { spill bays }=\text { SB1-SB18; turbines }= \\
\text { TU11-TU18 or Unknown Turbine = UnkTurb; B2CC=BCC; Juvenile Bypass System = } \\
\text { JBS) }\end{array}$ \\
\hline $\mathrm{J}$ & Assigned pool of dates for virtual releases at John Day Dam for estimating dam survival \\
\hline J_TW & $\begin{array}{l}\text { Assigned pool of dates for reference releases in the upper John Day Dam tailwater for } \\
\text { pairing with variable J above }\end{array}$ \\
\hline B_FB & $\begin{array}{l}\text { Assigned pool of dates for virtual releases at the Bonneville Dam forebay entrance array for } \\
\text { estimating Bonneville Dam survival }\end{array}$ \\
\hline B_FB_TW & Assigned pool of date for reference releases for pairing with B_FB above \\
\hline
\end{tabular}




\section{Appendix M}

\section{Burnham Test 2 and 3 Tables}


Table M.1. Burnham et al. (1987) Test 2 and Test 3 P-values for goodness-of-fit to the single releaserecapture data for spring Chinook salmon smolts passing John Day Dam. Test 2 examines whether upstream detections affect downstream survival or detection, and Test 3 examines whether upstream capture histories affect downstream survival or capture. Cells with NC could not be calculated because of high detection rates on the primary and secondary arrays. Shaded cells had P-values $<0.10$ indicated a violation of model assumptions.

\begin{tabular}{lll}
\hline Virtual Release & \multicolumn{2}{c}{ P-Values from Fisher's Exact Test } \\
\cline { 2 - 3 } Date & Test 2.2 & Test 3.1 \\
\hline $5 / 02-5 / 03$ & $\mathrm{NC}$ & $\mathrm{NC}$ \\
$5 / 04-5 / 05$ & $\mathrm{NC}$ & $\mathrm{NC}$ \\
$5 / 06-5 / 07$ & $\mathrm{NC}$ & $\mathrm{NC}$ \\
$5 / 08-5 / 09$ & 0.8409 & 0.5186 \\
$5 / 10-5 / 11$ & $\mathrm{NC}$ & $\mathrm{NC}$ \\
$5 / 12-5 / 13$ & $\mathrm{NC}$ & $\mathrm{NC}$ \\
$5 / 14-5 / 15$ & 0.8661 & 0.2784 \\
$5 / 16-5 / 17$ & $\mathrm{NC}$ & $\mathrm{NC}$ \\
$5 / 18-5 / 19$ & $\mathrm{NC}$ & $\mathrm{NC}$ \\
$5 / 20-5 / 21$ & $\mathrm{NC}$ & $\mathrm{NC}$ \\
$5 / 22-5 / 23$ & 0.3077 & 0.3823 \\
$5 / 24-5 / 25$ & $\mathrm{NC}$ & $\mathrm{NC}$ \\
$5 / 26-5 / 27$ & $\mathrm{NC}$ & $\mathrm{NC}$ \\
$5 / 28-5 / 29$ & $\mathrm{NC}$ & $\mathrm{NC}$ \\
Pooled & 0.2843 & 0.2626 \\
\hline
\end{tabular}

Table M.2. Burnham et al. (1987) Test 2 and Test 3 P-values for goodness-of-fit to the single releaserecapture data for spring Chinook salmon smolts passing John Day Dam tailwater. Test 2 examines whether upstream detections affect downstream survival or detection, and Test 3 examines whether upstream capture histories affect downstream survival or capture. Cells with NC could not be calculated because of high detection rates on the primary and secondary arrays. Shaded cells had P-values $<0.10$ indicated a violation of model assumptions.

\begin{tabular}{lll}
\hline Virtual Release & \multicolumn{2}{c}{ P-Values from Fisher's Exact Test } \\
\cline { 2 - 3 } Date & Test 2.2 & Test 3.1 \\
\hline $5 / 02-5 / 03$ & $\mathrm{NC}$ & $\mathrm{NC}$ \\
$5 / 04-5 / 05$ & $\mathrm{NC}$ & $\mathrm{NC}$ \\
$5 / 06-5 / 07$ & $\mathrm{NC}$ & $\mathrm{NC}$ \\
$5 / 08-5 / 09$ & $\mathrm{NC}$ & $\mathrm{NC}$ \\
$5 / 10-5 / 11$ & 0.9872 & 0.1039 \\
$5 / 12-5 / 13$ & $\mathrm{NC}$ & $\mathrm{NC}$ \\
$5 / 14-5 / 15$ & $\mathrm{NC}$ & 0.7859 \\
$5 / 16-5 / 17$ & $\mathrm{NC}$ & $\mathrm{NC}$ \\
$5 / 18-5 / 19$ & $\mathrm{NC}$ & $\mathrm{NC}$ \\
$5 / 20-5 / 21$ & $\mathrm{NC}$ & $\mathrm{NC}$ \\
$5 / 22-5 / 23$ & $\mathrm{NC}$ & $\mathrm{NC}$ \\
$5 / 24-5 / 25$ & $\mathrm{NC}$ & $\mathrm{NC}$ \\
$5 / 26-5 / 27$ & $\mathrm{NC}$ & $\mathrm{NC}$ \\
$5 / 28-5 / 29$ & $\mathrm{NC}$ & $\mathrm{NC}$ \\
Pooled & 0.9868 & 0.3362 \\
\hline
\end{tabular}


Table M.3. Burnham et al. (1987) Test 2 and Test 3 P-values for goodness-of-fit to the single releaserecapture data for spring Chinook salmon smolts passing the John Day Dam powerhouse. Test 2 examines whether upstream detections affect downstream survival or detection, and Test 3 examines whether upstream capture histories affect downstream survival or capture. Cells with NC could not be calculated because of high detection rates on the primary and secondary arrays. Shaded cells had P-values $<0.10$ indicated a violation of model assumptions.

\begin{tabular}{lll}
\hline \multirow{2}{*}{$\begin{array}{c}\text { Virtual Release } \\
\text { Date }\end{array}$} & \multicolumn{2}{c}{ P-Values from Fisher's Exact Test } \\
\cline { 2 - 3 } $5 / 02-5 / 05$ & Test 2.2 & Test 3.1 \\
$5 / 06-5 / 07$ & $\mathrm{NC}$ & $\mathrm{NC}$ \\
$5 / 08-5 / 09$ & $\mathrm{NC}$ & $\mathrm{NC}$ \\
$5 / 10-5 / 11$ & 0.7216 & 0.6359 \\
$5 / 12-5 / 13$ & $\mathrm{NC}$ & $\mathrm{NC}$ \\
$5 / 14-5 / 15$ & $\mathrm{NC}$ & $\mathrm{NC}$ \\
$5 / 16-5 / 17$ & 0.8000 & 0.4000 \\
$5 / 18-5 / 19$ & $\mathrm{NC}$ & $\mathrm{NC}$ \\
$5 / 20-5 / 21$ & $\mathrm{NC}$ & $\mathrm{NC}$ \\
$5 / 22-5 / 23$ & $\mathrm{NC}$ & $\mathrm{NC}$ \\
$5 / 24-5 / 25$ & 0.175 & 0.4945 \\
$5 / 26-5 / 29$ & $\mathrm{NC}$ & $\mathrm{NC}$ \\
Pooled & $\mathrm{NC}$ & $\mathrm{NC}$ \\
\hline
\end{tabular}

Table M.4. Burnham et al. (1987) Test 2 and Test 3 P-values for goodness-of-fit to the single releaserecapture data for spring Chinook salmon smolts passing the John Day Dam turbines. Test 2 examines whether upstream detections affect downstream survival or detection, and Test 3 examines whether upstream capture histories affect downstream survival or capture. Cells with NC could not be calculated because of high detection rates on the primary and secondary arrays. Shaded cells had P-values $<0.10$ indicated a violation of model assumptions.

\begin{tabular}{llc}
\hline \multirow{2}{*}{$\begin{array}{c}\text { Virtual Release } \\
\text { Date }\end{array}$} & \multicolumn{2}{c}{ P-Values from Fisher's Exact Test } \\
\cline { 2 - 3 } $5 / 02-5 / 06$ & Test 2.2 & Test 3.1 \\
$5 / 07-5 / 12$ & $\mathrm{NC}$ & $\mathrm{NC}$ \\
$5 / 13-5 / 18$ & $\mathrm{NC}$ & $\mathrm{NC}$ \\
$5 / 19-5 / 24$ & $\mathrm{NC}$ & 0.4615 \\
$5 / 25-5 / 29$ & 0.5769 & 0.5333 \\
Pooled & $\mathrm{NC}$ & $\mathrm{NC}$ \\
\hline
\end{tabular}


Table M.5. Burnham et al. (1987) Test 2 and Test 3 P-values for goodness-of-fit to the single releaserecapture data for spring Chinook salmon smolts passing the John Day Dam JBS. Test 2 examines whether upstream detections affect downstream survival or detection, and Test 3 examines whether upstream capture histories affect downstream survival or capture. Cells with NC could not be calculated because of high detection rates on the primary and secondary arrays. Shaded cells had P-values $<0.10$ indicated a violation of model assumptions.

\begin{tabular}{lcc}
\hline \multirow{2}{*}{$\begin{array}{c}\text { Virtual Release } \\
\text { Date }\end{array}$} & \multicolumn{2}{c}{ P-Values from Fisher's Exact Test } \\
\cline { 2 - 3 } $5 / 02-5 / 07$ & Test 2.2 & Test 3.1 \\
$5 / 08-5 / 11$ & $\mathrm{NC}$ & $\mathrm{NC}$ \\
$5 / 12-5 / 15$ & 0.7805 & 0.7159 \\
$5 / 16-5 / 19$ & $\mathrm{NC}$ & $\mathrm{NC}$ \\
$5 / 20-5 / 23$ & $\mathrm{NC}$ & $\mathrm{NC}$ \\
$5 / 24-5 / 29$ & 0.3247 & 0.4843 \\
Pooled & $\mathrm{NC}$ & $\mathrm{NC}$ \\
\hline
\end{tabular}

Table M.6. Burnham et al. (1987) Test 2 and Test 3 P-values for goodness-of-fit to the single releaserecapture data for spring Chinook salmon smolts passing the John Day Dam spillway. Test 2 examines whether upstream detections affect downstream survival or detection, and Test 3 examines whether upstream capture histories affect downstream survival or capture. Cells with NC could not be calculated because of high detection rates on the primary and secondary arrays. Shaded cells had $\mathrm{P}$-values $<0.10$ indicated a violation of model assumptions.

\begin{tabular}{cll}
\hline \multirow{2}{*}{$\begin{array}{c}\text { Virtual Release } \\
\text { Date }\end{array}$} & \multicolumn{2}{l}{ P-Values from Fisher's Exact Test } \\
\cline { 2 - 3 } $5 / 02-5 / 03$ & Test 2.2 & Test 3.1 \\
$5 / 04-5 / 05$ & $\mathrm{NC}$ & $\mathrm{NC}$ \\
$5 / 06-5 / 07$ & $\mathrm{NC}$ & $\mathrm{NC}$ \\
$5 / 08-5 / 09$ & $\mathrm{NC}$ & $\mathrm{NC}$ \\
$5 / 10-5 / 11$ & $\mathrm{NC}$ & $\mathrm{NC}$ \\
$5 / 12-5 / 13$ & $\mathrm{NC}$ & $\mathrm{NC}$ \\
$5 / 14-5 / 15$ & $\mathrm{NC}$ & $\mathrm{NC}$ \\
$5 / 16-5 / 17$ & $\mathrm{NC}$ & $\mathrm{NC}$ \\
$5 / 18-5 / 19$ & $\mathrm{NC}$ & $\mathrm{NC}$ \\
$5 / 20-5 / 21$ & $\mathrm{NC}$ & $\mathrm{NC}$ \\
$5 / 22-5 / 23$ & $\mathrm{NC}$ & $\mathrm{NC}$ \\
$5 / 24-5 / 25$ & 0.4505 & 0.5000 \\
$5 / 26-5 / 27$ & $\mathrm{NC}$ & $\mathrm{NC}$ \\
$5 / 28-5 / 29$ & $\mathrm{NC}$ & $\mathrm{NC}$ \\
Pooled & $\mathrm{NC}$ & $\mathrm{NC}$ \\
\hline
\end{tabular}


Table M.7. Burnham et al. (1987) Test 2 and Test 3 P-values for goodness-of-fit to the single releaserecapture data for spring Chinook salmon smolts passing the John Day Dam TSW bays (15 and 16) in 2008. Test 2 examines whether upstream detections affect downstream survival or detection, and Test 3 examines whether upstream capture histories affect downstream survival or capture. Cells with NC could not be calculated because of high detection rates on the primary and secondary arrays. Shaded cells had P-values $<0.10$ indicated a violation of model assumptions.

\begin{tabular}{llc}
\hline \multirow{2}{*}{ Virtual Release } & \multicolumn{2}{c}{ P-Values from Fisher's Exact Test } \\
\cline { 2 - 3 } Date & Test 2.2 & Test 3.1 \\
\hline $5 / 02-5 / 05$ & $\mathrm{NC}$ & $\mathrm{NC}$ \\
$5 / 06-5 / 09$ & $\mathrm{NC}$ & $\mathrm{NC}$ \\
$5 / 10-5 / 13$ & $\mathrm{NC}$ & $\mathrm{NC}$ \\
$5 / 14-5 / 17$ & $\mathrm{NC}$ & $\mathrm{NC}$ \\
$5 / 18-5 / 21$ & $\mathrm{NC}$ & $\mathrm{NC}$ \\
$5 / 22-5 / 25$ & 0.2273 & $\mathrm{NC}$ \\
$5 / 26-5 / 29$ & $\mathrm{NC}$ & $\mathrm{NC}$ \\
Pooled & 0.1785 & $\mathrm{NC}$ \\
\hline
\end{tabular}

Table M.8. Burnham et al. (1987) Test 2 and Test 3 P-values for goodness-of-fit to the single releaserecapture data for steelhead smolts passing John Day Dam. Test 2 examines whether upstream detections affect downstream survival or detection, and Test 3 examines whether upstream capture histories affect downstream survival or capture. Cells with NC could not be calculated because of high detection rates on the primary and secondary arrays. Shaded cells had P-values $<0.10$ indicated a violation of model assumptions.

\begin{tabular}{lll}
\hline \multirow{2}{*}{ Virtual Release } & \multicolumn{2}{c}{ P-Values from Fisher's Exact Test } \\
\cline { 2 - 3 } & Test 2.2 & Test 3.1 \\
\hline $5 / 02-5 / 03$ & $\mathrm{NC}$ & $\mathrm{NC}$ \\
$5 / 04-5 / 05$ & $\mathrm{NC}$ & $\mathrm{NC}$ \\
$5 / 06-5 / 07$ & $\mathrm{NC}$ & $\mathrm{NC}$ \\
$5 / 08-5 / 09$ & 0.473 & 0.195 \\
$5 / 10-5 / 11$ & $\mathrm{NC}$ & $\mathrm{NC}$ \\
$5 / 12-5 / 13$ & $\mathrm{NC}$ & $\mathrm{NC}$ \\
$5 / 14-5 / 15$ & 0.4771 & 0.2985 \\
$5 / 16-5 / 17$ & $\mathrm{NC}$ & $\mathrm{NC}$ \\
$5 / 18-5 / 19$ & $\mathrm{NC}$ & $\mathrm{NC}$ \\
$5 / 20-5 / 21$ & $\mathrm{NC}$ & $\mathrm{NC}$ \\
$5 / 22-5 / 23$ & 0.7473 & 0.7647 \\
$5 / 24-5 / 25$ & $\mathrm{NC}$ & $\mathrm{NC}$ \\
$5 / 26-5 / 27$ & $\mathrm{NC}$ & $\mathrm{NC}$ \\
$5 / 28-5 / 29$ & $\mathrm{NC}$ & $\mathrm{NC}$ \\
Pooled & 0.1365 & 0.2607 \\
\hline
\end{tabular}


Table M.9. Burnham et al. (1987) Test 2 and Test 3 P-values for goodness-of-fit to the single releaserecapture data for steelhead smolts passing John Day Dam tailwater. Test 2 examines whether upstream detections affect downstream survival or detection, and Test 3 examines whether upstream capture histories affect downstream survival or capture. Cells with NC could not be calculated because of high detection rates on the primary and secondary arrays. Shaded cells had P-values $<0.10$ indicated a violation of model assumptions.

\begin{tabular}{llc}
\hline Virtual & \multicolumn{2}{c}{ P-Values from Fisher's Exact Test } \\
\cline { 2 - 3 } Release Date & Test 2.2 & Test 3.1 \\
\hline $5 / 02-5 / 03$ & $\mathrm{NC}$ & $\mathrm{NC}$ \\
$5 / 04-5 / 05$ & $\mathrm{NC}$ & $\mathrm{NC}$ \\
$5 / 06-5 / 07$ & $\mathrm{NC}$ & $\mathrm{NC}$ \\
$5 / 08-5 / 09$ & $\mathrm{NC}$ & 0.6509 \\
$5 / 10-5 / 11$ & $\mathrm{NC}$ & $\mathrm{NC}$ \\
$5 / 12-5 / 13$ & $\mathrm{NC}$ & $\mathrm{NC}$ \\
$5 / 14-5 / 15$ & 0.9836 & 0.9167 \\
$5 / 16-5 / 17$ & $\mathrm{NC}$ & $\mathrm{NC}$ \\
$5 / 18-5 / 19$ & $\mathrm{NC}$ & $\mathrm{NC}$ \\
$5 / 20-5 / 21$ & $\mathrm{NC}$ & $\mathrm{NC}$ \\
$5 / 22-5 / 23$ & 0.9577 & 0.4037 \\
$5 / 24-5 / 25$ & $\mathrm{NC}$ & $\mathrm{NC}$ \\
$5 / 26-5 / 27$ & $\mathrm{NC}$ & $\mathrm{NC}$ \\
$5 / 28-5 / 29$ & $\mathrm{NC}$ & $\mathrm{NC}$ \\
Pooled & 0.9614 & 0.284 \\
\hline
\end{tabular}

Table M.10. Burnham et al. (1987) Test 2 and Test 3 P-values for goodness-of-fit to the single releaserecapture data for steelhead smolts passing the John Day Dam powerhouse. Test 2 examines whether upstream detections affect downstream survival or detection, and Test 3 examines whether upstream capture histories affect downstream survival or capture. Cells with NC could not be calculated because of high detection rates on the primary and secondary arrays. Shaded cells had P-values $<0.10$ indicated a violation of model assumptions.

\begin{tabular}{llc}
\hline Virtual & \multicolumn{2}{c}{ P-Values from Fisher's Exact Test } \\
\cline { 2 - 3 } Release Date & Test 2.2 & Test 3.1 \\
\hline $5 / 02-5 / 04$ & $\mathrm{NC}$ & $\mathrm{NC}$ \\
$5 / 05-5 / 06$ & $\mathrm{NC}$ & $\mathrm{NC}$ \\
$5 / 07-5 / 08$ & $\mathrm{NC}$ & $\mathrm{NC}$ \\
$5 / 09-5 / 10$ & 0.8413 & 0.8302 \\
$5 / 11-5 / 12$ & $\mathrm{NC}$ & $\mathrm{NC}$ \\
$5 / 13-5 / 14$ & $\mathrm{NC}$ & $\mathrm{NC}$ \\
$5 / 15-5 / 16$ & 0.6471 & 0.5909 \\
$5 / 17-5 / 18$ & $\mathrm{NC}$ & $\mathrm{NC}$ \\
$5 / 19-5 / 20$ & $\mathrm{NC}$ & $\mathrm{NC}$ \\
$5 / 21-5 / 22$ & $\mathrm{NC}$ & $\mathrm{NC}$ \\
$5 / 23-5 / 24$ & 0.7692 & 0.7000 \\
$5 / 25-5 / 26$ & $\mathrm{NC}$ & $\mathrm{NC}$ \\
$5 / 27-5 / 29$ & 0.2937 & $\mathrm{NC}$ \\
Pooled & 0.4762 & 0.4015 \\
\hline
\end{tabular}


Table M.11. Burnham et al. (1987) Test 2 and Test 3 P-values for goodness-of-fit to the single releaserecapture data for steelhead smolts passing the John Day Dam turbines. Test 2 examines whether upstream detections affect downstream survival or detection, and Test 3 examines whether upstream capture histories affect downstream survival or capture. Cells with NC could not be calculated because of high detection rates on the primary and secondary arrays. Shaded cells had P-values $<0.10$ indicated a violation of model assumptions.

\begin{tabular}{lcc}
\hline \multicolumn{1}{c}{ Virtual } & \multicolumn{2}{c}{ P-Values from Fisher's Exact Test } \\
\cline { 2 - 3 } Release Date & Test 2.2 & Test 3.1 \\
\hline $5 / 02-5 / 15$ & $\mathrm{NC}$ & $\mathrm{NC}$ \\
$5 / 16-5 / 29$ & $\mathrm{NC}$ & $\mathrm{NC}$ \\
Pooled & $\mathrm{NC}$ & $\mathrm{NC}$ \\
\hline
\end{tabular}

Table M.12. Burnham et al. (1987) Test 2 and Test 3 P-values for goodness-of-fit to the single releaserecapture data for steelhead smolts passing the John Day Dam JBS. Test 2 examines whether upstream detections affect downstream survival or detection, and Test 3 examines whether upstream capture histories affect downstream survival or capture. Cells with NC could not be calculated because of high detection rates on the primary and secondary arrays. Shaded cells had P-values $<0.10$ indicated a violation of model assumptions.

\begin{tabular}{llc}
\hline Virtual & \multicolumn{2}{c}{ P-Values from Fisher's Exact Test } \\
\cline { 2 - 3 } Release Date & Test 2.2 & Test 3.1 \\
\hline $5 / 02-5 / 04$ & $\mathrm{NC}$ & $\mathrm{NC}$ \\
$5 / 05-5 / 06$ & $\mathrm{NC}$ & $\mathrm{NC}$ \\
$5 / 07-5 / 08$ & $\mathrm{NC}$ & $\mathrm{NC}$ \\
$5 / 09-5 / 10$ & 0.8448 & 0.8163 \\
$5 / 11-5 / 12$ & $\mathrm{NC}$ & $\mathrm{NC}$ \\
$5 / 13-5 / 14$ & $\mathrm{NC}$ & $\mathrm{NC}$ \\
$5 / 15-5 / 16$ & 0.6774 & 0.619 \\
$5 / 17-5 / 18$ & $\mathrm{NC}$ & $\mathrm{NC}$ \\
$5 / 19-5 / 20$ & $\mathrm{NC}$ & $\mathrm{NC}$ \\
$5 / 21-5 / 22$ & $\mathrm{NC}$ & $\mathrm{NC}$ \\
$5 / 23-5 / 24$ & 0.7692 & 0.7000 \\
$5 / 25-5 / 26$ & $\mathrm{NC}$ & $\mathrm{NC}$ \\
$5 / 27-5 / 29$ & $\mathrm{NC}$ & $\mathrm{NC}$ \\
Pooled & 0.4981 & 0.4054 \\
\hline
\end{tabular}


Table M.13. Burnham et al. (1987) Test 2 and Test 3 P-values for goodness-of-fit to the single releaserecapture data for steelhead smolts passing the John Day Dam spillway. Test 2 examines whether upstream detections affect downstream survival or detection, and Test 3 examines whether upstream capture histories affect downstream survival or capture. Cells with NC could not be calculated because of high detection rates on the primary and secondary arrays. Shaded cells had P-values $<0.10$ indicated a violation of model assumptions.

\begin{tabular}{llc}
\hline Virtual & \multicolumn{2}{c}{ P-Values from Fisher's Exact Test } \\
\cline { 2 - 3 } Release Date & Test 2.2 & Test 3.1 \\
\hline $5 / 02-5 / 03$ & $\mathrm{NC}$ & $\mathrm{NC}$ \\
$5 / 04-5 / 05$ & $\mathrm{NC}$ & $\mathrm{NC}$ \\
$5 / 06-5 / 07$ & $\mathrm{NC}$ & $\mathrm{NC}$ \\
$5 / 08-5 / 09$ & 0.5466 & 0.1464 \\
$5 / 10-5 / 11$ & $\mathrm{NC}$ & $\mathrm{NC}$ \\
$5 / 12-5 / 13$ & $\mathrm{NC}$ & $\mathrm{NC}$ \\
$5 / 14-5 / 15$ & 0.5874 & 0.4023 \\
$5 / 16-5 / 17$ & $\mathrm{NC}$ & $\mathrm{NC}$ \\
$5 / 18-5 / 19$ & $\mathrm{NC}$ & $\mathrm{NC}$ \\
$5 / 20-5 / 21$ & $\mathrm{NC}$ & $\mathrm{NC}$ \\
$5 / 22-5 / 23$ & $\mathrm{NC}$ & $\mathrm{NC}$ \\
$5 / 24-5 / 25$ & $\mathrm{NC}$ & $\mathrm{NC}$ \\
$5 / 26-5 / 27$ & $\mathrm{NC}$ & $\mathrm{NC}$ \\
$5 / 28-5 / 29$ & $\mathrm{NC}$ & $\mathrm{NC}$ \\
Pooled & 0.2786 & 0.2937 \\
\hline
\end{tabular}

Table M.14. Burnham et al. (1987) Test 2 and Test 3 P-values for goodness-of-fit to the single releaserecapture data for steelhead smolts passing the John Day Dam TSW Bays (15 and 16) in 2008. Test 2 examines whether upstream detections affect downstream survival or detection, and Test 3 examines whether upstream capture histories affect downstream survival or capture. Cells with NC could not be calculated because of high detection rates on the primary and secondary arrays. Shaded cells had P-values $<0.10$ indicated a violation of model assumptions.

\begin{tabular}{llc}
\hline Virtual & \multicolumn{2}{c}{ P-Values from Fisher's Exact Test } \\
\cline { 2 - 3 } Release Date & Test 2.2 & Test 3.1 \\
\hline $5 / 02-5 / 03$ & $\mathrm{NC}$ & $\mathrm{NC}$ \\
$5 / 04-5 / 05$ & $\mathrm{NC}$ & $\mathrm{NC}$ \\
$5 / 06-5 / 07$ & $\mathrm{NC}$ & $\mathrm{NC}$ \\
$5 / 08-5 / 09$ & 0.675 & 0.3522 \\
$5 / 10-5 / 11$ & $\mathrm{NC}$ & $\mathrm{NC}$ \\
$5 / 12-5 / 13$ & $\mathrm{NC}$ & $\mathrm{NC}$ \\
$5 / 14-5 / 15$ & 0.6699 & 0.4331 \\
$5 / 16-5 / 17$ & $\mathrm{NC}$ & $\mathrm{NC}$ \\
$5 / 18-5 / 19$ & $\mathrm{NC}$ & $\mathrm{NC}$ \\
$5 / 20-5 / 21$ & $\mathrm{NC}$ & $\mathrm{NC}$ \\
$5 / 22-5 / 23$ & $\mathrm{NC}$ & $\mathrm{NC}$ \\
$5 / 24-5 / 25$ & $\mathrm{NC}$ & $\mathrm{NC}$ \\
$5 / 26-5 / 27$ & $\mathrm{NC}$ & $\mathrm{NC}$ \\
$5 / 28-5 / 29$ & $\mathrm{NC}$ & $\mathrm{NC}$ \\
Pooled & 0.3625 & 0.3469 \\
\hline
\end{tabular}


Table M.15. Burnham et al. (1987) Test 2 and Test 3 P-values for goodness-of-fit to the single releaserecapture data for fall Chinook salmon smolts passing John Day Dam. Test 2 examines whether upstream detections affect downstream survival or detection, and Test 3 examines whether upstream capture histories affect downstream survival or capture. Cells with NC could not be calculated because of high detection rates on the primary and secondary arrays. Shaded cells had P-values $<0.10$ indicated a violation of model assumptions.

\begin{tabular}{ccc}
\hline Virtual Release & \multicolumn{2}{c}{ P-Values from Fisher's Exact Test } \\
\cline { 2 - 3 } Date & Test 2.2 & Test 3.1 \\
\hline $6 / 16-6 / 17$ & 0.7661 & 0.6842 \\
$6 / 18-6 / 19$ & 0.4492 & 0.7086 \\
$6 / 20-6 / 21$ & $\mathrm{NC}$ & $\mathrm{NC}$ \\
$6 / 22-6 / 23$ & $\mathrm{NC}$ & $\mathrm{NC}$ \\
$6 / 24-6 / 25$ & $\mathrm{NC}$ & $\mathrm{NC}$ \\
$6 / 26-6 / 27$ & 0.7073 & 0.4921 \\
$6 / 28-6 / 29$ & $\mathrm{NC}$ & $\mathrm{NC}$ \\
$6 / 30-7 / 01$ & $\mathrm{NC}$ & $\mathrm{NC}$ \\
$7 / 02-7 / 03$ & $\mathrm{NC}$ & $\mathrm{NC}$ \\
$7 / 04-7 / 05$ & $\mathrm{NC}$ & $\mathrm{NC}$ \\
$7 / 06-7 / 07$ & 0.9546 & 0.7376 \\
$7 / 08-7 / 09$ & $\mathrm{NC}$ & $\mathrm{NC}$ \\
$7 / 10-7 / 11$ & $\mathrm{NC}$ & $\mathrm{NC}$ \\
$7 / 12-7 / 13$ & $\mathrm{NC}$ & $\mathrm{NC}$ \\
Pooled & 0.3859 & 0.2188 \\
\hline
\end{tabular}

Table M.16. Burnham et al. (1987) Test 2 and Test 3 P-values for goodness-of-fit to the single releaserecapture data for fall Chinook salmon smolts passing John Day Dam tailwater. Test 2 examines whether upstream detections affect downstream survival or detection, and Test 3 examines whether upstream capture histories affect downstream survival or capture. Cells with NC could not be calculated because of high detection rates on the primary and secondary arrays. Shaded cells had P-values $<0.10$ indicated a violation of model assumptions.

\begin{tabular}{llc}
\hline Virtual Release & \multicolumn{2}{c}{ P-Values from Fisher's Exact Test } \\
\cline { 2 - 3 } Date & Test 2.2 & Test 3.1 \\
\hline $6 / 16-6 / 17$ & $\mathrm{NC}$ & $\mathrm{NC}$ \\
$6 / 18-6 / 19$ & $\mathrm{NC}$ & 0.7466 \\
$6 / 20-6 / 21$ & $\mathrm{NC}$ & $\mathrm{NC}$ \\
$6 / 22-6 / 23$ & $\mathrm{NC}$ & $\mathrm{NC}$ \\
$6 / 24-6 / 25$ & $\mathrm{NC}$ & $\mathrm{NC}$ \\
$6 / 26-6 / 27$ & $\mathrm{NC}$ & 0.8382 \\
$6 / 28-6 / 29$ & $\mathrm{NC}$ & $\mathrm{NC}$ \\
$6 / 30-7 / 01$ & $\mathrm{NC}$ & $\mathrm{NC}$ \\
$7 / 02-7 / 03$ & $\mathrm{NC}$ & $\mathrm{NC}$ \\
$7 / 04-7 / 05$ & $\mathrm{NC}$ & $\mathrm{NC}$ \\
$7 / 06-7 / 07$ & $\mathrm{NC}$ & 0.9000 \\
$7 / 08-7 / 09$ & $\mathrm{NC}$ & $\mathrm{NC}$ \\
$7 / 10-7 / 11$ & $\mathrm{NC}$ & $\mathrm{NC}$ \\
$7 / 12-7 / 13$ & $\mathrm{NC}$ & $\mathrm{NC}$ \\
Pooled & 0.9865 & 0.5948 \\
\hline
\end{tabular}


Table M.17. Burnham et al. (1987) Test 2 and Test 3 P-values for goodness-of-fit to the single releaserecapture data for fall Chinook salmon smolts passing the John Day Dam powerhouse.

Test 2 examines whether upstream detections affect downstream survival or detection, and Test 3 examines whether upstream capture histories affect downstream survival or capture. Cells with NC could not be calculated because of high detection rates on the primary and secondary arrays. Shaded cells had P-values $<0.10$ indicated a violation of model assumptions.

\begin{tabular}{|c|c|c|}
\hline \multirow{2}{*}{$\begin{array}{c}\text { Virtual Release } \\
\text { Date }\end{array}$} & \multicolumn{2}{|c|}{ P-Values from Fisher's Exact Test } \\
\hline & Test 2.2 & Test 3.1 \\
\hline $6 / 16-6 / 17$ & $\mathrm{NC}$ & $\mathrm{NC}$ \\
\hline $6 / 18-6 / 19$ & 0.7317 & 0.9667 \\
\hline $6 / 20-6 / 21$ & $\mathrm{NC}$ & $\mathrm{NC}$ \\
\hline $6 / 22-6 / 23$ & $\mathrm{NC}$ & $\mathrm{NC}$ \\
\hline $6 / 24-6 / 25$ & $\mathrm{NC}$ & $\mathrm{NC}$ \\
\hline $6 / 26-6 / 27$ & $\mathrm{NC}$ & $\mathrm{NC}$ \\
\hline $6 / 28-6 / 29$ & $\mathrm{NC}$ & $\mathrm{NC}$ \\
\hline $6 / 30-7 / 01$ & $\mathrm{NC}$ & $\mathrm{NC}$ \\
\hline $7 / 02-7 / 03$ & $\mathrm{NC}$ & $\mathrm{NC}$ \\
\hline $7 / 04-7 / 05$ & $\mathrm{NC}$ & $\mathrm{NC}$ \\
\hline $7 / 06-7 / 07$ & $\mathrm{NC}$ & 0.907 \\
\hline 7/08-7/09 & $\mathrm{NC}$ & $\mathrm{NC}$ \\
\hline $7 / 10-7 / 11$ & $\mathrm{NC}$ & $\mathrm{NC}$ \\
\hline $7 / 12-7 / 13$ & $\mathrm{NC}$ & $\mathrm{NC}$ \\
\hline Pooled & 0.752 & 0.6941 \\
\hline
\end{tabular}

Table M.18. Burnham et al. (1987) Test 2 and Test 3 P-values for goodness-of-fit to the single releaserecapture data for fall Chinook salmon smolts passing the John Day Dam turbines. Test 2 examines whether upstream detections affect downstream survival or detection, and Test 3 examines whether upstream capture histories affect downstream survival or capture. Cells with NC could not be calculated because of high detection rates on the primary and secondary arrays. Shaded cells had P-values $<0.10$ indicated a violation of model assumptions.

\begin{tabular}{lll}
\hline \multirow{2}{*}{$\begin{array}{c}\text { Virtual Release } \\
\text { Date }\end{array}$} & \multicolumn{2}{c}{ P-Values from Fisher's Exact Test } \\
\cline { 2 - 3 } Test 2.2 & Test 3.1 \\
\hline $6 / 16-6 / 17$ & $\mathrm{NC}$ & $\mathrm{NC}$ \\
$6 / 18-6 / 19$ & $\mathrm{NC}$ & $\mathrm{NC}$ \\
$6 / 20-6 / 21$ & $\mathrm{NC}$ & $\mathrm{NC}$ \\
$6 / 22-6 / 23$ & $\mathrm{NC}$ & $\mathrm{NC}$ \\
$6 / 24-6 / 25$ & $\mathrm{NC}$ & $\mathrm{NC}$ \\
$6 / 26-6 / 27$ & $\mathrm{NC}$ & $\mathrm{NC}$ \\
$6 / 28-6 / 29$ & $\mathrm{NC}$ & $\mathrm{NC}$ \\
$6 / 30-7 / 01$ & $\mathrm{NC}$ & $\mathrm{NC}$ \\
$7 / 02-7 / 03$ & $\mathrm{NC}$ & $\mathrm{NC}$ \\
$7 / 04-7 / 05$ & $\mathrm{NC}$ & $\mathrm{NC}$ \\
$7 / 06-7 / 07$ & $\mathrm{NC}$ & 0.871 \\
$7 / 08-7 / 09$ & $\mathrm{NC}$ & $\mathrm{NC}$ \\
$7 / 10-7 / 11$ & $\mathrm{NC}$ & $\mathrm{NC}$ \\
$7 / 12-7 / 13$ & $\mathrm{NC}$ & $\mathrm{NC}$ \\
Pooled & 0.9013 & 0.819 \\
\hline
\end{tabular}


Table M.19. Burnham et al. (1987) Test 2 and Test 3 P-values for goodness-of-fit to the single releaserecapture data for fall Chinook salmon smolts passing the John Day Dam JBS. Test 2 examines whether upstream detections affect downstream survival or detection, and Test 3 examines whether upstream capture histories affect downstream survival or capture. Cells with NC could not be calculated because of high detection rates on the primary and secondary arrays. Shaded cells had P-values $<0.10$ indicated a violation of model assumptions.

\begin{tabular}{|c|c|c|}
\hline \multirow{2}{*}{$\begin{array}{c}\text { Virtual Release } \\
\text { Date }\end{array}$} & \multicolumn{2}{|c|}{ P-Values from Fisher's Exact Test } \\
\hline & Test 2.2 & Test 3.1 \\
\hline $6 / 16-6 / 17$ & 0.7692 & 0.825 \\
\hline $6 / 18-6 / 19$ & $\mathrm{NC}$ & $\mathrm{NC}$ \\
\hline $6 / 20-6 / 21$ & $\mathrm{NC}$ & $\mathrm{NC}$ \\
\hline $6 / 22-6 / 23$ & $\mathrm{NC}$ & $\mathrm{NC}$ \\
\hline $6 / 24-6 / 25$ & $\mathrm{NC}$ & $\mathrm{NC}$ \\
\hline $6 / 26-6 / 27$ & $\mathrm{NC}$ & $\mathrm{NC}$ \\
\hline $6 / 28-6 / 29$ & $\mathrm{NC}$ & $\mathrm{NC}$ \\
\hline $6 / 30-7 / 01$ & $\mathrm{NC}$ & $\mathrm{NC}$ \\
\hline $7 / 02-7 / 03$ & $\mathrm{NC}$ & $\mathrm{NC}$ \\
\hline 7/04-7/05 & $\mathrm{NC}$ & $\mathrm{NC}$ \\
\hline 7/06-7/07 & $\mathrm{NC}$ & $\mathrm{NC}$ \\
\hline 7/08-7/09 & $\mathrm{NC}$ & $\mathrm{NC}$ \\
\hline $7 / 10-7 / 11$ & $\mathrm{NC}$ & $\mathrm{NC}$ \\
\hline $7 / 12-7 / 13$ & $\mathrm{NC}$ & $\mathrm{NC}$ \\
\hline Pooled & 0.8382 & 0.8465 \\
\hline
\end{tabular}

Table M.20. Burnham et al. (1987) Test 2 and Test 3 P-values for goodness-of-fit to the single releaserecapture data for fall Chinook salmon smolts passing the John Day Dam spillway. Test 2 examines whether upstream detections affect downstream survival or detection, and Test 3 examines whether upstream capture histories affect downstream survival or capture. Cells with NC could not be calculated because of high detection rates on the primary and secondary arrays. Shaded cells had P-values $<0.10$ indicated a violation of model assumptions.

\begin{tabular}{|c|c|c|}
\hline \multirow{2}{*}{$\begin{array}{c}\text { Virtual } \\
\text { Release Date }\end{array}$} & \multicolumn{2}{|c|}{ P-Values from Fisher's Exact Test } \\
\hline & Test 2.2 & Test 3.1 \\
\hline $6 / 16-6 / 17$ & 0.7011 & 0.6557 \\
\hline $6 / 18-6 / 19$ & 0.4724 & 0.7797 \\
\hline $6 / 20-6 / 21$ & $\mathrm{NC}$ & $\mathrm{NC}$ \\
\hline $6 / 22-6 / 23$ & $\mathrm{NC}$ & $\mathrm{NC}$ \\
\hline $6 / 24-6 / 25$ & $\mathrm{NC}$ & $\mathrm{NC}$ \\
\hline $6 / 26-6 / 27$ & 0.6679 & 0.5102 \\
\hline $6 / 28-6 / 29$ & $\mathrm{NC}$ & $\mathrm{NC}$ \\
\hline $6 / 30-7 / 01$ & $\mathrm{NC}$ & $\mathrm{NC}$ \\
\hline $7 / 02-7 / 03$ & $\mathrm{NC}$ & $\mathrm{NC}$ \\
\hline 7/04-7/05 & $\mathrm{NC}$ & $\mathrm{NC}$ \\
\hline 7/06-7/07 & 0.9659 & 0.8353 \\
\hline 7/08-7/09 & $\mathrm{NC}$ & $\mathrm{NC}$ \\
\hline $7 / 10-7 / 11$ & $\mathrm{NC}$ & $\mathrm{NC}$ \\
\hline $7 / 12-7 / 13$ & $\mathrm{NC}$ & $\mathrm{NC}$ \\
\hline Pooled & 0.4021 & 0.3117 \\
\hline
\end{tabular}


Table M.21. Burnham et al. (1987) Test 2 and Test 3 P-values for goodness-of-fit to the single releaserecapture data for fall Chinook salmon smolts passing through the John Day Dam TSW bays (15 and 16) in 2008. Test 2 examines whether upstream detections affect downstream survival or detection, and Test 3 examines whether upstream capture histories affect downstream survival or capture. Cells with NC could not be calculated because of high detection rates on the primary and secondary arrays. Shaded cells had P-values $<0.10$ indicated a violation of model assumptions.

\begin{tabular}{lll}
\hline \multirow{2}{*}{$\begin{array}{c}\text { Virtual Release } \\
\text { Date }\end{array}$} & \multicolumn{2}{c}{ P-Values from Fisher's Exact Test } \\
\cline { 2 - 3 } $6 / 16-6 / 17$ & Test 2.2 & Test 3.1 \\
$6 / 18-6 / 19$ & $\mathrm{NC}$ & $\mathrm{NC}$ \\
$6 / 20-6 / 21$ & $\mathrm{NC}$ & $\mathrm{NC}$ \\
$6 / 22-6 / 23$ & $\mathrm{NC}$ & $\mathrm{NC}$ \\
$6 / 24-6 / 25$ & $\mathrm{NC}$ & $\mathrm{NC}$ \\
$6 / 26-6 / 27$ & 0.7708 & 0.7297 \\
$6 / 28-6 / 29$ & $\mathrm{NC}$ & $\mathrm{NC}$ \\
$6 / 30-7 / 01$ & $\mathrm{NC}$ & $\mathrm{NC}$ \\
$7 / 02-7 / 03$ & $\mathrm{NC}$ & $\mathrm{NC}$ \\
$7 / 04-7 / 05$ & $\mathrm{NC}$ & $\mathrm{NC}$ \\
$7 / 06-7 / 07$ & $\mathrm{NC}$ & $\mathrm{NC}$ \\
$7 / 08-7 / 09$ & $\mathrm{NC}$ & $\mathrm{NC}$ \\
$7 / 10-7 / 11$ & $\mathrm{NC}$ & $\mathrm{NC}$ \\
$7 / 12-7 / 13$ & $\mathrm{NC}$ & $\mathrm{NC}$ \\
Pooled & $\mathrm{NC}$ & $\mathrm{NC}$ \\
\hline
\end{tabular}

\section{Reference}

Burnham KP, DR Anderson, GC White, C Brownie, and KH Pollock. 1987. "Design and Analysis Methods for Fish Survival Estimates Based on Release-Recapture." American Fisheries Society Monograph No. 5. 


\section{Appendix N}

Time-of-Arrival Plots for Treatment and Reference Releases of Fish Used for Paired-Release Survival Estimation 


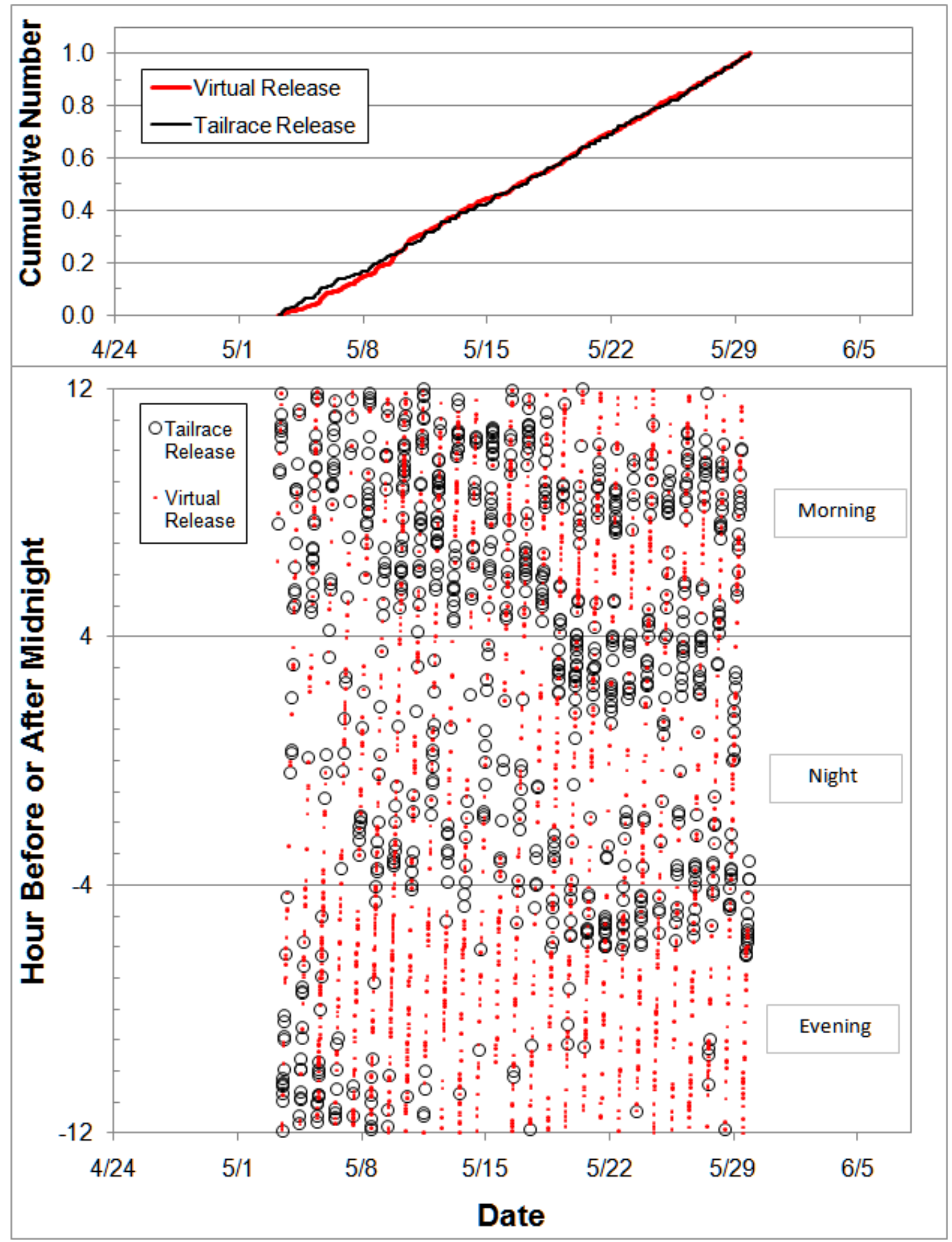

Figure N.1. Cumulative frequency of arrivals of tagged steelhead smolts from virtual releases at John Day Dam and references releases in the John Day Dam tailrace (top) and a scatter plot of arrival hour of each released fish before or after midnight by date (bottom) 


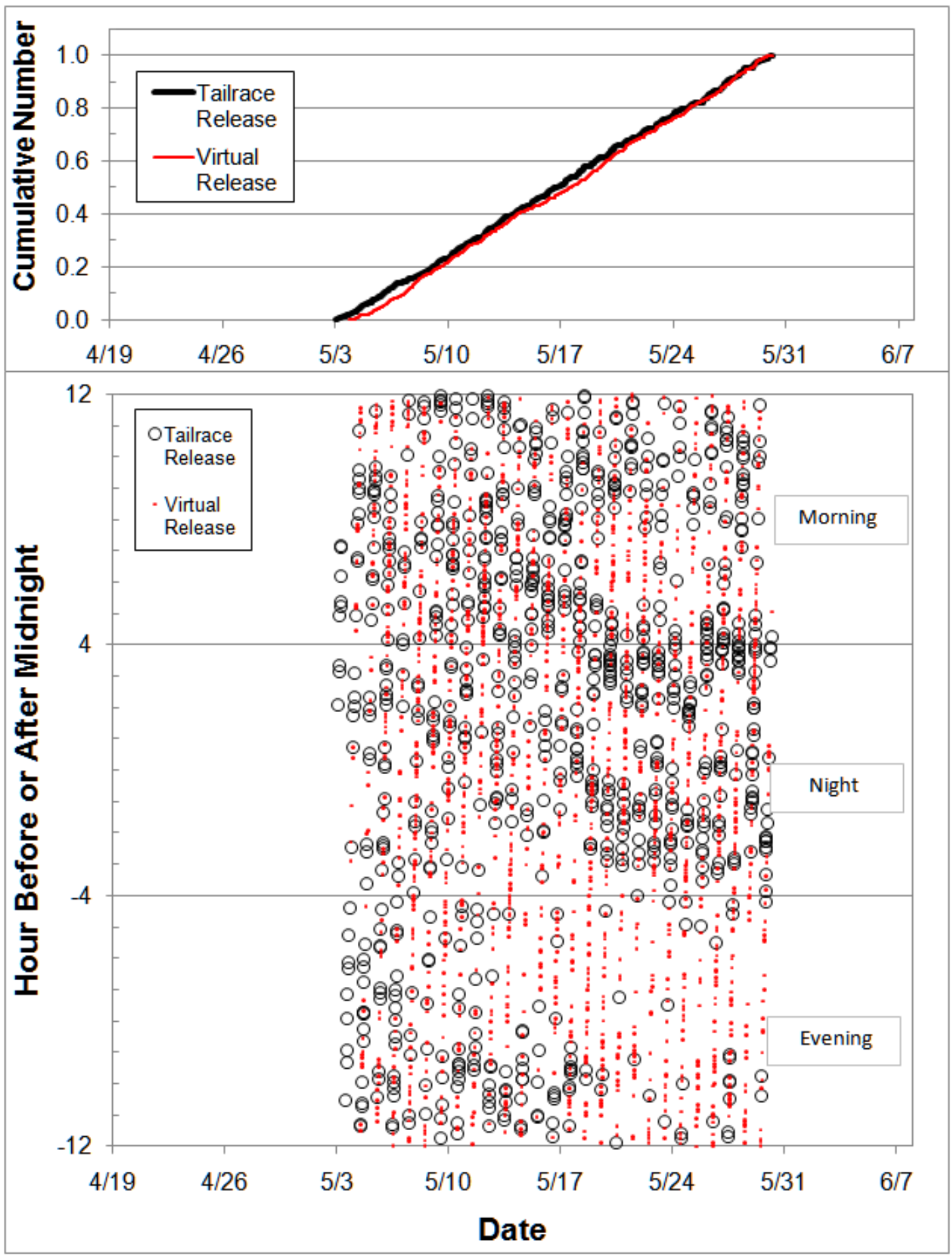

Figure N.2. Cumulative frequency of arrivals of tagged yearling Chinook salmon smolts from virtual releases at John Day Dam and references releases in the John Day Dam tailrace (top) and a scatter plot of arrival hour of each released fish before or after midnight by date (bottom) 


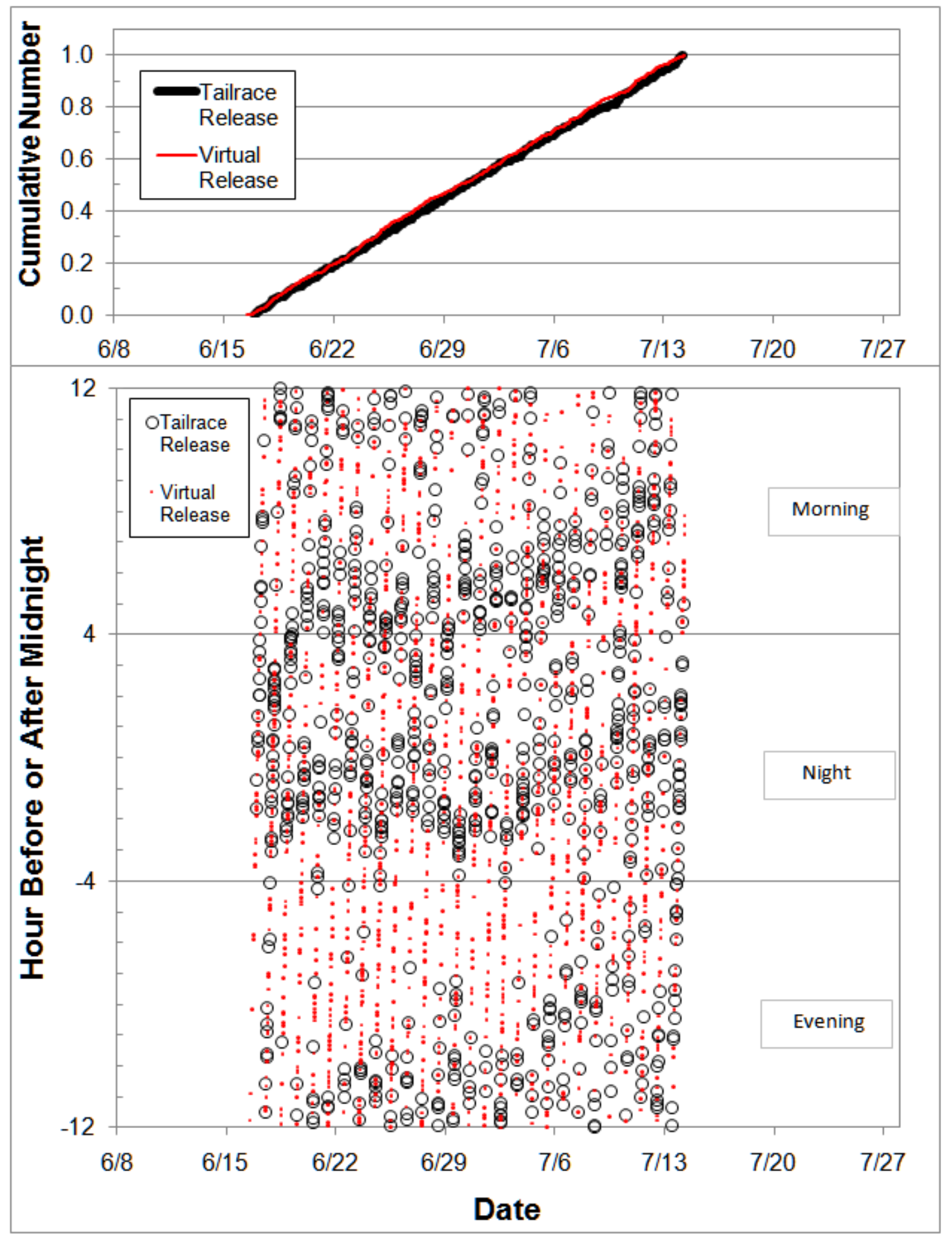

Figure N.3. Cumulative frequency of arrivals of tagged subyearling Chinook salmon smolts from virtual releases at John Day Dam and references releases in the John Day Dam tailrace (top) and a scatter plot of arrival hour of each released fish before or after midnight by date (bottom) 


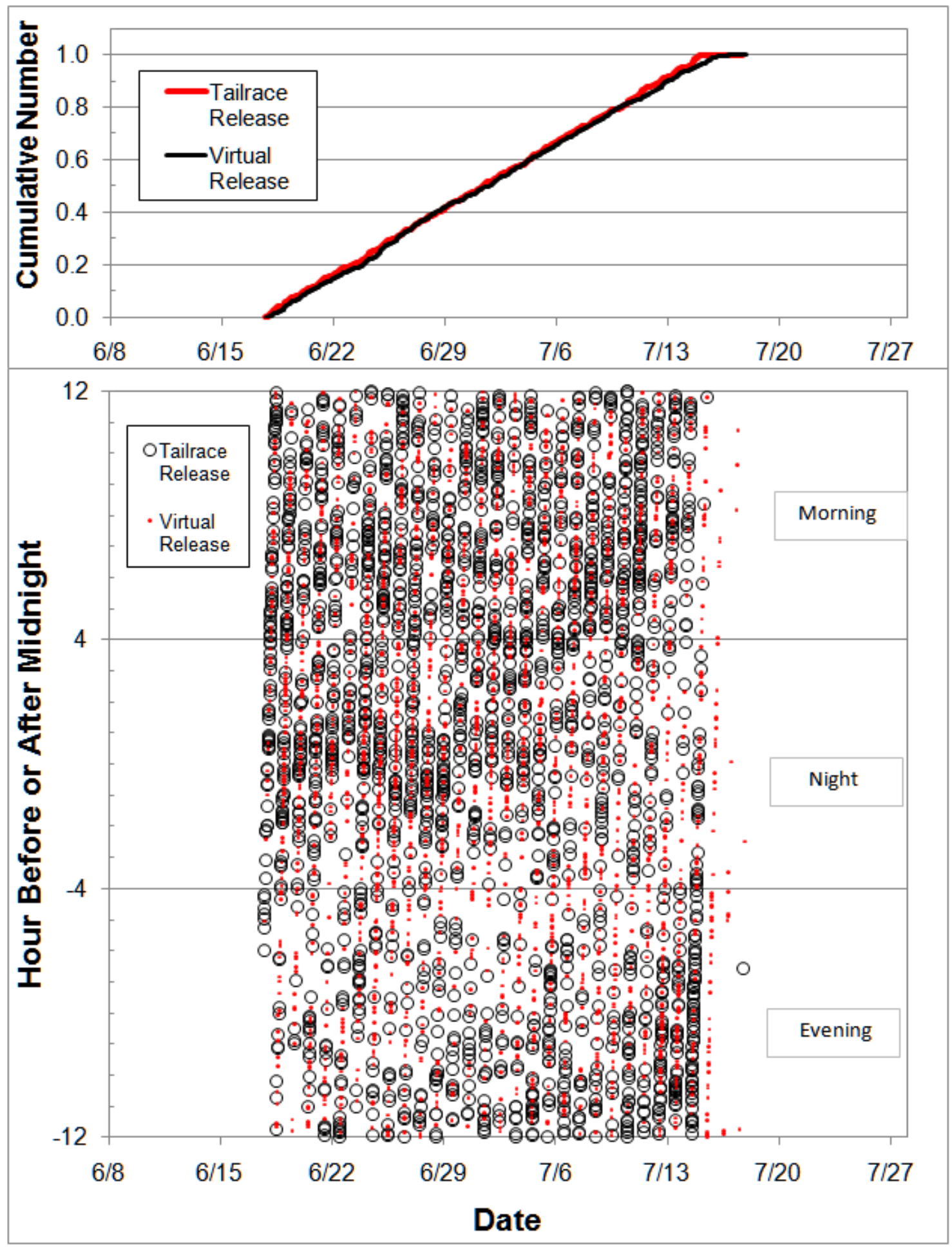

Figure N.4. Cumulative frequency of arrivals of tagged subyearling Chinook salmon smolts from virtual releases at The Dalles Dam and references releases in the The Dalles Dam tailrace (top) and a scatter plot of arrival hour of each released fish before or after midnight by date (bottom) 


\section{Distribution}

No. of

Copies

OFFSITE

30 Paper \& CD with PDF \& Appendix Files

Brad Eppard and Sean Tackley

USACE District, Portland

CENWP-PM-E

333 SW 1st Avenue (R. Duncan Plaza)

Portland, OR 97204-3495

19 Paper \& CD with PDF \& Appendix Files

Mark Weiland and coauthors

PNNL for authors

380 Evergreen Drive

P.O. Box 241

North Bonneville, WA 98639
No. of

Copies

\section{ONSITE}

3 Paper \& CD with PDF \& Appendix Files

Pacific Northwest National Laboratory

KD Ham

K6-85

DR Geist

K6-85

Hanford Technical Library 


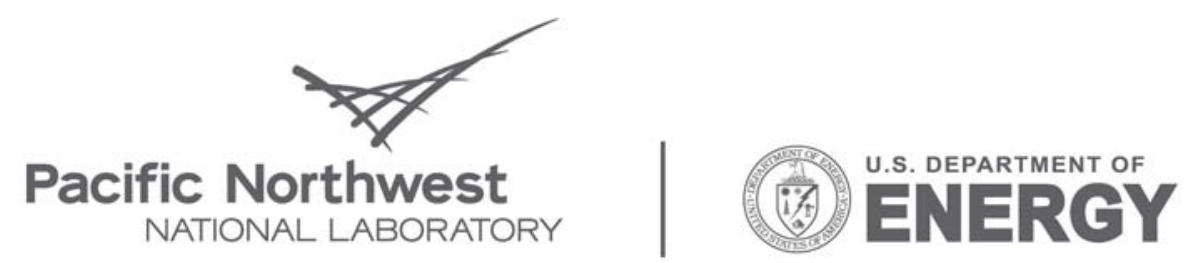

Proudly Operated by Battelle Since 1965

902 Battelle Boulevard

P.O. Box 999

Richland, WA 99352

1-888-375-PNNL (7665)

www.pnl.gov 